

\section{COPY NUMBER}

1

2

3.

4

5

6

$7-8$

9

10

11

12

\section{DISTRIBUTION}

F. K. McCune - Yellow Copy

B. H. Kingdon

K. R. Van Tassel

W. E. Johnson

J. E. Maider

A. B. Greninger

Atomic Energy Commission

Hanford Operations Office

Attention: D. F. Shaw, Manager

Atomile Energy Commission

Hanford Operations Office

Attention: J. J. Joyce

Atomic Energy Commission

For: B. M. Fry, AEC, Washington

700 File

300 File

\section{DISCLAIMER}

This report was prepared as an account of work sponsored by an agency of the United States Government. Neither the United States Government nor any agency thereof, nor any of their employees, makes any warranty, express or implied, or assumes any legal liability or responsibility for the accuracy, completeness, or usefulness of any informution, apparatus, product, or process disclosed, or represents that its use would not infringe privately owned rights. Reference herein to any specific commercial product, process, or service by trade name, trademark, manufacturer, or otherwise does not necessarily constitute or imply its endorsemint, recommendation, or favoring by the United States Government or any agency thereof. The views and opinions of authors expressed herein do not necessarily state or reflect those of the United States Government or any agency thereof.

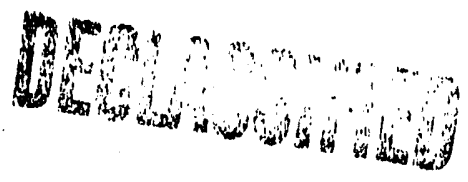


General Surmary

$\cdots \cdot \ldots-1$

Number of Employees . . . . . . . . . . . . . . . . B-I

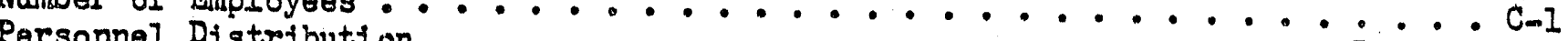

D-I and D-2

Manufacturing Department ................ E-I through E-5 MonthIy Operating Report .................. Ea-1 thr ough Ea-6

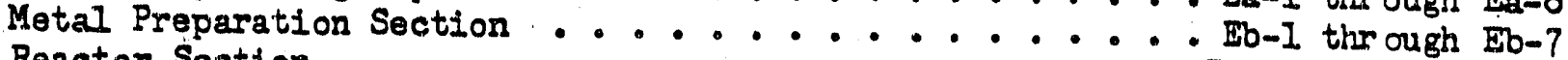
Reactor Section ................ Ec-1 through Ec-11 Separations Section................ Ed-1 through Ed-18

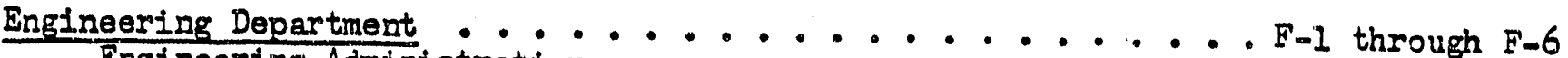
Engineering Administration ............. Fa-1 through Fa-3 Pile Technology ...................... Fb-1 through Fb-22 Separations Technology .............. Fc-1 through Fc-19 Applied Research ..................... Fd through Fd-13 Design.................... Ff-2 through Ff-14

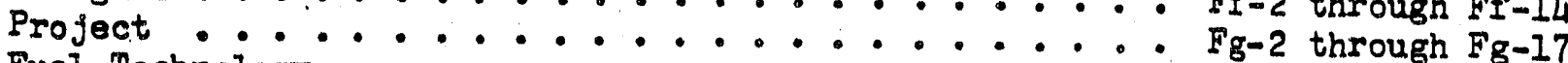

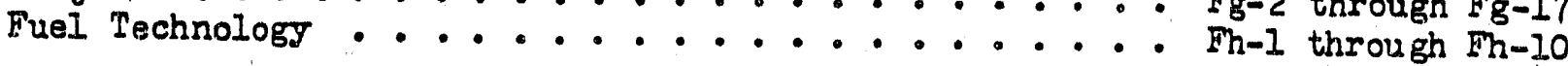

Medical Department ................ G-I through G-15 Radiological Sclences Department ........... H-I through H-18 Financial Department ................. I-I through I-2I

Plant Auxtliary Operations Department

Plant Protection Section ...............

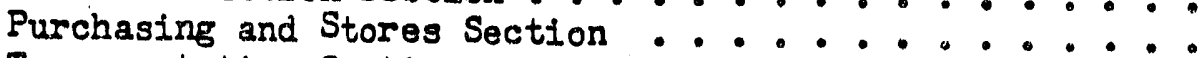

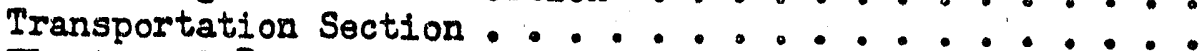
Electrical Distribution and Telephono Section .....

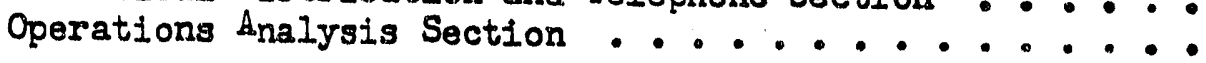

Emploree and Public Relations Department
Ja-1 through Ja-27 $\mathrm{Jb}-1$ through $\mathrm{Jb}-9$ $\mathrm{Jc}-1$ through $\mathrm{Jc}-6$ $J d-1$ through $J d-5$ Je-2 through Je-17 K-1 through $\mathrm{K}-36$ Community Operations and Real Estate Department ........ L-I and L-2 Community operations Section ................. La-1 Richland Electrical Unit $\ldots \ldots \ldots \ldots$ Lb-l through Lb-5 Public Works Unit . ................... Le-1 through Lc-L Recreation and Civic Affairs Unit $\ldots \ldots \ldots \ldots$ Id-1 through $\mathrm{Ld}_{\mathrm{d}-4}$ Richland Public Library .................. Le-l and $\mathrm{L}_{-}-2$ Richland Police ............. If -1 through $\mathrm{Lf}-12$

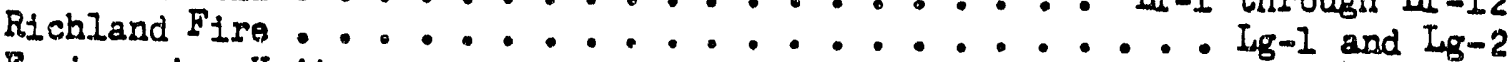
Engineering Unit $\ldots \ldots \ldots \ldots$. . . . . . . . .

Real Estate Sect1on ............................ I1-1 Housing and Real Estate Maintenance Unit $\ldots \ldots \ldots$ igjil through $L_{j-9}$ Commercial Property Un1t ............... il-1 through L1-5 
JANUARY 1954

\section{Production Operations}

GENERAL SUMMARY

Iri the Metal Preparation Section production of normal charge material for the month was ten percent below forecast. This schedule varlance resulted from the diverting of personnel to the accelerated P-10 program. The overall canning yield was 71 percent for January.

The total reactor input production of plutonium during January was 114 percent of forecast and exceeded the previous monthly record established in December, 1953, by 7.1 percent. Increases in the reactor operating levels were largely responsiblo for this achievement. The reactor output production was 100 percent of forecast.

Higher than forecasted operating

levels and postponement of the P-10 material discharge were primarily responsible for exceeding the forecast. There was a total of 17 regular uraniun slug failures during the month. In addition to these failures there were seven enriched aluminum alloy slug failures (two P-10 enrichment and five "enrichment") and one thorium slug failure.

Redox production for the month was 56 percent of forecast due to operation and maintenance difficulties. I Plant production for the month was 231 percent of forecast. TBP production was 185 percent of forecast and the $\mathrm{UO}_{3}$ facility production was 130 percent of forecast. The overall comitments for $234-5$ production were met.

\section{Engineering Technology}

Design on Project CA-512-R, 100-K Reactor Facilities was essentially completer during January. Detail design on the 200 Area Expansion Program, Project CA-513, was continued on the Purex Outside Facilities, which was advanced to 100 percent completion. Design of the Hot Semiwnrks conversion is 90 percent complete.

A design and development program for the Dual-Purpose Reactor was established and a document issued outlining program and design objectives, target schedules, cost estimates for design and development, and basic design-development criteria.

Hanford 3X. Program studies were performed during January to provide a basis for establishing Hanford extraction and purification plant requirements for additional P-10 production and the estimated cost of these facilfties. A preliminary project proposal is being prepared requesting authorization to start design work on the required facilities and establishing dates, with respect to the authorization of funds, necessary to the successful. completion of the overall program. Design was started on the 300 Area portion, consisting of modifications to the 313 and $303-\mathrm{J}$ Buildings to provide space for fuel element canning, and is now 25 percent complete. Twenty-eight informal, eleven Class I and three Class II radiation insidents were recorded.

\section{Personnel and Services}

Two Major injuries were recorded during January. There were 295 minor injuries reported during the month.

The employee separation rate decreased from .77 percent for December to .66 percent for January.

The total number of housing applications pending is 248 . 

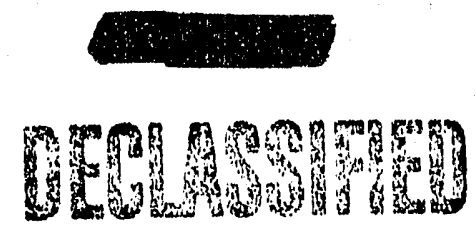

$\underline{\text { STAFF }}$

General Manager, Atomi: Products Division ............. F. K. McCune General Manager, Hanford Atomic Products Operation . . . . . . . W. E. Johnson Manager, Administrative Practices ................. . . K. MacCready Counsel ............................. . . Butler

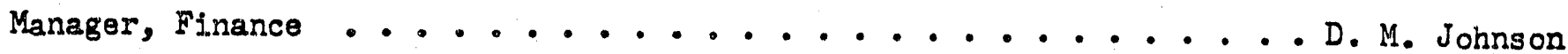
Manager, Employee and Public Relations ................ G. Gross Director, Radiological Sciences .................... Parker

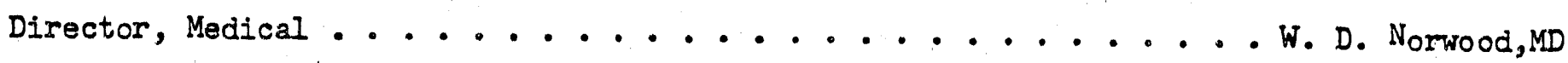
Manager, Engineering. . . . . . . . . . . . . . . A. B. Greninger Manager, Manufacturing ....................... Maider Manager, Plant Auxiliary Operations ................ H. D. Middel Manager, Community Operations and Real Estate ............ ... F. Huck 
HANFORD ATOMIC PRODUCTS OPERATION

NUMBER OF EMPIOYEES

JANUARY 31.1954

DEPARTEENT

EXEMMPT

$1-31-5412-31-53$

OTHERS

TOTAL

Engineering Department

\begin{tabular}{l} 
General \\
Design \\
Project \\
Technical Section \\
\hline General \\
Applied Research \\
Separations Technology \\
Pile Technology \\
Fuel Technology \\
Advance Technology \\
Gufacturing Department \\
General \\
Reactor \\
Separations \\
Metal Preparation
\end{tabular}

Plant Auxiliary Operations Dept.

General

Electrical Dist. \& Telephone

Transportation

Purchasing \& Stores

Plant Protection

General

Patrol \& Security

Safety \& Fire

Office Services

Administration Main. Service

Operations Analysis

Cormunity Oper. \& Real Estate Dept. 97

Financial Department

General

Accounting

Payroll \& Auditing

Emplovee \& Public Relations Dept. Radiclogical Sciences Department

General

Records \& Standards

Biophysics

Biology

Engineering

Medical Department

Law

General
17

173

254

$\begin{array}{rr}17 & 17 \\ 173 & 174 \\ 254 & 254 \\ & \\ 6 & 6 \\ 122 & 123 \\ 127 & 130 \\ 100 & 100 \\ 65 & 62 \\ 11 & 12\end{array}$

16

252

293

94

31

31

45

1

59

43

20

10

41

15

252

293

91

1

31

45

49

1

58

43

20

10

41

99

4

47

27

49

4
27

59

36

6

40

3

12

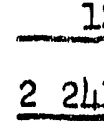

1 TOTAL

$1-3 I-5412-3 I-53$

$1-31-54$ 12-31-53
69
148
1.99
53
39
62.
59
1

88
299

451

8
174

174
166

164

133

12 .

86

322

453

68

7
1047

1200

439

$\begin{array}{rr} & 7 \\ 1 & 045 \\ 1 & 195 \\ 420\end{array}$

23

1299

1297

493 " 1488

$533 \therefore$

511

1
137

448

222

1

138

455

222

1

452

173

285

52

63

2
168

493

271

2

169

500

$27 i$

1

451

112

284

53

61

329

328

- 5

203

53

203

54

138

139

512

156

305

62

104

426

9
250

80

187

189

43

168

120

72

6

2

509

155

304

63

102

427

5.1

36

212

2

254

$25]$.

5

$26-39$

38

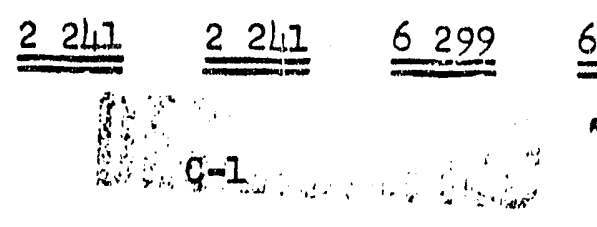

628

8540

8526 


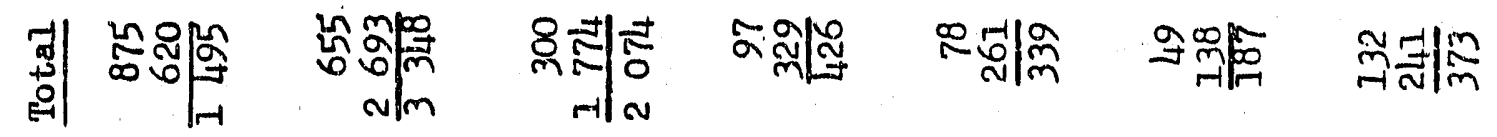

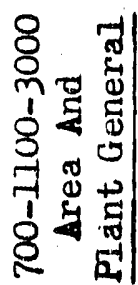

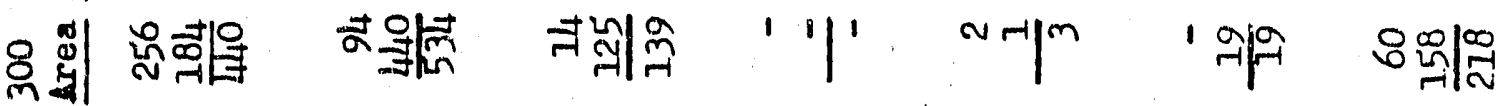

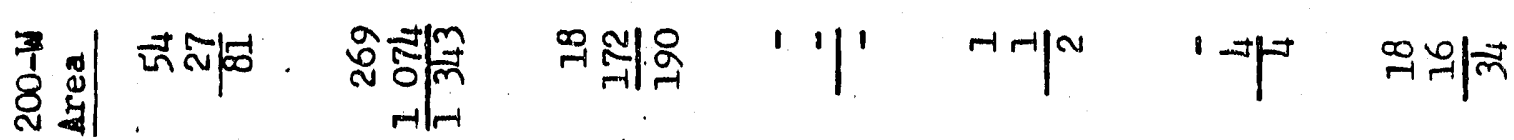

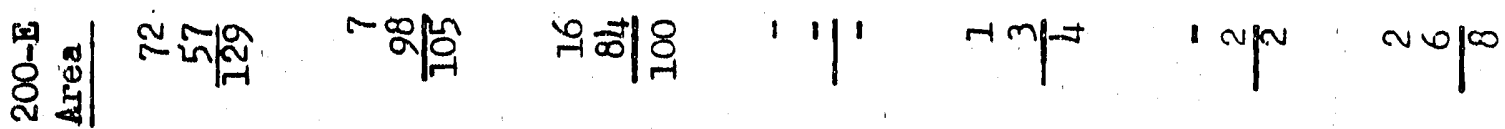

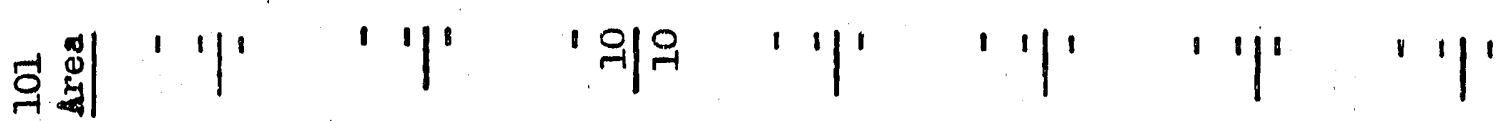
管递

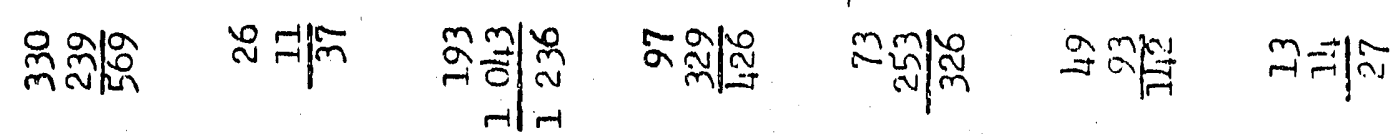

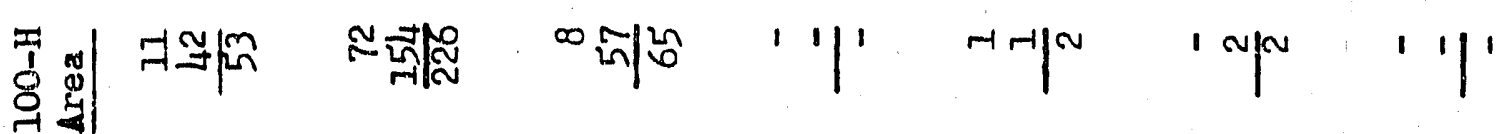

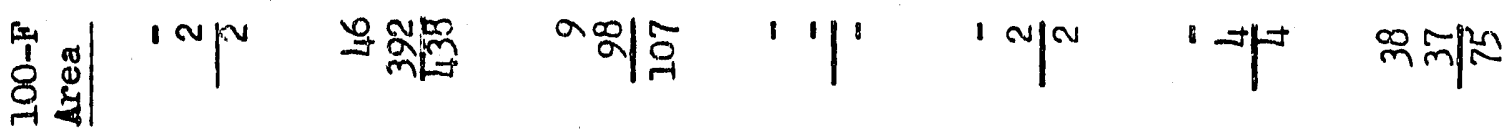

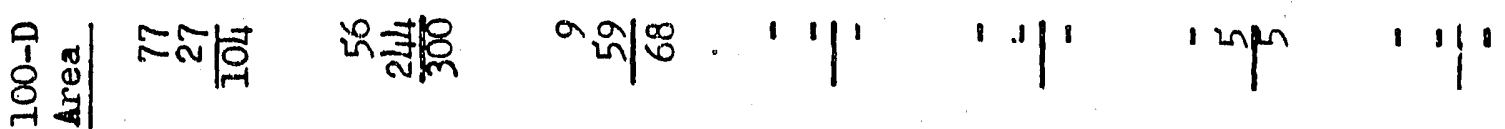

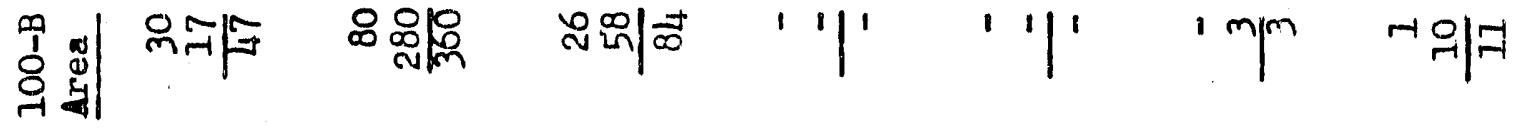

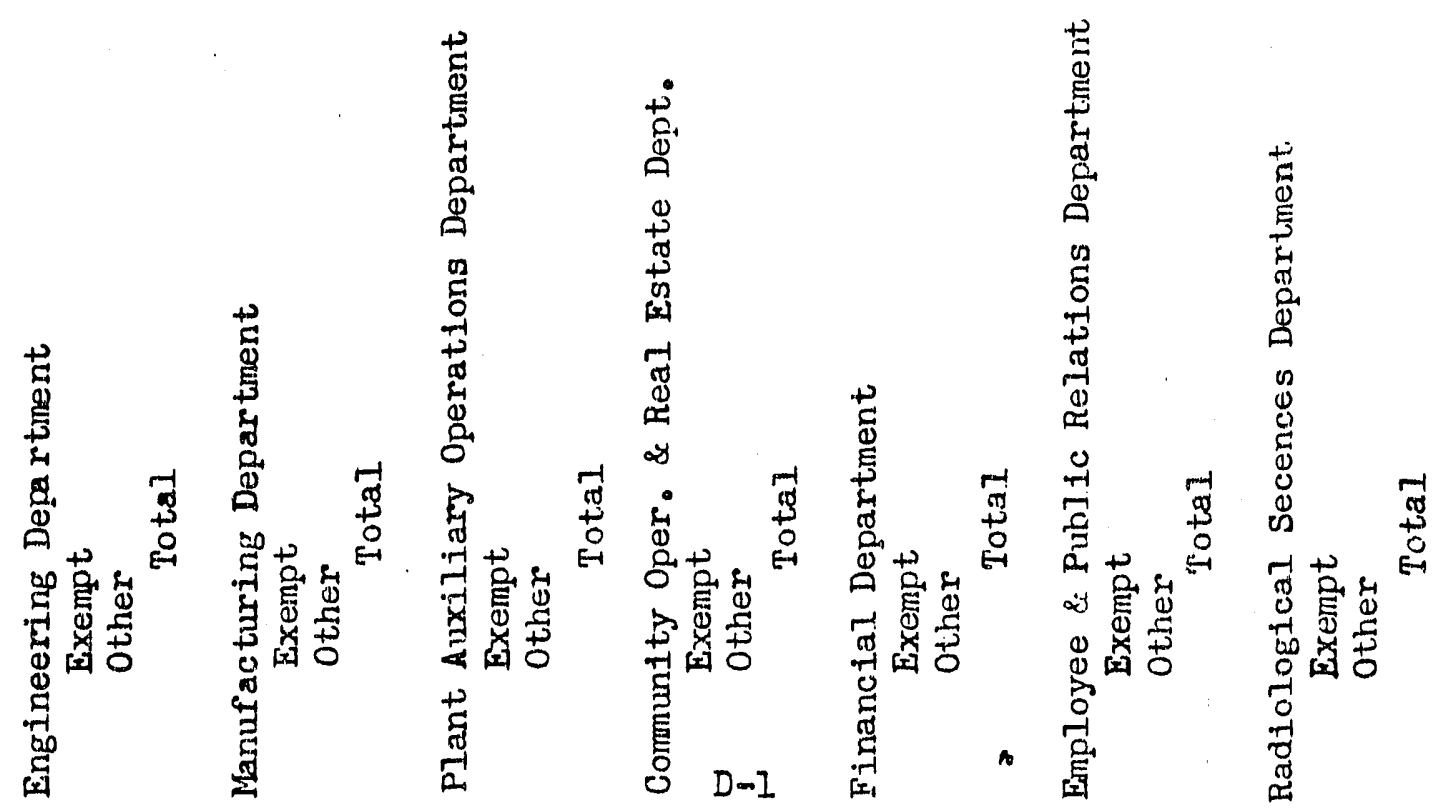




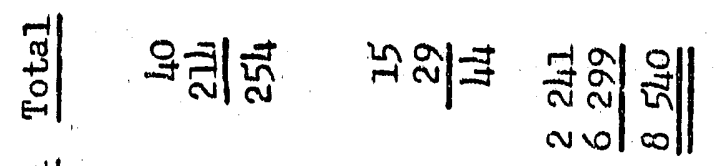

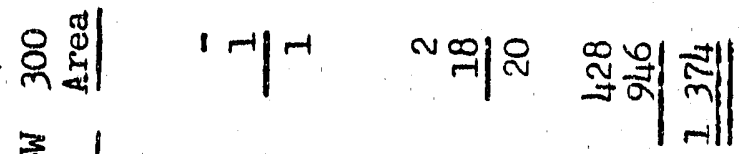

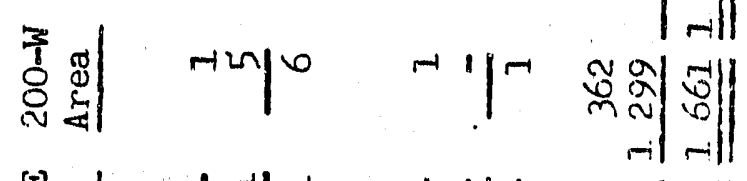

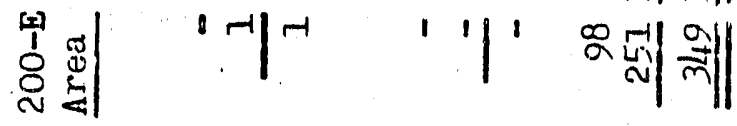

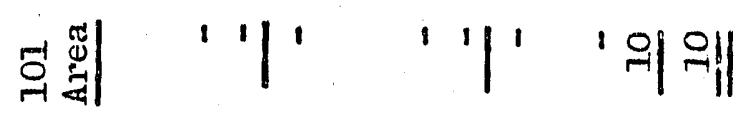

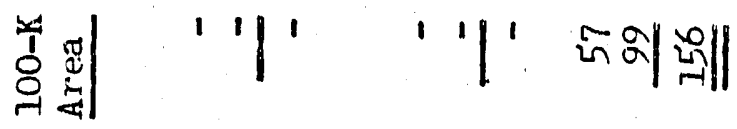

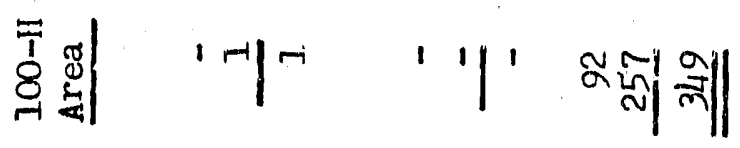

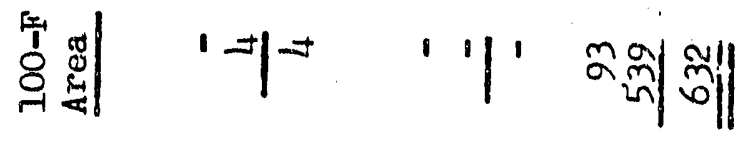

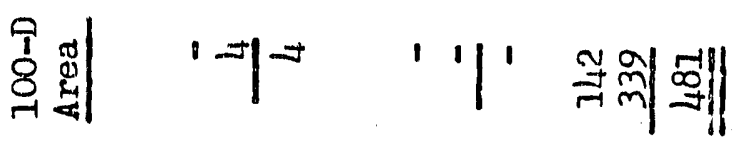

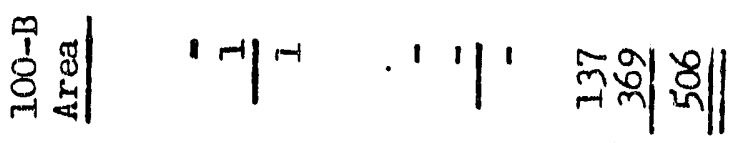

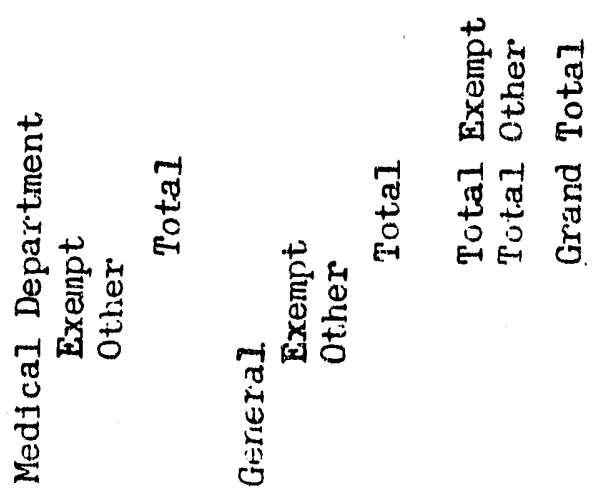




\section{MANLFAC'IURING DEPARTMENT}

$$
\text { JANUARY, } 1954
$$

\section{METAL PREPARATION SECTION}

The monthly production of acceptable canned slugs was 203 tons which was ten percent below the offlcial forecast. Thls schedule varlance results from the diverting of personnel from urantum slus fabrication to the accelerated P-10 program. A total of 188 tons was canned as elght-1nch and the remaining 15 tons as four-inch pleces, with canning ylelds of 71.9 percent for the eight-1nch and 62.9 for the four-inch. These respective ylelds were 5.6 and 8.8 percent lower than those for the previous month. Thts reduction was the result of increases in the non-seat, marred surface and poor bond reject categorles and can be attributed to the readjustment of crew personnel to accommodate the F-10 program. The overall canning yield was 71 percent as compared to 76.5 in December.

One four-inch and three elght-Inch pleces falled the autoclave test.

The cold press canning of Al-U-235 fuel slugs and LI-Al target slugs for the next DR loading was proceeding satlsfactorlly at month end. Hot press canning of slugs for the $3 X$ program production test in $C$ pile was started on January 21 with the goal to complete the test material by February 18.

\section{REACTOR SECTION}

The total reactor input production of plutonlum during January was 114 percent or" the official forecast and exceeded the previous monthly record established in December, 1953 by 7.1 percent. Increases in the reactor operating levels were largely responsible for this achlevement as the time operated efficlency of 86.3 percent was essentially the same as that durlng December.

The established maximum operating levels of the reactors lncreased a total of $252 \mathrm{MW}$ 1n January, as follows: B - 20 MW, C - $137 \mathrm{MW}, \mathrm{D}-30 \mathrm{MW}, \mathrm{DR}-55 \mathrm{MW}$, and F - $10 \mathrm{MW}$. At $B, D$, and $F$ Reactors, the increases were princlpally due to lower river water temperatures. The DR Increase resulted from the removal of the $425 \mathrm{KW}$ pover limft on P-10 tubes when the in-plie tritium production required for the 1954 goal was achleved. Increased levels at $c$ were due also to an Increase in tube power limits made in December as prescribed in production test PT-1.05-533A.

A total of 17 regular uranium slugs falled in January. Elght of these were the regular in-pile ruptures (seven 8-inch slugs and one 4-inch slug), and all occur ad at the $C$ Reactor except for one elght-1nch rupture at the $B$ Reactor. Four of the $C$ plle ruptures occurred in the bumper zone durlng January. The other nine fallures (8-1nch slugs) were classed as broken slugs, and are belleved to have occurred during discharge operation at the $B$ Reactor since they were transverse Practures and were discovered in the basin following discharge. No reason has been established yet for this type of slug behavior. The total outage time for the removal of the regular metal ruptures was 142.9 hours.

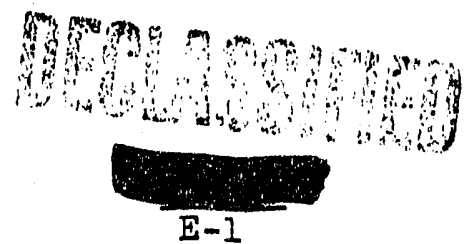




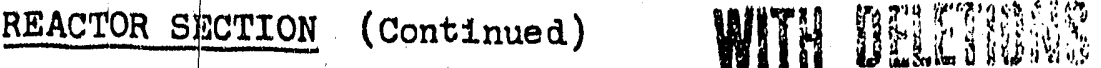

In addition to the fallure of the regular slugs, two " $\mathrm{J}$ " (P-10 enrichment) slugs falled at DR, and flve "C" (enrichment) slugs and one thorlum slug falled at the H Reactor. The total outage time resulting from these fallures was 46.2 hours. The use of the equipment for fast discharge of ruptured slugs functioned satisfactorliy durling the month and made it possible for operations to be resumed within scram recovery time following four shutdowas. Fallure to recover occurred on two occasions when the charges were stuck and on two other shutdowns there was insufficlent reactivity for operation to be resumed:

A scheduled one week outage at $F$ Reactor was begun on January 25 and continued through the month end. The major work accomplished by th1s outage was the installation of venturis and secondary ortflees on process tubes, removal of the four discharge area catwalks, rearrangement of tubes on crossheaders to redistribute water flow, and installation of aluminum nozzles in place of 25 rear face galvanized fringe tube nozzles.

An accldental pressure surge on the $\mathrm{B}$ Reactor panelilt system during a routine gauge calibration check resulted in extensive damage to the panellit gauges. This incident occurred during a scheduled shutdown and resulted in extending the planred outage of 48 hours to 136 hours. Approximately 10 percent of the gauges were damaged beyond repalr and reuse.

On January 17, the H Reactor was shut down due to a water leak in a tube containing a ruptured urantum glug and operation was resumed on January 18 after tube replacement. On January 20 the reactor was shut down again when Indications of further water leakage developed. Approximately 700 tubes were tested before finding the leaking tube which contalned a ruptured thorfum slug. Total outage time to correct these leaks was 71.4 hours.

During the month of January there were 19 reactor scrams, ten of which were attributable to normal panellit system difficulties, five to pressure surges in water quality production test tubes at the D Reactor, two to Beckman electrical trouble at F Reactor, one to 1mproper valving at $190 \mathrm{DR}$, and one to a partially plugged cone screen at DR. The total outage time charged to the above scrams
was 5.9 hours.

Also, during the month $81 x$ tubes at the $C$ Reactor were discharged from the bumper zone after having attilned an exposure of $900 \mathrm{MWD}$. One additional tube was dis$105-533 \mathrm{~A}$.

The first discharge of four tons low concentration metal requested by the AEC in the $3 X$ program was made at $C$ Reactor on January 25.

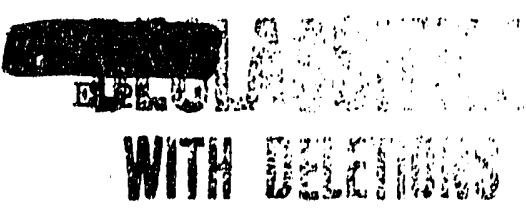




\section{SEPARATIONS SECTION}

The Redox production was 56 percent of forecast due to operation and mantenance difficulties. The plant was shut down on January 6 to effect the rerouting of waste froth the depleted $S$ storage farm to the $U$ farm and the installation of a waste neutralizer (D-8) purm. During this scheduled outage a number of urgently needed replacements were made including the first extraction 1-A column feed pump, the H-5 caust1c scrubber clrculation purp, the E-7 ab1tator electric connector, and the 3-DW letdown valve. In addition, flush down sprays were installed in the B Celi. A severe ruthentum emission from the stack occurred just prior to the shutdown and resulted in blgh level contamination of a considerable expanse of the surrounding area. Because of this, the shutdown was prolonged, and an attempt, was made to divert the ruthenlum bearing effluent gas from the $\mathrm{J}-1$ flbreglass filter to the sand filter. This work was not accomplished due in lack of adequate "as-bullt" drawings. Operations were resumed on January 13 with feed consisting of materlal colleeted from the equipment flushes and high uranium aqueous wastes produced prior to the shutdown. 'mls type of feed continued until January 20 when a plug in the neutrallzed waste line forced a shut down. A spare waste IIne was activated and operations were resumed on Jenuary 24 , but a leak developed in the waste system diversion box causing another shut down. Th1s diffleulty was resolved on January 26 and operations were resumed at a 5 ton per day rate and continued unintermupted to month end. The total outage time for the month was 399 hours. On January 30 a leaking steam co1l made the D-12 salt waste concentrator 1noperative and severe vibration developed in the $\mathrm{H}-2$ centrifuge. Preparations were in progress at month end for shut down and the replacement of both of these pleces of equipment early in February.

The production through the $T$ glant was scheduled for maxtmum throughput when it became evident that the Redox faclilty would be unable to process the scheduled amount of material. T plant production was 231 percent of forecast, and the concentration bullaling output for the month set a new record with a total of 83 muns plus one actd wash belng processed.

The TBP plant production was 185 percent of the forecast, princlpally because good uranlum decontamination forestalled a previously antlclpated 10 day shut down to effect series operation. The plant operated at an average rate of 5.9 tons per day. Only the B Line in the TBP plant was operated unt1l January 12 due to a shortage of feed materlal whlle keeping A line in standby in event the test processing of shorter aged materlal from the BX Tank Farm 1ndicated two cycle processing was required. Parallel operations were resumed on January 12 after the satisfactory processing of BX materlal was demonstrated. Operations cont1nued for the balance of the month at average rates of 5 tons per day for each line, except that both Ines were shut down on January 18 for two days for replacement of the condenser vent blower motor and Installation of (temporary) organic segregation faclitites.

The $\mathrm{UO}_{3}$ fac1lity production was 130 percent of the forecast. The normal operating rate was interrupted intermittently throughout the month due to lack of feed material. A total of seven cars of powder was shlpped offsite.

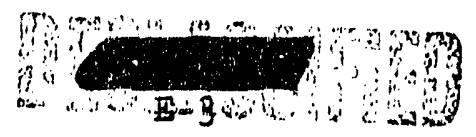




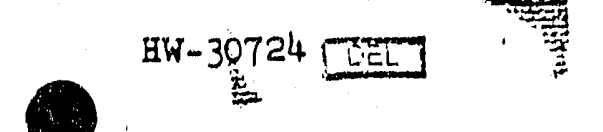

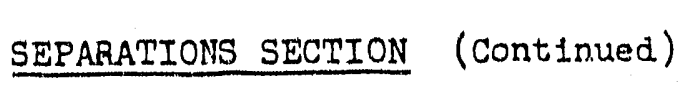

The metal removal from the waste tanks was serlously hampered, particularly during the latter part of the month, by adverse weather conditions and a serles of equipment fallures. A pump fallure occurring at $001 \mathrm{BXR}$ and a fallure of a Byron-Jackson pump in tank 101-TX effected a continulty of feed supply to 'CBP. Two waste metal tanks were declared empty in January.

1?.1. 23/4-5 commltment of shapes was exceeded and the commitment of buttons and nitrate was attalned and the materlal was accepted by the AEC.

The waste evaporators operated during the month on TBP waste with a volume reduction of 39.7 percent at $B$ and 39.2 percent at $T$.

\section{GENERAL}

Effect1ve January 1, John M. Fox, Jr. was appointed Plant Metallurglcal

Engineer in the Plant Engineering Section.

\section{Personnel}

Total on Roll December 31, 1953

Accegsions

3317

Separations

Total on Roll January 31,1954

$33 \overline{4}$

*Does not include intra-department transfers.
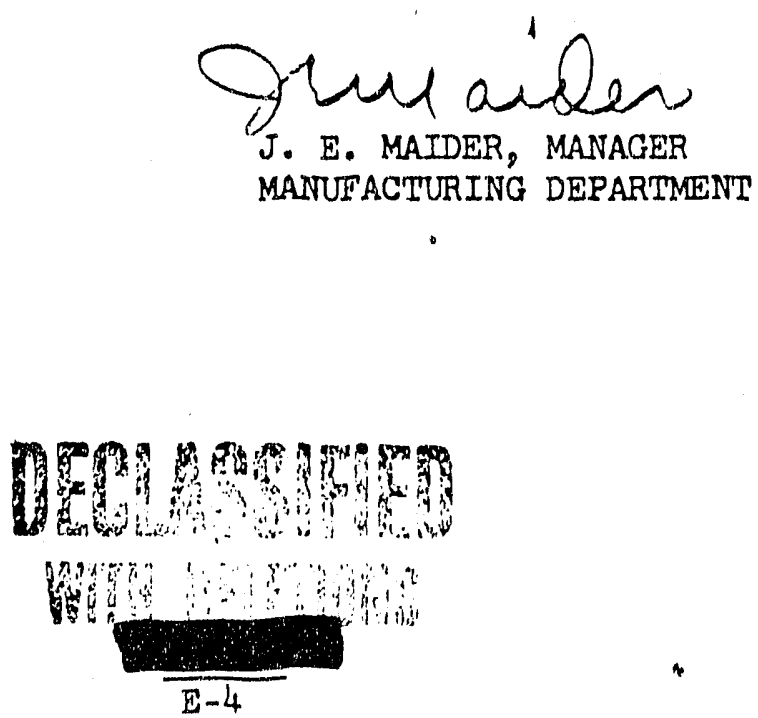
MANUFACTURIIIG DEPARTMEIVT

PATEITT REPORT SUMMARY

FOR

MONTE OF JAINUARY, 1954

All persons engaged in work that might reasonably be expected to result in inventions or discoveries advise that, to the best of their knowledge and belief, no inventions or discoveries were made in the course of their work during the period covered by this report except as listed below. Such persons further advise that, for the period therein covered by this report, notebook records, if any, kept, in the course of their work have been examined for possible inventions or discovertes.

INVENTOR

M. Tomazin, Reacto: Sectiun

G. F. Owsley, Reactor Section

H. A. Moulthrop, Separations Section

R. Overson, Separations .
TIIIE

Wooden Tank Bend Wrench.

(Submitted 12-29-53)

Modiflcation of Charging Procedures for Flattening Columns.

Plastic Bubble Sealing for Contanination Control.

Remote Metal Cutter - General Purpose Model.

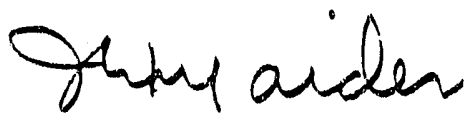

J. E. MATDER, MANAGER

MANUTFACTURING DEPARTMENT 


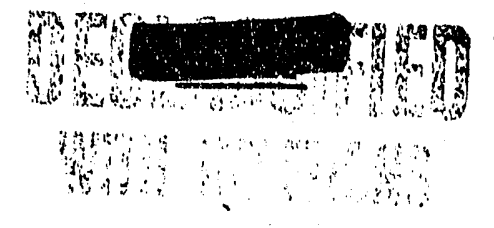

MOMIELT OPERALING REPORT

JANUARY 1954
सम-30724 …7

1.

2.

3.

4.

7

(c)

20

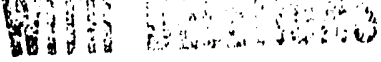

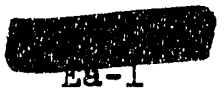


5.

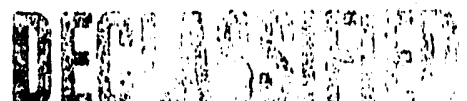

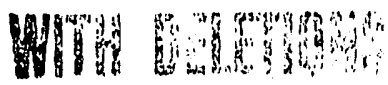

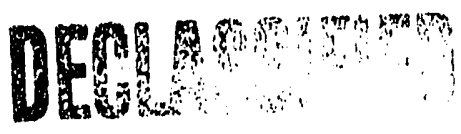

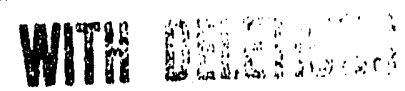

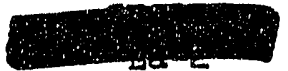




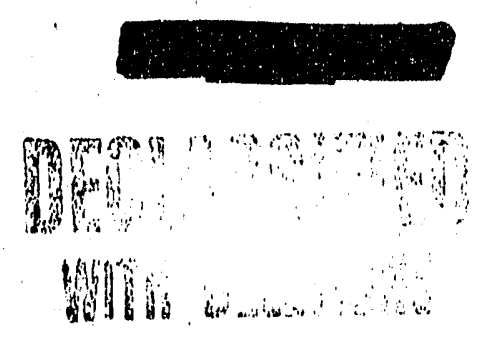

耳W-30724 DT:
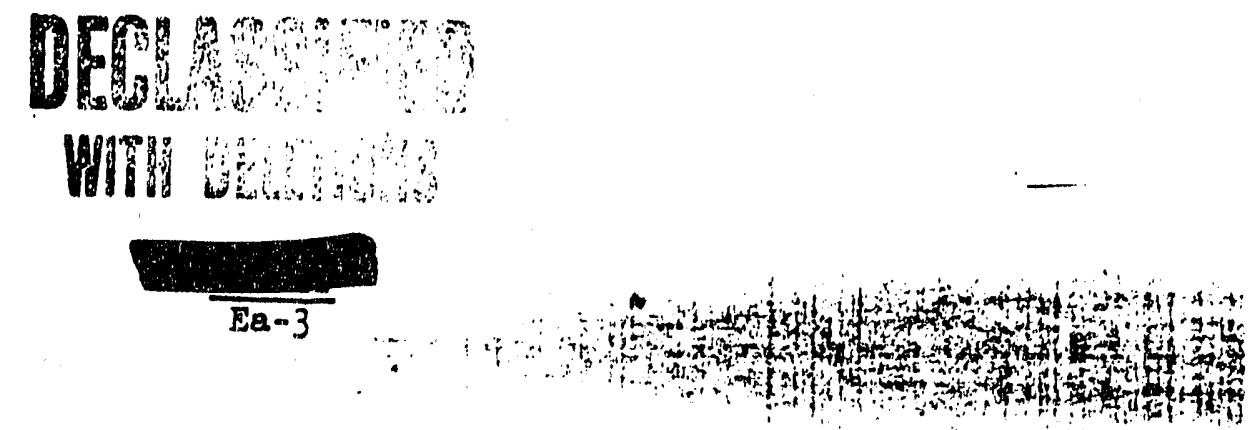


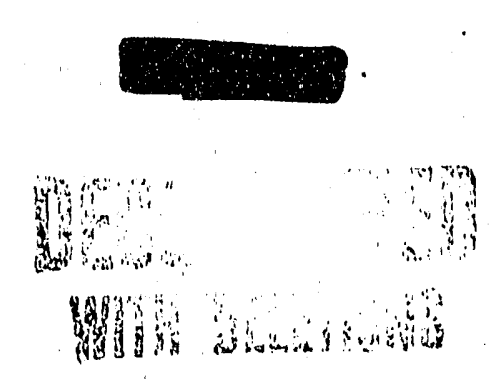

HW-30724

CUE

-

7.

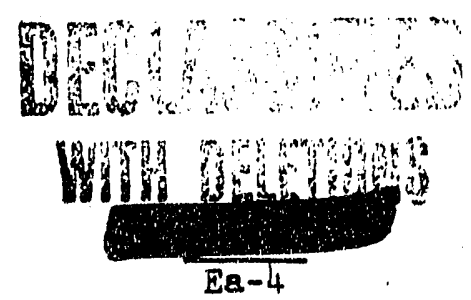


Whents

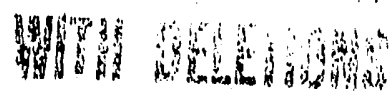

8. 
10.

1:

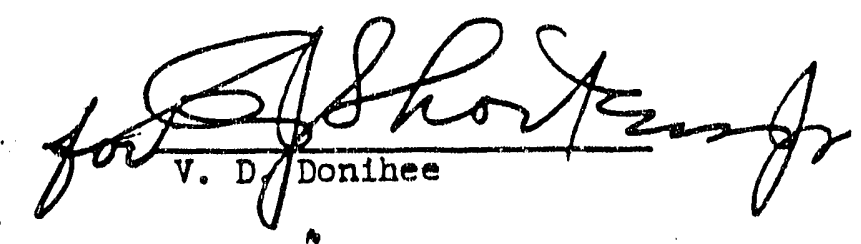


MANUFACTURING DEPARTMENT

METAL FREPARATION SECTION

$$
\text { JANUARY, } 1954
$$

\section{RESPONSIBILITY}

There were no changes in responsibility during this period.

\section{ACHIEVEMENT}

\section{A. Operating Experience}

\section{Statistics}

\begin{tabular}{|c|c|c|c|}
\hline & January & December & $\begin{array}{ll}Y \sim m \\
t ! 11\end{array}$ \\
\hline Acceptiable Plenes Canned (4")(Tons)Gross & 16 & 10 & 1. \\
\hline $\begin{array}{l}\text { Acceptable Pleces Canned (4")(Tons) Net } \\
\text { Canning Yleld }(4 ")(\%)\end{array}$ & $\begin{array}{l}15 \\
62.9\end{array}$ & 10 & $\because$ \\
\hline Acceptiahle Pleces Canned (8")(Tons)Gross & 190 & 229 & $1(x)$ \\
\hline $\begin{array}{l}\left.\text { Acceptiable Pleres Canned ( } 8^{\prime \prime}\right) \text { (Tons) Net } \\
\text { Canning Yleld }\left(8^{\prime \prime}\right)(\phi)\end{array}$ & 188 & 229 & $\because \vdots$ \\
\hline Total Acceptable Pleces Canned (Tons)Gross & $206^{\circ}$ & 239.5 & 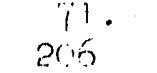 \\
\hline $\begin{array}{l}\text { Total Acceptable Pleces Canned (Tons) Net } \\
\text { Acceptable Pleces Canned ( } 4 \text { " and } 8 " \text { ) }\end{array}$ & 203 & 239 & 203 \\
\hline $\begin{array}{l}\text { ( } \% \text { of Forecasi ) } \\
\text { Autoce }\end{array}$ & 90 & 103 & 90 \\
\hline Autoclave Frequency (4")(No./M) & .01 & .00 & .01 \\
\hline $\begin{array}{l}\left.\text { Autoclave Frequency ( } 8^{\prime \prime}\right)(\text { No./M) } \\
\text { J-3 Slugs Canned (pleces) } \\
\text { N Slugs Canned (pleces) }\end{array}$ & $1743^{.05}$ & .01 & $1743^{.05}$ \\
\hline
\end{tabular}


1. Statigties (Continued)

Chemical 10-66 Canned (pleces)

Special Request (man-hours)

305 Routine Tests (man-hours)

305 Spectal Testo (man-hours)

Average Steam Generated (M Ibs/hr)

Maximum Steam Generated (M Ibs/hr)

lotal Steam Generated (M Ibs)

Coal Consumed (Tons)

Santtary Water from 3000 Area (mflilion gals)

Total Water Prom 3000 Area

Average Rate (gpm)

Chlorlne Reslduel (ppm)

\begin{tabular}{ccc} 
January & December & $\begin{array}{c}\text { Year } \\
\text { to Date }\end{array}$ \\
\cline { 3 - 3 } 125 & & 125 \\
790 & 764 & 790 \\
144 & 95 & 144 \\
1597 & 1648 & 1597 \\
53.3 & 36.5 & \\
81.0 & 54.0 & \\
39800 & 26300 & \\
2535 & 1799 & \\
43.9 & 38.5 & \\
984 & 362 & \\
.41 & .49
\end{tabular}

\section{Actl.vities}

The net production of acceptable slugs was 203 tons of whlch 93 percent were elght-1nch. The conning yleld for elght-inch slugs decreased approximately four percent largely as a result of increases In non-seat, poor bond, and narred surface reject categorles.

To meet the manpower needs for the P-10 program, 1t has been necessary to take off the fourth canning IIne and remove all lunch rellef.

There have been one four-inoh and three elght-1nch autoclave fallures during the month. One elght-inch was a sidewall failure; cause of the other three was undetermined.

A statistical inspection procedure for recovered reject slugs was put Into effect. This appears to be an economical and practical method of checking this materlal for conformance to standards.

Vendor lialson for essential material procurement has been established. During the month, prints for thick bottom cans and wafers for the P-10 program were drawn and 1savied. Steel sample cans for laboratory analysis of hydrogen were expedited.

3. Speclal Operations

The canning of $\mathrm{J}-3$ enriched urantum-aluminum alloy fuel slugs for the Eot Press Canning Production Test in 314 Bullding was begun on January 21. Two crews have been tralned for the hot press canning method. and 1t is planned that the third crew will be put on February 1 . It is anticlpated that the canning of both enriched fuel slugs and 11thlum alloy target s.lug for this test wlll be completed during the second week in February.

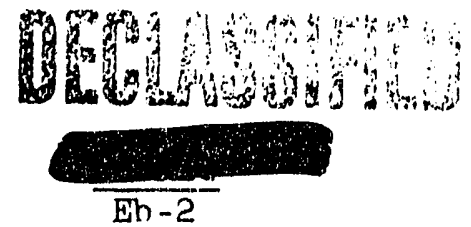


3. Spectal Operations (Continued)

A total of $1743 \mathrm{~J}-3$ enriched fuel slugs were canned by the regular "C" process with an overall canning yleld of 87 percent.

The equipment needed for canning of lithlum alloy target slugs has been installed in $303-\mathrm{J}$ and production has begun at month end.

4. Schedule Varlance

Acceptable slug production was ten percent below forecast as a result of diverting personnel from uranium slug fabrication to the P-10 operation.

B. Equipment Experience

1. Operating Continulty

Production time lost due to equlpment fallures was at a minimum during, the month. Repalrs were made to seven furnaces durlng the month, the same number as the previous month. '

\section{Improvement Expertence}

1. Production Tests

PT-313-105-24M "P1le Evaluation of Tru-11ne Caps and Cans" (HW-280440). A decision is still pending on final disposition of the slugs canned in December. No slugs were sent to Reactor th1s month.

PT-313-105-25M "Lead D1p Canning and Irradiation of Urantum Slugs Machined from Salt Bath Heat Treated Fernald Rolled Rods" (HW-28149). No slugs were canned on this production test during the month.

Pri'-313-105-27M "Evaluation of Normal Uranium Produced from UF6 Parent Material" (BW-28605). All slugs canned on th1s test were forwarded to Reactor during the month. Approximately 1400 slugs were sh1pped, which completed this test in the 300 Area.

2. Process Tests and Revisions

One of the twelve autoclaves were revised to use water instend of stanm as a heating medium. Materlal processed through this autoclave has more unlform oxide coating and an absence of stalns. Results thus far are encouraging.

3. Inventions and Discoveries

Personnel In the Metal Preparation Section engaged in work whlch might. be expectied. to result in inventions or discoverles have reported thrt nu inventions or discoveries were made during the period covered by this report.

\section{at 18


D. Events Influencling Costs

1. Labor Varlance

The Re-assignment of operators in the preparation of slugs to permit. the transfer and traintng of manpower for the produntion of slugs under the expanded $3 X$ Program w1Il 1nerease direct lahor costs slightly.

\section{Materlal Varlance}

No slgntfleant change.

3. Other Costis

The diversion of maintenance forces to the altieration, relocation and installation of additional. equipment for the 3X Program will reduce malntenance nosta. Th1s decrease w1ll be offset by increases in operator trainjing and applied matertal inventories for normal s.lug preparation so ot,her costs will. remain relatively unchanged.

E. Plant, Expansion

1. Project Statius .

Project, CA-514 "Expansion of 300 Area Production Fac1litieg." Detalled design for the overall project is $82 \%$ complete and con. struction $1826 \%$ complete. The second phase of construction on the 313 Bullding addition 1 a about $9 \%$ complete. The renovation of the existing 31.3 Butlding fandilties is $29 \%$ complete.

Wnrk on the stinrage hays in both the extsting 313 Bu1ldinf nul ardition to the hillding ts betng held in abeyance pending n forta: deciaion on what fire protertion measures should be provilat for uranium storage.

Destan of nther non-promess fartilities is about $54 \%$ romplrtie and construntion 1.\%. Design has reen rompleted on the outslde steam Ilne, the renovation of the 3707-A change house for use by Power and Malntenance personnel and the 3707-B Bullding for use by Janitorlal Services. The Atromin Energy Commissinn has asked for re$h 1 d s$ on the 3701.-L Gatie House addition, parking lot expansion and trunk tiurnout to allow contractiors to bld on separate phases of the work. These hids are scheduled to be opened Frbruary in.

Prci, Iect, Cr-573 "Hanford 3X Frogram - 300 Area." infermel. aluthortzo.tinn was grantied January 8, 1.954 for Ganaral Eleatrle forces to proceed on the destgn, fromurement, and ropstruction of 300 production facilitties as requled for the $3 x$ Program. A preliminary projent; proposal. Wa.t suhmitted hy frojert.

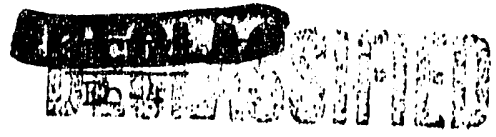


$\mathrm{HW}-30724$ Her

F. S1gndflcant Reportis Issued (Contlgledu)

2. Non-Routine

\begin{tabular}{|c|c|c|c|}
\hline Number & Tht.le & Autinor & Date \\
\hline HW-30489 & $\begin{array}{l}\text { Suspented Discrepancy of } 3 \mathrm{H} \\
\text { Matiertal C] a.salfied as a Scrap } \\
\text { In tihe Test Reactor Balance Area }\end{array}$ & FE Jochen & $2-8-5 / t$ \\
\hline $\mathrm{HW}-30432$ & $\begin{array}{l}\text { Proposed Lot Identification System } \\
\text { For Charging Reactors }\end{array}$ & LT Hagle & $1-4-54$ \\
\hline
\end{tabular}

11. FERTOHNEL

A. Orgnindation

No change.

B. Forge Summary

\begin{tabular}{|c|c|c|c|}
\hline & $\begin{array}{l}\text { Start of } \\
\text { Month }\end{array}$ & $\begin{array}{l}\text { Find of } \\
\text { Month }\end{array}$ & $\begin{array}{c}\text { Net } \\
\text { Change }\end{array}$ \\
\hline Sertis on Ceneral. & 4 & 4 & 0 \\
\hline Operations & 200 & 2.1 .4 & 1.4 \\
\hline Power and Malntienance & $25: 1$. & 254 & 3 \\
\hline Process & 37 & 37 & 0 \\
\hline Plant Englneerting & 1.2 & 24 & 5 \\
\hline Sertion Total & 51.1 & 5.33 & 22 \\
\hline
\end{tabular}

\section{Safety Experience}

There was one major infury in whlch a carpentier caught, two fingers in a jolnter, removing a fragment, of bone from one finger. There wis cus sidh-major injury in whirh a millwrtght flnohed a finger hetween two pleces of materlal, cainsing a fracture.

D. Radiation Experience

There were no radiation expnsures reportied in excess of 300 mrep per week durling the month.

\section{E. Personnel Antivitiles}

\section{V1.stis and. Vistitors}

E. W. O'Rorke and T. D. Naylor vistted the A.E.C. Inatelingtilons nt Oak Rldge. Tennessee. Alken. South Carollina and F'arnald, Dhlo. Thm

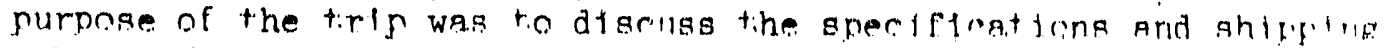

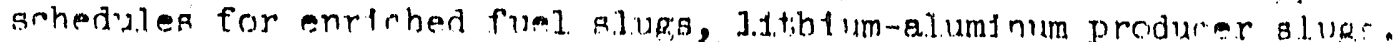
ant normal urantum fuel alugs.

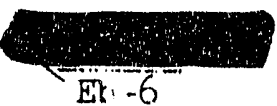




\section{Project Status (Continued)}

Englneering on January 14, 1954, outlining the work to be performed and requesting funds amounting to $\$ 800,000$. Th1s amount was formally authorlzed by A.E.C. Dlreot1ve HW-318, dated January 15, 1954, and Project Authorlzation No. 472, dated January 18, 1954. Funds are to be taken from Budget Item 2-231-20631 - Expansion of Plutonlum Facilities - 300 Area Facillties.

Work to be accomplished under this project 1ncludes the following: Existing equiprent is to be relocated and altered, and additional equipment installed, as necessary to process enrlched fuel slugs in 313 Bullding and target slugs in 303-J Bullding by the dry canning process until about May 1, 1954. The new location for spectal canning in 313 Bullaing, as deslgnated under Project CA-514, 1s to be expanded by approximately 1750 square feet, equipment installed for hot press canning ready for use by May 1, 1954. The existing dry canning equipment in this bullding is to be moved to the new location following the completion of the aforementioned work.

Other work to be performed in 303-J Bullding Includes the lining of the Interlor, adding approximately 1,000 square feet of floor area, and installing hot press canning equipment ready for use by May 1, 1954 .

\section{Plant Englneerling}

A tray-type basket was developed and testied. In the Slug Recovery operation. The results indicate that a larger batch size of slugs may be handled with bet.ter utilization of the chemical solutions. It is estimated that a reduction of about $20 \%$ may be realized in direct labor cost and ahout $30 \%$ in materlal cost may be reallzed at present. recovery rates, amounting to approximately $\$ 4,800$ annually.

Production testing of a pneumatic slug stralghtener developed for the slug recovery operation has been completed. Performance of this equipment was satisfactory. Only minor modiflcations are belng made to include additional safety features.

Tests have been completed to establish the proper design of dumm slugs for the frost test wachlne. This work w1ll serve to minimize power devlations encountered between dummy and normal slugs on exist.1.ng equipment. It will also be utlilzed in the design of the new frost test unit to be provided by the expansion project.

F. S1gniflcant Reports Issued

1. Routine

Number

$\mathrm{HW}-30453$
Title

Monthiy Report, Process Sub-Section Metal Preparation Section, December, 1953

\section{Author}

EW O'Rorke

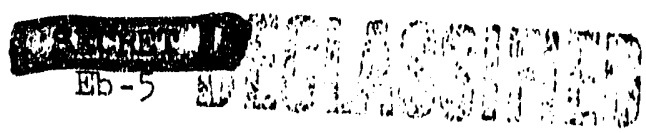


E. Personnel Activities

1. Visits and Visitors (Continued)

T. E. Ault spent a week at the laboratory of the H1gh Voltage Engineering Company at Cambridge, Massachusetts in the study of malntenance problems on high voltage particle accelerators.

E. Hligeman attended the Fifth National Plant Malntenance and Engineering Show in Chleago.

T. B. Corry visited the Afax Engineering Corporation; Trenton, New Jersey and Metal Wash Products Company, Ellzabeth, New Jersey. The purpose of thys visit was to approve final design drawings for canning furnaces and silug plckle equipment being provided by these manufacturers for Froject CA-514.

\section{Meetings}

Exempt and non-exempt personnel of the Power and Malntenance and Plant Englneering Sub-Sections attended information meetings on January 12 and 14 .

Two general information meetings were held for exempt and nonexempt personnel of the Operations Sub-Section. 


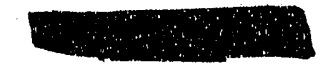

$\mathrm{HW}-30724$

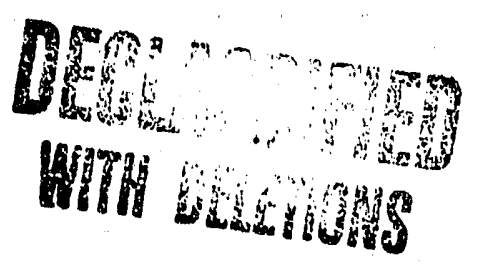

February 10, 1954

MANUFACTURINO DEPARTMENT

REACTOR SECTION

JANUARY, 1954

\section{RESPONSIBIIITY}

Concurrent with the transfer of landlord functions from the Manufacturing Department to the Plant Auxillary Operations Department, responsib1lity for malntenance of miscellaneous facilities at Hanford and the P1stol Range was transferred to the Administration Area Maintenance Unit.

II. ACHIEVEMENT

\section{A. Operating Experlence}

The total reactor input plutonium production during January was 113.9 percent of forecast. Th1s represents new monthly and per diem production records, exceeding those established last month by 7.1 percent. Recent Increases in reactor operating levels are largely resporisible for this achlevement as time operated efflclency was essentlally the same durting December. A scheduled extended outage at $F$ Reactor, outages caused by ruptured slugs, and extension of a normal scheduled outage at H Reactor for repalr of damaged panellit gauges were the major abnormal factiors adversely affecting production. Reactor plutonium output production was 100.0 percent of forecast.

Increases in established maximum operating levels ( $P$ in and $P-10$ only) during January were B Reactor - $20 \mathrm{MW}$, D Reactor - $30 \mathrm{MW}$, F Reactor - $10 \mathrm{MIN}$, $\mathrm{DR}$ Reactor - $55 \mathrm{MW}$, and C Reactor - $137 \mathrm{MW}$, for a total of $252 \mathrm{MW}$. At $\mathrm{B}$, $D$, and $F$ Reactors, the increases were principally attributable to lower

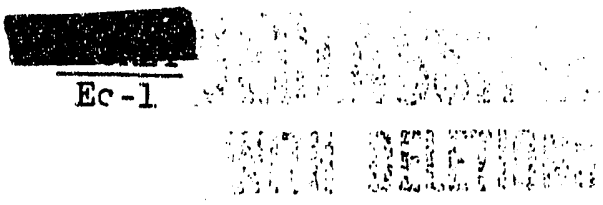




\section{A. Operating Experience (Continued)}

river water temperatures; at $D R$ Reactor, to appliryng standard process limits to P-10 tubes instead of the administrative tube power Iimits; and at $C$ Reactor, to the increase in tube power limits made in December under PT-105-533-A.

A total of 17 regular urantum slugs failed during January. Elght of these were the usual type of rupture (seven 8-1nch slugs and one fourInch slug) and ell occurred at $C$ Reactor except for one elght-inch rupture at $\mathrm{B}$ Reactor. The other nine fallures (eight-inch slugs) were classed as broken slugs and were found during pick-up of a discharge s.t. H Reator, possibly as a result of falling onto otiher slugs in the discharge chute. The reason for this new phenomenon bas not yet been establ1shed. Outage time for removal of the regular metal muptures was 142.9 hours.

In addition to the fallure of regular slugs, two " $\mathrm{J} "$ ( $P-10$ enrichment) slugs failed at DR Reactor and five "C" (earichment) slugs and a Chemlcal

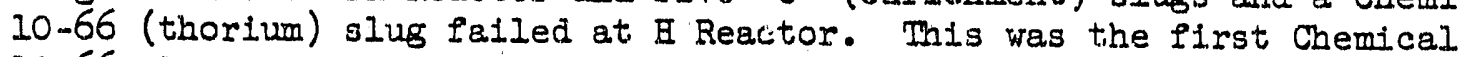
10-66 slug rupture. Total outage time resulting from these fallures was 46.2 hours.

F Reactor was shut down on January 25 for a scheduled one-week outage to permit installation of venturls and other project work. Operation was expected to be resumed on Febmuary 2.

A normal scheduled outage of approximately 48 hours at H Reactor was extended to 136 hours when an accldental high pressure surge during panelilt testing damaged a number of the gauges.

Detalls of reactor and water plant operation are set forth below:

1. Statisties

\begin{tabular}{|c|c|c|c|c|c|c|c|}
\hline & B & $\mathrm{C}$ & D & $\mathrm{DR}$ & $\mathrm{F}$. & H & $\begin{array}{l}\text { Total or } \\
\text { Average }\end{array}$ \\
\hline $\begin{array}{l}\text { Reactor Thro Operated } \\
\text { EfPlclency ( }) \\
\text { Reactor Outage Time (Ers.) }\end{array}$ & 90.3 & 82.8 & 99.8 & 95.9 & $77 \cdot 3$ & 71.7 & 86.3 \\
\hline $\begin{array}{l}\text { Plutonium Production } \\
\text { Special Irradiations }\end{array}$ & 71.0 & 127.9 & 0.3 & 0.5 & $169.0 *$ & 150.6 & $51.9 \cdot 3$ \\
\hline and Tests & 1.5 & - & 0.9 & 30.3 & - & 59.6 & 92.3 \\
\hline $\begin{array}{l}\text { Totat" } \\
\text { Reactor Unschedured }\end{array}$ & 72.5 & 127.9 & 1.2 & 30.8 & 169.0 & 210.2 & 611.6 \\
\hline $\begin{array}{l}\text { Outage Time (Hrs.) } \\
\text { Metal Discharged (Tons) } \\
\text { Water Quality (ppm Iron) }\end{array}$ & $\begin{array}{r}0.4 \\
41.0\end{array}$ & $\begin{array}{r}127.9 \\
26.2\end{array}$ & 1.2 & $\begin{array}{l}30.8 \\
15.0\end{array}$ & $\begin{array}{r}1.1 \\
30.1\end{array}$ & $\begin{array}{r}162.2 \\
52.1\end{array}$ & $\begin{array}{l}323.6 \\
164\end{array}$ \\
\hline $\begin{array}{l}\text { Raw Water - Average } \\
\text { Raw Water - Maximum }\end{array}$ & $\begin{array}{l}0.05 \\
0.06\end{array}$ & $\begin{array}{l}0.04 \\
0.05\end{array}$ & $\begin{array}{l}0.03 \\
0.05\end{array}$ & $\begin{array}{l}0.05 \\
0.07\end{array}$ & $\begin{array}{l}0.02^{*} \\
0.02 *\end{array}$ & $\begin{array}{l}* 0.03 \\
* \quad 0.07\end{array}$ & -- \\
\hline
\end{tabular}

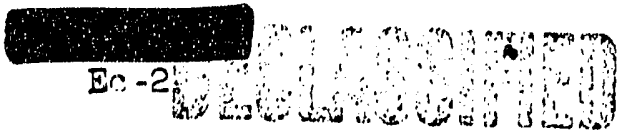




\section{i. Statistics (continued)}

\begin{tabular}{|c|c|c|c|c|c|c|c|}
\hline & B & 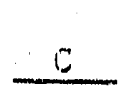 & D & ER & $\because$ & $\ddot{r}$ & $\begin{array}{l}7021 \text { or } \\
\text { Average }\end{array}$ \\
\hline Process Water-Average & 0.007 & 0.005 & 0.004 & 0.004 & 0.003 & 0.005 & - \\
\hline $\begin{array}{l}\text { Process Water-ilaximum } \\
\text { Water Pumped (MM gals.) }\end{array}$ & 0.020 & 0.014 & 0.009 & 0.009 & 0.015 & 0.009 & - \\
\hline Bldg. 190 to Reactor & 1658 & 3196 & 2120 & 18.38 & 141.9 & 1804 & 12035 \\
\hline Bldd. 182 to 200 Areas & -- & - & - & $\ldots$ & $-\overline{6}$ & 336 & 336 \\
\hline Steam generated (MM 1bs.) & & & & $\therefore$ & $\begin{array}{r}17.20 \\
119\end{array}$ & $\begin{array}{r}2443 \\
109\end{array}$ & $\begin{array}{l}342 \\
\because 7\end{array}$ \\
\hline Coal Consumed (Tons) & 101 & & 14 & & 6727 & 6791 & $384: 33$ \\
\hline
\end{tabular}

*167.9 hours was for January portion of scheduled venturi installation outage.

* The agreement of these flgures is attrikuted to use of the new permanganate method for iron analysis.

\section{Activities}

A scheduled one-week outage was begin at $F$ Reantion on January 25 and was continiling at wonth end. Major work scheduled during this outage was the installation of venturis and secondary orifices on process tubes, rearrangement of tubes on erossheaders to redistribute wate: flow, installation of aluminum nozzles in place of the rear face galvanized fringe tube nozzles, removal of the four discharge area catwalks, installation of a water cooled facility in "B" test hole, installation of a "half-rod" in No. 8 borlzontal rod position, repairs to "B" horizontal rod thimble, and installation of a Groves valve to afford automatic operatilon of the emergency export water supply system. At month end, the scheduled outage work was essentlally complete w1th the exception of galvanized nozzle replacement.

In the venturl and secondary orlplce program, venturis were installed on approximately 915 central tubes and secondary oriflces on tubes which are active in the zone bounded by the 850 outer tubes, thus leaving approximately 240 tubes with single orlfices in a clrcular pattern surrounding the venturl tubes. This program also involved recalibration and resetting of all panelilt gauges at whlch time the new long-vane mercolds were installed in them.

Acclidental high pressure surges on the $\mathrm{B}$ Reactor panellit gauges during a routine gauge callbration chesk resulted in extensive damage to the panell1t, gauges. This incldent occurred during a scheduled shut down and resulted in extending the plawned outage from approximately 48 hours to 136.2 hours. After preliminary evaluation of the extent of gauge damage (approximately 10 percent of the gauges were damaged bevond repal. and another 80 percent required recalibration), it was decided to replace a]l panellit gauges to fac1litate repairs. Gauges belng readied for the F Reactor ventur1 installat1on were utillized. Steps have been taken to prevent recurrence of this type incident which resulted from poor communications between the point of supply pump operation and the panellit

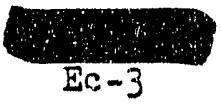


HW-30724

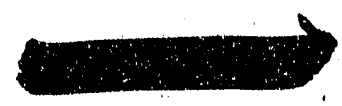

Reactor Section

2. Actirities (Continuer)

calibration work. Pressure rellef valires are to be instialled wh1ch will prevent recurrence of this incldent. The gauges installed also have new long-vane mercolds.

On January 17, H Reantor was shut down due to Indications of a water leak. A leak was found in a tube containing a ruptured uranlum slug and operation was resumed on January 18. On January 20, the reactor was again shut down when indications of further water leakage developed. In order to locate this leak, approximately 700 tribes were tested before finding a leaking tube which contalned a ruptured thorium slug. Operation was resimed on January 22 and at month end a totial of 2,000 gallons of water had been removed from the reactor as a result of the two tube leaks. Total outiage time for correstion of these leaks was 71.4 hours and is included in the mupture removal outage time reported above.

Satisfactory water quality was maintalned in all areas during the month without the use of activated silica which had previously been considered necessary for January raw water conditions.

The first discharge of low concentration metal requested by the AEC was made at $C$ Reactor on January 25. Approximately four tons of material were discharged at an average concentration of about onethird of goel.

The P-10 Irradiation program at, DR Reactor continued during January. Removal of the administrative tube power limits and returning to standard process limits permitted substantial power level increases. Four additional enrichment tubes were charged to compensate for reactivity losses due to burnout.

The following tabulation Indicates activities during January assoclated with special 1rradiations other than the P-10 Program noted above:

Tubes

Thibes

Charged Discharged Shipped

Chemical 10-66

Chemical $72-60$

Production Tests

Total

$\begin{array}{ll}2 & -7 \\ 29 & \frac{10}{29}\end{array}$

\begin{tabular}{rr}
1 & - \\
10 & - \\
18 & 7 \\
\hline 29 & 7
\end{tabular}

B. Equipment Experlence

During January, 19 reactor scrams occurred. Ten were attributable to normal panellit system difficulties, flve to pressure surges on water quality production test tubes at $D$ Reartor as the result of f'reezing in a heat exchanger, two to Beckman electrical difflculties at $F$ Reactor, one to 1mproper valving at Bullding 190-DR, and one to a partlally plugged cone screen. The latter was an Intentional manual scram to correct a condition

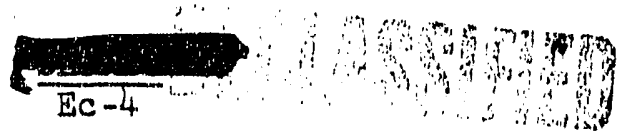




\section{B. Equignent Expertence (Continued)}

which was limiting power level. Material found on the screen appeared to have become dislodged from the crossheader screens during repair work. Total outage time charged to the above scrams was 5.9 hours.

As a result of the difficulties experienced during December with failure of a Building 190-C proces; pump speed increaser assembly, a comprehensive inspection program has been started which will encompass all components of the Building 190-C units. One pump shutdown was experienced during normal operation as the result of failure of an inboard mechanteal water seal on the pump shaft.

At $\mathrm{E}$ Reactor, the water leak in "A" horizontal rod was repaired and the rod was returmed to service. No. 7 and 8 horlzontal rods developed bending during the month and No. 8 rod thimble was found to be leaking. These rods are out of service at month end. No. 14 horizontal rod was converted to a "half-rod." At $F$ Reactor, "B" horizontal rod thimble was replaced to correct a leak and No. 8 rod was converted to a "half-rod."

No. 8 rod at $B$ Reactor 13 st.111 only partially operable as reported in December.

Fallure of the stainless steel bellows type pigtalls at the rear face of C Reactor was excessive during January. Approximately 30 pigtails falled, principally on the hotter tubes. Procurement of suitable replacement pigtalis 1 s belng expedited.

A number of gas leaks were found in the rear face process tube bellows during an extensive leak testing program at H Reactor. Repalrs were made as outage time permitted. Several other items of maintenance accomplished durlng the month are indicated above under "Astivities."

C. Improvement Experience

The most significant Production and Process test activities are reported below along with other items of "Improvement" significance.

PT-105-5-MR (Use of Hellum Gas to Reduce React1vity Transients on Minimum Startups)

A Process Standard revision authorized this method of operation for all reactors during January.

PT-105-529-E (Increasing Power Levels at H Pile by Raising Permissible Exit Watcr Temperature)

PT-105-530-E

PT-105-531-A

PT-MR-105-12

Supp. A

(Full Plie Burnout Experiment)

(Enrlchment of $\mathrm{H}$ P1le)

(Operation of $\mathrm{H}$ Reactor with Maximum Protection from the Panell1t System)

The above four tests continued to govern operation at

B Reactor. Four "C" metal tubes were discharged due

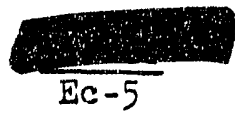


C. Improvement Experience (Continued)

to suspected slug fallure. Inspection revealed five " $C$ " metal pieces to be mptured. The number of enrlchment tubes remains at 56 as these tubes were recharged with " $\mathrm{C}$ " Metai.

PT 105-531-E (Full P1le Distortion and Annealing Experiment) This test at D Reactor continued during the month. Lower river water temperatiures permitted a $30 \mathrm{MW}$ increase in established naximum power level under the test conditions.

PT-105-533-A (Local Controlled Increase in C P1le Tube Powers) The increase in tube power limits made on Desember 30 was primarily responsible for the $137 \mathrm{MW}$ (Pu) gain in established maximum level at $C$ Reactor during January.

Equipment for "fast" discharge of ruptured slugs functioned sat1sfactorlly during the month, and was responsible for being able to resume operation within the scram recovery time limit on four occasions.

Redesigned cone screens were installed on the process tubes at F Reactor durling the venturi outage. This new type screen is less pointed in shape so that the openings are more uniform for a glven wire mesh s1ze. The advantage lies in reduced screen plugging and less resistance to flow.

Storage basin Irradiated metal bucket loading has been increased from 140 to 280 eight-1nch slugs (or their equivalent). This increased loadIng has avoided the purchase of approxinately 600 additional stainless steel burikets $(\$ 90,000)$ and will reduce annual shlpping costs an est1mated $\$ 128,000$.

F1ve revised Process Standards - Reactor were approved during the month. These were standards t1tled, "Process Tube Water 'Can-End Temperature' Temperature Rise Limits," "Reactor Atmosphere Composition," "Reactor Atmosphere Pressure and Flow," "Graphit,e Temperature and Rate of Rise Limits," and "handling of Irradiated Enriched (U-Al Alloy) Slugs." The major changes involved use of belium during reactor startups, relaxation of graphlte temperature 11mits from $460^{\circ} \mathrm{C}$ up to $500^{\circ} \mathrm{C}$ when spec1fied amounts of helium are used, and speciflcation of an automatic trip to shut down the reactor in case of high reactor atmosphere pressure.

The Pollowing invention reports were submitted by Reactor Section personnel during January.

Title

Wooden Tank Band Wrench

Modification of Charging Procedures for Flattening Colums

\section{Inventor}

M. Tomazin (dated 12-29-53)

G. F. Owsley

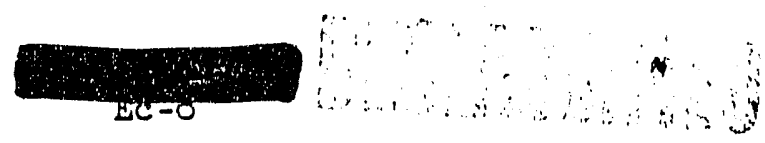


D. Eyents Influenolng Cost,

The panellit 1urlient at H Reactor $1 \mathrm{n}$ reased Lakor ard material costs. particularly in view of the amount of overtime work required.

Colder weather reslilted in hj.gher coal costis during January. However, 1mproved steam generation efficlency partially off-set this so that a net increase of only approximately $\$ 8900$ is antiripatied.

Other 1tems affecting costis were the Bullaing 190-C process pump inspection program, the large amount of work pert'ormed during the F Reactor ventur 1 outage and rescheduling of Power Sib-Sention safety meetings.

Reactor Input plutonium production increased 7.1 percent during January. This was the major factor in reducting the Reactior Section plutonium 1rradiation unit cost by approximately 5 percent sompared to December. This Januery unit cost is approximately 3 percent above the record established in November, 1953.

E. Plant Development and Expansion

1. Project St,atias

The most slignificant Reactor Section project activity is reported below. Eurther deta1ls concerming projects may be found in the report, "Status of Reactior Section Projects, Informal Requests and Budget Items," F. A. R. Stainken to J. H. Warren, dated January 20, 1954.

CA-431 (100-C Plant)

Minor construction forces continued work tioward completion of this project during January. Princlpel activity was directed at the Bullding 183-C automat1c backwesh system, Bullding 107-C retention basin beffling, and Bullding 105-C gas analysis equipment.

CG-438 (Ball. 3X Facilities for $B, D, F, D R$, and $B$ Plles) The water pressire clrcult was modipled at $\mathrm{B}$ Reactor during January completing th1s phase of the Ball $3 X$ system modificat1on program. Also, the hopper door solenolds were replaced at $B$ Reactor making DR Reactor the only reactor having the original type solenolds.

CA-512 (100-K Farilities)

Reactor design $1 \mathrm{~s}$ estlmated to be 98.8 percent complete and water plant design 99.5 percent complete. K Reactor project representatives have recomended that the temperature montor system serve as back-up against fallure of the panellit syotem. However, Lndependent, sensing lines will be provided on the front face of the reactor should further back-up be desirable. at a later date. A strike of construction forces hampered 100-K Area construction progress during the first one-half of January.

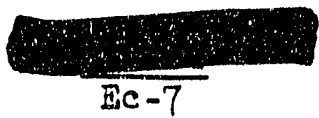


1. Project Status (Continued)

CG-558 (Reactor Plant Modification for Increased Production) Scope design of thls project was approximately 50 percent complete at month end. A final draft of the project proposal covering detalled design and material procurement is being prepared. The new estimated project cost for the complete reactor plant modification is approximately $\$ 35,000,000$. Initlal fund limitations of approximately $\$ 27,000,000$ presently make 1 t appear that some modifications w1.11 not be possible in certain areas.

RDS-D-10 (Reactor and Water Plant Design Development)

Engineerling study by Proness Englneerling is belng directed at formulating a specific plan for dual purpose reactor plant development. A program outline has been prepared (HW-30573) which includes deslgn objectives, general plan of action, and basic design - development criterla. Present studies are centered around the number of tubes, lattice ispacing, slug diameters, design power level, whether the reactor would be single or twin faced, and location of the j)lant.

\section{Plant Eng1rieering}

A number of engineering and development studies were active in the Section during January. The studies are, in general, aimed at decreasIng costs and/or increasing production. Detalis are given in documents HW-30704 and EW-30721. Several 1tems of interest are reported below:

A report covering the 100 Areas coal utilization study which has been In progress for some time was 1ssied during January. Th1s report sumarizes the results of a study of problems assoclated with the development of coal utilization standards and points out the extent of inaccuracles assoclated whth present boller operational measurements.

Stiudy was inltiated on centralization of the 100 Area mechanical maintenance shop equipment in a single shop at Bullding 1717-H. Costs have been estimated and space arrangement is under study.

A prototype backseating cyllnder which w1ll displace polson columns upstream in a process tube is being developed. If successful, this will be an additional means of adjusting polson column strength during reactor operation.

\section{F. Signiflcant Reports}

1. Routine

Monthly operating reports 1ssued for Deoember were:

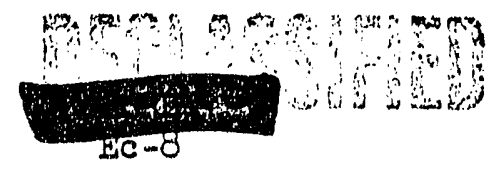


1. Rolitine (Continued)

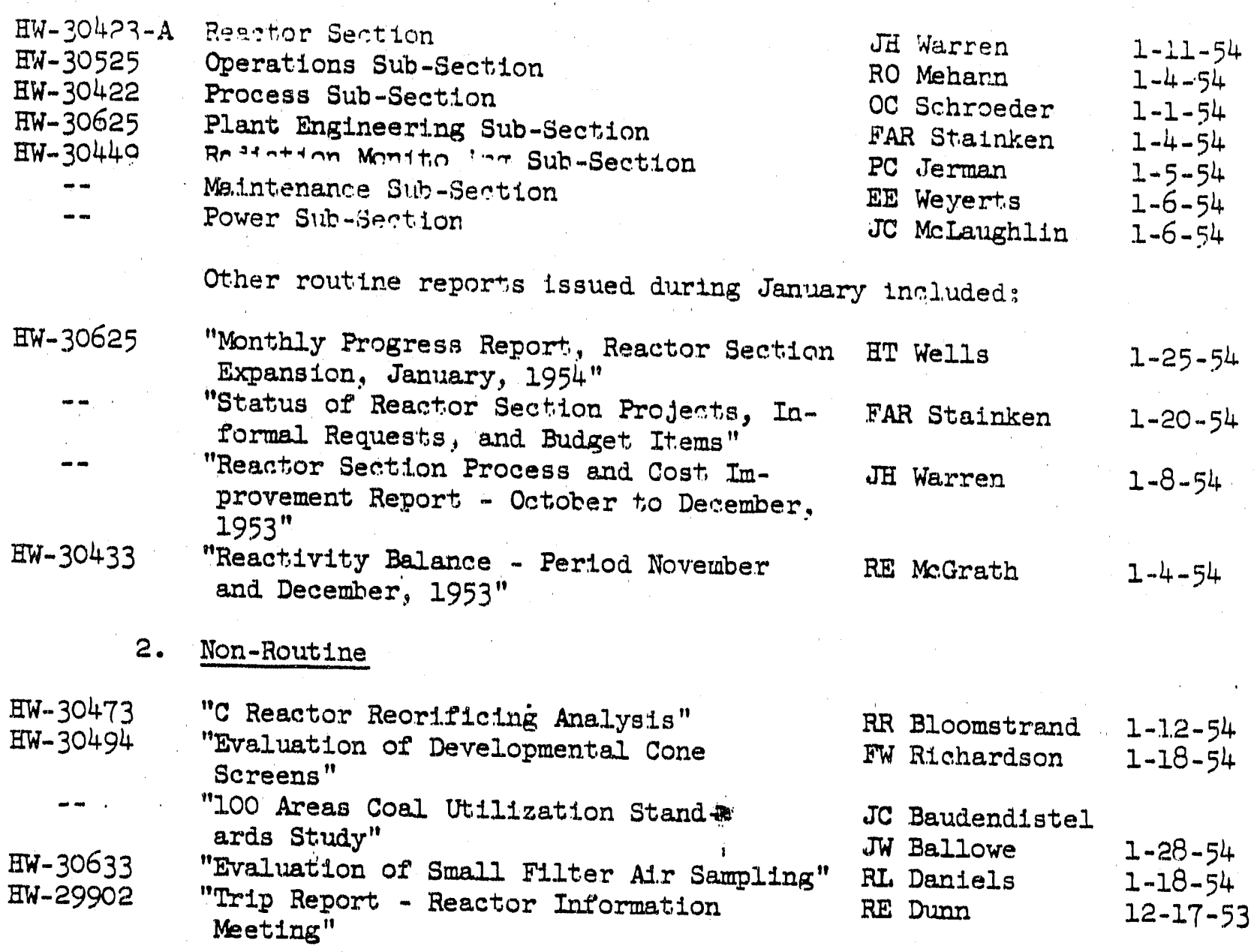

III. PERSONNEL

A. Organization

There were no appodntments made in the Reactor Section during January.

B. Force Summary

\begin{tabular}{|c|c|c|}
\hline $\begin{array}{l}\text { Beglinning } \\
\text { of Month }\end{array}$ & $\begin{array}{l}\text { End of } \\
\text { Month }\end{array}$ & $\begin{array}{l}\text { Net } \\
\text { Change }\end{array}$ \\
\hline $266^{3}$ & $269^{3}$ & \\
\hline $\begin{array}{r}483 \\
31\end{array}$ & $\begin{array}{r}482 \\
31\end{array}$ & $\begin{array}{l}1 \\
0\end{array}$ \\
\hline 414 & 41.5 & 1 \\
\hline 40 & 40 & 0 \\
\hline 59 & 58 & $=1$ \\
\hline 1296 & 1298 & 2 \\
\hline
\end{tabular}

Section General

Operations

Meintenance

Plant Engineering

Power

Process

Radiation Monitoring

Section Total

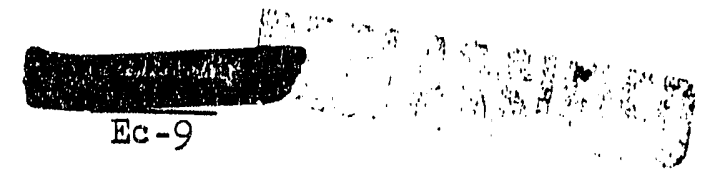




\section{B. Force Siumary (Continued)}

Changes during January consloted of 3 terminations, 2 deautivations. 1 reactivation, 4 transfers out and 10 transfers into the section.

\section{Safety Experience}

There were no Major or Sub-Major Infuries or Near-Serlous Accidents involving Reactor Section employees during January.

Power Sub-Section schedule for holding non-exempt employee safety meetings was changed effective Janlury 1, 1954. These meetings, wh1ch were formerly held on an overtime basis each Friday, are now belng held during the day shift. A sufficient number of meetings are being held to permit attendance by essentially all personnel. The annual savings will be approximately $\$ 8,000$.

D. Radiation Experience

One Class I and two Class II Radiation Incidents occurred in the Section during January. The Class II Incidents, No. 67 and 68, occurred in the C Reactor and $\mathrm{H}$ Reactor discharge areas, respectively, when highly radioactive specks were depositied on two Reactor Section employees. Maximum possible exposures were calculated to be 1100 rep in the first case and 780 rep in the second. The Class I Incident, No. 338, occurred at $H$ Reactor when a Maintenance employee recelved an estlmated exposure of 365 mrep to the knee from contamlnation which was picked up in the discharge area on his outer coveralis. Another incldent was tentatively placed in the Class I category but later removed based on flndings during the 1nvestigation. Investigations of the Class I and II Incidents are reported in documents $\mathrm{HW}-30691$, HW-3068I and EW-30797, respect1ve to the order discussed above.

Radiation detection alarms have been installed on the charging elevators at all reactors. These alarms will provide additional warning in case of abnormal radiation levels.

E. Personnel Activities

At month end, 14 employees are recelving on-the-fob training for engineering or supervisory asslgnments in the Section; 8 of these are on assignment under the rotational training program.

Seven Navy personnel assigned to the SIR Project were in training in the Operations Sub-Section for a two-week perlod. Also, six General Electric employees from KAPL began a four-week tralning gertod on January 11.

Princlpal 1tems of Interest during January in connection with employee comunlcations were (a) two additional meetings in the serles of non-exempt employee information meetings on the subjects of venturls and orfflce program and radiation monitoring experience and plans, (b) use of the $100-\mathrm{K}$ 
E. Personnel Activities (Continued)

Reactor model during the week of January 4 to inform appropriate personnel of sallent features of design, and (c) continuation of the serles of comprehenglve radlation hazards review meetings for nonexempt personnel which were begun last month.

J. H. Warren and E. J. O'Black attended the Plant Maintenance and Englneering Conference in Ch1cago, January 25, 26, and 27.

G. B. Jex attended a conference on Chemlcal Weed Control at Washington State College on January 13.

F. W. Richardson visited the Metal Sales Company at Kirkland. Washington, on January 7 and 8 to inspect cone screens whlch were belng fabrlcated for HAPO.

W. J. Faller of Panellit, Inc., advlsed; on site, section personnel relative to problems encountered during the panelilt incident at $B$ Reactor. 
MANTFACTURING DEPARTMENT

\section{RESPONS IBILITY}

Responsibilities of the Separations Section were unchanged during the month of Jariuary.

II. ACHIEVEMENT

\section{A. Operating Experience}

1. Statisties

a. B1smuth Phosphate Operations

$\begin{array}{ll}\frac{\text { January }}{\text { Ac1d }} & \frac{\text { December }}{\text { Acld }} \\ \text { Normal Wash } & \text { Normal Wash }\end{array}$

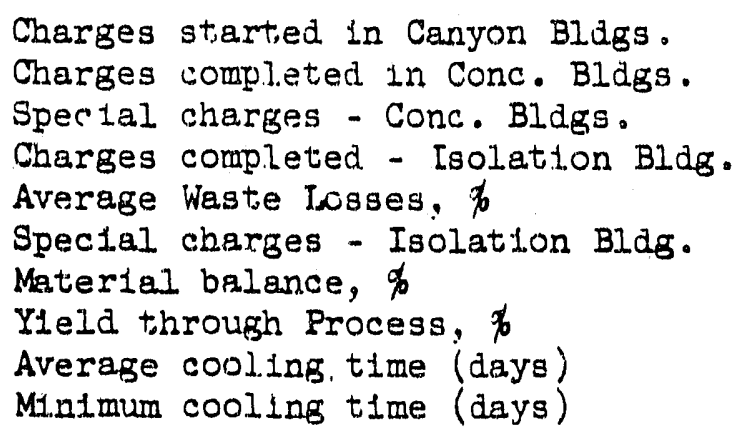

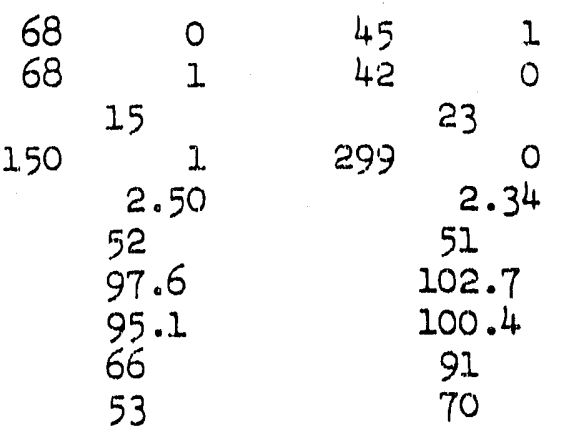

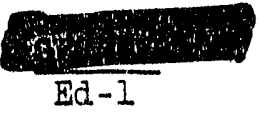


1. Stat1st1os (Continued)

b. Redox Operat1ons

(4)

期解

December

Equvalent oharges started

Charges completed

Tons Uranlum dellvered to storage

Average Produstion Rate per Operating

day, Tons

Average Dally Operating Rate for the month, Tons

Average yleld, of

Urantum

Plutonium

Total Waste Losa, \&

Urandum

Plutonium

Average cooling time, days

Minimum cooling time, days

Percent down time

\section{January}

97.0

97.5

67.4

4.7

2.2

96.9

97.7

1.16

1.17

83

77

53.5
262.2

268.2

191.4

6.6

6.2

98.7

100.0

1.13

83

69

6.2

c. 234-5 Operat1ons

Januery

Batches completed through Task II Runs completed through Task III

Reduction yleld, RM

Waste Disposel, untts
157

102

96.6

2.07
December

262

183

96.2

4.79

d. $\underline{U O}_{3}$ Operat1ons

$\begin{array}{cccc}\text { January } & \text { December } & \text { To Date } \\ 261 & 260 & & 4736 \\ 223 & 255 & & 4669 \\ 9.1 & 91 & \\ 83 & 77 & \\ 0.2 & 0.1 & \end{array}$

e. TBP Operations

January Deoember To Date

Tons recelved from Metal Removal 192

Tons shlpped to $\mathrm{UO}_{3}$ Plant 185

91

2726

$91 \quad 2601$

Uranturn drurnmed, Tons

Uran1um sh1pped, Tons

Minige cooling time, days (Redox)

Minimum cool1
Waste $1008, \%$

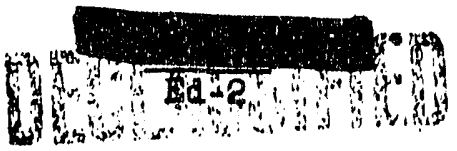

Wha 
ค. TBF Oparations (contuned)

January Dacember

Average Production Rate per operating day, Tons

Average Da1ly Operat1ng Rate for the month, Tons

Average yield, \%

Total Wastie loss, $\%$

Rat1. Waste Volume returned to Volume removed

Percent Down Time

\subsection{5}

5.98

96.69

1.28

1.40

32.59

$$
4.18
$$

2.92

96.17

2.74

1.96

i!.?

\section{B. Fower}

200 East,

Raw water pumped, gpm

Filtered water pumper, $8 \mathrm{pm}$

Steam generatied, 1hs/hr

Maximum steam generated, lbs/hr

Total steam generated, $M$ lbs.

Coal consumed, tons (est. .)

h. Waste Storage

\section{Waste storage}

$\begin{array}{rr}1167 & 6346 \\ 402 & 965 \\ 65727 & 211379 \\ 100000 & 312000 \\ 48901 & 159497 \\ 3259 & 10036\end{array}$

200 Weot 346

10036

$$
\cdots \frac{\frac{\text { Equlvaj.ent Then } U}{\text { Jenuary }}}{\text { December }}
$$

Matal Waste reserte storage capac1ty - T Plant lst Cycle reserve storage capacity - T Plant, Metal Waste Reserve starage capacity - B Plant l.st Cycle reserve storage capac1ty - B Plant Redox Wate reserve storage capac1ty

$\begin{array}{lr}827^{*} & 21.5 \\ 141^{* *} & 235 \\ 145 & 145 \\ 4 & 4 \\ 481 * * * & 222\end{array}$

* $104,5,7,8,9-U$ tanks added to regerve

* 112-TX tank removed from reserve, 104-105-T tanks added to reserve

** 110, 11, 12-U tanks added to restrve

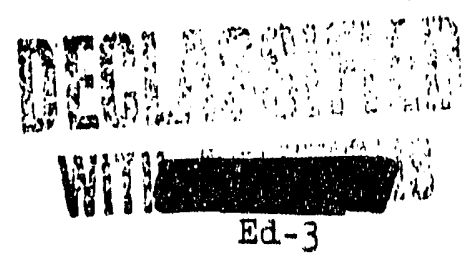




\section{Activities}

c. $\underline{\mathrm{UO}}_{3}$ Processing

month with two of the cars having materlal exceeding by $3 \mathrm{ppb}$ the specification for plutonium concentration in $\mathrm{UO}_{3}$ (10 ppb parts of uranium).

\section{d. Waste Metal Removal}

Equipment fallures and adverse weather conditions at the tank farms serlously hampered metal removal operations, particularly in the latter part of the month. Production was primarlly obtained from BXR and TXR supernate tanks and the CR farm 200 serles tanks. Two slulce pump and two sludge pump fallures were experlenced, and replacement was time consuming and very difficult due to the problem of high radiation and inclement weather.

\section{e. T Plant Processing}

Production through T Plant was scheduled for maximum throughput when 1t became evident that the Redox Plant would not be able to process the scheduled amount of materlal. The Concentration Bullding output, amounting to 83 runs plus an acld wash, established a new all time record for a blsmuth phosphate plant.

\section{f. Isolation and Metal Fabrication Processing}

Cperations were essentially normal in the Isolation and istal Fabrication Plants as production commitiments for nitrate, buttons, and final shapes were attained and the material was accepted by the AEC.

\section{P-10 Processing}

P-10 production proceeded ahead of schedule due to the early avall.. ablilty of all P-10-A materlal. All material discharged from the presentDR load was extracted by January 5 except for three tubes scheduled for special extraction runs. Feed materlal after January 5 was P-10-A flattening materlal and included all that above $20 \%$ of the goal concentration.

\section{Spectal Operations}

\section{a. Waste Evaporator}

January operating data for the $242-B$ and $242-T$ waste evaporators are as follows:

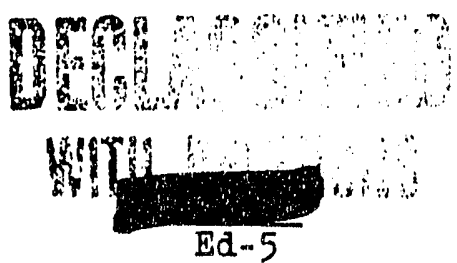


A. Operating Experience (Continued)

2. Activities

a. Redox Processing.

Since the resldual waste storage volume in the 241-S Tank Farm had become depleted, the Redox Plant was shut down on January 6 to effect the re-routing of salt wastes to the 241-U Tank Farm via the tie lines recently installed on Project CG-538. During the shutdown, certain urgently needed equipment flushes and changes were made which included installation of a waste neutralizer (D-8) pump, replacement of the first extraction IA column feed pump, replacement of the H-5 caustic scrubber circulation pump and installation of sprays in $\mathrm{H}$ cell. An unsuccessful attempt was wade to divert the J-I fibre-glass filter ruthenium-bearing effluent gas to the sand filter. Operation: rere resumed on January 16 with feed consisting of retreated material from equipment flushes and high uranium aqueous wastes produced prior to the shutdown. The extraction batteries processed this rework material at an equivalent rate of 5 tons per day until Jarruary 20 when a plug in the neutralized waste line to the 241-U Tank Farm forced a shutdown. A spare waste IIne was activated, and operations were resumed on January 24 , but a leak soon developed in the waste system diversion box and dictated another shut down. This difficulty was resolved on January 26 and operations continued uninterrupted for the balance of the month at feed rates averaging 5 tons per day.

b. TBP Processing

Only the B Line in the TBP Plant was operated until January 12 due to a shortage of feed materlal and keeping A Line in standby in event the test processing of shorter aged material from the BX Tank Farm Indicated two cycle processing was required. Parallel operatinns were resumed on January 12 after the satisfactory processing of BX material was demonatrated. Operations continued for the balance of the month at average rates of 5 tons per day for each line.

The new RA decontamination column Installed in December continued to give good performance as regards waste losses with RAW losses averaging $0.35 \%$ for A line and $0.48 \%$ for $B$ line. A maximum throughput rate of 6.5 tons per day was achleved by each 11ne, but feed shortages prevented sustalned operations at this rate. Both lines were shut down for two days durinis the third week in January for replacement of the condenser vent blower motor and installation of Stage I organic segregation facllities.

c. $\mathrm{UO}_{3}$ Processing

Operations were essentially normal in the $\mathrm{UO}_{3}$ Plant with production rates being limited only by the avallabllity of feed from the Redox and TBP Plants. A total of seven cars of $\mathrm{UO}_{3}$ was shipped during the

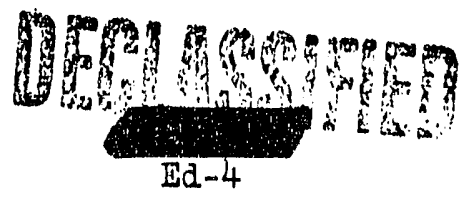


3. Spectal Operations

a. Waste Evaporators (Continued) $191 /$ H

\begin{tabular}{|c|c|c|c|c|}
\hline Evaporator & $\begin{array}{l}\text { Gallons } \\
\text { Feed } \\
\end{array}$ & $\begin{array}{l}\text { Gallons } \\
\text { Bottoms }\end{array}$ & $\begin{array}{c}\text { Gallons } \\
\text { Condensate } \\
\end{array}$ & $\begin{array}{l}\text { \% Volume } \\
\text { Reduction }\end{array}$ \\
\hline $\begin{array}{l}242-B \\
242-T\end{array}$ & $\begin{array}{ll}320 & 375 \\
361 & 810\end{array}$ & $\begin{array}{l}193188 \\
220000\end{array}$ & $\begin{array}{ll}127 & 187 \\
141 & 810\end{array}$ & $\begin{array}{l}39.7 \\
39.2\end{array}$ \\
\hline
\end{tabular}

Feed for both concentrators was current TBP wastes.

b. Pu Recovery $-234-5$

The equivalent of 15.8 bottles of product was processed in Metal Recovery (Hood 40), 10.4 bottles was processed In Powder Recovesy (Hood 41), and 26.3 botties of material was transferred to the Concentration and Isolation Bulldings for reprocessing.

4. Schedule Varlance January production vartance from the January Annual Forecast is as
follows:

Redox plutonfum and urantum production were both 10 w wh th $56 \%$ and $53 \%$, respectively of the forecast being attained.

T Plant production was $234 \%$ of the forecast. The combined plutonium production of the two separations plants was $78 \%$ of the forecast.

The $\mathrm{UO}_{3}$ Plant produced $130 \%$ of the forecast.

The TBP Plant production was $185 \%$ of the forecast.

The Metal Fabrication Bullding produced 100\% of the January commitment for buttons and 105\% of the commitment for final shapes.

B. Equipment Experience

1. Operating Continuity

Redox down time totalled 399 hours and was primarlily for replacement of the waste neutralizer pump, lA column feed pump, caust1c scrubber circulation pump, installation of sprays in $B$ cell, and activation of a salt waste line to the 241-U tank farm. Other mafor factors contributing to the down time were plugging and leaking of the salt waste system lines, and fallure of the $\mathrm{H}-2$ centrifuge.

The total down time for the TBP Plant IInes was 346 hours for A Line and

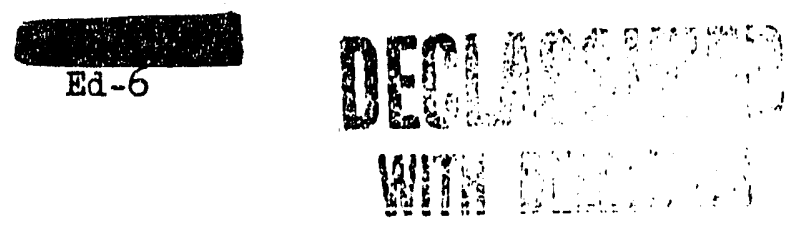




\section{B. Equipment Expertence}

\section{Operating Continuity (Continued)}

189 hours for B Line. These outages were due primar1ly to holding A Line in standby during the test processing of BX feed material, installation of solvent segregation facilities on both lines, and lack of sufficlent feed inventory to maintain parallel operations.

\section{Inspect10n, Maintenance and Replacement}

a. A-3 Silver Reastor - Redox

The A-3 silver reactor was replaced with a two-plece spare unit when frequent fuse replacement and inoperability of five of the nine heater banks made lt difflcult to maintain the desired temperature during dissolving. A total of 5.11 tons of metal had been processed through the A-2 dissolver since installation of the old reactor.

b. Major Equlpment Replacements - Redox

Valves, tanks, pumps and Jumpers replaced durlng the January shutdowns included the $2 D$ and $3 D$ column waste valves; $H-I$ and $H-5$ pump Jumpers; G-5 centrifuge feed tank and jumpers; $D-8$ pump; $D-13$ vent jumper and 240-S catch tank transfer jumper.

c. Salt Waste Line Fallure - Redox

The newly activated salt waste IIne to the 241-U Tank Farm plugged on January 20 necessitating a complete shut down. A spare line was activated, but soon developed a jumper leak in the $241-5$ diversion box. Relmpacting the jumper resolved the difflculty on January 26 .

a. H-2 Centrifuge Fallure - Redox

Severe vibration detected in the $\mathrm{H}$ cell centrifuge on January 28 indicates bearing fallure. Replacement of this unit is planned in the flrst week of February.

e. D-12 Pot Failure - Redox

Severe leaking from the D-12 salt waste concentrator (fourth fallure since start-up) was detected on January 30 indicating complete failure of the unit. A spare has been readied for installation during the first week of February.

f. Slulce Pump Fallure - BXR Tank Farm

On January 8, the 001-BXR purp lailed for the third time in three months. Investigation disclosed the pump to have falled due to a fractured colum flange, which was identical to the fallure expe- 
2. Inspection, Maintenance and Replacement

f. Slulce Pump Failure - BXR Tank Farm (Continued)

rlenced in December. Further Investigation disclosed the cause to be improper seating within a long sleeve type screen whlch had been Installed several months ago to combat a plague of pump plugging. This screen had become bent, and installed pumps were subjected to a severe bending motion which was further aggravated by the pump's starting torque. The screen and the falled pump were removed to the burlal grounds. Replacement was made with a rebuflt pump and operations were resumed on January 24.

B. Byron-Jackson Sludge Pump Failure - TXR Farm

Byron-Jackson pump \#33 falled in service in Tank 101-TX on January 8 after only 33 hours of service. This is the second fallure of this pump, since it failed previously in Tank 101-T after 73 hours of operation. Both of these failures resulted from bearing selzure and conclusively demonstrate the inadequacy of the cast iron bearings with which these pumps are equipped.

h. EB-I UNH Concentrator Fa1lure - $\mathrm{UO}_{3}$ Plant

The EB-1, $60 \%$ UNE concentrator falled in service due to leaks in the process tubes. The unit was dismantled and it was necessary to blank six of the tubes to effect repair. A total of 19 of the concentrator's 751 tubes are now blanked due to leaks with no significant loss in capacity.

1. Casting Furnace Failure - Metal Fabrication

Fallure of a limit switch combined with the failure of a shear pin to function at the proper time resulted in cracking of the lift arm to furnace \#I and stripping of the travel gear. The lift assembly was replaced and the furnace returned to satisfactory operation. A closer Inspection and adjustment of the limit swltches to the lift mechanism is now being carried out.

j. Bell Jar Rupture - Task VII - Metal Fabrication

During routine coating in Unit No. 2, when the second increment of coating gas was being admitted, a sudden flash and pressure build-up occurred, shatterling portions of the bell jar. Subsequent finvest1gation revealed that alr was pulled into the bell jar through a ruptured Saran dlaphragm in the coating gas valve. Since telion diaphragm installed in one of the other unlts had operated four times as long as the Saran dlaphragm and appeared in excellent condition, double teflon dlaphragms were Immediately installed in Units 1,2 and 4. Further modifleations are being made to these valves to operate them with an Inert gas and vent them through a check valve system. Units 3,5 and 6 , which have a different type valve, are being held as stand-by units until they can be equipped with the safer, modifled coating gas valve.

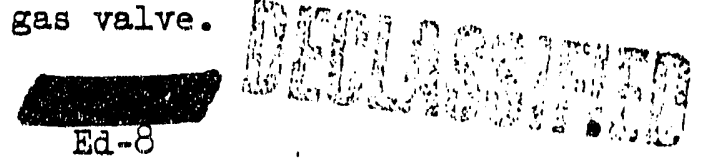


2. Inspection, Maintenance and Replacement (Continued)

k. Can Opening Unit, - P-10

The rlght hand mantpulator of the can openting untt falled and made operations very difflcult. One pulley and two sections of cable required replacement and three sectlons of Elglloy tape required repalr.

\section{Improvement Experience}

1. Process Tests and Rev1sions

a. Test Processing of BX and TX Feed - TBP

The amount of BX and $\mathrm{TX}$ ( $3 \mathrm{yr}$. minlmum age) metal waste supolled $\mathrm{P}$, the TBP prosess was increased to as much as $83 \%$ (U basig) of the 81 column feed. The gama activity of the RAF was increased by a fnct, of 3-4 over the average feed act1v1ty for December 1953. The phns rin. to uranium rat10 averaged about twl.ce the $B W=4$ flowsheet and the sil. fate, sodium, and nitric acld to uranium rat1os averaged about 1.5 times the $\mathrm{HW} 4$ flowsheet. The high salt content of th1s feed elimi. nated the concentrating restrictions relative to total salts and sulfate plus phosphate content with some benefit to RAW Losses and throv put capacitles.

The new louvre plate RA columns are belleved to be primarily responsible for a pooled waste loss of less than $1.5 \%$ for the month, as cor pared to the $2.66 \%$ loss in December. Single cycle operation produce RCU with an average gamma percent $Q f$ less than 200 and a maximum, $Q x$ cluslve of two start-up batches, of 339 .

\section{b. Weste Scavenging Test - TBP}

Soll sample analyses followlng the 101-T waste scavenging test have Indfcated that the scavenged TBP waste supernate can be cribbed to a volume limlt of at least 6000 gallons of supernate per square foot of crib bottom. Approximately 2400 gallons of waste storage space per ton of uranlum processed can be saved by scavenging instead of concentrating TBP waste. On the basis of the results obtalned a pro ject proposal 18 belng prepared to permlt waste scavenging of TBP waste by Apr11 1, 1954 .

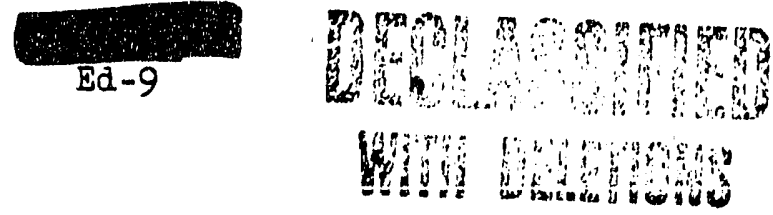


1. Process Tests and Revisions

c. $\mathrm{UO}_{3}$ Reactivity Process Test $-\mathrm{UO}_{3}$

It has been determined that the reactivity of the oxide can be improved by the addition of sulfamic acid to the pot oharge. One test using 0.256 welght percent of sulfamic acld increased the reactivity of the powder from 1.1 to 1.4 units. As pot agltator stalling indlcated a change in the physical properties during calcination, the test was repeated with less $(0.09$ and 0.16 wt:\%) sulfamic addition and normal furnace cycles, were achleved. The effect of increased sulfur content, over $700 \mathrm{ppm}$ for the first test, of the powder w111 need to be evaluated by the customer.

d. Tyme Cycle Reduction - T Plant Concentration Bldg.

The effective time cycle of the Concentration Bullding has been reduced 35 minutes by making product reductions in the catch tank of the lanthanum fluoride by-product cell during centrifugation. Product reduction in the lanthanum fluoride product. cell is thus eliminated with a resultant shortening of the product cycle.

e. Test Preheater, Task II - Metal Fabrication

Since tests of several montibs duration have demonstrated that preheating of the process gases before introduction to the dry chemistry furmaces will improve hydrofluorination, reduce time cycles and probably fncrease furnace life due to lower temperatures required on the retort walls, process gas preheaters are being installed for all bydrofluorination units.

1. Dowadraft Iodine Condenser, Powder Recovery - Metal Fabrication

A downdraft lodine condenser was installed on the existing reflux condenser of the Powder Recovery Hood and makes possible the recovery of calclum and lodine bearlng Task III sweeplngs and unreduced fluoride powders. The bulk of the chemicals are removed from the powder by screening prior to powder dissolution in the hood. Further processing of the resulting recycle solution is then performed in either the 224-T or 231 Bullding.

2. Inventions or D1scoverles

There were two Inventions reported during the month:

Inventor

B. A. Moulthrop

R. Overson
Tytle

Plast1c Bubble Sealing for Contamination Control Remote Metal Cutter - General Purpose Model 
D. Events Influencting Costs

1. Lahor Variance

Total force of the Separations Section increased by five as one craftsman was added to the Malntenance Un1t, and four operators were added tio the Operations Sub-Section.

2. Materlal Variance

Use of a composite sample instead of four small samples for recycile solution in the Isolation Bullding w1.1.1 result in estimated annual savings of $\$ 3,500$ in sampling equipment.

3. Other

In the Analytical laboratorles, the addition of the $\mathrm{X}$-ray analysis for PR samples and a control analysis of first cycle waste solutions prior to discharge to the ground, coupled whth routine hourly surveys of analytical personnel and special monitoring of SWP clothing will result In Increased labor costs approximately $\$ 15,000$ per year.

E. Plant Development and Expansion

1. Projest Status

a. Project CT-551. Expansion Program. 234-5 Bu1lding

In a meeting beld January 22, 1954, material procurement problems on Task III, 234-5 Bullding, were reviewed. It was concluded that a more realistic completion date for the mock-up and run-in of Task III equipment in the shops would probably be December 1, 1954 , rather than July 1, 1954. On this basis, it appears that the actual installation in the bullding may be delayed until January 1955. This is compatible with our presently forecasted need for the increased production.

b. Project CCr-496. Recipplex, 234-5 Butiding

Work on the Underground Storage Facillties by Clsco Construction Company progressed satisfact;orily during the month. There has been no change in the schedule for resumption of construction in the 234-5 Building and March 1, 1954.appears to be the earliest date that construction can be resumed.

c. Profect, CG-549, Task I, 234-5 Burlding

Detalled deslgn for Task I activation progressed according to schedule. Revision No. 3 of the Project Proposal is beint; held up pending re view of the justification of this project in lieht of the latest production forecast. A construction schedule is being prepared on the

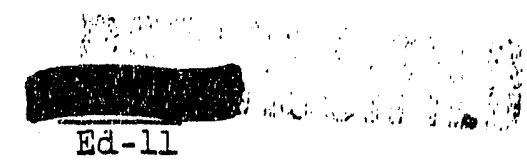


1. Project Status

c. Project CG-549. Task I. 234-5 Building (Cont Inued)

basis of material procurement. It is anticipated that the readyfor-use date of September 1, 1954 cannot be met because of materlal procurement and fabrication.

d. TBP Modiflcat1ons. Project CG-562, New Extraction Columans

All "Stage I" solvent-treatment equlpment was installed on January 17 and 18 and was successfully operated for the balance of the month.

e. Project CA-539, Add1tional Redox Wastie Facilities, 241-SX

At the end of the month, construction was approximately 13\% behind schedule at $53 \%$ complete. Backfilling was continued and some pipe work was accomplished in the diversion box. Eruptions in the $S$ Farm tanks and the high radiation levels encountered on the self-concentratIng condensers have led to a scope change in the 241-SX condenser system, which will be covered by Revision II of the project proposal scheduled for release to the AEC in February. It is proposed to install a barik of six condensers in a concrete shlelded bullding to serve the first six tanks. The condenser system on the other nine tanks $w 111$ be completed later, as a separate project, after operation of the proposed system has been eveluated.

f. Project CG-187-D-II - Redox Production Fac1lities

The ventilation of the north and south sample gallerles in the 202-S Bullding was originally planned to consist of necessary duct work, fans, etc., for ventilation of the samplers. It was subsequently decided to enlarge the scope of the work to provide means for elimination of "blow-backs" which had occurred from t1me to time at the samplers. To date, most of the duct work has been completed. However, addition of the permanent modifications to the samplers themselves to eliminate "blow-backs" and the installation of hoods around the samplers has not yet been started. It 1 s expected that this work w1II not be completed before July 1, 1954.

The design of the jumper to enable backcycling of the third uranium cycle waste stream to the Plrst cycle uranium concentrator was completed and it is planned to Install this jumper in April simultaneously with the stage I portion of Project CA-535.

\section{Profect CA-535 - Redox Capac1ty Increase, Phase II}

Recurrent contamination of ground surfaces 1mmediately adjacent to the Redox facll1ty postponed construction work on the Phase II product concentration bullding (233-S) and the 211 and 204 tanks. A decision to place this job under SWP restrlctions appears to be the loglcal solution so that the work may proceed; although th1s will increase construction

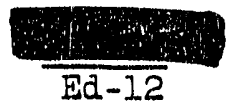


1. Project Status

g. Project CA-535 - Redox Capac1ty Increase, Phase II (Cont1nued)

costs. The new production requirements may force deglgn changes or alterations to 233-s equipment for criticality reasons. The extent of this change has not yet been determined.

Jumper construction schedule for Stage I has been 1ssued and design of the approximately 68 jumpers is cormlete with the exception of minor revistons to eleven of these tracings. Issulng of these prints w11l. be completed in February.

Fabrication of the jumpers and major equipment pleces continued to be held up due to unavallabllity of stalnless steel plate and piplng, control valves, and connector heads. Although procurement relief is promised in February, it 1s. doubtful if fabrication will permit equipment installation by April 15. Any delay beyond this date will serlously interfere with the ablilty of the Redox plant to meet forecasted commitments.

h. Project CG-538, Redox Waste Tie IIne to U Farms

Construction remalns at $94 \%$. Although the piping was placed in service, additional work in U Farm remains to be done.

1. Project CA-187-D-III, Redox Waste Water Disposal Basin

Construction 1s $50 \%$ complete. Approximately $70 \%$ of the course backf1Il has been made and the chemlcal sewer ditch is almost complete.

j. Project CA-513-A, Purex

Purex design 1s $93 \%$ complete compared with a scheduled 99\%. Construction of Part A 1s $16.7 \%$ complete and the 202-s Biliding is 13.5\% complete. Construction is lagging $20 \%$ behind schedule which compares w1th an 11\% lag last month. Progress during January was only $0.8 \%$. The carpenter strlke and adverse weather were the main contributors to poor construction progress during the month. A realistic "Ready for Operation Date" is estimated by the Section to be July 1, 1955.

\section{Plant Englneering}

\section{a. Work S1mplification}

The Separations Section's proposed cost-reduction campaign for nonexent employees, featuring the distribution of Work Simpliflcation I1terature, is belng consldered by the Suggestion Board Secretary and may be sponsored by the Board as a plant-w1de operation, w1th Separations personnel acting as consultants. Employee Commications

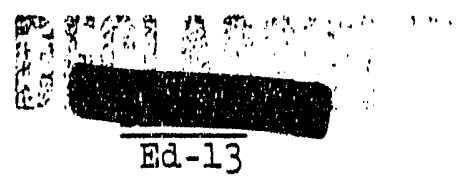


2. Plant Englneerling

a. Work Simpliflcation (Continued)

have completed the first rough draft of pamphlet's to be used, and they predict actual distribution in April.

The Work S1mpliflcation Round Talles were started on January 15. Combination work-study conference-type sessions are belng held blweekly w1th $Z$ Plant exempt or supervisory employees and w1th a group consisting of all Separations Section Manufacturling Englneers and one Reactor Section. Manufacturing Engineer. Durlng January, the 19 conferees in the two groups devoted 56 man-hours to conference participation of this type.

b. Engineering Assigtance

An operations analysis of the decontamination work performed in the 222-S Laboratory was completed. Proposals for the improvement of contamination and radiation control, safety, and eppiciency were dissussed w1th Process Analytical personnel. Modiflcations resulting from this conference are being incorporated into soope design of the new equipment.

c. Property Maragement

Renovation of the $2705-Z$ facility in preparation for Malil and Dupl1cating Services was completed permitting thalr transfer from the $2704-z$ Bullding on January 27, 1954. The area released 1n the 2704-Z Building will be utilized by Classifled Files for a branch offlce which will slmplify considerably the transmittal of classifled documents within the 200 Areas.

F. S1gnificant Reports Issued

1. Routine

Number

Thtie

Author

HW-30715 Separations Section-Operations Sub-Section Monthl.y Report

V. R. Chapman

EW-30714. Separations Sect1on-234-5 Operat1ons Monthly Report

V. R. Chapman

HW-30771 Separations Sect1on-Plant Englneerlng Sub-Section Monthly Report

C. P. Cabell

HW-30699 Separat1ons Sect1on-Process Sub-Sect1on Monthly Report

W. N. Mobley

EW-30746 Separations Section-Radiat1on Mon1tor1ng Sub--Section Monthly Report

A. R. Keene

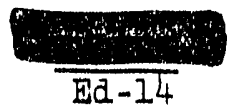


1. Routine (Continued)

Number Titile

Offictal Use Only

Separations Section-Power \& Maintenance Sub-Section Monthly Report

EW-30711

None

HW -30790

BW-30546

2. Non-Routine

P.E. Report, No. 110

P.E. Report No. 102

EW-30507

BW-30560

HW -30530

HW-30604

패 -30661

EW-30668

BW-30'739

घW-30735

EW -30547

BW -30556

\section{Separations Section-P-10 Extraction Unit Monthly Report}

Monthly Progress Report, Plant Expansion Plant Engineering Sub-Section, Separations Section, January 1954

Separations Sestion - Essential Materials

Separations Proness Counc1.1 Meet1ng

Heavy Equipment Requirements for

Tank Farms

Standard Analytical Requilrements, Metal Recovery Untt,

A Review of the Purex Plant Capacity, F.E. Report No. 106

Radiation Incident, Class I, No. 333

Radiation Incldent, Class I, No. 334

Radlation Inc1dent, Class I, No. 335

Radiation Incldent, Class I, No. 336

Radiation Incident, Class I, No.. 339

Radiation Incldent, Class I, No. 340

Radiation Incldert, Class I. ITo. 341

Purlty Analysis of Plutionium Solution Uaing a TBP Extiraction

The Hanford Remote P1petter
Author

R. T. Jessen

O. V. Solset

F. A. Hollenbach

J. P. MeBride

O. F. Beaulieu

R. H. S1Iletto

R. H. Silletto

B. E. Clark, Jr.

D. R. Koberg

W. G. Westover

D. R. Koberg

J. P. Corley

J. P. Corley

D. R. Koberg

W. G. Westover

D. M. NewelI,

L. A. Bray

K. ㅌ. HarmiII

III. PERSONNNEI

A. Organization

The three Un1t Superintendents wlthin Separations Sect1on, Operations Sub-

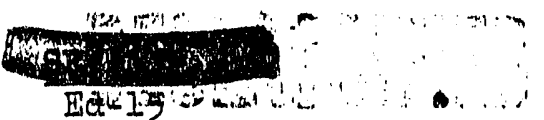


A. Organization (Continued)

Section, recelved new assibnments effectlve tranuary 4: E. A. Foskett from $T, B$, and S Separations to Metal. Recovery; C. T. Groswlth from Metal Recovery to Isolation and Fabrication; and T. Prudich from Isolation and Fabrication to the $T, B$, and $S$ Separations Unit.

B. Force Summary

\begin{tabular}{|c|c|c|c|}
\hline & $\begin{array}{l}\text { Start of } \\
\text { Month }\end{array}$ & $\begin{array}{l}\text { End of } \\
\text { Month }\end{array}$ & $\begin{array}{c}\text { Net } \\
\text { Change }\end{array}$ \\
\hline $\begin{array}{l}\text { Section General } \\
\text { Operations Sub-Section }\end{array}$ & $588^{5}$ & $\begin{array}{r}5 \\
592\end{array}$ & $\begin{array}{l}0 \\
4\end{array}$ \\
\hline Power and Maintenance Sub-Section & 557 & 558 & 1 \\
\hline $\begin{array}{l}\text { Process Sub-Section } \\
\text { Radiation Monitoring Sub-Section } \\
\text { Plant Engineering Sub-Section } \\
\text { P-IO Extraction Unlt }\end{array}$ & $\begin{array}{r}202 \\
72 \\
29 \\
35 \\
\end{array}$ & $\begin{array}{r}202 \\
73 \\
28 \\
35 \\
\end{array}$ & $\begin{array}{r}1 \\
0 \\
1 \\
-1 \\
0 \\
\end{array}$ \\
\hline Section Total & 14.88 & 1493 & 5 \\
\hline
\end{tabular}

C. Safety Experlence

There were no major or sub-major infuries in ihe Separations Section in January.

D. Radiation Experlence

A total of seven Class I Radiation Incidents was expertenced in January. Four of the Incidents were characterlzed by violations of established procedures, and the other three were directly or indirectly caused by insufficient control of radio-mathenlum emission from the Redox Plant stack. Deseriptions of the incluents are as follows:

1. Abnormal emission of an estimatied 260 curles of ruthenlum from the Redox stack caused by a malfunctioning caust1c scrubber (\#333). "The ruthenlum caused wldespread ground and vegetation contamination within and outslde of the 200 West Area. Appropriate measures were taken to avold exposure to personnel.

2. Potent1al internal plutonium deposition to four operators during removal of the P-2 fllter stick from Cell 3 in the Isolation Bullding (\#334).

3. Potential intemal deposition of alr borme pission product contamination to two employees whlle worktng in the Redox crane cab (\#335).

4. Personnel contamination result1ng from unexpected contamination encountered at two unused slutce and pump p1ts in the 241-TX Tank Farm (\#336).

5. Potential overexposure to two employees takjng electrode measurements in the 241-BX Tank Farm (\#339).

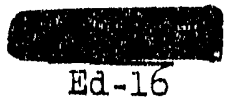


D. Radiation Experlence (Continued)

6. Contamination of a trainman, three locomotives, and three eask cars apparently resulting from necessary operations in the bighly contarai. nated Redox ra1lroad tunnel $(\# 340)$.

7. Grose personal contimination of an operator in the Isolation Butlding during sampling of the final product golution and subsequent removal of contaminated surgical gloves (\#341).

A serious threat to fundamental contamination control methods occurred Wh the uncontrolled release of several hundred curles of ruthenlum from the Redox stack. Surface dose-rates up to $7.5 \mathrm{rep} / \mathrm{hr}$ on the ground inside the 200 West Area neressitated road resurfacing and access dental of extensive ground areas in order to prevent further spread of contamination.

Several cases of locomotive contamination and personnel clothing contamnation of the train orews occurred. Even with amission rates as low as 1 curle of ruthentum per day, ground contamination up to $50 \mathrm{mrep} / \mathrm{hr}$ accumulated within 5 days around the Redox stick area and rallroad out area. The thaw of the snow, whlch is contamlnater around the stack area caused more frequent tlire contamination in the latter part of the month. All unnecessary vehlole trafflo was restricted from the exclusion araa.

The condensers on the selff-concentrating 1.01-s and 104-S tanks were observed to discharge steam and liquid at inf requent intervals which resulted in ground and snow contamination up to $600 \mathrm{mrep} / \mathrm{hr}$ at a distance of 50 feer. Metal shelters with class wool filters were instelled on an emergency basis to confine this source of contamination.

E. Personnel Act1vities

\section{Conference Leading Program}

On January 18, elght additional Separations Section personnel completed the Conference Leading training course conducted by Training and Development Personnel.

\section{Report Writing Course}

Seven Separations Section exempt personnel completed the course in report writing offered by Technical. Information on Januery 4 and. 6 .

3. Process Training Courge

Thirty-one non-exempt Power and Malntenance personnel completed the Process and Special Hazards Training Course offered on January 12 and 19.

4. Emergency-Disaster Training

In January, eleven Separations Section personnel completed Technlcal Rescue Training in connection whth the Emergency-Dlsaster program.

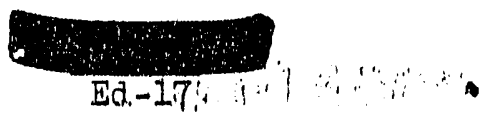


E. Personnel Activities (Continued)

5. G.E. Supervisory Selection Program

Evaluation was completed for flve Fower and Malntenance personnel during the month.

6. Non-Exempt Employee Information Meeting

The twelftih and final meeting in the current serles of information meetings for non-exempt employees was held on January 15 with total
attendance of 100 .

\section{Visitations}

P.E.I. Nussbaum attended the Fifth Annual National Maintenance Conference in Chicago on January 25-27, and visited the Malinekrodt Chemical Plant in St. Louls on Jaruary 28 and 29 for consultations on mutual maintenance problems.

C. C. Hinson also attended the Maintenance Conference In Chicago on Jenuery 25-27.

B. D. Wilson addressed the annual meeting of the Brewster, Washington Chamber of Commerce on January 20 in regards to work in the atomic energy field.

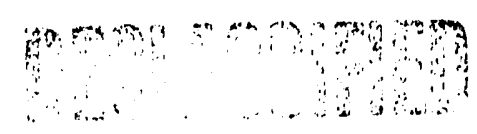




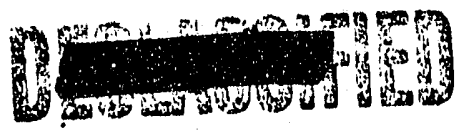

HW-30724

ENGINEERING DEPARTMENT

JANUARY 1954

\section{TECENICAI SECTION}

Two basic techniques for the bonded jacketing of uranium which were being developed in 1953, have now been adapted for the production of bonded J slugs: a hot-pressing technique for diffusion bonding and a vacuum canning process for Al-Si bonding. The canning of about a thousand slugs in each of these manners for production test irradiation in the hot spot in C Pile started this month. Several hundred $J$ slugs are also belng canned by the " $C$ " process (cold canning - unbonded), as previously used in the DR-10 load, for this test at high tube powers to get direct information on their performance and serve as a basis for comparison to prospective superior performance of the slugs cenned by the other methods.

The hot-pressing technique is also being used to effect diffusion bonding of the cap-to-can closures of lithlum aluminum target "N" slugs (the slug jacket is also bonded as a consequence of the process). These slugs and some "C" process-canned II-AI slugs will also be charged as part of the high tube power test.

Canning of thorlum cores in thick-walled cans by the $C$ process--cold sizing--was initiated this month, recognizing that production conditions will be more severe in the future. Radlographic inspection of the closures will ensure detection of most of the slugs with faulty closures and these can be rejected from lots to be charged. Radlographle inspection of the lithium-aluminum, tritium target slug closures has apparentily contributed to reducing the failure rate by a factor of at least 25 as evidenced by the performance of radiographed "C". process slugs in the DR-10 load as compared to non-radlographed "B" process slugs in the $H-10$ Ioad.

One or more unbonded thorlum slugs, " $B$ " process canned, falled in tube 3884-H this month at an exposure of about $800 \mathrm{MWD} / \mathrm{AT}$, necessitating interruption of pile operation. The process tube was split by action of the slug rupture and water admitted to the graphite. Arrangements have been made to examine these fallures as soon as possible.

At month's end, all piles except $C$ and H were operating on tube outlet temperature limits. H was limited by maximum allowable graphite temperature at 30 percent helium, and $C$ operated on a tube power limit. The tube power limit at DR was relleved because of assurance of attaining the P-10 production commitment and was on outlet temperature limft at month end.

Production test evaluation of 900 MWD exposures in the "hot spot" at C produced four cleavage faliures of elght-inch metal in the exposure range of 700 to $850 \mathrm{MWD} / \mathrm{AT}$. There were elght uranium slug failures during the month.

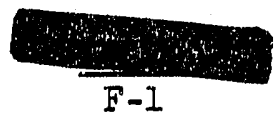


Study was given the physics and operational aspects of full-plle J-N loadings for P-10 production in DR Pile. A speclal production test to evaluate the performance of $J-N$ pairs at high specific powers at $C$ PIle

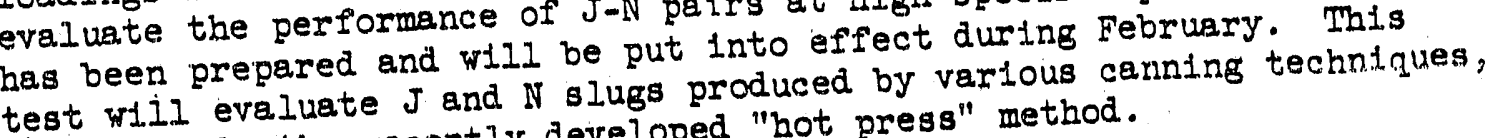
partlcularly the recently developed "hot press" method.

Studies are also in progress to determine the conversion efficiency of a full-pile J-thorium loading.

Major problems encountered during the month at the Redox Plant stemed principally from mechanical equipment difficulties which directly and Indirectly led to ruthenium contaminatinfluence of other mechanical diffiProcess performance, exclusive of the rol "head-end" treatment achleved culties, was improved by better control feed tank and variable flow jetby installation of a new centrifuge feed tank permitting concurrent processfeeder system. A modified rewor and waste rework solution was evolved from ing of dissolver metal solution and and utilized in the recovery of specificalaboratory studies, demonstrated, ano waste batches. An increased amount of tion grade product streams from the underground waste storage tanks which eruptive action was noted from power levels during irradiation, (2) higher is attributed to: (1) HIghor Plant, and (3) decreased waste volumes (mod1fled flowsheet) per ton of uranium processed.

The performance of the new RA Columans for their firgt month of operation has demonstrated that extraction waste losses can he reduced to less than 0.5 percent. In addition, decontamination achieved (dF values of 4.5 to $4.7 \mathrm{vs}$. 4.2 to 4.4 with old columns) exceeded estimates and indicates that the new scrub section has more than double the number of contactor atages found in the former columns. Adequate decontaminat on of wastes aged as Ilttle as 3.2 to 3.4 years bas cycle operation equivalent to the performance may permit deferment of tweliminary results indicate that the production of 1500 tons of uranlumalc acid (about 0.25 wt. percent relative addition of small amounts of sulfame acld (about of um concentrators and to UNE) is effective in reducing $\left(20\right.$ to 40 percent) of the product $\mathrm{UD}_{3}$ from calcination.

Further semiworks studies on nozle type perforated stainless steel plates for pulse columang disclose the column capacity to be increased approximately 10 percent over plastlc plates and 30 percent over standard stainless steel perforated plates; the helght of a transfer unlt remains about the same relative to a standard plate and increases about 10 percent over a plastic plate Semiworks scale studies of acidic total dissolution of jacketed slugs (present process uses caust1c jacket removal step) bave been successful.

The critical mass of plutonium in weter solution depends on the content of Pu-240 in the plutonium. The separations plants at Hanford have been pro-

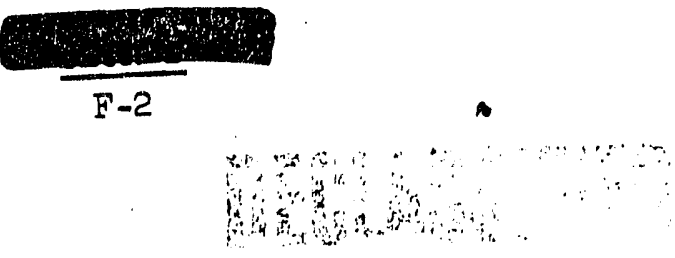


cessing $600 \mathrm{MWD} / \mathrm{T}$ uraniun and are now required to process extensive amounts of $200 \mathrm{MWD} / \mathrm{T}$ uranium. The concomitant decrease in the Pu-240 content leads to a decrease in plutonium critical mass and therefore a revision of nuclear sarety requirements is needed. This revision has been largely made and in most cases requires either safer geometry or smaller batch sizes. Alternative methods not requiring a reduction in the capacity of the plants are being sought.

Anisotropic growth of zirconium is reported to occur under certain conditions when the metal is heated in alr. As air is a comon pile gas impurity and since any such growth of process tubes would be very objectionable, study has been inltiated of this growth phenomenon. The elongation of a $1 / 2$-inch diameter $x$-inch long rod of zirconium heated in air at $700 \mathrm{C}$ was followed dilatometrically. Gross longitudinal growth, lncliding surface corrosion, amounted to 17 mils in 10 days. However, after mechanical removal of the surface corrosion product, the net change in length of the base metal was found to be a decrease of five mils. It is planned to expose specimens of Zircaloy -2 , which has been obtained recently, under conditions precluding surface corrosion interferences with growth measurement.

Preliminary examination has been made of six washer-shaped specimens of zircortum which had been exposed 60 days in an H-Pile dry process tube at an estimated temperature of 475-500 C. A. black coating had developed on all surfaces, except for some peripheral areas whlch had turned white. Fine grain metaliographic paper scratch marks were stili visible on the surfaces. The average welght gain of all samples was $0.45 \mathrm{mg} / \mathrm{cm}^{2}$, with no correjation being evident elther in appearance or in weight change with degree of cold work $(0-50 \%)$. This welght gain corresponds to a minimum penetration of only $0.5 \mathrm{mil} / \mathrm{yr}$. The condition of the base metal will be investigated by hardness and density measurements.

A concerted attempt is under way to demonstrate by July 1 the feasibility of a new solvent extraction separations process. The use of a heavier than water solvent--carbon tetrachloride--35-50\% TMP, and operation at an elevated temperature is expected to yield higher uranium or thorium capacity, greater safety and more decontanination per cycle than is possible with Purex process.

\section{DESIGN SECTION}

During the month direct engineering effort for the Section was distributed approximately 35\% to Expansion Program activities, 35\% to research and development studies and $30 \%$ to other projects and design orders. This reflects a gradual decline in Expansion Program activity as the major items near completion and a corresponding increase in research and development effort.

Design on Project CA-512-R, 100-K Reactor Facilities, was essentlaliy completed during the month. The Water Studies Semi-Works was advanced $7 \%$ during the month to $100 \%$ complete. A project proposal was submitted recommending the inclusion of the recirculation facility in the scope of the profect.

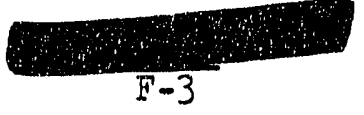


Detail design of the 200 Area Expan:isn Program, Froject CA-513, was cortinued on the Purex Outside Facilities, which was advanced $2 \%$ during the month to $100 \%$ complete. Design of the Ect Sem1-7orks Conversion is $90 \%$ complete, an advance of $17 \%$ during the month.

Detall design of the 300 Area Expansion Program, Project CA-514, was advanced $1 \%$ during the month to $79 \%$ complete. The small advance resulted from changes in the 313 Bullding design due to the $3 X$ Program and the diversion of englneering personnel to the latter program.

Deslgn work on Project CǴ-549, Act1vate Task I, Bullding 234-5, was advanced $23 \%$ durling the month to $68 \%$ complete.

Over-a.1.1 deslgn on Project CG-551, Expansion of Bullding 234-5 Facilities, was advanced $7 \%$ dixing the month to $76 \%$ complete.

Scope des1gn work on Reactor Plant Modiflcation for Increased Production, Project CC-558, advanced to approximately $56 \%$ complete, an increase of $12 \%$ during the month. Detall deslgn is $3 \%$ complete. Additional design funds were authorlzed maklng a total authorization of $\$ 200,000$.

Reviaion 4, Project CG-562, Waste Metal Recovery Plant Modiflcations, to provide solvent treating faclilties, was submitted and approved by the Commssion. Over-all design of these Pacilities is $25 \%$ complete.

De: ign on Project CG-567, Alum-Activated Silica Treatment Facilities, was advanced 15\% during the month to $90 \%$ complete. Design work for 100-B was completed and 100-H was revised to include 1tems requested by the Manufacturing Department.

Eanford 3X Program atudies were performed during the month to provide a basis for a letter to the Comasion establishing Hanford extraction and puriflcation plant requirements for additional P-10 production and the estimated cost of these facilities. A preliminary project proposal is being prepared requesting author1zation to start design work on the required facilities and establishing dates, w1th respect to the authnrization of funds, necessary to the auccessful completion of the over-ali program. Design was started on the 300 Area portion, consisting princ1paliy of modifications to the 313 and $303-J$ Buljdings to provide space for fuel element canning and $1 \mathrm{~s}$ now $25 \%$ complete.

A design and development program for the Dual Purpose Reactor was estabIlshed and a document lssued outlining program and design objectives, target schedules, cost est1mates for design and development and basic design-development criteria.

\section{PROJECT SECTION}

At the end of the month, construction completion status of major projects was as Pollows: CG-496, Recuplex, 31\%; CA-512, 100-K Area Fac1lities Water Plants, KW, 52\% KE, 39\%, General. Faclilties, 57\%; Reactors and Bulldings, KW, 53.2\%, KE, 22.3\%; CA-513, Purex Fac1lity, Part "A," over-

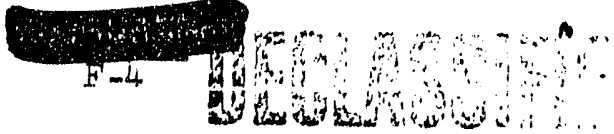




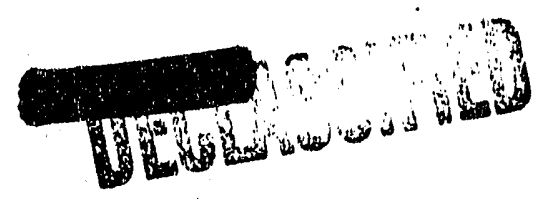

a11, 18\%, Part "B," 98\%, Part "D," 9\%; CA-514, 300 Area Expansion, cver-al1, 26\%; CG-535, Redox Capacity Increase, Phase II, 8\%; CA-539, Redox 241-SX Tank Farm, 56\%; CG-573, Hanford 3X Program - 300 Area, 4\%.

The two-week work stoppage by carpenters and millwrights reduced the effective construction forces by an estimated 40-50\%: On January 11, about 40 General Electric employees were furloughed for lack of work in 2101 Bullding. On January 18, the strikers returned to work following transfer of Jurisdiction to the Ching Fanel. A brief work stoppage on January 21 was caused by $35 \mathrm{Kalser}$ machinists who protested the relocation of a radial drill. When another drill was obtained, the machinists returned to work on swing shift of the same day,

Continuous efforts were made to obtain qualified off-site inspectors to care for the increasing workload. Inspection was completed on 164 orders, and 189 new oxders which will require inspection were recelved. At the end of the month there were 932 orders for 1tems which required inspection.

The last three major bulldings of the Hanford Laboratory were declared complete as of the end of 1953. The 2101-M Bullaing was declared complete, with a minor exception, at the end of January. Most outside work in 100-K Aree was delayed by the corpenter-millwright atrike and adverse weather. Small amounts of concrete were placed in the 105-115 KE Buildings, and work was completed on catwalks and miscellaneous steel in main tunnels of 183-KW. The 181-KW River Pump House was structurally complete, and the firgt pump is belng prepared for setting. In the 105-110-115-KW Bulldings, installation wes continued on electrical and control systems. For the 105-KW Reactor, Installation of cast iron was completed on both right and left sides. All rlght slde thermal cooling tubes have been installed and leaded, and the left side tubes are being installed. Five sections of downcomers were finish-machined, and five of the longer sections were fabricated but not machined. Of the 6,032 process tubes recelved, 1020 have been tested, reamed, and annealed on the inlet end. For the 105-KE Reactor, grouting was completed in the following crates: Second tier sides, third tier inlet, and fourth tier outlet. Mock-up of 205-KTH graphite was completed January 26 . For KE graphite, production shop work was $26 \%$ complete and the fabrication bhop work was $17 \%$ complete.

Because of the carpenter-miliwright strike and adverse weather, only 2466 yards of concrete were added to $202-\mathrm{A}$ Building and related structures. Some 11 mited progress was made on burled plping, condult, and ventilating ductwork. Blaw-Knox and X-Ray Products executed a subcontract for X-ray inspection of welded stainless piping in fixed canyon installations. Shop fabrication was continued on piping for Hot Pipe Trench and drains in 272-E Mock-Up Bullaing; steel Installation was completed on January 11. and four mock-up tanks were installed. Construction of the $13.8 \mathrm{kV}$ Trans mission Iine was stopped during the extreme weather. Work on the 2901 Export water line was stopped to await parts for repaling damage incursed-A during testing. Excavations were begun for 2ll-A Chemlcal Excavation for Stack, and 291-A Fan Eouse, to about $75 \%$ complete. P1pe-laying for the $8 "$ raw water line was begun. For 24I-5X Tank Farm, a design change to accom-

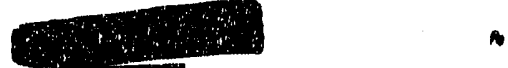


plish self-evaporation of liquids was requested of AEC. 'This change is expected to incraase the life of the tank farms three to five times.

ORGANIZATION \& PERSONNEL

Total on Roll, January 1, 1954 Accesslons

Separations

$$
\begin{array}{r}
1,514 \\
14 \\
31 \\
\hline 1,497
\end{array}
$$

Total on Roll, January 31, 1954

The 21 employees in the drafting splinter groups throughout the Plant were tranaferred to the organizational component for whom they were performing drafting work.

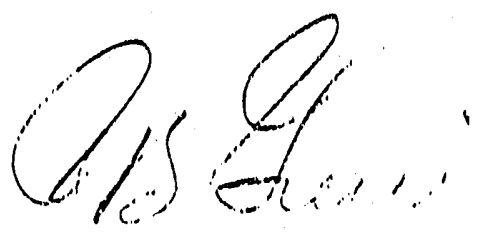

A. B. GRENINGER, MANAGER

ENGINEERTNG DEPARTMENTS
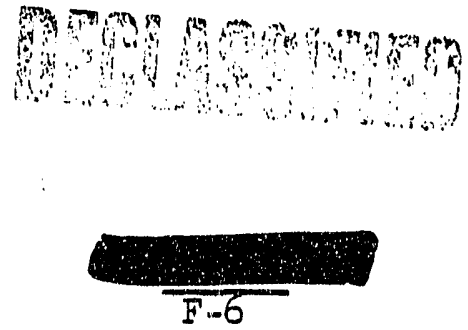


\section{(2) \\ ENGINEERING ADMINISTRATION SUB-SECTION}

EWW -30724

JANUARY 1954

The price of graphlte delivered under the third increment of Speclal Agreement G-5 was negotiated with the National Carbon Company in New York Clty during the month. The prlce agreed to was the same as for the second increment--\$0.34442 per pound. This price is one cent per pound less than National Carbon sought, and the savings thus obtained amount to about $\$ 12,000$. Agreement was not reached, however, on a price for graph1te to be delivered under the second increment on G-23. National Carbon had sought an Increase of about $1 \frac{1}{2}$ cents per pound, but had Insufficient data to back up this increase. They will submit additional information in the near future.

At the request of the AEC, the quantity of graphite to be produced under the G-12 contract was reduced an additional 625 tons to a new total of 2,000 tons of acceptable pile grade materlal. This step was taken by the Cormission to reduce the contemplated slze of the stockpile at Hanford. The cost of cancelling the 625 tons of graphite on G-12, together with the 500 tons prevlously cancelled, w11l amount to about $\$ 245,000$ versus about $\$ 437,000$ to complete at this time.

Testing of Speer graphite for radiation damage characteristics by the Technical Section Indicated that the material is satisfactory for use as filler blocks in the central regions of a plie and in reflector zones. About 950 tons of Speer material will be used in these locations in the KE Unit.

Examination of graphite produced with a sodium caronbate inhibitor, and using shrink sticks in the sagger bake, by National Carbon under G-12 Indicated that internal crackl.ng of bars has been greatly reduced by this means. Whereas uninhibited bars showed a cracklng propensity of $75 \%$ to $85 \%$, cracking in bars produced with the use of the Inhibitor appears to be only about 2\%. The density of this materlal is about 10\% higher, also.

A new Security classification, CONFIDENTIAI-UNDOCUMENTED, was established at Hanford durling the month. This classification w1ll generally replace the "Restricted" classification formerly used, and provides a means of issuing documents containing fragmentary defense information or restricted data without the necessity of rigid document control.

Stechert-Hafner, technical book brokers of New York City, were low bidders on a requisition to supply the Library's reference materlal for 1954. Last year's requisition, which was also awarded to Stechert-Hafner, will be kept open for a two months' perlod to permit the shipment of as many onorder 1tems as possible. This procedure w111 minimize the number of items to be transferred to the new order when the old order is closed out.

Work was started January 6 on converting the basic classified document accountability records to IBM cards.

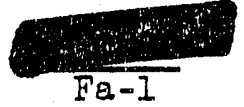


Englneering Administration Sub-Sect1on

$\mathrm{EW}-30724$

Considerable progress was made during the month in setting up Files extensions in the 200 $\mathrm{W}$ and 100-D Areas. Space bas been located in both of these areas (Room 17, 1717-D Bullding in the 100-D Area, and Room 9, 2704-Z Bulla1ng in the 200-W Area) and renovation of these rooms for Files' use was under way.

A member of the Radiological Sclences monftoring group spent some time in the 300 Area Classifled Files monitoring documents returned by a chemist whose flle was found to be contaminated. Four documents had to be removed. These documents, plus fifty-seven others too radionctive to be handled outside the laboratory, were destroyed after the contents of the packeges in which they were wrepped were vlewed by representatives of Files and GE Security.

The Manager, Englneering Administration Sub-Sect1on, was appointed Top Secret Document Custodian early in the month. The 700 Classifled Flles Supervisor was made his alternate and the Top Secret repository moved 1nto her offlce. An Inventory was completed of all Top Secret documents In the repository and of those documents charged out to 700 Area personnel.

On January 18 coples of HW-28965 "Readying Papers for Publlcation" were distributed and more than 520 had been sent out at month's end. The document, whlch apparentily fliled a long-felt need for a compliation af publication clearance procedures and declassiflcation data, was well recelved. Coples were also distributed to a number of interested personnel ofistite.

Durlag the month the following major contract actlvitles were handled:

1. Prlces have been negotlated covering changes in egtlmated quant1ties of work to be performed by Telef1lm, Ino., under proposed special. Agreement No. G-39.

2. Mod1f1cation No. 5 to Subcontract INo. G-283 between Sheppard T. Powell and General Electrle covering an extension of time is st111 in the hands of the comission for review and approval, having been sent to them December 24.

3. Modiflcation No. 4 to Spec1al Agreement No. G-22 between General Electric and Future Farmers of America, Ine., cover1ng an extension of time and transfer of title of sheep was approved by the Comission January 20.

4. Spec1al Agreement No. G-37 between General Electr1c and Paclfic Sclentifle Company of San Francisco covering the calibration of a BaldwinSouthwark testing machine was approved by the Comission January 4.

5. Durling January, all necessary close-out papers and estlmates coverlng Speclal Agreement No. G-2l between General Electrlc and Bird Machine Company were executed and final payment was made to the contractor and

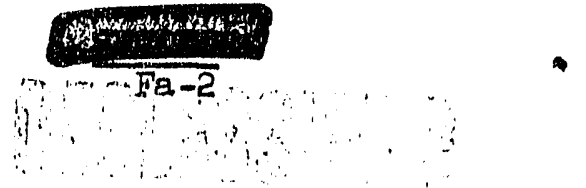


Engineering Administrat on Sub-Section

the account closed.

6. Consultant Agreement No. 118 between General. Electric and Joseph P. Dieves of San Francisco covering services as a camera man and consultant 'in connection with General Electric's documentation film program was approved by the Commission January 7.

7. Consultant Agreement No. 119 between General Electrlc and Panellit, Inc., of Chicago, Illinols, covering consultation services in connection w1th instrumentation was approved by the Comission January 12.

8. Consultant Agreement No. 120 between General Electric and Applied Research Laboratorles of Glendale, Californla, covering consultant services in connection with the quantometric analysis of standard samples furnished by General Electric was sent to the Commission for approval January 27. 


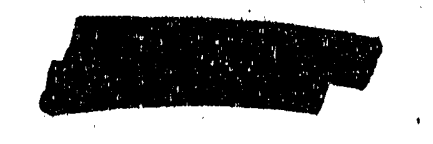

$H W-30724$

\section{PILE TECHNOLOCY SUB-SECTION \\ MONTHLY REPORT \\ JANUARY, 1954}

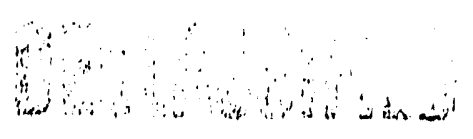


N.E. Hustion and C. W. Wheslook visited A. B. Carson from North Amertoan Avlation, Ino., Downey, Callfornla, January 19 and 20, 1954, for tochnical conferences on the reactor safety profoot and Hanford tests.

L. P. Bupp and J. F. Musio viofted Battello Memorlal Inotitute, Columbur, Ohio, January 18, 1954, Speer Carbon Company, St. Mary's, Pennsylvan1s, January 19, 1954, and Speor Carbon Cormpany, Nlagara Falls, Now York, January 20, 1954, for technical conferences on graphito. Mr. Mus1c aloo v1sited National Carbon Company, Columbia, Tennesseo, January 15, 1954 , for tochnfeal disoussions on graphite.

J. C. Fox and Q. E. Wado visited Fhillipg Petroloum Company, Aroo, Idaho, January 26 and 27,1954 , to arrangements for the operation of radiation facllity.

S. Goldemith vialted Argonne National Laboratory, Lemont, IIlino1s, January 12, 1954, to attend the A.E.C. Project Corroston Meeting and to discuse corrosion problems. He also visited Westinghouse Atomio Power Division, Pittgburgh, Pennsylvania, January 13,1954 , and the A.1uminum Company of Amertca. New Kensington, Pennaylvanta, January 14 and 15,1954 , to discusa corrosion probleme.

$R . S_{0}$ Paul went to the Bureau of Standarda, Waghington, D.C., January 26 and 27, 1954, to atterid the Scintillation Counter Symposium, and then attended the Amerloan Phyalcal Soclety Meeting In New York O1ty, January 28 through 30,1954 .

ORGANIZATION AND PERSONNER

Personnel totalo are an follow:

\begin{tabular}{|c|c|c|}
\hline & Deoembar & January \\
\hline $\begin{array}{l}\text { Adminlstrative } \\
\text { P1le Englneerling } \\
\text { P1le Materlals Development } \\
\text { Speclal Irradiations } \\
\text { Technical Ilalson }\end{array}$ & $\begin{array}{r}4 \\
78 \\
59 \\
23 \\
0\end{array}$ & $\begin{array}{r}4 \\
74 \\
59 \\
24 \\
4\end{array}$ \\
\hline Total & 164 & 165 \\
\hline
\end{tabular}

i. Llineering: One Technical Graduate - Rotational trangferred in from " "incturtng-Reactor-Plant Englneerling, one Technlcal Graduate trangferred I" trom Fuel Technology, one Technical Graduate - Rotational trangferred to Profect-Reactor Projects, three Englneers were trangferred to form the Technical Lialoon Sub-Unit within Plie Teohnology, one Junior Engineer cerminated to enter the Army, and one Technical Graduate was converted to Junfor Englneer. One Technical Graduate - Rotational wa remasigng P1]. Englneering Unit to P1lo Materlale Development Un1t。 


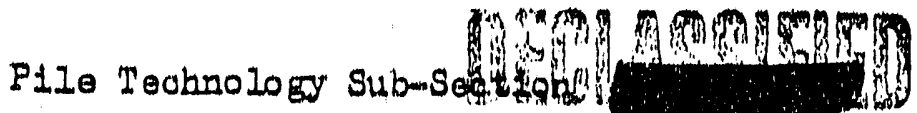

HW- 30724

Pile Materlals Development: One Engineer wes transferred to form the Techniogl Lila1son Sub-(InIt within P1le Technology, and ore Tochn1oal Graduate - Rotational was ro-asslgned from Plie Englneerding Undt。

Spectal Irredtationa: One Seoretary o transferred in from the Plant Protection Section.

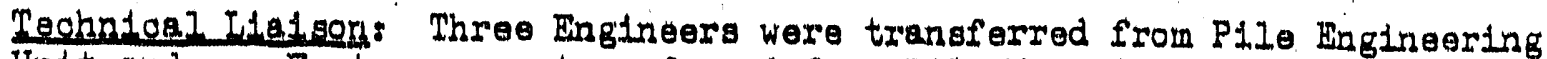
Unit and one Englneer wa tranaferred from P1lo Matorials Development Unit to form this now subundt.

\section{PROCESS TECHNOLOGY}

Power Level Intitio

At the end of January all piles except $B$ and $O$ were operating on tube outilet temperature limftr as determined by corrosion effects. H was Iimited by the maximum a.1lowable graphIte temperatura at 30 per oent hollum, and $C$ operated at a maximu tube power. At DR the power per tube limit was raised by steps and at the end of the month the pile was on a tube outlet temerature limit, whloh $1 \mathrm{~s}$ specifled a $90 \mathrm{C} ; \mathrm{D}$ and $H$ are authorlzed by Production Test to operate at $95 \mathrm{C}$. New high levels were attalnad at a.ll plles primarily as a result of decreased inlet water termerature, except at C P.1le where the maxtrum tube power had been increased 14 per cent at the end of Deoember, and at DR as discussed above.

Slug Rupture Expertance for January

Elght urantum slug fallures occurred during the month.

Six urantum oleavage fallures occurred in elght-inch slugg in the oentral orlfilce zone at C PIle, with four of these at exposures between 700 and $850 \mathrm{MWD} / \mathrm{AT}$. One fallure was a Group 9 Metal plece, and the others wero Group 11 Metal. One oap faliure, the flrgt of this type at $C$, occurred In a Group 8 Metal. plece in the fringe zono.

A aide fallure of a Group II Metal plece occurred in the cential orffice zone at $\mathrm{A}$ PIle, cousing a procese tube loak。

S1x broken elght-inch p1eces have been discovered in the metal discharged from $H$ P1le durting a regular outage. Each of thee plecea was broken Into two cylinders approximately four luches long. No rupture Indications were detected before this motal was disoharged.

Ruptures in Special Loadings - "wo ruptured AI-U235 alloy "J" pleces were discharged from DR P1le. Each plece had a crack in the can wall near the weld ond. Th1s brings to five the total of" "J" elug miptures at RR.

Flve ruptured Al-U235 alloy "C" pleces were discharged from four H-P1Ie tubes. One of these pleces had a pin-bole in the gide of the can; one was cracked at the cap end, and the other three pleces exhlbited swelling near the cap and. Th1s brings to 35 the total number of observed ruptured "C" plecea. 
A ruptured thorium slug caused a water leak in the central orifice zone at H P1Ie, Inspeotion of the tube showed two swolien areas on one of which was a craok approximately one lnch long.

\section{Hgher Specific Power Operation}

Production Test 105-533-A - The effects of Inoreased tube power localized in a dentral region of C P1lo aro being invest1gated by changes in the poison arrangement. The plie has nominally operated for one month under higher tube power Ilmits authorlzed on the basis of this test. There are insuff1clent data at the new (935 KW per tube) linit at this time from which to draw significant conclusions. The high percentage of nonequilibrium operetion this month has further reduced the quantity of hlgh-power data.

Production Tegt 105-549-1 - This test authorizes the exposure of 200 tubes covered by Production Test 105..533-A to a concentration of 900 MWD/AT. Four of the Group 11 Metal cleavage fallures this month occurred in metal being Irradiated under Production Test 105-549-A. Exposures of the tubes ranged from $700 \mathrm{MWD} / \mathrm{T}$ to $850 \mathrm{MWD} / \mathrm{T}$. These were the firgt muptures to ocour In this "high exposure" metal, although approximately 50 tubes were discharged at the production test goal expogure in December. Shortly before the occurrencie of the first of these fallures, tube powers were inoreased. During January these four tubes had operated at powers 50 to $100 \mathrm{KW}$ above the previous tube power limt.

Production Test 105-531-A - The flnal report on the H P1le enrlchment test is complete and will he sent in for printing in February. This report (HW-29166) was co-authored by persomnel of Pile Physics and Process Technology organizations and primarily presents the physles problems associated with this test.

Production Test 105-551-A - The iest to expose thordum slugs to about 1,500 MWD/AT is continuting with six tubes in three piles providing deta. These data wlll be pertinent to the problems associated with large scale U233 production.

U233 Production - A rough draft titled, "Recommendations Concerning the Production of 30-Kg of U233 by ApriI I, 1955" was prepared and 1s being circulated for comment. Approxtmately 400 tubee loaded with 19 pairs of" $J$ and thorium slugs could provide this quantity.

\section{PIIE PHYSICS}

\section{Physios Aspects of Spectal Loadings}

In accord with the present plan to oharge the avallable J-N naterial Into the DR P1.le during the next few months, recommendations were forwarded to the Reactor Section concerning the method of harding the loading. It was recormended that $20 \mathrm{~J}-\mathrm{N}$ palrs centered w1th an eight-1nch natural uranium slug at elther end be charged per column in all but approxdmately 300 column; these consisted of approximately 25 columns to be used for flatienIng and posstbly later for enrichment, approximately 50 ooluma in locations

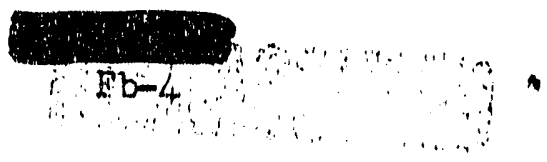




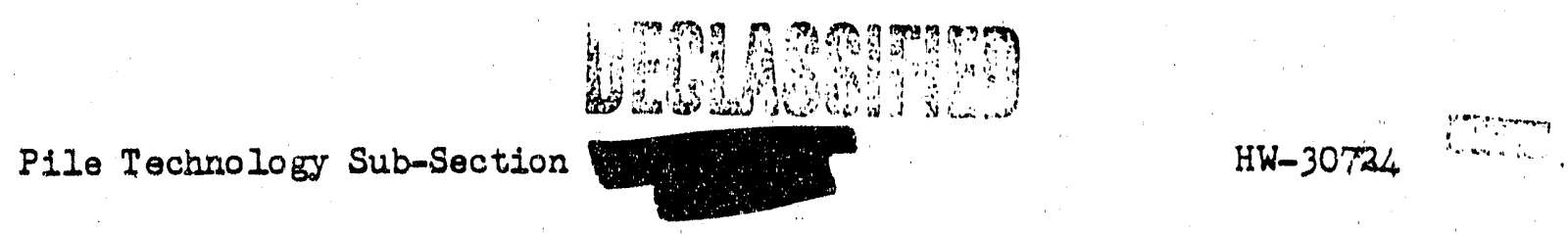

suitable for temporary poison colums to bo chargad with ratural urarium with a goal exposure of $200 \mathrm{MWD} / \mathrm{T}$, and the remainder low heat generation columas whych would not achieve goal exposure in the avallable time under present tube ismits.

The physics aspects of the proposed J-N production tests in C P1le were coordinated with the Heat Transfer and Pile Graphite Sub-Units and the Prucess Sub-Section Physics Application group. The 13-column block loading for studying heat transfer characterlstics and graphite burmout as a paris of the test will require some flattening re-location and the use of 100 per cent helium at some time during the exposure. It is felt that by employing present flattening re-location plans and by obtaining the 100 per cent helfum data shortly after starting up, the desired data. will be made available without significant production loss.

A study is currently in progress to determine the convergion efficiency of a J-thorium loading. The meager yield data avallable from flattening column irrodiation indicates apprecially lower yleld rates than would be expected on the basis of neutron economy in a J-thortum loading. Results of this study wlll be used by the Process Technology Sub-Unit in planning the short term 1rradiation program. Should the tubes loaded under this program be located in the DR P1le, they would replace a central block of $J-N$ columns but would otherwise not affect the recommendations previously mentioned for the DR P1le J-N loading. Recent test pile measurements by the Experimental Physics Sub-Unit of both J-N and J-thorium configurations will be employed in establishing the appropriate length of thorium slugs to be used.

\section{Safety Control Studies}

Results of the first test of the scram transient technique for measuring the control strength of the vertical safoty eystem appeared to give consistent but alightly lower values than had been anticipated. S1x scram transients were followed at $D P 1 I$ ie on December 30 , 1953, under Production Test 105-554-A which indicated a value for the 29-rod aystem under the excising flattening conditions of approxdmately 1300 in-hours. Further tests wlil be performed to establish the reproducibility of the data, part1cularly with respect to gamma beckground effects and to temporary poison column conf1gurations. Teata will also be performed comparing alde hole chamber data to under-pile chamber data to establish the effect of shadowing on test rellability.

Discussions have been held with Manufacturing, Design, and other Technical. personnel concerning modification of the present pile nuclear safety ph1losophy. The possibility that residual fisston heat would render a pile useless in the event of water loss requires that more emphasis be pleced on continulty of plle cooling, and Indicates that it is unrealdstic to demand sufficient capacity in the vertical safety system to control the pile against "any concelvable circumstance" once the pile has been rendered ineffectual by residual fission product heating effects. A document will be 1ssued shortly explaining the modiffed ph1losophy.

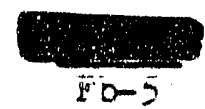


Shield Attenuation Studies

Analysis has been completed of the neutron attenuation data from conventlonally placed magnetite concrete and from conventionally placed ironIlmonite concrete which had been heated to $100 \mathrm{C}$ for three weeks prior to beling placed in the test wells. Because of 1ts lower water content and lesser density the magnetite concrete shows a longer relaxation length for fast neutrons than does 1ron-11monite concrete. The $100 \mathrm{C}$ exposure resulted as expected in greater neutron attenuation lengths in the iron-limonite concrete than were observed in the unbeated slabs.

The gamma intensity data may be used to estimate the intensity of the garmas incident on the blological shield. This estimated activity is approximately $6 \times 10^{6} \mathrm{mr} / \mathrm{hr}$ at the shield position corresponding to the front to rear centerline of fringe process columns which are on the average generating $100 \mathrm{kw}$ per column.

Intensity measurements in the simlated burned out iron-masonite shield (DT 105-548-A) are continuing with the second state of deterioration now in place and the foils from the first state now being counted. The first test configuration resulted in an average iron-hydrogen ratio over the entire shield thickness of 110 and the second in an average of 130, whereas there is a normal iron-hydrogen ratio of 840

\section{Shield Damage Studies}

Calculations regarding front and rear sinjeld demage rates relative to the active charge length indicate that neutron economy considerations and front face radiation tolerances should be the controlling factors. Because the front and rear shield temperatures are very nearly the same as local water temperature and because radiation damage in masonite is light relative to thermal damage at high temperatures, the front shield, regardless of charge length, will not receive damage rates comparable to those experienced in the uncooled side shields; rear shleld damage rates will be a function almost entirely of the extt water temperature.

\section{HEAT STUDIES}

\section{Tibe Flow Studies}

Preliminary economic studies by the Advance Technology Sub-Section have Indicated that a dual purpose reactor coolea by the vaporization of water at the slug surfaces might be far more economical than one cooled by the present method. Consequently, preliminary experimental tests were performed on the process tube mock-up to study two phase (steam-water) flow and cooling at high static pressures. The primary objective of the tests was to determine the effect of static pressure on the maximum outlet steam quality which could be attalned under equilibrium cooling conditions. The assembly consisted of an $\mathrm{H}$ type process tube annulus, C type outlet fittings and a beater tube which gave uniform (rather than cosine) heat generation along the length of the tube. The laitial operating conditions selected were 500 $\mathrm{kw}$ tube power, $200 \mathrm{psig}$ pressure in the rear crossheader and an inlet water temperature of about $6 \mathrm{C}$. It was found that the flow through the tube

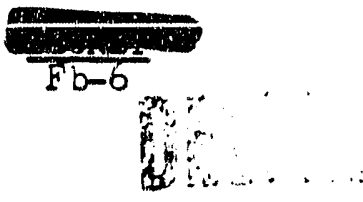


Pile Technology Sub-Section . HW-30724 ind

could be reduced to abcut $5.5 \mathrm{grm}$, and the computed steam quality at the end of the active zone for this flow we.s gbcit. 25 per cent by welght. The recorded outlet water temperature was $400 \mathrm{~F}$ and the maxcmum tube (surface) temperature was $462 \mathrm{~F}$. The pressure drop across the tube was about 85 psi. There is no evidence that the maximum quality condition. (minimum stable Slow) was reached; rather, lower flow conditions could not be studied due to limitations in the equipment. Modifications to the equipment are in progress, and plans have been made to perform further tests at 200 psig back pressure and also at 300 and possible 400 psig pressure. Should these tests show that high steam quality can be attained under equilibrium cooling conditions, they may greatly influence the basic design decisions for the dual purpose reactor.

The present process tube mock-up was designed for relative low static pressure conditions ( 0 to about 300 or 400 psig). Since it is extremely probable that any dual purpose reactor built at HAPO wlil utilize static pressures in the range of 300 to $2000 \mathrm{psig}$, the existing mock-1p is being modified and/or supplemented with equipment which will permit studies to the limit of that pressure range. The extsting electrical generators will be utilized in this modified rig, but new piping, pumps, heat exchanger, and a test section will be installed. The basic design of the system has been formulated although many detalls are lacking. Bids have been requested for a high pressure pump and a heat exchanger, the design of the heater tubes is progressing, and the piping requirements are essentially defined.

A former limit to pile operation was the high pressure drop which accompanies two phase flow in a standard process tube. Consequently, calculations were made to estimate the effect of static pressure on this preswire drop. It was found that, for a geometry moderately similar to that of an $H$ tube and for a 1300 psi static pressure, the usual hump in the boiling curve was completely missing. If this calculation can be verifled by experimental data, it wlll indicate that stable operation in the steam-water mixture flow range should be no problem insofar as excese header pressure requiroments are concerned. The range between 300 and 1300 psi static pressure has not been explored.

Assistance is being given on the design of the high pressure, recirculation loop at $H$ P1le. Safety against melting of the slugs is the primary point under consideration.

Tests were conducted on the process tube mock-up to simulate pile power excursions. However, it was found that insufficient control of the equipment variables prevented accumulation of worthwhile data. Modifications are being made to the equipment so that further tests can be made.

The experimental portion of the Meletron production test at $\mathrm{H}$ Pile was completed. On January 6, a pressure surge occurred in the Panellit test manifold and caused replacement of the Panellits; it was found that the Meletrons withstood this surge without any leaks and without any significant change in calibration.

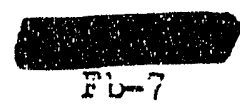


Tests were performed at the 190-D Butlding to determine the flow rates and pressures supplied by a pump set after loss of either steam or electrical power. It was found that the steam power loss resulted in a significantly greater decrease in flow than an electrical power loss. The study is continuing with particular emphasis on determining the probability of a steam power $10 s s$ and on determining more precisely the time delays butlt into the power $108 s$ and safety circulta.

Test3 were rade on a $K P_{1 l}$ prototype venturl in accordance with Design Test Request No. 45 to determine whether the venturi.met specifications. It was found that it did not.

The remaining drawings for the 189-D Hydraulics Laboratory were checked and approved. Construction has started.

\section{Frel Element Studies}

Thermal tests were made on a slug in which the urantum surface temperature was held at about $200 \mathrm{C}$ for one and three quarters hours. The axtal temperature was calculated to be about $475 \mathrm{C}$. No thermal cycling occurred except for the initial temperature rise and the finel decrease. Attainment of the high surface temperature was accomplished by coating the slug with an insulating varnish. Upon completion of the test the varnish was removed and the slug was axamined. The appearance of the uranium surface was found to be comparable to pre-test conditions except for the presence of "pimples" of uranium oxide. The cause for the randomly spaced pimples is not fully understood since they occurred without water contact.

Tests were performed to determine the thermal conductance of the Al-Si Lead Di.p type of bond. Only one sample has been tested and the conductance value was found to be relatively high, about $22,000 \mathrm{~B} / \mathrm{hr}$. ft. ${ }^{2} \mathrm{~F}$. Additional tests were made to determine the conductance value for the J-metal to aluminum hot pressed bonds. The preliminary results indicate that the conductance for this type bond is far higirer than the 22,000 value above. In fact, the temperature drop acrose this bond was less than the experimental accuracy of the equipment.

Production Test 105-522-A, "Measurement of Slug Axdal Temperatures," was issued and an enriched uranium slug with two thermocouples at the axis was installed in tube 2877-C. No difficulties wera encountered in installation. During operation axial temperatures as high as $638 \mathrm{C}$ have been recorded. However, control rods have always been positioned near the slug (for other reasons) during equilibrium operation and the heat generation rete within the slug has been relatively unknown. Thus, an accurate comparison between measured and calculated values can not be made although there are Indications that the actual temperature may be $50 \mathrm{C}$ lower thas the calculated value.

\section{Moderator and Other Studies}

Further calculations were made to determine the temperatures to be expected in the new boron carbide cortrol rods to be used as replacement rods in the older piles. It was concluded to be extremely unlikely that the outer aluminum sheath could exceed $400 \mathrm{C}$ above the rod cooling water even for $\mathrm{J}-\mathrm{N}$ loadings at $1000 \mathrm{kw}$ per tube.

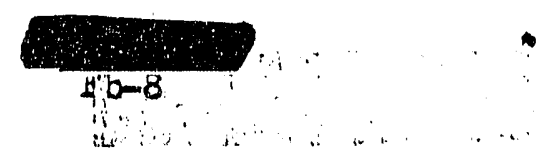


Pile Technology Sub-Section

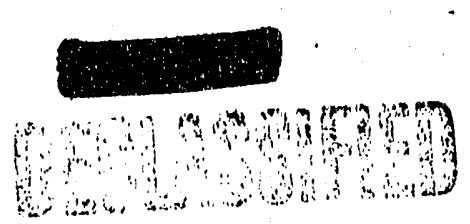

HW- 30:24

En:?

MECHANICAL DEVELOPMENT

Charging and Dischargtng Studies

The two charging machlnes being revised in accordance with the suggestions outlined in HW-28996 have been completed and are now in service. Their use for quickie discharges has been demonstrated in the 108-D Laboratory and approval for their use to perform this function is expected shortly. Work Orders have been issued for modifying the 100-D Area machines in the same manner.

The Design Test to determine the flushing characteristics of the poison column control system for the K P1les has been scheduled on the 108-D mockup and will begin as soon as remodeling is accomplished to accommodate the $\mathrm{K}$ tube.

\section{Hortzontal Rod Studies}

The rod tip extrusions for the horizontal rod conversion program have been completed by Alcoa and were shipped during the last week of this month. One of the tips w11l be installed on the 189-D rod mock-up and tested for functional characteristics. Upon completion of testing, a prototype installation will be made at one of the piles.

The development of a molded washer seal to fit the new rod has continued. The optimum diameter, number of washers, degree of interference and configuration have been determined. An order will be placed to obtain samples for testing.

A supply of a more pure form of boron carbide for use in the sintered ring coatings for the horlzontal control rods was received during the month. A complete set of rings for one tube will be fabricated and, if completed in time, will be used on the in-pile test of the converted rod.

An order was placed for a ribbed sphincter seal for application on the 105-C replacement rods.

Verticel Rod Studies

A report is being prepared discussing the results of test adepting the $K$ type vertical rod to permit alr acceleration of the rod during insertion into the pile.

Laboratory tests of the molded seal for use on the vertical rods have indicated very satisfactory operation at high temperatures. Damage occurred to the seals only after temperatures on the order of $800 \mathrm{~F}$ had been reached.

The built up washer seal installed on VSR-16C continues to operate sat1sfactorily. No leakage or apparent damage has occurred to date. 
A sertes of hardress rading were taker. on secticns of VSR'g $12 B$ and $35 B$ that salled recently while ir service Tha readins taken tndicated the hardness to be approxdmately ten undt; on the Rockwell C scale above that specified for the rod. Additicnal readings will be taken of the other rods that are in service to determine if this is a general characteristic.

\section{Process Tube Assambly and Plping}

Conslderable progress was made in the out-of-p1le phase of the program to determine maximum allowable tube inlet pressures. Only one major test remains to be performed. This test concerns the strength of the tubes with annealed Van Stone flanges. In connection with this program, a series of strain gages have been mounted on the periphery of a standard tube to determine the distribution of the radial stress, particularly in the vicinity of the ribs。

A Design Test request hes been accepted to determine the flow and pressure drop characteristics of four different types of crossheader strainers contemplated for use. on program CG-558 and the K P1les.

Work on the Design Test to determine the effects of temperature and irradiation on the rubber bellows to be used as gunberrel gas seals has been started. Four of the seala have been placed on the rear face of 105-H in a location that will aubject them to the greatest amount of heat and radiation to be expected in actual service. Another set of bellows has been placed in an oven in the 189-D Bullding for testing at elevated temperatures.

The flexure tests of the K Pile poison column tube connectors have demonstrated that the aluminum fittings are undesirable. Repeated flexure causes the surface of the stainless steel to work into the soft aluminum fitting, causing a leak。

\section{Materials Testing Reactor Test Faciltty}

During the past month the AEC Form 320 for this irradiation program was recelyed and approved at the MMR, which means that they will now be able to approve officially the design of the various components of our facility. The design work and procurement are completed. Delivery of the equipment from the vendors will now determine the installation schedule, with Indications that the facility will be avallable for use in early May.

\section{Phyglcal Congtant. Testing Reactor}

The design of the combination horizontal control and gafety rod was completed during the month. Shop drawlings have been made and an order placed for fabrication of the prototype. The design of the movable carriage for the front face section of the reactor was started and 1s now approximataly 50 per cent complote. A design ordor was placed for the detaling of the graphite layout. Preliminary plan, view, and elevation drawings will bo 1ssued in the near future.

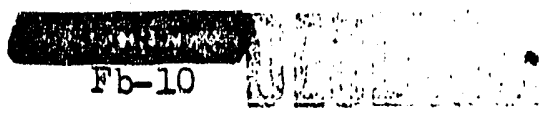




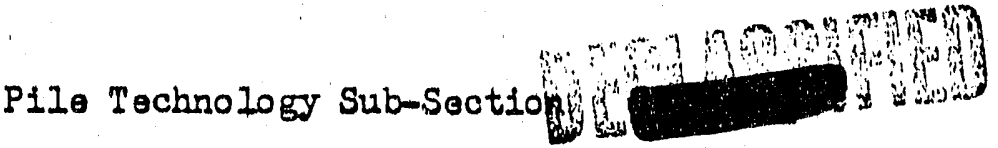

$\mathrm{HW}-30724$ TER

The design criterta for the reactor bullding has been flnalized and the criteria forwarded to. the Design Section for final bifldirg design. Plot, plan, and architectural drawings ar expected to be avallablo for comont in the near future.

\section{Other Engineoring Dovelopment Work}

As a result of the Supplementary Report 1ssued last month on the application of television as a rear face monitoring device, the Plant Engineering Unit has started scoping work for a permanent television instaliation at B Pilo. Present plans are that the installation will consist of two cameras mounted on the barricade wall and having oufflclent movement to permit adequate coverage of the entire rear face.

Design and drafting work has been completed on the core boring device for the Graphite Sub-Unit. Procurement of equipment and fabrication of the components has started.

The new drive unit for the graphite mining device was inatalled in the 305-A Laboratory. The control panel has been altered. Test runs will be conducted early in February.

\section{EXPERIMENTAL PHYSICS}

\section{Slug Rupture Detection}

The prototype gamma ray spectrometer slug rupture detector continued to monftor effluent activities as cyclically sampled from eight crossheaders and both risers at $\mathrm{H} P$ ile in a reliable and maintenance-free fashion. A rupture which later resulted in an $\mathrm{H}$ P1le water leak was detected several hours prior to the initial indication on the dew point monitors. The beta system did not detect this rupture at any time; this performance again points up the need for improved rupture detection in minimizing the production $10880 s$ and potential permanent damage to the piles accruing from undetected ruptures. The project proposal authoriaing the replacement of the beta systerns at all areas by the gamma spectrometer units has been prepared by the Design Section to be submitted to the A \& B Committee for approval early next month.

An initial series of on-pile meesurements of the gamm intensities and spectra assoclated with the contaminant deposit on tube rear nozzle assemblies following a rupture was completed. These data indicate that the expected ten-fold increase in the sensitivity of detection techniques employed in 1solating the specific tube containing the rupture cen be reallzed. Colilmation of the source radiations, increased detector sensitivity, and energy selectivity are the major contributing factors lending to the higher over-all sensitivity。

The instrument components for the adaptation of the garma spectrometer slug rupture detectar to be employed as the effluent monttor in the Materials Test Reactor slug testing facility have been received. System mock-up and test w1ll be performed next month. The system has been sufficlently slextble to accormodate the process modifications made to date in the mode of faclilty operation. 
Mog sidrement. df the Neutron Diffiston Length in the KW PtIe Graphite

The necessary arrangements for experiments to determine the diffusion length for thermal neutrons in the KW P1le graphite have been jointly developed with Project Section personnel and are reported in HW-305I8 by D. C. Pound. The pre-test scheduling, preparation of data forms, and scheduling of "on the spot" data treatment are now about 80 per cent complste. The equipment 1s largely avalieble at present and Instrument tests w1ll be inftiated early next month. It is now expested that the measurement will be made late next month.

Investigations of the nature of the correction terms to be employed for process tubes, density and the presence of holes have been made. A supplementary experiment has been designed to determine the correction for "steaming" through large openings such as rod and test holes.

\section{Measurament of Lattice Constants}

A method of experimentally determining the lattice efflctency for converting $U^{235}$ to plutonium has been devised which appears to have promise. The distributions of fission and plutonium producing reactions through a slug are normalized via the thermal cross sections with the epi-thermal corrections made from the appropriate cadmium rat1os and the fast fission contributions experimentally subtracted. This method was employed in a measurement utilizing standard uranium slugs in the Test Pile Lattice to yield a conversion ratio of 0.86 with the major uncertainty appearing in the cholce of cross sections used to nornalize the experimental distributionso Plans are now under way to make this determination in an operating $105 \mathrm{P}$ ile Lattice。

\section{Instmament, Development}

Development Test 105-561-A has been prepared to authorize in-pile test1ng of an irnproved process tube ion chamber design. These chambers are expected to be used in a quadrant or octant-type monitoring application at those plles where adequate monitoring facilities are not provided. These chambers should provide response characteristics whlch meet Technical specifications for a primary control instrument such as the galvanometer system.

A "gray wedge" pulse height analyzer is being fabricated to provide a crude but economical equivalent of a mult1-channel energy analyzer. An automatic scanning and recording spectrometer is also being built. This and the "gray wedge" analyzer will have primary applications in ganma spectroscopy.

Development Test 105-56/4-A was prepared to authorize on-p1le tests of a 12 point prototype of the K P1le temperature monitor. These tests are expected to point out major weakeresses in the syotem prior to the full pllo Installations at the K P1les. The major portion of the equipment is now on hand and the tests should be infitated naxt month.

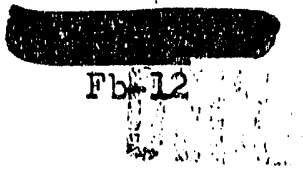


Automatic Tube Outide+ Water Temperature Recordtug Fac1l1t19g

The Flexowriter automatic outlet water temperature recording facilities operated routinely although minor component servictng was required. The Flexowriter installation at C P1le still does not conform to the specificam tions to which the vendor contracted.

\section{Induced Radiations in P1le Materials}

In-pile irradiations have been made of zirconium and zircalloy to asseas the handling problems regulting from the radioactivities which are induced through neutron capture. The Ilmitad number of samples studied to date indicate that primary zirconium activities are of prime importance and impurities are not a major contributor to the gross activity. Th1s study on zirconium and zircalloy is continuting to yiold a firm ploture of the Induced activities for HDPR as well as potential exdsting pile applications.

Test P1le - Routine Tests

Regular metal testing procoeded routinely. Thirteen b1llet egg lots yielded value ranging from 12 to 15.

Test P1le - Graphite Tests

The general purity level of TS-GBF graphite produced under contract G-j continued to be erratic. In general, material from the ends of the furnace yielded a purity index of greater than 100 while the midale portions averaged less than 90. The TS-GBF material produced under contract G-12 hos improved substantially in purity while maintaining a high density of about 1.70 grams per $\mathrm{cm}^{3}$; $211 \mathrm{G}-12$ material tested this month was allocatod grean.

Three heats of National Carbon graphite which had been Impregnated with sodium carbonate as a growth inhibitor to reduce ber cracking were tested to yleld acceptable purlty and a high density areraging about 1.73.

The purity of graphite produced by Speer continued to be very good with about 85 per cent of the material ylelding a purity index exceeding 105. The density continued to average about 1.64 。

Test Ptile - Special Testo

An oxtengive series of single column meesurements were made in the Test Pile studying the reactivity characteristics of onriched loadings designed for large scale tritium and/or U233 próduction. The U235 was introduced Into the load in the form of "J" slugs - 7 por cent U235 - aluminum alloy and "E" metal - 2.75 per cont U235 in uranium - while the target ploces were If thium - aluninum alloy and thorium slugs。

The effective neutron absorption cross section for K Pile aluminum process tubes was determined to be 0.225 barns. This value is equivalent to that determined for C P1le process tubing and $1 \mathrm{~s}$ to be compared with 0.219 berms for super pure aluminum.

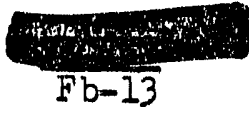


P1.10 Tochnology Sub-Section

Progress has been mado in the analys1s of the natural uranlum motal temperature coefflolent of reactivity which was prevlously dotermined in a caroful Tost P1lo oxporinent. Tho largeat uncertalnty 18 in oorrections for the atyploal lattice coll whlch was modifled for the toot.

\section{Prototyoe Physiegl Constants Test Reactor}

The design of the prototype of the Physical Oonstanta Test Reactor has proceaded on schedulte. Graphite dotalling 1.s beling carried forth jointly with Deglun Section personnel, the full scale model. of the safety mechanism 1s undergolng test, a full sçelo model of a control rod 1s now betng fabrlcatod and speclfications for lnatruments and olroultry are beling prepared. Scope deslgn and design ortterla aro complote. Tho factor wh1ch w11l dictate the date the reactor can be made oritical 18 the completion of reactor housing fac1lit108. The General Eloctrlo Company has not yet recelved authorization from the Atomio Energy Comisalon to proceed with butlding englneerting and construotion.

\section{SPECIAL IRRADIATIONS}

Oparation of the experiment for the studying of the oreep rate of nickel (KAPL 105) under out-of-plle conditions has bogun. All throe nickel specimens exh1bit gat1sfactory functioning. In-p1lo operation at $F$ PIlo 1 s to follow Immediately upon completion of the ourrent work.

The release of energy after a pllo shutiown has been meagured in a singlo channel of heavy metal (Design Request 42). These data w11l be used to determine the adequacy of the clear, wello at h1gh powor lovelo.

Experiments are being designed to determine the effect of cortain gases on zircontum and zircalloy process tubes exposed to pllo radiation.

Reprosentativo samples of Ifthium target slugs and aluminum used in the alloying of these slugs are betng prepared for lrradlation to determine activity levele wh1ch w:1ll be encountered in future P-10 separation processes.
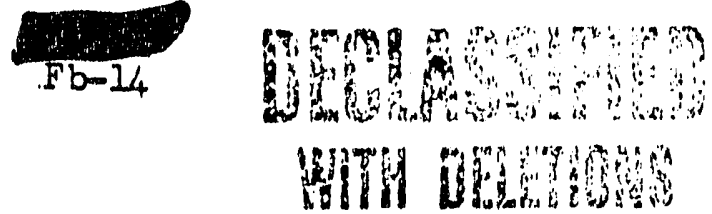
P110 Tochnology Sub-Sectiols

A saturation-soram recorder has been destgned and lo now being butit as a portion of the work in support of operating the low pressure, low temperature reclrculation loop at H Plle at higher temperatures and pressures.

Confirmatory values for the heat generation in aluminum by plle radiations have been obtalined. Two additional oalorimeters have been fabricated to obtaln sirilar data for ziroonium and 347 stalnless steol.

Two new cooled magazine facilities whthout thimbles were installed in the $D$ and $B$ holes at $H$ and $F$ Piles respectively.

Aotivities in support of 1sotope produation and additional off-site and plant asalatance irradiations continue.

\section{GRAPHITE STUDIES}

\section{Alternate Pfle Atmospheres}

Planning is essentially completed for experiments to determine whether nitrogen would be a sultable plle atmouphere. N1trogen has the advantage of being chemioally unreactive with graphite under irradiation. Therefore, a plle with pure nitrogen as the atrosphere would not have a temperature limit on the graphit comparablo to the one with carbon dioxide. However, considerablo ovidence exists that nitrogen in the presence of water vapor under Irrudiation forms oxtdes. This may be true with concentrations of water vapor such as are normaliy in plle atmospheres. The oxides may form nitric acid which could be corrosive to plle compononts. It is recognized that even though oxfdes of nitrogen are formed, they could be rendered. harmless by sultable chemical reduction. This type of ohomical reduction might bo provided by carbon 1tself at relatively high temperatures or by the addition of a sultable gaseous reducing agent such as carbon monoxide.

An in-pile experiment will determine:

1. The magnttude of corrosion caused by the reaction of nitrogen and water vapor under rather severe conditions.

2. The magnitude of corrosion caused by the reaction of nitrogen and water vapor when carbon is present for relatively high temperatures.

3. The magritude of corrosion caused by the reaction of nitrogen and water vapor when carbon monoxide is present.

4. The magnitude of corrosion caused by the reaction of nitrogen and water vapor when both carbon and carbon monoxide are present.

IS-GEF Graphite for the KE Pile

Production grade TS-GBF graphite has been received in which an additive was used in extrusion to decrease the cracking. Out of some 135 bars examined, less than five per cent were cracked. This represents a considerable improvement and if the quality is maintained will make it simpler to: obtain a satisfactory pile structure of $\mathrm{KE} \mathrm{e}_{\text {. }}$

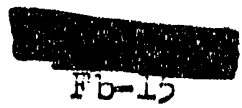




\section{Sneer Grenghtio}

A short term frrudiation evaluation of graph1te produoed by the Speer Carbon Company has been comploted. Samplea were tested in Hanford Iest Holes and at the MIR at Aroo. The material has boen found sultablo for use in three relatively noncritioal portions of the ICE staoking:

1. Top rofiector.

2. Bottom refloctor。

3. Green zocie filler blocks.

Insuffiolent time was avaliable to test the materlal for use in more critical pile locationa.

\section{Nav Purffítcation Procedures}

Tour experimental graphito heata have been mu at the Clarkaburg, Weat Virginia plant of the National Carbon Corapany. For these heats, vartables were the rate of freon gas flow, time, and maximum temperatiure of purification. AGOT material was purifled in al1 guns along with standard TS stook. The matorial has boen rocelved and teating in the 305 P1le will determine the effectiveness of these altemate purificam tions methods.

\section{Graphite Oxtdation}

As part of the burnout monitoring program, graphite gamples contained in aluminum wire birdoages were discharged from $D P_{110}$ and $H$ P 1 le. The temperature history of the samples from $D$ PI. Ie 18 varled In that the first month's exposure was about $450 \mathrm{C}$ whlle the second month's exposure was about 490-500 C. Samples almilarly oxposed at H PIIo had exposure temperature of about $500 \mathrm{C}$. The burzout rate in each case was observod to be loas than one por cent per 1000 days. A decided difforence in burnout rate was observod for tho two alzes of samplos exposed. Samplos of 1.25 Inches in diameter oxidized at a rato sIightly moro than half of those samplos of 0.425 inches diameter. Oxidation ratos for gamplos exposod in the front and rear fringe zone wers the same and we re measured at 0.07 per cant per 1000 days.

A supplement to Production Test 105-532-E was propared and is now boing o1rculated for upproval. The supplament authortzes a total of four procoss channols, located in the four gradianta of the pilo, for the monitoring of graphite burnout under the now process apocifications of maximum graphite temperature of $500 \mathrm{C}$. Samples wero charged at C Pilo on the original of the production tost.

A production togt 1s being prepared to authorizo the charging of a 13tube diamond array of J-N loading to explore graph1to bumout at tomporatures of $600 \mathrm{C}$ under pilo flux and gas atmosphare conditions。

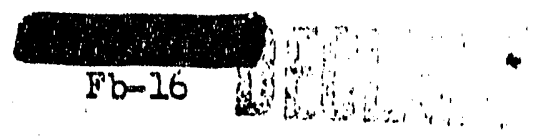




\section{P110 D1stortion}

Routine vortloal holght traverses have hoon made at $H, D$, and $B$ Pllos. In general, the traversea show continued annoding in the oenter of the plie with little or no change in the fringe reglons. At $H$ and $D$ P Ile, the traverses taken from the rear faco matched those from the f'ront face at the center Hire of the p1lo. However, at $B$ P1le, the two traverges did not matoh up by about 0.2 incheg. There 1 s no apparent explanation for this discrepanoy. The daty are betug chocked as to acouraoy and interpratation.

\section{P1 lo operation}

Operation of $\mathrm{H}$ PIIe under Production Teat 105-530-E continues in normal fashion. Plle power was Ilinited by maximum graphite temperature IimitatIons adjacent to tubes contalning enriohment. Maximum level continues to be about 24 per cont higher than previously obtalned.

Opexation of D P1le under Production Teat 105-531- continues with'. some Inorease in level as a regult of more efflolent operation. The plle power levell continues to be Ifint.ted by water corrosion limits. Operation under this production test for the past two monthe has shown no adverse distortion effects and burnout data reported above are encouraging.

Recent borescoping of the HSR thimbles at F P110 has indicated that some of the rod trouble at F PIle is the direct regult of thimble deformation.

\section{Graphdte Helium (Bulde) Dengity}

It is well known that the bulk denaity of artiflolal plie graphtte is mach lower than the density obtalned from x-ray measurements. By measuring the real density by digplacement of helium gas one oan show that about 25 per cent of the total pore apace cannot be reached by hellum gas unless the grephite is reduced to a very fine particle e1zo, or part of the stimcture is removed by unfform oxidation.

For the artificlal plle graphites used here at Hanford the helfum dengity $1 \mathrm{~s}$ found to be botween 2.10 and $2.17 \mathrm{gm} / \mathrm{cm}^{3}$. The beltun density of pure flakes of natural Madagascar graphlte was found to be $2.26 \mathrm{mg} / \mathrm{cm}^{3}$. The $x$-ray denglties of these graphites is f'ound to be in the nelghborhood of $2.2 .7 \mathrm{~cm} / \mathrm{cm}^{3}$.

Several experimenta on the beltum density of vartous graphite samples. reveal that the density deoreasea with low temperature 1rradiation. For a CSF sample exposed in MTR at the equivalient of $2500 \mathrm{MD} / \mathrm{CI}$ and at $08.50 \mathrm{C}$ the density found was $1.82 \mathrm{~cm}^{-\mathrm{cm}^{3}}$, or approximately a 14 per cent decreage a compared to 1to belium denalty value previous to irradiation.

The densitiy of graphlte 1ncrease日 with 1ncreasine oven oxddat1on. Several experiments have lndicated that, g.light inftial oxddation causes dansity to Increase more rapidly than in later stages of the oxidation. Preliminary experiments indicate that grephite density also increases with oxidation in the pile.

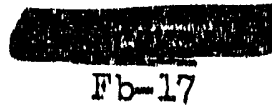


Denalty measurementa oan be very useful in monitoring the extent of oxidation of graphite latitioe in the Hanford plies. Exporinents are under way to establish relationshlpg between hellum densyty and oxldation, denslty and mechandar orrating strength, as well as oxidation versus mechanioal orushing strength. These experimenta w111 involve 1rradiated and nonlrradiated as well as oven and In-plle oxldized graphite samples.

\section{WATER PLANT' DEVETOPMENT}

\section{Flow Laboretort Studies}

Two In-pile tubes uging rew river water at pH 7.5 , and with 5 ppm diohromate added, operatad altisfactorily for flve weeks. No appraclable f1. Im formation occurred. Further out-of-plle data were obtalned ahowing that a pH of 7.0 results in lowered corrosion rates than does 7.5 , but alfighty higher fliming tendencios are observed at the lower pH value. The In-p1lo test of process water at pll 7.3 continued to optrate without diffioulty, although there is evidence of slow film bulld-up in the tubes out-of-ptide tests at $120 \mathrm{C}$ have shown that tho sorragiveness to aluminum of four water qualities descends in the following order, with very little difference $1 n$ the flist two: process water, flltered water w1 th $0.2 \mathrm{ppm}$ dichromate, process water at pH 7.3 , and raw water at pll 7.0 with 5.0 ppm dichromato.

Plang have been completed for the Installation of equipment to atudy the erosion-corrosion effects on aluminum of partially condensed steam at 105-D Flow Laboratory。 Design oonditions are 70 per cont steam quality at a. velocity of 200-250 feet per second. A degign teat of a "Cuno" type continuously cleaned filter has been comploted. Prellminary scanning of the data indicate that the "Cuno" fllter oould advantageously replace the presently used "Y" type strainers used in the plle purge systoms. The detalled degidgn of the 100-KD Water Studies SemL-Works 1s essentia,11y complete. Work is now proceeding on approved drawling for use by construction bidders.

\section{Water Quality Testis}

Examination of Irradiated slugs from the chlorine evaluation teat showed no difference in corrosion rates between slugs exposed to chlorinated and unchlorinated process water. The remaining tubes in this test are scheduled for discharge durlng the next shutdown. l'he lime-firee teat at 100-F operated sat1sfactorliy. Inspectlon of the Ime-iree clearwell showed that a conslderable portion of the settled materilal present at the start of the teat had been ramoved by the Ifmo-free water. A supplement to the production test was prepared to permit addition of amall amounts of Itme during the spring, and also to permit ine pH control by the acdition of gulfurlo actd.

\section{Water Plant Expension Studies}

All 183-D filter controllers have been modifled for tha high fliter rate plarit test, and are set for 7000 gpm \pm 10 per cent. Short term tests Indicate that satisfactory control will be obtalned, Jute delivery of the faw water flow meter has delayed the test, whlch 1s now expeoted to begla

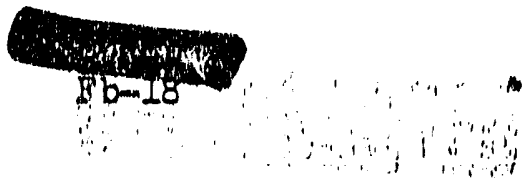


early in Fi mary, Sevarel water plart pr:mts cor Cu-558 were revieved,

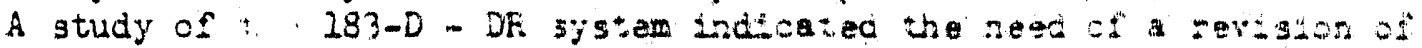

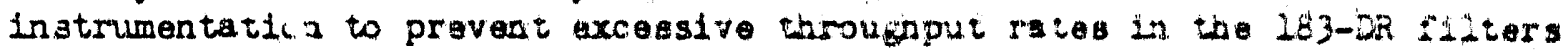
during backwash periods.

\section{Roctrculation Studios}

The recirculation test of process water in the 200-1/ 30op was complated. Modiflcation of the loop for blgh temperature operation is now in profress and is proceeding aatisfactorily. It now appoars that dolivery of a

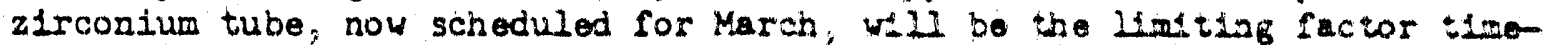
wise. Calculations were made to show that this joop car be used for an 1n-pile bolling tast at outlot pressures of $250-300$ psi. Work is progressing to determine the wact operating conditlons and procedures for a bolling test.

Work continued toward making the outwof-plle loops in 105-F Flow Latoratory operational. One loop has been adapted for bolling studfes. Outlet temperatures of about $180 \mathrm{C}$ at varying steam qualities are obtained with this apparatus. Operation of the 1sothermal (175 C) loop was delayed because of fallure of the liquid level control system. A pressurized delonizer was designed, built, and installed in the system. Also, a detonizer was constructed for installation in tho in-pilo loop at 100m. Sharal preliminary scope drawligs of the recirculation facilities in the 1700-KE Laboratory have been revieved. It is ant1cipated that approved scope drawlags will be available by the flrst week in March, 1954.

\section{PILE COOJANT SIUDIES}

\section{Production Tests}

The nine tubes of Production Teat 105-519-E in 100-C Pile have operated during January with average outlet temperatures between 90 and $100 \mathrm{C}$. The cause for these low average temperatures is the fact that C P1le has been below full power an appreciable percentage of total operating time. No slugs were discharged under the test during the month. H P1la has operated normally under Production Test 105-529-E during the month. The corrosion tubes have maintained 85 to $90 \mathrm{C}$ outlet water temperatures. Other production tests operating normally from which corrosion data will become available are Production Test 105-531-E at 100-D which allows $95 \mathrm{C}$ temperatures and Production Test 105-549-A allowing exposure increases in high power tubes at C Pila. Wolght loss data are being obtained from two tubes under the latter test that were discharged at 712 and $808 \mathrm{MWD} / \mathrm{T}$, respect1vely.

\section{Tube Examination}

Seven pile process tubes were examined during January. A total of nine were removed from the various plies. Observations on the tubes included further findings of severe slug function pitting and 72-S removal from tubes at $D$ PIIs and a light pltting attack at alug junctions in C tubes. No pitting has been found to penetrate into the 2-S alurinum of tubes from $C$ $\mathrm{P} \pm 10$, although local penetrations of the 72-S have occurred.

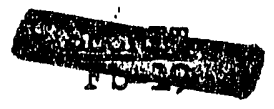




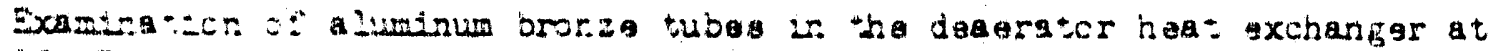

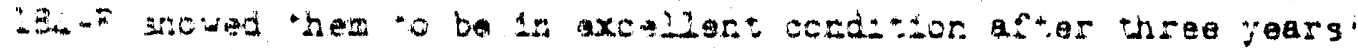

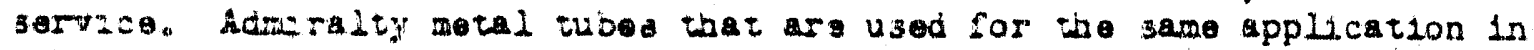
other areas lost approxumely two yars. It 1.3 beang recomended that: aluminam brome cubes be used is the futuro.

Tho tabe axamination p1t in tho IDS-P Storago Axua is now roady to oparato.

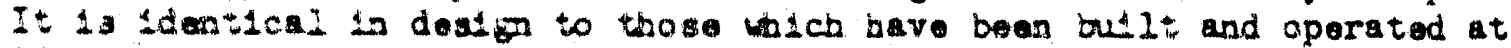
DR and $D$ Areas. Tho fac121ty for promstallat1on marking of $K$ P 10 tubes Is aso ready to operate whers tho tubos are put through their ingpoct1on.

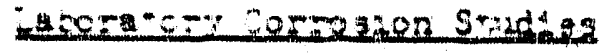

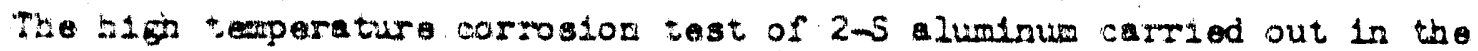
Mizizube pparatus was complosed during the moth. Cormsion data wero obrazied at cemparature of 95.215 , and $135 \mathrm{C}$ in proceas water for operatiog periods up to 60 dayn. At the end of 30 days, the corrosion ratas in $2 \mathrm{~g} / \mathrm{cm}^{2} /$ any wera $0.02,0.09$, and less than 0.01 for the throe tempraturses. respectivaly. The low rate observed at $135 \mathrm{C} 13$ the result of he protec:2on offered by the calcium carbonato 11/m deposited at this :aperature and above.

Thirty-fi7e sZug 3 that waro etched and autoclaved (somo in water and some In steam) in the laborawory have bean axposed for sevan woaks to process water at $90 \mathrm{C}$ a.long with 12 control sluga from 300 Arsa. Average wolght losses war 0.104 grams from the laboratory-propared slugs and 0.281 grams from the control alugs. The differance $1 \mathrm{~s}$ belloved to be rolated to the difforance in the integrity of the autoclave coats produced in the laboratory and in the manuacturing procoas.

Studies of corroaion in low dichromate concentration water are almost completed. These studies ahow no noticable difference from process water with respect to front tube corrosion, and slug corrosion at 90 and $120 \mathrm{C}$. No severo erosion-corrosion was diacovered elther. A production teat of low dichromate water 13 belng planned to start as soon as tho laboratory blgh temperature tests are completed during Fobruary.

Construction of new equipment which w11 allow testing under dual-purpose pile conditions is taking place and lncludes the following:

1. A natural convection loop designed to operete up to $300 \mathrm{C}$ with velocities of six to ten fps. Any desired motal sample may be exposed to any typo of water in this apparatus. It should start operation during February.

2. A Minitube apparatus 1s being installed in the 100-D powerhouse. Soft water avaliable there w111 be used to reach tamperatures not practical with p1le process. water. Oporation to $180 \mathrm{C}$ w11 begin in Fabruary. Addition of an electrically heatad tube to operate under bolldng and nonboliting conditions up to $230 \mathrm{C} 1 \mathrm{~s}$ being carried out.

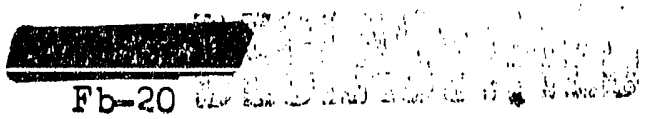


P1le Technology Sub-Section

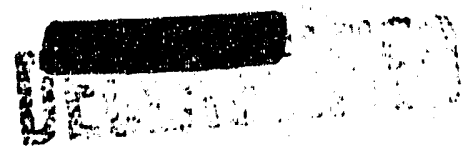

HW-30724

TECHNICAL LIAISON

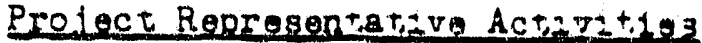

Technical Section representation was provided on $C G-512-R$ and $C G-558$ activities. For the former, approval was given to the $\mathrm{K} \mathrm{P}_{1} \mathrm{le}_{\mathrm{e}}$ temperam ture monitor system as back-up instrumentation for process tube water flow. For the water plant expansion program, approval was given to the choice of an improvad Panellit pressure monttoring system as back-up tube flow instrumentation. Other items given attention included justification for ald pilo rod thimble removal, bases for computation of comparative pcwer levels, header pressures expected under vartous pumping conditions, and back-up flltered watar supply。

\section{KE L LOOP}

Assistance was given to Design Section in preparing scope drawings on this facility. Final dimensions were chosen on those items affecting pile construction. Prollininary drafts of criterta wero prepared. Problems involved in procurement of zircalloy process tubes were discussed with Fuel Technology and representatives of Bridgport Bress. Proliminary process tube specifications were prepared and schodule requtrements outlined.

Attention was givey to the cholce of primary pumps for the recirculation loops. To obtaith the degree of water quality control desired, pump leakago must be kept to values much smaller than that possible with normal mechanical seals. Zero leakage can bo obtainod with "cannod rotor" pumps such as aro used on the STR, but with this design it is difficult to pro vide adequate fly-wheel offect for meintaining water flow in ovent of power loss or pump fallure. No dection has been reached on chotce of pimps.

\section{Foop}

No work specifically directed to the design of this facility was accomplished during the month. It is planned that those now working on the $\mathrm{KE}$ loop will continue on the F loop project as the KE loop work is completed.

\section{HDPR}

Assistance was given to Design on proliminary economic analyses of representative duel purpose reactor dosigns, with detailod consideration given to the operating and capital cost effects of in-pilo boliting.

\section{Tampar-Proof Safety Sygtems}

Representatives of North American Aviation visited Hanford January 19 and 20 to discuss progreas on their dovelopment of a tamper-proof, self-contained A reactivity control devico. Tho trigger under consideration is a solder plug designed to melt in caso of 1088 of cooling water or increase in neutron flux level to 150 per cont of normal. Control is to be obtained by a high noutron cross section gas such as hollum-3 or $\mathrm{BF}_{3}$ onrichod in the boron-10 1sotope. In the untripped condition, the gas would bo stored at 1200 to

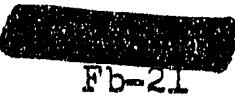


1:00 psi in a small fraction of the element volume. Molting of the solder plug wculd release the gas in to the remainder of the element, increasing the "black" volume by a factor groater than tan, and the reactivity offect by three or more. The feasibility of full pilo use of such dovices depands on the number roquired to obtain adequate control as well as roliability. To assiat in the ovaluation, it was agreod that Toat P1Lo mensuroments would be mado to determine the amount of reactivity taken up in the untripped condition, and the lncrease in reactivity of foct obtalined by tripping. From these data, an estimato will be mado of the effect on pile operating costs of amioying devices of this type.

INVENTIONS

All persons ongaged in work that might reasonably be expoctad to result in inventions or discoverios advise that, to the best of their knowledge and belief, no inventions or discoveries were made in the course of their work during the porlod covered by th1s roport, except as Ilsted below. Such persona further advise that, for the perlod therein covered by this report, notebook records, if any, kupt in the course of their work have been examined for possible inventions or discovarios.

\section{Inyentor Iitio}

W. E. Cawley Mothod for Ellminuting Direct Electrical Connoctions to Electric Appliancos

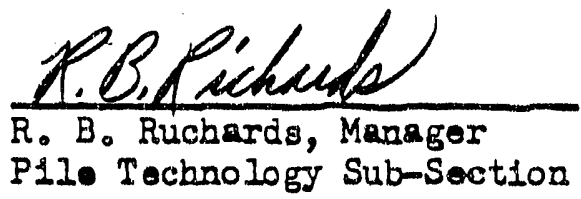

$R B R:$ INt 


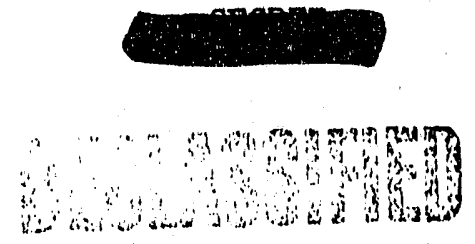

HW- 30724

and a

SEPARATIONS TECHNOLOGY SUB-SECTION

MONTHLY RFPORT

JANUARY, 1954

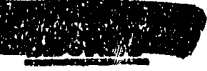




\section{VISITORS AND TRIPS}

G. W. Watt visited here from the Untversity of Texas, Austin, Texas, Jamuary 25 through 29 , on techridoal coprultations.

R. W. Levin visited here from chipld and Carbon Chemical Corporation, Paducah, Kentucky, January 12 and 13 , to discuss mutual process problems.

B. Schwennesen and W. Ginkle visited here from the AEC, Arco, Idaho, January 25 , on process consultation on "25" process.

D. L. Tima visited here from Mound Laboratory, Dayton, Oh1o, January 18, discussing $\mathrm{P}-10$ analytical problems in mass spectrometer.

L. E. Crean and F. Fahnoe visited here from Vitro Corporation of America, New York, New York, January 18 through 20 , on Iong range disposal problems.

E. P. Galbraith visited the Montana State College, Bozeman, Montana, January 11 and 12 , and University of Utah, Salt Lake City, Utah, January 13 through 15 , recruiting technioal personnel.

E. F. Kurtz visited the Eastem Industrifes, Norwalk, Connecticut, January 26 through 28 , far consultation on agitator procurement and Geo W. Dahl Company, Bristol, Rhode Island, January 29, for consultation on valve procurement.

W. R. Dellollander visited the Los Alamos Scientiflc Laboratory, Ios Alamos, New Mexico, January II through 15, on P-10 program liaison.

R. D. T1llson visited the Consolidated Engineering Corporation, Pasadena, California, January 21 and 22, on mass spectrometer and Knolls Atomic Power Laboratory and General Englneering Laboratory, Schenectady, New York, January 25 through 27 , on mass spectrometer and process control.

ORGANIZATION AND PERSONNEL

Personnel totals are as follow:

$\begin{array}{lrc} & \text { December } & \text { January } \\ \text { Adminlstrative } & 2 & 2 \\ \text { Chemical Development } & 82 & 7 \% \\ \text { Plant Processes } & 52 & 52 \\ \text { P-10 Process Studies } & 6 & 6 \\ \text { Analytical Laboratories } & \frac{36}{35} & \underline{172} \\ \text { Total } & 178 & 178\end{array}$

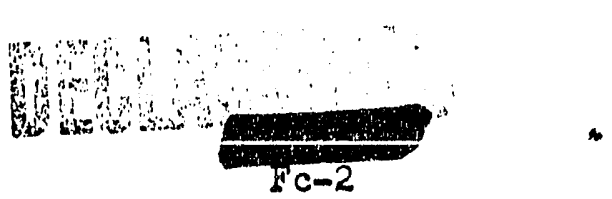


Chemical Development: One Technical Graduate - Rotational was transferred in from Operations Analysis - Procedures, one Technical Graduate - Rotational was transferred in from Project Auxillarles, one Technioal Graduate Rotational was transferred to Manufacturing - Separations, one Technical Graduate - Rotational was transferred to Manufacturing - Reactor, one Technical Graduate - Rotational was transferred to Design - Process Englneering, one Technical Graduate - Rotational was transferred to Radiological Sciences - Biology, on Technical Graduate - Rotational was transferred to Manufacturing - Separations, one Junior Engineer was transferred to Manufacturing - Separations, one Technical Graduate - Rotational was transferred to Analytical Laboratories, and one Stenographer was promoted to a Secretary "C".

Analytical Laboratories: One Technical Graduate - Rotational was transferred in from Chemical Development, one Junior Engineer was terminated and one Chemist was terminated.

\section{PUREX DEVELOPMENT}

\section{Process Studies}

Economic Comparison of Purex and Redox - In HW-30620, "Economic Comparison of Redox and Purex Operating Costs (New Installations)", comparative separations cost data are presented for new Redox and Purex Plants designed to process 4800 ton 13 of urantum annually. The flowsheets chosen as bases for the operating cost cal.culations are not the conventional "degign-besig" flowsheets but represent nore optinlacic operating conditions expected to be attained after the respective new plants have been "shaken down". ThIs evaluation shows that expected annual operating costs for a new Purex Plant operating with 2WW backcycling at 4800 ton uranium per year rate are approximately $\$ 2,100, C 00$ less than for a new Redox Plant employing complete waste backcycling.

Purex Vacuum HNO Fractionation - Pertinent design specifications and fabrication and operating techniques in support of technology and design basis for the Hanford Purex nitric acld vacuum fractionator were obtained by visits to the DuPont Company at Wilmington, Delaware and the Mallinckrodt Chemical Works in St. Louls, Missouri. The information indicatos the desirabillty of low pressure operation and is presented in Document HW-30484.

\section{Purex Plant Design Liaison}

Recomendations vere submitted to the Purex Project Unit for additional piping required to dispense nitric acld recovered from future separations plant operations. The piping additions embrace the minimum header requirements for introducing recavered nitric acld from outside sources to the dissolvers, and extension of the Purex recovered acid header to enable supply to the 20 Column.

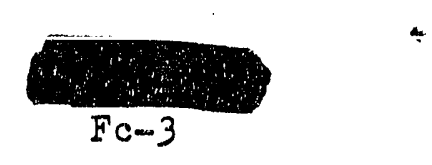


Future Purex separations processing of low exposire plutonium has required a review of plutonium equipment slaing and location with regard to nuclear safety. Initial recommendations calling for reduction in Raschig ring packed plutonium steam strlpping and deentralnment column diameters from 7.5 Inches to 7.0 Inches have been transmitted to the Purex Projeot UnIt.

\section{Chemical Engineering Development}

Three-Inch Pulse Column Studies wh th Nozzle Plates - N1neteen "C"-Type Column studies were carried out during the month in a three-inch diameter glass pulse column with "cold" uranium. Stainless-steel perforated plates (with 5/32-Inch diamoter holes, 23 per cent free area, two-inch plate spacing) with $1 / 16$-inch long nozzles (indentations) protruding downward from each perforation were employed. 'lhe functiou of these nozzles was to prevent the aqueous phase from wetting the underside of the plate, giving much the same effect as plastio undercoated plates. The result of these preliminary investigations were promising. With the organic as the continuous phase, the superficlal colum capacity was at least ten per cent higher than with plastic sleve plates of a more "open" design, at least four times as high as with "standard" (unindented) stainless-steel sleve plates with the organic phase continuous, and at least 30 per cent higher than with "standard" plates and the aqueous phase continuous. The measured H.T.U. values are not belleved to be the best obtainable, but even so they were lower than the most favorable "standard" stainlessmsteel plate H.T.U.'s and only slightly (ten to 20 per cent) higher than the best plastic-plate H.T.U. values. The flooding frequencies, and hence presurably the amplitude-frequency product requirements for good performance, were higher than for plastic plates.

\section{Techntcal Manual}

The writing of the Purex Tecinnical Manual was begun. On January 25 the preparation of the manual was approximately four per cent complete.

\section{Mechantcal Development}

Bearing Development - A 10 per cent conper - 15 per cent gilver - 75 per cent gold bearing has run in Iffe test on a bearing test machine for 180 hours. The bearing is running against a stell1te No. I journal at 1800 $\mathrm{rev} . / \mathrm{minute}$, under a load of $40 \mathrm{Ib}$ /sq.1n. with water as the luhricant. No wear ( $<0.0002$ inch) occurred on either the bearing or the journal and the surface finish of both bearing and journal was sligrtily Improved under areas of load.

Pulze Generator Development - The recomnended procedure for testing the PIrst production model of the Purex pulse generators at the vendor's plant has been forwarded to the Project Section.

Ifiguid-Liquid-Solid Centrifuge for IOO - Tasting of the 40-inch solid-w bowl centrifuge modifled for Ifquid-Ilquid-solid centrifugation was continued with sodium carbonato-washed Purex solverit and with simulated Purax IOO. Clear organic offluent was obtalnod in fivo-hour 50 gallons/ minute run with $50 \mathrm{C}$ faed, cascaded to the centrifuge diredtiy from a Io Pulse Colurm.

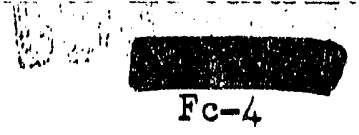


Heat-Transfer-Surface Corroglon Studies - Pllot plant scale corrosion tests of stainless-steel heat transfer elements in Tank F-4, Building 321, are being continued in cooperation with the Applied Research Subusection.

The beating elements have boen exposed to bolling simulated Redox Waste Concentrator (D-12) solution under total reflux for 41 days. The solution was replaced with fresh solution twice weekly.

After 41 days exposure it was found that none of the heating elements of elther the bayonat or steam-jacketed process tube type had undergone severe corrosion. The Carpenter 20 elements appeared to have been attacked more severely than those of Types 304J, $309 \mathrm{Cb}$, or 34.7. Both types of welds Lred on the test elements, $308 \mathrm{~L}$ and fusion welds of the parent metal, had exhibited good corrosion resistance in this test.

\section{REDOX DEVELOPMENT}

Process Studies

Self-Concentretion of Redox and Purex Wastes - Reduction of the integratedp1le-exposure level of the slugs processed in the Redox and Purex Plants from $600 \mathrm{MWD} / \mathrm{T}$ to $200 \mathrm{MWD} / \mathrm{T}$ does not, by itself, eliminate the need for the self--concentration vapor-handling facilities on the Purex ard hodox Waste Tanks. Actually, in roducing from 600 to $200 \mathrm{MWD} / \mathrm{T}$ the gross fissionproduct content of the 90 day "cooled" slugs 1s only slightly reduced (Iess than flve per cent). The concsintration in the slugs of short halfIf e flssion products which contribute most of the heat ovolved in the storage tanks during the tank fllling pertods encountered in Redox and Purex is proportional to the operating level of the plile rather than the integrated exposure level. Sinoe the operating level of the Hanford plles will more than Ifkely continue to increase in the imediate future, the duty on the tank farm condensers shortly after the tanks have been filled will probably be increased during the proposed processing of $200 \mathrm{MWD} / \mathrm{T}$
slugs.

\section{Process Chemistry}

Behavior of Activity Leaving the Ruthenlum Scrubber (H-5) - The invest1gation of the fission-product activity associated with the solids evolved from the Redox Plant stack was continued by studying the behavior of gases drawn from the vent sysiom downstream from the Ruthenium Scrubber $(H-5)$. The activity, Identified as 100 per cent Ruthenlum by the gamma-ray spectrometer, is only partially stopped by a sand filter, and is not stopped by or plated on agents or surfaces which would reduce RuO (e.g., Tygon tubing). It is completely stopped only by media auch as Fiberglas or paper filters which are designed for the physical removal of very flne particles. This is taken to indicate that the Ruthenium in the gas sample was probably in the form of particulate $\mathrm{RuO}_{2}$ (rather than gaseous $\mathrm{RuO}_{4}$ ), perhaps as the result of gasmphase reduction in the Redox Oxcldizer tower. 


\section{Mechanicg Development}

Mercury Catalytic D1ssolving - Five mercurymcatalysed dissolving runs of aluminum-jacketed fuel elements (two cuts/run) have been completed in the 321 Butlding Semiworks downdraft dissolver. Contrary to previous laboratory studies, $\mathrm{Hg}_{\mathrm{g}}\left(\mathrm{NO}_{3}\right)_{2} \cdot \mathrm{H}_{2} \mathrm{O}$ catalyst equal to two per cent of the weight of aluminum was insufficient to obtain somplete dejacketing of the slugs. However, complete aluminum dissolution was effected in the first cut of one run by using five per cent $\mathrm{Hg}\left(\mathrm{NO}_{3}\right)_{2} \cdot \mathrm{H}_{2} \mathrm{O}_{3}$ based on the weight of aluminum, and the total dissolving tirne for two cuts (about 100 per cent of the charge) was 19 hours, compared with approximately 28 hours for the present Redox Plant dissolvers.

\section{URANTUM RECOVERY DEVELOPMEAVT}

\section{Process Chemigtry}

RA Colum: Effect of Chemical Flowsheet Variables - A serles of ininiature mixer-settler runs was made to determine the effect of flowsheet variables on decontamination, urarium waste losses, and plutonium partitioning. The data obtained with three extraction and two scrub stages, Lndicate the following:

1. Hydroquinone was at least as effective as Fett as a plutonium partitioning agent and had no adverse effect on decontamination ox. uranium waste losses.

2. Recyciling of a used solvent without retreatment increased uranium wastie $1088 \theta 8$ by a factor of four to flve.

Evaluation of Plant BA Celum Scmpbtag Effictency - A serles of minlature mixer-settier rung was made in a 12-stage Mint minjature mixer-settler using 2,3 , and 4 scrub stages (stage efflctency not determined) in an attampt to duplicate the decontumination currently obtalned with the new "louverplate" RA Columns. Previous determinations showed that two "Minl" scrub stages duplicated the decontamination achleved with the old RA Columns. The new data Indfcate that $3.5 \mathrm{MInl}$ sorub stages are required to duplicate current plant performance, hence indicating an apparent 75 per cent improvement in scrubbing efficlency of the new column design over the old RA Columns. This lmprovement may only be due to the fact that the new colum.s have not yet become loaded with "crud" to an extent that their performance is lmpalred, or 1 t may be a real irprovement resulting from the new type tangential RAF feed distributor and the louver plates in the scrub sections.

RO Column: Rate of Urantum Trangfer - The rate of urantum transfer determinations for similated RO Column conditions using pulse-column-typo agitation, as reported last month, were extended to Include a comparison of aqueous-wet vs. organlc-wet ag1tators. The data indlcate that the organicwet agltator (which produces an aqueous-in-organic emulaton) is definitely superior. This tends to confirm the recent superior performace of fluorothene Raschig rings in three-Inch RO Colum studies operated with the organic phese continuous.
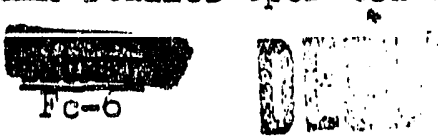


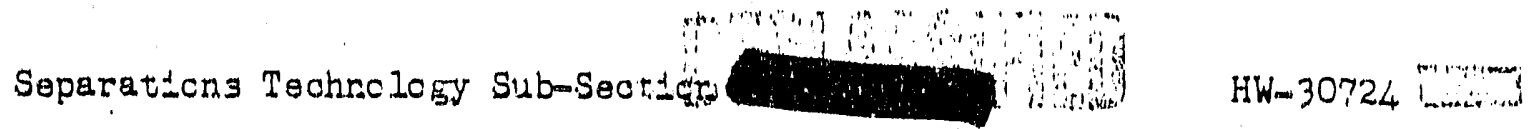

Reclatmed Kel-F and Teflon - Samples of "reprocessed" Kel-F and Teflon Impregnated with an ollve-drab dye were teated for thelr suitablilty as Ro Colurn packing material. On the basis of contact angle measurements, as well as disengaging times and rate of uranium transfer measurements made on solutions after prolonged ountact with the finely divided plastics, no differences could be seen between these materials and virgin Kel-F and Teflon.

Qlass Fiber UO Filters - Five samples of glass fabric recelved from the National Filter Media Corpcration, Salt Lake City, Utah, were tested as possible substitutes for the wool bag filters ourrently in use in 224-U Bullding ( $U \cap_{3}$ Plant). None of them retalned the $\mathrm{UO}_{3}$ under simulated $224-U$ Building conditions.

Reactivity of $\mathrm{UO}_{3}$ - It has been determined that the reactivity of $\mathrm{JO}_{3}$ may be Increased by 30 to 40 per cent by the addition of small. amounts ( 0.1 to 0.5 weight per cent on aNH bas1s) of certaln chemicals. The most promisting additives found to dato include sulfamtc actd, sulfurle actd, some ammontum salts and certain amines. Two plant tests using 0.5 welght per cont sulfamio acid (UNH bas18) wero made in the 224-U Building calcination pots and the following information was obtained:

1. As anticlpated from laboratory data, reactivity was increased by about 40 per cent, from a ratio of about 1.0 to 1.4 (relative to the Ma.llinckrodt standard).

2. The alfur added as oulfamlc acid was almost quantitatively retalned in the $\mathrm{UO}_{3}$ (confirmed by analysis of laboratory-calclned $\mathrm{UD}_{3}$ samples from INNH spuked with $\mathrm{H}_{2} \mathrm{SO}_{4}$ and sulfamic acid).

3. The agitatorg froze in both pota contalning sulfamic acid, indicating temperature-time cycle studies will be necessary to determine optimum operating conditions.

4. No foamting resulted from the oulfamio acid addition,

5. No 1ncrease in corrosion resulted from the preance of sulfamic acid as evidenced by spectrographic analysia of tho resulting $\mathrm{UO}_{3}$.

From the information to date, 1t appears that the Improvement in reactivity is contributed by the sulfate ion.

HOT SEMIWORKS

The decontamination of the Hot Semlworks continued.

Conversion to Purex

The design phase of the conversion effort 1s nearing completion. The design of the specialized equipment by the Technical Section 1899 per cent complete, and the ovor-all deaign effort 1888 par cent complote.

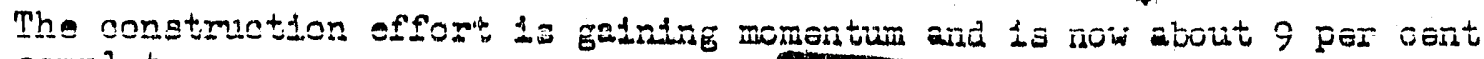
complote。 


\section{UEANIIN PESOYERY PROCESS TECTNOLOCL}

\section{Waste Soavenglag}

Approval to orlb up to 6000 gallons of forrooyandde-scavenged waster per square foot of ertb area was $g$ dver by the Radiologloal Scionces Section per memo of January 21, 1954. No restrictions conceming the utilization of oxalic aold as an RA Column plutonilum partitionlng agent vice ferrous ton arg indicated. A protat proposal for the construetion of $12,20 \times 20$ feet, cribs with assooiated 221-us Butlding chemical addition fiallities, trangfer equipment, and crib area test wells is in preparation. It is agreed tentatively to utiliza 106, 107 , and 110-BY Tanks for settling and sludge storage tanks and to locatio the ortbs in 200-E Area to the North of the storage tanks pending Planning and Scheduling approval.

\section{Solyent Extroctidon}

Solvent extraction operations were carried out at 71 per oont of nominal dosign capaoity using 20 volume por cont $M B P$ and dual scrub RA Columns to process the above tarks farm feeds along with 15 additional wolght per cent of rowork uranium. Highlighta of now information may be summarized as follows:

1. The nowly designed and instilled RA Columns permit processing "greener feeds": at lower solvent to feed uraniun ratios a illustrated by the following average performance data at 60 to 70 per cent of nominal design rate。

\begin{tabular}{|c|c|c|c|c|c|c|}
\hline & $\begin{array}{r}\text { Feed Ago } \\
Y \text { Y }\end{array}$ & $\begin{array}{l}\text { RAX FIOW } \\
\text { \& TAP HW\#4 }\end{array}$ & $\begin{array}{c}\text { Pulse } \\
\text { Cyco/ming }\end{array}$ & $\begin{array}{l}\text { Por Cont } \\
\text { P1nch Lل/ }\end{array}$ & $\begin{array}{l}\text { RAW Loss } \\
\text { Per Cent }\end{array}$ & $\begin{array}{c}\text { Gamma } \\
\end{array}$ \\
\hline $\begin{array}{l}\text { Now Columns } \\
\text { Ortg. Coluraris }\end{array}$ & $\begin{array}{l}3.4 \\
5.7\end{array}$ & $\begin{array}{l}120 \\
125\end{array}$ & $\begin{array}{l}85 \\
50\end{array}$ & $\begin{array}{l}65 \\
55\end{array}$ & $\begin{array}{l}0.3 \\
1.8\end{array}$ & $\begin{array}{l}4.5 \\
4.2\end{array}$ \\
\hline
\end{tabular}

2. RA scrubbing officlency, basod on laboratory roproducibility runs, appears to be throe to four theoretioal scrub stages comparad with 1.5 to two using the orlginal colurans.

3. RC Column cepacity, under prosent conditiona, Including low actd in reed (RCF) and RCX, and 20 volume por cont TBP requiling flowsheot $\mathrm{L} / \mathrm{N}$ of 1.28 to give consistentiy low. ( $<0.5$ per cent) losses, at ambient tomparature $1 \mathrm{~s}$ probably not ovor 6.5 tons of urantum por day. The volume per cent THP In RAX may noed to be increased, acid in RCX may be required to be roturned to the $0.01 \mathrm{M}$ flowahoot valua, ard oporating tomporature may be roquired to bo Increased to aanuro the expected required olght to ton tons per day processing rates in the presentiy installed column with satiafactory lossed.

4. Continued high solvent purity, $\left(E^{0 / a}<0.01\right)$ and 1 (n) gama activity in RAX (avorage 30 to 50 microcurles por gallon) has boon ruatalned, while procosalng 3.3 years aged feed, by the accolerated three wolght per cont sodium carbonat washing schedulo.

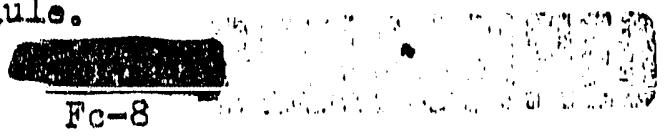


5. A sldght Improvement in RO Column ganma dr has been observed using tho less than optimum three weight per cents sodium carbonate to organis fllow ratio of 0.1 in the continuous aqueous phase, stalniess ateel Raschlg ring proked kO Collums.

6. Continued operation of a single cyole to produce epeolfitoation uranium produot from 3 to 3.5 years "aged" metal appears foasible oubjeot to sustalned grosa gamu. dir performanoe at tho present high 4.4 to 5.0 level as the flayion produot spectrum ahanges w1.th ohanging food sources and subject to sustalned low solvent activity levela.

\section{URANIUM PRODUCT PROCESSING - ACID AECOVEHY}

\section{Caloination}

Calolnation operations produced $\mathrm{UO}_{3}$ at approximately 63 per cont of design oapaolty during the report perlod. The production was composed of 65 per cont TBP and 35 per cent Redox-source feed. Production was limited by lack of feed. Total netali1c impurities averaged 201 parts par milion parts of uranjum. Plutonlum specifications were exceeded by alxand three parts per billion on two carloads and gamma flssion product speclfilcatiu.s was oxceeded by 15 and 23 per cent aged natural uranlum on two carloada. A.II carloads ware aocepted.

Reactivity improvement tests began with exploratory rung using 0.25 welght per cent sulfamic aold (uranium basis) added to a normal pot charge. Rakctivity increased 30 to 40 per cont but cakdng and Inoreased sulfur contaninant in the powdar presented two new problems.

The 60 per cont UNH Concentrator, E-B-1, falled January 21, 1954, for the fourth time since plant atart-up. S1x tubes had to be plugged making a total of 19 plugged tubes. The leakage was observed to occur at a polnt threefourth way up the tubes. Pot No. 9 liner was removed f'or purposes of furtiter corrosion study and posatble repalr. Sovern Intargranulax corrosion was observed on the vapor region of the Iner.

\section{Nitric Acid Rocovery}

Pot vacuum was Increased two-fold by Increasing the length of the Nitric Acta Absorber seal log from 60 to 100 inches. The increased vacuum not only - liminated almost all pot $\mathrm{NO}_{2}$ eruptions but decreased the number of bag fallures in the pot ventilation filtor syotem. Furthor inorease in pot vacuum is expected by use of Teflon plus Blue Afrioan mabeatos gasketing and. improved agttator stuffing box paoking.

Decrease in pressure drop across the Nitric Aold Fractionator indicates Increase in plate leakage. It is estlmated that geven plates are now "offective". Reduction in acid concentration from 60 to 40 por cent nitric aold should decrease this corrosion rate three to 15 fold.

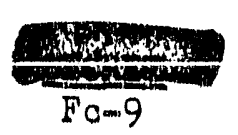




\section{BEDOK PROCESS TECHNOLCGY}

\section{S1xmmary}

Redox Plant pexformance during the firgt powtion of the mont's was normal Whth the use of a permargarate oxtdation of IAF, throe Urantum Cyolos, and throe Plutonium Cycles. Howover, during the remalnder of the month, - Lght salt wate batchos wero roworked' for reoovery of uranium and plutondum lost as a rogult of oxtraction columa flooding. Several uranium and plutonium product batohes required rework for additional fisgion produot decontamination. In addition, seven plutonium batohos required rework through 22.4-T Butlding for ramoval of exicossive urantum contaninatirn.

Prior to a planned shutdown on January 6 , for dxtensilvo maintenanos and gquiprent replacoement, gross quantities of radio-ruthentum were discharged from the ventilation stack as a regult of fallidre of the Hins Ruthonium Sorubber odustic reclrculation systam. The reolroulation pump was replaced, and additional procautionis aro to be taken to foreatall a rocurrance. Also, whon oquipment changas wore belng made during the shutdown, oxtensive recontamination of the canyon and crano with radiomruthanlum vccurred. Decontamination offorts are in progress. Eixtengivo contamination (approxtmately 90 per cont zirconium-nlobium and ton per cont cortum) of the area surrounding the water-cooled condensers in 241-S Tank Farm has occurred as a result of aporacilo "bumplng" of the bolling tanks and omisation of atean and ontralined aotivity; motal sheds have boen placod over those condensers in order to confine the sotivity.

\section{Process Performance}

Decontamination performance during the flrst portion of the month was normal. Hlghor than normal (approxtmately one por cont) wasto losses wero the result of axtraction column flooding. Elght salt wasto batches (Inoluding one from Decamber) were reworked for recovery of urantum and plutonium, As a regult of inaufificient decontamination from some of these rework operations, approximately four tons of uranium and 600 units of plutonlum required rewark by the normal rowork prooodures. In addition, seven plutonlum product batches roqutred rework through 224-T Bullding because of excoasive ( 16 to 58 per cont) uranium contamination resulting from an lnadvertent draling of approximatoly 90 gallons of IBP from the IB Column (without IBS scrubbing) during column start-up on January 16. Approxtmately 5.6 tons of uranium (containing an average of 140 parts of plutonium por billion parts uranium) requirad blending with below specification material. Although the cause of this irregularity is not dofinitely known, it may have boon the result of a colncidental lowferrous ion IBX batch and high $3 D F$ doddzty。

\section{Feed Preparation}

The dissolvors wors charged during the moth with uranium having an avorage pilo exposure of 592 (51.5 to 622) MWD/T。 No changes in dissolving procoduro wer mado during the month. The motis hools were removed from $A-2$ and $B-2$ D1ssolvors during tho ghut down, and these dissolvers were 
given a $2 \mathrm{M}$ HF and $3.5 \mathrm{M} \mathrm{HNO}_{3}$ flush (ten minutes at approximately $100 \mathrm{C}$ ) in order to remove accumilated siliceous materials which were belleved to be partially responsible for recent poor uranium decontamination. The $\mathrm{C}-2$ Dissolver and all metal solution tanks were water-flushed for the same purpose. Definite conclusions on the effectiveness of the flush are difficult to drawn but it is evident that uranium decontamination has been generally superior to last month.

All regular IAF batches wero oxidized by a permangarate $(0.02 \mathrm{M}-0.05 \mathrm{M})$ Head-End treatment procedurs uaing chromic nitrate as the reductant. The "catalytic kill" tochnique has boen used to roduce residual pormanganate following oxidation for all batches, and partial manganese dioxide. scarenging has been employed. Since the installation of the new G-5 Centrifuge peod Tank on January 9 , the centrifuge feed rate has been under better control. Although the centrifuge offluent still contains small amount of manganese dioxdde, centrifugation has been improved. Eight salt waste batches were processed through the Head-End equipment under varying conditions for rocovery of uranium and plutonium via the First Extraction Cyale.

\section{Stack Acivivity}

An estimated 230 curies of ruthenium wore ovolved on Jaruary 2 and 3 , apparently as a result of failure of the H-5 Ruthentum Scrubber recirculation pump. Another 70 curies were reported to be ovolved on January 5 and 6 , after the buflaing was shut down. Because of a nonrepresentative stackgas scrubber sample, this flgure is of dublous validity. The $\mathrm{H}-5$ pump was replaced on January 11 , with a now regenerative turbine pump. Tho failed pump was installed in May, 1952, and operated successfully for approximately 5800 hours. The A-3 Silver Reactor was replaced on January 3, with a now two-pioce reactor when five of the nine heaters failed. During installation and testing of a jumper which was built for rerouting of the J-I Ruthenium Scrubber Off-Gas F1Iter discharge to the sand filter, the canyon and crane wore recontaminated with ruthenium. Since the jumper did not appear to match the discharge holes into the ventilation air tunnel (to the sand filter), the previous system has been temporarily restored.

\section{Uranium Extraction and Decontamination}

Nominal solution compositions of the ORNL June, 1949, (ac1d-deficlent) Flowsheot wero amployed for the Uranfum Cycles. The Firat Extraction Cycle Flowsheet was modifled for rowork operation (woe below). The concentrated $2.45 \mathrm{M}$ UNH Flowsheots wore used for the Second and Th1rd Uranium Cyclos except for brief poriods when the dilute $2.0 \mathrm{M}$ UNH $2 \mathrm{D}$ Colum was used during uranium rowork. Because of the maloperation of the 2DW and 3DW control valves, both jumpers were replaced during the month. The 3DW jumper has proviajons for future installation of the wate backcyclo plping. 
Wa.j,e Prccessing

Elght salt-waste batches were reworked for recovery of uranium and plutonium during the month. One batch was oxtdized with potassium permanganate since a relatively large amount of plutonium was present in tank heels, improved decontamination could be expected, and the time was available. Two other batches were only concentrated because of a lack of time and the small amounts of plutonium involved. The ISS $\left(1.3 \mathrm{M} \mathrm{AI}\left(\mathrm{NO}_{3}\right)_{3}, 0.2 \mathrm{M} \mathrm{HNO}_{3}\right.$-deficient, containing dichromate) was made in the IAS head tank by dilution of normel. IAS with water. Apparently inadequate mixing was achieved by sparging, and 36 per cent uranium and 60 per cent plutonium losses resulted. An extra conservative flowsheet (for recovery) was adopted for reworking these wastes, and, since plutonium was present, they were oxidized by the dichromate technique. Since the ISS flow was halved and the ISX flow was increased by 25 per cont, decontamination of both uranium and plutonium suffered and rework of product streams was therefore required. The last two waste batches were reworked by a blending technique where approximately one volume of waste was blended with three volumes of metal solution, and a permanganate oxidation and manganese dioxide scavenging were performed. The IAS/IAF flow ratio was adjusted, dependent on the aluminim nitrate in the feed, and the solvent flow was two times the sum of the feed and scrub filows. Excellent decontamination and recovery were experienced.

On January 9, after the installation of the new three-stage deep-well turbine pump for D-8 Waste Neutralizer, diversion box changes were completed which route salt waste to $241-U-110$ Tank via the new threeInch cross-country line, Pumping rates were limited by a plug in the line which developed apparentiy as a result of either or both of the following causes:

1. Accumlation of gelatinous hydrated alumina formed in large quantities during neutralization of aluminum nitrate by direct strike or without agitation; and

\section{2. freezing of the salt solutions during the extremely cold weether.}

One of the two spare lines is now in service. The pumpling rate is approxinately 80 gallons per minute.

Extensive localized contamination (approximately 90 per cent zirconiumniobium and ten per cent cerium) has occurred at the 241-S Farm. The sources of the contamination are the 101 and 104 Tanks which experience sporadic "bumpleg" or a similar phenomenon apparently as a result of the high temperatures (considerably in excess of $300 \mathrm{~F}$, the maximum temperature of present thermometer) of the alumina sludge. A pressure recorder recently Installed in Tank 101 has indlcated two sudden increases in pressure to 30 Inches of water. In order to confine the contamination which is entrained In the steam emission from the tanks through the water-cooled condensers, metal sheds have been mounted over the condensers and auxiliarles. Similar provisions have been made at 24l-U Farm. This phenomena is attributed to: 1) higher power levels during irradiation, 2) higher processing rates in the plant, and 3) reduce waste volume per ton of unnotum processed.

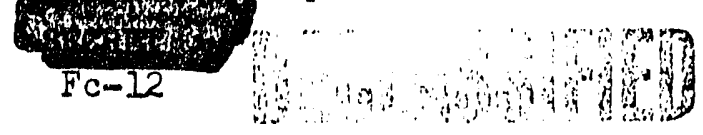


Separations Technology Sub-Sechon

HW-3072L

\section{In-Iine Instmunentation}

Application of la-ine automatic instrumentation for determination of uranium in the fsed strean (RAF), waste stream (RAW) as well as determination of ganma activity in the product stream (RCU) and pH of neu.tralized weste continue to disclose details of construction and fabrication requiring modification. The reliability and usefulness of the principle has been demonstrated and wider application should develop.

\section{Extractabjifty Tester}

An extractability tester for determining feed and solvent quality has reached the final stages of development in Chemistry Unit Laboratories and is ready for service testling with plant solutions. This device automaticalily determines rates of extraction and equilibrium distribution ratios (EA). It is expected to replace many routine determinations presently required to establish optimum column operating conditions and feed salting strengths.

\section{Z PLANT PROCESS TECHNOLOGY - ISOIATION PURIFICATION AND FABRICATION}

\section{Isolation Building (Task I)}

The number of first cycle peroxide cake washes for F-10-P solution strikes was decreased from three $5 \mathrm{Kg}$ washes to one $5 \mathrm{Kg}$ wash. Limited button and/or casting purity data show that adequate purification was realized with no first cycle washing when the starting solution aluminum content of the $F-10-P$ solution was adjusted to $0.5 \mathrm{~g} / 1$ instead of $1 \mathrm{~g} / 1$. Nevertheless, one wash appears necessary to reduce the amount of hydrogen peroxide present; otherwise. vigore" hydrogen peroxide decomposition sccurs during cake dissolution.

\section{Dey Chemistry (Tesk II)}

Based on fluortde color, 23.1 per cent of all mas required rehydrofluorination. This is comparable to 21.9 and 17.6 per cont for November and December, respectively. The "500 C maximu" heating cycle has beon used in furmace two to process a total of 77 rung whth only one requiring rehydrofluorination.

\section{Reduction (Task III)}

The average yield of plutonium from Task III reductions of plutonlum fluorlde powders was 97.1 per cent. Th1s compares with the 97.6 per cont average plutonium yleld reported during November and December. One run resulted in a yield $: 86.5$ per cent. During the firing of this run the pressure increased rapidly, reduced slightly and then increased to a maximum of 173 psig. During removal of the button, the slag was noted to be tinted green and the button sparked when scraped. Presence of molsture in the can pack or in the reduction charge was suspected as the cause for the abnormal effects noted. 


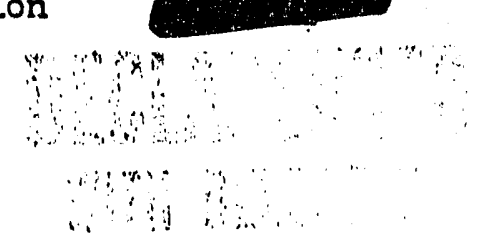

Plutonium Valence in AT Solution

A series of plutonium(IV) nitrate solutions was evaporated to $350 \mathrm{~g} / \mathrm{l}$ plutonium, to evaluate the dependence of the final plutonium(IV/VI) ratio upon the initial nitric acid concentration. Initial nitric acid concentrations of 3.1 to 11 molar gave valence ratios ranging betwesn 3.3 and 99. The results ahow that 1t should be possible to reduce the butld-up of prossure over AT oolution in sealod samplo cans, by the wge of higher nitric acid concentrations in the S-1 still.

\section{Plutonium(IV) Sulfates}

A laboratory study of the dissolution of the red plutonium(IV) sulfate which precipltates from AT solution has shown that the best conditions for dissolution are the use of water at room temperature. The solubility is rotrograde and is inversely proportional to the nftric acid concentration.
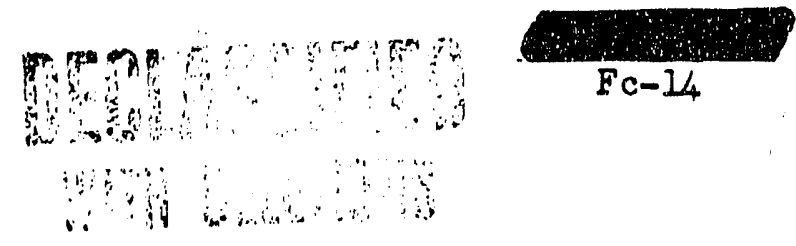


\section{Calcium Plutonium(IV) Fluoride Process}

A large-8cale (300 grams of plutonium) precipitation of calcium plutonium(IV) fluoride was carrted out successfully, using a reverse otrike at room temperature. The preclpitato was oasly filtered, giving a filter-cake with a bulk density of $0.9 \mathrm{~g} / \mathrm{cc}$ plutonium, and was dried in nitrogen to give a free-flowling powder of bulk density $I \mathrm{~g} / \mathrm{cc}$ plutonium. Reduction of the powder, with a booster ratio of 0.5 mole $I_{2}$ per molo plutonium, gave a metal yiold of 97.7 per cent.

\section{Continuous Task II}

Construction of the equipment to be used in testing the continuous calcination of plutonium(IV) oxalate has been nearly completed by the Technical Shops. Cold runs, with a stand-in material, aro planned for oarly Fobruary.

\section{Task III Vessel Pretotype}

The stainless steol reduction bomb simflar to that designed for the new Task III facillty has been tested, but temperature measurements and with the reduction of UF $4^{\circ}$ The reduction-casting of a simulated model 130 gave uranium metal with 2.99 .35 por cont yiald.

Crucible Shop

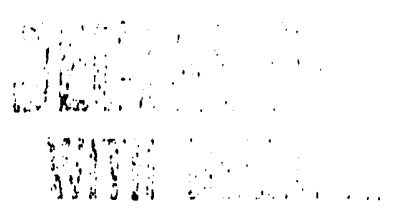

Two alternate mothods of fabrlcating MgO casting crucibles, to roduce costs, are belng considered. One is by coating a thin-wall eruciblo by the prosent olfp-cagting technique, and using this crucible as a finer within a heavier cructble which can bo used ropeatedly. The other method 18 by casting higher density magnesia slip (often called the colid-casting as contrasted with tho drain-casting of slipa) into a plaster mold to form the cructible and allowing the slip to solidify thereln. A plaster core shapes the Inside dimensions of the crucible. Plaster molds will bo cast as soon as the luctto patterns, now on order, sio recelved.

\section{Hecuplex}

The deposition of allica, by hydrolysis of allicon tetrafluorlde, in the condenser system of the Recuplox olag and cruclble dissolver was lnvestigated. It was shown that addition of ono-half mole of aluminurs per molo of fluoride Ion in the slag was needed to prevent volatilization of S1F $4^{\circ}$ Since this 
much oluminum cannot be to lerated durfing the fnltial stages of the dissolution, a means of removing sillca from the condenser system should be provided.

Plutonium peroxide and plutonium(IV) oxalate were precipltated from Taak Itype feed solutions to which had been added olther two volume per cent of the "oll" resulting from over-concentration of plutonfum nitrate solution conteinting Recuplex solvent or ten volume per cent of 15 per cent TBP in $\mathrm{CCl}_{1}$. Losses were normal, and settling and flltration rates wore comparable to those for control runs.

\section{Technical Manual}

Preparation of the Plutontum Purification and Fabrjcation Techntcal Manual is estimated to have reached 77 per cent of completion.

\section{RECUPLEX CONSTRUCTION}

Resumption of Recuplex construction in the 234-5 Bullding, originally anticipated for January, 1954, was not attained due to the vessel vendor's inllure to comply with the revised fabrication schedule. The current procurement status of the vessels and process valves prevents the immediate scheduling of construction start-up.

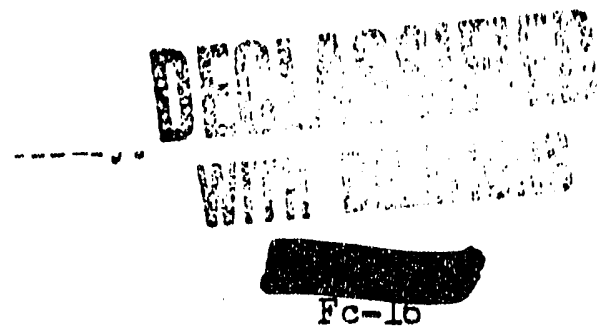


Shift process englneering ass continued effective January 11, 1954. The engineers were assigned to stiudies related to the HAPO program for expansion of tritium production. For similar reasons, the Los Alamos Scientific Laboratories were visited January 12, 1954 through January 15, 1954, by Dr.W. R. Dellollander to discuss thermal diffusion column technology. Drawling of the Los Alamos colum are located now in Blue Print F1le No. 7858 .

Acceptance Specifications for Producer Slug Cores, and Extraction Process Specifications have been drafted and remain in reviow.

The design of fumace pots and vacuum tank valves is beling reviewed in an attempt to effect cost reduction for the 3X Program.

Representatives of P-10 Process Studies mot with Messrs. McCarthy and Time of Mound Laboratory, Walker of the $A_{0} E_{0} C_{0}$, and others, to consider the design of another package for tritium shipments. It seems that Mound will accept lead responsibility for any package modification, although the interested sites would support Mound's offort. In this regard, a review of possible packsiging schemes 1s being preparod.

\section{ANALYTICAL IABORATORIES}

Some reduction in work load within the 300 Area Laboratories was noted as a result of the various Technical Units being involved in moves from 3706 Butlding to the new Technical Center.

General Chemical Laboratory - Considerable analytical service was rendered in support of dissolver studies performed by the Chemical Development Unit. The composition of samples submitted were rather complex and the analysis somewhat involved. The requested analyses were for the following constituents: $U, \mathrm{HNO}_{3}, \mathrm{ANN}, \mathrm{Hg}, \mathrm{Na}, \mathrm{NH}_{4}$ and $\mathrm{Sp}_{0} \mathrm{G}_{0}$ Standard methods of analyses were adapted to satisfy the requirements. It is interesting to note that sodium (Na) can be determined in the presence of uranium by a flamephotometric method if appropriate urasium corrections are made, as Indtcated below:

\begin{tabular}{ccccc} 
Solution & gLU & ppm Na added & ppm Na found & ppm Na found (coniected) \\
\hline a & 36.8 & 80 & 82.0 & 76.8 \\
$1 \mathrm{~b}$ & 36.8 & 80 & 85.0 & 79.8 \\
$2 \mathrm{a}$ & 50.6 & 100 & 107.0 & 101.8 \\
$2 \mathrm{~b}$ & 50.6 & 100 & 105.6 & 100.4
\end{tabular}

Radiochemical Laboratory - A now scaler and high voltage oupply was rocolvod. The tnstrument appears to have many desirable oporating characteristics, not the least of these being high voltage stability. At present the scalor is being ovaluated at a $0.45 \mathrm{Mev}$ threshold to permit U237 gaman discrimination and ruthentum detection in plant uranium product (as weli as detection of more energetic enfitters). The Gama Ray Energy Spectrometer has been omployed in uranlum slug cross section studies. 
Spectrochamical Laboratory - Work continues on the transfer of analyses to the Baird Assoc1ates Grating Spectrograph. The method for 1mpurity analyeses of aluminum was completed. It 1s now possiblo to determine $\mathrm{Mg}$, $\mathrm{Cu}_{1} \mathrm{Fo}, \mathrm{Si}, \mathrm{Zn}, \mathrm{N} 1, \mathrm{~Pb}, \mathrm{Sn}, \mathrm{Co}, \mathrm{B1}, \mathrm{Mn}, \mathrm{Cr}, \mathrm{T} 1$, and $\mathrm{B}$ quantitativoly, and I1 will be determined som1-quantitatively. It was determined that in uranium analyses, the elements $\mathrm{Ca}, \mathrm{Na}$, and If aro considerably moro sensitive on the BaIrd than on the B \& I Spectrograph.

Mess Spoctrometry and Water Quality Laboratory - Continued leakage of the valve manifold on the C-N Spectrometer bas made it necessary to bulld a now manfold with sleeved folnts and a moro convenlent lino arrangement. A power outage occurring tho last part of the month caused extensive olectronic troubles in both the $C-N$ and GE Mess Spectrometers. Data is still being studied to provide a current estimation of precision of results obtained on the $\mathrm{C}-\mathrm{N}$ Spectrometer.

Work volume stat1stics for the Analytical Laboratorfes are in follows:

Number of Number of Number of Number of
Samples Detinge Samples Det'nge

Research and Devalopment

Applied Research

Pilo Technology.

Fuel Technology

Separations Technology

Process Assistance

Qthers

Totel

$$
\begin{array}{r}
1169 \\
210 \\
16 \\
547 \\
121 \\
127 \\
\hline
\end{array}
$$

2184

$$
\begin{array}{r}
2254 \\
1221 \\
95 \\
651 \\
505
\end{array}
$$

.856

5582

\section{Stardards and Colibrettong}

Number of standards solutions propared Stock nolutlons dispansed

Nurnber of caltbrations porformed

Number of callbrated glassware dispansed

Number of checked glasewne disponsed

\section{Decomber Januaxy}

$\begin{array}{rr}1065 & 1879 \\ 152 & 469 \\ 6 & 9 \\ 394 & 829 \\ 139 & 1336 \\ 119 & 529 \\ 1875 & 5051\end{array}$

12

19

65

35

3

3

0

59

70

137

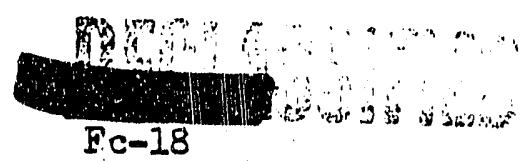




\section{INVENTIONS}

All persons engaged in work that might reasonably be expected to result in inventions or discoveries advise that, to the best of thoir knowledge and belief, no inventions or discoveries were made in the course of their work during the period covered by this report. Such persons further advise that, for the perlod therein covered by this report, notebook records, if any, kept in the course of their work have been examined for possible inventions or discoveries.

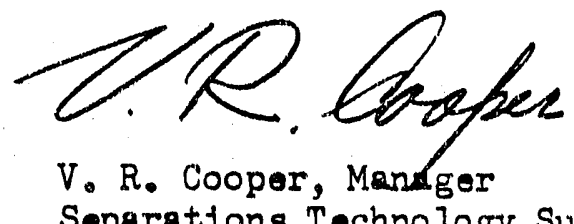

Separations Technology Sub-Section

Fobruary 5, 1954

VRC :mvt 


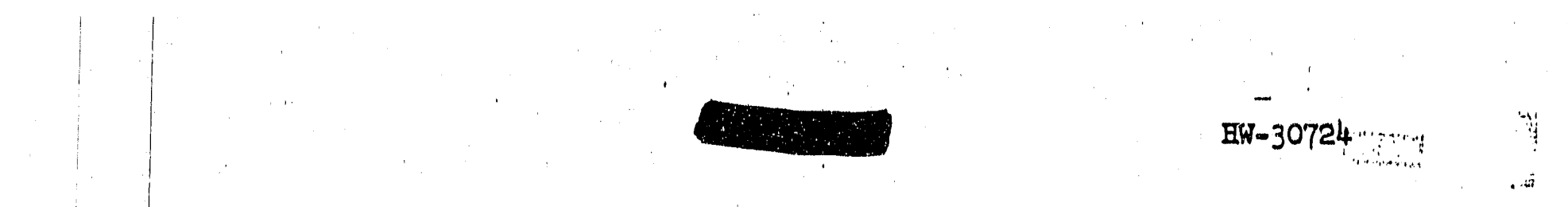

Fobruary 12, 1954

\section{APPLITHD RESTEARCH SUB-SECTION}

MONTIETY REPORT - JANOARY, 1954

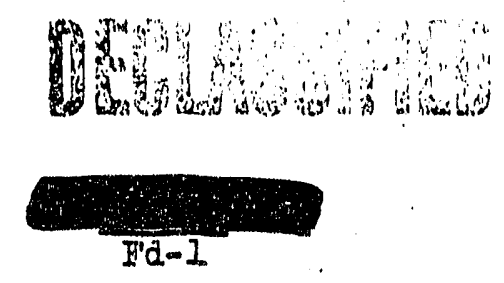


R. W. Levin, Carbide and Carbon Corporation, Paducah, Kentucks, spent January 1.1-15 at Hanford discussing laboratory problems.

D. - H. Mendenhall, Pacific Sclentiflc Company, Seattle, Washington, spent January 11-15 at Haniord callbrating a Baldwin-Southwark Testing Machine.

R. H. Mariner, Corning Glass Works, Corning, New York, spent January 18-19 here discussing radiation shlelding windows.

J. P. Den Hartog, Massachusetts Institute of Technology, Cambridge, was here January 27 discussing stress anelysis problems.

G. W. Watt, University of Texas, Austin, was here January 25-29 as a technical consultant.

M. C. Lambert spent January 5-6 at the General Engiviaering Laboratory and January 7 at the Research Iaboratory, Schenectady, New York, discussing the x-ray photometer and z-ray. fluorescence and Ilght scattering, respeotively.

W. H. Reas spent January 6 at the University of Idaho, Moscow, and January 7-8 at the Washlngton State College, Pullman, recruiting technical personnel.

J. E. Faulleger, D. J. Donahue and B. R. Leonard spent January 7-8 at ARCO, Idaho Fal1s, Idaho, discussing a proposed irradiation and neutron cross section measurement.

J. E. Minor and G. A. Last spent January 8 at Oak Ridge National Laboratory, Oak Ridge, Tennessee, January 12-13 at Knolis Atomic Power Laboratory, Schenectady, New York, and January 14 at the Alleghney Ludlum Corporation, Brackenrldge, Pennsylvania, discussing metallurgy research problems.

J. E. Minor visited the Sylvanla Electric Products Inc., New York, on January 11 and Argonne National Iaboratory, Iemont, Illinois, on January 15 for the above purpose.

G. A. Last spent January 11 at the Alcoa Aluminum Plant, Edgewater, New Jersey, discussing metallurgt research problems.

K. I. Sanborn spent Jaiuary 14 at the Lambert and Lend Laboratories, Seattle, Washington, testing equipment.

H. R. Schmidt spent January 18-19 at Oregon Stato College, Corvallis, and January 20 at the Jniversity of Oregon, Bugene, recruiting technical personrel.

I. A. Hartcorn spent January 18-19 at the U. S. Bureau of Mines, Albany, Oregon, discussing metallography of zirconlum and rolated problems.

G. J. Alkire spent January 20-24 at the Consolidated Engineering Corporation, Ios Angeles, Callforala, and January 25-29 at the Knolls Atomle Power Laboratory, Schenectady, New York, consulting on mass spectrometry.

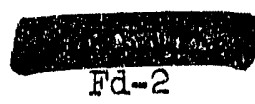


Applied Research Sub-Section

M. B. Ieboeuf spent January 26-27 attending the AIEW, IRT, AEC and INBS Sc1ntillation Counter Symosium in Washington, D. C. Januery 28 was spent at the Research Laboratory, Schenectady, New York, and January 29-30 at the Detecto Laboratory Company, Chlcago, Illinols, discussing counting instruments.

J. E. Taulkner, G. W. Stuart and W. J. Ozeroferattended the American Physical Soclety Meeting in New York City on January 28-30.

W. J. Ozerofe spent January 26-27 at Knolls Atomic Power Laboratory, Schenectady, Now York, discussing temporaturo coefflcient measurements.

D. C. Kaulitz and T. W. Evans spent January 26-28 at ARCO, Idaho Falls, Idaho, d1scussing Irradiation experiments, zirconfum chemlstry and hlgh pressure pumps and valves.

\section{ORGANIZATION AND TYRSONNNEI}

Personnel totals as of January 31 were as follows:

Exempt

Physics Unit Metallurgy Unit

Chemistry Unit

Equipment Design

Administration

Total.

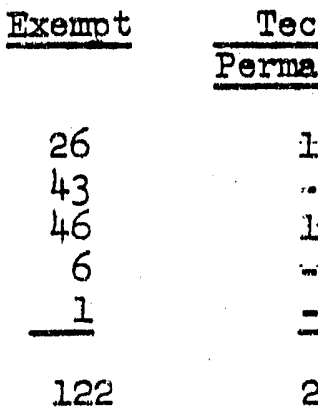

Non-Exempt

Total

Rotational

$\begin{array}{ll}1 & 5 \\ 1 & 1 \\ 2 & - \\ & 5\end{array}$

71

62

124

$-2$

4

50
8

5

179

\section{PEYSICS UNIT}

Iattice Measurements for EDPR

About 50 tons of graphlte and eive tons of uranlum metal have been moved into the 326 Building in preparation for a serles of $4^{\prime} \times 4^{\prime} \times 4^{\prime}$ exponential experiments. These experiments will supplement the larger $8^{\prime} \times 8^{\prime} \times 8^{\prime}$ experiments which are continuing in the 189-D Bullaling.

A set of eight Po-Be sources having a combined strength of $5.8 \times 10^{8}$ neutrons per second has been recelived and w1II be used for buckling and conversion efficlency measurements in the experlments mentloned above.

Modiflcations in the laboratory and counting room are belng made. It ls hoped that measurements w1ll be well under way during February.

Measurements of the epfect on react1vity of larger vater annuld have begun in the $8^{\prime} \times 8^{\prime} \times 8^{\prime}$ oxponential piles. The first slug to be used 1s the $0.925^{\prime \prime}$ diameter slug with a water annulus of four times the volume of the previously measured annulus. This ha, been obtalned by uslng process tubes deslgned for the 1.175" diameter slug and by centering the smalier slugs in this tube with plastic rings. W1th no water in the

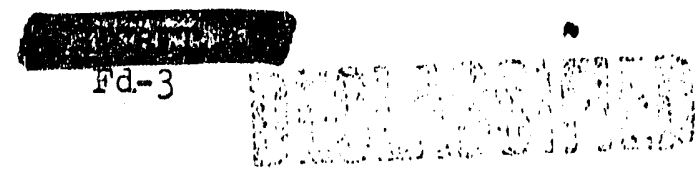


Applfed Research Sub-Section

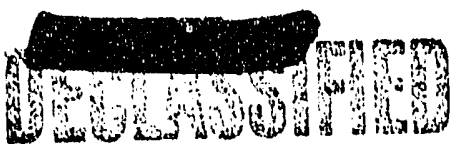

EIN-30724

arnulus, the buckling in the $71 / 2 "$ lattice was found to be $89.8 \times 10^{-6} \mathrm{~cm}^{-2}$. The . effect of the larger dry anmulus is to reduce the buckling by $5.5 \times 10^{-6} \mathrm{~cm}^{-2}$. A measurement with coolisg water is to be made next.

Further measurements were made with the large hollow slugs. These are given in the table below:

\begin{tabular}{|c|c|}
\hline Iattice Spacing & Dry Bucklins \\
\hline $\begin{array}{rl}6 & 3 / 16^{\prime \prime} \\
12 & 3 / 8^{\prime \prime}\end{array}$ & $\begin{array}{r}2.8 \\
24.4\end{array}$ \\
\hline
\end{tabular}

These slugs ar of interest in connoction with internel. cooling and in checking the reliablitty of theoretical methods of computing the reactivity effects of coring.

Nuclear Physics

The feasibility of reducling the Pu-240 content in product plutonium by irradiation with neutrons whose energy spectrum contains a meh reduced thermal component is being experimentelly investigated. Samples of plutonlum of known Pu-240 content are being prepared by Mr. Kinderman, of the Chemistry Unit. Aluminum capsules to hold these samples have been fabricated. Formal arrangements are being made to have these capsules inserted into the MIR on March 4.

An analysis has been made of what the errors in this measurement are likely to be. It is to be reniembered that such an analysis makes use of present values of cross sections about which there is a good deal of uncertalnty. The results are that a three montb trradiation will. reduce the Pu-240 content from $5 \%$ to $2.5 \%$. The latter value will be known to 11 e between $2.75 \%$ and $2.25 \%$. The percentage luss of Pu-239 will be smalit.

Equipment is belng fabricated for the measurement of $\alpha(25)$ as a function of energy.

A method of extending the plutonlum fission cross section measurements to low neutron energies is being studiod. This method involves flitering the neutrons in the beam with a powdered crystal pilter in order to remove all neutrons with energies above the Brugg cut off energy.

The TWR has been moved into the basement of the 326 Building where it is belng assembIed fur the purpose of tes ${ }^{+}$ing control mechanisms.

\section{Plant Physics}

The critical mass of plutonlum in water solution depends on the content of Pu-240 in the plutonium. The separations plants at Hanford have been processing $600 \mathrm{MWD} / \mathrm{T}$ uranium and are now required to process extensive amounts of $200 \mathrm{MWD} / \mathrm{T}$ urantum. The concomitant decrease in the Pu-240 content. leads to a decrease in plutonium critical mass and therefore a revision of nuclear safoty requirements is needed. This revision has been largely made and in most cases required ofther safer geometry or smaller batch sizes. Alternative metrods not requiring a reduction in the capacity of the plants are being sought. 


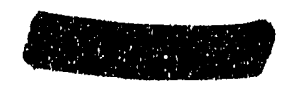

IIV-3072L

Applied Research Sub-3ection

VTEAICURGI UNIT

Properties of Uranium

Preformed uranium spectmens for study of the affects of Irradiation upon mechanical. and physical properties have been discharged from the 100 H PIle and the exposure levels calculated. The specimens in Tube No. 1071 recelved an exposure of $313 \mathrm{MWD} / \mathrm{AT}$. and those in Tube No. 2080 recelved $309 \mathrm{MWD} / \mathrm{AT}$, a value of $310 \mathrm{MWD} / \mathrm{AT}$ corresponding to an integrated exposure of $9.6 \mathrm{x} 1019 \mathrm{nvt}$. Values for the exposure level for each assembly have also been obtained from a consideration of the flux distribution along the length of the process tube.." The specinens will be transferred to the 327 Building in the near future for post-irradiation examination and testing.

In continuation of the same program, machining of the uranium specimens and aluminum inserts for test assemblies to receive exposures of 150,750 , and 1,200 MIND/T is nearw Iy 50\% complete. A comparison of the mechanical properties, chemical composition, and microstructure of pickled-derby uranium metal and the uranium oringinally scheduled for this test is in progress. The chemical analyses received to date and listed in Table I indicate that the selected production-run uranium originally scheduled for this Irradiation program compares very favorably with the pickled-derby metal.

\begin{tabular}{|c|c|c|c|c|c|c|}
\hline \multicolumn{7}{|c|}{ TABIE I } \\
\hline Element & $\operatorname{Max}$. & Avg. & Min. & Max. & Avg. & MIn. \\
\hline $\begin{array}{l}\text { Carbon } \\
\text { Nitrogen } \\
\text { Megnes Ium }\end{array}$ & $\begin{array}{l}630 \mathrm{ppm} \\
63 \\
175\end{array}$ & $\begin{array}{l}41.0 \mathrm{ppm} \\
48 \\
18.2\end{array}$ & $\begin{array}{c}210 \mathrm{ppm} \\
34 \\
1.1\end{array}$ & $\begin{array}{l}\frac{512}{8} \mathrm{ppm} \\
2\end{array}$ & $\begin{array}{l}490 \mathrm{ppm} \\
7.4 \\
1\end{array}$ & $\begin{array}{l}480 \text { ppm } \\
6.9 \\
I 1\end{array}$ \\
\hline
\end{tabular}

A more detailed evaluation of the quality of plckled-derby metal and the uranium metal. ordered for this production test is in progress.

A Iiterature survey on methods and techniques applicable for the study of metal diffusion processes as a function of pilo parameters is being conducted. Available 1Dformation on systems having possible application for future htgh power reactor fuel components is being surveyed in order to obtain pertinent out-of-p1lis diffusion data.

Fuel Element Studies

Six enrlched cored slugs (3/8" a core, 4" length) have been machined, canned, and tested. Four of these passed the pre-irradiation tests and wll be charged in the C Pile "bot spot" at the nert scheduled shutdown. The other two were rejected, one having a cracked end cap, and the other belng a $100^{\circ}$ mf I non-seat.

Mechanically bonded four Inch slugs aro boing prepared for a production test to evaluate the behavfor of such a bond when irradiated. About two-thirds of the slugs propared for this teist showed cracks aftor plckling, which was unoxpected since the mam terlal used was aria a group of rods which had been satisfactory for the machinlag of standard sizo slugs. Sizing the can over the anodized slug with 12 mils roduction of total can well thickness in every case produced bonds whlch passed the frost test.

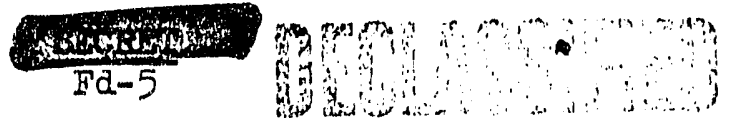


Examination of the can closure prepared by foming the cap directiy on the slifs by upsetting of a thick can wall section has been completed. Oxide stringers were present at the center of the cap, but were confined to an area of less than $0.10^{\prime \prime}$ in diameter. The broken nature of the oxide stringers indicated that pressure welding had occurred during the upsetting operation. A new punch for the present die is being prepared in order to investigate the effects of extruding a somewhat greater quantity of aluminum from the center section of the cap. This should improve the quality. of the closure by further reducing the quantity of oxides remaining at the center of the cap.

Six pounds of $0.16^{\prime \prime}$ diameter wafers have been punched from $0.07^{\prime \prime}$ thick uranium sheet. These wafers are to be used In lleu of uranium shot in investigating those properties of the uranium-magnesium fuel material which are not dependent upon particle shape, i.e., fabrication and reactivity.

To date, attempts to obtain high purity magnesium sheet for use in preparing uraniummagnesium reactivity test specimens have been unsuccessful.

The Washington AEC office has approved the request to Install and operate a fuel element testing facility in the Materlals Testing Reactor. Construction of the testing facility is continuing; the design work 1s ossentially complete and virtually all the necessary equipment has been ordered with delivery expected during February and March:

A method for determining residual stresses remaining in a fuel element after cooling is under development. Such a method may be extended to correlate and predict the effects of thermal cycling.

\section{Dual Purpose Reactor Studies}

Tube and Jacket Materials - Two tubes for the irradiation of zirconium test sanries for Production Test No: 105-509-SI have been scheduled to be charged on January 30 , 1954. The tubes, $3670-\mathrm{F}$ and $3683-\mathrm{F}$, wi11 be used for the 150 and $1,200 \mathrm{MWD} / \mathrm{T} \in \mathrm{x}-$ posures of the cold-worked zirconlum samples. Pre-irradiation tharmal expansion data for the materlal have been obtained for the temperature range 25-700 C. The coeffic $1-$ ent of thermal expansion was found to be 4.5 to $6.5 \mathrm{in} / \mathrm{in} /{ }^{\circ} \mathrm{C}$ for ald or these samples through this temerature range. The pre-irradiation tensile data will be completed for this material in the near future.

Substantial cost savings might be realized if zirconium or Zircalloy-2 tubing could be welded satisfactorily to type $304 \mathrm{I}$ stainless steel in the fabrication of process tubes for the dual purpose reactor. Fusion welding of the stalnless steel with olther zirconium of Zircalloy-2 produced weld doposits which were brittig and which generally cracked durlng welding. Resistance "flash" welding was attempted, and a strong but brittle jolnt was obtained. "Flash" welding using an inert-gas shield or percussiom welding may produce a satispactory jolnt; howe, ver, the probability of success is very Low.

Metaliurgically sound joints have been obtalned when samples of Zircalloy-2 have welded together using the Inert gas shielded tungsten-arc.process w1th convent1onal oquipment and techniques. 
Reaction of Zirconium and P1le Gas - A literature survey covering the reactions of zirconlum with gases at varlous temperatures has been completed and will be lssued shortly. Thts report considers the rate of formation of scale, motal growth, and. loss in mechanfcal proportios. Avallablo data aro ovaluated and a program suggested to complement existing information by tests in and out-of-plie conducted in approprlate atmospheres. Equlpment orders have been placed and design of gas flow and electrical control equipment is in progress, alming at an initial operation dato of mid-April.

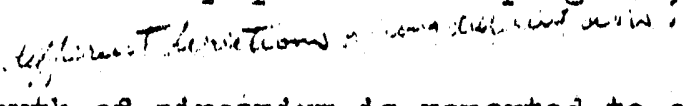

Anisotrop 1c growth of zirconium is reported to occur under cortaln conditions when the metal is heated in alr. As air is a comon plie gas impurity and since any such growth of process tubes would be very objectionable, study has been inftiated of this growth phenomenon. The elongation of a $1 / 2$ " diameter $x$ l" long rod of $z 1 r-$ conlum beated in air at $700 \mathrm{C}$ was followed dilatometrically. Gross longitudinal growth, including surface corrosion, amounted to $17 \mathrm{mils}$ in 10 days. However, after mechanical removal of the surface corrosion product, the net change in length of the base metal was found to be decrease of $5 \mathrm{mlls}$. It is planned to expose spec1mens of zircalloy-2, whlch has been obtalned recently, under condltions precluding surface corrosion interference with growth measurement.

Preliminary examination has been made-of six washer-shaped specimens of zlrconium witch had been exposed 60 days in an H-P1le dry process tube at an estimated temperature of 475-500 C. A black coating bad developed on all surfaces, except for some peripheral areas which had turned white.' Iine grain metallographic paper scratch marks were still visible on the surfaces. The average welght gain of all samples was $0.45 \mathrm{mg} / \mathrm{cm}^{2}$, with no corrolation being ovident oither in appearlance or in welght change with degree of cold work $(0-50 \%)$. Thls welght gain corresponds to a minimum penetration of only $0.5 \mathrm{mil} / \mathrm{yr}$. The condition of the base metal will be investigated by hardness and density measurements. Tensile specimens of Z1rcalloy-2 w1ll be chargea in-pile shortly.

H1gh Temperature Uranlum-Water Reaction - Cost and delivery data are belng obtained on the purp and other components of a pressurized water loop (to $600 \mathrm{~F}$ and 2,000 psi) for investigating the reaction of uranium with water at hlgh temperatures. A suitablo location for this test faclilty is also belng sought.

\section{Radiometallurgical Ezaminations}

Metallographic examination of the 63-S aluminum samples from PT-105-501-M was begun with a prelininary conclusion that there is no apperent change to the microstructure as a result of the irradiation.

During the plckip of slugs after a discharge on January 5, 1954 at 100-H, s1x sluga were observed to be broken Into two pleces. One of these slugs was meroscoplcal15 examined. From the "observation of the fractured edge of the aluminum can, 1t appearod that the slug failed in the pile. Discharging and impact marks on tho extorlor of the can, and the small amount of oxlde on the smoothly fractured uranium surfece gives the appearance that the slug may have broken in the basin. Another one of the six broken slugs will be examined to conflirm or deng one of these postulates..

Metallurgical examination-has been completed and reports are being written on the defect1vo pleta1ls from 105-C, on the ruptured 63-s jacketed sluegs and on the first two 万-slug mptures.

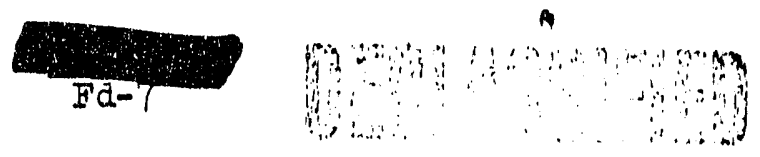


Applied Research Sub-Section

The cut-ofe cell was utilized to cut some cold samples of 24-5 aluminum and stainless steel. Surface conditions resulting from the cut were very good. After more shielding is installed and the waste handling is improved, non-irradiated uranium will be sectioned. 'Samples with one dimension under 2 1/2" can be sectioned into any rectangular shape. Irradiated materlals will be sectloned during February 1954 if maintenance forces are available to complete the installation. The metallographic cell has all equipment installed and will be ready for motallographic processing when strip coating is completed. The slug examination cell was used to examine five irradiated slugs with contamination of the order of $7.5 \mathrm{Rep} / \mathrm{hr}$ at $4{ }^{\prime}$ resulting within the cell. Density determinations were made of six zirconium samples to an accuracy of $0.02 \%$. The Rockwell Remote Hardness tester was recelved and evaluated. Cathodic otching equipment, formerly used in the metallurgy laboratory, will bo modified for Irradiated materlal etching. Electrical resistivity equipment. has been designed for remote operation and construction will begin soon. The tensile testing equipment was partially shielded and tests can now be made of irradiated materials. The $X-Y$ recordor attachment for the tensile tester was found to be defective and has been retumed to the-Pacific Sclentific Company of Seattle for repair. As soon as it is avallable, stress-strain data can be obtained from irradiated materials.

\section{Plutonium Metal Production}

Study of the method for preparation of plutonium tetrafluoride by the reaction between plutonium oxide and amonium blfluorlde has been extended. The optimum procedure for the preparation of plutonium tetrafluorlde consists of heating plutonium oxide with a 4 (1) excess of ammonium bifluoride at 150 to $200 \mathrm{C}$ for one hour followed by amonium fluoride volatilization and dehydration at 450 to $500 \mathrm{C}$ for $1 \mathrm{I} / 2$ to 2 hours. The plutonium tetrafluoride thus obtained can be bomb reduced with calcium and a calclum-iodine booster to produce well-shaped plutonium buttons and yields of $98 \pm 0.3 \%$. The dehydration at $500 \mathrm{C}$ is necessary to prevent high pressures during the bomb reduction and to prevent poor button jields. The decomposition and dehrdration reactions should be carrled out in metallic equipment to avoid the reduction of plutonium tetrafluoride to plutonium trifluorlde, a reaction which is apparently cataljzed by glass surfaces.

The feasibility of preparing plutonium metal by the electrolysis of molten plutonium fluoride baths depends, in part, upon the use of fabrication materlals which are chemically inert to both the fluorlde bath and molten plutonium metal. An electrolyte of approximately 19 mole per cont cerlum fluoride, 76 mole per cent lithium fluoride, and 5 mole per cent barium fluoride is currently being used for materials test1ng. It has been found that both zircon porcelain and zircontum metal are unsultable materials for the molten metal product collection cup as they are rapidiy corroded by the ingredients of the molten bath.

X-ray diffraction patterns kave been obtained of two more calcium plutonfum eluorlde precipitates. These patterns differ distinctly from all others previously obtalnod and, while the results are not clear-cut, may indicate the presence of the double salt rathor than a mixture of calclum fluorlde and plutonium fluoride.

Metallurgy of Plutonlum

Two as-cast plutonlum tens1le specimens - one of pure alphe plutonlum and the othor of an 0.5 welght per cent gallium-plutonlum alloy - were tested. The values obtalned for 
Applied Research Sub-Section

the modulus of elasticity for the pure alpha plutonium specimen were 9.4 and 9.5 $x 10^{\circ}$ psi on two separate trials. These values are significantly lower than the Ios 4lamos data, approximately $14 \times 10^{6} \mathrm{psi}$. Premature fallure of the tensile spec1men prevented the measurement of the other physical properties. The yield polnt, ultimate tensile strength, and modulus of elastlcity for the 0.5 welght per cent gallium-plutonium alloy were 10,000 psi, 18,600 psi, and 4.6 x 106 psi, respectively.

\section{Plutonium Coating Studies}

The solubility of nickel in molten calcium-nagnesium eutectic is being stidied, the aim being to provide a low melting solution of nickel from which diffusion coatings can be deposited upon plutonlum in the stablized delta phase. Preliminary results indicate that at least 10 welght per cent nickel is soluble in the colciun-magnesium eutectic. The melting temperature of this nickel solution is approximateily $350 \mathrm{C}$.

\section{Corrosion and Welding}

Attenpts are being made to remove the SAE-1020 steel specimens which have been exposed for one year to boiling Redox waste in Tank 104, 241-S Tank Farm. the recovery of these specimens may be time consuming and costly due to the strong gama radiation at the location of the sample port. These particular specimens are ciute important since examination of these samples will proride the only data appilicable to the condition of the Redox waste tanks..

A materials testing program has been initiated wherein titanium and types $304 \mathrm{I}$ and $3095 C b$ stainless steels are being exposed to bolling, Redox phase II, D-12 solution for 480 hours in 10 pertods of 48 hours each. The corrosion rates of all specimens after 96 hours exposure are not appreclably different from the rates obtalned in bo1lIng, Redox Phase $I, D-12$ solution. All corrosion rates observed thus far have been in the order of 0.0007 IPM which is considered falrly low.

\section{CHEMISTRY UNIY}

In-Iine Analrsis

Continuing work with process in-line analytical techniques was concerned nostly with means for assured delivery of semples to the varfous monitoring devices. The previously Installed pH cell for Oraniun Recovery noutralized waste has boen further inproved by introduction of a flush system which prevents clogging in the jet sample Iine and which provides a positive indication of satisfactory monitor performance. The unit has been reinstalled to accept neutralizer tank sauples from near the add1tion point and is being used as the basis for neutralization control and adjustment; it reflects a change of flow rate in about flve minutes and allows pH control to about $\pm 0.5 \mathrm{pH}$ units. More reliable sample feed to the RAF uranium monitor was assured by. Introdaction of an automat1c Plush cycle in the jot sampling line. Interference to the in-Iine gama monftior caused by accumalation of radioactive organic dropiets will bo corrected in the Purex installations by a redesign which places the scintillation crystal at the bottom of the cell; similarly, organic droplet finterference to the ...................... RAW polarograph for uranium has been avolded by use of a gas sparge to corlesce the droplets.

Plant success with a nimber of In-Iine analytical devices and promising laboratory
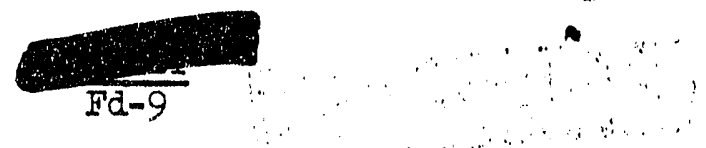


\section{Applied Research Sub-Section}

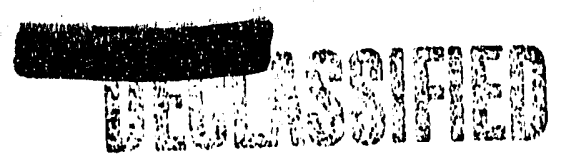

\section{HW-30724?}

results with others has led to a joint program with Separations Techology to install about 20 monitors in the Eot Semi-Worls; these w1ll speed up the Purex pilot program and will provide a rigorous test of units intended for Purex Plant instaliation.

Uranium Recovery Process operating personnel have requested a monitor for uranium in the RCW organic waste stream to detect flooding that may occur readily in the larger RC column and to avold the assoclated problems of organic clean-up. A colorimetric monitor is unsultable because red oil is present in the organic stream in sufficlent quantity to interfere. Consequently, a polarographic unit on the ROW stream (organic clean-up colum aqueous waste) is proposed even though a slightly longer response time resulta.

The P-10 installation that feeds samples directly to the mass spectrograph has operated in a highly successful manner, providing rapld product and waste analyses and - liminating the troublesome problem of sample contamination. In prospects of increased P-10 production at Hanford and the consequent need for additional mass spectrometers, a research chemist visited the General Engineering Laboratory and the Consolidated Engineering Corporation to inspect and test recently marketed candidate instruments.

\section{Analytical Development}

The coulometric titrator described last month for the determination of higher cuncentrations of plutonium has been introutuced to the control laboratory where it will be employed for F-10-P and -- later -- Recuplex sample assays. A visit to the General Engineering Iaboratory allowed final inspection of the Hanford-designed $x$-ray photometer and led to several minor modifications before shipment o which is expected in the near future. A survey completed several morths ago susgested tbe feasibility of Installation of a direct reading spectrometer in the 234-5 Buildins laboratory. r bsequent discussions with 200 Area analytical personnel lent encouragement to tl : proposal and 1 a to arrangements for conduct of test analyses on the Quantometer at the Applied Research Laboratory in Pasadena; analyses to be considered are those for impurities in plutonium - using uranium as a stand-in for the tests and for uranium isotope ratio. The latter is of particular value since it is desired to replace the expensive mass spectrographic method for isotoplc analysis of $\mathrm{UO}_{3}$ product. Recent tests show that spectrographic methods using photographic recordIng can yield a precision of only $\pm 10 \%$; the lower backeround associated with direct reading instruments, however, promises precise analyses.

In ccoperation with the 100 Area analytical laboratorles, a program has been started to examine the turbidity of pile water with the light scattering photometer. This Lnstrument is much more sensitive then any others proviously omployed and has already yielded Interesting information. Varlations in turbldity aro apparent in water from different filters and in alum vs. ferri-floc treated water; further, it is ovident that relatively high turbidity exists in illtered water for ubout one hour apter backwashing of the e1lter.

Other analytical' items Included establishment of a techique to locate bubbles in slug Al-S1 layers and to sample the contained gas for analysis; issuance of spectelcations for scalers to be used with gama scintillation counters in the Purex laboratory; trouble shooting assiatance to the control laboratory that led to Improved

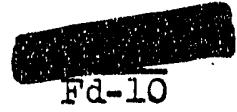


1.sotopic anolyses of $\mathrm{UO}_{3}$ product; and completion of three standards - representinc 22 control laboratory determinations - In the standard sample procram.

Dual Purpose Reactor

If zirconium-clad slugs are employed in the proposed power reactor, there exists the possibility of a $Z r-U$ diffusion layer and a consequent explosion hazard durlng subsequent slug dissolution. Investlgations are under way to explore the situation. A standard procedure has been established to sensitize samples of U-Zr alloy (exposure to hot nitric acld) and is serving as the basis for isolating the factors responsible for the sensitization and explosion. Observations to date with U-Zr (1.5\%) alloy are thet sensitization is obtained in hydrochloric acid; that the flecks of material sluffing from the surface during acid treatment are sensitive; that no sensitizution results if hydrofluoric acid is included in the acid etch; and that a more vigorous explosion results if the uranium nitrate crust is allowed to remain on the surface after acid treatment. Observations with a U-Zr (4.9\%) alloy are that annealed metal yields an explosive surface but that quenched metal does not. PreIiminary z-ray diffraction and infrared exminations reveal zirconium carbide in both sensitized material and explosion product and have revealed the presence of zirconium oxide in the latter. Iiterature surveys reveal established methods for determining oxygen and nitrogen in zirconium; laboratory work is being initiated on methods for hyarogen.

Worls was reported previously on the dissolving of U-S1 alloy slugs. Additional studies were directed at the occlusion of activity on the $S i-S O_{2}$ residue of the dissolving. After a water and an acid wash, the residue was found to contain $8 \%$ of the $\mathrm{Zr}, 18 \%$ of the $\mathrm{Tb}$, and $0.5 \%$ of the $\mathrm{Pu}$ in the dissolver sample; additional water and nitric acid washes reduced the occluded Pu to $0.3 \%$.

\section{Radiochemistry}

A group of 30 samples have been obtained from selected locations in an irradiated. uranium slug and are belng analyzed for U-235, plutonfum isotopes, beta and gamma activity, and some Individuel fission products. Preliminary indications are that tho nuclear reaction products are not symetrically located along the diameter and thet there has been no relative migration of $\mathrm{Zr}, \mathrm{Ce}$, and $\mathrm{Cs}$.

\section{Waste Treatment}

The production test on the scavenging of cesium from Jranium Recovery waste with nlckel ferrocjanlde has been judged successtul, and plans are under way to scavenge future wastes and crib the supernate. About 30 million gallons of waste will be treated in this manner to effect a savings of about $\$ 7,000,000$ worth of storage tanks.

A second aspect of the scavenging treatment is that of recovering radioactive cesium in large quantity for 1ndustrial utilization. Two tentative recovery flow sheets have been established, one using caustic treatment and one using pyrolysis. Further labnrator vork on the subject is directed toward a more simple and effective recovory system.

\section{Separations Processes}

A concerted. attermt is under way in the Chemistry Unit to de 
tions process. The atterpt is occasioned by two sicrificant factors: first, the Greatly increased separations load resulting from the Hanford comitment for low exposure plutonium; and second, the availability of a wide variety of research results and ideas that can be of optimum utility only if brought together as a new process. Thro separate approaches are envisaged at present: I) solvent extraction using 35\% TIBP for greater capacity, elevated temperature for improved colum behavior, and larger colums where necessary; 2) an extension of the same using 40\% TBP in carbon tetrachloride, which gives an inverted system, and elevated tempers.ture to reduce viscosity; and 3) use of an effective TTA partition step between the first and second cycles that would lessen the number of necessary colums and make parallel operation possible. Other aspects to be factored into the process include improved slug dissolving, control of muthenium, waste treatment, etc.

Work directed toward these ends include establishment of uranium equilibrium data in Amsco-40\% TBP and carbon tetrachloride-TBP systems at $25 \mathrm{C}$ and $60 \mathrm{C}$. Parallel studies with the $1^{\prime \prime}$ constant diameter laboratory pulse colum have shown that the capacity of the purex flowsheet is limited by the scrub section behavior; that the Purex flowsheet operating at $55 \mathrm{C}$ ylelds a $25 \%$ increase in $B A$ columacapedity and that the scrub section limits still hlgher throughput; and that the CCI4-TBP system offers a major increase in capacity. Operating with 40\% TBP in CCL 4 , at room temperature, and with the standard Purex TBP to $U$ ratio, a 216-fold increase in scrub section flooding capacity was noted; considering the higher TBP percentage, this corresponds to a 260 -10ld increase in throughput over Purex.

Some attention had beren glven to scavenging with calcium eluoride as a partitioning step for plutonium. Further work shows that the separation is less effective in simulated process soliations than in the pure solutions initially tested. This observation, coupled wilih process difflculties assoclated with the operation - corrosion, critical quantities, etc. - Ied to the abandonment of the proposal. Preliminary examination of perition with TTA shows a plutonium distribution coefficient of 20 to 100, reveals an induction period in the platonium extraction, and indicates rapid and effective stripping into high acid aqueous solution. The relatively high solubility of ITA in aqueous streams suggests the need for recovery treatment of these streams; if none is employed, the process would sustain a TTA loss from this cause of $\$ 120$ per ton of uranlum.

Other 1tems pertinent to separations processes include the observations that barlum fluozirconate and cerous oxalate tend to scavenge plutonium ef.Pectively from waste solutions, that oxidizing und reducing agents (ceric, cerous, ferric, chromic, copper, or titanous lons) do not catalyze slug dissolving rates but that uranium complexing agents (calcium fluoride, ammonlum sulfate, or hydrofluoric acid) tend to increase the dissolving rate up to five-fold; and that uranlum daughter-UX $I_{1}$ can be directed to Purex waste by employment of a low acid scrub.

\section{Weste Treatment and Decontamination}

Work of Laboratory Waste Disposal and Decontamination personnel for January may be sumarlzed as follows:

1,000,000 8jellons of "reterition" level waste from the Works Laboratory Area was processed to ground; 75 gallons of organic and aqueous low level uranlum waste was discarded via the 300 Area pond; elght trips were made to 222-s Building, 200 West Area, to

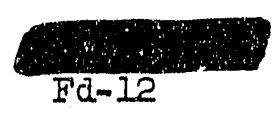


Applied Research Sub-Section

dispose of 60 gallons of "underground storage" level waste from 3706 Building; 30 waste cartons requiring special handling were discarded via the 300 Area Burial Ground; and two tank loads $(10,000)$ gallons of "crib" level waste from the Woriss Laboratory Area were trassported to 200 West for disposal via 200 Area cribs.

Assistance vas given in the decontamination of 222-S multicurie cell and in the movement from 3706 Bullding to the Radiochemlstry Bullding. Laundry service was initiated for 325 and 326 Bullaings. Other service functions were carrled out in a routine manner.

\section{IIVIENTIONS}

All Applied Research Sub-Section personnel engaged in work that might reasonably be expected to result in inventions or discoveries advise that, to the best of their knowledge and belief, no inventions or discoveries were made in the course of their work during January, 1954 except as I1sted below. Such persons further advise that, for the period thereli covered by this report, notebook records, if any, kept in the course of thelr worls have been examined for possible inventions or discoveries.

Thero were no inventions during the month.

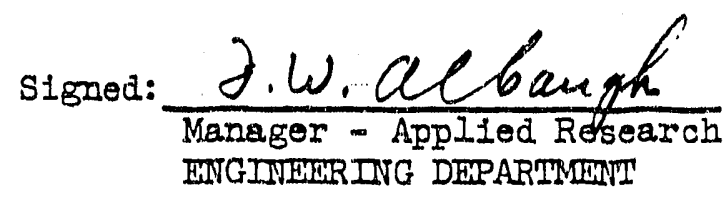

FWA: Itc 


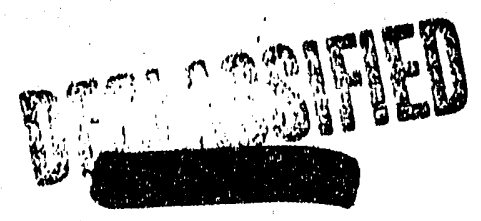

MONTHE I REPORT

DESTGN SECT ION

\section{VISITORS AND BUSINESS TRIPS}

T.G. Cullin and P.E. Sharpe, Carboline Company and Burhan's Sharpe Company, rospectively, Seatile, Wash., visited here January 5 to discuss surface coatings.

Walter J. Falier, Panellit Ina, Chicago, Illnois nsited here January 8 - 15 to assist. in repalr of damaged gages.

S. Davis and E. Willnitz, Vitro Corp. Cf'Amerlea, Ne'm Yorx Clty visited here January 7 to inopect the liquid level and interface minitos.

J.G. Gates, Continental Electric Equipnert Compant, C.n:ingati, Ohio visited here January 12 and 13 to roview Vendor's drawings on alxillary battery supply systiem.

Don R. Combs, Bumsread-Woolford, Seattle, Wash., visited here January 26 for consultation on meteorological instruments.

Mr. Lovejoy and Mr. Mulins, AEC Accounts Bransh, Washington, D.C. visited hore January 26 and inspected the canning machine test installation.

Gordon Colizns, General Electric Company, Spckane, Wagh., visited here January 27 regarding canning machine controls.

J.K. Flickinger visited the Royson Engineering Company, Hatboro, Pa., December 2.6 - 31 to approve Venturi test equipment and methods.

A.J. Karnio visited the Peerless Pump Company, Los Angoles, Calif., January 7 and 8 for consultation with prospective suppliers of special fumps.

R.T. Jaske attended the American Society of Heating and Ventilating Engineers Meeting, Portland, Oregon January 7 and 8 to give talk at Oregon chapter of ASHVE.

R.A. Huggins visited the General Electria Company, Schenectady, N.Y., and Babcock \& Wilsox Compang, Akron, Ohio January 9 - 15 to obtain design and technical information on high pressure piping.

H.S. Davas visited the North Pacitic Divisicn Laboratory, Corps of Engineers, Troutdale, Oregon, January 13 to discuss technical phases of concrete test program and preparation of report.

E.S. Day, Jr. and R.C. Mann attended the ISA Meeting in Portland, Oregon January 15 and 16 to assist in organizing Portiand Section Instrument Societ.j of Amorica.

W.J. Dowis at,tended the AIEE Meeting, New York City and risited the General

Electric Company, Schenectady, N.Y. to discuss power roactor, January $18-22$.

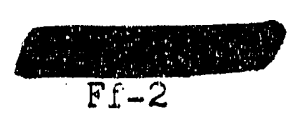


C.I. Cobler visited the Instrument Laboratories, Inc., Seattle, Wash., January 20 22 to examine rod position and indicator panel and approve chamber ilting changes.

L.T. Pedersen visited the Standard Steel Corp., Los Angelos, Calif., January 22 to discus. shielding door fablrcation for Projoct CA-512-R.

P.W. Swart: and C.L. Cobler visited the Yakima Valley Iron Worka, Yakima, Wash., January 28 to inspect control room console panel for 105-K.

J.W. Kolb visited the Motalwash Machinery Corp., Ellzabeth, N.J., January 29 to approve vendor prints and General Electric Company, Schenectady, N.Y., Fobruary 1 for consultation regarding further mechantzation of fuel element canning.

ORGANIZATION AND PERSONNEI

Personnel Statistics:

Design Management

Process Engineering Sub-Section

Design Planning Unit

Design Engineering Sub-Section Drafting Unit

Total Section Personnel

Technical Graduates (Rotational)

TOTAL

$\frac{\text { December } 31}{\text { Non }}$

\begin{tabular}{rrr}
2 & 1 & 3 \\
61 & 11 & 72 \\
18 & 12 & 30 \\
84 & 12 & 96 \\
9 & 112 & 121 \\
\hline
\end{tabular}

174

148

322

- 8 $8=9$

330

$\frac{\text { January } 31}{\text { Non }}$

$2 \quad 1 \quad 3$

$60 \quad 11 \quad 71$

18 - $12 \quad " 30$

$85 \quad 11 \quad 96$

$8 \quad 90 \quad 89$

$\begin{array}{lll}173 & 125 & 298\end{array}$

$173 \quad 134$

Accessions - 5

Separations - 28

Drafting splinter groups comprising 21 people were transferred to the organization where they had been assigned.

\section{GENERAL}

Design Section engineering effor for January was distributed approximately as follows:

Man Months Expended

1952 Expansion Program Research and Development Other Projects and Design Orders

$$
56.5
$$$$
55.1
$$$$
48.5
$$

$$
160.1 *
$$

\& of Total 30.3

100.0

* Equivalent man months expended Includes 3.3 months of overtime

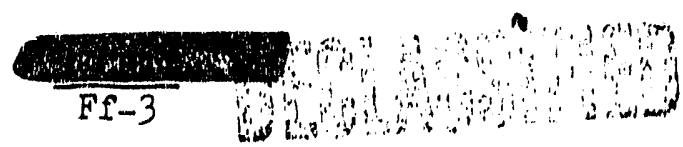


This restects a gradual decline $" 4$. ing increase in resear an and devolopmerte t: $20 \%$

Design Section drafting manpower ice the month of January was diatributed as follows:

Man Montrs Expended

of Total

Desigr Se tion

Project Section

Touhntoa! Section

Other

$$
\begin{array}{r}
89.3 \\
.6 \\
2.9 \\
1.5 \\
\hline
\end{array}
$$

$5.4 \cdot 3$
94.7

.6

3.1

1.6

100.0

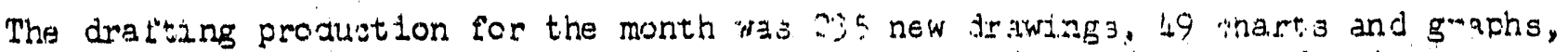
and 201 revisicns. The drafting room avera玉a was 7.9 man days par drawirg.

Work is under way on the preparation of the budget for Fl 1956 and raview of the budget for FY 195;, both for Plant and Equifment and Operating Funds.

\section{DESIGN DEVELOPMENT}

\section{Statistios:}

The total number of engtneering man menths expended on research and development during January was distributed as fullows:

\section{Man Months Expended}

RDS-D-10 Reactor Design Development RDS-D-11 Water Plant I: $51 \mathrm{~m}$ Development RDS-D-12 Separation: Desiem Development. RDS-D-13 Mechanical. Design Development RDS-D-14 Ut,iltties and Services Design Development

RDS-D-15 Engineering Standards and Materials Development

\begin{tabular}{rr}
23.3 & 42.3 \\
4.1 & 7.4 \\
12.3 & 22.3 \\
8.7 & 15.8 \\
$2 . .1$ & 3.8 \\
1.5 & 8.4 \\
\hline 55.1 & \\
\hline
\end{tabular}

\section{RDS-D-10 - Reactor Design Development}

Feasibility studies were being made of the high pressure recirrulation factlities for the 100-KE Reactior. The proposed lacility includes four separate htgh pressure recirculating loops, each containing one tube on a separate crossheader in the fringe of the flattened zone. Design will prorlide for operat ton at 2,000 psi, $1600 \mathrm{~kW}$ per tube, and liquid phase or 10-pile boling cpezation. The activity due to recirculation of the water should not pregent a sermous operational problem at the front face of' the roactor.

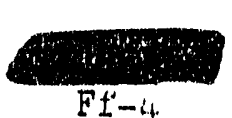


Design Section

HW-30724

RDS-D-10 and D-11 - Peactor Plant Derelolment "DPR Program"

A deslgn and development program for the Tual Purpose Rezctor was established and a dosument issued outlining program and degign objectives, target schedules, cost estimates for design and development and basic design-development criteria.

Further study work progressed on the factors affecting a cholce of lattice spacing. Cost and performance data for various spacings and slug dimensions were prepared and distributed for information. Work was done on the selection of water annulus dimensions, water flow rates and pressures, influent and effluent steam pressures and other items. The required flow rate is approximately $135,000 \mathrm{gpm}$ for operation at $3000 \mathrm{MW}$ when the influent and effluent temperatures are $400^{\circ} \mathrm{F}$ and $500^{\circ} \mathrm{F}$ respectively.

Consideration was given to alternate process pipjng design having a maximum capacity of $200,000 \mathrm{gpm}$. Cont Inuous charging and discharging presents additional problems in the plping design in order to prevent flashing of steam at discharge.

A site adjacent to the river and midway between $K$ and $D$ Areas at 460 feet elevation was tentatively recomended. Further development on the selection of the site and building layout was continued. A dual ventilation system is being considered for the 105 Building. This would permit separation of process ventilation (Including relatively high heat loads from the piping) and the normal building ventilation.

RDS-D-12 - Separations Design Development

Studies were continued with the problem of reckcing corrosion in a nitric acid fractionator for the Purex. Plant. One approach is to operatie at a reduced pressure (100 am mercury) and thus at a lower temperiture. The firgt approach specifies location in the canyon where any radiaion level can be tolerated but where the facilities would be crowded. The question of remote handling al so Indicates that the scope should be increased to study possible installation of a high vacuum fractionator outside the canyon where the radiation level is questionable.

The problem of contamination by radioactive ammonium nitrate is being studied and the scope for one possible solution is near completion. This is the removal of ammonia from coating removal off-gases in the Purex Plant by scrubbing. Similar scrubbers are being scoped for the Redox. Plant and these studies are being extended to include the desirability of recovering nitrogen dioxide.

A preliminary scope was prepared for a vapor system which would handle pressure surges in the SK. Waste Tank. Farm (under construction) similar to the current Redox Waste Tanks. The presently filled tanks have highly concentrated wastes winich boil and surge under their internally produced heat. The scope proposed would vent all tanks through a single empty tank to a headered bank of fifteen condensers. Each tank would be gealed by a water trap which would contain normal boiling and allow all empty tanks to act as surge tanks.

A study of the feasibility and desirabillty of stopping construction of the 233-S Building and substituting continuous concentration equipment in the 202m Sample Gallery adjacent to the existing PB cage was completed. Though such a change

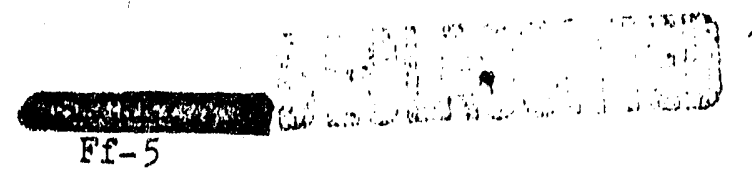


in program could save approximately $\$ 300,000$, other lases for the jyan, tre t. zming ot such an installatzon, the crowded nature of the resule.n. sacizities. and contamnation control problems could outweigh the saving.

In the 234-5 Building, Project CG-551 is being supported by design development on manual manipulators, on suitable pressure vessels, and on firrace sealing valves.

\section{RDS-D-13 - Mechanical Design Development}

Cold testing of the prototyfe fuel element canning ma:n ne was complated and hot testing of the machine is scheduled to start early in Fobraary. A continuous test of 41 hours was completed with 80\% actual operating afficlency. Individual items will be corrected as necessary and the quencn unit, wizich is omplete, will be installed. A safety device was installed to protect the machine in sase of binding in the horizontal direction. Overload trip devises are on order for the can and slug arms for protection against binding in the vertical dimestion.

A prototype of a Model II liquid level or interface monitor was completed. Thas instrument operates on a 60 cycle power for its serromechanism drive. Inetrument. errors due to instability, non-linearity, and hysteresiz effevts appar to be less than for the first model.

\section{RDS-D-14 - Utilities and Services Design Development}

Work was continued on the compilation of Columbia River Data from duPont, Bureau of Reclamation, U.S. Fonlogical Surver and Soil Conservation Servzces and Manhattan Distric: Corps of Engineers renords.

\section{RDS-D-15 - Engineering Standards and Materials Development:}

Cost to date for development of engineering standards for the current, fizcal jear is $\$ 23,103$.

The following standards and revisions to standardj were completed ard is 1 ued.

A-2-4 Fire Hose Boxes, Rev. 1

B-3-47 Water Closet, Single on Concrate Floor Slab, Rev. 1

B-3-48 Water Close:, Single With Under Floor Acsess, Rev. I

B-3-50 Latratory, Rev. 1

B-3-52 Urinal, Rev. 1

B-3-54 Drinking Fountain, Rev. 2

D-2-64 Pages 1, 2, 4 - Minimum Clearances - Elec. Standard, Rerr. 1

HW-4903-S, "Standard Specification for Welding Aluminum and Aluminum Alioys Rev. 1."

HW-4926-S, "Standard Specification for Welding Carbon Steels, Rev. 1."

HW-4953-S, "Standard Specification for Brazing and Braze Welding, Miscellaneous Metals and Alloys, Rev. I."

D-G-102-M Design Guide for Packing and Gasket, Materials, pages i's \& 13 revinoise 
D-2-1a Pin and Insulator Assemblies

Work on standaras and studies during the month is as follows:

a. Work was started on the electrical part of preparing a Standard Design Criteria (instructions to designers).

b. Major revisions are being made on the standards for qualifying welders and for welding stainless steels.

c. A study was made to determine the extent to which Federal Specifications may be used in the local construction specifications. It. was concluded that the specifications are being used to the fullest economical extent practicable.

d. A study was started on the possibility of limiting harmful noise in future design.

e. A study was started to determine the feasibility of using magnesium anodes for protection of retention basins.

\section{DESIGN PROJECTS}

\section{Statistics:}

Design engineering effort by the Section on projects for the month of January was expended in the following categories

\section{Man Months Expended \% of Total}

$\begin{array}{ll}\text { CA-512-R } & \text { 100-K Reactor } \\ \text { CA-512-W } & \text { I00-K Water Plant } \\ \text { CA-513 } & \text { Purex Separations Facility } \\ \text { CA-514 } & \text { 300 Area Expansion } \\ \text { CG-551 } & \text { Expansion of Building 234-5 } \\ & \text { Facilities } \\ \text { CG-558 } & \text { Reactor Plant Modification } \\ \text { CG-562 } & \text { TBP P7 ant Modification } \\ \text { CG-567 Alum-Activated Silica Water } & \text { Treatment Facilities }\end{array}$

Major Projects - Other than Expansion Program Minor Projects and Design Orders

TOTAL

\begin{tabular}{rr}
35.3 & 33.7 \\
2.3 & 2.2 \\
9.9 & 9.4 \\
4.2 & 4.0 \\
4.8 & 4.6 \\
20.2 & \\
1.6 & 19.2 \\
1.8 & 1.5 \\
21.6 & 1.7 \\
3.3 & 20.6 \\
\hline 105.0 & 3.1 \\
\hline
\end{tabular}

\section{CA-5I2-R $=100-K$ Reactor Facilities}

Design on the 1.00-K Reactor Facilities was essentially completed during the month. Three drawings were approved during the month and minor engineering work remains. The Water Studies Semi-Works was advanced $7 \%$ during the month to $100 \%$ complete. Expenditures to date are approximately $\$ 1,999,700$ against an estimate of $\$ 2,425,000$. 
Pro ject proposal, CA-512-R, Revision 2 was completed, approved by the Appropriations and Budget Committee and forwarded to the ATC. This proposal recomended the inclusion of the recirculation facility in the scope of the project. The design of the 1.706-KJ Building is such that present construction can go forward whether or not the macirculation facility is included. The recirculation facility will require in additional building of approximately the same size as the 1706-KE Building.

Tests were started on a 12-point prototype temperature monitor which was received from the vendor. The certified prints are currently being reviewed for approval.

Twenty-four vendor fabricated pigtails were received and checked on the front and rear face mock-up assembly. The pigtails as fabricated are not dimensionally adequate and changes in specifications will be made to correct this condition.

\section{CA-512-W - 100-K Water Plant Facilities}

Detail design of the 100-K-B-C telephone exchange was essentially completed during the month.

Review of electrical and instrument drawings and specifications submitted by the architect-engineer continued througl the month.

CA-513-Purex Facility

Over-all design of the Purex Outside Facilities is $100 \%$ complete, an advance of $2 \%$ during the month. Vendor's constmuction drawings were reviewed and approved. Five drawings and one specification were approved.

Design of the Hot Semiworks was advanced $17 \%$ during the month to $90 \%$ complate. Of a total of 85 drawings being prepared by the Design Section, 51 have been approved and 15 are out for comment. Checking of drawings is being done at the request of the Technical Section to change pulse drive assemblies for mounting in the vertical instead of the horizontal position.

It was decided that a fiber-glass filter for the canyon ventilation exhaust system should be added to the construction scope. It will be needed eventually and it will be cheaper to install it at the time of construction.

\section{CA-514 - 300 Area Expansion}

Detail design of the 300 Area Expansion Program was advanced 1\% during the month to $79 \%$ compiete. The small advance resulted from changes in the 313 Building design due to the 3X Program and diversion of engineexing personnel to the latter program. It is anticipated that design of the facilities for both projects will overlap with a resulting delay to Project CA-514 of approximately six weeks. Revisions are being made to the equipment layout in the 313 Building to accomodate space requirements of the 3 I Program.

Studies are being made relating to the question of fire protection in the uranium storage areas in the 313 Building. It was developed that there is a need for 
Design Section

more information on the chemistry of uranium fires and technlcal information to serve as a basis for selecting or developing methods of fighting such fires.

CG-431-B - 100-C Area Production Facilities

Failure rates of stainless steel pigtails have reached serious proportions. Ninety-eight per cent of the failures have occurred in the high temperature zone. Three alternate designs are being tested and a requisition for replacement pigtails will be ready early in February.

\section{CG-431-C - Metal Examination Facility Equipment}

Design work on the underwater metal examination at 105-C was advanced 5\% during the month to 100\% complete. All 97 drawings have been approved.

\section{CA-535 - Redox Capacity Increase - Phase II}

Final design for Redox Capacity Increase, Phase II, was advanced 6\% during the month to $90 \%$ complete. Revisions of the F-2 concentrator were completed and five drawings we re reissued for construction. Review of purchase requisitions, specifications and bids submitted by the architect-engineer continued through the month.

\section{CA-539 - Redox 241-5x Tank Farm}

Over-all design for the 24l-Sx Tank Farm is approximately $88 \%$ complete. Design completion was recuced from $95 \%$ to $88 \%$ complete due to required changes in the design of the condensing facilities to accomodate surges of vapor from the tank. This change is being made as a result of recent waste concentration problems at the 241-X tank farm. Approximately ten additional drawings will be required.

\section{CG-549 - Activate Task I, Building 234-5}

Design work on the Activation of Task I, Building 234-5, is approximately $68 \%$ complete, an increase of $23 \%$ during the month. Twenty-five drawings were approved and 32 drawings were out for comment. A total of 45 drawings out of 124 required drawings have been approved.

\section{CG-551 - Expansion of Building 234-5 Facilities}

Design work on Expansion of Building 234-5 Facilities was advanced 7\% during the month to $76 \%$ complete. Purchase requisitions and specifications issued for procurement of critical materials now total $\$ 62,600$. Of the 273 required drawings, 166 have been approved to date, an increase of 33 drawings during the month. Authorization was received for design of the final inspection facilities and for the remainder of the funds. Preliminary work was completed and detail design was started on the final inspection facilities.

\section{CG-558 - Reactor Plant Modification for Increased Production}

Scope design work on Reactor Plant Modification for Increased Production advanced to approximately 56\% complete, an increase of $12 \%$ during the month. Detail design is $3 \%$ complete. 
A revised 'construction budget data sheet was prepared, aproved by General. Electric and forwarded to the AEC as a means of obtaining an aliostion $n$ funds to Hanford for the project prior 'o the sutmi' $i$.' of a detailed project proposal. The Commission authorized an additional $\$ 100,000$ for design making a total of $\$ 200,000$. A final draft of the project proposal requesting authorization of procurement was prepared and completed for Design Council review the first week in February.

Commerit prints and check prints were is sued for modifications to the 181-B and 183-B Buildings, the 100-B Effluent System, and the raw water line from 181-B to 182-B. This work is based on the decision to provide $71,000 \mathrm{gpm}$ to the 105-B Reactor. The C-Plant will be changed to provide water flows of 72,000 91,000 gpm. The higher flow rates will depend upon higher core temperature (up to $800^{\circ} \mathrm{C}$ ).

CG-562 - Waste Metal Recovery Plant Mo alfications

Revision 4, Project CG-562, Waste Metal Recovery Plant Modifications, to provide solvent trating facilities, was completed, approved, forwarded to the Commision and a new directive modification was received based upon this revision. Over-all design of these facilities is $25 \%$ complete.

CG-567 - Alum-Activated Silica Water Treatment Facilities, Phase I

Design of the Alum-Activated Silica Water Treatment Facilities wis 7 tranced $15 \%$ during the month to $90 \%$ complete. Design work for 100-B Area was completed and 100-H Area design was revised to include sample lines requested by the Manufacturing Department. Work was initiated on Revision one to project proposal CG-567 requesting authorization of additional work at 100-C and 100-DR.

\section{CG-573 - Hanford 3X Program - 300 Area}

Design work was started during the month on the Hanford 3X. Program 300 Area and design is approximately $25 \%$ complete. Design for this program involves principally the initial modifications to the 313 and 303-J Buildings for reactivation and expanding the dry fuel element canning facilities and further building modifications and equipment design for a new process.

D.0. 100362 - Underground Waste Line Between "S" and "un" Area - 200-W

The increased scope of the work includes condensers on the waste tanks and condensate Iine and new crib. The condenser shielding wall was changed to increase the thickness to two feet. Drafting on the change was completed at the end of the month.

D.0. 100473 - Hot Ball Detector, Ball 3X System

Design of a "hot" ball separator for the Ball 3-X System was advanced $4 \%$ during the month to $80 \%$ complete. The electronic equipment of a prototype is nearly complete and is being tested.

D.0. 100529 - Ball Third System - Ball Recovery System

Proposed altemate sites and cost studies, were investigated for tale ball whisher
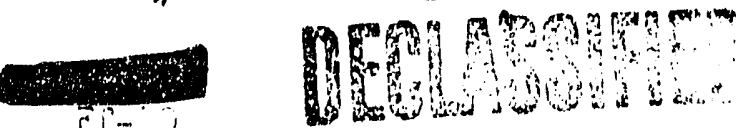
Design Section

installation at the 100-H Area wash pad and 100-D Area cask pad. Ore drawing was issued for comment. Completion of the job will be delayed pending ordering of the ball washer and selection of site location by the Manufacturing Department.

D.0. 100630 - Fuel Element Pilot Plant

The equipment layout drawing was revised to include cent changes in types of equipment te be installed and was forwarded to the architect-engineler. The A-E floor plan, room finish and door schedules, and laboratory furriture drawings were reviewed during the month.

D.0. 100638 - Gamma Type Water Monitoring Improvements

The project proposal, Effluent Water Monitoring Improvements - Existing 100 Areas, was completed, approved and submitted to the Appropriations and Budget Comnittee.

D.0. 100652 - Auxiliary Ventilation System - Redox Ce1.s

Preliminary design necessary for a project proposal was completed.

D.0. 100675 - X-Level Flow Equipment, 105-C

Design work on the flow and recording equipment for the 100-C test hole facility was completed except for one acceptance test procedure.

D.0. 100681 - Recuplex Acceptance Test Procedures

Work continued on the preparation of acceptance test procedures and these are $80 \%$ complete.

D.0. 100686 - Process Tube Flow Facility (CG-559)

Design of a process tube flow facility for installation in the 189-D Building was advanced $6 \%$ during the month to $100 \%$ complete.

D.0. 100718 - Installation of Foxboro Dewcells in Gas System - 100 Areas

Several meetings wore held with representatives of the Manufacturing Department and assistance was given in the preparation of cost estimates for the project proposal.

D.0. 100724 - Modifications to the 314 Building for Fuel Development (CG-563)

Design for modifications to the 314 Building was advanced 10\% during the month to $30 \%$ complete. Approximately two weeks design delay will result from the higher priority work on the 3X Program.

D.0. 100740 - Modification of the 115-C Gas System (CG-431-B)

A letter was prepared giving proposed recommendations for modifications to the gas system to increase the gas flow rate capacity to $3000 \mathrm{cfm}$. 
Design Section

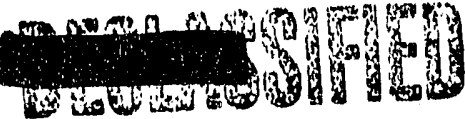

HW-30724:

D.0. 100742 - Electro-Magnetic Counter System

Design of a pulse counting instrument for letermining pul sation rate of several columns in the Hot Semiworks was advancea to $50 \%$ complete.

D.0. 100746 - Warehouse Modification Design

Design was started for the modification of warehouse 13 and a check print was issued.

D.Q. L00750 - Profect Proposal, Modifications 100-C Reactor Plant

Work was initiated on a project proposal for modifications at 100-C to increase the water flows to meet the requirements of the 100 Area Modification Program.

D.0. 100753 - Building for Physical Constants Test Reactor

Lesign was started on the design of a butlding for a physical constanta test reactor. A scope drawings was issued for comment.

D.0. 100754 - Modification of the 189-D Process Tube Mock-UF

Engine ering assistance to the Technical Section was started comprising planning and scoping, design of facilities, procurement of materials and equipment, and assistance in preparation of cost estimates for alteration and extension of existing experimental facilities to provide a full scale process tube mock-up for dual-purpose reactor studies.

D.0. 100757 - "As-Built" Area Mars

A program to correct and improve Hanford project maps was set up to present data on the physical aspects of the over-all project area. Existing maps will be brought up to date by adding new facilities, utilities, railroads, roads and topography.

D.0. 100765 - Cell Air Cleaners - Redox Produstion Plant .

Preliminary design work for a new Redox cell ventilation unit was begun and a scope drawing showing the proposed unit was made.

D.0. 100772 - 3X Program - Extraction

Preparation was completed and securing approvals was started on the Project Proposal CG-575 for Hanford 3X Program, P-10 Extraction. Scoping was started on the basis of installing required extraction and isotopic enrichment facilities in the 271-B Building, sufficient to shut down the temporary facilities in the 108-B Building.

DESIGN SECTION WORK COMPLETED DURING JANUARY

D.0. 100577 Gamma Monitor Chambers - 107 Basins

D.0. 100671 Flow Test Instrumentation 
Design Section

D.0. 100711 Jumper 24,1-S-151 Diversion Box

D.0. 100715 Temperature Balance, Bun1 dz.ng 108-F

D.0. 100723 (CG-550) Reactiva', ion of P-10 Facliz:1es (Field Lial jon).

D.0. 100728 Wind Tunnel Installation, 222-U Building

D.0. 100743 105-D Process Sewer As-Built Drawings

\section{INACTIVE PROJECTS}

No active design work was performed during the month on the following assignment:

D.0. 100549 Rotox Back-Cyole

\section{INVENTIONS}

All persons in the Design Section engaged in work that might reasonabiy be expected to result in inventions or disccreriss advise that, to the best of their knowledge and belief, no inventions or tiscoveries were made in the course of their work during the period covered by this refort. Such persons further advise that, for the period therein sovered by this reports notebook records, if any, kept in the course of their work have been examined for possible inventions or discoveries.

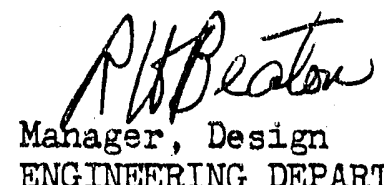

ENGINEERING DEPARTMENT
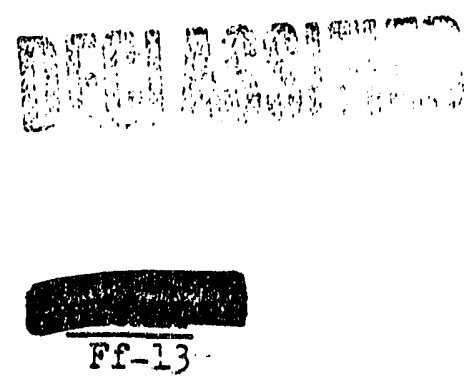


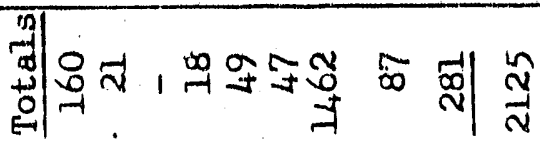

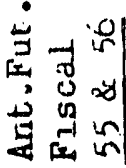

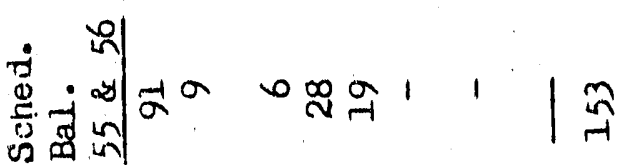
氯ovianing

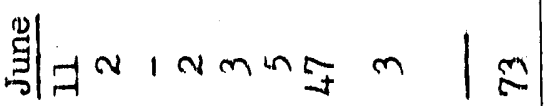

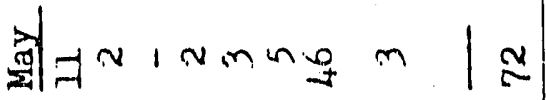

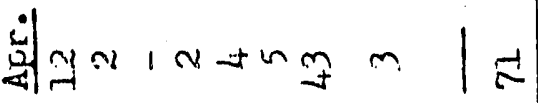

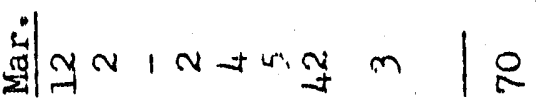

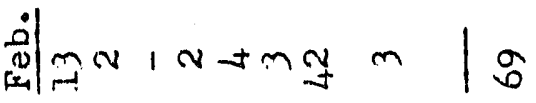

io

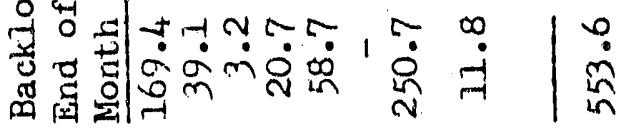

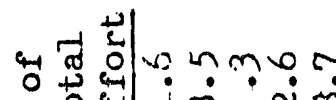

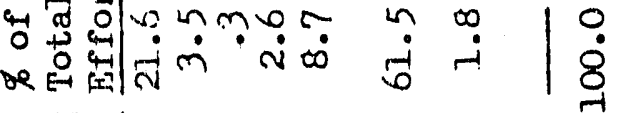

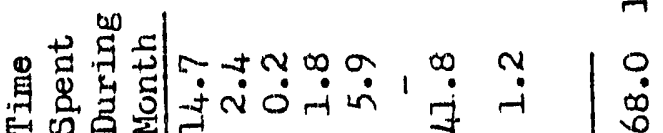

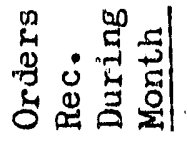

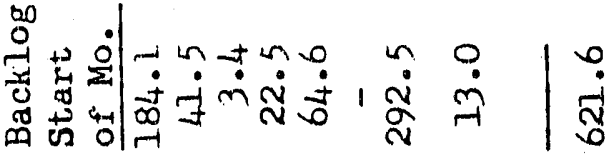

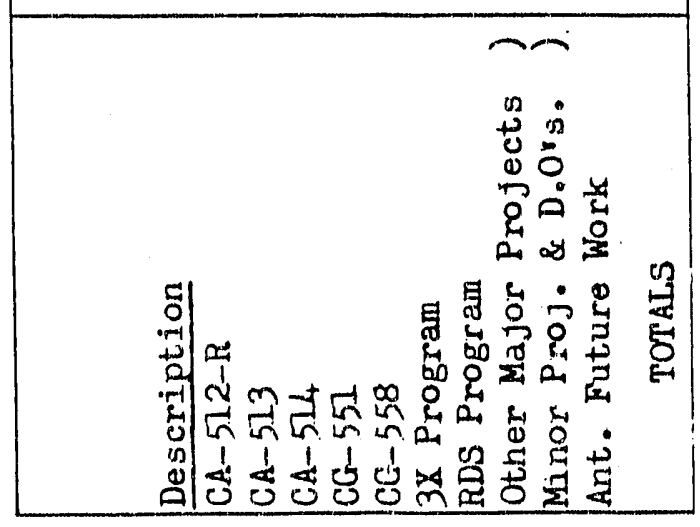

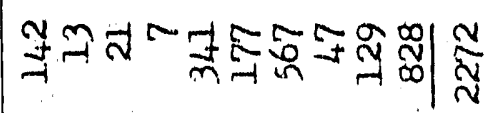

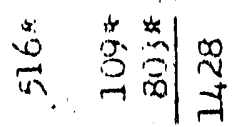

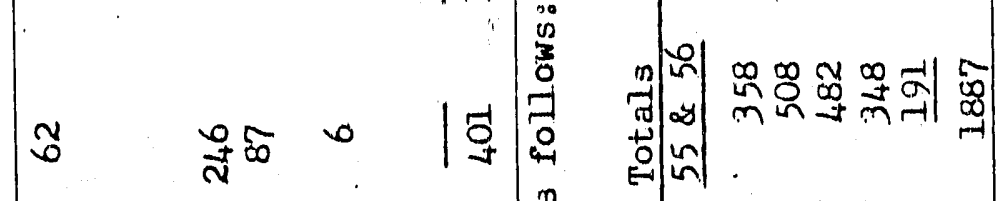

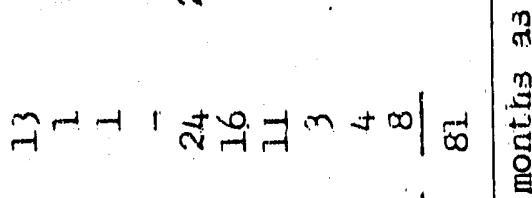
$\dddot{n}+\cdots+\infty$

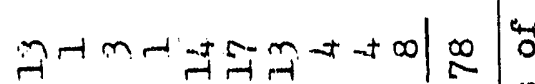
z)

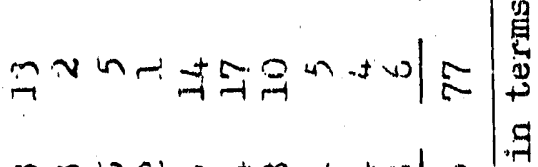

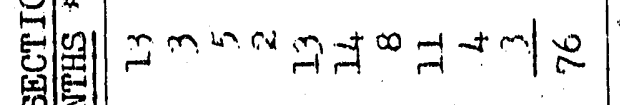
毁 瞝部 嵒

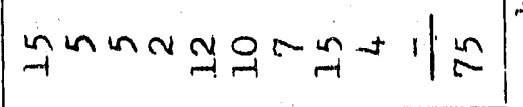

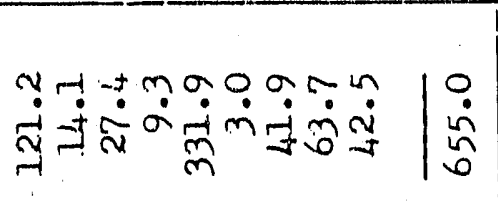

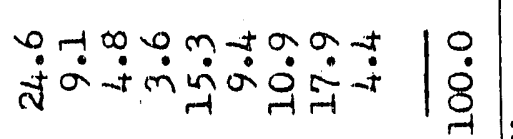

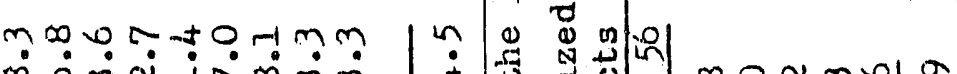

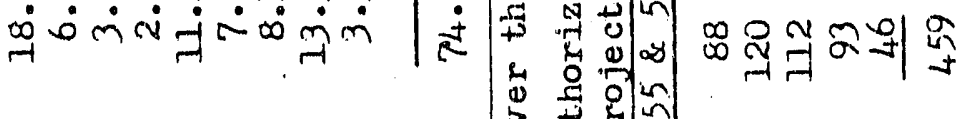

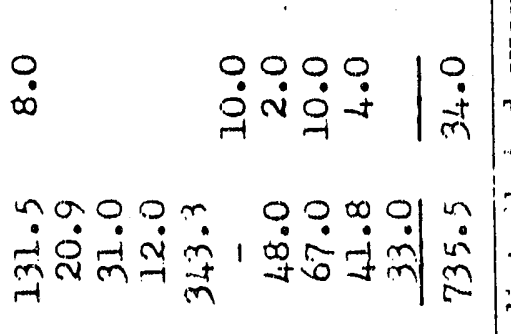

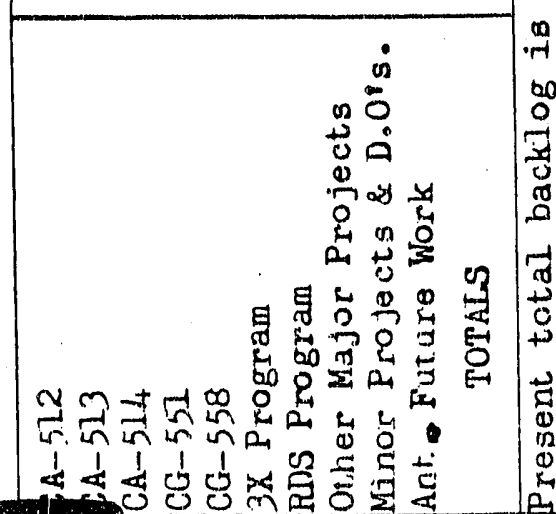
莫

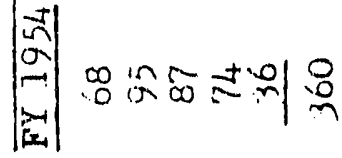

$H W-30724$ $\rightarrow \infty$ 


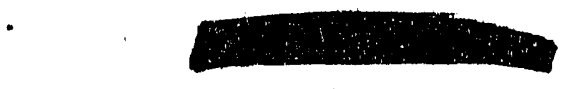

HW-30724 ind

\section{MONTHLY NARRATIVE REPORT - JANUARY 1954}

\section{PROJECT SECTION}

\section{SUMMARY}

A.: ORGANIZATION AND PERSONNEL

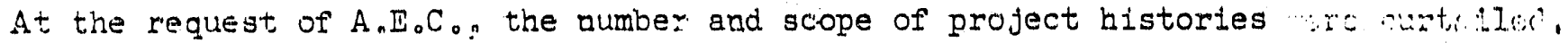
Five of the six General flectric people engaged in histories became avaliable tor reassignment. By the end of the month, two were reassigned and one was placed on loan to Technical Section. Followlag is a summary of personnel changes in Project Section during the month:

January 1, 1954 January 31, 1954 Net Change

Enployees on Payroll

Tech. Grad - Rotational

$$
454
$$

453

14
$-1$

The end-of -month status involved these changes:

Project Section Personnel Tech. Grad - Rotational

Payroll Adaltions

Payroll Removals

Transfers 1nto Section

Transfers from Section

Transfers within Section
4

4

2

3

Seven informative meetings were held for Project Section personnel.

\section{B. SCOPE OF ACTIVITIES}

At the end of the month, construction completion status of major projects was as I0llows; CG-496, Recuplex, 31\%; CA-512, 100-K Area Facllities - Water Plants, KW, $52 \%, \mathrm{KE}, 30 \%$, General. Facilities; $57 \%$, Reactors and Buildings, KW, 53.2\%, KE, 22.3\%; $C A-513$, Purex Facility, Part "A", overa11, 18\%, Part "B", 98\%, Part "D", 9\%; CA-514, 300 Area Expans10n, cvera11, 26\%; CG-535, Redox Capacity Increase, Phase II, 8\%, CA-539, Redox 241-5X Tank Farm, 56\%; CG-573, Hanford 3X Program - 300 Area, 4\%.

\section{CRAFT IABOR}

The two-week work stoppage by carpenters and millwrights reduced the effectlve construction forces by an estimated 40-50\%. On January 1.1, about 40 General Electr1c employees were furloughed for lack of work in 2101 Bullding. On January 18, the strlkers retumed to work following transfer of jurisdiction to the Ching Panel. A brlef work stoppage on January 21 was caused by 35 Kalser. machinists who protested the relocation of a radial drill. When another drill was obtained, the machinists

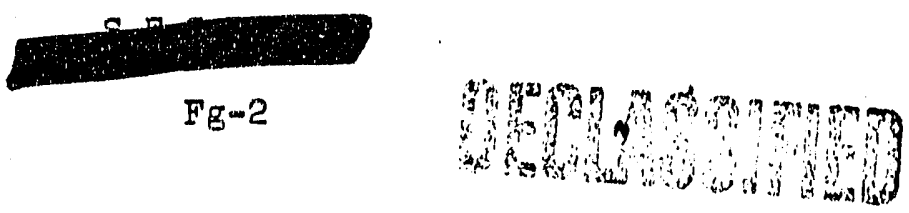


returned to work on swing shift of the same day. Negotiators on the "Master Agreament". accomplished minor settlements in a letter of understanding, but the major question of isolation pay remalned. The contractors prepared an eight-page statement of their position on 1solation pay and handed the document to the Bullding Trades Counc1I on January 26. International representat1ves of Machlnists and M11Iwright's Unlons met, with a representative of the Federal Mediation and Conclilation Service, to settle jurisdictional problems between the two crafts in 2101-M Bu1lding." No definite results have been announced.

\section{SAFETY AND SECURTTY}

There were eight regular meetings and discussions of safety, security, and health topics which were attended by about 350 personnel. The regular Monday morning "tool box" meetings were conducted in the field, and two safety meetings were held for service contractor personnel. Speclal hazards disclosures were given to 22 new service contractor personnel. During 1953 Minor Construction fleld forces worked about 700,000 man-hours of SWP work with only 17 cases of skin contaminat Ion.' In every case, decontamination was successful. As of January 26,1954 about 620,000 manhours were completed by Minor Construction without a lost-time injury.

\section{E. HIGHLIGHTS}

Minor Projects Sub-Section worked on 44 project 1tems and 3 informal requests, representing an estimated total of $\$ 20,920,600$. The Sub-Sect1on completed asslegned work on two projects, Repair of 105-D Reactor Effluent Line, and Transportation Garages 2713-1 and also informal request IR-I60 and three engineering requests. Four project proposaIs were approved by the A \& B Comnittee. Flve authorizations were granted by the A.E.C. The Sub-Sect1on began work on CG-573, Hanford 3X Program - 300 Area, CG-576, General Improvements to Laboratory Area Bullding - 300 Area, and ER-2747, Semiwo.ks - Purex self Concentrator Waste Storage Tank. Important projects now in progress include Recuplex Installation Bullding 234-5, 300 Area Expansion Program, Fuel Element P1lot Plant, Reactivation $\mathrm{IP}$ P-10 Facilities, Hot Semiworks Conversion, and Hanford 3X Program - 300 Area.

\section{Project Auxiliaries Sub-Section}

With the reduction in number and scope of profect histories to be written, action was begun to reassign five people. Two reassiguments and one loan were completed by the end of the month. Continuous efforts were made to obtain qualified off-site inspectors to care for the increasing workload. Inspection was completed on 164 orders, and 189 new orders which will require inspection were recelved. At the end of the month there were 932 orders for 1tems whlch required laspect1on. Reproduction output was 469,663 square feet for the 18 working days of the period. Estimating completed 38 estimates, lncluding those for 12 project proposels. Fleld surveys completed "As Built" informatior. for 200-East Area ut1lity maps, and also completed preliminary surveys for a proposed new 1.00-B effluent system.

\section{Reactor Profects Sub-Sect1on}

The last three major bulldings of the Hanford Laboratory were declared complete as of (

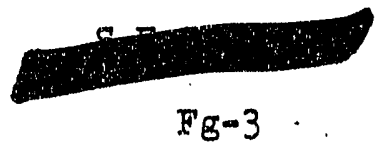




$$
\pi \pi-3072.4
$$

the end of 1953. The 2101-M Bullding was declared complete, with a minor exception, at the end of Jenuary. Most outalde work in 100-Kh Area was delayed by the carpentermillwrlght strike and adverse weather. Small amounts of concrete were placed in the 105-1,15 KT Bulldings, and work was completed on catwalks and miacellaneous ateel in main tunnels of 183-KW. The 181-KW RIver Purm Houge was structuralily couplete; and the elrst pump 1s being propared for setting. In the 105-110-115-KW Buildings, Installation was continued on electrical and control systems. For the 105-KW Reactor, Installation of cast 1ron was completed on both right and lef"t sides. AlI right side thermal cooling tubes have been lnstalled and leacled, and the left alde tubes are belng Installed. Five sections of downcomers were finish-machined, and flve of the longer sections were fabrlcated but not machined. Of the 6,032 process tubes recelved, 1020 have beet tested, reamed, and annerled on the lalet end. For the 105-KW Reactor, grouting was completed in the following crates: second tier gldes, third tier inlet, and fourth tier outlet. Mock-up of 105-KW graphite ves completed January 26. For KE graphite, production shop work was $26 \%$ corplete and the fabrlcation shop work was $17 \%$ complete.

\section{Separations Profects Sub-Section}

Because of the carpenter-millwrlght strike and adverse veather, only 2466 yards of concrete were added to 202-A Bulld Ing and related structures. Some Ilmited progress was made on burled piping, condult, and ventilating ductwork. Blaw-Kiox and X-Ray Products executed a subcontract for X-ray inspection of welded stalnless plping in flxed canyon installations. Shop fabrication was contlnued on plplang for Hot Plpe Trench and drains in 272-E Mock-Up Bullding; steel Installation was completed on January 11, and four mock-up tanks were installed. Construction of the $13.8 \mathrm{KV}$ Transinission Iine was stcpped during the extreme weather. Work on the 2901 Export water Ilne was stopped to awalt parts for repalring damage incurred during testing. Excavations were begun for 211-A Chemleal Tanls Farm, 291-A Stack, and 291-A Fan House, but 11ttle progress was made. Excavation for 241-A Tank Farm progressed to about 75\% cormlete. Flpe-laying for the 8" raw water 11ne was begun. For 241mX Tank Farm, a deslgn change to accomplish self-evaporation of liquids was requested of $A_{0} E_{0} C_{0}$. This change is expected to increase the life of the tank farms three to ilive times.

\section{F. MONTHLY REPORT OF INVENTIONS AND DISCOVERITS}

All persons in the Project Section engaged in work that might reasonably be expected to result in inventions or discoverles advise that, to the best of their knowledge, no inventions or alscoverles were made in the course of their work durlng the perlod covered by this report, except as listed below. Such persons further advise that notebooks and records, $1 f$ any, kept in the course of their work, have been exainined for possible inventions and discoveries.

NONE

January 31,1954

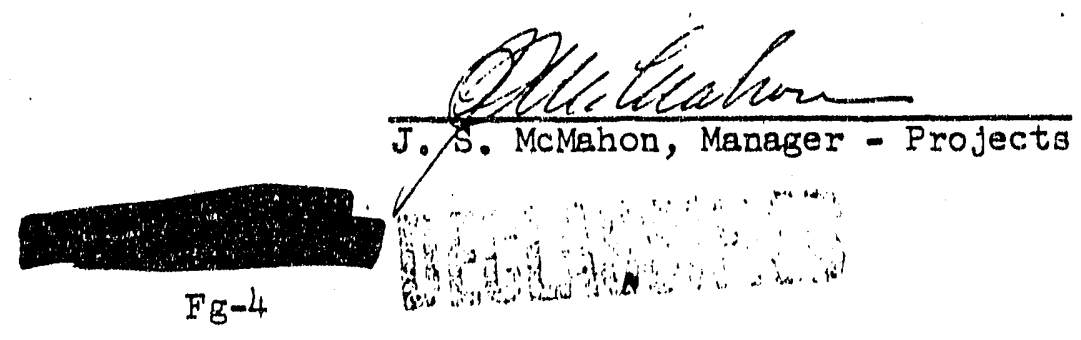


II. STATISTICAL AND GINTEAL

$\mathrm{HW}-30724$

A. SIGNIFICANI ASSTGIBUIDNIS

1. Intital Rerorting

C. -573 - Hanford $3 X$ Propram - 300 Area

Desien was 8\% complete, and construation was $4 \%$ complete. An inftial project proposal, Document HIV-30531, whioh outlined the scope of work, was submitted to AEC; and a directive dater Janiary 15, 1954, ras issued to authori2e reaotivation of existing facllities, procurement and installation of hot press equipment, and the necessary bullding additions. A revision is being propared to include a detalied estimate of cost and a completion schedule.

The south half of $303-\mathrm{J}$ Bullding was completed for reactitation of dry canning facllitios and turned over to Manufacturing on January 18. During the carpenter-millmright strike, the uniong furnished two millwights, a foreman, and six to ten carpenters as required for this critical work. Insulating and lighting work is progressing in the north half of $303 \mathrm{~mJ}$, and excavation for semers was started.

Reactivation of dry canning facilities in the 313 Bullding was 40\% complete on January 21 , $15:$.

\section{CG-576 - General Improvements to Laboratory Area - 300 Area}

Scoping was 60\% completie. The project proposal was being prepared for review by the $A \& B$ Committee on February 8, 1954. The present worls scope includes only the inuediate improvements to the 326 Building. A revision to the project proposal is being made to include ali necessary improvements to Buildings $325,326,327,328$, and 329.

ERa2747 - Semimorks - Purex Self-Concentretor Waste Storage Tank

Sconing was completed, and a rough draft of the project proposal has been prepared. A letter vas written from lianager, Engineering to Manager, Hanford Operations of'ice requesting advance authorization of 25,000 for design and procurement funds. Approval is expected so that design can start in February, 1954.

\section{Final Reroruing}

Completion notices, with exceptions, were issued for the last thrse major Buildings of the Hanford Laboratory Area. The exceptions, which include unitization and pork order costs and purchase order commitments, are being cleared.

CA-519 - Renlacement of $200-D$ Reactor Effluent Line

Construction progressed 3\% to completion. A Physical Completion Not1ce mas issued Januery 19, 1954 .

CA-568 - Transportation Garage and Facilities - 2713-E

With design at $15 \%$ complete, the proposed work was cancelled for lack of sufficient Justification.

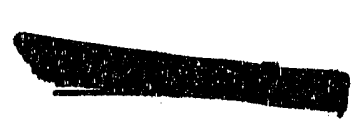




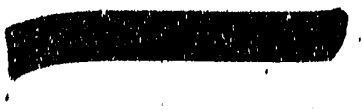

II.: -3072.4

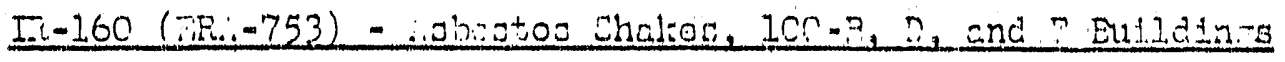

Three minor exceptions rere oleared, and the rork ras accopted on January 8, 1954. The Finysica.l Completion lotico was prepared.

\section{IR-3098 - Cobalt 60 Source for Radlation Studies}

Nith desien at 50\% complete, this mork ras cancelled January $c, 1954$.

\section{ERt-3101 - Ilectrorlatine Facility for Tuel Develormont}

:ith scoping at 60\% comlate, this worli we cancellec? January 22, 1.954.

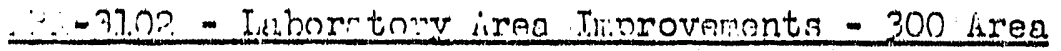

"ite ortginal scoving rorl: was sccomplished with the authorized funds. Frovaration of the rrorosal for CG-576, Cennral Irinrovements to Laborntory iron - 3Co irea, is being continued on in-i-3103.

\section{Current Erofects}

\section{CA-172 - Remodelin : Dullding 108-F for Biology Laboratory}

Completion status remalned at denlen 100\%, construction 99\%. The laboratory furniture has arrivad and is being installed by the contractor. The fice alarr and electrical installations are complete except for teating and tie-ins.

CA- $131-4$ - New Reactor - 100-C Plant (Trtermorins)

Completion status remained at desien 1C.0 construction 99.9\%, Repair of 107-C Tank baffles is about 20\% complete. An estimate is being prepared on proposed inr rovements in the ventilating system for the cushion chamber in Building 105-P.

\section{CA-43I-B - Ner Zeactor - 100-C Flant (Penctor)}

Completion status remained et design 1C0,', construction 99.9\%, rork proiressed on detailed design of ner tip sections of horizontal rods. Desigr was wodified on metal. loading elevators, and on gates and gate seals for the metal examination facilities.

\section{CA-43I-C - Letal Eramination Facilities 105-C}

Design had keen completed Freviously; construction progressed 3i, to a total of $10^{\prime \prime}$. Progress is being delayed because of higher priority mork in the shops. The project proposal is being revised to expand scope and to increase time and funds.

C.:-438- Ba.21 Thirci Safety System

Completion status remained at design 100\%, construction 98,. Improverents to maticr nressure circuitiry have heen completed by plant forces in all areas. Replacement of . colerolos and installation of battery revision mas complete in al.1 a reas except DR.

Becouse of contemination, none of the existini, lose feeder parts "ill be avallable ior the new hose fepders. Shn! mork on the hot on 1.?. separator has poen colayed because of Hanford $3 \pi$ Frofran.

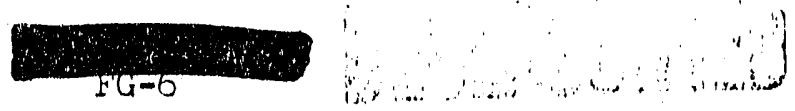




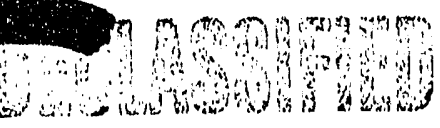
…-30724?

CG-406 - Recin 1ex Installation. $934-5$ Building

Desien had been ccrpleteci rreviously; construction progressed $2^{\text {ct }}$ to a total of $31 \%$. Some shop rork ras accomplished, but installation mork at Building 234-5 is still awaiting arrival of vessels, valves, agitators and other critical material. A bid on the Pulse Generator ras received from the Western Gear Company of Seattle.

The Iump sum contractor has been delayed by adverse licather conditions and by unforeseen soil conditions which required sheet piling around the excavations. One shi... . of tile failed to meet specifications; so there may be a delav of tro weeks in securing the proper tile. The order for the Silica Storage Tank has been Flaced, and the tank is being fabricated.

CA-512-100-K Area Facilities

$100-\mathrm{KW}$ and 100-KE Tater Plants

CVrrall desion of rater plants was $99.8 \%$ complete. Some minor revision to morking cimvines or bein marle bi the architect - ongineer field office. Construction prom giess ras as follows: KW proeressed 6\% to a toial of $52 \%$; KE progressed $4 \%$ to a total of $39 \%$; Creneral Facilities progressed $7 \%$ to 2 total of $57 \%$.

The cumulative total of concrete placed to date was: KW rater area 79,081 cubic Jards; iwi: water area 73,200 cubic jurds; General Facilities 11,752 cubic yards,

The 187.-KV River Fump House was structurally complete, and preparations are being made for setting the 32,000 CPPI pumps. Three of the pumps and all of the motors are now on site. The 183-KW Filter Plant installation work was continued on pipe and chenical pumning equipment in the headhouse. Piping and electrical work in the filter gal:eries have been started. The roof over the clear wells was completed. For the 190-Kit Frocess Fump House the siding and roof rere completed, and equipment to provide tempora$\because \mathrm{l}$ lient has been put into operation. Installation was continued on process vator lines, service water lines, and the first secondary process pump drive assembly. Three dri.ve assemblies are on site, and the fourth and fifth assemtilies are in transit. There has been considerable study of the problom of cracked castings of the bowls of the primary process water pumps. The pump vendor uas been advised of these difficulties, and action wa: begun for repair or replacement. In the 165-KH Building installation of switch gear was continued. Problems of aldgnment between breaker contacts and stationary contacts have been refered to AEC for correction by the vendor. Erection of bollers proeressed steadily. Two heatinir surfaces of the first boiler have been placer, and work on refractory material has heen started. Boiler drums and tubes for the remaining tro hoilers are on site.

Construction work on 100-kE Nater Plant buildings has foll orec closely behind constmaction of similax buildings on 100-hH; however, delays have been greater because of the carpenter-millwight strike and adverse weather conditions.

105-KW and 105-KE Buildings

Design ras $99.6 \%$ complete. Construction progress was as follows: KW progressed 1.4\% to a total of $53.2 \%$; KE proeressed $2.5 \%$ to a total of $22.3 \%$.

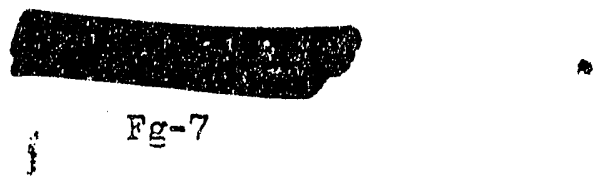


Cumulative totals of concrete were: 105-KW 25,719 yards; $105-\mathrm{KE} 22,853$ yards. The corresponding totals of steel placed were: 2,583 tons for 105-KW; 2,523 tons for 105 $\mathrm{kE}$.

In the 105-110-115-KW Buildings installation work was continued on electrical, control and Instrumentation systems. For the 105-KW resctor, installation of cast 1ron was completed on both right and left sldes. All right side thermal cooling tubes have been Installed and leaded, and the left slde tubes are being installed. Installation of gun barrels and "donuts" was started on January 28. Other Installations were continued as progress of the builaling permitted.

Five sections of downcomers were finish-machined, and flve of the longer sections were fabricated but not machined. Of the 6,032 process tubes recelved, 1,020 have been tested, reamed, and annealed on the inlet end. Some effort must be expended to repair tubes which were damaged in transit. Crossheader fabrication has continued on all parts required for both reactors. The 105-KW charging flow "Christmas Tree" was completed and checked.

For the 105-KE Reactor, grouting was complete in the followlng crates: second tier. side, third tier inlet and fourth tler outlet. The construction contractor is taking steps to control dimensions of crates during placement. Installation work was continued on electrical systems, Instrumentat1on, and control. systems.

Mock-up of graphite for 105-KW was complete January 26. At the end of the month production shop work for 105-KE graphite was $26 \%$ corplete, and the fabrication shop. work was $17 \%$ complete. Since the sodium-carbonate treatment has proved beneficial, Netional Carbon Company has advised that all heats after 1200 wlll be so treated. It has veen determired that about 950 tons of Speer Carbon wlll be used in the KE unIt; however, the tonnage may be reduced because of rejections. It now appears that graphite preparation may be placed on a six-day basis in order to meet the packing date on May 10, 1954 .

\section{CA-513-A - Purex Fac1I1ty}

Overall design for Purex progressed $2.6 \%$ to a total of $94.4 \%$. Construct1on progressed $1 \%$ to a total of $17.6 \%$.

Of the 43 specifled requirements, all have been recelved, and 41 have been approved. Of the 500 requisitions required from Vitro, 485 have been recelved, and 469 have been approved. To date 54 of the 69 acceptance test procedures bave been submitted.

Because of the carpenter-millwrlght strike and adverse weather, only 2466 yards of concrete were added to 202-A Bullding and relating structures, thus bringing this cumulat1ve total to 47,125 yaris. Some Ilmtted progress was made on embedded piping, condult, and ventilating duct work. Subcontract was executed for $X$-Ray Inspection of welded stalnless pipe in canyon installation. The contractor, X-Ray Products Company, was scheduled to begin operation about February 1, 1954.

Shop fabrication was continued or plplag for Hot Plpe Trench and arsin piping in the 272-E Mock-Up Bullding. Steel Installation was completed on January 11 , and four mock-up tanks were installed. Other minor progress wes made on electrical and ventilation equipment.

Construction of the 2901 Export Water Iine was stopped to awalt parts for repalring damage lncurred during hydrostatic testing. Excavations were begun for 211-A Chemlcal

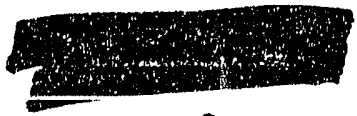

$\mathrm{Fg}-8$

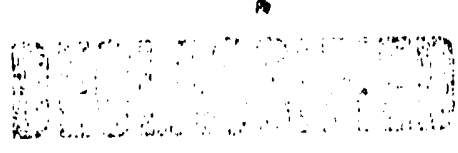




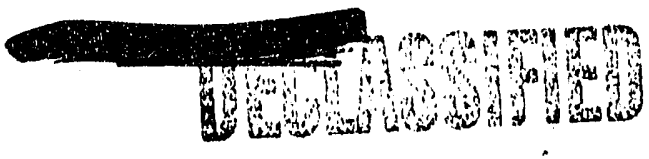

$$
\text { HT-30724 }
$$

Tank Frrm, 291-A Staok and 291- - Fan Ilouse, but little rrorress ras made. Excavations for 2.1-A Tank Farm profressed to abnut75\% complete. Pipe laving for the 8" rew vater line was begin.

For 247.-SX Tark Farm, a design change to accomplish self-evaporation of licuids ras rennested of $A E C$. This change is expected to increase the life of the tank farms three to five times.

\section{CA-513-B - Uranium Cxide Conversion Facility}

Design had been completed previously; construction progressed 1; to a total of $99 \%$. The remaining "punch list" items are being accomplished on Work Order CC-2625.

\section{CA-513-D - (ERA-747) - Fot Semirorks Conversion}

Design progsessed 2\% to a total of $82 \%$; construction progressed $5 \%$ to a total of $10 \%$. Progress was delayed by the carpenter-millwright strike, howevex, the dismantling of "B" cell was completed, and work was started or stripping of "C" cell.

\section{CA-51/ - 300 frea Excansion Frorram - Froduction Facilities}

Detail design progrossed $1 \%$ to a total of 82, ; overall construction progressed $1, j$ to a total of $26 \%^{\circ}$. The revised project proposal, Hil-29480, has been submitted to the Ar:B Committee. An equipment layout is being prepared for the dry canning area in the existing 313 Building。

\section{$A, B, \& E$}

The placing of concrete for floors, walls, and trenches is progressing in the addition to $3 i 3$ Building. However, the work stoppage and cold weather have delayed this rork. The process se:Ter line has been installed, tested, and backfilled. Some work ras continued on pipe supports and lighting systems. The steel subcontractor has submitted all shop dravings for approval. Miost of these have been revieved and returned. The first shirment of fabricated steel was scheduled for arrival during early February 1954. At the 31.7 Tank Farm the process semer line has been installed, tested, and backfilled.

The AEC has anproved the awarding of design and fabrication of the frost tank work station to the Ohio Crankshaft Company on a non-competitive basis. The Eeuseman partitions have been ordered tur delivery during early larch 195\%. The total estimated cost of engineerci equirment on order or out for bid is $\$ 960,000$.

\section{Lanufecturing Office Euildine, fate House, and Parking Lot}

Bids on the 3701-L Gate House, truck turnout, and parking lot are scheduled for opening on February 10, 1954. Further destgn mork wes stopped so that engineers could be assigned to the Hanford 3X Program, $3 \mathrm{CO}$ Area.

\section{Chanre House Renotations $3707-A$ and $B$} The design work has been completed, and the start of construction is amaiting AEC auth- = F
orization.

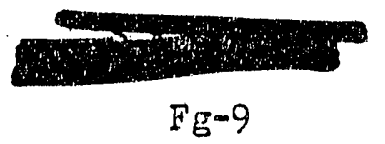




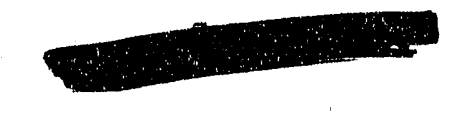

\section{i. Change House Renovations 3707-4 and 3}

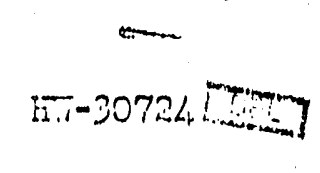

The design work has been completed, and the stcirt of construction is anaiting AIC authorization.

\section{R. Telenbone and Becurity Alarm}

The exchange equipment for 100 additional lines has been completed. $05-5,35$ - Rer:oz: Canacity Increase, Thase II

Design $=0$ gressed $2 \%$ to a total of $62 \%$; construction prorressed $1.5 \%$ to a total of $8.5 \%$. The revised scheduled conpletion for design and constmaction was 73" anc. 11\%, respectively.

Revision No. 3 to the project proposal res fortarc'ed to the ALC. The rortion of design to be performed by the architect-engineer mas 61\% comolete. With revision caused by the increased scope, the General Electric portion of design was 66\% comrlete. Further rork was delayed by contamination and by adverse weather.

\section{CA-539 - Additional ieste Storage for Redox}

Design completion status res revised domward from $94 \hat{i}$ to $88^{c \%}$ complete because of a revision to the scope. Contamination mas caused by abnormal vapor sur:res in the storage tanks of. 2.4-C Tank Farm. Overall construction progressed $4 \%$ to a total of $50 \%$, as compared to $68 \%$ scheduled completion. This project mas likevise delajed by actverse weather and the carpenter-milinright rork stoppage. The construction progress in generaf consisted of backfiling part of the tank area, pipe work for the encaserent, and setting of nozzle and plates in the diversion boz..

\section{CG-550-Reactivation of P-10 Facilities}

Design had been completed previously; construction progressed $7 \%$ to a total of $89 \%$. liost of the parts for the folur casks have been cut out, and two casks mere about 50\% assem-bled. Plant forces have completed most of the exceptions. The major remainine ex:ception Wes alteration of trucks used for hauling off-site casks.

\section{B. OTHER ASSIGIT-iNTS}

\section{CG-187-D-II - Recior Froduction Flant}

Design progressed $4 \%$ to a total of $48 \%$, as compared to scheduled coriletion of $95 \%$; construction renained at $9 \%$ complete. This project hes been delayed so that design effort may be concentrated on the Redor Capocity Increase. A revision to the project prorosal is being prepared.

\section{CA-187-D-III - (ER-2739) - Redo- Cooling Tater Disposal Basin}

Design had been completed previously; construction mork to bo performed by the lump sum contracter was $66 \%$ complete, and the portion to be performed by linor Construction ras 43\% complete. Overa.2I construction progressed 38\% to a total of 59\%. Ercevation of the chemical waste ditch mas a roleted. Coarse rock bacifill of the crib ras completed, and installation of the perforated metal distributor pipe wes started.

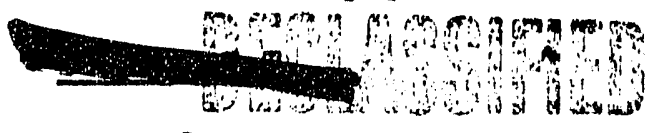

Fg-10 
CA-L3L- Nem Bicassey Laborator:

Design had been completed previously; phase I construction progressed 31, to a total of 95\%; nhase II construction profiressed 20\% to a total of 50\%. Overall construction completinn was 70\%. A second calload sf laboratory fumiture has arrived; however, installation must be delayed untic tons and fitting are received.

Phase II construction consisted of inside electrical rork and plumbing. The outside sterm line and tie-in were completed. Shon fabrication of the stainless steel duct mork started January $1.8,1954$ in the vendor's shop.

\section{CA-LLI - Solvent Building}

Desien completion status remalned at $35 \%$ A request to allow relocation of the Solvent Bilding to $A$ site north and rest of the 32.5 Building is being circulated for approval by General Electr:.c.

\section{CA-455 - Renlace Tro Elevated Water Tants in 200-I Area}

Completion status remained at design 100\%, construction $99 \%$. The completion of painting by the conirsctor was celayed because of acverse westher.

CG-477- Building 284- F - Fifth Boiler Acdition

Both design and construction had been completed previousi. contract is beine nezotiated.

Final settlement of the

\section{CA- 489 - Neutron lionitorine Calibration Facilities}

Desien had been completed previously; construction progressed $6 \%$ to a total of $98 \%$. The accelerator was shinved by High Voltage Engineering Corporation on February 15, 1954. The lump sum contractor work wes essentially complete except for installation of the accelerator. A letter has been written to the ADC requesting three months tine for installation, start-un, and testing.

\section{CG-511 - Completion of "..inor Constmaction Fabricating Shoes}

Completion status remainer nt design 100\%, construction $99 \%$. The revised project pro-

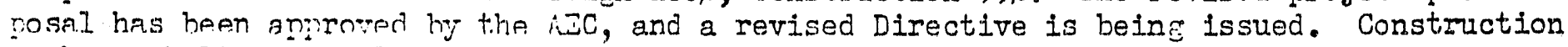
work was heltcd 'intil ndidtionol funds had been authorized.

\section{CA-516 - Gable Butte Railrnad}

Design had been completed provisusly. Bids for construction vill not be solicited until about liarch I, 1954, or until the possibility of freezing weather has passed.

\section{CA-529 - Personnel Meter Gatehouse Fecility Improvements}

Design had been completed previously; construction progressed $6 \%$ to a total of $99 \%$. The remaining mork consists of minor carpentry and painting of 2701-77 Badge House.

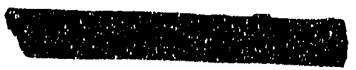

$\mathrm{Fg}-\mathrm{II}$ 


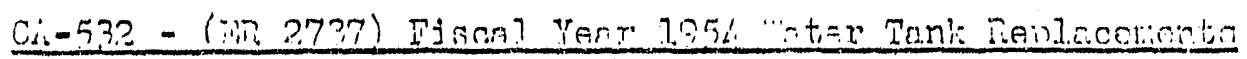

Desizn had been completed previously. Bià assemblies oro scheduled for issue bj fic in enrly Febmary 1954.

Ci-533 - (FRE-479) - Hanford Toris Officinl Telenhone Yuchine

Completion status remained at design 30\%, construction $0 ;$. Further modification of the nroject nronosal has been reguested by the ADC. The Telephone unit is prepering a pretiminary plan to judionte the recommended equi ment layout, and to serve as a nreliminary guide for the architect-ongineer and for the ecriment vendor.

$\mathrm{CG}-538$ - (ER-2734) - Insta.1 I Underoround liaste Line Between "II 4rea and "U" frea 200-it

Desion had been completed previously; constmintion pro ressed 2; to a tot I of 96;. Since Cascades 104 and 107 are being retainer for TBF wastos, the total worl: is being consicerably reciuced. Tork on the 110 Cascade is beilig completed as planned. All ex:cess equipment is beine cransferred to Manufacturing Department. Redox vaste has been run through one of the cross-country Iines. Minor Constmuction forces continued installation of the condensate line and urib.

\section{Ci-5L3 - (ER-2733) - Renlace Sanitary Tile Field 200 iest Administration irea}

iiith scoping completed, and local approvals obtained, the project provosal ras sent to the Hashineton $A E C$ for authorization.

\section{CA-544 - (ERA-66I) - Central Distribution Headauarters}

Design completion status remained at $30 \%$. This roiect provosal as not approved br the ARB Committee. The Electrical Distribution linit is consicioninc; tise reror: lin or existing fracilities which include the 2.71.3-E Building.

\section{CG-545-(EPA-724) - Soil Science Laboratory Facilities}

Completion status remained at design 100\%, construction 30\%. The revised project pronosal is still anaiting authorization by AEC; hovever, procurement has continued with funds now available.

\section{CA-546- $-(E R-3099)$ - Fuel Element Pilot Plant}

Design completion status was: Phase I, 95\%; Phase II, 40\%; General Electric design, 3\%. The Notice to Proceed for Phase I constmuction work was 1ssued January 8, 1954. Excavation mas started on January 25, 1954.

A request for $\$ 80,000$ is being prepared to obtain funds for performance for supplementary work by Linor Constmaction and Plant Forces.

\section{CG-549-(ER-273I) - Activate Task I, RMA Line - Building $234-5$}

Design progressed 25\% to a total of 70\%; construction remained at $6 \%$ complete. New bids have been requested by Task I services to assure conformence ith design specifications. Tests for tine determination of adequacy of the present heating and coor fing designs are
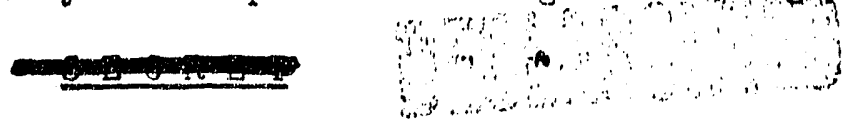

$\mathrm{Fg}-12$ 


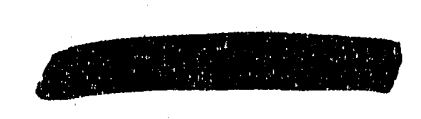

bein performed with a mock-up reactor. Or-site fabrlcation was continued for a tapered agitator shaft, seals, bearings, and draft tubes for test purposes.

CG-551 - Expansion of Bullaing 234-5 Fac1lities

Design progressed $15 \%$ to a total of $75 \%$; construction progressed $3 \%$ to a total of $7 \%$. Eighteen new design drawlags were spproved and distributed to the fleld. The construction schedule is being reviewed in consideration of procurement problems and man-power requirements. Work was continued on hoods and hood assemblies.

\section{CA-555- (ERA-735) - Graphite Hot Shop and Storage Building}

Wh1le considering the project proposal, the AEC requested information on availability and future use of room $24-\mathrm{A}, 326$ Building. The AEC was informed that this site was not avaliable. The final decision has not been announced.

\section{CG-556 - (ERA-1201) - X-Ievel Controlling and Recording Equipment}

Design progressed $4 \%$ to a total of $96 \%$; construction progressed $3 \%$ to a total of $13 \%$. Further work on design and construction has been delayed because of higher priority work.

\section{CG-558 - Reactor Plant Modification for Increased Production}

Deslgn Section is preparling a profect proposal for which a tentative schedule has been prepared. The schedule requires two shut-downs in several areas. The first shut-down would be for replacement of horizontal rods and other reactor work; the second shut-down would be for completion of total modifications. The first reactor shut-down was scheduled about ten months after recelpt of authorization. The ready-for-use date for all facilitles was about 24 months after authorlzation.

CG-559-(ERA-1200) - Heat Transfer Laboratory

Design progressed $15 \%$ to complet1on. Construction began and progressed to $2 \%$ complete. AIl engineered and criticel ltems are being ordered.

CG-562 - Waate Metal Recotery Plant Modiflcat1ons

Design had been completed previously; construction was revised downward to $76 \%$ complete because of the increased scope of work. Fabrication and ingtallation was accomplished on pump boots, jumpers, piping and instimmentation. The A\&dB lines were ready for serles feed on January $21,1954$.

CG-563-(ERA-3100) - Modifications to 324 Buliding and Instaliation of Electroplating Pliot Plant

Design progressed $32 \%$ to a total of $50 \%$. Detailed design was delayed because of higher priority work.

CG-564 - (ER-1209) - Instaliation of Additional Bal1 3-X Equipment, 105-C Build1ng

Fompletion status remained at des1gn 100\%, construction 92\%. Work was awalting delivery of ball valve parts for re-bullding and re-placing those borrowed from spare parts.

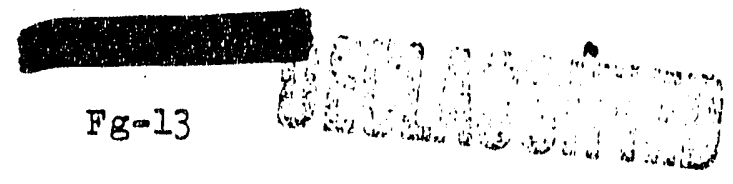




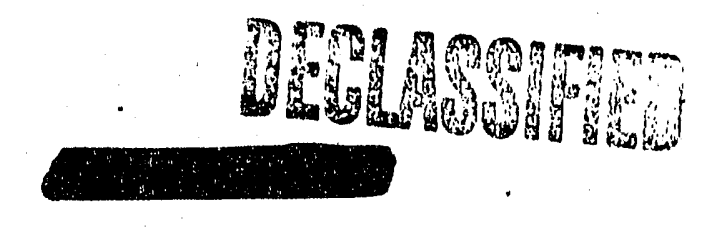

$\sin -30724 \ldots$

3-566 - (ERA-1205) - Dut] dinr for Trototine Thrsical Constasts Test Reactor

Sconine and the preparation of the project propusal had been conoleted. ("acien ras net completed, as reported, during December 1953.) The AEC has been requested to provide on Ineering funds for promet comrletion of this project.

CG-567 - (ERA-1208) - Alum-Activated S171 Ca Facilities - 100-B, D, F, and Ii.

Desigr conletion status remained at 30\%; construction procressed $7 \%$ to a total of

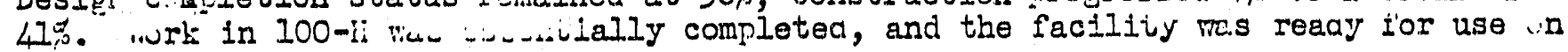
January $12,1954$.

CG-560 - Replacement of Catch Tanlss 311-ER and 302-BR - 200-E and iI

The AEC Directive ERT-317 was issued on January 5, 1954; and the Forli Authority Pli-2014 was issued on January 22, 1954. A mork order for detailed design ras formarded to Design Section.

CG-572 - (ERi-725) - Particle Problem Animal Exposure Equipment

Design completion status remained at 15\%. A letter of justification for estinated design costs has been prepared for submittal to the A\&B Comnittee.

Ir-116 (ASC,-P-1.38) - Comhined Citil Defense and Plant Disaster Control Center

Design had been completed previously; construction progressed $13 \%$ to a total of 70\%. The trajler has been moved to a location near the 744 Building and installation of telephones and puht $c$ address spstem was begun. Builiing $722-\mathrm{N}$ is being mored to the Frosser

Carricrie ts a storace place for emergency equipment.

\section{IR-159 (ER-27L2) - Improved Ventilation Facilities, 201-C}

Comoletinn status remained at design 100\%; constiuction 60\%. is recuest for approvel of ti-e extenston las been forwarded to the AEC, since this rorl is being coorcinated rith sut Semi-،orks Conversion.

\section{IP-162 - Fire Protection Buildines, $272 \mathrm{E}$ and $\mathrm{F}$}

Design completion status remained at $30 \%$. Bids have been opened, but awarding of a contrict by aEC mas ielayed by resolution of certain legal aspects.

The fnllowing studies and Engineering Requests, 1nvolving preparatory pork and scoping of future projects, rere active during the month:

\section{ERA-727 - 313 Building Roof Repair or Replacement}

Preparation of the project proposal remained at $50 \%$ cc.uplete. It has been decided that the rncle witi. be performen in the last calendar quarter of 1954 .

$$
\mathrm{Fg}-14
$$




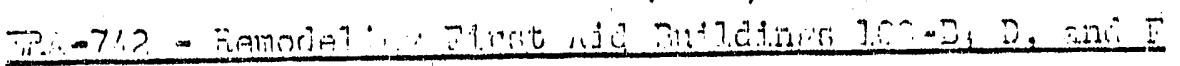

nesien remained at $15 \%$ complete. The lianufacturing nemartiment, has …tihntel this

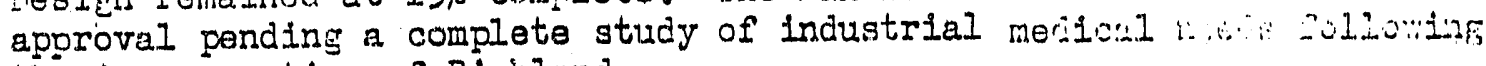
the incorporation of Ricliand.

\section{ERA-748 - Laboratory Sunnly Space, 3706 Euilding}

The project proposal was $a g \%$ complete, and it will be considered by the Acis Committee at the February meting.

\section{ERA-751 - Facilities for Special Tile lieasurement}

iith the project proposal $2 \%$ complete, work was delayed to arrait additional justification and information from the Technical Section.

ER-27L.4 - Nam Dry iaste Crib. 222 -s Building

Neaion completion remainea at $2 \%$. Further rork araits the rasult of tests of an alternate nethod of handing contaminated rastes from the $222-3$ Euilding.

\section{PELATED FOICTIONS}

The need for offasite ins vecrnrs increased during the month, chiefly because of the requirements to remove :elr aroters rom Purex vessels. This increase wes in addition to the $: x=11 \mathrm{y}$ expected increase for inspection of equipment for $100-\ddot{K}$ irea, Redox vessels, and equinment for Recuplex. The corrosion testing program remained abcut the same, with 690 samples being testied.

Folloring is a resune' of Inspection activities during the month:

\section{ITELI}

IMT:Bi:R

Total. orders reouling inspection

Cun:ulative number of orders assigned to inspectors

Number of orders assioned to inspectors this month

New orders recelred during the month

Crders completed

Total requisitions transmitted for Expansion Propram

Total orders placed for Expansion Program

$1 \pi: B=2$
932
835
178
169
154
129
139

At the end of January there had been grand totals of 2,426 Expansion Program requisitions transmitted, and 2,239 Expans:lon Zrosram orders placer for an -inacrar equirmer.t. According to current information, all materlal reguired for granhite paching of 105-kTi has been received.

For the Seperations Sub-Section work, deliveries of 3 " Schedule 40 piping are not satisfnctory, au Local stoclis are almost depleted. Type 347 :elding rod was in shnrt suonly, Iurine the last two reeks of January nine shimments of stainless stee:

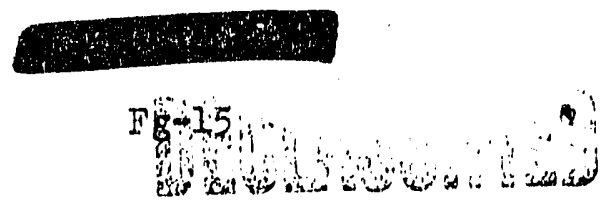




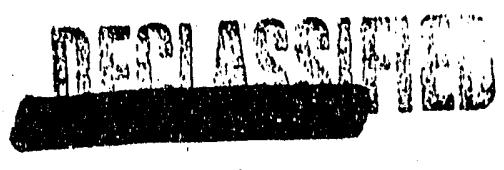

IIII -30724 mnterials ware made to fubricntors, of which six were loonted east of the lilsgissifpi
River.

Reproduction output mas 469,663 square feet during the 16 regular working days, ineluding 96 overtime hours. The larcest single orrler processed during January was 16,786 reints for Iurex.

Estimating Jnit completed 38 estimates during the month. The completed estimates comprised the fnljoring: project nroposals - 12, comparctive - 6, fair cost -4 , high snot -4 , scope -6 , and miscellaneous -4 .

Field Surveys completed "as-built" Information for utility maps of 200-E Area, also orelim: nary surviys for the proposed 105-B Effluent System and other miscellaneous work for the Design Section. The Surveys group began prelininary studies for a new effluent simn for Frocoss Engineering Sub-Section.

\section{CRAFT IALOR}

Percentage of voluntary terminations from Blar-Knox and associated contractors increased sharply from 7.7\% in December 1953 to $12.5 \%$ January, 1954. Other percenteges of roluntary terminations during the month: halser Enfrineers and associatos, 2.7, , J. A. Jones Constmaction Company, 1.2,j, rameinod ahout letrel.

The extended rork stoppage by carpenters and millwrights reduced the effective construction forces by 40-50\%. On January 11, about 40 General Electric employees mere fur. longhed for lack of torli at the 2101 Buflding. During the strike, 10 carpenters and a foreman were readily furnished by the union to perform critical work in the $303-\mathrm{J}$ Building for the $3 \mathrm{X}$ Program. The carpenters returned to work in 100-K and Purex Areas on January 18, 1954, following transfer of jurisdiction to the Ching Panel. An arbitration meeting was scheduled for February 3 in San Irancisco.

A brief walkout by 35 Kaiser machinists in the White Bluffs shops occurred on the morning of Januery 21. The walkout ras in protest against the emplojer's decision to move a radial. drill from the machine shop to the pipe shop. Following a decision to move annthar drill into the pipe shop, machinists returned to rork on swing shift of the same da.y.

At a meeting on December 28, 1953, between the Building Trades Council and construction contrcotors, the contractors agej.n rejected any incrense in isolation pay. Hinor nestions Fere cleared in a letter of understanding. The Contractors ilegotiating Committee nrepared an ei.ght-page document which gives a comprehensive statement of the contractors' position on isolation pay. This document was handed to the Building Tradas Councit. on Janizary 26, 1954, with a fortal request for consideration.

International representatives of Machinists' and bil' mights' Unions met in midTanuary in an effort to settle jurisdictional problems between the tro crafts in 2.CI Building. The meetings were attended bv John Dunlop, representative of the rederal liediation and Conciliation Service. To definite results have been announced.

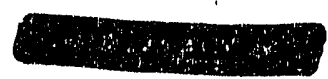

$\mathrm{Fg}-10$ 


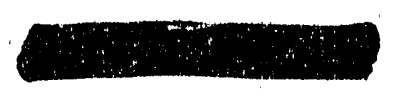

TI.-3CT2L. Ting

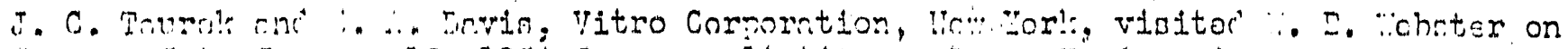

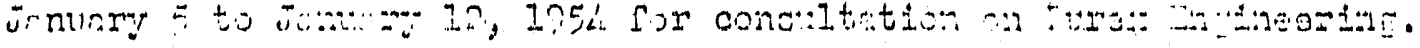

G. Hirfield, Titro Corporation, lew York, visited $i$. B. Tebeter on January 13 to Jinuary 19,1054 to disouss Tesign of Furez:.

J. A. Cronin Fortland, Orogon office of Travlers Insurance Comrnanv, visited J. A. Aliord and.$\therefore$. Clark on January 16,1954 to inspect unfired pressuro vecsels.

\section{ifiolel iriss to Othes Inatilutions}

0. - Lanson visitod G. 0. Carlson Company, Philadelphia, Pennsylvania on January 6 , to Jannary 12, 1954 to coordinats instrection activitiea.

J. J. liciliahn and J, O, Familtor ....: the folloring visits to cooritnate inspection activitites:

Jan. 1]. to 12,1054

Jen. 13

Jan. 1.4

Jan: 15

$\operatorname{Jan} .13$

$\operatorname{Jan} .17$
Eloctrio Eoat Corrany, Goroton Conne aticut and O. G. Kolley Iostion, inssnchisettr.

Cheiran Vivo dom any, Serinefield irassachugetts.

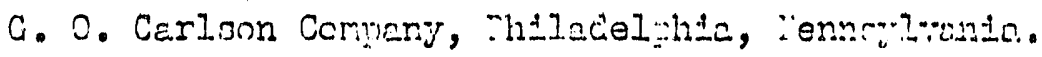

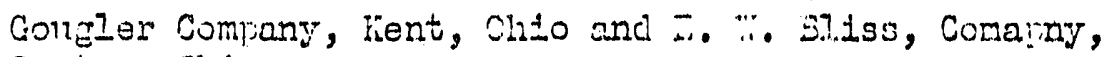
Canton, onio.

Fanelu.it Coryoretion, Chicaso, Illinois.

$\therefore$ O. Smith, lillmaul:ee, Tisconsin.

E. C. Larn risited Panel.it Jornoration, Chicaso, Illinois, January l6́ to January 25, 1954 for revier ui encineering and aproval of prints.

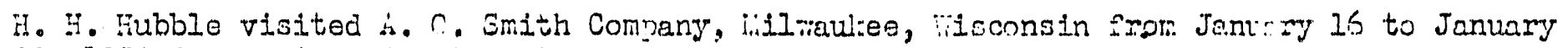
22, 1954 for ingineering Consultation.

G. r. Gablor visiteci Crane Company, Chicaso, Illinois from Jonuery 22, to Ianliary 25,1954 to e peritite delivery of material for project CG-5:5.

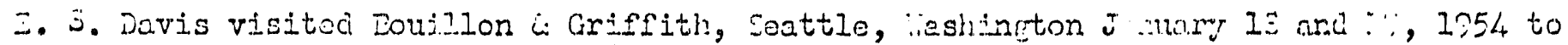

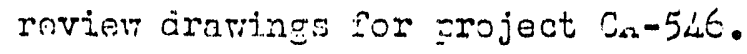

B. J. Cavanaugh and G. L. W":erea visited Ajax Engineerine, Trenton, Ier Jersey, January 27 ani 23,1954 to consu't rith vendors for 300 hroa Eapansion.

H. Radow visited Eastern Ind., Norralk, Connecticut from January 23 to the end of the month to resolve aluestions on Recinglex.

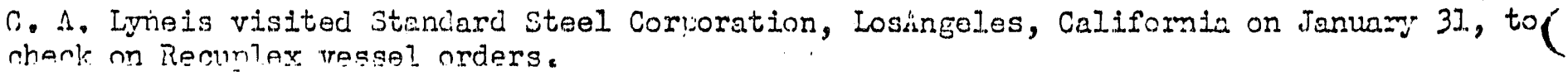

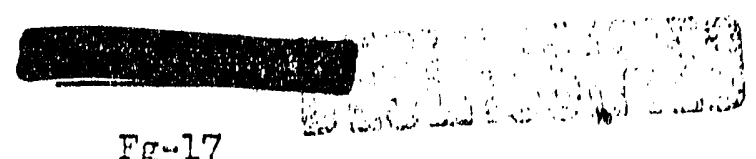


$a-1912.1-0$

\section{GENERAL ELG ELTRIC}

COMPANY

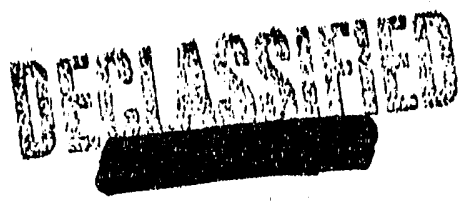

HANFORD ATOMIC PRODUCTS OPERATION
RICHLAND, WASHINOTON
JANUARY, 1954

February 4,1954

\section{MONTHLY REPORT
FUEL TECHWOLOCY SUB-SECIION \\ MONTHLY REPORT
FUEL TECHWOLOCY SUB-SECIION}

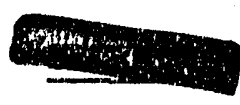

A 
VISTTORS AHD BUSITESS TRIPS

$\begin{array}{ll}\text { Name } & \text { Date } \\ \text { E. E. Hayes } & 1-27,28,29-54 \\ \text { Name } & \text { Date } \\ \text { H. A. Johnson } & 1.3,14 . .54\end{array}$
Addregs Purpose
du Pont Co." Fabrication digruiato:-a Wilmington, Del.

\section{Place Vtsitied. Purpose}

Oak R1dge National Fabriagtion of Laboratory mater 1als for the P-10 program

Sarrannah River Same th 7.bove Operztions Office

ALCOA

Same gs above

Fernald

Same as a.bcye

R. I. Knecht

$1-16,24-54$

Fernald

Discuss metal manufacture

G. S. Cochrane

$1-17,20-54$

Boutilon \&

Deslgn of P1lot Plant:

T. G. Marshall

$1-23,31-54$ Griffith

KAPL

Discuss fuel element.

MIT and component fabricarion Same as above

Chase Brass Co, Same as above

Bridgeport Brass Same as above
P. T. Pankaskie
$1-23,31-54$
L. J. Lucas
$1-23,31-54$

Same ga 'T。G。Marsha1.1.

du Pont Co., Alugusta, Ha.

Inspertion of equipment,

R. A. Thlede $1-31-54$

KAPT

GEL

Washington State College
Stiddy thop operation

Study shop operation Corrosion conference 
Fuel Technology sub-section

ISRANIUM QUALITY

Slug core Characteriatica

Splitt1ng was lnduced In tro rolled urarium elght-lnch slugs and four largnium powder compacts by electrical induction heating and water cooling in sush a way as to approximate the therwal conditions 10 slugs durlng irradiation. The two elght-1nch slugs developed longltudinal mptures along stritat1ons, while the powrier. cormacts are belleved to have falied transversely under thermal stress bec iuse of their brittlenesa. Optimum cycilng conditions were better dofined and mora was learned of core temperature ditati-tbution under the experimental conditions. Th1s work will be continued to define tha alug characterlatics which promote fracture under thermal stress thereby assisting in indicating how such fractures can be aroided in the pilies.

The following two practices appear to be desirable to minimize the hydrogen content of uranium cores. Use uranium cores with a minimum of lnclusions and atriations, and use a chloride salt in preference to a carbonate salt for preheating, for rolling, and for salt bath beta heat treatment of rods. The distribution of hydrogen in as-rolled uranium, the effect of plakle times and temperatures on hydrogen content of slug cores, and the effect of impurities in uranium on hydrogen content, w1II be studied to conclude the present stage of the investi. gation of hydrogen in uranium. With the Information to be obtalned in thits Investigation and the study of lead dip canning process varlables, porosity of the Al-S1 bond layer will be held under adequate control.

Reduction and Casting

Large Ingots weighing up to one-half ton, cast at Mallinckrodt, using good metallurgical practice to reduce secondary piping, were rolled at Fernald. The Hanford observer reported that the large lngots tend to turn over in the new edging pass but that there is a good prospect that this tendency can be corrected by minor modifications of the rolls. Two 400 pound ingots, directly cast in the reduction bomb and hence known as "dingots", were also rolled at Fernald in the presence of a Hanford observer. Successful application of "dingots" w1ll permit several process simpliffications with associated metallurgical advantages. The "dingot" technique may be particularly advantageous in the manufacture of ur.andilm.. silicon alloy by co-reduction.

Six of the fourteen control tubes in the production test of slugs from urardum hexarluoride parent materlal were charged in the centrgl zone of $105 . \mathrm{m}$. It $1 \mathrm{~s}$ anticipated that the rest of the slugs wili be charged In February. This test is of interest because of the prospect that an important part of Hanford's future uranium metal may come from Oak Ridge via urantum hexafluoride.

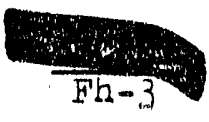


Fuel Technology Sub-Section

$\mathrm{HW}-30724:$

Folling Processes

The statistical difference between the slug fallure rates of Fernald and Simonds rolled urantum as of December 3.1, 1953, for slugs charged in the pile after April 30, 1953, is not large and has diminished from that calculated as of November 1, 1953. Nevertheless, studies are belag conducted to cast light on the causes of failures per se in Fernald rolled uranium. Cor: history data were obtained for only three of the fourteen failures which have occurred in Fernald slugs. Arrangements are belng made to obtain this core information on the other Fernald failures. The possibility that the blooming operation at Fernald may create planes of weakness in the rolled bar also is to be investigated.

Heat Treatment

Serenteen supplementary tubes of salt bath transformed, lead dip canned, eightinch slugs were discharged at $600 \mathrm{MWD} / \mathrm{T}$ under PT7-M. A PT7-M control tube containing elght-inch slugs, which was scheduled for discharge at $1000 \mathrm{MWD} / \mathrm{T}$, was discharged at $8225 \mathrm{MWD} / \mathrm{T}$. The anticlpated detailed examination of salt bath transformed lead dip canned slugs was not made this month, so there are no new post-irradiation data to report.

\section{URANIUM DEVELOPMENT}

Fabrication of Zirconium-Clad Uranium

Five production size ingots have been cast in zirconium sleeves for subsequent rolling to clad rod. Complete bonding between the uranium and airconium was readily achieved during the casting of 4-1/2 inch diameter ingots; however, the $6-1 / 2$ inch diameter cast ingots had unbonded areas near the top. The use of a. hot top decreased the unbonded area and will probably make possible completely bonded 6-1/2 inch diameter castings. Three of these ingots were shipped to Fernald for rolling and arrangements are being made to alpha extrude the balance.

Direct casting of uranium into one-inch diameter zirconium cans was attempted using a hot top mold to produce a flat top fuel element. Results were encouraging; however, some metal was spilt on the outside of the can and tests are continuing to determine the degree of fit required between the hot top and the zirconium can.

Trenty-one hundred ingot powder metal compact slugs were received from sylvania and arrangements are underway to irradiate these slugs under PT 313-105-28M.

The rolling of uranium rod from varlous salt baths to determine the effect of the salt bath environment on the bend ductility of uranium was completed. A portion of the rods were sealed in evacuated quartz tubing to protect them from the salt during heat treatment. All of the rods have now been heat treated and bend tests are proceeding. 
Jranium Alloys

The uranium-silicon alloy provides a fine grain size arter heat treatment $4 . .1$ little loss in reactivity. Tests are being performed to determine the other properties of this alloy. Four uranium 1.5 atomic per cent slificon ingotis cast at HAPO were rolled at FMPC. One of the ingots split three-quarter: of $1 \mathrm{t}$ a length during the roughing operation, and another was partialily split but was salvaged by cropping. It 1 s belleved that the problems experienced in rolling the uranium-silicon alloy can be alleviated by smaller reductions in the rough.a. mill and by rolling in the upper limit of the temperature range. Mallinikrodt has completed the co-reduction of one uranium-silicon alloy derby. No yitilisity is encountered in this process and we have requested that they co-reduse suffirfent. derby for producing cast rods at Ames and pickled derby lngots for rol.ling az Fernald

\section{COMPONENTS}

\section{Zirconium Process Tubes}

Extruded tube blanks to be elnished to the "H" Pile slze by the tube reducing method have been successfully fabricated from the stronger zircalloy 2 as well as pure zirconium.

\section{Zirconium Cans}

Two hundred efght-inch length zirconfum cans have been successfully f'abricated by Bridgeport Brass and are on the way to HAPO. Hot colning of such cans to produce square bottoms has been demonstrated at HAPO. It appears that the fabrication of cans from zircalloy 2 by the drawing tools and methods employed for zirconium may not be completed without process renovations.

\section{Zirconium Can Fabrication by "Uniskanning"}

The successful fabrication of eight-inch flat-bottomed Eanford slug can by applying "uniskanning" has been demonstrated. Unlskanning is applied at room temperature to reduce by as much as 90 per cent in a single step the wall of a conventionally formed thick wall cup of final inside diameter.

Iranium Thbe Fabrication by "Uniskanning"

A uranfum cup was successfully reduced in wall thickness by 80 per cent at room temperature in two "Uniskanning" passes Instead of a gragter reduction in one due to equipment limitations. The resulting surface quality appears to be very gond although orlentation and physical properties have not been determined.

\section{Aluminum Process Thbe日}

In addition to conventional metallurgical studies of 635 , sections of tubing flve feet in length were hydrostatically muptured. At room temperatures, process tubes of 635 aluminum appear to be half again stronger than 25 tubes as ruptures tonk place at $2400 \mathrm{psi}$ and $1800 \mathrm{psi}$, respectively.
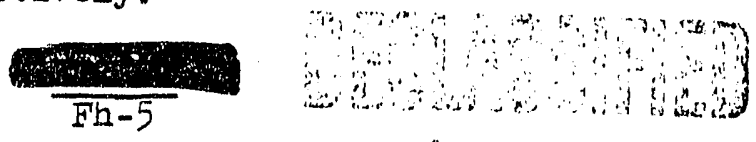


\section{Aluminum Cans}

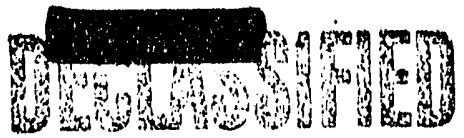

The in-pile ruptures of 635 jacketed slugs can be ascribed with great certalnty to faulty cans. A detalled Inspection lncluding metallograph1c methods indicates that in addition to laps, graphlte inclusions from lubrlcants and unldent1fled whlte crystalline Inclusions are excessively numerous.

\section{CANNING PROCESS}

\section{Canning Process for Thorium}

Cold sizing ("C" process) of thorium cores in thick-walled cans was instituted this month. Calculationg indicate that the heat transfer characterlstics of the "C" canned slugs w111 be adequate to permit 1rrediation to $1500 \mathrm{MND} / \mathrm{AT}$. Radlographlc inspection of the closures will Insure detection of most of the slugs with faulty closures and these can be rejected from lots to be charged. Radlographic inspection of target slug closures has apparently contributed to reducing the fallure rate by a factor of at least 25 as evldenced by the performance of radiographed " $C$ " process slugs in the DR-10 load as compared to non-radlographed "B" process slugs in the H-10 load. One or more unbonded thorlum slugs, "B" process canned, however, falled in tube $3884-\mathrm{H}$ this month at an exposure of about $800 \mathrm{MWD} / \mathrm{AT}$, necessitating interruption of pile operation. The process tube was split by action of the slug rupture and water admltted to the graphite. Although many "B" process slug closures have been known to become perforated durling charging or irradiation, this is the first known case where a thorlum slug core'was distorted or partially destroyed during 1rradiation.

Arrangements have been made to examine these failures as soon as possible. At least one of the slugs in the tube section removed from, the pile will be examined in the Radiometallurgy facility. It is expected that the results of this examination may indicate the need for the prompt development of a bonded jacketing technique.

\section{Welding}

Manufacturing was given technical assistance in adapting and equipping the standard welding equipment for the F1llerwelding of "C" process slugs. Operators were trained in the Flllerweld technique using the avallable experimental equipment.

\section{Tru-Line Slugs}

Additional slugs were canned for the non-cocking fuel element test. Tearing of the can wall by excessive manipulation of the well-type cap was noted for the flrgt time. Further canning w1ll be delayed unt1l completion of the high tube power test of "J" alloy slugs as the thlck base, thlck well Tru-Iine cans are being used for thy test.

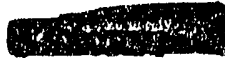

$$
\text { Fh-6 }
$$




\section{CANMING DEVELOPMENT}

\section{Vacuum Canning}

Stmulated "J" slugs (U-238 aluminum alloy) were successfully canned by the AI-S1 vacurum canning process. Chisel tests on ten canned dumbles lndleated that elght wore completely vonded; the remalning two had unbond areas of one or two square Inches due apparently to lnadequate prior cleaning of the cores. Equipment 1s beling procured to produce 700 "J" pleces for an 1n-pile test.

\section{Hot-Pross Canning}

Evaluation of the pressure velded elosure indlcates that higher Integrity welds result from increased times at temperature, pro-heating the cap punch (resulting in a higher temperature of the cap-can Interface), and the use of a cap slightly larger in diameter than the slug.

\section{DEVELOPMENT EQUIPMENT}

Study drawings for a 16-unlt gang press for hot-press canning have been completed. Th1s is the prototype gang press intended to be moved to 314 Bullding at the completion of the development (sbout May 1). The press is designed to can 16 slugs at once w1th a probablo output of 1000 canned slugi per day. Work orders havo been Inftiated to Minor Construction to Install a 400-ton press in the mockup shop of 328 Bullding where the development of the gang press w11l be cerrled out. Proliminary drawings for a 4-untt pilot model of the 16-untt gang pross here been prepared. The pllot untt can be bullt repldis and w11l bo used to obtain operating information and performance data while awalting materials for the fabrication of the 16-unit press.

\section{FUEL EXAMINATION}

Following a regularly scheduled discharge at H-P1le several fractured alght-inch regular metal slugs were observed in the storage basin. Since no unugual actiolty had been observed from plle effluent water and the slugs had apparently recelved a hard blow on one end, 1teppears that they wore broken elther durfing or aftar. diacharge. Photographs of the broken surieces of two of these pieces indicated a difference in the grain structure around the pertphery of the urantum.
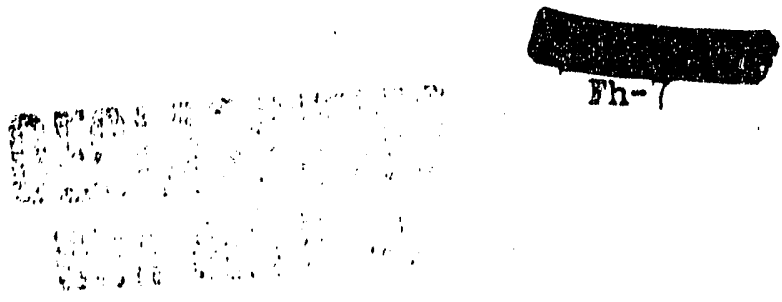


\section{Examination Facilities}

An 1mproved model of the underwater ultrasonic grain size measurement equipment to be installed in the 105-B facility wes completed and is presently undergolng tests in the 300 Area.

A revision to Section C of Project C-431 was completed and submitted for conslderation at the February meeting of the $A$ and $B$ Comittee.

\section{TESTING}

\section{Al-S1 Penetration}

Sixty slugs have been carefully examined by the MIZ-I equipment for correlation purposes. Of these only eight have been stripped, however. In this group there were three apparently spurious rejections, one questionable, and four proper. None of the proper rejections, however, were for Al-S1 penetration. In a negat1ve way, no penetrations were missed.

\section{Unbond Test}

An ultrasonic pulse-echo test for unbonding has proven very satisfactory on both uranium and aluminum alloy canned slugs. Prototype equipment is now belng prepared for use in connection with the current hot-press canning of " $J "$ slugs.

\section{Ultrasonic Power Pulser}

A breadboard pulser unt has been bullt which was proven capable of drivirg pulses through a four-1nch urandum blllet. The pulser overcomes the high absorption of uranium with sheex power, and may permlt development of laternal defect locators in both ingots and slugs.

\section{COATINGS AND CORROSION}

\section{Corrosion Tests}

Some samples of sintered aluminum were obtained and tested in the Flow Cup Laboratory. A general pittling attack and formation of small corrosion mounds was obsertred. Small dark crystals in the alloy appeared to act as cathodes.

The slugs have been made for Production Test 105-29M, "The Measurement of the Thermogalvanfc Effect on Slugs." Drawings are beling made, and equipment is belng ordered for the Hot Flow Cup Laboratory for the 325 Bullding. Polarization studies show that one type of pltting attack on aluminurn is inhibited by agltation, but it has not been shown that this type of attack occurs in the p1leg.

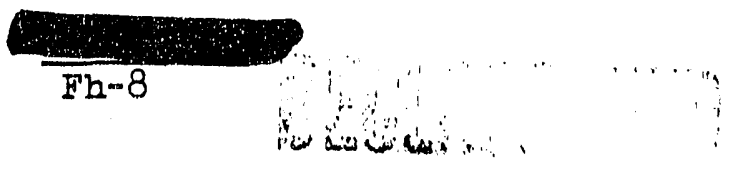


Anod1e F1Im

The data from the in-pile test to determine the effert of pile opera-1on n anodic films have been analyzed. In general, the pienes which had been anodized corroded at a slightly higher rate than the autoclaved controls; but, at the same time, the anodized pieces showed less evidence of mechanical damage durtag charging. Newer types of anodic flims are being studled; the most promising appears to be the films sealed with a barrier type film.

Graphite Removal

The best solution for removing graphite appears, at present, to be the chromic sulfuric acid mixture. Plans suitable for treatment, of large numbers nf slugs have been completed.

\section{Electroplating}

Slugs plated by different procedures are belng evgluated. The nickel plate on al:L silugs except those plated at KAPI appear to be very adherent. The s.lugs from Battelle have been heat treated to change the nickel to a nickel-uranium alloy layer. Samples of all types of slugs are being hot pressed and evgluated. The effects of heat treating, current density, etchling, and temperature of arid bathe on the quality of the Hanford slugs are also being evaluated. An autoclave test which will permit a rapid, comparative evaluation has been developed.

Two types of baths for electroplating iron on uranium have been studied. The ferrous sulfate bath appears to glve promising results and will be stidied further..

Recovery Procedures

A one-step solvent extraction procedure for recovery of uranium from spent anodizing baths was developed. Sowe recovered solution appeared to glve as good results as did the fresh solution.

\section{BUILDINGS AND GROUNDS}

During the month the move into the 325 and 326 Bulidings w9.s begun. Preredence was given to the 326 Bullding move in order that the malin occupents of the 325 BuIlding could be moved as a unlt after the 32.6 move was completed. Project proposals and informal requests covering the relocation of the Solvent stcrage Building, the location of the Stores in the 325 Building, and the Laboratory Area Improvements were approved by the $A$ and $B$ Committee this month.

\section{FTEI ELEMENT PILOT PLANT}

Sicheduling of design and construction of vamiolis phases of the Fuel Element pilot Plant - Project CA-546 has been delayed up to as much as two weeks. Adverse

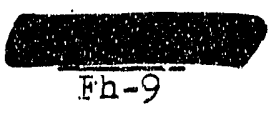


weather conditions and the recent carponters surke aro experter a delay

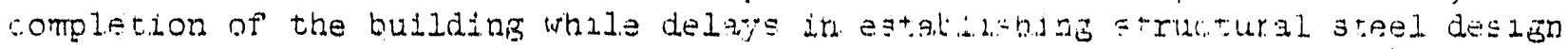
may result in a two-week delay in completing Phase II, interior design An approprlation request covering the procurement of shop and laboratory equipment for the plict plant has been approved and some order's have been placed.

\section{INVENTIIONS}

A.1. persons engaged in work that wight reasonably be expected to result in intrentions or discoveries advise that, to the best of their knowledge and belief, no lnvention.or discoverles were made in the course of their work during the peryod covered by this report. Such persons further advise that, for the pewiod therein covered by this report, notebook records, if any, kept in the course of their work have been examined for possible inventions or discoveries.

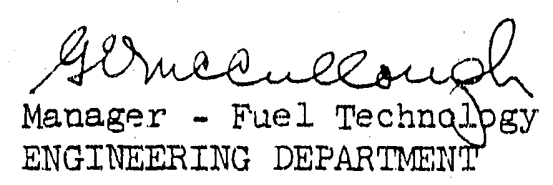

GE MCCUllough:acj
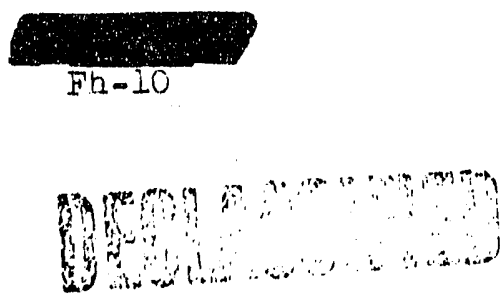
MEDICAL DEPARTMENT

JANUARY 1954

Cenerzi

As of Marin 1st the Medical Department will become a section of the Employee and Public Relations Department and Safety and Fire Protection will become, 2 unit of the Health and Safety Section.

Personnel Changes

The roll increased from 251 to 254.

Visits

Mr. Bakko attended a meeting of the Board of Trustees of the Washington State Hospital Association in Seattle.

Dr. Fuqua atrended the Health and Safety Workshop in Berkeley, California, held by members of the Health and Safety Section of the Now York Offlce.

Dr', Sachs attended a meeting for local health off'icers held at the State Health Department in Seattie.

Employee Relations

Employee attendance at 18 meetings was 152.

Industria Mediclne

Medical examinations decreased from 902 to 881. Dispensary treatments dropped Irom $493 \ddot{i}$. to $431 \%$ due largely to fewer injury treatments. Two major and one sub-major injuries of General. Electric employees were treated. Contractor employees sustained no major or sub-major injuries.

The hea?tin topic of the month discussed "Back Problems."

The sizkness absenteeism was $1.94 \%$ as compared with $1.68 \%$ for the previous month and the absentee rate due to 211 causes was $2.60 \%$ as compared with $2.13 \%$ for the previous montho

Kadlea Hospital

The average dally census increased from 64.8 to 77.9 as compared to 88.1 a year ago。

The occupancy percentage of the mixed service was 77.3 . Nursing hours per patient day were 3.81 on the mixed services.

Publi: Health and Welfare

The incidence of commicable diseases rose sharply due to an outbreak of measles. This resulted in a 50\% increase in home visits.

Costs. December

Incustrial Medicine (Oper。)

Public Health (Oper.)

Kadlec Hospital (Net)

Hospital Exuense Credits

Sub-total-Medical Dept. (Oper.)

Construction Medical (Industrial and

Public Health.)

Total-Operations \& Construction

\begin{tabular}{|c|c|c|}
\hline Nov。 & Dec。 & Dec.Budget \\
\hline$\$ 41,706$ & $\$ 42,881$ & $\$ 42,462$ \\
\hline 10,754 & 10,541 & 10,934 \\
\hline 13,653 & 32,969 & 578 \\
\hline$\frac{2,2709}{68,702}$ & $\frac{1,001}{87,472}$ & $\frac{2,2,474}{72,4}$ \\
\hline$\frac{1,265}{\$ 69,967}$ & $\frac{1,513}{\$ 88,985}$ & $\$ \frac{1}{72}$ \\
\hline
\end{tabular}

Q-1 
MEDICAL DEPARTMENT

JANUARY 1954

General (Continued)

Costs-December (Continued)

The net cost of operating the Medical Department before charges were assessed to other departments was $\$ 88,985$, about $\$ 19,000$ more than for November and $\$ 16,831$ above the budget.

Major factor was the very low hospital census with revenue down $\$ 10,000$ 。 A generally higher level of gross cost (up \$9000) also prevalied and contributed to the increase.

For the six months to date, Kadlec Hospital is the only section which is over the budget by $\$ 6,391$. With $50 \%$ of the fiscal year completed, we have consumed slightly more than 49\% of the total budget for the year. 
Industrial Medical Section.

The total number of physical examinations was 881 as compared to 902 the previous month. Dispensary visits decreased from 4931 to 4317 , largely due to fewer non-occupational treatments. Ceneral Eleotric employees sustained two major injurtes and one sub-major infury. Contractor employees sustained no major and no sub-major infuries. Vistes dropped, chlefly 270 in the $200 \mathrm{~W}$ Area and 143 in the $100 \mathrm{~B}$ Area e.s compared to last month. Industrial nurses on the active roll remained at 24 .

One information meeting was held during the month for Industrial Physicians. One industrial physictan attended the Health and Safety Workshop held in Berkeley, sponsored by members of the Employee Relations Department of the New York office. Company-wide pollcy in regard to health and safety, noise and electrical hazards, medical records, toxic materlals, and alcoholism were the major topios of discussion. The industrial physiclan staff vacancy was filled during the month when Dr. Charles Martin of Chicago accepted the position and will go on the roll approximately March 1st. Another staff member, $\mathrm{Dr}$. O. Hover, will terminate his employment during the next month due to license complications.

The proposal. for a new first aid bullding with the Purex facility was rejeoted by the Approprlations and Budget Committee The stated intention is to maintain a station in this area for minimum emergency service only and requirements beyond this are to be met by sending personnel to the $200 \mathrm{~W}$ facility approximately five miles away, or to Rlchland, approximately twentyfive miles away.

Details for the regular and routine IBM tabulation of accident repeaters were completed. Employees sustaining four or more infuries in the immediate past six month' period, or eight or more in the immediate twelve months perlod w1ll be tabulated and reported and investigated as indicated. Also the "Unit" frequency rate will be reported at regular intervals for comparison and investigation as indicated. The supervisory training course in Human Relations began during the month and included discussions of the personal factors involved in accidents.

The Health Activj.ties Committee met on Jaruary 2lst and the health toplc on back pain was presented. Materlal on this subject was prepared for plantwide distribution. The sickness absenteeism was $1.94 \%$ as compared with $1.68 \%$ for the previous month.

Net costs for December amounted to $\$ 35,397$, an Increase of approximately $\$ 7,500$ or $4 \%$, when compared with the November level. The princlpail reasons for the increase were the addition of two persons to the roll during the month and higher than normal building maintenance costs. 


\section{MEDICAL DEPARTMENT}

JANUARY 1954

Industrial Medical Section (Continued) Costs-operations (Continued)

Salarles

Continuity of Service

Laundry

Utilities, Transportation, Malntenance

Supplies and Other

Total Cross Costs

Less: Revenue

Expense Credits

Net Cost of Operation

$\begin{array}{rr}\text { Dec. } & \text { Nor. } \\ \$ 31,672 & \$ 30,400 \\ 3,167 & 3,040 \\ 241 & 275 \\ 4,507 & 3,819 \\ 4,497 & 5,411 \\ 44,084 & 42,945 \\ 1,203 & 1,239 \\ 7,4,84 & 7,751 \\ \$ 35,397 & \$ 33,955\end{array}$

Increase

(Decrease)

$\$ 1,272$

127

(34)

688

$\frac{(914)}{1,139}$

(36)

(267)

At the conclusion of six months operation, net costs amount to $\$ 2.11,711$ a compared with a budget of $\$ 227,037$. This is a net underrun of $\$ 15,326$ or $7 \%$.

Costs-Construction

Expenses Incurred by Industrical Medica]-Construction durling December amounted to $\$ 232$ representing the same general level as November. Salartes and related continuity of service of one person accounted for the entire charge.

Salaries

Continuity of Service

Supplies and Other

Total Cross Costis
$\$ 211$

21

$\$ \frac{0}{232}$

25

8

$\$ 284$
$\$(40)$

(4)

(8)

$\$(52)$ 
Industrial Medical. Section (Continued)

Physical Examinations

1953

Dacember

Operations

Pre-employment . . . . . . . . . . . . . ....

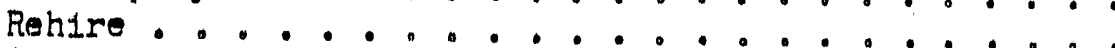

Arnual - . . . . . . . . . . . . . . . . . . .

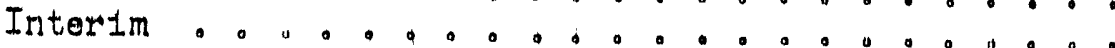

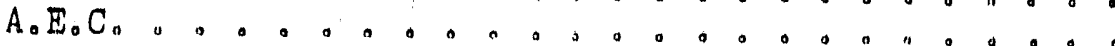

Reuramination and rechecks $0.0,0.0,0.0 .0$

Termination $, 0,0,0,0,0,0,0,0.0$.

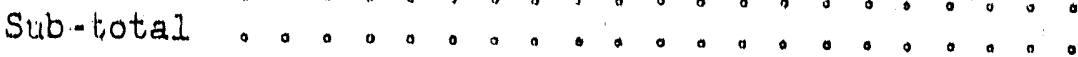

Contractor"s

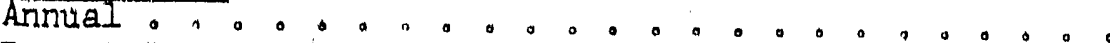

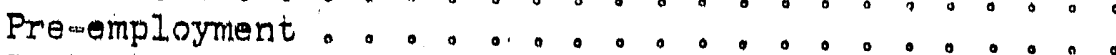

Reoheok 0.0 .0 .0 .0 .0 .0 .0 .0 .0 .0 .0 .0 .0

Termination and Transfer Sub-total

Total Physical Examinations ...........,

Laboratory Examinations

\section{CIInical Laboratory}

Government $0.00,0.0 .0 .0 .0 .0 .0 .0$.

Precomployment, Termination, Transfer

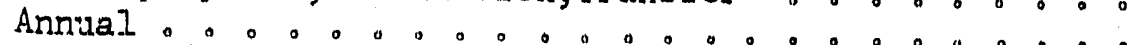

Recheck (Area)

First Ajd 0.000 .000 .00000000000

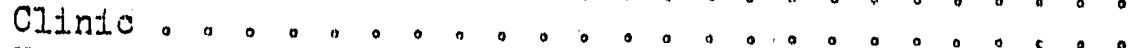

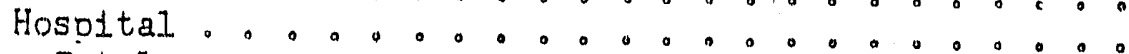

Tota.1

$X-$ Ray

Government 。, $0.0 .0 .0 .0 .0 .00,0.0$

Pre-employment, Termination, Transfor Annual " 0.000 .0000 .000 .000 .000 .0

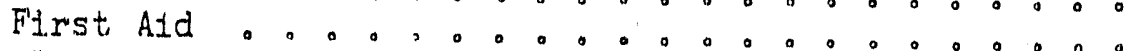

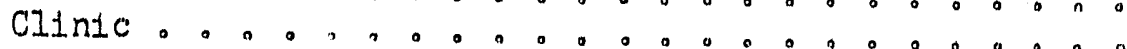

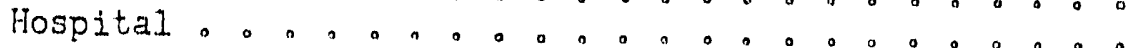
Public Health $0.000,0 ., 0.000 .0$ Total $0,0,00000000,00,0.00000$

134

814.

1441.

1.225

12

358

4.218

8102

39
9

254

26

195

70

838

25

211

9

64

902

$\begin{array}{rr}16 . & 17 \\ 84 & 123 \\ 537 & 538 \\ 101 & 94 \\ 151 & 202 \\ 239 & 299 \\ 7 & 16 \\ 1135 & 1289\end{array}$

Electrocardiographs

Industrlal $0.0,0.0, \ldots, 0 ., 0.0$

49

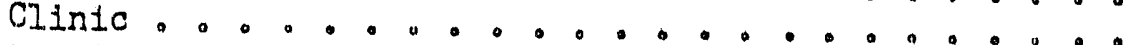

Hospltal . . . . . . . . . . . . . . . . . . .

Total
1

39

89
881

1954

January

49
21
461
16
25
189
54
815

1.9

66

117

938

2474

105

49

4690

8740

17

538

94

202

1.6

1289

110

1

47
158 
Industrial Medical Section (Continued)

1953

1954

First Ald Treatments

Operations

New Occupational Cases . . . . . . . . . . . . .

December

Jantary

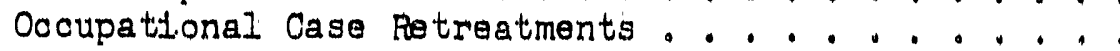

1215

Non-ocoupational Treatments ............

Sib-total

3.138

4682

Construction

New Oocupational Caseg ... . . . . . . . . . . .

Non-occupational Treatments . . . . . : : :

Sub-total , . . . . . . . . . . ..

Faollity Operators . . ...........

Total Flrst Ald Treatments . . . . . . . . . . . . .

Major Infuries

General EIectrio ...............

Contractors - ., . . . . . . . . . . . . . Total

Sub-Major Injuries

General Electric . . . . . . . . . .

Contractors . . . . . . . . . . .

Total .................

Absenteel sm Investigation

Calls Made....................

14

10

Employee Personal IIlness . . . . . . . . . .

12

No. absent due to jilness in family .........

No. not at home when call was made . . . . . : ". 


\section{MEDICAL DEPAR'TMENT}

\section{JANUARY 1,954}

Hospital Section

The average dally adult census increased from 64.8 to 77.9 as compared to 88.1 a year ago. This represents an occupanoy percentage of 71.5 , broken down as follows: Mexed Service (Medical, Surgical and Pediatrios) 77.3; Obstetrioal Servioe 47.1. The minimum and maximum daliy census ranged as follows:

\begin{tabular}{|c|c|}
\hline $\begin{array}{l}\text { Meded Service } \\
\text { Obstetrical Service } \\
\text { Total Adult }\end{array}$ & 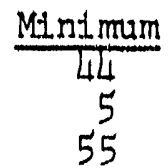 \\
\hline
\end{tabular}

The average dally newborn oensus decreased from 13.7 to 10.6 , as oompared to 13.9 a year ago.

Nursing hours per patient per day:

$\begin{array}{ll}\text { Medioal, Surgical, Pediatrics } & 3.81 \\ \text { Obstetrioal } & 6.46 \\ \text { Newborn } & 3.39\end{array}$

The increase in nursing hours on the obstetrical service and in the newborn nursery resulted from a twenty per cent decrease in average patient census on each of these services, from 12.4 to 9.9 on obstetrioal service and from 13.7 to 10.6 in the newborn nursery.

The ratio of inpatient hospltal employees to patients (excluding newborn) for the month of December was 2.57. When newborn infants are Included, the ratio is 2.12. This is a considerable increase over the previous month and over the average throughout the year. It $1 \mathrm{~s}$ due to the substantial drop in our centsus durling December, that month being lower than any previous December since 1950。

The net expense for the operation of Kadlec Hospital for December was $\$ 32,969$ as sompared to $\$ 13,653$ for November. Sunmary is as follow:

$$
\begin{aligned}
& \text { Kadlec Hospital net expense \$32,969 } \\
& \text { This is an increase of approximately } \$ 19,000 \text {. } \\
& \text { Cross costs increased } \$ 9,000 \text { due primarily to } \\
& \text { greater salaries (actualiy four less employees } \\
& \text { on roll at end of December, but additions and } \\
& \text { deletions occurred in such a manner that costs } \\
& \text { were increased), and increased food and drug } \\
& \text { costs representing payments for purchases made } \\
& \text { In earlier perlods. Revenue and expense oredits } \\
& \text { decreased by } \$ 10,000 \text { due primarliy to a substan- } \\
& \text { t1.ally reduced patient census during December. }
\end{aligned}
$$


Hospital Section (Continued)

Mr. O. E. Bakko attended a meeting of the Board of Trustees of the Washington State Hospital Association in Seattle.

At the annual meeting of the Kadlec Auxdliary various members were presented with pins in recognition of further volunteer work in behalf of the hospital. Some members received bronze pins for 50 points, others received silver pins for 100 points, and one member recelved a gold pin for 150 points. A meeting was held with the new president of the Auxiliary to organize plans for 1954.

Two excellent films were shown in four sessions to 151 employees. One was in connection with everyday human relations and the other was concerned with telephone courtesy.

There were 18 employee relailons meetings held during the month of January with an attendance of 152 , summarized as follows:

Hospital

Industifial Medicine

Public Health

Ceneral

Total

\begin{tabular}{cc} 
Meetings & Attendance \\
\cline { 1 - 2 } 11 & 99 \\
1 & 7 \\
4 & 36 \\
$\frac{2}{18}$ & $\frac{10}{152}$
\end{tabular}

G-8 


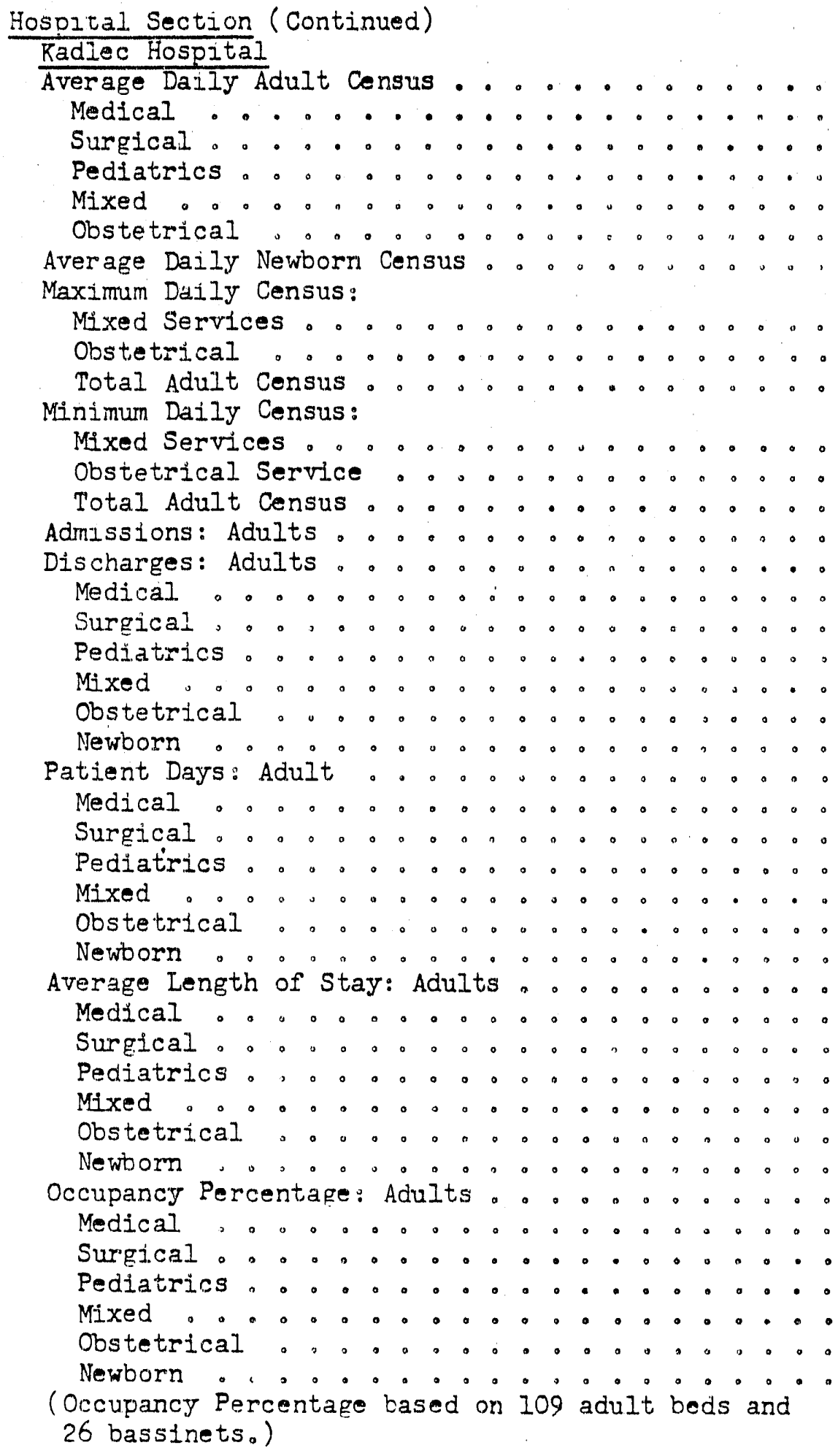

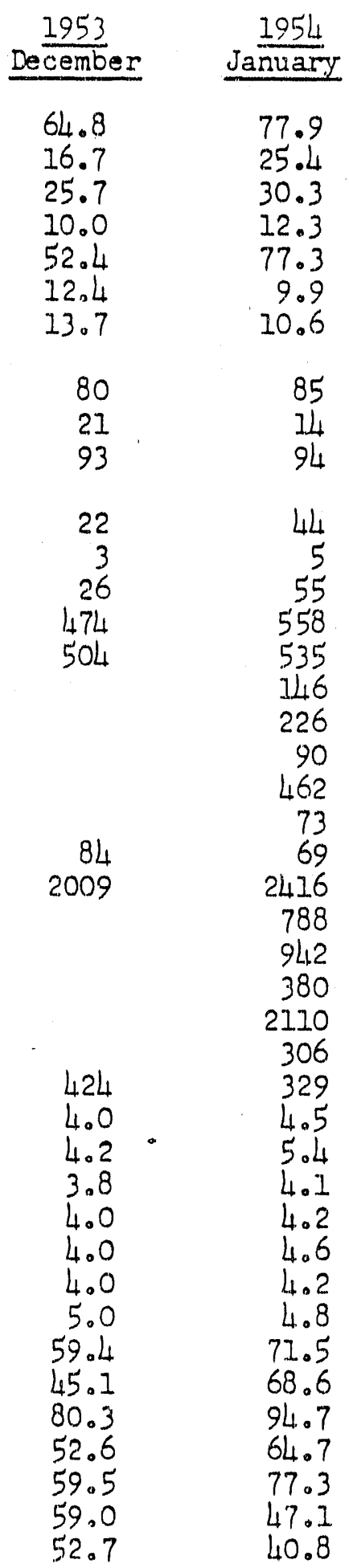


Hospital Section (Continued) Kadlec Hospital (Continued)

Avg. Nursing Hours per Patient Day:

Medical, Surgical, Pediatrics......... Obstetrics ................... Newborn ..................... Avg. No. Employees per Patient (excluding newborn) ............ 2.57

Operations: Major . . . . . . . . . . . . . . . Minor . . . . . . . . . . . . . E.E.N.T。 . . . . . . . . . . . . . Dental

\section{Births: Live}

$$
\text { Still }
$$

Deaths

$\operatorname{sti11}, . . . . . . . .$.

Hospital Net Death Rate.... . . . . . . . .

Net Autopsy Rate ....... . . . . . . . . .

Discharged against advice . . . . . . . . . . .

One Day Cases........ . . . . . . . ...

Admission Sources:

Richland ......................

North Richland . . . . . . . . . . . . . . .

Other . . . . . . . . . . . . . . . . . . .

Admissions by Employment:

General Electric

Government . . . . . . . . . . . . . . . .

Facility . . . . . . . . . . . . . . . . . .

Contractors . . . . . . . . . . . . . . .

Schools.......................

Others

Hospital Outpatients Treated-F.A. ........

Recovery Bed Patients-F。.............

Pliysical Therapy Treatments

Clinic ..........................

Hospital . . . . . . . . . . . . . . . . .

Industrial: Plant . . . . . . . . . . . . . .

Personal . . . . . . . . . . . .

Total

- $\cdot$.

Pharmacy

No. of Prescriptions Filled............ 2355
506

1954

January

3.81

6.46

3.39

65

81

77

102

67

1

3

85

67

$.68 \%$

30.0

140

69.2

15.8

72.4

14.0

13.6

64.1

2.7

5.7

22.4

1.5

3.6

573

32

304

86

260

2

652

70.3

2.1

3.6

19.0

.7

4.3

504

24

291

120

167

0

578

2422

489 
MEDICAL DEPARTMENT

JANOARY 1954

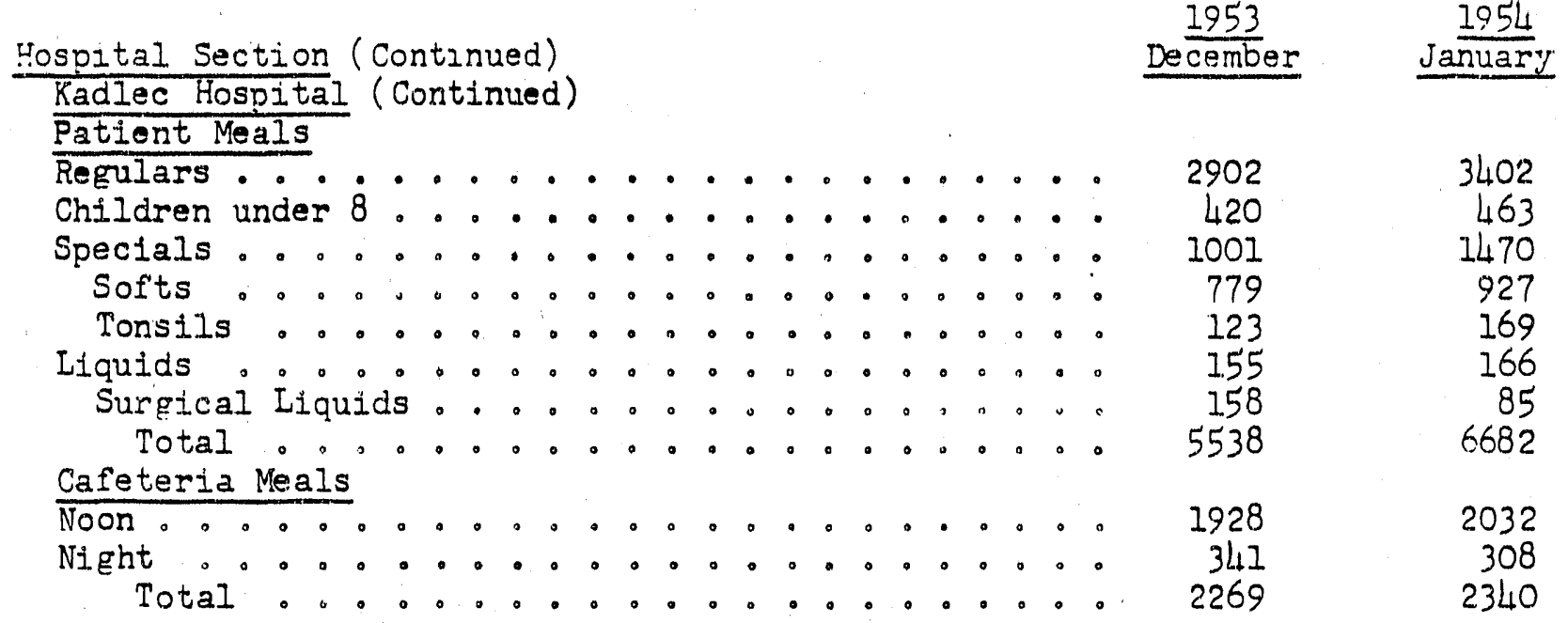


Public Health Section

Communicable disease cases reported rose sharply due primarily to the measles outbreak, which will apparently result in another heavy year. The last widespread outbreak occurred in 1951 when 1115 cases were reported. This resulted in a sharp increase in communicable disease home visits. Total home visits also increased by about $50 \%$ as another outcome.

A clinic for handicapped children was held. Dr. Platner saw six children and made recommendations for their followup.

Elght children were seen at the hearing clinic hold here during the month.

School activities included a conference concerning the screening of children for the handicapped children's clinic and conferences on the wetzel Grid at several schools.

The Fealth Officer attended a meeting for local health officers held at the State Heal th Department.

Sanitary surveys were made in grocery stores and meat markets. Principle violations were cleaning of equipment and rest rooms. Employees of the meat departments were requested to have health cards renewed.

Permits were issued to grocery stores, bakeries, taverns and restaurants. Results of routine inspection of food handling establishments were satisfactory. One new restaurant was approved for operation.

Insecticides for the mosquito control program have been requisitioned. Work on the program will begin about March 15 .

Bacteriological results of 18 pasteurized milk samples were very good. Dhe to bad weather only nine Grade A dairy barns weie inspected.

One parakeet sent to the State laboratory for possible psittacosis, however, no results have been received as yet.

Private water supply at the new animal hospital showed presence of contamination. A negative sample was obtained after sterilizing well with a hypochlorite solution. A recheck will be made.

Bacterlological results of water and sewage samples were satisfactory.

During January the Social Service counselors had 159 consultations regarding family problems; 87 consultations regarding problems of individual adjustment, 55 of which were with children or adolescents; 13 consultations regarding physical or mental illness; and 6 consultations with people who were having financial or employment difficulties. In addition, there were 3 consultations with persons stranded in $\mathrm{Bichland;} 2$ people discussed arrangements for opening the ir homes to foster children, and one person asked for help in making plans for $2 \pi$ aged parent. 


\section{MEDICAL DEPARTMENT}

\section{FEBRUARY 1954}

Public Health Section (Continued)

The counselors spent 16 hours in direct consultation with teachers regarding classroom behavior problems. 


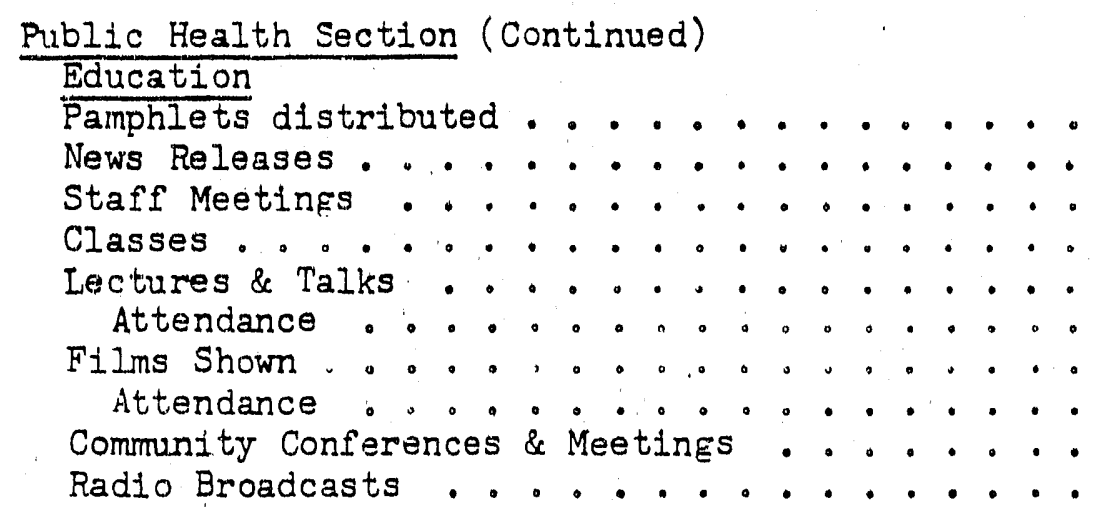

$\begin{array}{rr}\text { December } & \frac{1954}{\text { January }} \\ 10,989 & 9,038 \\ 12 & 5 \\ 1 & 1 \\ 8 & 12 \\ 6 & 4 \\ 515 & 767 \\ 20 & 7 \\ 720 & 151 \\ 17 & 41 \\ 3 & 8\end{array}$

Immunizations

Diphtheria . . . . . . . . . . . . . .

Diphtheria Booster . . . . . . . . . . .

Tetanus . . . . . . . . . . . . . . .

Tetanus Booster . . . . . . . . . . . . . .

Pertussis . . . . . . . . . . . . . . . .

Pertussis Booster . . . . . . . . . . . .

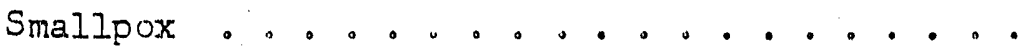

Smallpox Revaccination . . . . . . . . . .

Tuberculin Test . . . . . . . . . . . . .

Immune Globulin ., ...,...,.......

$\begin{array}{rr}23 & 6 \\ 11 & 1 \\ 23 & 7 \\ 12 & 0 \\ 7 & 5 \\ 0 & 0 \\ 5 & 4 \\ 13 & 3 \\ 9 & 0 \\ 6 & 35\end{array}$

Social Service

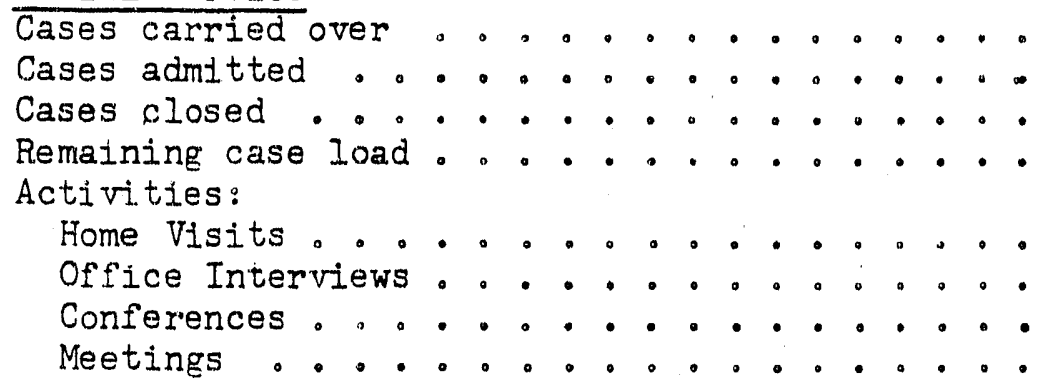

$\begin{array}{rr}84 & 86 \\ 7 & 18 \\ 5 & 19 \\ 86 & 85\end{array}$

$\begin{array}{rr}6 & 7 \\ 301 & 264 \\ 107 & 57 \\ 17 & 6\end{array}$

Sanitation

Inspections made .. . . . . . . . . . .

113

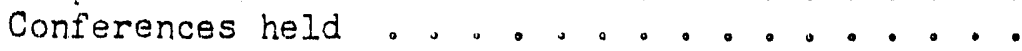

100

21

Bacteriological Laboratory

Treated Water Samples .. . . . . . . . . .

Milk Samples (Inc. cream \& Lce cream)......

Other bacteriological tests........... 
Public Health Section (Continued)

Communicable Diseases

Chlckenpox . . . . . . . . . . . . . .

Diphtheria . . . . . . . . . . . . . . . .

German Measles . . . . . . . . . . . . . .

Gonorrhea . . . . . . . . . . . . . . . .

Impetigo . . . . . . . . . . . . . . . . . . . .

Infectious Hepatitis . . . . . . . ... . . . .

Measles . . . . . . . . . . . . . . . . . . .

Murms o. . . . . . . . . . . . . . . . . . . .

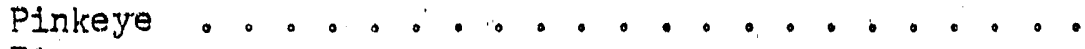

Ringworm . . . . . . . . . . . . . . . . . . . . .

Scabies . . . . . . . . . . . . . . . . . .

Scarlet Fever $0^{\circ} \cdot 0^{\circ} \cdot 0^{-} \cdot 0^{-} \cdot 0^{\circ} .0^{\circ}$

Streptococcal Infections-Throat . . . . . . .

Syphilis . . . . . . . . . . . . . . . . . .

Tuberculosis . . . . . . . . . . . . . . . . .

Total . . . . . . . . . . . . . . .

Total No. Nursing Field Visits ..........

Total No. Nursing Office Visits ........

\begin{tabular}{|c|c|}
\hline December & $\frac{1954}{\text { January }}$ \\
\hline 1 & 18 \\
\hline 1 & 0 \\
\hline 3 & 6 \\
\hline 2 & 0 \\
\hline 0 & 1 \\
\hline 1 & 0 \\
\hline 2 & 82 \\
\hline 1 & 3 \\
\hline 2 & 0 \\
\hline 15 & 2 \\
\hline 0 & 1 \\
\hline 5 & 18 \\
\hline 0 & 2 \\
\hline 1 & 0 \\
\hline 1 & 0 \\
\hline 35 & 133 \\
\hline 644 & 945 \\
\hline 53 & 103 \\
\hline
\end{tabular}




\section{and \\ ㅍN -30724 [D]}

Rediological Sclences Department

RADIOLOGICAL SCIENOES DEPARTMENVI

JAITUARY 1954

\section{Sumerry}

TwentJ-elght Informal, eleten Class I, and three Class II radiation incidents were recorded. One of the class I incidents involved a major spread of radioruthenlum contominaticm from the Redar Plant. If the severity had been acmewhat greater, a major interference with operation could have resulted.

Research and development 1tems included a conflrmation of the predictions on spread of contamination underground, and encouraging realits on temperature sensitifity of local salman өgge and fry.
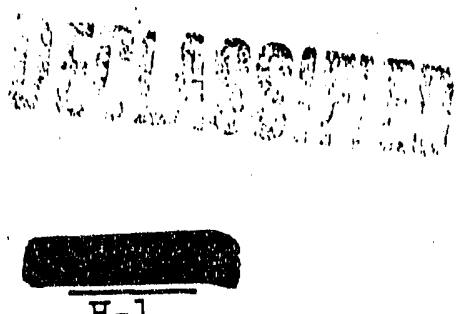

H-1 


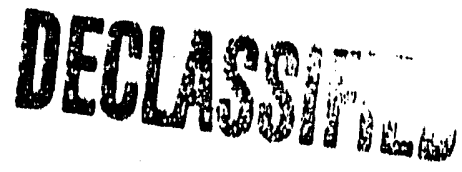

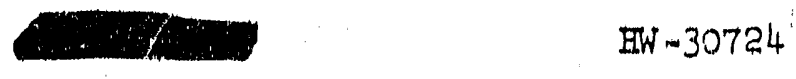

Radiologtoal Solences Department

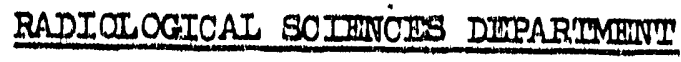

IANUARY 1954

\section{Organlzation}

The month end force of 374 included 28 supervidars, 104 englneers and aclentists, 18 clorlcal, and 224 other personnel.

Trumber of Pmployeer on Payroll

Beglnaing of month - 371

Fnd of month - $\quad 374$

Net Increnge $\quad-\quad 3$

\section{General}

There were 28 informal, 21 Class I, and 3 class II radiation incldenta. None was lonown to have been of auffelent magnitude to affect the tolerance status of an emplojoe. One lnoldent, technlcally only in Class $I$, lntolved the relese of grose quant1ties of mithentum from the Redco plant. Considerable acceptance of contamination condltions ineppropriate for long-continued operation was resorted to, in order to hold the disruption of operation and construction to a minlm. Whon 1t is approclated that the actual. releese was only about is af that routinely areilable in the procese, the hazard potential of a repetition is clear. A.1I components of organlzation 1nvolved are conslderlng approprlate strengthening of control meseures.

At a b1o-modical directorg' moeting, the blologlcel effucts of atcolc weepons were well presented, with many flndlngs aharply reversing the premature optimlatic concluelone of the repart "iffects of Atantc Weepons". Spec1flca.11J, the neutron contribution 1o now found to be

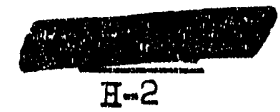


Radi ologtoal Sclences Department

$B W-30724+\cdots \cdots$

\section{General (Continued)}

h1ghls algniflcant. It 1s noteworthy that this reault appears fugt at the time when the department is propered to begin a major attack

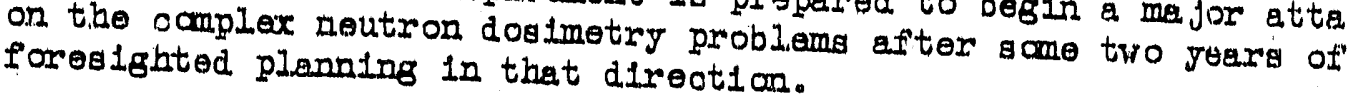

The oft-postponed NCRP report on pexmisatble external exposures 1s now belne printed. Thls now document will be a dangeroug one in the hands af those pertialiy informed on radiation hazarda. A bor of adminlatrat1vo dertoos a olderably mare latitude in appear, aluperplolally, to promote cantenor of the report is to encourage In actual fact, the intended polnt were caxefull replewed with lrioreased canservatiam. Those sponsible ocmmitteo follla, ohalman of the dro-

During the perlod covered by thlo report, all persons in the Rad10loglcal Solences Department engaged in wark whtoh intght reas onably be besected to reault in inventions, or disooveries, adrled that to the made in the oourse of thel boller, no 1nventions or discoverles were furthor advised that notebook recorda, 1f any, pertod. therein covered by this report, examined for poesible intent in the course of thelr work have been

\section{Inrentor Title}

None

None

* The wrlter has fuat loamed that two of hla former Brltish aseoclater in radium work have rocently dled of aupposedly radiation-1nduced malignonoy after 20 to 25 jears in the cleld. Since one af these men always worked under exposure conditions that wero at loest reesonably woll cantrolied, present operation 18 providederm implications of the 
ENA -30724.1

Rad10log1.0al Sclencea Depertinent

\section{RADIOLOGICAI FWYGINHERRING}

Congtratiotion work at tho Bl0logg laboratory addit1on, and tho Pos 1 tivo Ion Acoelerator laboratory approeched complet1on. Installat1 an of equipment at each alte wlll be complete in everal months. Impxove-

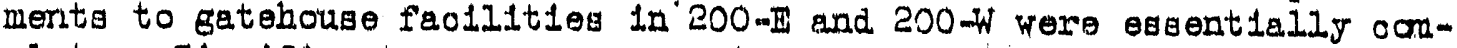
plete. Slgnifloant progresa was noted on the Bloagary laboratory construction, w1th Phese I work 95\% complete, and Pheso II wark $50 \%$ completie.

The recamendation for Purex exhaust alr flitration was reafilimed, basod on Redox findings, and the ourrent algnifloent pertiolo emiasion at Redax wes oumar1zed. Sooplng of fac1lit1es at Purex to prevent the formation of amontum nitrate in the stack 1s in progress.

Aaglatanco was gitren in the promsopling of trit1um extraction and 1sotoplc puriflcation feoll1ties proposed for buliding 271-B. Chronlo ganme radiation and alr contemination probleme indicate that the presont bullding 108-B facilities are not sultable for long-term operation. Bafo atack diapoal criterla wore rovlowed.

Stack emlsalon from the Redox plant has lncreased the risk of approving use of off-plant construction workers at Plant and Army congtruct lan aroes in the 200-W Area and Vlolnity.

Criterla for large scale ground dlaposel of eupermatant fram scavenged bleh level weate tran the metal recovery operation wore formatiod.

\section{RADIOLOGICAL FECORUS AND STANDARDS SECTION}

1. Radiation Monltorlng

General Stat1at1og

Speclal Work Permita Routine and Speolel Surveya Alr Semploo Sisin Contamination

$\begin{array}{rrr}\text { December } & \text { January } & \text { Tota1 } \\ 1953 & \frac{1954}{512} & \frac{1954}{512} \\ 1,432 & 1,51.9 & 1,51.9 \\ 1,720 & 1,835 & 1,835 \\ 58 & 25 & 25\end{array}$


Radlologion Solenoeg Department

\section{Radiation Montt orting (Continued)}

On. Januars 2 and 3, Large quarit1t1es of flasion products, prodaminatois ruthentum, wero reloased from the Redar atack followirg the fallure of the caust 1o sorubber. Ixtena1vo ground contamination resulted, and requlred special oontrol. measures in and near the $200-\mathrm{W}$ Area and acme intermption of oconetruation work. Smalier quantities aubsequenti's released on Jamary 5 and 6 caused additional ocmitrol problems. (Olass I)

An onglnoer of tho Applied Rosearah group rocelred hand exposure in axoesa of the permisalbie linit while handing a emell bottle af redioactive solution after removal fram the 1-F oublole in the Redar laboratory. The maximum dose to the fingers of the left hand wes eatlmated a.t. about 8 rede. (CLass II)

Canslderablo rallroed equlpment was found bady contaminated in the 200-W Area. The contemination wes spread to several orewmen and Later to a residence in Rtohland. The souroe of the contamination has not yot been ertabliahed. (OIara I)

\section{Kadiological Standarda}

Three Clese II, eleven Class I, and twonty-elght informel radiat ion Ineldenta were reported. In addition to the one clase II froldent sumerized above, two others 1ntolving localized sleln overexposure occurred. In addition to the two reported abovo, the clase I 1no1dents Included two cases of contamination spread at the 105-H reactor, two otherg at tank Perms, two at the 231 bull.ding, one at the Redcox plant, one at the 224-I Concertration buliding, and one at the $100 \mathrm{~m}$ burning ground. One Inoldent Inrol.Jing the hendIIng of eraphite aamylog reported last month was recleasifled as Informial.

\section{Mxposure Recarde}

During 1953, 42 Goneral Electrlo employees recelved whole body ganme. exposure in excess of two roentgens and 100 recolved whole body bete. and game exposure in excesa of three reds. Similar flgures for Mincr construct ion employees were 4 and 0 , respectirely.

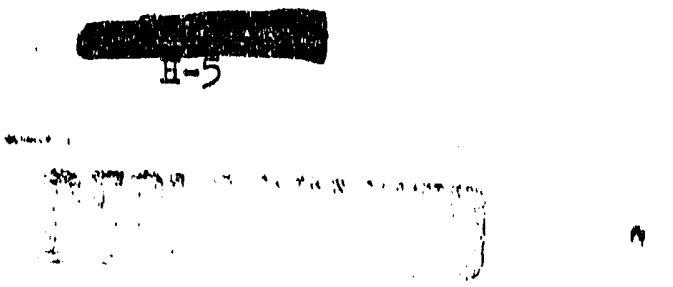




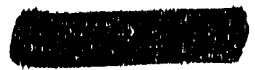

Radiological Sclanceg Department

3. Expogure Reoords (O ont Inued)

(a) Personnel Meterg, and Reoords and plotometry

Genorel Stat1at1os

\begin{tabular}{|c|c|c|c|}
\hline & Decamber 1953 & Jenuary 1954 & $\begin{array}{l}1954 \\
\text { Iotal }\end{array}$ \\
\hline molla rot & 198,400 & $2.03,820$ & 203,82 \\
\hline $\begin{array}{l}\text { Potent1al overexpooures } \\
\text { Conf 1 rmed overexposureg }\end{array}$ & $\frac{12}{0}$ & 13 & 1.3 \\
\hline $\begin{array}{l}\text { Conf } 1 \text { rmed overexposurea } \\
\text { 310w neutron pencils regd }\end{array}$ & $\begin{array}{r}0 \\
1,020\end{array}$ & 798 & 708 \\
\hline Potentlal avereaposureg & 0 & 0 & \\
\hline Conflrmed overexposures & 0 & 0 & 0 \\
\hline Beta-ganma film bedges processed & 9d. 31,175 & 35,965 & 35,965 \\
\hline $\begin{array}{l}\text { Potential orerexposures } \\
\text { Conf } 1 \text { rmed orerexposures }\end{array}$ & $\begin{array}{r}45 \\
4\end{array}$ & 63 & 63 \\
\hline $\begin{array}{l}\text { Confirmed overexposures } \\
\text { rast neutron badger procoesed }\end{array}$ & $542^{4}$ & 386 & 386 \\
\hline Potential oterexposures & 0 & 0 & 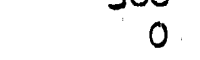 \\
\hline Conf 1zmed overexposures & 0 & 0 & 5 \\
\hline Lout readinga & 26 & 42 & 42 \\
\hline
\end{tabular}

(b) B10asgay

1. Plutontum Analyeses

December 1953 January 1954

1954

Samples usajed

Rogulta above detectlon limft*

718

Resamplea assayed

25

25

Rearults above detection Lim:tt*

1.05

667

17

35

12

Maximum a/m/sample

e.12.

Total

*Detect1 on Limit wae $0.05 \mathrm{~d} / \mathrm{m}$.

2. Fliselon Product Anglyge日

Samplos assayed

Results abote $10 \mathrm{c} / \mathrm{m} /$ samplo

Decembor $1953 \quad$ January 1954

815

1

705

2

667

27

35

12

2.12

The two resulta above $10 \mathrm{o} / \mathrm{m}$ were aseoclated with a radiat1on incldent.

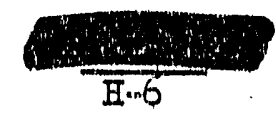


Radiological Sciences Department

3. Exposure Recorda (Continued)

3. Urantum Ane 1 zBes

Results of 322 samplea procesed this month are tabliated below.

$\frac{\text { End of 4th Dey Exposure }}{\text { Ind of } 2 \text { Defe-no Expogure }}$

Sample

Description

Marimum Average Number

Semples

Mexlmum A veraze Samplos

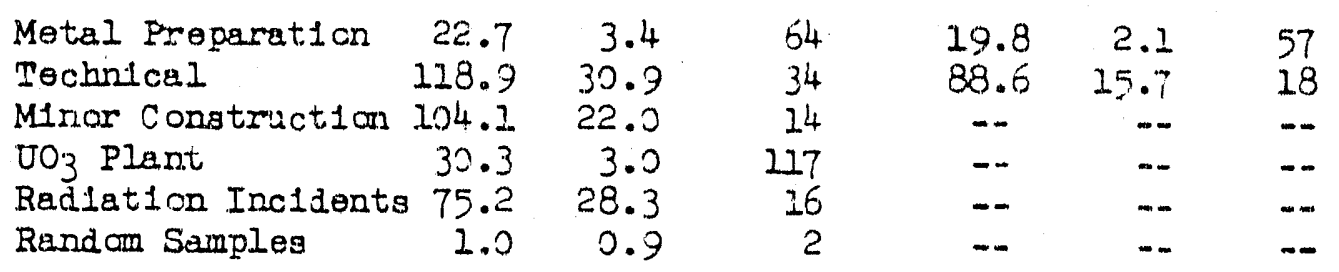

4. Tritium Analjeeg

Act1rj.ty Dengity $\left(\mu \mathrm{c} / \mathrm{r}: \mathrm{c} \times 10^{3}\right)$

Number of semples $\frac{0-5}{330} \quad \frac{5-10}{1} \quad \frac{10-35}{2} \quad \frac{35-70}{0} \geq \frac{70}{0} \quad \frac{\text { Total }}{333}$

(c) Thyrola chocks

A.I thyrold checks reported were below the warning level.

(d) Hand Score Summery

Thers were 36,488 alphe and 60,684 beta scores reported. About $0.02 \%$ of the alphe and about $0.001 \%$ of the beta scores were above the warnIng level. Decontamination of the reported hlgh cases was attempted. and successful.

4. Cal1brat1ong

Number of Routine Calibrations December 1953 January $1954 \quad 1954$ Total.

Fixed Instmments Portable Instrumente Pex.somel Meterg Total. $\begin{array}{r}41 \\ 3,113 \\ 16,723 \\ \hline 19,877 \\ \hline\end{array}$

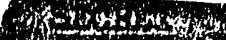

Ii $\rightarrow$ - 


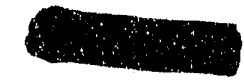

EW $-30724 \ldots \ldots ?$

Radiologtcal Sclences Department

\section{BIOPEYSICS STECTION}

COTHROL UITIT

Reglanal Surrey

The genoral eladiag aro sumartzad in the followlog table:

SAMPLE TYPE ATD LOCATIONS

Average

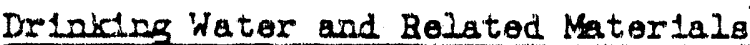
Benton C1t] Water Co. Well

RIChland, N.RIchland, Bouton Clty Wello 100 Areas

Pasco, Kannew Ick, Mcirary Dam

Backwarh gollda-Pasco Fliter Plant

Backwash 11qu1ds-Pasco F1Iter Plant

Sand P1zter-Pesco F1lter Plant

Anthracite fllter-Pagco Fliter Plant

Act1Fity Trpe Act1Fity Density (uc/cc)

Other Waters and Related Materialg

300 Aree Wells \#1,2,3

300 Area Well \#4

Woll \#4 meesurid as urentum

Other wells on the reaervation

Columbia River-Fanford Ferry

Columbia R1ver-Below reactors

Columbla R1ver-Patterson to Mcllary

alpha

alpha

beta

beta

beta

beta.

beta

beta

$1.1 \times 10^{-8}$

$(<0.5$ to 1$) \times 10^{-8}$

$(<0.5$ to 8.8$) \times 10^{-7}$

(<0.05 to 1.2$) \times 10^{-6}$

$9.3 \times 10^{-2} \mathrm{\mu c} / \mathrm{s}$

$4.8 \times 10^{-7} /$

$1.4 \times 10^{-4} \mathrm{pc} / \mathrm{s}$

Not in operation

Columbla River-shore wad

Raw water-Operating areas

Reactor effluent retention besing

Reector effluent retention besine

Il3I in farm waster
Il3I In Columbla R1ver-Hanford Operation

alphe $\quad(<0.05$ to 1.6$) \times 10^{-7}$

a.pha

$1.2 \times 10^{-7}$

ए $9.0 \times 10^{-8}$

bete $(<0.5$ to 3.5$) \times 10^{-7}$

bete $1.2 \times 10^{-5}$

beta $1.3 \times 10^{-5}$

beta $(1.6$ to 2.5$) \times 10^{-7}$

beta

beta

beta

alphe

131
$I^{13}$

$(0.3$ to 1.2$) \times 10^{-4} \mathrm{pc} / \mathrm{s}$

(< 0.05 to 1.9$) \times 10^{-6}$

$(3.0$ to 5.4$) \times 10-3$

$<5 \times 10^{-9}$

$6.3 \times 10^{-7}$

1. $4 \times 10^{-7}$

Atmospherle Pollution

Grose alphe emitters

Gross dose rate-Separations arees

Crose dose rete-Re日ldential areas

F1Iterable beta-Separations areas

II3I-Separat 1one area日

I I31-Separati ons stacks

alpha

beta-gemma

beta-ganna

beta

I 131

I 131

Act1ve pert1cles Wash. , Ide., Ore. , Mont.

Active pariticles - EAPO

Tr1tilum (as cxides)-Reactor atacks

1.1 curles/day

- $<0.001$ to $0.04 \mathrm{pt} 10 / \mathrm{m}^{3}$

- $\quad 0.02$ to $0.3 \mathrm{ptI \theta} / \mathrm{m}^{3}$

I 0.77 curle/day

$(<0.4$ to 2.6$) \times 10^{-14}$

0.7 to 8.0 mrads $/ \mathrm{daj}$

0.4 to $0.8 \operatorname{mrads} / \mathrm{da}$

$(0.4$ to 2.4$) \times 10^{-12}$

$(0.05$ to 1.0$) \times 10^{-12}$

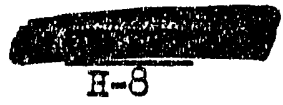




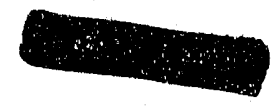

$$
\mathrm{EN}-30724
$$

Red1ologival Sclences Department

\begin{tabular}{|c|c|c|}
\hline SAMPIE TYTE AND LOCAIIONS & \multirow[b]{2}{*}{ Act1V1ty Typo } & ATe \\
\hline Act1 $\nabla 1 t g$ & & Act1 11 g Dens 1ty $(\mathrm{ac} / \mathrm{s})$ \\
\hline 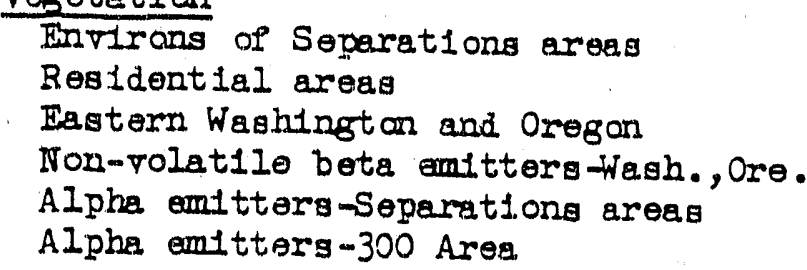 & $\begin{array}{l}I 3 I \\
I I 3 I \\
I I 3 I \\
\text { bota } \\
\text { alpha } \\
\text { alpha }\end{array}$ & $\begin{array}{l}(0.6 \text { to } 6.3) \times 10^{-5} \\
(<3 \text { to } 6) \times 10^{-6} \\
(<3 \text { to } 8) \times 10^{-6} \\
(0.3 \text { to } 1.1) \times 10^{-4} \\
(1.6 \text { to } 6.8) \times 10^{-6}\end{array}$ \\
\hline
\end{tabular}

Homlasion of 260 curles of ruthentum over a 27 -hour period on January 2 and 3, and 70-170 curies on January 5 and 6 , in the Redox ef fluent gas resulted in dosage readings as bigh as 1 rad per how an the ground In 200 - Arsa, and as high as 100 mrad per hour on the rodway between the Batch plant and 200w gatehouse. The deposition was traced along a narrow trajectory as far as the Spokane-Reardan hilghway where activ1ty or ruthenlum on regetation was an the arder of $1 \times 10^{-3} \mu \mathrm{c} / \mathrm{s}$. Further emiasion of flsalon products lncluding ruthenium, rare earths, strontilum, and zirconilm fram the Redox stack during the later pert ifis the month caused signiflcant localized contamination in the southenst corner of the 200 W Area.

Analyticel Control Laboratory

Routino and speclel analyses were carrled out as follows:

\section{Leboratory}

Trpe Semple

Vegetation

Water

Soltas

Air samples

Uranlum (Pluorophotameter)

O1I fog (Pluorophotamoter)

Special ourrey eamples (RMSS)

Special surger samples (RMU \& RS) Total
Ana lyge日 Completed

Jenuary- 1954 Total

\begin{tabular}{rr}
1247 & 1247 \\
1714 & 1714 \\
189 & 189 \\
404 & 404 \\
521 & 521 \\
0 & 0 \\
24 & 24 \\
14 & 14 \\
4113 & .113 \\
\hline
\end{tabular}




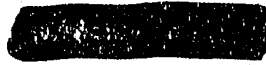

$E W-30724+\ldots$

Radiologicel Sciences Department

Analytical Control Laboratary (Continued)

Anal yses Completed

Counting Room

Beta measurementa (recounts included)

Alpha measurements (recounts included)

\begin{tabular}{cr}
\multicolumn{2}{c}{ Analyses Canploted } \\
Jenuary & $\frac{1954 \text { Total }}{5878}$ \\
\hline 5878 & 2119 \\
2119 & 2679 \\
2679 & 3199 \\
3199 & 99 \\
99 & 13974 \\
\hline 13974 &
\end{tabular}

Control polnts (alpha and beta)

Decay ourte polnts

Absorption curre polnts

Total

A sample of ges released trom a ruptrured $\mathrm{J}$ alug on January 14 at 100-DR

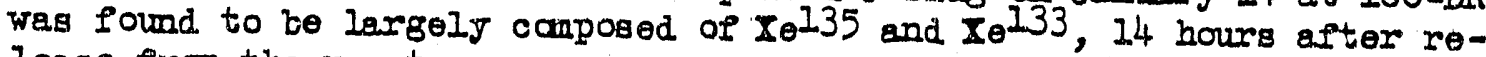
lease fram the reactor.

\section{Control Sertices}

Statisticel eveluations were made of data measuring the concentration of indifidual bete perticle amitters in reactor effluent water frcm a.11 production areas through Decenber, 1953. Calculat1ons were completed to show the theoretlcal quant1ty of ruthentum whlch would be present in a slus at the Seperations process under exlating operating conditione.

\section{Symoptic Meteorolagy}

\begin{tabular}{|c|c|c|}
\hline Forecesta & mumer made & $\begin{array}{l}\text { Jenuery } \\
\text { Percent rellablilt }\end{array}$ \\
\hline $\begin{array}{l}\text { Production } \\
24 \text { hour } \\
\text { Spec1al }\end{array}$ & $\begin{array}{l}93 \\
62 \\
95\end{array}$ & $\begin{array}{l}79.2 \\
76.4 \\
82.1\end{array}$. \\
\hline
\end{tabular}

A verage temperature for the month was $28.9^{\circ} \mathrm{F}$ with an average of and $19^{\circ}$ for the final 16 days, and a 10 temperature of $-6^{\circ}$ an Januery 20. Snowfall totaled 14.3 inches, reaching a maximum depth of 9.5 inches on Jenuary 27.

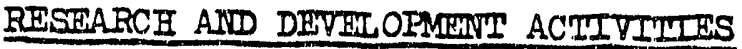

\section{Ixperimental Metearolosy}

Development work continued on a mothod for predicting the morement of alr contamirants at 5000 feot elevation on a reglonal scale resulting from a major plant disagter. 


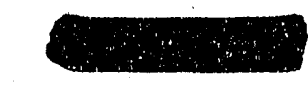

$$
\text { EW }-3 \underline{0} 724
$$

Radiological Sclences Department.

\section{Feperimental Metecrologr (Continued)}

Analyses of the fleld testa conducted during aloft conditions during I952 contlnued. Prelfminary results Indlcated that both the lons and short perfod concentrations decreesed with distence to a power lese then one (campared with Sutton's 1.5) during stable conditions. These results would Indicate higher ooncentrations at great distances from the sourece then would Sutt on's Hypotbes1s.

The average air concentrations and the probablifty of radisact1ve perticle inhelations at varlous locations wero computed fran average anal meteorological data, talelng into account wind drection and atablifty rarlation, and were applied to a pertlcular gaseous wasto dispoeal problem. Tho reaults campered closely with Reglonal Surrey data taken at the selected locatlons.

\section{Earth Sclences}

The cancentrations of sodlum and altrate lons and of beta-gama cimitters in new wells completed in three ereas of ground water contemination in the 200 Areas followed the predicted relues, lndicating the relidity of the evaluation inethode used. Ixperimental work indicated that calcium lons are also usable 0.8 erldence of contamination.

Infiltration rate teste west of Gable Mountain and adjacent to the proposed 105-C effluent ditch showed the low ralue $23 \mathrm{gal} . / \mathrm{ft}^{2} / \mathrm{dag}$ at the site tested.

Simulated silica gel regeneration solution, $0.24 \mathrm{M}$ in callc ac1d, increesed the permeablitty of the soll in a soll column through which it pessed. Intense srajling of the soll and an increase of total selts in. the elfluent over that in the influent indicated podzolization, or acid leaching of the so1l, which maj limit or deny ground disposal of the wastes.

Semples of the Hall, the Ringold, and a composite Hanford noll were used in laboratory equilibrlum experiments and were found to hare olnilar adsorption for $\mathrm{Sr}$ belor the soll cepacity.

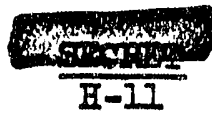


Rad1ological Sclences Department

$\mathrm{EW}-30724$

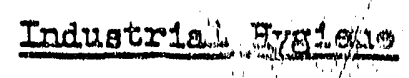

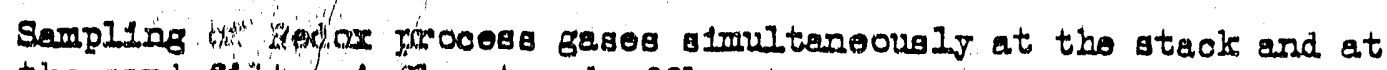

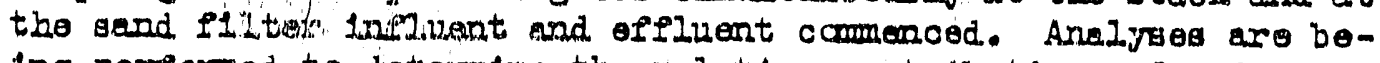
Ing perpormed to determine the rolat1vo contributions a radioactive particulates by tho rent lines and the send filter ofeluent.

A sampling apparatus was ingtalled in tho Redox amplo dallery to obtaln ruthenlum particulater for 10halation atudies by B10log.

Alr semplea were collected at tho 108-B urinelysid laboratory and analyzod for lmitants to ascortaln tho causo of oyo 1rritation of persomel engeged in thle work. It was found that the nelyt Icel procedures Ilberated amonla, calclum chlorldo, and calocium bydrcox1de, all or whlch were present in the atmosphore. Reccmondations for control were mado.

A study was made of the contamenation loeding of the exhaust rent1lation syotem for bidid1ns 3730. Partiole s1zo and act171ty density woro detormined for the uranium fume and dust producod by exper1mental motaliurglcal operations.

Methode

A gema repoctrometor was sabrlcated, assembled, and teated. Tho sanme ray spectre of $\mathrm{Ru} 103$, RuI06, II3I, and Cal37 wore dotormined for callbration purposes and for obtalning performanco charecter1st1cs necessery for the des18m of a stack gas mantor for Rulo3-106 and $I$ I3I.

The rates of solution in distilled weter of $\mathrm{UO}_{3} \cdot \mathrm{H}_{2} \mathrm{O}$ propared in tho laboratory and of plant-recovered $\mathrm{UO}_{3}$ wore meesured; no difference in rates wes not1ced. In exch case, tho inftial rate of golution was rap1d w1th ono-hale the seturation amount diseolving in less than one hour. The retes of aolution in ploural flu1d will next be doterminod.

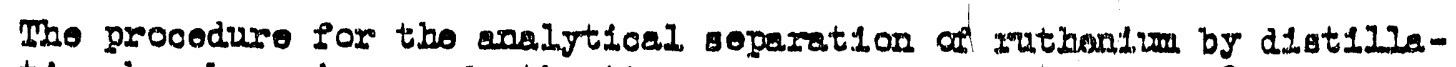

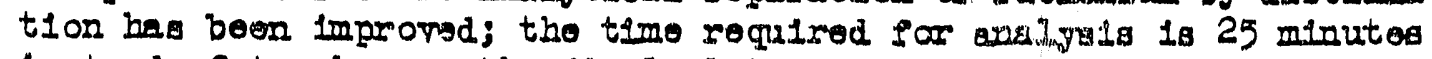
Insteed of two hours; the plnal plater rea1duk 18 ovenly diatributed. and mey be obtalned carrior-froo for Ru103-Ru106 Irtio stud1os.
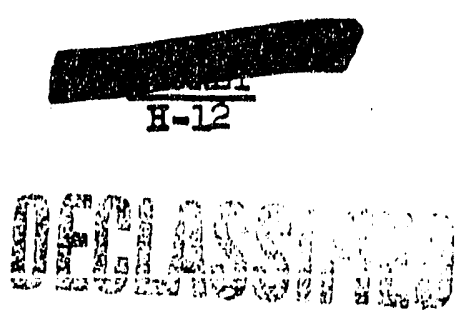


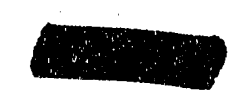

BW -30724

Radiological Sclences Department

\section{Phro10s}

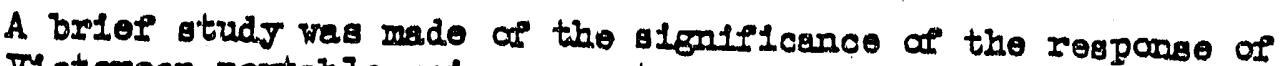
Vlotoreen portablo gelger counters and CP instruments used by

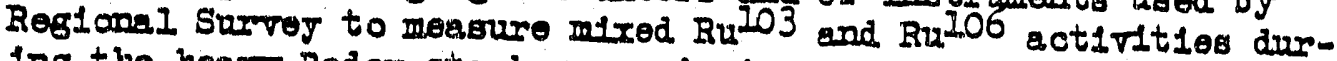

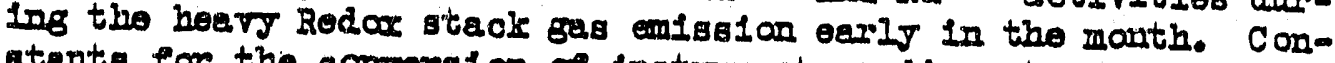

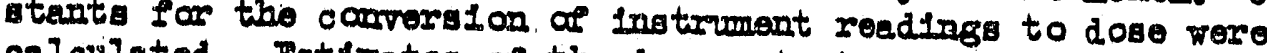
calculated. Brtimates af the dose rate to mouse lungs from such activity wero mede $f$ or tho Bloloes section.

The dopendence of deadtimo and recorery time of gelfor conaters upon the relue of 1 ignal realstanco was measured proparatory to a otuds of tholr dependence upon counter age.

F1Im badge sens1tivity varlations with emergy woxe found to be the same for hear1ly f1Itered $I$-rajs as $I$ or monoenerget 10 radlat 1 an fram the $\mathrm{K}$-gowree, in contrat to certein oerlier date lndicating otborw1se. The Burean of Standarde elim tosts wore repeated using

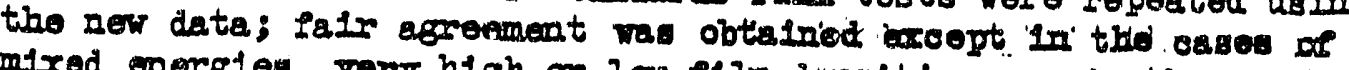
mixed orgles, rers high or low f1lm denelties, or in the exergs region 0.16 to $0.30 \mathrm{Mer}$ whoro no data at present are avallablo.

Instrument Devolognont

Successful. use of an morgency arrengement $f$ mor montoning tho Redar Inoldent road contemination by cer promptod a roquest for wuch oqulp-

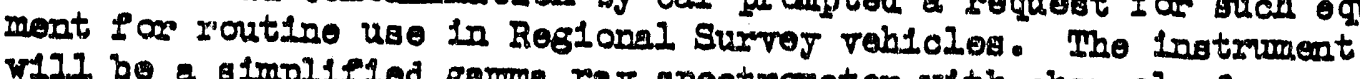

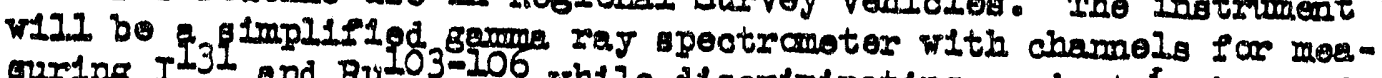
orring IIJ1 and BuI03-106 whilo discriminating agalnat beclesround.

The desion of the repeeter otatian for the radotelemetering Wind Station notwerls was noariy completed and the major components wore
terted.

Disital and analog integrators for the new Ra $103, \mathrm{Bu}^{106}, \mathrm{I}^{231}$ monftor wero wtradiod intensivolj. A docado scaler whloh intom gratos tho difierence betwoen two pralso rates mes deroloped about a camercial docado scaling tubo for possiblo uso as a digital

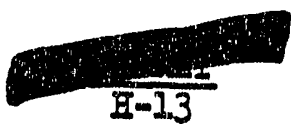




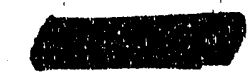

BV -30724

Radiologioal Solenceg Department

\section{BIOTOGY SECTION}

\section{AQUATIC BIOLCGY}

\section{Blologlcal Chaing}

A short-texm test was undertaken to atudy adoorption in comparison to blological fixation of $\mathrm{p}^{32}$ an glase and aluminum aurfaces of equipment used in a previous experiment. The surfaces were exposed in two aquarla eptiked with $\mathrm{p} 32$, one contalning microorgarisme, and the other kept sterlio w1th formaldehjde. Uptake of the 1eotope was equal on like surfaces during the firgt few hourg but subsequent IJ became oureral times greater an ourfeces in the blologically active aquarium. Uptake per unit area of aluminum was over 100 times that for glasa under both Flable and aterile conditions.

\section{$\underline{E \operatorname{col} l o g} \pi$}

Survey of the Columbla R1ver

W1th river tomperatures nger minlmu for the jeer, activity densitiea

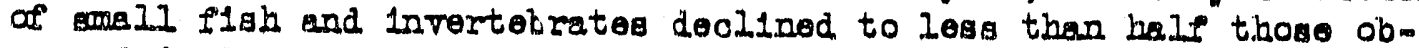
orved in Docmber. Valuell for bottom algeo and planderton remainod

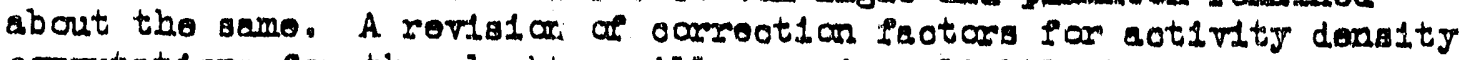
conputation for tho plankt on w111 now 81 vo ollght $1 \mathrm{y}$ lower rosults.

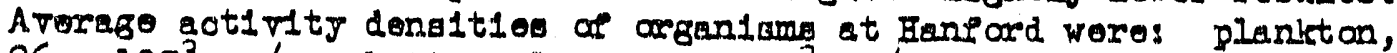
$26 \times 10^{-3} \mu \mathrm{c} / 8$; bottan aleve, $5 \times 10^{-3} \mu \mathrm{\mu o} / \mathrm{s}$; cadd1s larrae, $4.0 \times 10^{-3}$ $\mu \mathrm{o} / \mathrm{s} ;$ and amell $1 \mathrm{sih}, 0.6 \times 10^{-3} \mu \mathrm{so} / \mathrm{g}$.

Camparatively large amounts of radioat1vo materlalis peraluted in some wh1 tor 1ab caught 1modiately bolor the 100-F Ares. Marima woro:

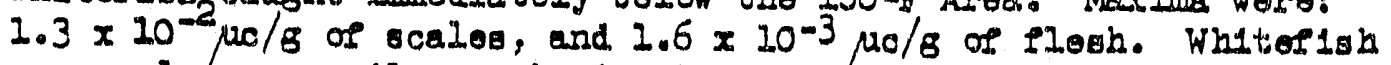

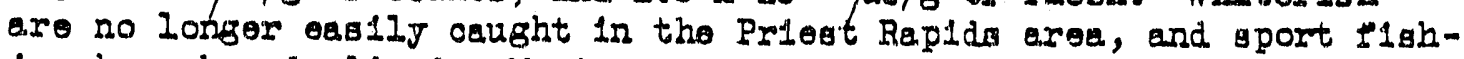
Ing here has declined. Marimum act17tty of Prlogt Rap1ds wh1torish wes $7 \times 10^{-5} \mu \mathrm{o} / \mathrm{s}$ of sosiog, whtch compuras Parorably w1th $7 \times 10^{-4}$ $\mu \mathrm{c} / \mathrm{s}$ of scales at Banford and those bolow MoNery Dam.

\section{Effluent Monitmeng}

Mortalities among chlnook selmon eggs and frot have ranged from to in river water to 99 in 10\% els luent. Rate a derelopment has been rotarded in $10 \%$ and greater atrength of dechlorinated reactar influent and sileht martality Incroases have occurrod at tho 25\% and 50\% 1.0role.

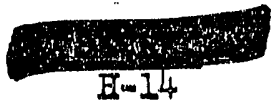




\section{HW -30724}

Rad1 olegleal So1enoeg Department

Effluent Monitoring (Continuesd)

Temperature sengitivity tests with locel salmon have, as jet, ahown no adverse effect at the temperature increment (2X) antiolpated from future racetor operation. A.ppreclable mortality among fry has reeulted at the $2 x$ level, however.

\section{BIOLOCY CONTROL UNITI}

\section{B10log1cel Monitoring}

Contamination (ruthenlim) in the ricinlty of 200-W Aroa rosulted in the following rodent tissue and excreta activity denalties:

\begin{tabular}{llll} 
& $\frac{\operatorname{Jan} .5}{\operatorname{Jan} .8}$ & $\operatorname{Jan} .19$ \\
\cline { 2 - 3 } & $5 \times 10^{-4}$ & $1 \times 10^{-3}$ & $2 \times 10^{-3}$ \\
Fidney: & $6 \times 10^{-2}$ & $9 \times 10^{-2}$ & 0.2
\end{tabular}

Rodent thyrold act1Fity densitles increased, with the maximum of $1.4 \times 10^{-2} \mu \mathrm{c} / 8$ occurring one mile SE of Redox.

\section{Clinical Laboratory}

There were 1,119 routline blood analgeas performed, and 58 miscellaneous ensigses.

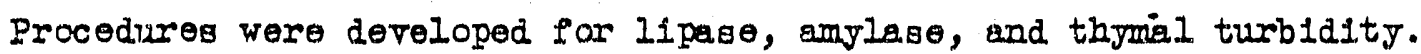

M1.croscopy

A new imbedding method was uged, incorporating cedar o1I 1nto the tissues by means of a vaculm oren, on skin blopeles fram the beta plaque lrradiations.

Routine serflces were perfarmed in autoradlography and eloctron microscopy.

Rad1ochandgtry

Rout1ne sexvices congleted of preperation of 35 isotope soluticns, aneljses of 800 amples for I ${ }^{131}, \mathrm{P} 3$, RulO6, or $\mathrm{Cs}^{137}$; 198 tritium analyses; and 51 TTA extract 1 ons for plutonlum.

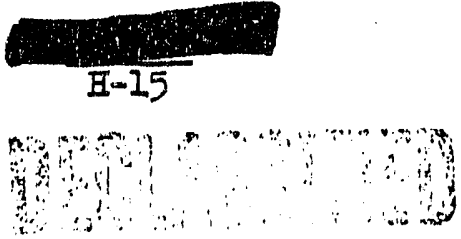




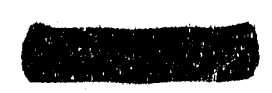

$$
\text { HIT }-30724 !
$$

Radiologlcal Sclences Departinent

\section{MBIABOIISM}

P1ss1an Product Absorpt1 on and Metabol1sm

The distribution of $\mathrm{Cs}^{137}$ in three rata was determined 21 dags apter feeding each ret $55 \mathrm{\mu c}$ in one ml of saline solution. Reglults were In good grement with those of camar; total recovery averaged $100 \%$.

\section{Tritium Absorption and Metabollam}

Three preliminary rune were made w1th alx rate ench to deternine the best conditions $f$ or tho exposure of rats to tritlum gas.

\section{Mechanism of Radiat1 on Domage to Aigeo}

Irradiation of chlorella resultad in an increase in phosphoproteln and nuclelo ac1d phosphorus, and in scme interererenco in tho conversion of glucose to nuclelo acids. Results also indicatod that the Krob's cyclo reactlons and the reactlons leading to the gynthesis or protelns, sterches, and collulose frcm acotate were not solect1voly" damered by irradiatian.

\section{PIANTI NUTRTIIION AIND MICROBIOLOGY}

\section{Absorpt1 on and Trenglocation of Fad10oleanents in Plants}

The effect of $p H$ on the uptake of muthenlum from nutrient solutions was found to be almilar to the effect of $\mathrm{pH}$ on Jttrium uptake. Increesed acldity betweon $\mathrm{pH} 7$ and $\mathrm{pH} 4 \mathrm{gave}$ Increesed uptake with a maximim $\mathrm{L} / \mathrm{R}$ relue of 0.002 obtalned at $\mathrm{pH} 4$.

Soll studies on the uptake of ruthenfum unexpectedis 1ndicatod that uptake Iram 8011 may be groator then from autrlent golut10ns. A lesf:soll rat10 fram Ephrate send af 0.0119 was obtalned, canpared with a I/B ratio of 0.0002 obtalned from studies with nutrient golutions.

Proliminary realta fram the experimonts to ovaluate 1sotoplo diffor. atlation of boen planto lndicato a slentelcent differanco betwoen tritium and deuterium, and, of course, a marked differentlation of these two fran protizu. 


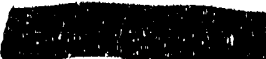

$B N-30724+2, \ldots$

Rediologioal Sclences Department

\section{RBE of M1orob1ologloal Methodo}

Recelculation of Gurelueg of $\mathrm{p}^{32}$ bete pert loles reported last month ladicated a ralue of 12.9 rather than the 1.5 .5 prevlougly reported. Thls palue agrees well with reports fram Oak RIdge and la very close to values found for tritiun in this laboratory. Thus, it appears that there 1s no marked energy dependence of tho iron dosimeter within the range of these two beta particles.

\section{Genet1c Hefocts of Internal1 y Depos 1.ted Rad 1oelements}

Mutant atralns obtained by $\mathrm{p} 32$ treatment of Neurospore are beling 1dent1fled as to their nutritional requiremente. Although all have not been succesefillg ldentifled, it appears that the kelnds of mutants obtained are afmilar to those expected from $x$-rays or ultra-riolet 1rradiation.

\section{TOXICOLOGY}

Experimental Andmal Farm

Tox 1 cology of $I^{13 I}$

The ration of I 131 in the thyrold gland to I $I^{131}$ fod dally $(Q / q)$ in Jw vary were essentlally the same as in November and December.

No appreclable change in the blood plcture of sheep fed 5 rac $I^{131} /$ day and control, sheen accurred durlog the past twelve monthe. This apecial test lncluded a host of chemical and collular determinations, and was deslegned to determine whether a gredual shift is occurring in sheep being fed. Il31 that is marginal in demage potential.

Fourteen or1g1nsl sheep that were elther controls or that wer'e fod 5 or $0.15 \mathrm{pc} /$ day were secrifleed. The three moet comon finding in order of prevalence were: chronic hopatic absceseos, chronto pulmonary abscusser, and chrontc nephritis. There appeers to jo no varlation between the groups with respect to the occurrence or yreralence of these conditions. The averege welght of thes thyrold gland in tho control group was $17.6 \mathrm{~g}$, that of the $0.15 \mu \mathrm{c} / \mathrm{day}$ group $17.3 \mathrm{~B}$, and of the 5 Mc/day group $5.6 \mathrm{~g}$. Thyrolde from the control and $0.15 \mathrm{pc} /$ day antmals appeared relatively normal in color and texture with no obrlous alons ar Induration flbrosil. With tho excoption.

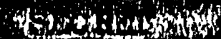
H -17 


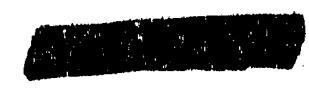

Rad1ological Sclencer Department

Toxioglogx of $I^{131}$ (Continived)

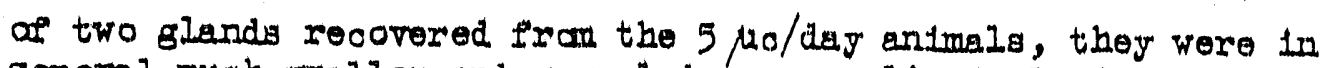
Bemeral much amaller and revealed a generallzed glandular fibrools

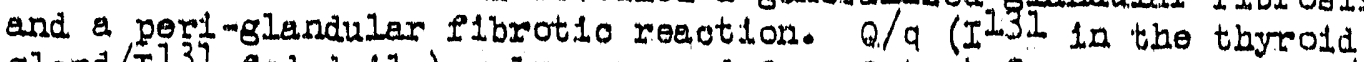
gland/I I3I fod dalig) ralues wenged fram 3 to 4.8 in tho $0.15 \mu \mathrm{o} / \mathrm{dag}$ group, whllo in the 5 po/day group peilues ranged fram 1.8 to 3.3 . There was aloo some oroes-over in thyrold woilghts among animals fran these two eroups. One entmal's thyrold from the 5 po/day group show od no htatologioal damage. These observations appor to ind cate that for adult shoep 5 po/day $1 \mathrm{~s}$ about tho threshold ralue.

\section{Phy 10logy}

Red1oect1te Part10les, Motabollam, and Tox100logI

In proliminary work no lncrease in tumor incldence in excess of spontaneoug appearance was found in the group of mice whtch recelted 0.12 $\mu$ PuOn tracheobronchlal injection. Tho miloe had aurvived the 100.-day perlod cons1dered necessary to produce deteotable increase in tumor 1acidence. Autorad agrephy and histopethology reverled no recagnizable correlation between $\mathrm{PuO}_{2}$ location and tumor s1tes, although abscese日s were produced.

Plutonfum Toric1ty and Thorapeutica

No result. 


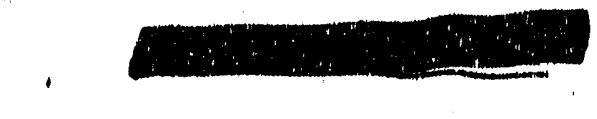

FINANCTAL DEPABTHENT MONTHCY REPORT JANUARY, 1954

Preparation of the budgets for the f1sual year 1956 and revis on of the 1955 budget were gotten under way before the ond of the month. Asumptilons were recelved from the Atomle Energy Commission on January 27, but tentative estimates were used by the three cost units of the Flinanalal Department to get the work atarted earlier.

As the result of meetings attended by Finanalal Department representatives and AEC Budget personnel, a conalderable reduction in the volume of detall required for thmom budgets was agreed upon. Items eliminated or consolldated Included: ( 1 ; the consolidation of $A E C$ Schedule $\mathbb{E}$ ' with the GE "short form" schedules prevlously prepared; (2) the elimination of Schedule $F$, whlch detalled the organlzational pattem and Included shlft covorage, a breakdown of exempt and non-exempt personnel, etc.; and (3) the elimination of a narrative justification as a separate prosentation, the lnformation being provided 1.n the consolidated Schedulo $\mathbb{E}$ and the justification accompanylag department personrel estinates. Along wl.th the reduction in the materlal required, time achedules have ueen established with a view to eliminating as much overtime as posulble in preparing the budget. Preliminery work was started on manpower and material requirements and the historleal information necessary was prepared and distributed, together with necessary forms.

It is anticipated that the varyous budget programs will be avallable for review by managoment during the porlod from Fobruary 4 to Apri1 12, and aubmission of the entire budget to the Commisaton $1 \mathrm{~s}$ acheduled to be completed by April 30 .

In connoction with a report on radiation detection instruments requested by the Washingtion office of the AEC, the Financlal Department assisted in a physical inventory of non-portable monitoring devices in the 100,200 and 300 Areas, supplied data on purchase and fabrication costs- of certain equipment, and furnished cost figures on repals and malntenance as well as those for research and development. The report is scheduled for completion on February 10.

The flrst major physical Inventory for the calendar year 1954, that of fuels and lubrtcants in the custody of the Transportation Section, was taken on Januarry 20.

The first consolidated standard cost report for the Manufacturing Department wos Issued in January. The report compares the current month's and year-todate costs with standard costs, and gives explanations for variances. It is scheduled for monthly issuanse.

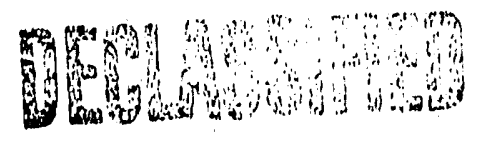

$$
I-1
$$


A new gyatem for payting and distributing travel oogta has boen developed, and having boen reviewed and approved by the Comminalon, wlil go into effect 1n February. The spealal bank acoount fior the payment of travel expenme, malatalned as an Lmprest fund, 1s to be oldminatad and ohooks w111 be drawn on one of the contrsot bank aosulutis hereafter. Under the new aystem travel

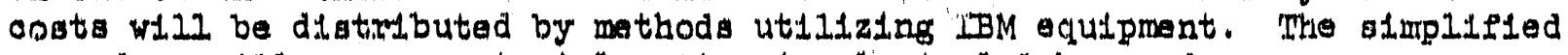
procedure will mean a material aaring 1 a olerfoal labor and expense.

A repreventative from the Walington, D. O. of floe of the Atomlo Energy" Comntsaton's Division of Construction and Sigply and one from the ADC Controller's staf' began a revlow of accounting procedures, policies and Intermal controls relating to plant inventoriles on January 25.

A moving pleture flin entltied "Pleraling the Unknown," a presentation of aome of the newer IBM equipment, was shown to a group of Finanolal Department enployees at the public library on January 18.

Detalled reports for the Financlal Department appear on succeeding pages, as followa:

Summary of Cash D1sbursements, Recelpts and Advances

Accounting Section Reports

General Accounting Unit

General Cost Undt

Manufacturing Cost Unit

Engineerling Cost Unit

Appropriations SectI.on Report

Payroll and Auditing Section Reports Payroll Unft

Intermal Audit UnIt

Perscanel and Organization Statistics
$I-3$

I- 4 through I -9

$I-10$ through $I-11$

$I-12$

$I-1.3$

$I-14$ through $I-16$

I $-1 T$ through I -19

$I-20^{\circ}$

$I-2 I$ 


\section{STATI STICS}

A summary of cash disbursements and receipts (excluding advances of $\$ 6,250,000$ and $\$ 7,000,000$, respectively, by the Atomic Bnergy Commission) for the months of January, 1954, and December, 1953, 1s shown below:

\section{Disbursements}

Payrolls (net)

Materlals and Freight

Payments to Subcontractors

Payroll Taxes

United States Savings Bonds

Group Insurance Premium

Pension Plen - Employees' Portion

All Other

Total
January

$\$ 2674023$

1507104

2235473

628834

207923

131400

119960

181544

7686261

December

\section{Receipts}

Rent

Eospital

Electricity

Telephone

Seles to AEC Cost-type Contractors

Refunds from Vendors

Sundry Accounts Recelvable

Bus Fares

Other

Total

$\$ 3209702$

1249178

836424

531424

269070

131371

98826

173649

6499644

Net Disbursements

131576

59497

69258

42730

10550

2075

24817

8013

4771

353287

119573

76447

67096

42884

15674

13274

9692

8115

6351

359106

$\$ 7332974$

$\$ 6 \quad 140 \quad 538$

Outstanding advances as of January 31, 1954, and December 31, 1953, were a.s follows:

\begin{tabular}{crr} 
& January & December \\
Cash in Bank - Contract Accounts & $\$ 3497.546$ & $\$ 4580520$ \\
Cash in Bank - Salary Accounts & 50000 & 50000 \\
Travel Adrance Funds & 125000 & 125000 \\
\multicolumn{1}{c}{ Total } & $\$ 3672546$ & $\$ 4755520$
\end{tabular}




\section{Accounts Payable}

Expanding purchasing activity in recent months is now beginning to affect the volume of work handled in the Accounts Payable group. The number of and the dollar value of orders from 1,630 in December to 1,971 in January, an $\$ 1,047,783$ to $\$ 1,731,378$.

The number of vouchers booked and paid also reflected the rising volume of orders placed. The increase, however, of approximately $\$ 1,400,000$ in bookings and $\$ 1,800,000$ in peyments included a number of large involces covering graphite purchased from the Mational Carbon Company under
Special Agreement G-12. Comitiment records intalned on 28 construction projects showed an open
balance at the end of January of $\$ 7,401,006$.

Active contracts handled by the Accounts Payable group, excluding requirements contracts, numbered 16 , and open contract comitments amounted to $\$ 4,194,696$. Payment on these contracts in January totaled $\$ 1,750,545$. The total amount disbursed. on the 25 active requirements contracts during
January was $\$ 363,223.62$. Other statistics on activities in the Accounts Payable group are given
below:

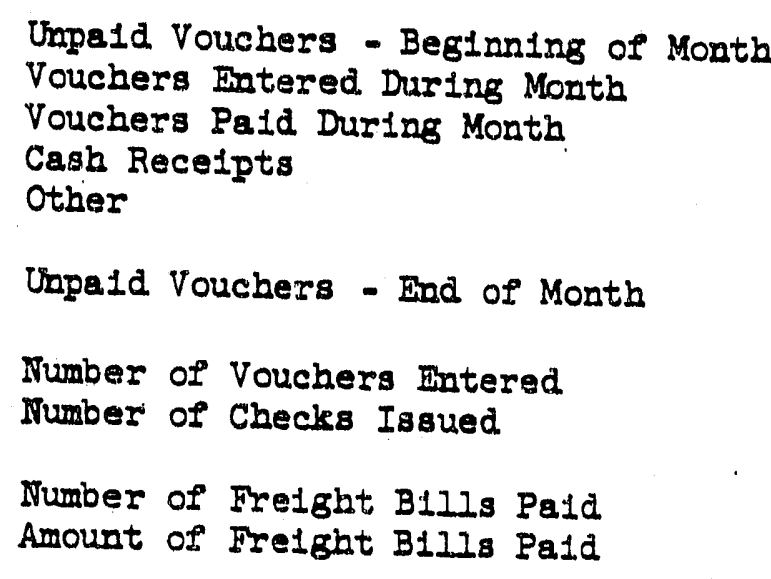

\section{Accounts Rece1rable}

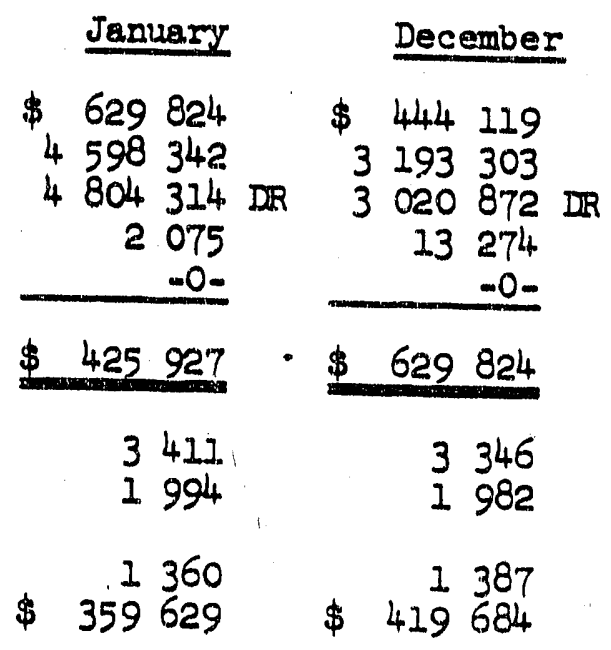

The quarterly accounts recelvable report was issued in January, show1ng a bsiance at December 31, 1953, of $\$ 294,903$. Of th1s amount $\$ 174,218$, or $59 \%$, represented current accounts; $\$ 47,758$, or $16 \%$, accounts th1rty to s1xty days old; $\$ 15,485$, or $5 \%$, accounts sixty to ndrety days old; and $\$ 57,442$, or $20 \%$, represented accounts over alnety days old. Th1s latter amount 1ncluded 1tems totaling $\$ 11,294$ whlch we consider 
Accounts Recelvable Cont.

uncollectible and which have been assigned to collection agericies. Total accounts recelvable charges booked during the quarter amounted to $\$ 1,851,492$, while collections were $\$ 1,936,462$, or $105 \%$ of the charges entered on the books. The general ledger balance of $\$ 294,903$ reflected a decrease of $\$ 84,970$, or $22 \%$, as compared w1 th the balance at September 30, 1953.

As Indicated by the statistics at the close of this narrative, the general ledger balance for accounts recelvable showed an increase of $\$ 52,806$ as of January 3I, as compared with December's closing balance, accounted for principaliy by larger balances in bospital, rent, sundry and electricity accounts.

An increase of $\$ 12,114$ in hospttal recelvables was primar1ly the result of two factors: an 1ncrease in the number of patients, charges to patients belng $\$ 7,331$ higher than for the prior month; and delayed receipts from the Metropolitan Insurance Company on group insurance claims. Out-patient invoices issued in January at Kadlec Hospita]. numbered 1,757 and totaled $\$ 10,853$, as compared with 1,732 in December, totaling $\$ 9,737$. In-patient revenue totaled $\$ 64,340$, as compared with $\$ 58,126$ in December. The hospital census rose from 64.8 in December to 77.9 in January.

The larger balance of receivables for rents, $\$ 8,906$ over December, was due to increased charges to facilities operators, whose rentals are based on gross sales. December rentals, due in January, were $\$ 17,444$ bigher than for the previous month.

The increased balance of $\$ 8,075$ on sundry accounts was primarily due to a billing to Schenectady of $\$ 13,871$ of charges against the overhead. allowance for the quarter ended December 31 .

The late explration of the grace period for the payment of electriclty bills 1ssued in January accounted for the ircrease of $\$ 17,158$ in the balances due for electricity. The penalty assessed for tardy payment did not became effective until February 2 .

Other data reflecting the activity of the accounts handied by the Accounts Receivable Broup are given below:

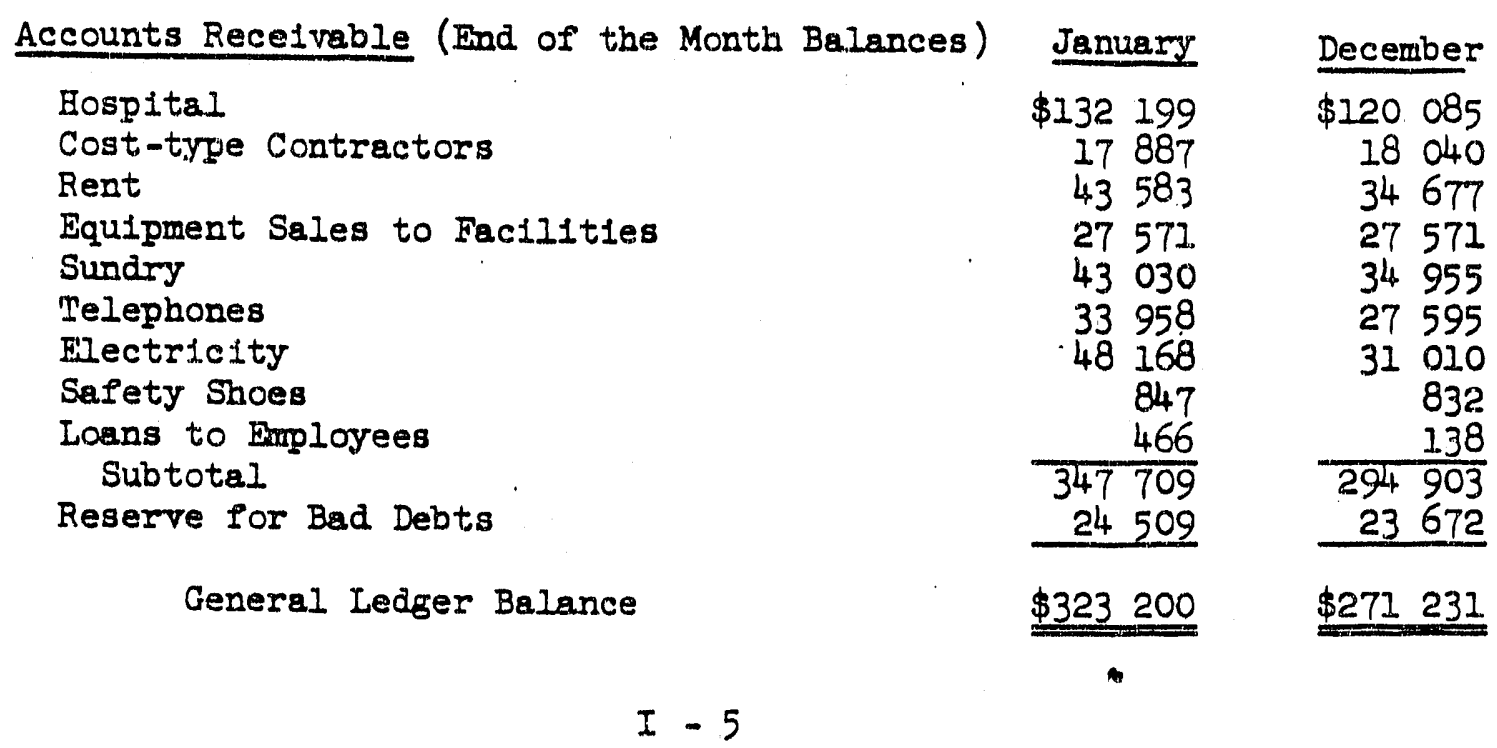


Accounts Recelvable Cont.

Hospital

January

Number Out-Datient Involces Issued

Charges During the Month

Collections - Cash

- Payroll Deductions

1757

$\$ 75193$

59497
4273

$\$ 10397$

10550

Rent

Eouses

Number Houses Occupied

New Leases and Lease Modifications

Lease Cancellations

Charges During the Month

Collections - Cash

- Payroll Deduct1ons

Dormitories

Number Rooms Occupied

New Ass ignments

Removals

Charges During the Month

Coliections - Cash

- Payroll Deductions

$\begin{array}{rrr}6031 & 6036 \\ 83 & 53 \\ 62 & \\ \$ 307278 & \$ 307 \\ 4845 \\ 518 & 53750 \\ 256734 & 258662 \\ & \\ 799 & 805 \\ 53 & 60 \\ 59 & 91 \\ \$ 18248 & \$ 18437 \\ 5236 & 5445 \\ 12974 & 13350\end{array}$

162

$\$ 77822$

162

$\$ 60378$

53750

805

60

5445

13350

Revenue

246

$\$ 6681$

15674

67862

76447

6054

Sundry

Number Involces Issued

Amount of Involces Issued

Cesh Recelved

$\$ 32168$

24817

290

$\$ 7538$

9692

Teleplzones

Working Telephones (excludes official telephones)

Telephone Works Orders Processed

6193

396

Charges During the Month

Cash Recelved

$\$ 50535$

42730

6136

280

$\$ 47917$

42884

Electrleity

Number of B1.11s Issued Amount of B1Ils Issued.

Cash Received

7274

$\$ 86717$

69258
7272

$\$ 75430$

67096 
Accounts Recelvable Cont.

\begin{tabular}{|c|c|c|}
\hline & Number & Amount \\
\hline collectible Accounts (Total to Date) & & \\
\hline $\begin{array}{l}\text { Accounts Forwarded to Collection Agencies } \\
\text { Accounts Returned as Uncollectible } \\
\text { Collections }\end{array}$ & $\begin{array}{l}596 \\
264 \\
202-1)\end{array}$ & $\begin{array}{r}\$ 50141 \\
29125 \\
7 \quad 926-2 \\
\end{array}$ \\
\hline $\begin{array}{l}\text { Balance at Collection Agencies } \\
\text { December } 31,1953\end{array}$ & 162 & $\$ 12934$ \\
\hline
\end{tabular}

(1- Includes 170 accounts collected in full and 32 accounts partialis collected.

(2- Represents total collections, half of which is remitted to General Electric.

\section{General Accounts}

December financial statements for the Hanford Atomic Products Operation and the Atomic Products Division were 1ssued on January 14 and 19 , respectively. Other major financial reports were finished on the scheduled dates. The December trial balance was completed on January 8 this year, as compared with January 13, 1953, for December, 1952.

Unexpended advances from the Commission amounted to $\$ 3,672,546$ at January 31 , as compared with $\$ 4,755,520$ at the end of December. This decrease was due to the payment of invoices in excess of $\$ 1,000,000$ for which funds were obtained fram the Comission during December. Adaltional advances of $\$ 8,600,000$ were requested in January to cover February expenaitures.

The quarterly statement, "Application of Funds," was revised in Jenuary. This report details cash and materials recelved by $B A P O$ from the Commission and the application by HAPO of such funds and materials.

Through the elimination of a quantity control of stores tickets forwarded to IBM for distribution, one employee was made available for transfer. from general ledger to expense account work. Travel expense work has increased considerably in the past several months due to the larger number of ermloyrees traveling on compeny buslness and the additional deta1led information now being furnished management.

During January, 277 travel and I1ving expense reports totaling $\$ 50,293$ were booked, as compared w1th 302 reports totalin/3 $\$ 51,077$ in December. Cash advances issued to employees totaled $\$ 67,939$, as compared with $\$ 52,485$ for the previous month. Additional informition concerning travel expense is given below. 
Generel Accounts Cont.

January December

Travel Advances and Expense Accounts

Cash Adrances - Beginning of Month

Advances During the Month

Expense Accounts Submitted

Cash Refunded

Cash Advances - End of Month

$\$ 67849$

67938

$50449 \mathrm{CR}$

$9402 \mathrm{CR}$

$\$ 74463$

52485

$50181 \mathrm{CR}$

$8918 \mathrm{CR}$

$\$ 75936$

$\$ 67849$

Outstanding Cash Advances

Current

Over 30 Days

$\$ 73204$

2732

$\$ 58883$

8966

Total

$\$ 75 \quad 936$

$\$ 67849$

Travel and Iiving Expenses

Actual Expenses

$\$ 50293$

47933

$\$ 51077$

$48 \quad 174$

Balance as of December 31 . billed to Schenectady office to be applied against Administrative Fund and Overhead Allowance

Balance in Variation Account at End of Morth

$10116 \mathrm{CR} \quad-0-$

$2360 \mathrm{IR} \quad 10116 \mathrm{DR}$

Inyentory Accounting

Except for routine work involved in maintaining controls and inventory reporting, the efforts of this group in January were concentrated on details relating to physical inventories, the largest project being the preparation for the physical inventory of fuels and lubricants in the cuatody of the Transportation Section and reconcillation of inventory values with ledger figures. Meetings were held with Transportation Section personnel to review in detall the procedures to be followed in taking the inventory and to clarify questions as to those materials to be inventoried and those to be considered as shop stock. The inventory took place on January 20. The reconcillation of physical inventories and boak figures is in progress and a report of results is scheduled for issuance about February 15 .

The Manufacturing Department's evaluation of spare parts fabricated by the Engineering Laboratory to establish revised values, previously scheduled for completion by the end of January, has been deferred because of higher priority worik and is now scheduled to be fintshed by the end. of February.

Plant Accounts

A revised estimate of depreclation expense for FX 1954 was prepared during the month. The revised figures result in an increase of $\$ 1,510,000$ over the previous estimate prepared in July 1953 .

$$
I-8
$$


Plant Accounts Cont.

A. special fire evaluation report was submitted ti draft form to the Atomic nergy Comission in January. This report included the asset and reserve values of all areas except costs applicable to improvements to land, roads, walks, and paved areas, plping systems and all underground facilities. We were informed that this information is to be used in estimating the replacement cost of facilities in case of fire damage or other destruction.

Responsibllity for 1Bsuance of reports on Spare Equipment Held in Storage and control of entries affecting spare equipment was transferred from the Inventory Accounting group to Plant Accounts group during January.

Meetings were held with Cost, Operating, and Stores personnel relative to the establishment of procedures for control of spare equipment in r lock-up. In the past, spare equipment in mock-up has been the responsibility of Stores but revised procedures place the control and responsibility for recording movements with the custodian of the equipment.

In connection with unitization of projects, inventories of the $108-F$ building, bullding service equipment and laboratory equipment (Project C-192), and the 3000 Area Central Stores Warehouse (Project $A E C-111$ ) were campleted. The time and cost of unitization have been reduced considerably by inventorying facilities as construction progresses, rather than waiting unt1l the project is complete, as had been done in the past.

Work in connection with the reconciliation of fleld inventories and the establishment of new plant record cards is progressing satisfactorily, and is expected to be completed by April 1. 


MONTHLY GENERAL COST UNIT

\section{Consolldated Costs and Budgets}

This group assisted in the preparation of material for the annual report entitled "1953 at HAPO," currently beling completed by representatives of the Technical Section and the Employee and Public Relations Department. Data on related unit costs and production wes provided for about 20 charts which will appear in the publication.

Charts showing the fluctuation in the average hourly earnings at HAPO since 1947 as related to the Buregu of Labor Statistics price index and the unit conversion costs of plutonium were prepared.

A comparative analysia of varlous budget estimates prepared for FY 1954 was completed, to be used by management in a cost and budget review. A comparison of budget estimates for FY 1955 to date was also submitted.

\section{IBM Liaison}

This group is conducting an over-all review of IBM reports prepared by the Computing Unit for the various Cost Units, analyzing their usefulness and distribution. A total of 17 copies per month of eight salary distributions were eliminated in January as one of the results of this survey.

Plant Auxiliary Operations

An improvement in presentation and content of future unit cost and financlal statements will be apparent as the result of revisions made in the course of a review completed in January. All liquidation rates were also examined after the completion of reports for the first half of the flscal year and several changes made to correct over- or under-11quidations of recorded costs.

Analysis letters for their respectlve organizational components are now being malled to managers and unit beads as soon as possible after the 1ssuance of operating reports, followed by a personal visit from the cost analyst to explain any deviations from a normal cost period and to discuss other cost problems.

Commun1ty Operat1ons and Real Estate

The accruals for purchased electricity, electrical revenue and comercial faclilty revenue, previously prepared by the Accounts Recefvable untt, are now being made by this cost group. Charts for previous years have been prepared to show the trend of the volume of these transactions, to be used as guldes in setting up accruals.

The 11quidation of costs for servlces performed by the Commuity EngineerIng unit, previously made on a clerical basis, has been converted to an IBM operation. This change is expected to save approximately four mandays per month for Englneering Unit and Совt personnel.

$$
I-10
$$




\section{Medical}

A study of unit costs for the Industrial Medical Section was prepared for use in the Section's annual report for 1953.

Discussion between cost representatives and Medical Department management concerning costs for Kadlec Hospital, as operated at present and as it would be if the hospital were operated as a public institution In a normal commintty, laid the Broundwork for the preparation of a hypothetical budget to be used in conjunetion with a study to be performed by the Public Administration Service, a consulting firm, in the near finture.

\section{Stapf Departments}

A review of accruals for the first six months of the FY 1954 for the services of private law firms retained by the Legal Department was made in January to determine whether any adjustments were necessary. An analysis of purchase requisitions for plant and equipment to verify expenditures and commitments relating to the equipment budget for the FY 1954 to date was also made. This was necessary for the preparation of a report on Equipment Not Budgeted in Construction Projects whlch was previously prepared by the Plant Accounts group, General Accounting Unit. 
MANUFACTURING COST INIT

MONTHEY REPORT - IANTJARY, 1954

Three comparisons of Manufacturing costs and undt costs were made in January and submitted to the Manager - Manufacturing. These were:

1. The July performance estimate for first six months of FY 1954 as agalnst the first six months' actual;

2. The annual estimate prepared in July, 1953, as against the six months actual and the six-month January estimate; and

3. The December actual compared with the October forecast.

A sitatement for P-10 Extraction was Included in the Product Cost Report for December, prepared in January.

The number of work order overruns has shown a marked decrease recently, and $1 \mathrm{t}$ is hoped that by continued stress on better estimetes, more accurate distribution of labor and materlal costs, and the anticipation of costs in excess of original estimates in time to obtain proper approvals for increases, these overruns can be eliminated.

Cost figures for several cases in connection with the 3X Program were supplied to the Manager - Manufacturing for incorporation into special production studies being made for the Atomic Energy Commission.

Revised studies of janitor and electrical costs were made for the Separations Section in January for use in arriving at a more equitable distribution of these costs.

The Separations Section's portion of the quarterly Savings and Improvement Report for the period from October 1 to December 31, 1953, was prepared for the manager of the Separations Section, while the Reactor and Metal Preparation Sections' portions of the report, prepared by those sections, were reviewed by the financial advisors with their respect1ve management groups.

Rental rates for four new bulldings in the 300 Area were established this month. They were the 303-J slug storage, 324 Radio Chemistry, 326 Plle Technology, and 3707 - D Change House. 
ENGI NEWERING COST UNIT

MONTELY REPORT - JANUARY, 1954

Twelve draftsmep and a supervisor were transferred fram the Design Section to tile Technical Section on a permanent basis as of January it, and an additional elght draftsmen were transferred to other departments. Th1s necessitated a budget transfer between the Design and Technical Costs grourps which was accomplished in January. In connection with the shange, the Technical Costs group also wrote an accounting procedure for the draftsmen to supplement an operating gulde issued by the drafting supervisor. This transfer of personnel will substantialiy reduce the cost transfer billings issued by the Design Costs group.

\section{Design Costs}

A survey of Design Section management has revealed that a revised method of presenting sosts in the monthly statements would increase the value of the reports and possibly eliminate the necessity of the manager's booklet. Consequently, preparations were made to issue reports in the new form for January. Cost statements for December were completed January 4 .

Technical Costs

December research and development detall reports were 1ssued January 11; operating cost reports for the Technical Section and the Engineering Administration Sub-Sect1 on on. January 12; and analysis letters for the Manager - Technical and the Manager - Engineering Administration on January 18 。

\section{Project Costs}

The Construction Work in Progress - Engineering report for December was furnished to the Atomic Bhergy Cormission on January 8, while the monthly report and the quarterly detail report of Project Section operating expenses were sent to the section managers on January 13.

A financial closing report was issued in January on Project CG-447 Portable Meteorological Mast.

An analysis of all accruals and charges to completed projects carried in the general ledger account 0807 (Accrued Costs - Closed Projects) wes completed for the AEC. Further analyses of Minor Construction Management Unit indirect expenses, based on a revised manpower forecast furnished by the Minor Projects Sub-Section, were completed and reviewed by the manager of the Project Section and the manager of the Minor Projects Sub-Section. Total over-liquidations to date have resulted in a credit balance which in past months has shown a cont1nuous decrease and further consideration is being given to the adjustment of the standard overhead. rate. 


\section{APPROPRIATIONS SECTION \\ MONTHEY REPORI - JANUARY, 1954}

Project proposals, informal requests and appropriation requests which were processed by the Appropriations and Budget Comittee and directives issued by the Comnission during the month of January are shown in the following Ilst:

CG-496 - RECUPIEXX INSTALIATION - BUIIDING 234-5

Proposal requesting minor scope revisions and additions and an increase in funds to $\$ 1,482,000$ was approved by A \& B Committee January 22, 1954, and forwarded tio the Conmission.

\section{CA-512 - 1952 HANFORD EXPANSION - 100-K AREA FACIIITIES - 1706-KE RECIRCULATION FACIIITIES}

Proposal requesting inclusion of $1706-K E$ recirculation faclitities in the next revised proposal to be 1ssued by the AEC was approved January 19, 1954, by the A \& B Committee and forwarded to the Comission. This proposal requests total funds of $\$ 1,530,000$ GE $\$ 165,000$ and AEC $\$ 1,365,000$.

\section{CA-513 - EXPANSION OF 200 AREA FACIIITIESEPART D - HOT SEMI-WORKS CONVERSION}

Proposal requesting authorization of $\$ 25,000$ for infitation of design and procurement of stainless steel pipe for the Hot Semi-Works Conversion was approved by the Comittee January 26, 1954, and forwarded to the AEC. Fac1lities consist of prototype tank to investigate self-concentration problems of Purex wastes and a pipe line to existing tank farm system to supply additional storage facilities for Hot Semi-Works wastes.

\section{CG-535 - REDOX CAPACITY INCREASE, PHASE II}

Revision to proposal requesting design revisions and inclusion of a silica gel system to reprocess off-standard uranium product at a net increase in cost of $\$ 300,000$ was approved by the A \& B Comittee January 19, 1954, and forwarded to the Commission.

\section{CG-549 - ACTIVATE TASK I RMA IINE - BUILDING 234-5}

Revision to project proposal requesting a change in work authorization to perform onsite fabrication of engineered equipment, testing and associated fleld engineering work was approved by directive dated January 7 , 1.954.

\section{CG-558 - REACTOR PLANT MODIFICATION FOR INCREASED PRODUCTION}

Rerision to proposal requesting an additional $\$ 100,000$ to permit continuation of design work without interruption until approximately March 15, 1954, was approved by the Comittee December 23 and Porwarded to the Commission. Directive dated January 8, 1954, authorized GE $\$ 200,000$ for desiga.

A revised construction data sheet was submitted to the Comission at their request in the amount of $\$ 27,200,000$. This data sheet will be used for the basis of obtalning release of funds from the Bureau of the Budget. The scope on whlch the amount is based includes a full 1ngtallation of pumplng equipment in three water plants and modifications to existing faclifties in the other two areas. Also included is the removal of horizontal control rod thjmbles and replacement of horlzontal. rods.

$$
I-14
$$


CG-50E - WASTE LETIL RECOVERY PLANT MODIFICATIONS

Revision to proposal incopporating all authorized revisions into one proposal, requesting change of scope to include solvent treatment facilities, and additional funds of $\$ 92,000$ was approved by the A \& B Comittee January 12, 1954. Directive dated January 26, 1954, authorized GE $\$ 220,000$ for combined work.

CG-569 - REPLACEMENT OF CATCH TANKS 3I1-ER AND 302-BR - 200 E \& W

Project proposal requesting $\$ 45,000$ for replacement of tanks was approved by A \& $B$ Comittee December 14, 1953, and forwarded to AEC. Directive authorizing this wor's was issued January 5, 1954.

CG-570 - REPIACE RAW WATTER IINE - \#15 WELI. TO IEE BOULEVARD

The project proposal requesting $\$ 110,000$ for the subject work was approved by the A \& B Committee January 22, 1954, and Corwarded to the Comission Junuary 26.

\section{CG-572 - PARTICIE PROBLEM ANIMAL EXPOSURE EQUIPMENT}

Project proposal requesting $\$ 22,500$ was approved by the A \& B Comittee January 28 , 1954, and forwarded to the AEC.

CG- 273 - FANTFORD $3 X$ PROGRAM

Letter dated January 7, 1954, A. B. Greninger to D. F. Shaw requested $\$ 800,000$ for initiation of work in 300 Area in connection with 3 X Program. Request authorized by letter dated January 8, D. F. Shaw to W. E. Johnson. Project proposal covering this allocation was approved by A \& B Comittee January 14 and forwarded to AEC. Directive authorizing this request was issued January 15 .

CG-576 - GENERAL IMPROVEMENISS TO LABORATORY BUIIDING

Proposal requesting $\$ 6 c, 000$ was approved by the A \& B Comittee famuary 22, 1954, and forwarded to AEC.

CG-577 - IMPROVEMENTS TO EXISTING STREETS - GEORGE WASHINGTON WAY - FY 1254

Project proposal requesting $\$ 65,000$ for the subject work was approved by the $A$ \& $B$ Committee January 25, 1954, and forwarded to the AEC.

REQ,UEST FOR INFORMAL APPROVAI FOR INSTALTATION OF AUTOMATIC BAR SCREENS AT SEWAGE LIFT STATION

Informal approval requesting $\$ 16,000$ was approved by the Comnittee January 25,195 ', and forwarded to the AEC January 27.

REQUEST FOR IIFFORMAL APPROVAL OF 300 AREA SUPPLY SPACE - 325 BUTIDING

Informal approval requesting $\$ 15,700$ was approved January 22, 1954, and forwarded to the AEC January 27. 
Appropriation Requests approved were as follows:

Equipment for Fuel Element Pilot Plant

$\$ 275,550$

One Centrifugal. Pump

5,000 (Addition)

Frames and Plexiglass for Civil Defense Plotting Maps

1,300

Procurement nf Three Electric Fork Iift Trusks, 2 Ton, for the "B", "D" and "F" Reactors

1], 000

Procurement of Telephone and Associated Equipment $3 r d$ and 4th Quarters - Fr 1954

16,430

Replacement of Pickup Truck Bodies with Telephone Installers Truck Bodies

2,700

200 Gallon Unloading and Transfer Tant and Appurtenances

14,700

Replace Existing No. 4 and 5 Dryer Blower Drives with Larger Drives - Bldg. 115-D

12,000

Procurement of Hoists and Trollies - 100. Areas

10,300

Pilot Plant In-Iine Analytical Instrumentation

$4 I, 500$ 


$\frac{\text { PAYROLI UNIT }}{\text { MONTHEY REPORT }}$

W1thholding Statements, Form W-2, coverlag earnings and tax deductions for the year 1953 were prepared and delivered to all employees on Friday, January 8, 1954.

The procedure for distributing salary checks to montbly pald employees who are asslgned to the outer areas was revised effective with the month of January. Salary checks for these employees are now delivered to supervision in the areas for distribution to employees. These checks were previously dellvered by Payroll to the depextment manager's offlce in Rlchland.

Annual reports of state and federal payroll taxes were prepared and f1led in January for the year 1953. Reports were flled with fourteen state agencies covering lucome and unemployment taxes.

Yacation Not1ce Cards for the year 1954 were distributed to departments, corering non-exempt employees who will be eliglble for a vacation during the yrar. These card 3 will be used to notify payroll of the dates employees will take their vacation so that Payroll may make advance vacation payments on the payday prior to the start of vacations.

Effective with the month of January, the report of absenteelsm was revised to Include all hours absent by non-exempt employees. Prlor to January, this report lncluded only full days absences of these employees. In addition, the bases for determining the percentage of absenteelsm has been revised to exclude vacation hours and hours spent in military encaupments.

The anaval report of employee contrlbutions to the Pension Plan was coimleted durtag Janusry and was forwerded to huployee Benef1t Accounting Services Section, Schenectady. The report was in the form of an IBM card record for each employee ladicating amount contributed durlag 1953.

Round-table discussions were held by supervisors with all non-exempt Payroll employees durlag January.

Rerlizions of the following OPG's were prepared in January and forwarded to Adrlaistrative Practices Planaing:

OPG 18.9 - Distribution of Salary Checks, Earnings and Deduction Statements, U. S. Savings Bonds and Custody Recelpts.

OPG 18.8 - Monthly Atteudance Report

OPG 18.1 - Weekly T1me Cards

Revisions of these OPG's were necessary to correct nomenclature and to 1ncorporate current practices in the guides.

The audit by the F1nance Divis1on of B00-AEC of personnel adminlstration and payroll policies and practices continued throughout the month of January.

$$
I-17
$$


Paysoll Unit (continued)

\section{STATISTICS}

NUNBER OF ENPLOYEES

Changes During Vonth

implioyees on Pay roll at beginning of month

Mdditions and transfers in

Removals and transfers out

Tran sfers from weekly to monthly payroll

Transfers from monthly to weekly payroll

Employees on payroll at end of month

OVERTIME PAYMENTS DURING MONTH

Weekly Paid Employees -a)

Nonthly Paid Employees

Total
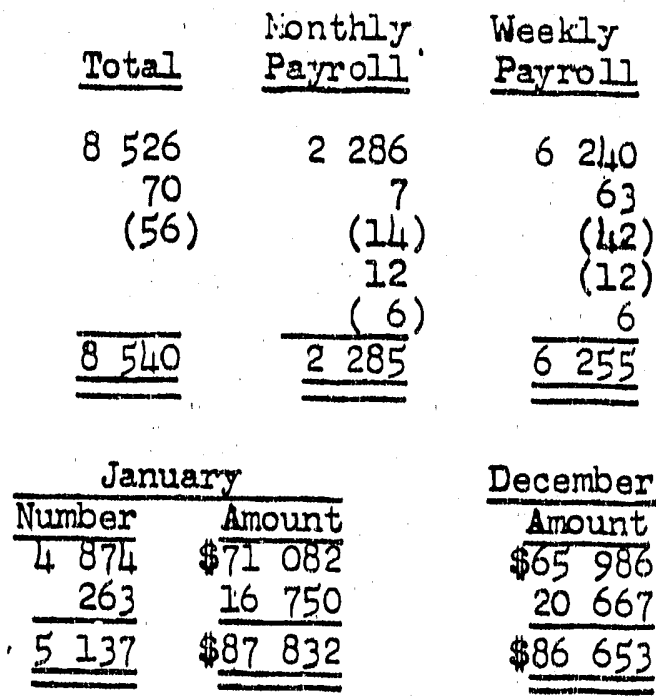

December

Amount

$\$ 65986$

20667

$\$ 86 \quad 653$

December

NURMER OF CHANGES IN SATARY RATES

AND JOB CLASSIFICATIONS

Temporary changes

Retroactive changes

Normal changes

Total

GROSS PAYROLL PATD DURING MONTH -

Engineering

Manufacturing

Plant Auxiliary Operations

Community Operations \& Real Estate

Other

Total

$\underline{895}$

\begin{tabular}{|c|c|}
\hline $\begin{array}{r}\frac{\text { January }}{764814} \\
1598144 \\
830510 \\
179 \\
174 \\
496 \quad 547 \\
\end{array}$ & $\begin{array}{l}\text { December } \\
\$ 831551 \\
1898195 \\
1006590 \\
206759 \\
575144 \\
\end{array}$ \\
\hline 869189 & $\$ 4518.239$ \\
\hline
\end{tabular}

DNIPLOYEE BENEFIT PLANS

Participation in Benefit Plant at Month End

$$
\text { Pension Plan }
$$

Insurance Plan

Personal Coverage

Dependent Coverage

U. S. Savings Bonds

Stock Bonus PIan

Savings Plan

Both PIans
Number Participating

$\frac{\text { Jan. }}{7846} \frac{\text { Dec. }}{7834}$

8450

5838

8436

It 060

1070

4651
5824

3965

2024

4531
Percent

Participation Jan. Dec. $97.3 \% 97.2 \%$

$99.0 \quad 99.0$

$47.5 \quad 46.5$

$12.5 \quad 12.0$

$54.5 \quad 53.1$

(a- Includes January payments for four weeks and December payments for fite weeks to weekly paid employees. 
Payroll Unit (continued)

EIPLOYEE BENEFIT PLANS (contInued)

Pension Plan

ilumider Reticed

Number who became eligible for participation

Number who applied for particlpation

Number who elected not to participate

Replies not received

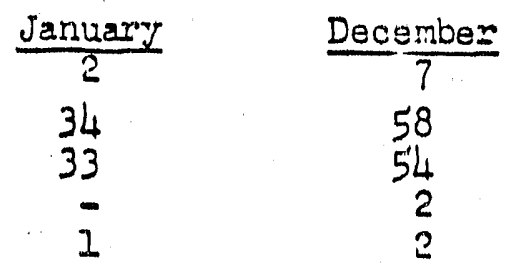

Insurance Plan - Claim Payments

Employee Life Insurance

Employee Accident \& Health Insurance

Dependent Accident \& Health Insurance

Total

\section{SUGGESTION AWARDS}

Number of awards

Total amount of awards

\section{PREFEEENTIAL RATES}

Number (Eliminated) or added

12

672

Number Currently in Effect

NUNEER OF NIIITARY AIIOWAIVE PAYMENTS

Number

NUMBER OF PAYROIL DEDUCTIONS - OTHER THAN TAXES

\section{Earracks Rent \\ Dormitory Rent \\ Hospital \\ House Rent \\ Insurarice \\ Pension - 1 ) \\ Safety Shoes \\ Sarings Bonds \\ Trailer Space \\ Union Dues \\ Other}

Good Neighbor Fund

Total
19

571

9338

447

5133

8351

24100

551

14028

156

1718

170

64582

GCOD NEIGHBOR FUND

Number Participating

Percent of Participation

5703

$66.8 \%$

5668

$66.5 \%$

(a- Approximate number of proll deductions rounded to nearest hundred. 
INTERNAL AUDIT' UNTT

MONIHLY REPORT

JANUARY, 1954

The following audits were continued:

Accounts Receivable - Telephone

Accounts Receivable - Safety Shoes, Equipment Sales to Employees, and AEC Cost-TJpe Contractors

Accounts Recuirable - Rent

Accounts Receivable - Electricity

Accounts Receivable - Kadlec Hospital

Accounts Receivable - Sundry

Source and Flssionable Accountabjility Records = 300 Area

Audit reports on the two audits first listed above will be issued during the early
part of February. An audit of Work Order Procedures was started on January 28, 1954 . 


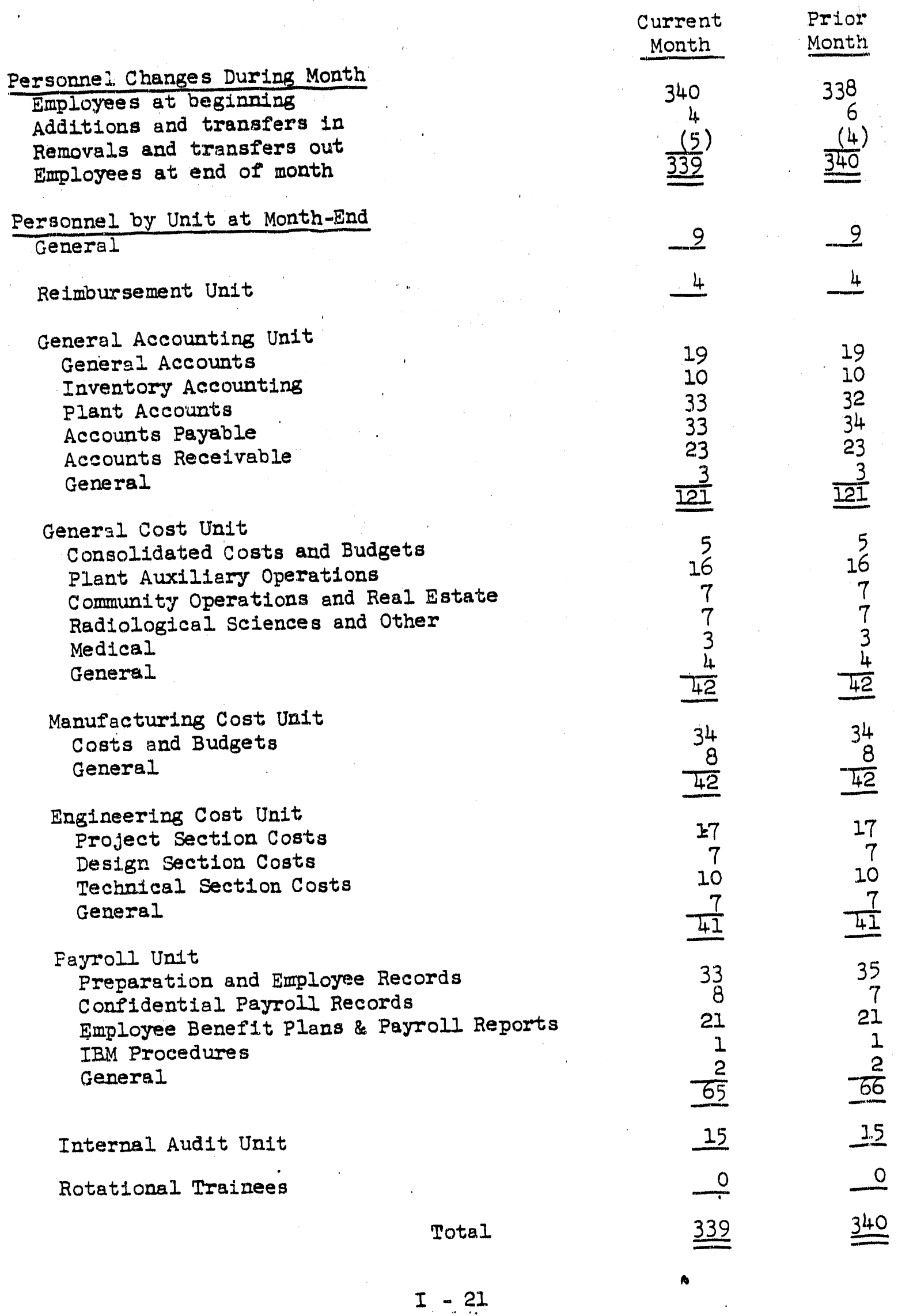


PLANT PROTECTION SECTION

MONTHII REPORT - JANUARY 2954

ORGANIZATION AND PERSONNEI

Number of employees on payroll:

Staff

Beginning End of

of Month Monch Increase Decrease

Adninistration Area Malntenance

$2 \quad 2$

Security and Patrol

$63 \quad 62$

$2(a)$

Safety and Fire Protection

$.508 \quad 5: 0$

2(b)

Office Unit

(Laundry and Building Services,

$155 \quad 156$

I (c)

Clerical, and Records Control)

$30 ; \quad 303$

TOTALS

$\overline{1,031} \quad-$

NET INCREASE: 2

(a) - Administration Area Maintenance

3 - Transferred in

4 - Transferred out

(b) - Security and Patrol

2 - New Hires

2 - Reactivated

2 - Transferred in

3 - Transferred out

1 - Termination

(c) - Safety and Fire Protection

2 - Transferred in

1 - Transf'erred out,

(d) - Laundry and Building Services

4 - Reactirated

1 - Deactivated

Clerical Services

2 - New Hires

1 - Reactivated

3 - Transferred out

1 - Deactivated

Records Control

1 - Transferred out 


\section{Injury Statistics}

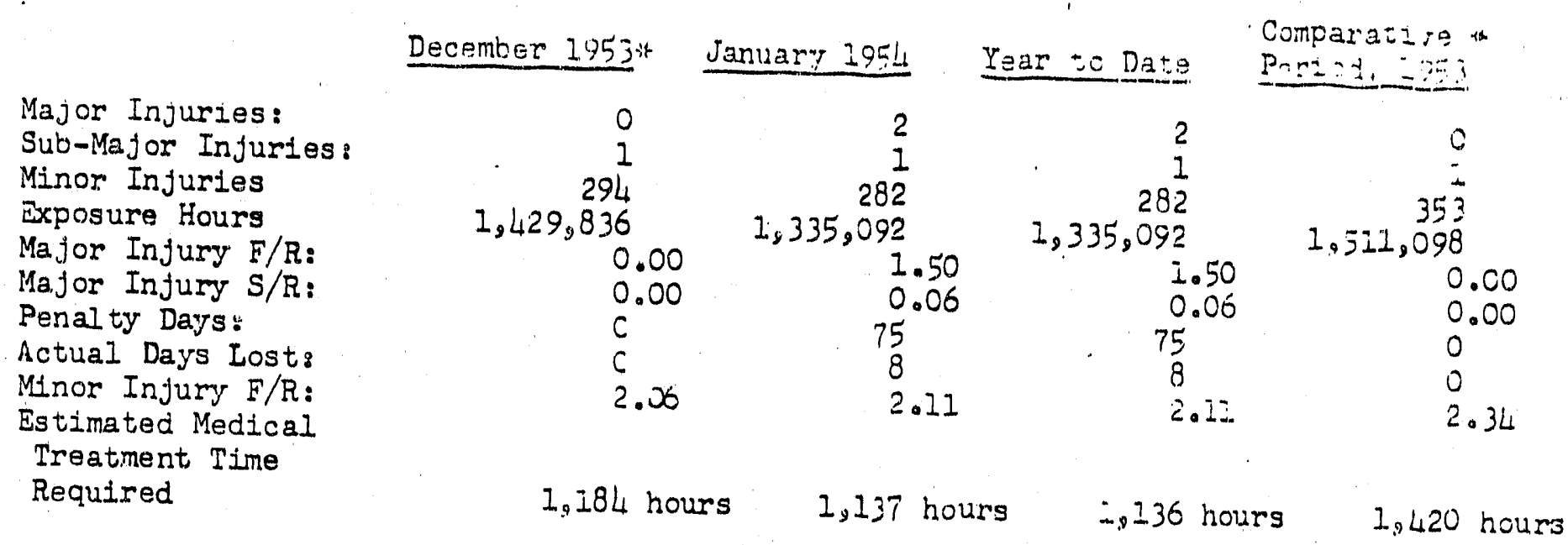

* Community Operations and Real Estate Department and Community Medical were included in 1953 statistics.

Safety Activities

The injury trend shows an improvement over the previcus month, in spite of the $4 \%$ increase in minor injuries. The majority of the increased number can be attributed to inclement weather and bad underfoot conditions.

A composite of the award achievements experienced during 1953 was complled and submitted for final approval from the National Safety Council and the Atomic
Energy Commission.

Recognition was given through a display page in the Works NEwS to the Area Accident Prevention Committees of all industrial areas.

\section{Industrial Fires}

\begin{tabular}{|c|c|c|c|c|}
\hline Department & Area & No. of Fires & Cause & Loss \\
\hline $\begin{array}{c}\text { Engineering } \\
" \\
"\end{array}$ & $\begin{array}{l}100-H \\
300 \\
200-E\end{array}$ & $\begin{array}{l}1 \\
1 \\
1\end{array}$ & $\begin{array}{l}\text { Buming and welding } \\
\text { Electric } \\
\text { Combustiblles toc near } \\
\text { heat or flame }\end{array}$ & $\begin{array}{l}\mathrm{NiZ} \\
\mathrm{N} 1 \mathrm{I} \\
\$ 750\end{array}$ \\
\hline $\begin{array}{c}\text { Manufacturing } \\
\text { n }\end{array}$ & $\begin{array}{l}200-E \\
200-W\end{array}$ & 1 & $\begin{array}{l}\text { Combustibles too near } \\
\text { heat or flame } \\
\text { Smoking or matches }\end{array}$ & $\begin{array}{r}\$ 20 \\
\text { Ni? }\end{array}$ \\
\hline TOTAIS & & 5 & & $\$ 77$ \\
\hline
\end{tabular}

Flre Prevention Activities

Bullding surveys were completed on Butldings 170L-H, 1720-H, and 276-S.

The new fire detector system in the 2704-2 Bullding was tested and placed in service. This system operates through newly Installed Box No. 42. 
The Purex construction group is installing ten fire alarm boxes in its area and w1ll soon connect them into the area system.

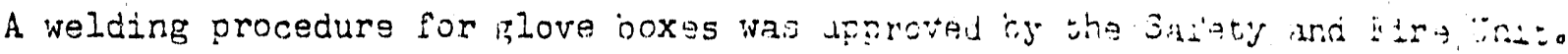

The fire extinguishers have been installed and the fire alarm system check out in the new 326 Building.

OFFICE UNIT

Laundry and Building Services

200-West Laundry

Pounds Delivered

Pounds Rewashed

December

January

200,082

10,511

187,234 8,307

Total Dry Weight

210,593

$195,54=$

Monitoring Group

Poppy Check - Pleces

172,720

$182,51=$

Scaler Check - Pleces

278,107

273,921

Total Pieces

450,827

456,432

700 Area Laundry

Flatwork - Pounds

Rough Dry - Pounds

Finished - Pounds

\begin{tabular}{|c|c|}
\hline $\begin{array}{r}34,331 \\
39,473 \\
2,042\end{array}$ & $\begin{array}{r}33,896 \\
28,661 \\
2,300\end{array}$ \\
\hline 75,846 & 64,857 \\
\hline 99,358 & 84,962 \\
\hline
\end{tabular}

Clerical Services

Central Mail and Addressograph

Inter-office and postal mall dropped back to normal after the exceptional month of December.

Addressograph work was normal through the month. Special work was done on the files and plates which were flattened and damaged by use were replaced with new plates。 
Types and Pleces of Mall Handled

Internal

Postal

Sperial

\begin{tabular}{rr}
$\begin{array}{rr}\text { January } \\
1,973,449 \\
86,778 \\
2,00 .\end{array}$ & Deoember \\
\hline $2,092,372$ \\
$2,062,270$ & $2,177,058$ \\
$\$ 3,552.71$ & $\$ 3,714017$ \\
2,966 & 2,929 \\
813 & 991
\end{tabular}

Addressograph

Type of Iist

Plant Name List

Housing List

Payroli List

Total new plates

Total corrected plates

\begin{tabular}{|c|c|}
\hline \multicolumn{2}{|c|}{ January } \\
\hline $\begin{array}{l}\text { Number } \\
\text { of Runs }\end{array}$ & $\begin{array}{l}\text { Toran } \\
\text { Copias }\end{array}$ \\
\hline $\begin{array}{r}106 \\
13 \\
\quad 12\end{array}$ & $\begin{array}{r}166,4.80 \\
71,235 \\
57,853\end{array}$ \\
\hline
\end{tabular}

2,221

2.566

\begin{tabular}{rr}
$\frac{2}{2}$ December \\
\hline $\begin{array}{c}\text { Number } \\
\text { of Runz }\end{array}$ & $\begin{array}{r}\text { Totai } \\
\text { Copies }\end{array}$ \\
\hline 106 & 197,362 \\
21 & 72,297 \\
11 & 32,301
\end{tabular}

3.685

1,867

$$
4,687
$$

5,552

Office Equipment - Furniture

Delivery of furniture held in storage for 300 Area Works Laboratory Projects has been completed. This work was planned and scheduled in advance of final of chalk boards. Chalk boards The used fumiture, located in offices vacated by technical groups who are moving into new facilities, is belng returned to stock. This material is additional plant requirements.

A meeting was held by Offlce Equipment and Stores to discuss the transior of office letter trays and waste baskets to the Office Equipment inventor: caption. It was agreed that this material would be transferred irom stationery purchases and issues.

Furniture and equipment requirements for $100 \mathrm{mK}$ and $K W$ projects were reviewed prior to preparing a request for appropriation. At this dace, 1 t appears that sufficient quantity of wood desk and tables and some office machines will be available from inventory stocks to flll most requirements. 
A request for office equipment required for project $A E C-114$, Contral Trans portation Faodlities, was recelved from Transportation Department. The delivery requested was scheduled for September 1, 1954.

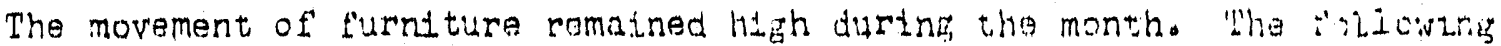
is a list' oi items, by quanisty, handieds

\begin{tabular}{lcrr} 
Item & Redeived by Credit S.00 & Issued & Salvaged \\
\cline { 2 - 3 } Blackboard & 0 & 28 & 0 \\
Bookcase & 0 & 35 & 0 \\
Chair & 212 & 533 & 34 \\
Clock & 0 & 0 & 0 \\
Costumer & 9 & 55 & 6 \\
Card F1ie & 7 & 3 & 0 \\
Cabinet & 16 & 72 & 8 \\
Desk & 127 & 127 & 3 \\
Table & 32 & 123 & 1 \\
MIsc. & 11 & 40 & 4
\end{tabular}

\section{Offlce Equipinent - Machines}

The AEC arranged to have representatives of the Dictaphone Company holit a demonstration of their dictaphone telecord dictating system. This meeting was attended by both AEC and General Electric emploje es on January 5, 195ilo On January 25, arrangements were made with the Engincering Department to make a temporary installation of a six-station telecord system in the 326 Building on a 30 .. day trial basis.

Office machines 10cated In Varohouse 12, 3000 Area storage, have been moved to 722-C. This move has completed a goal set to warehouse all stock machines in one building.

The movement of offlce machines was active during the month. A total of 76 machines were excessed. Seventy-geven machines were placed in plant service, 36 machines in service were plcked up and retumed to stock. F1ve new machines were recelved.

Central Printing

Katser Engineers Constmuction Progress Report, which was prevlously printed of fsite, was printed by Central Print Shop personnel in January. By printing the report here, three important advantages are accomplished:

1. More rigid securlty control.

2. Lower cost and 1inproved quality.

3. Approxtmately four worktng days cut from printing schedule.

Thirty-one fonts of assorted printers hand set type were receired and put into use setting type for Manufacturing's Annual Report and "1953 at Hanford". Type setting for Manufacturing report is about $85 \%$ complete. 
Central Printing (Contin.)

Work Completed

Orders recelved

Orders Completed

Back Log

Coples Printed

Negat lves masked

Negatives processed

Photo oopy prepared

Litho plates processed

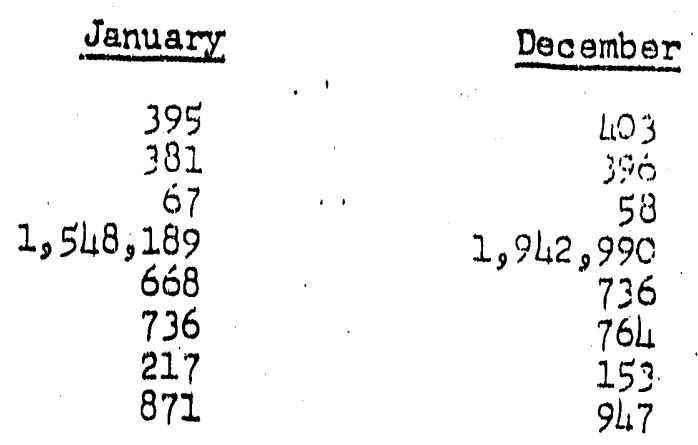

\section{Stenographic Services}

Tivo now employees were assigned to the Stenographio Pool in January and three stenographers were transferred to other departments. Throe additional transfers were arranged to become effectlve as soon as replacements are provided from
Employment.

Due to reduoed number of personnel and the volume of work sent in to the Pool, it was impossible to fll1. all requests for temporary loan assignments. Sixteen such requests were filled.

The work load was consistent throughtout the month and a number of large assignments were completed within the requested time limit. Work is current at
month's end.

Breakdown of Hours

Dictation and Transoription

Machine transcription

Lettars

Rough Drafts

Ditto, duplimats, xerography

Miscelliano ous

Trajining Time

Meeting Time

تinassigned Time

- Absentee Time

Holiday and vacation time

mployees on loan to other departments
January

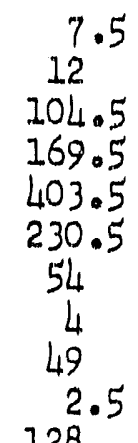

128

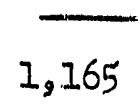

951.5

$2,116.5$
December

15

37.5

62

176.5

167.5

251.5

204.5

5.5

16

- 8

72

1,016

775.5

$1,791.5$

Area MajI and Duplicat1.ng

On January 26, the 200-West Mail and Duplicating offlce was mored from $2704-\mathrm{Z}$ Building to $2705 \mathrm{~m}$ Building. The two functions were placed in separate of fices, and additional office furniture was installed at this time. This ohange of location should greatly 1mprove efflclency of operations due to the additional working space. Better securdty control will also be possible. I.t will no longer be necessary to allow Separations personnel to enter Matl ard Duplicating offices.

$$
\text { Ja-6 }
$$


(Area Mali and Duplioating offloe space in 2704-Z Buliding was shared with Separations personnel). Th1s move was made without interrupting regular
ma1l gervice.

Work loads this month were generally lighter than islat. ai thoun serers. priority duplicating fobs were handled. The 703 Duplloating office printed the Attitude Survey Report for the Employes Reiations Section.

The 300 Area Dupllcating. offlce was able to bind 2,907 formal report booklets this month by utilizing the backstripping machine recently installed at this location. Thts plece of equipment has proven very helpful in accelerating the job of processing techntcal report manuals.

Duplicating and Mall Statistics

\begin{tabular}{rr} 
January & December \\
\hline 3,276 & 3,254 \\
3,218 & 3,248 \\
58 & 26 \\
16,030 & 17,286 \\
914,356 & 775,697 \\
476 & 709 \\
6,342 & 9,261 \\
763 & 678 \\
22,160 & 18,665 \\
1,789 & 1,440 \\
4,833 & 4,561 \\
1,146 & 1,130 \\
576,329 & 678,009
\end{tabular}

Records Control

Quantity of records recelved, processed and stored:

Community Operations \& Real Estate Department Engineering Department

Flnanctal Department

Legal Department

Manufacturing Department

Plant Auxiliary Operations Department

Radiological Sciences Department

Sub-Contractors

Charles T. Main Company

TOTAL

$\begin{array}{rccc}5 & \text { Standard } & \text { Storage } & \text { Cartons } \\ 26 & 11 & 11 \\ 77 & 11 & 11 & 11 \\ 1 & 11 & 11 & 11 \\ 13 & 11 & 11 & 11 \\ 99 & 11 & 11 & 11 \\ 5 & 11 & 11 & 11 \\ 1 & 11 & 11 & 11\end{array}$

TOTAL
Persons provided records services
Records Destroyed:
Records cartons issued

227 Standard Storage Cartons

Records Destroyed:

Records cartons issued

$$
\begin{array}{r}
1,050 \\
82 \text { cartons } \\
532
\end{array}
$$

Percentage of Records Servtce Center vault (exclusive of North Richland)
occupied by records is $83.6 \%$. 
Twenty-four requests for file cabinets received. Nine requests were filled, II requests were cancelled. Four requests are pending. Two key locked cabin $\$$ is and one combination locked cabinet were picked up with no exchange and revurred to stock。

Four Requests for authorization for records disposal were aproved by che Atomic Energy Commission. Twelve Evaluations of Records for disposalwere developed and submitted for internal departmental approval.

Unjiform filing was established in two offices during the ionth. A total of 469 offices have installed the uniform filing system to date. Nine rechecks were made on established files.

In the search for classified materzal, 1,013 cartons of recorcis were reviewed. A total of 581 man hours sere expended.

ADMINISTRATION AREA MAINTENANCE UNIT

CA-504 Improved Lj.ghting 760,761,762 Buildings: Pnysizai compietion notice issued January 15, 19540

-. New Administretion Bullding: AEC advises that letter has been dispatched to Washington office requesting approval to investigate possibility of obtaining a new Administration Building, constructed by private capitai.

CA-525 Conversion of Basement, 5 th Wing, 703 Building to Civil Deiense Auxiliary Centex: Landlord responsibilities accepted following release by AEC.

AEC-114 New Transportation Facilities: Actual completion 20\%; scheduled completion 20\%. No progress made in past two weeks because of weather conditions.

IR-149 Partitioning, 761 and 762 Bulldings: Physical Completion Notice issued January 18, 1954.

CA-434 BiouAssay Laboratory: Phase I, 88\% complete; Phase II, Lo\% complete; GE, 62\% complete.

CA-56I 713 Bullding Alterations: Project proposal not yet released by IocaI AEC Office.

IR-169 Warehouse 113, A2terations, Stores Yard No. 2: Final desirn in preparation.

A total of 10.3 lineal feet of hauserman partitioning and elgit doors were reclaimed from $7.12-\mathrm{A}$ Building and returned to stock.

Seventeen offjce fumiture moves were made during the month.

Hutment $722-\mathbb{N}$ was revised for use as temporary Conference Room to replace AEC Conference Room in Hutment 712-A。 
Majority of space in Building 770-B, formerly occupled by Emergency Officer and Civil Defense, has been assigned to Hanford Contractors' Negotiating Committes.

Bids for trash removal equipment are to be opened in Fen:aror.

Installation of filler over Hauserman partitions in 762 Building was completed.

Fiberglas accoustical tile was installed on walis and ceiling of Emergency Officer's room in 703 Building basement. The room vacated in Building $770-B$ is being renovated for new occupancy.

Services of two carpenters were required in the Excess shipping program.

Fifteen offices in 700 Area buildings, the reception room in Building 705 and the interior of Hutment $722-\mathrm{N}$ were repainted.

Repairs were made to seven steam rediators in 700 Area buildings and eipht in Kadles Hospital.

Additional temporary electrical and oll heaters were provided to outlying locations in connection with recent cold weather.

Special door closer service was requtred because of cold weather.

A few isolated freeze-ups were promptly handled.

Repairs were made to Kim-start heaters on ten buses, and batteries were recharged at 716 Garage。

Electric trucks at Central Stores were inspected and lubricated, and truck batteries were checked and watered.

All 700 . Area fire alarm circuits were checked and tested.

Fire protection system for Buildings $770,770-\mathrm{A}$ and $770-\mathrm{B}$, formerly tied into Emergency Officer's desk, was revised and connocted to communty lines.

Additional fire-stats were installed in 703 Building basement.

Our portion of work on the Mobile Civil Defense Center was completed with exception of final coat of paint and installation of awning.

New B10-Assay Laboratory Building was connected to the steam distribution system。

Overhaul work on No. 2 boiler stoker was completed.

Miscellaneous work during the month included repairs to electrical systems and equipment; Installation of electrical panels; hot water heaterhookup; busser installations; safe andcombination lock service; machine shop fabrication of bearings and shafts; repairs to steam lines; over haul of air conditions minor duct revisions; sign painting; partition revisions; fabrication of cabinets and shelving; carpentry repairs; gutter and downspout repairs. 


\section{Steam Operation}

Appropriation Request to install steam meters on a portion 0 stre bujitings 0.42 a the $700 \mathrm{Area}$ was dropred, f'oliowing receipt of verbal informatien :

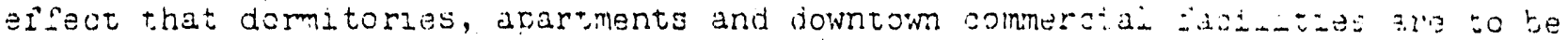
appraised ior sale on the basis that they will not indefiniteiy continue to receire steam from the 784 Heating Plant Distribution System.

Numbers 1,3 and 4 bollers were in service at the beginning of the month. Wh tho. 2 in reserve. No. 2 boiler was placed on the Ilne January 1 i and No. 1 boilen taken out of service for minor repairs, the nature of which did not decrease 1 ts availability.

Three boilers thus were in service on January $2 C$, the co: des: day experienced in four years. Although these boilers were operating siightiy over sapacity on tits date, they appeared to be handling the load in a satisfactory manner (a favorable type of coal being a major factor).

In anticipation of even colder weather, and with a desire tc avoid posstis further overload, No. 1 boller was added to those in service on Janiary 21 leaving no boiler in reserve.

The suddenly moderating weather experienced on Jamary 22 fermitted No. 3 boiler to be removed from the line and held in reserve.

The quantity of steam generated at 784 Plant was $13.1 \%$ greater than in Jamuary of 1953 .

During the period of extremeit cold weather it was necessary to cease ra.1 coal receipts and to bulidoze coal from the stockpile because of the frozen condition of coal in cars received.

The heavy snowiall during the latter part of the month presented a rare opportunity to check location and position of most of the expansion loops of the underground steam distribution system. A number of loops were found whose existence had been suspected, but were not shown on any available prints; also the position of a number of loops was found to be reversed from that shown on available drawings. Some difficulties have been experienced in the past because of lack of definite information on these loops. A corrected "as built" drawing of the steam listri." bution system will be made.

Coal Consumed:

Steam generated:

Steam leaving plant:

Steam delivered:

Total water softened:

Total soft water sent to Kadlec Hospital:

Total soft water sent to 784 Heating Plant:
$1,998.00$ net ton:

$29,970,3 \mathrm{M}$. Los. 25,975.2 Mo Lios. $23,743.2$ M。 Lbs。

$3,779,100$ gallons 72,320 gallons 3,706,780 gallons 
Operations at 1131 Area Heating Plant were essentially nomal throughodt the merith. the second boller having been placed in service on January 20. Bcth boiders remained in service for the remainder of the month. Mithough one ritier ias acie

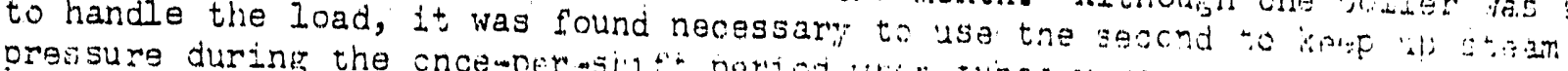

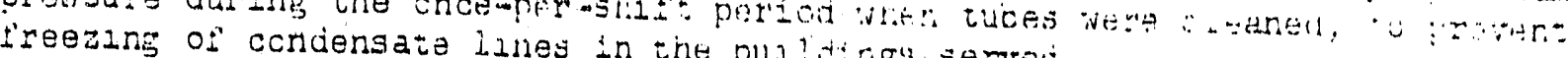
ochdengate lanes th the bulidingu served.

Operation at Central Stores Heating Plant was watohel oloselyr during the $=\mathrm{w}$ temperature period to prevent freezing of water Ines in the toiler room. Ihis installation appears vilnerable to such danger because of design, which requias all atr for combustion to be brought into the boller rocm without preineating.

SECURITY AND PATROL UNIT

Document Repcrt

Number of classifled documents unaccounted for as of Jaruary i. IThis

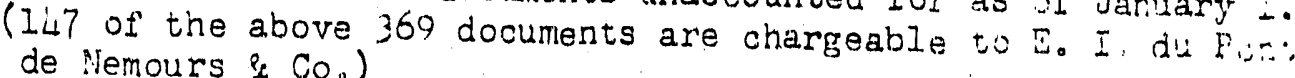

Number of classified documents reported as unaccountad for during january"

Number of classiffed documents et ther recovered or downgraded during

(One of the above 27 documents is chargeable to E. I. du Poni de
Nemours is Co.)

Number of classifiled documents remaining unaccountad for as of Februaty it i i Nemours 3 Co.)

\section{Security Education}

Six security articles were published in the Works NEwS during the month. There were 286 securlty meetings held and attended by 4,457 employees of the General Electrie Company. A representative of the Security and Patrol Unit: showed one of the security flims at some of these metings as indicated below:

"The Calcula ted Risk" was shown at 26 meetings, each with an average
attendance of 25 employees.

"Only the River" was shown at one security meeting with 13 presento

"Sabotage" was shown at one meeting with 40 employees in attendareis.

"Operations Crossroad" was shown at one security meeting with 23 present.

Two thousand copies of a security poster with the slogan "Nol Nod Remember the Safe Combination" were posted throughout the areas during January.

GE Security Bulletin No. 82, dated January 18, 1954, emphasizing indiridual responsibility for compliance with the Federal statutes in confunction with working at Hanford Atomic Products Operation was issued during the menth. 
On Jamary 6, a security memorandum was issued to all department and sectin managers on the subject "Classifled Document Control", concernting revised accountability for classifled material and the installation of the IBM sistem for accountability of classifled material at Hanford Atomio Prodicots Opuraicon within the near future.

A Security Fleld Memorandum entitled "Security Classification" was issued January 14, 1954, regarding the revislons of classifying documents "Restricted", "Confidential" and "Confidential-Undocumented", according to Executive Order 10501 issued by the President of the United States.

On January 18, Office Letter No. 191, entitled "Appointment of Hanford Atomic Products Operation Top Secret Document Custodian" was issued. This latter also emphasized the accountability of all material recelved by Generai Electria personnel classified "Top Secret".

Sixty-five employees of the General Electric Company recelved a "Q" security orientation talk from elther a representative of the Security unit or a Security Patrol supervisor during the month of January.

Statistical Report of Security Patrol Activities

\begin{tabular}{|c|c|c|c|c|c|c|c|}
\hline & $100-B$ & $100-D$ & $100-E$ & 200-H & $100-K$ & $200-W$ & 300 \\
\hline Pat Searches & 66 & 93 & 65 & 93 & 0 & 0 & 2 \\
\hline Escorts & 7 & 7 & 3 & 14 & 55 & 38 & $4 \mathbf{1}$ \\
\hline Ambulance Runs & 3 & 4 & 1 & 3 & 0 & 2 & 3 \\
\hline \multicolumn{8}{|l|}{ Passes issued: } \\
\hline One day temporary & 88 & 16 & 5 & 11 & 1 & 54 & 48 \\
\hline Travel & 0 & 0 & 0 & 0 & 0 & 0 & 49 \\
\hline Red Tag & 170 & 121 & 56 & 45 & 0 & 426 & 159 \\
\hline Telephonic & 0 & 1 & 0 & 1 & 0 & 0 & 1 \\
\hline Supervisor's Post Contacts & 426 & 384 & 356 & 282 & 369 & 958 & 580 \\
\hline \multicolumn{7}{|c|}{ Other Security Patrol Act1vities: (Computed by Hourg) } & $\begin{array}{l}300 \& \\
700\end{array}$ \\
\hline $\begin{array}{l}\text { Security File Check } \\
\text { Building Check }\end{array}$ & $\begin{array}{l}158 \\
327\end{array}$ & $\begin{array}{r}350 \\
31\end{array}$ & 207. & $\begin{array}{l}396 \\
--4\end{array}$ & $\begin{array}{l}491 \\
525\end{array}$ & $\begin{array}{l}538 \\
586\end{array}$ & $\begin{array}{r}1,426 \\
7444\end{array}$ \\
\hline
\end{tabular}

*In the 100-F and 100-H Areas, the File Check and Building Check are cumbined into one flgure.

Arrest Report

Violations

No Arterial Stop

No Drlver's Itcense In Possession

Failure to Obey Traffle Offlcer's Hand signal

Citation Tickets Issued: Warning Tickets Issued:
Number of Violations

Cont. Cases
from Dec.

Cases

Cleared

Pending E'ined

3

0

3

0

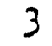

1

0

$\frac{1}{5} \quad \frac{0}{0}$

5

18 
Number of Security Patrolmen receiving classroom instruction during the monthg

Number of Security Patrolmen receiving firearms training during the month:

Field Inspection Activities

Contacts made to locate unaccounted for documents: 38

Contacts made concerning security violations:

File combinations changed that were overdue for change:

General

The Security force was increased with one additional Field Inspector on January 4 , 1954 to provide better security coverage in the field.

Effective Jamary 4, a thorough search was started in the General Electric Company Records Center in an attempt to locate unaccounted for documents and to segregate classified materiai inadvertently misfiled. In the latter case, material that is located is reviewed with the department concerned and is either documented or destroyed.

On January 8, all of the buildings in the Works Laboratory Area at the 300 Area were fenced into the 300 Area proper, and they are now a part of that area.

The Security Patrol Emergency Office was moved January 12 from the $770 \mathrm{mB}$ Building location to the basement of the fifth wing Administration Building.

The Non-Technical Document Review Board held four meetings during the month and reviewed a total of 143 classified documents and blueprints. Of this number -

44 documents were downgraded to "Official Use Only",

33 documents had their classification retained,

22 documents were declassified,

23 documents were not within the scope of the Board, and

4 documents were referred to the Coordinating Organization Director.

8 blueprints were downgraded to "Official Use Only",

8 blueprints had their classification retained, and

$I$ was not with the scope of the board and referred to the Coordinating Organization Director.

Security Administration Information

$\begin{array}{lr}\text { Da1ly badge log entries: } & 2,458 \\ \text { "Q" Cl earances } & 87 \\ \text { Formal "Pn clearances issued } & 12 \\ \text { "P" approval clearances issued } & 21 \\ \text { Category access granted } & 31 \\ \text { Category access withdrawn } & 19\end{array}$

The following photographs were processed by the Security office during January?

$\begin{array}{cr}\text { Number of "A" badges } & 33 \\ \text { Number of "B" badges } & 137 \\ \text { Photos for passes } & 15 \\ \text { Total } & 185\end{array}$



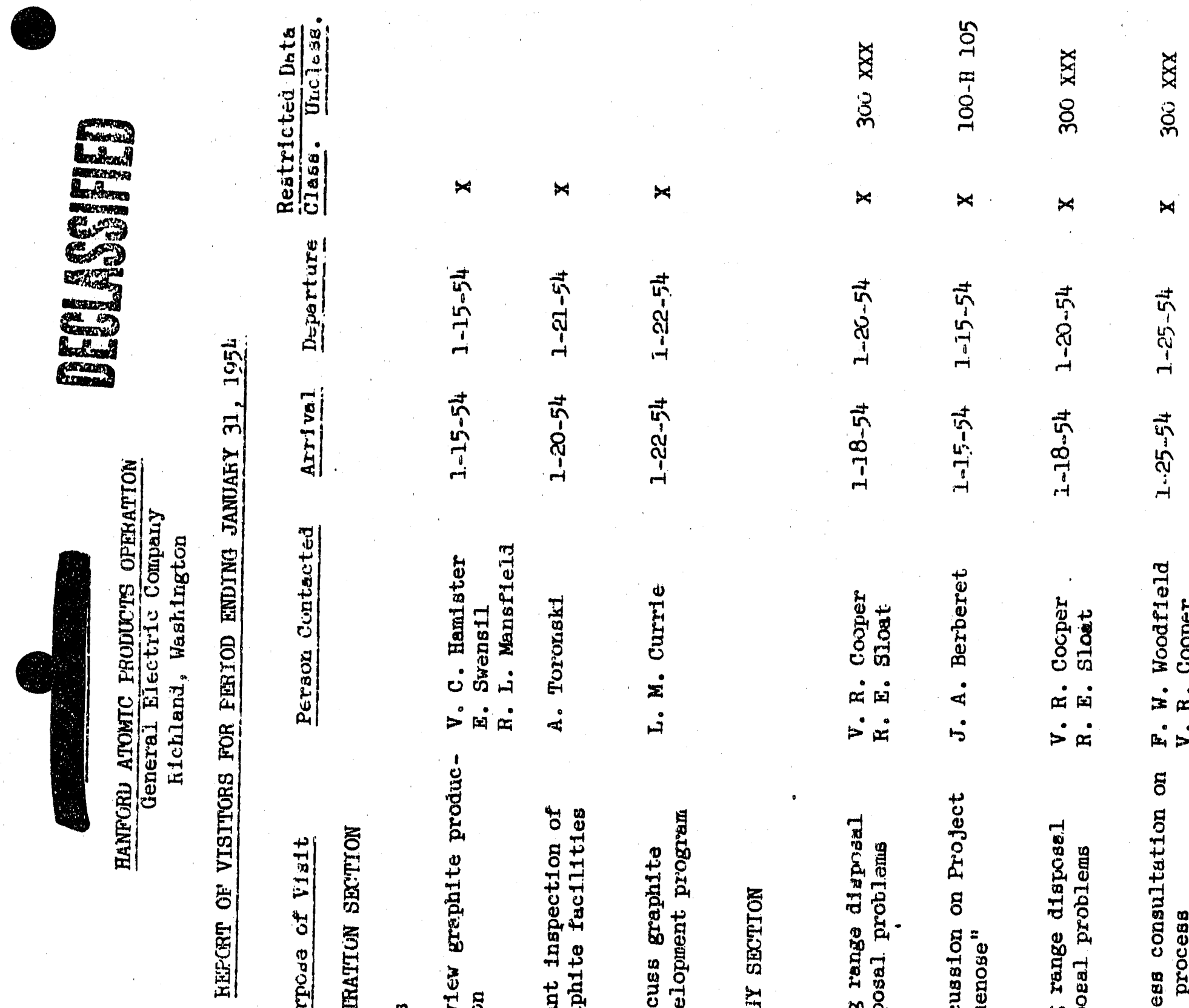

$x \quad x$

产.

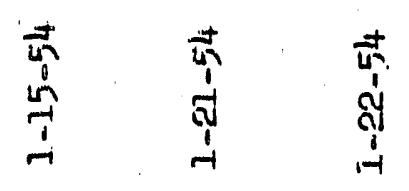

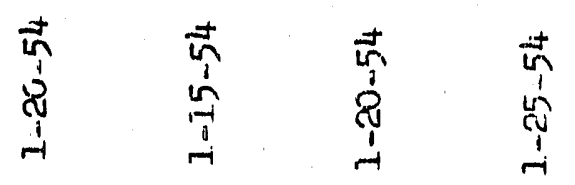

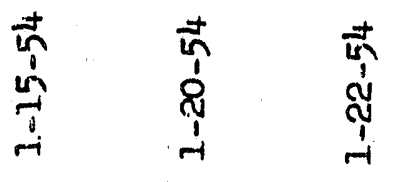

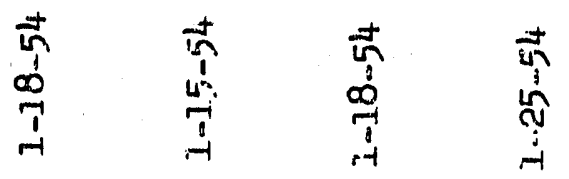
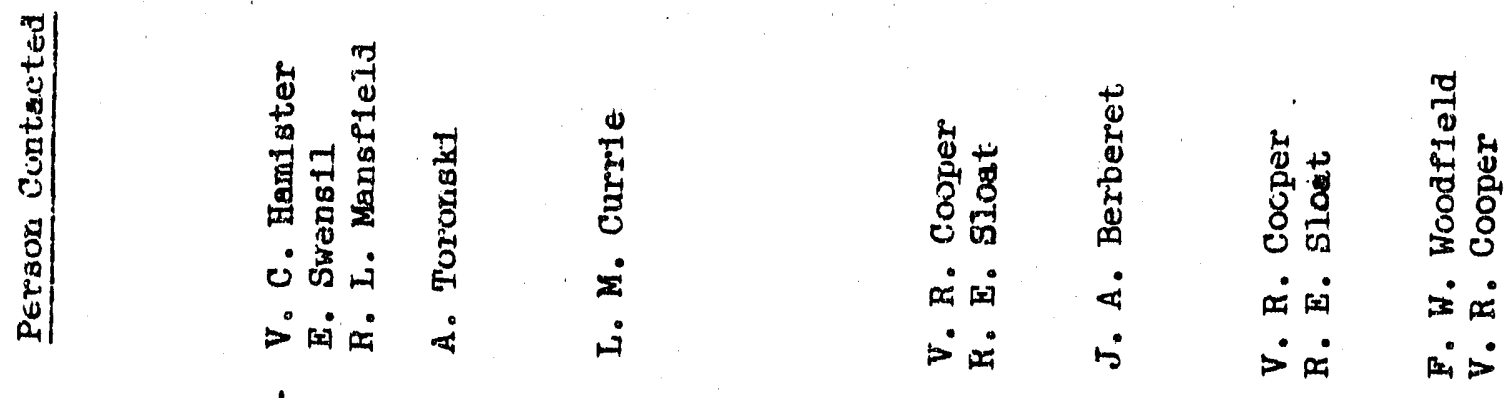

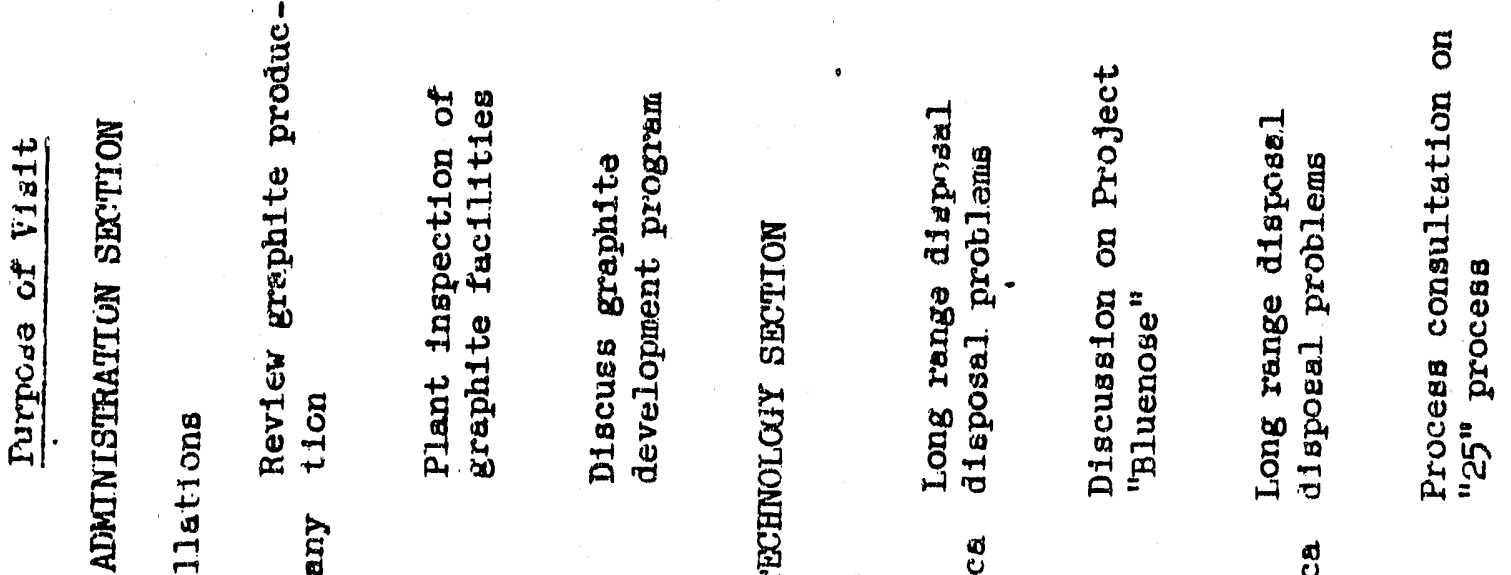

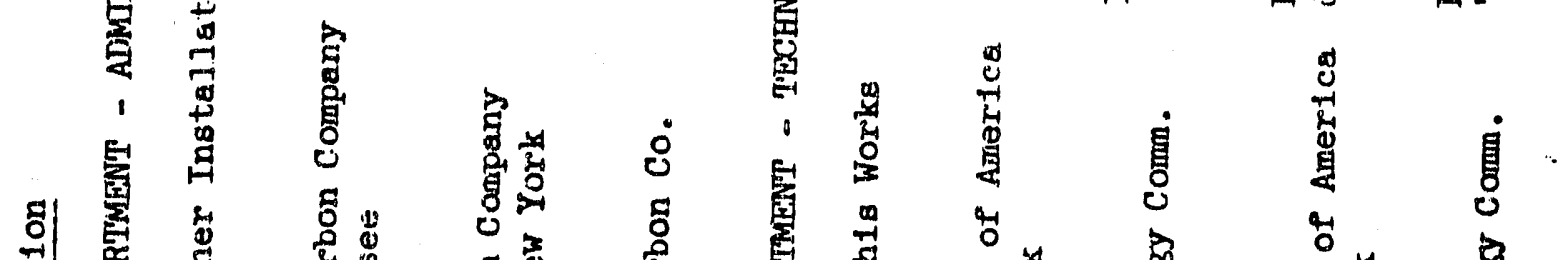

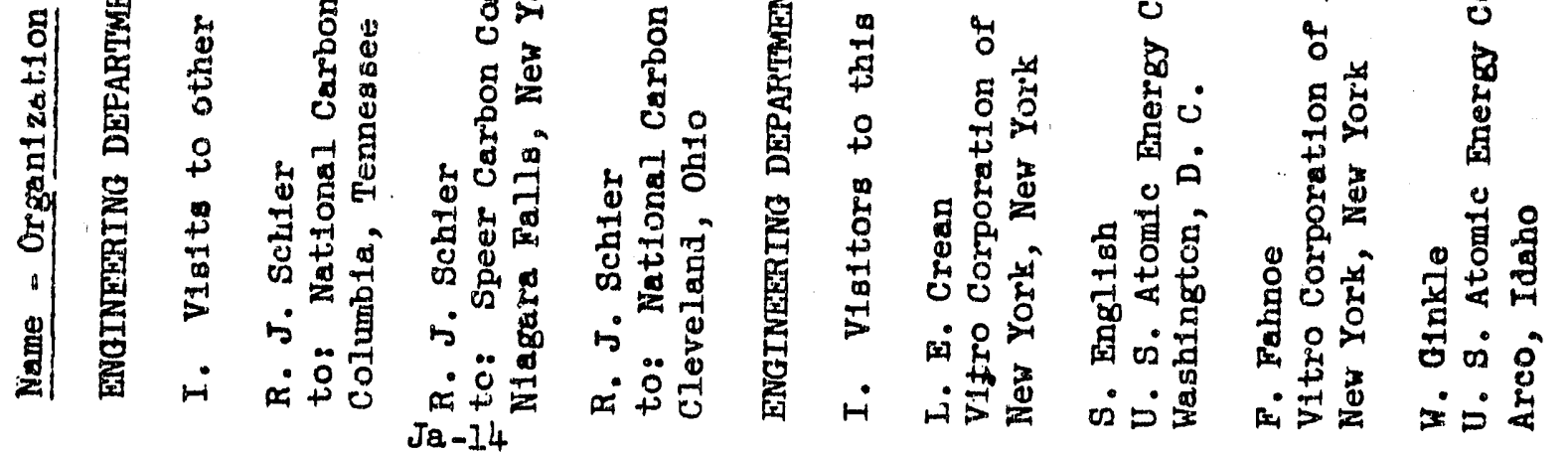


影

景

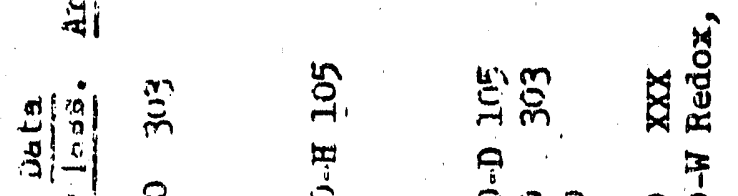
Fis!

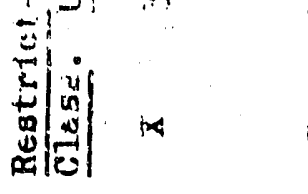

蓉

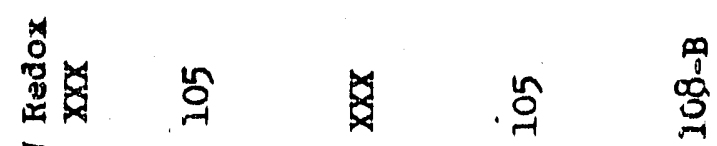

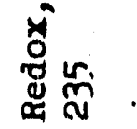

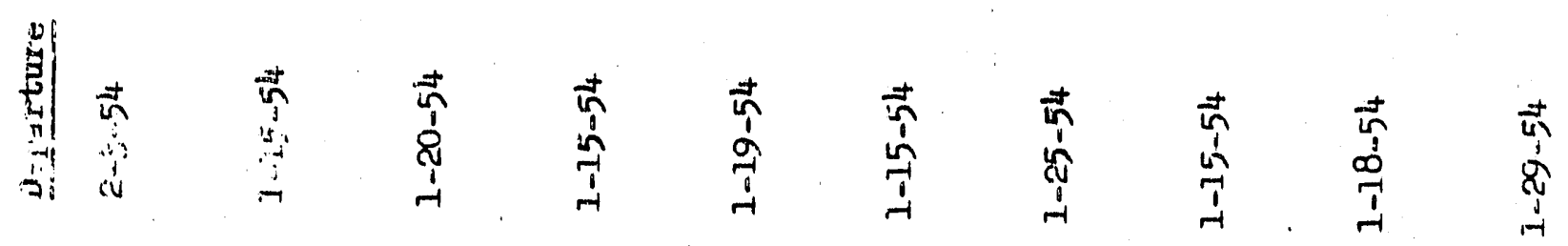

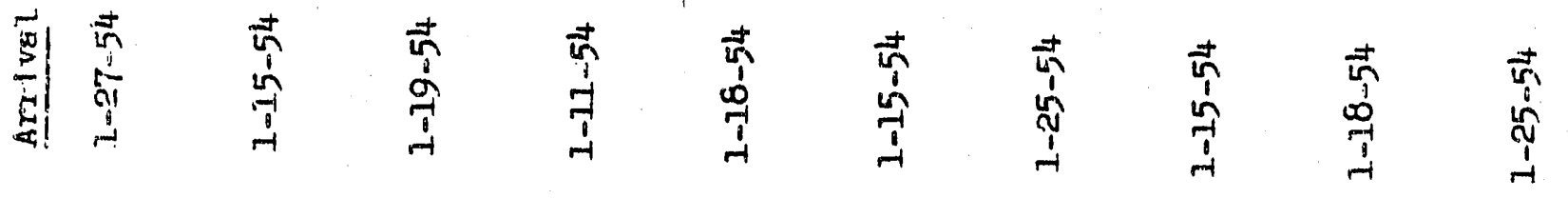

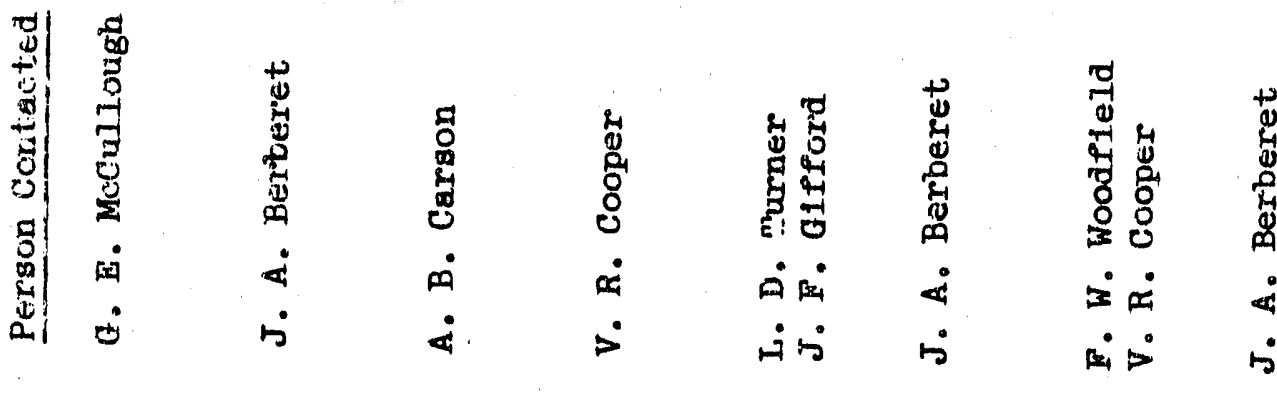

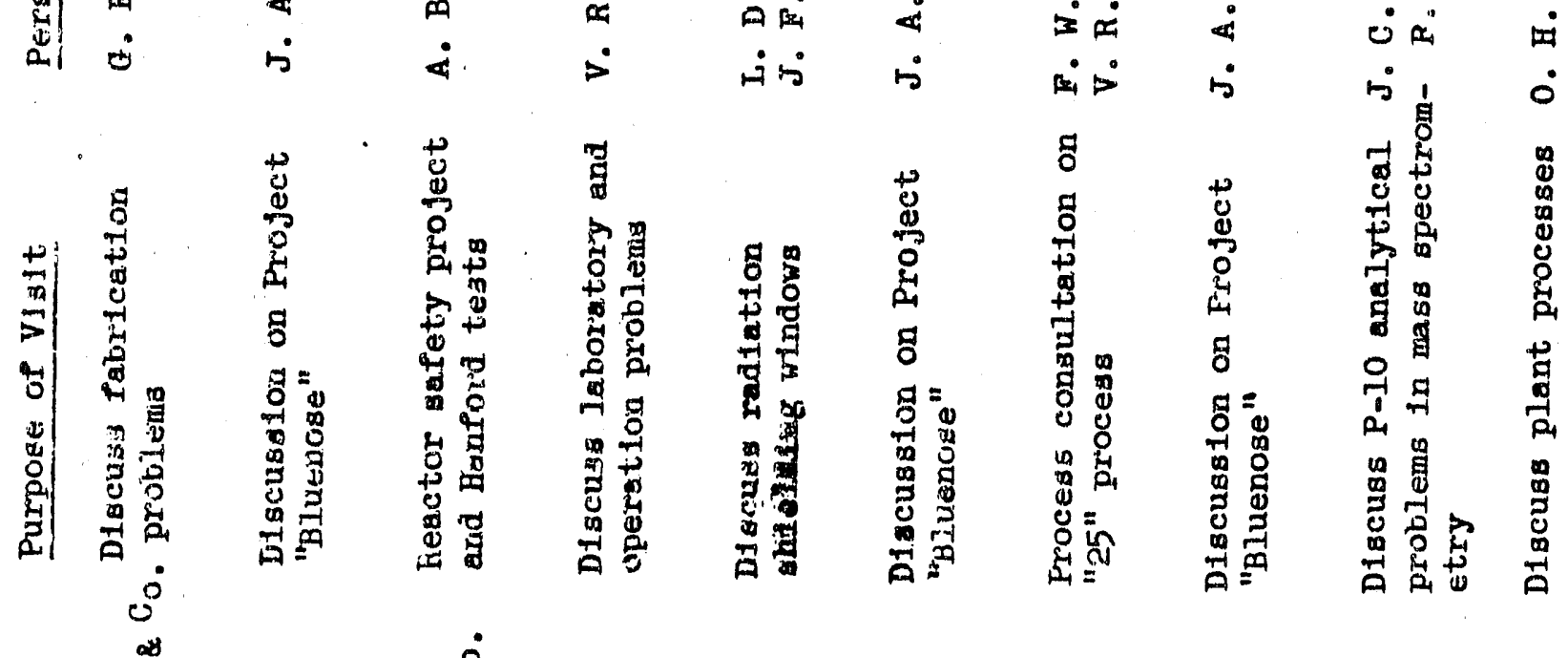

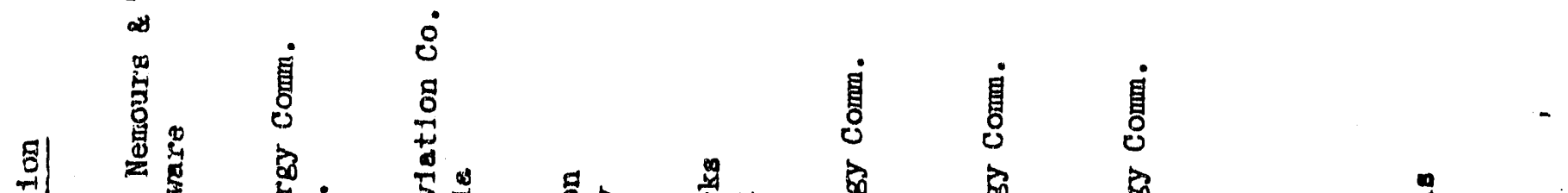

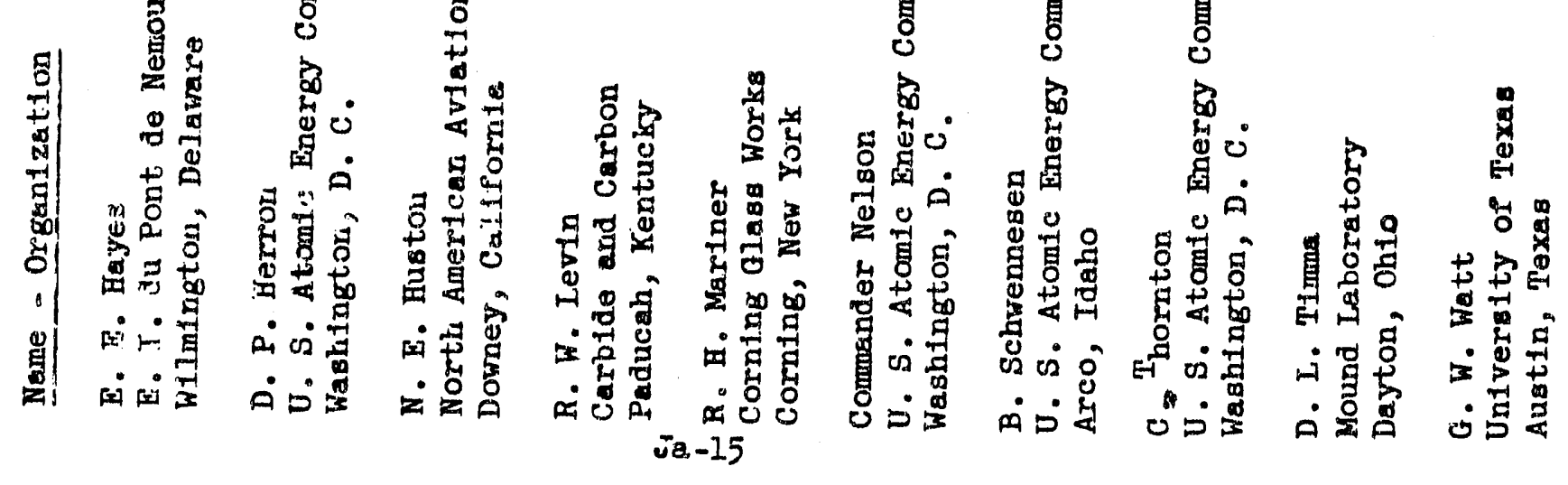


ㅊ.
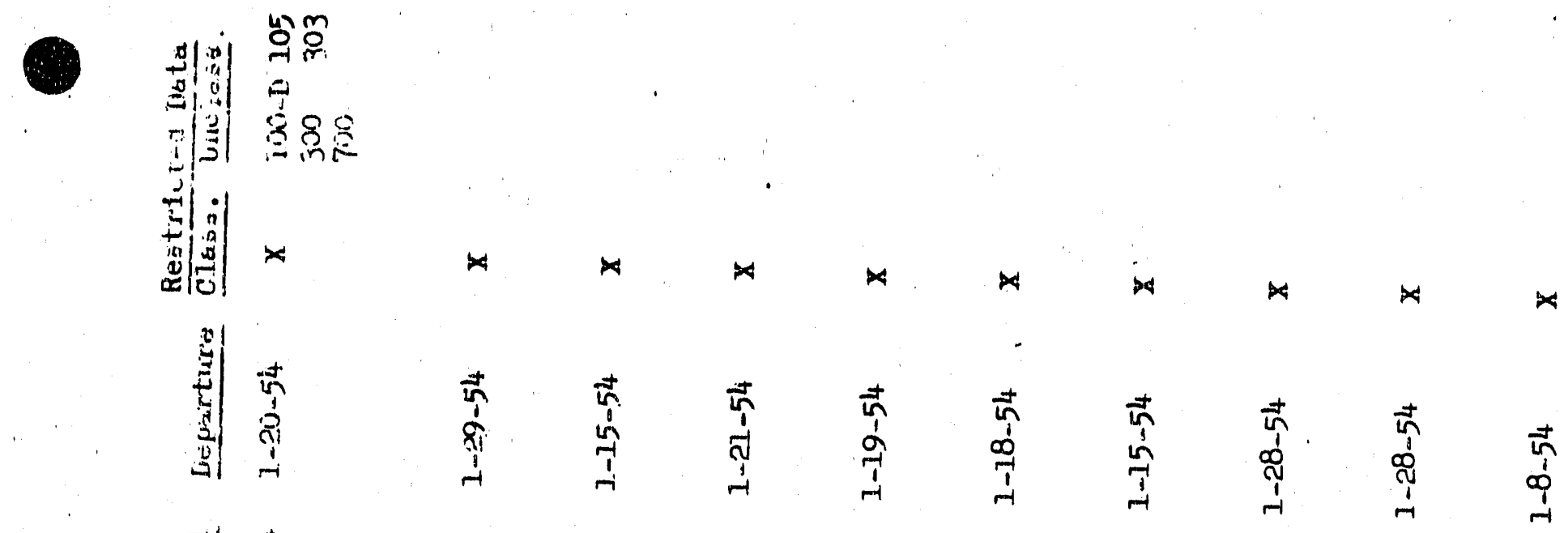

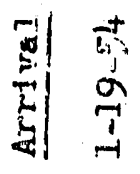

变

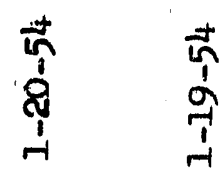

离

苞

荬

$\frac{\pi}{1}$

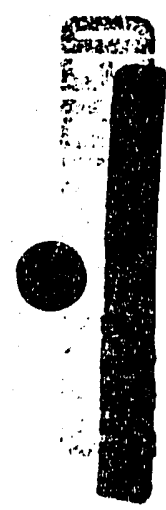

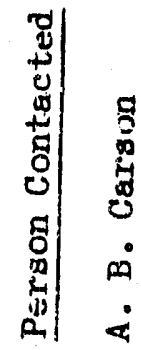
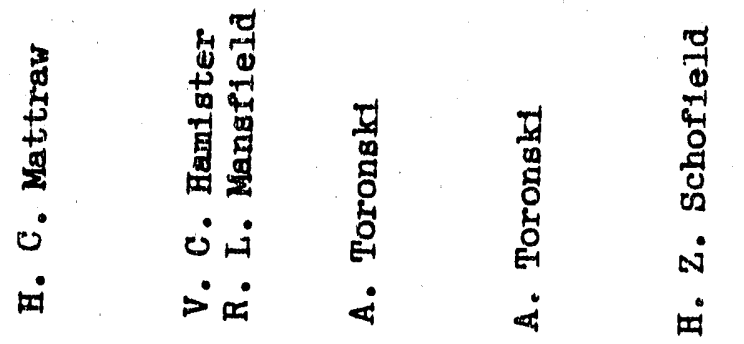

焉

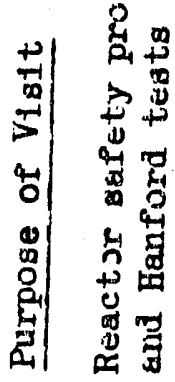

苏

告

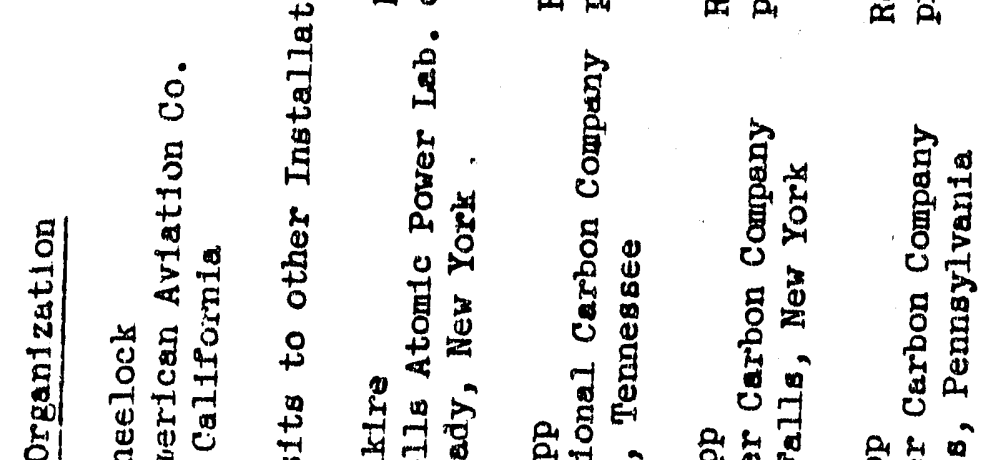

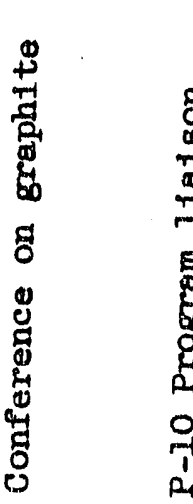

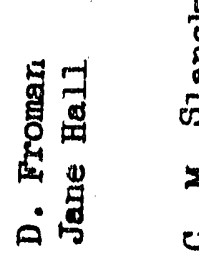

窝

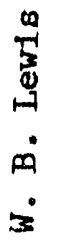

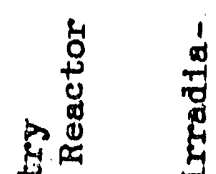

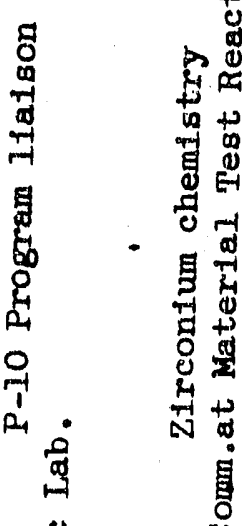

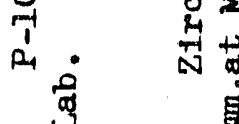

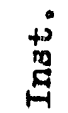

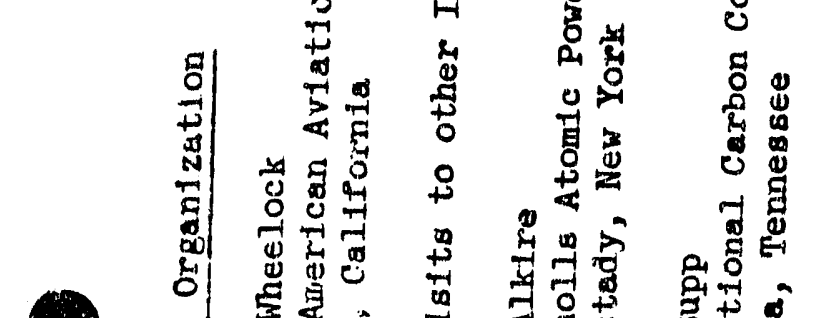

苨

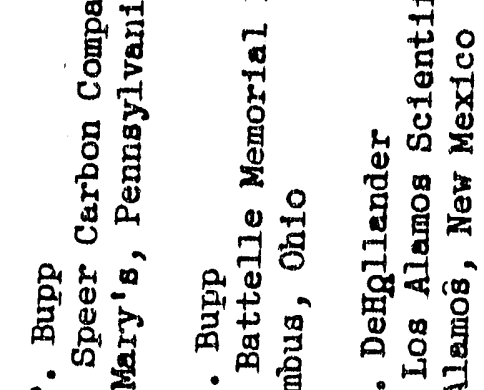

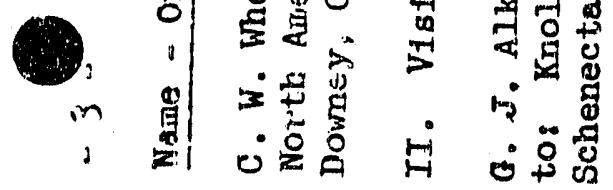

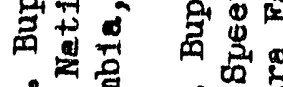

的宣

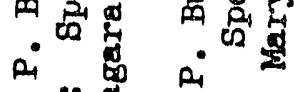

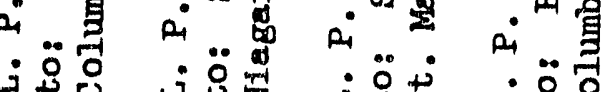

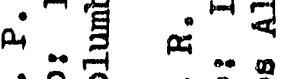

Ja-16

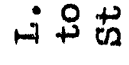

둥ㅇㅇ

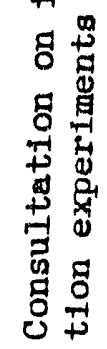

点

pq

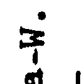

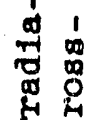

点点 品

엉 옹

罗专

安票

思军日

总吕焉

㣮

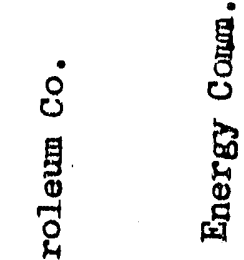

通

密

鿓

$\stackrel{0}{\text { 首 }}$

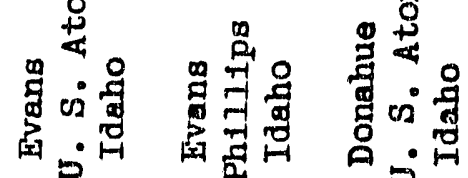

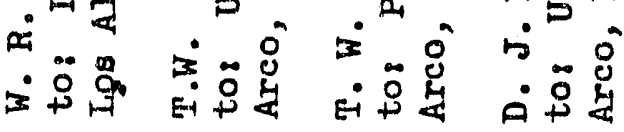


gi:

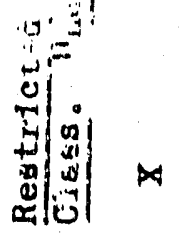

$x$

$x$

$\times$

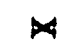

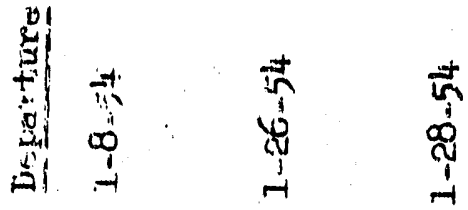

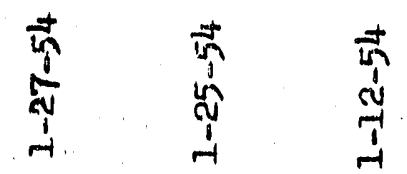

苟

$\vec{n}$
$\substack{1 \\ 1}$
0

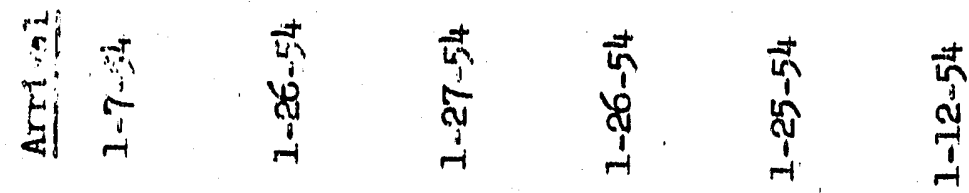

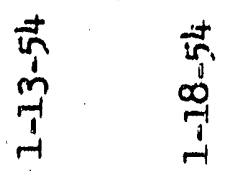

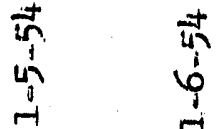

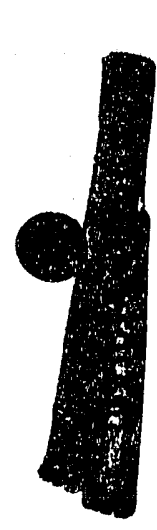

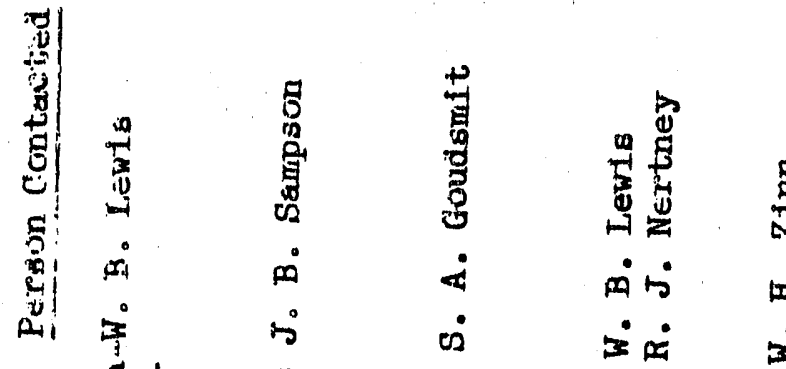

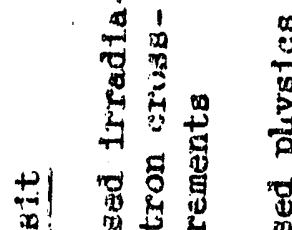

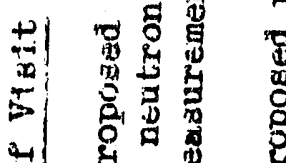

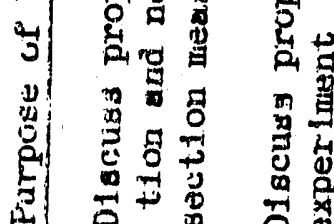

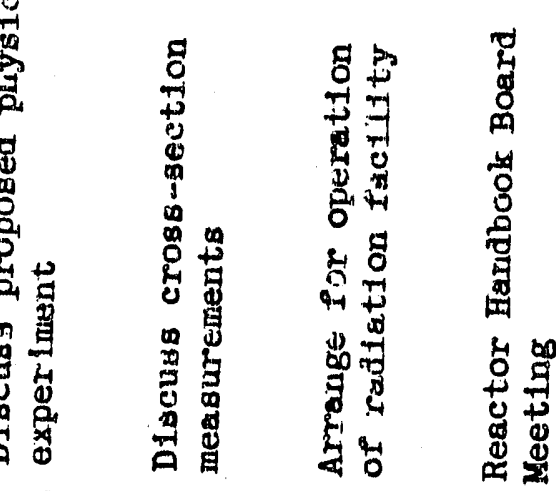

尊 漂

曾

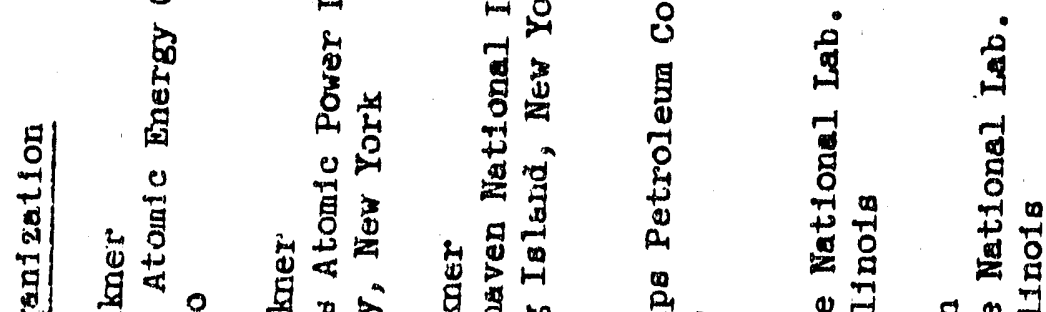

造

害

密

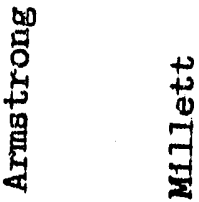

5

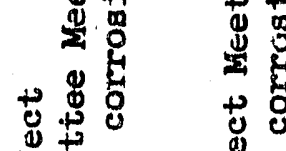

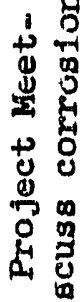

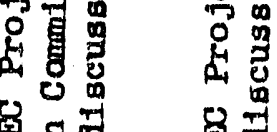

䎹要严

然整

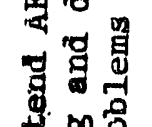

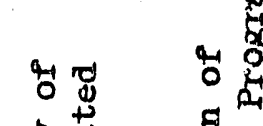

的界 的

co

연운

要 品

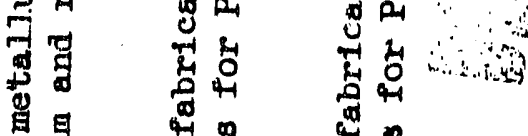

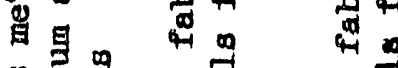

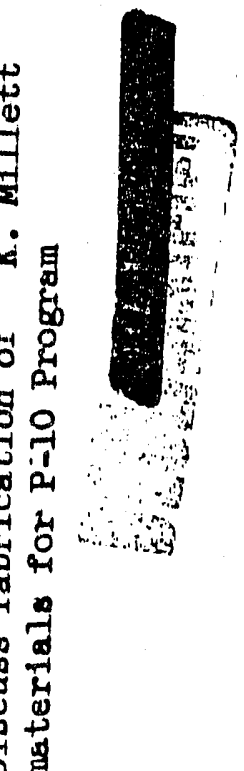

อํํㅇㅁำ

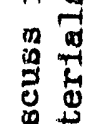

\$ व्र

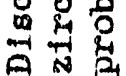
造

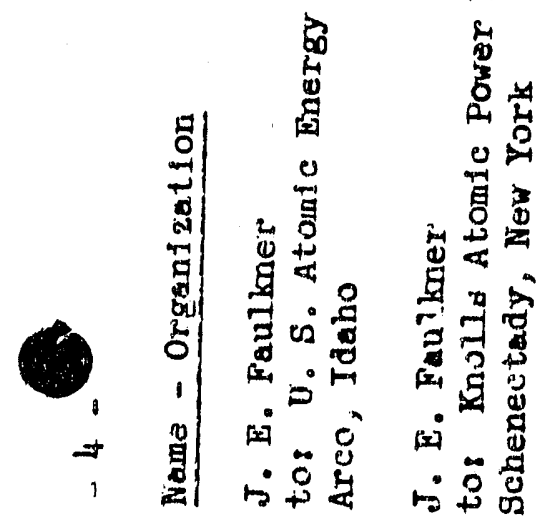

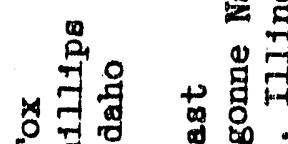

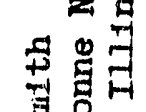

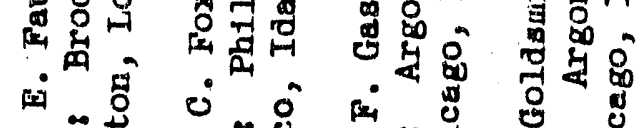

மீ

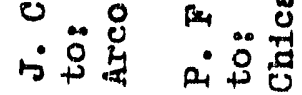

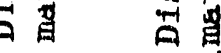

圄

$$
\text { 苜 }
$$

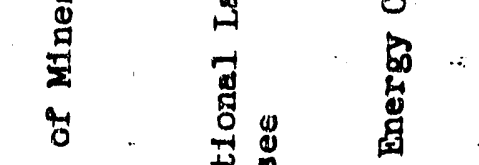

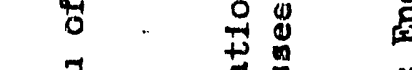

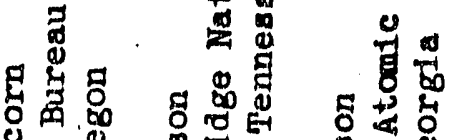

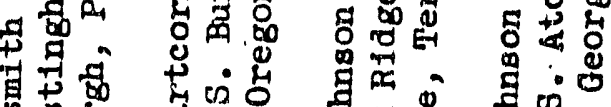

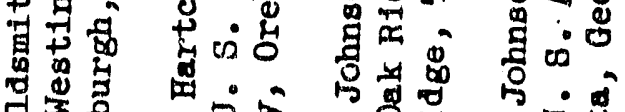

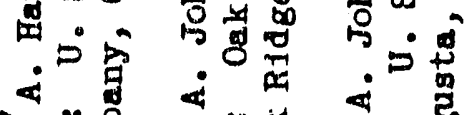

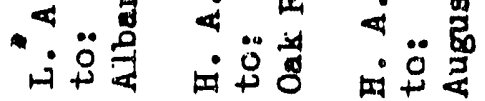


닌

(n)

$x \quad x$

4

$\infty$

$x$

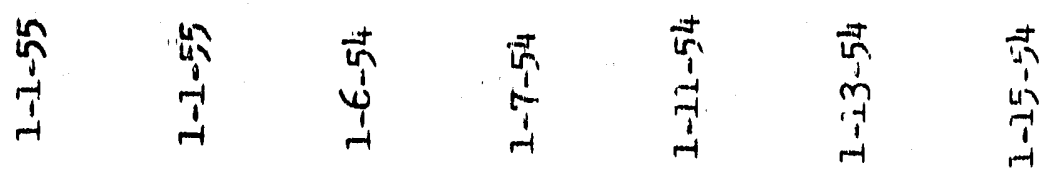

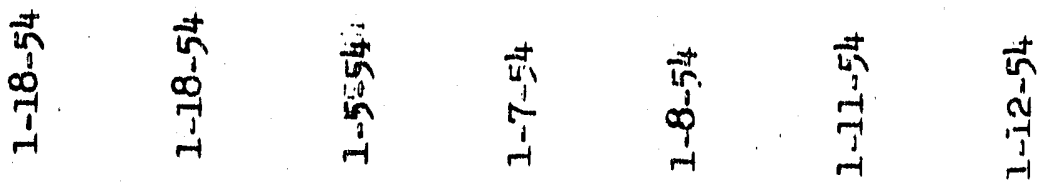

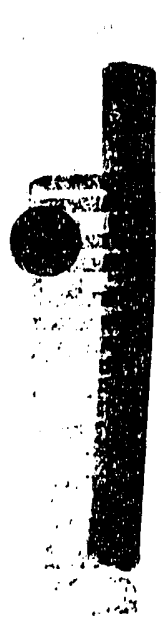

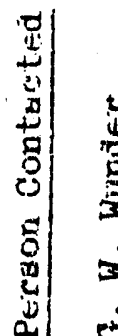

焉

密

:

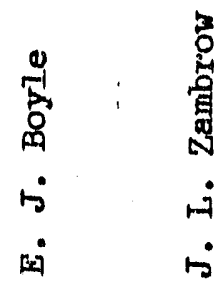

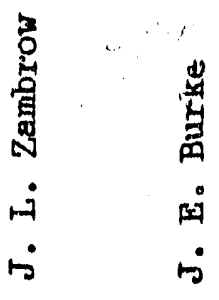

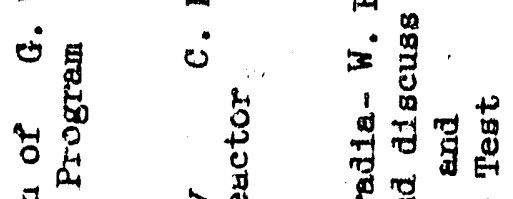

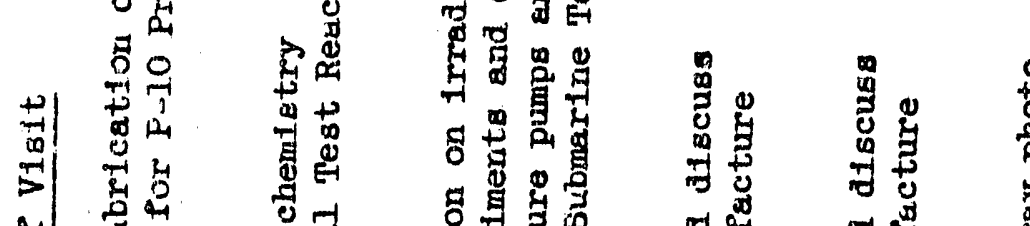

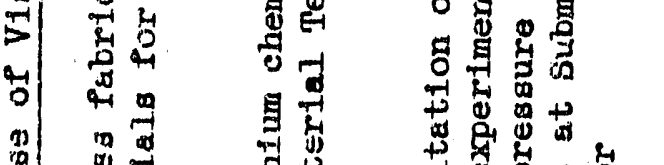

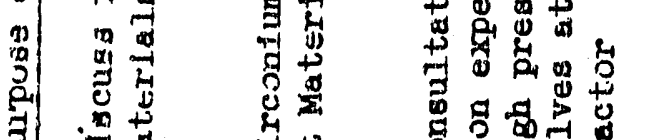

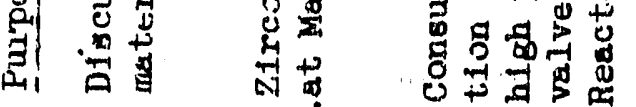

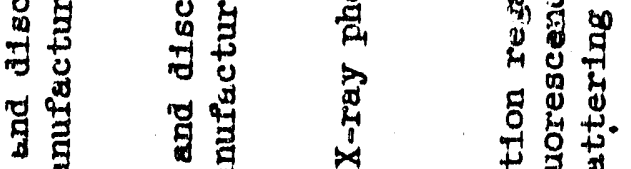

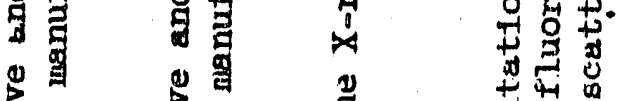

总忽

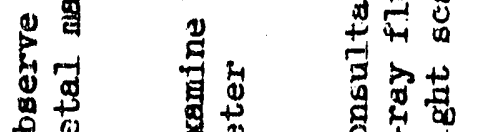

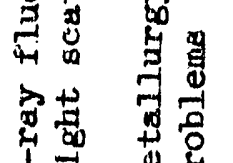

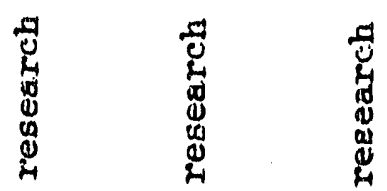

它

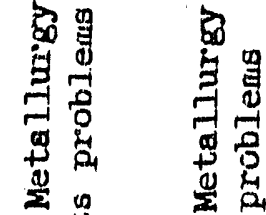

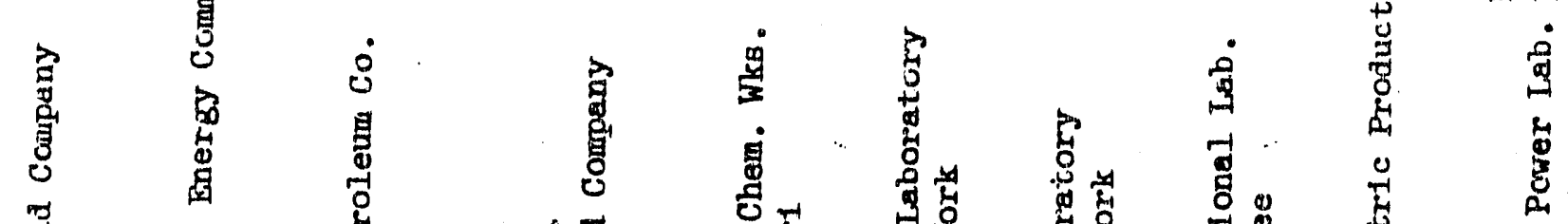

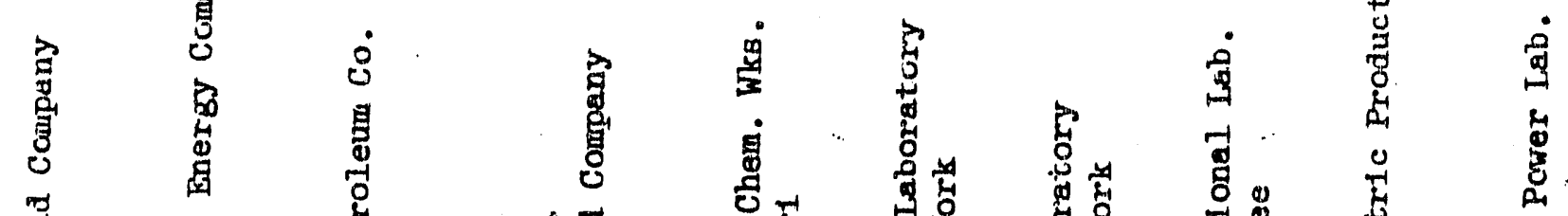

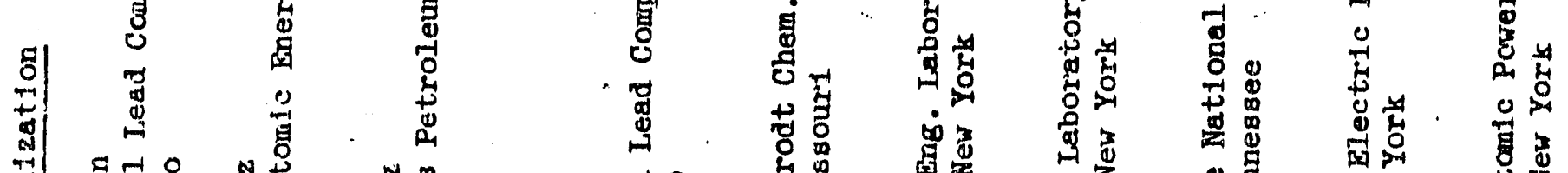

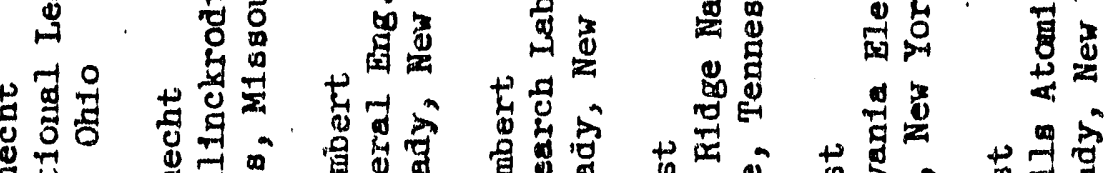

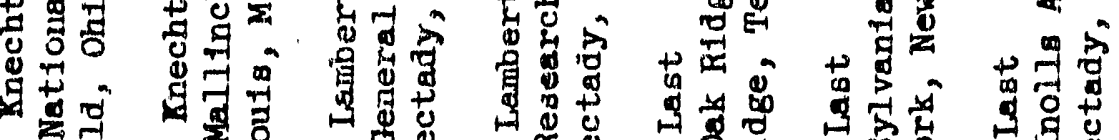

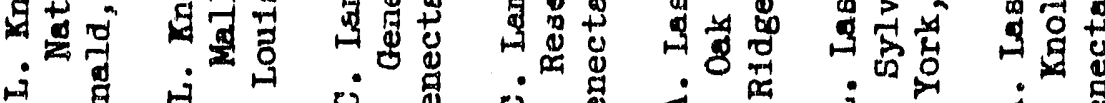

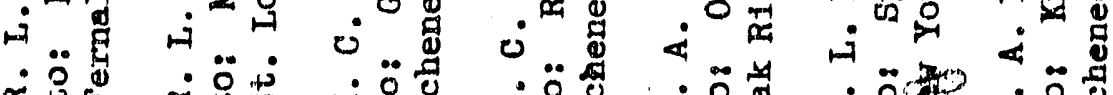

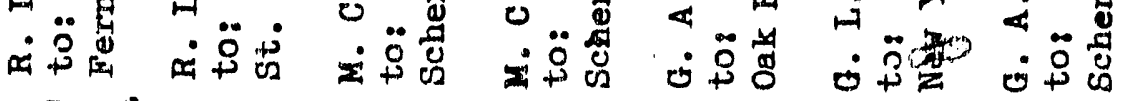




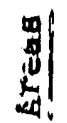

11

ए)

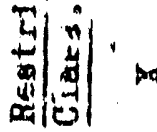

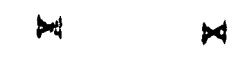

$x$

4

4

w

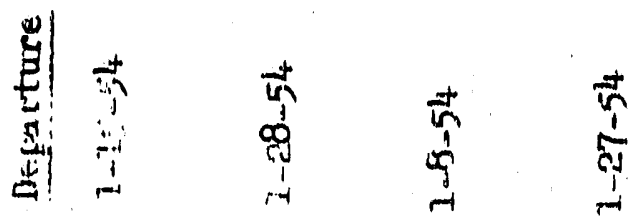

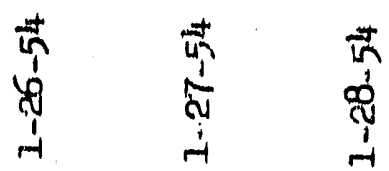

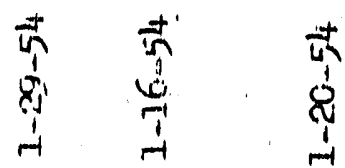

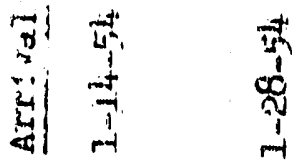

$\overbrace{-1}^{m} \quad \frac{1}{4}$

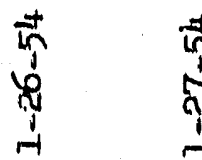

索

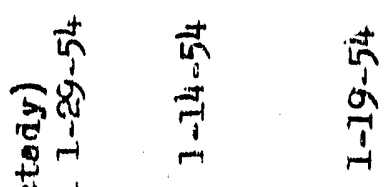

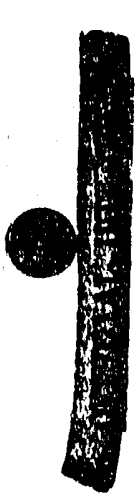

品

की 10

息

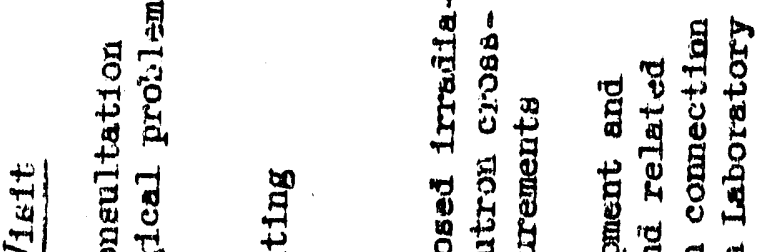

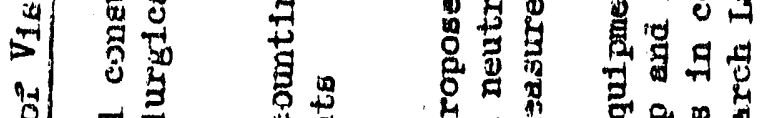

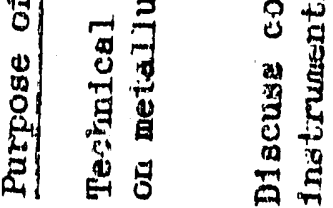

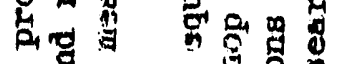

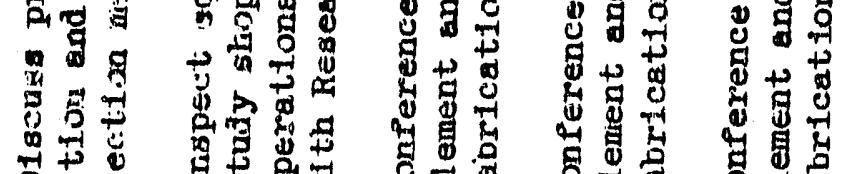

自
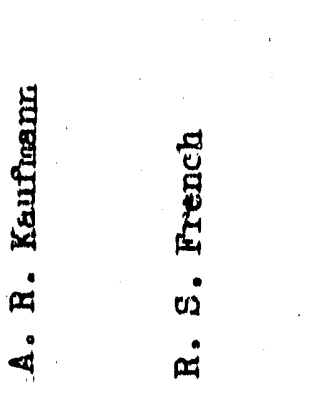

过

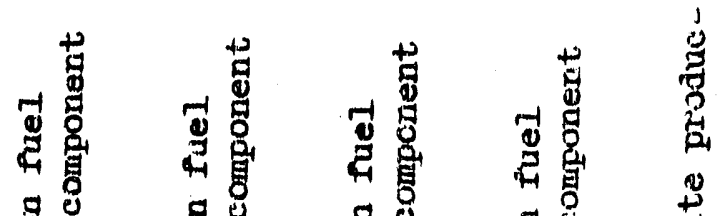

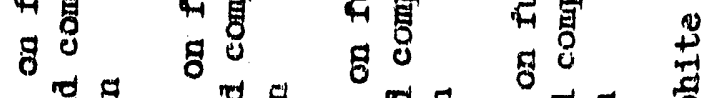

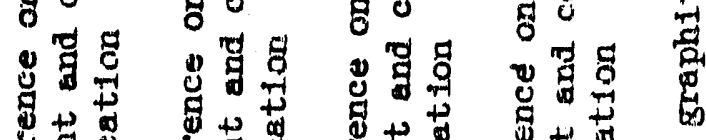

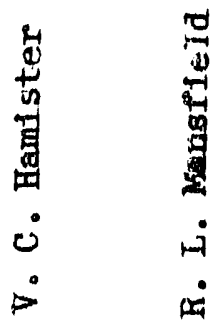

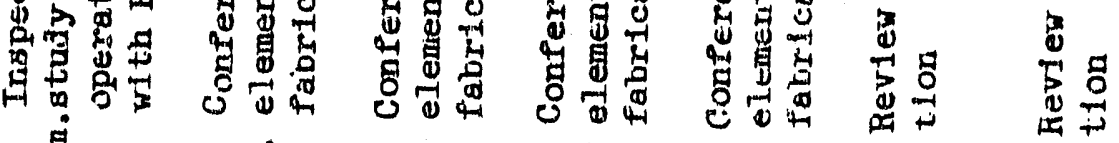

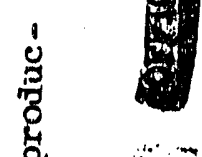

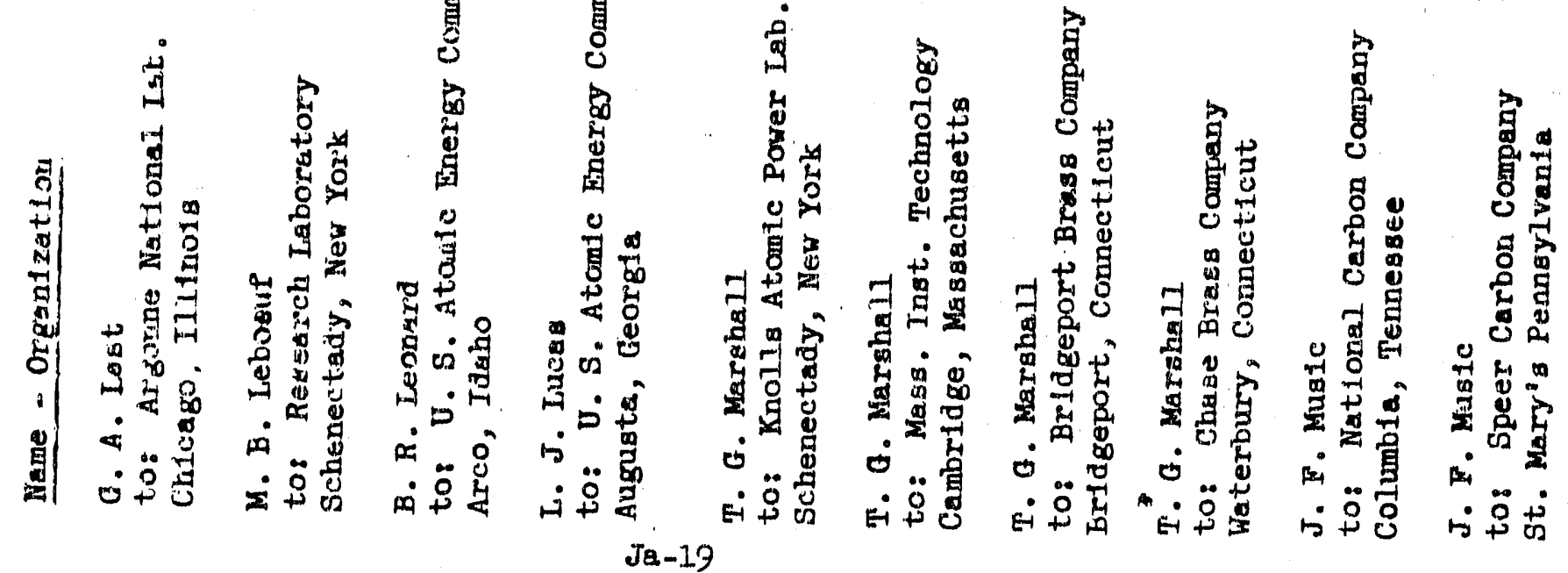


:

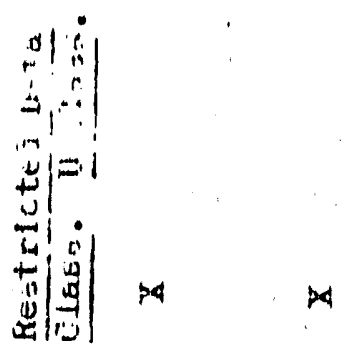

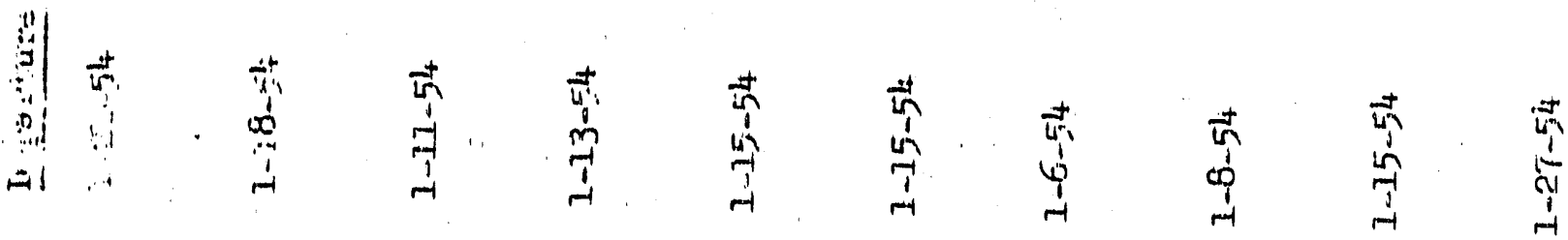

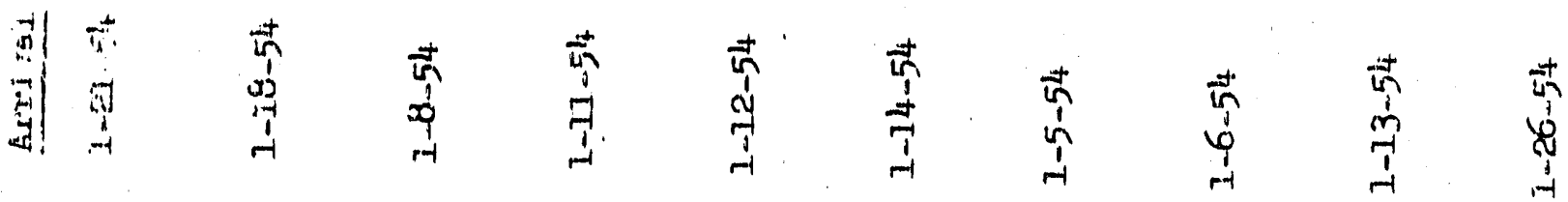

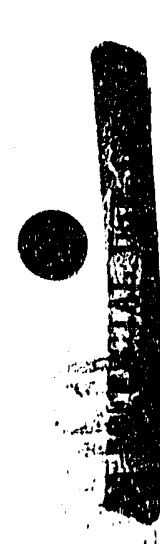

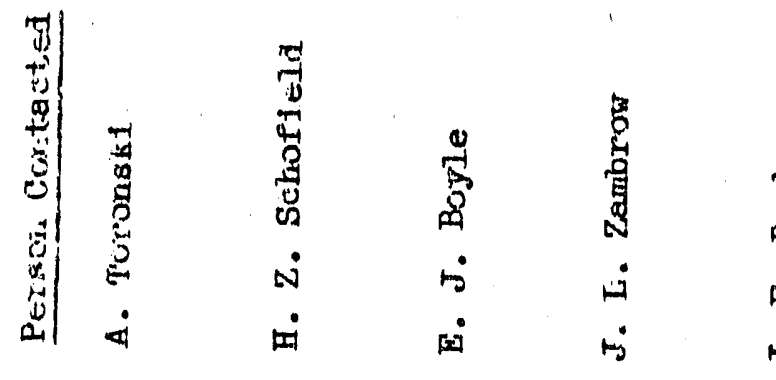

产

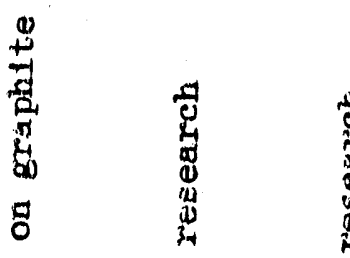

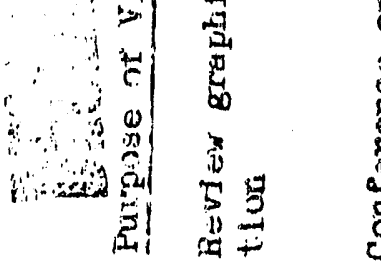

苟

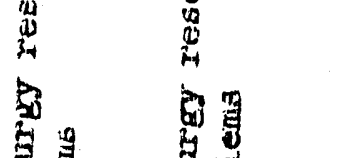

番

跑

章

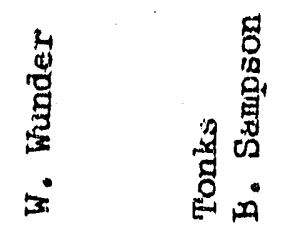

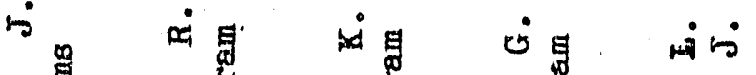

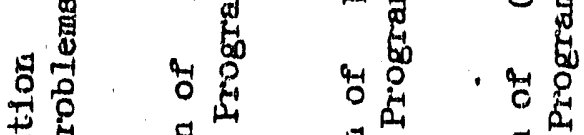

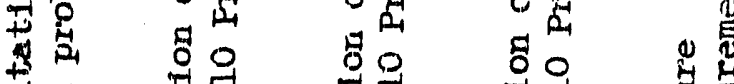

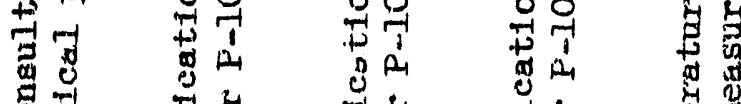

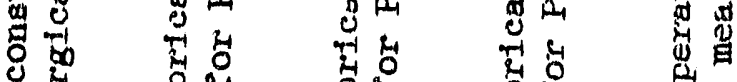

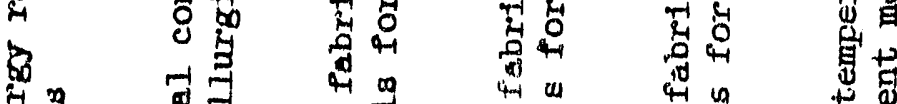

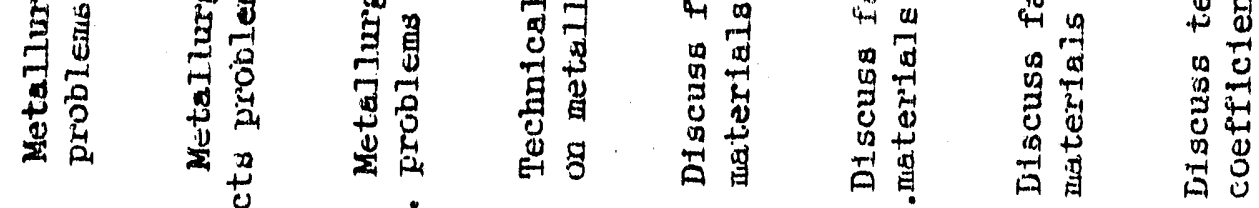

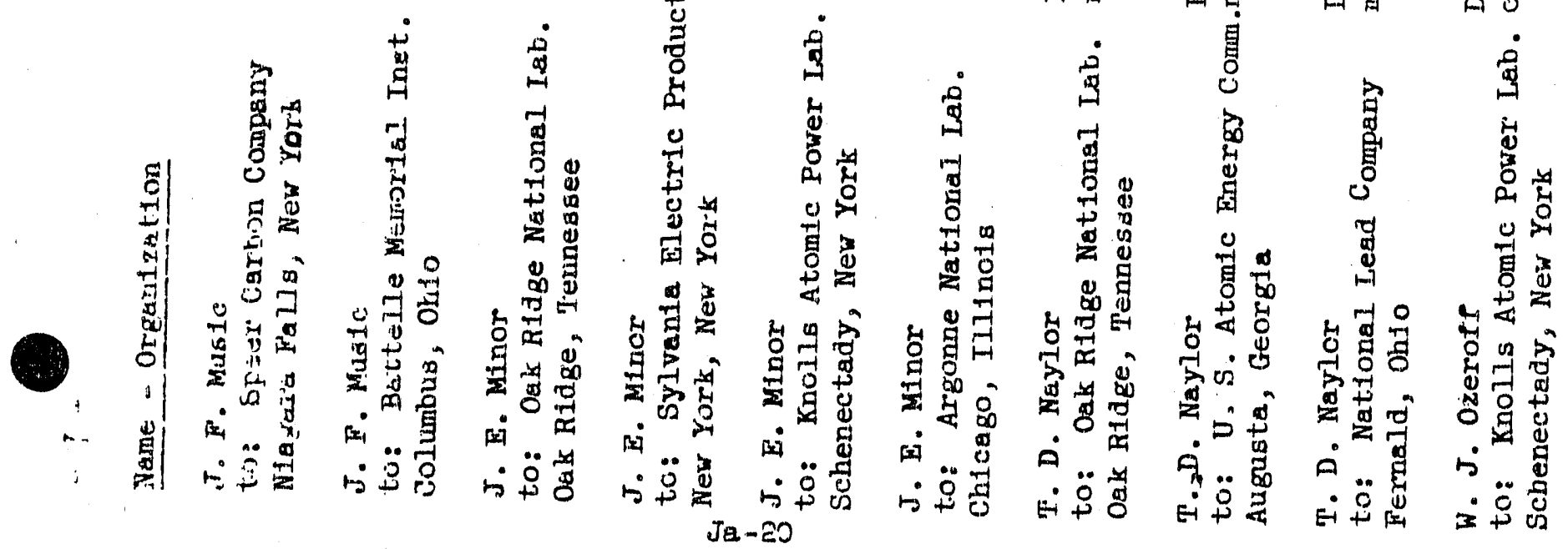


!

至

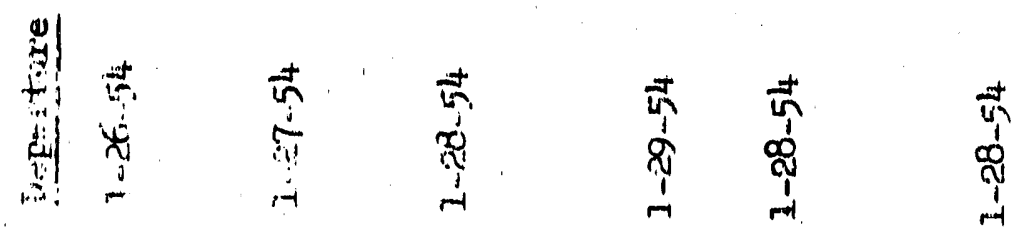

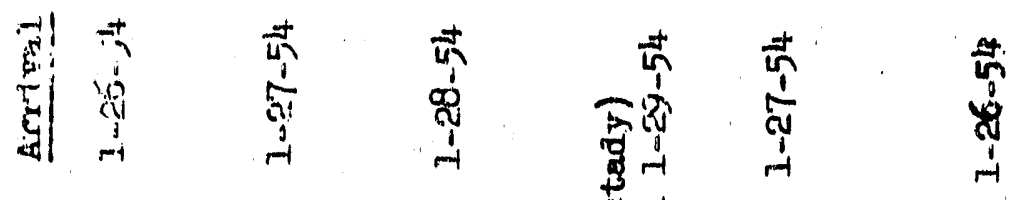

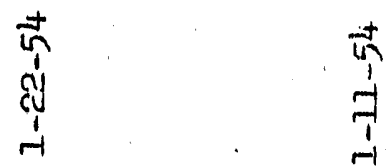

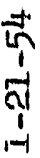

志

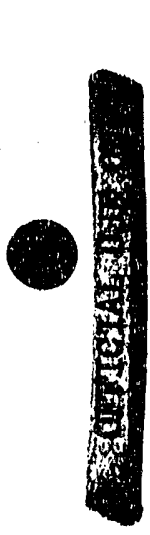

م|

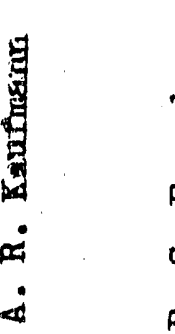

它

年

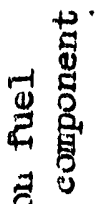

岱焉

का

की

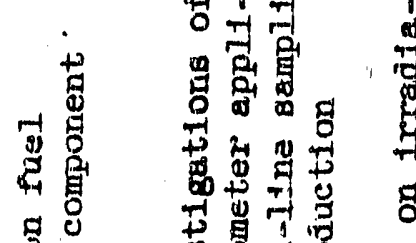

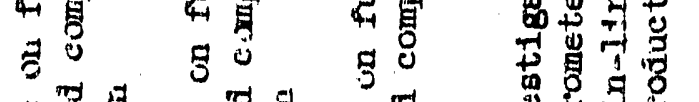

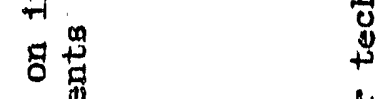

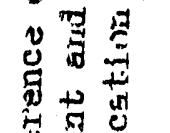

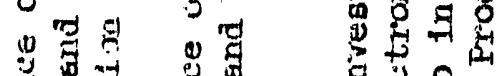

号县

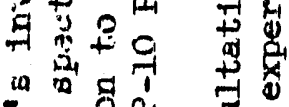

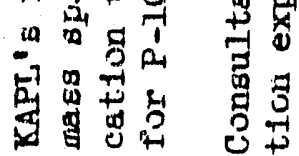

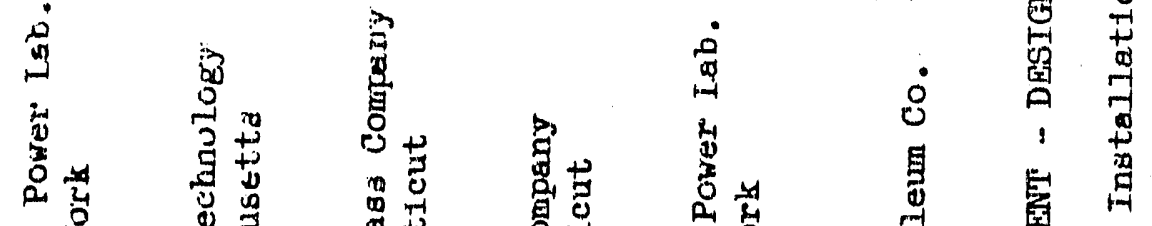

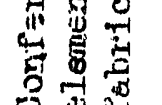

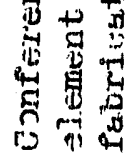

焉

空

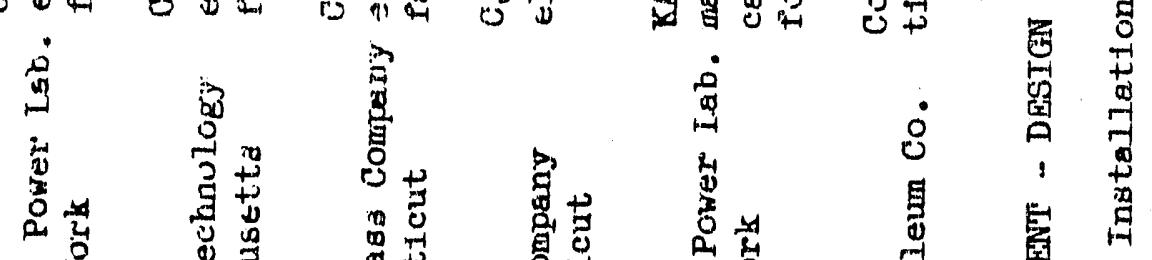

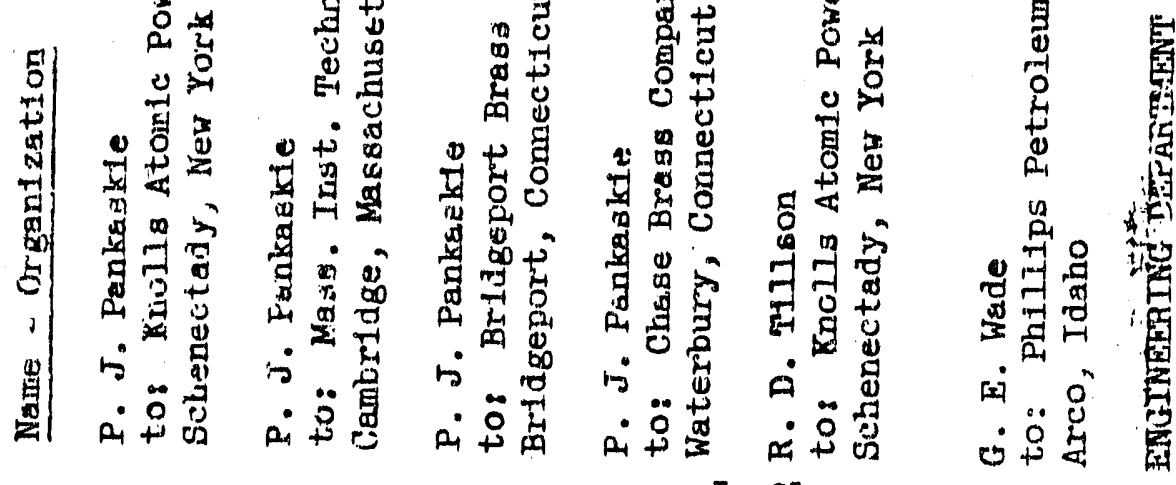

象

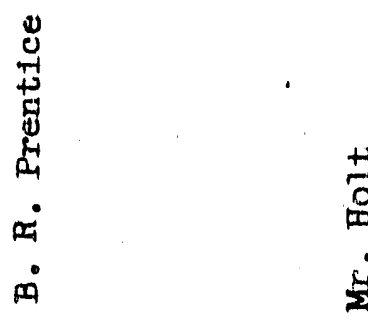

S

焉

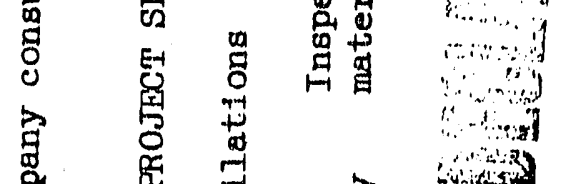

witst

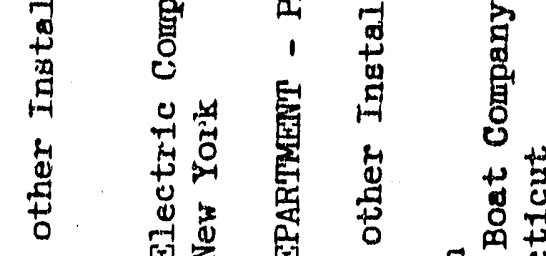
g 0 过

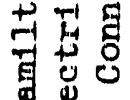

空

ن Ja-2I 


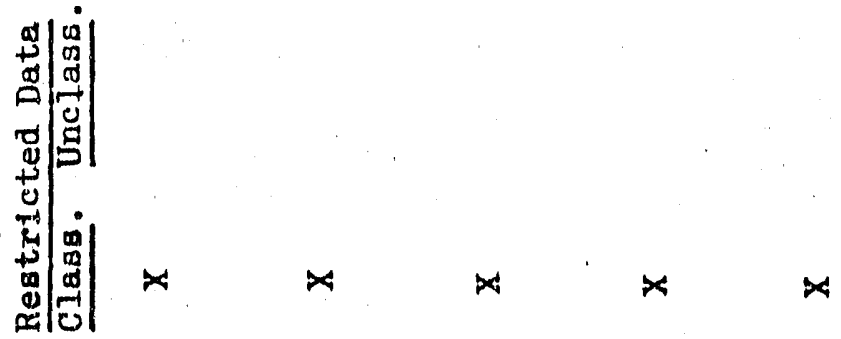

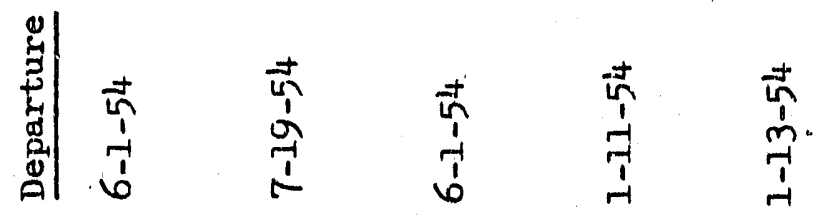

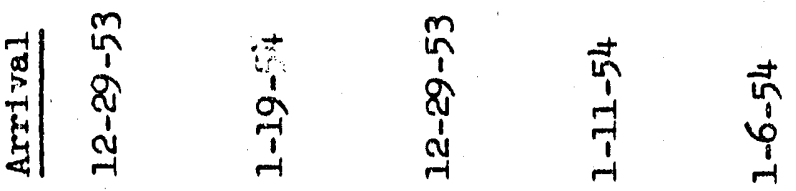

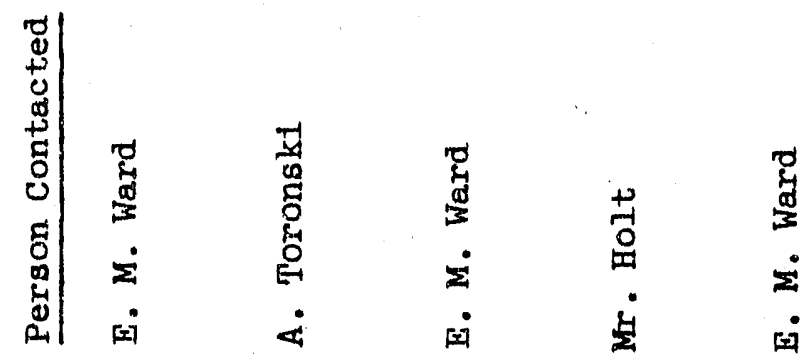

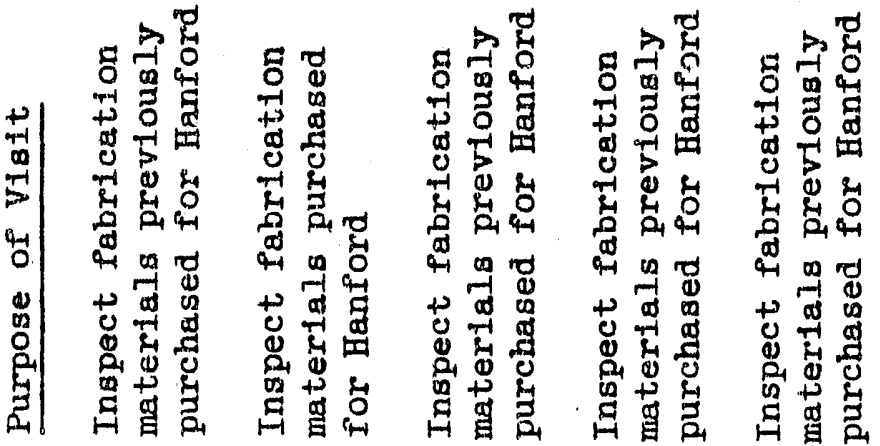

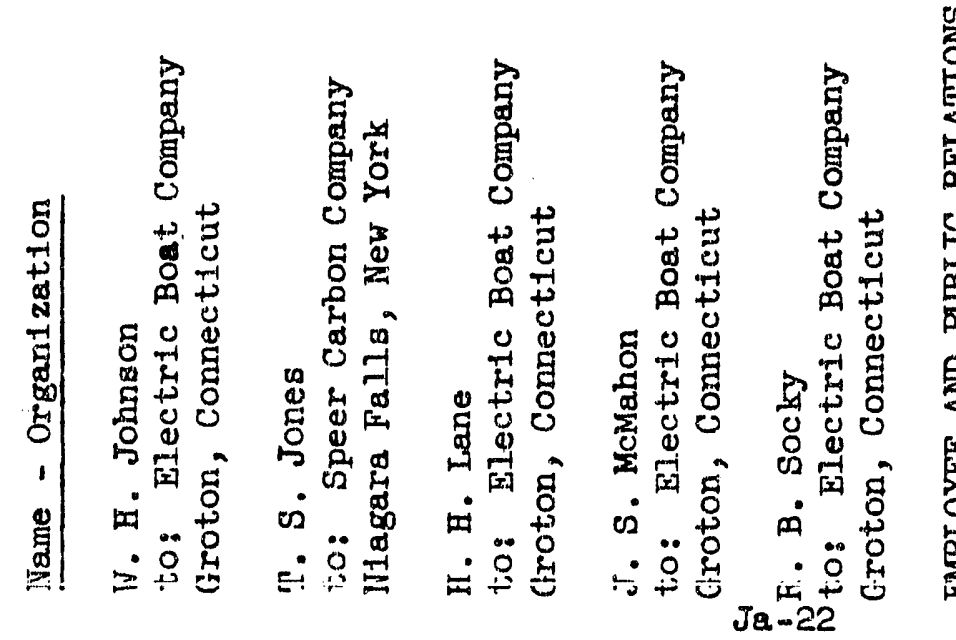

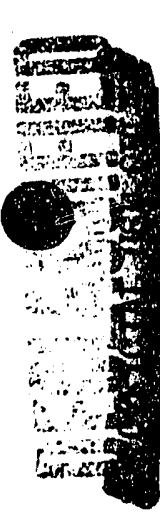

政

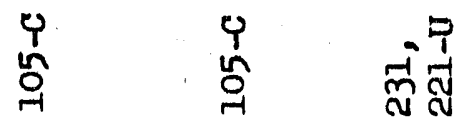

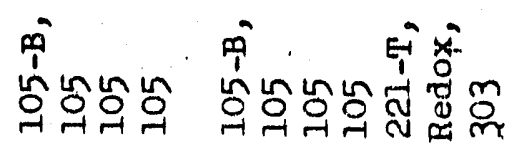

ำ

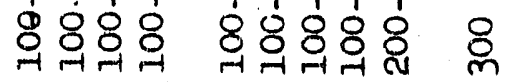

$x+\infty$

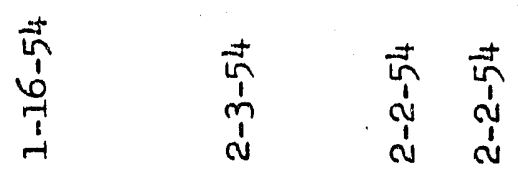

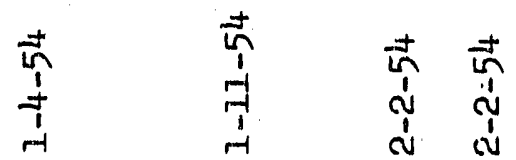

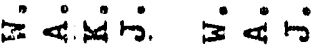
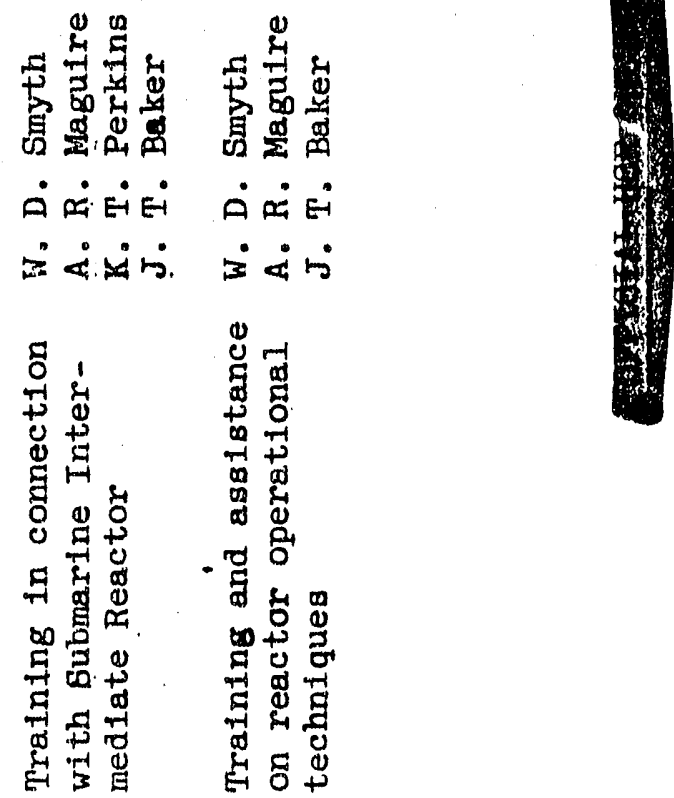

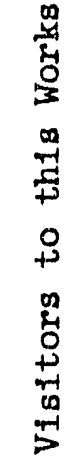

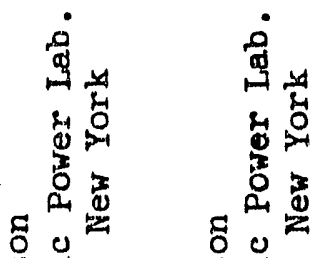

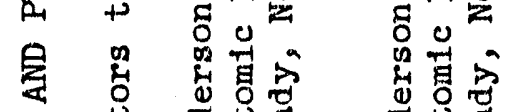

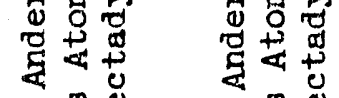

ن

的宾 


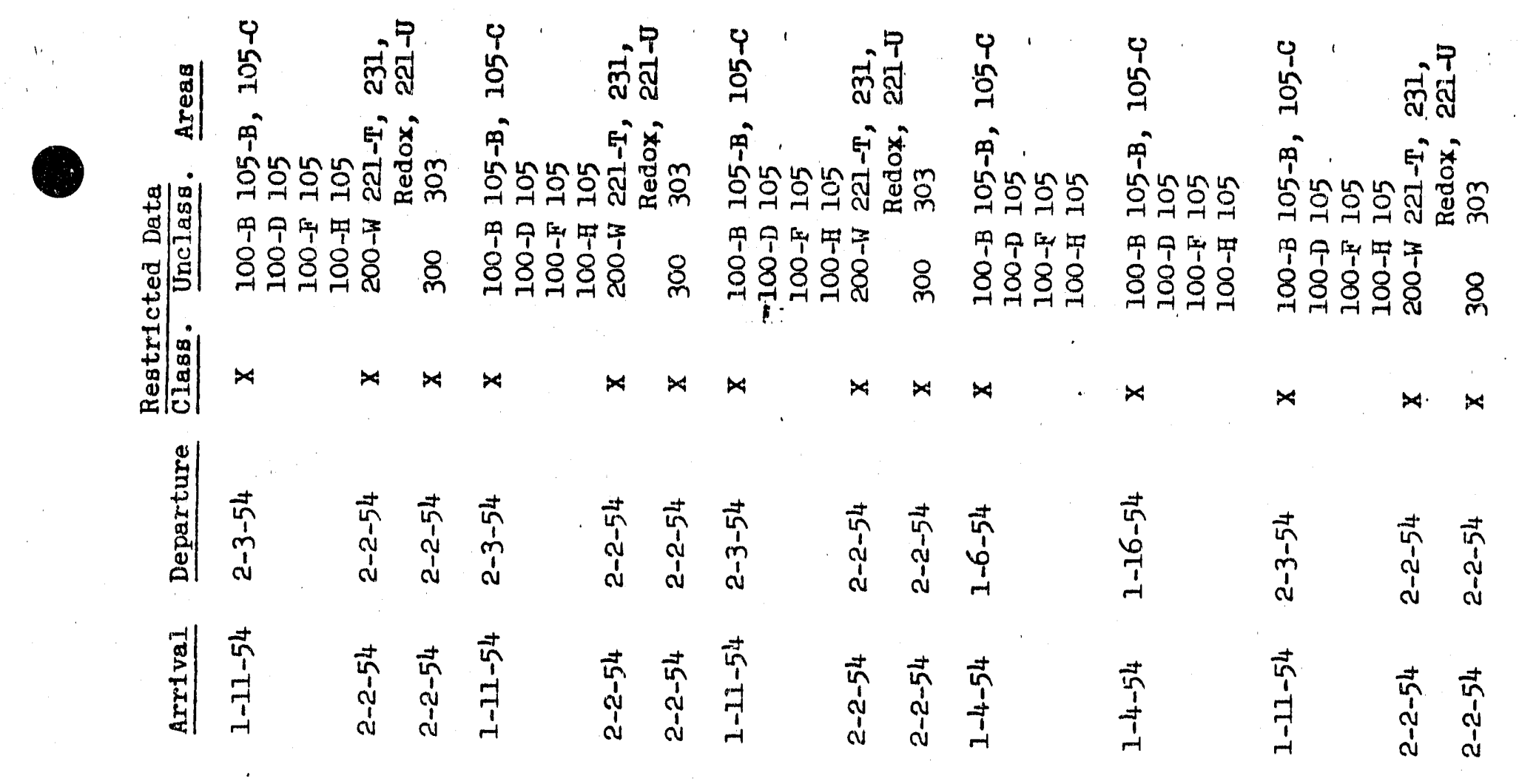

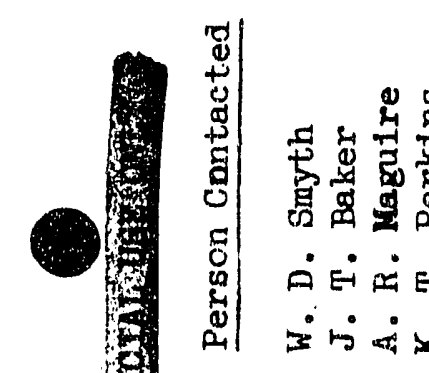

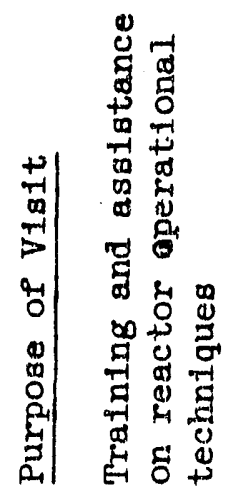
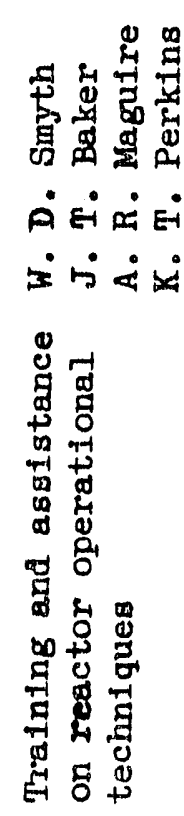
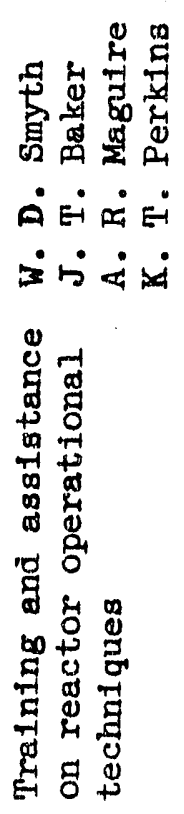
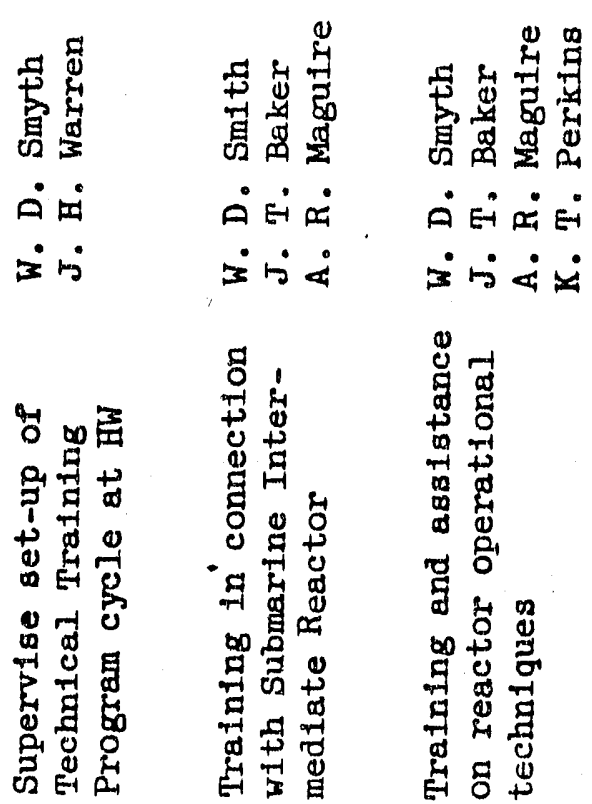
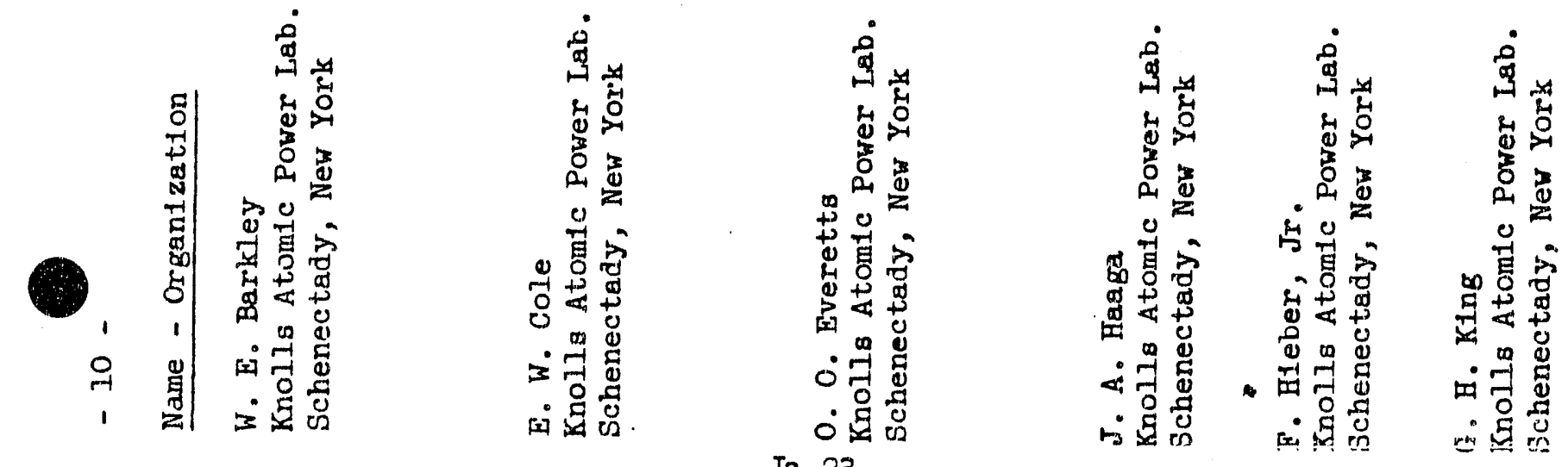


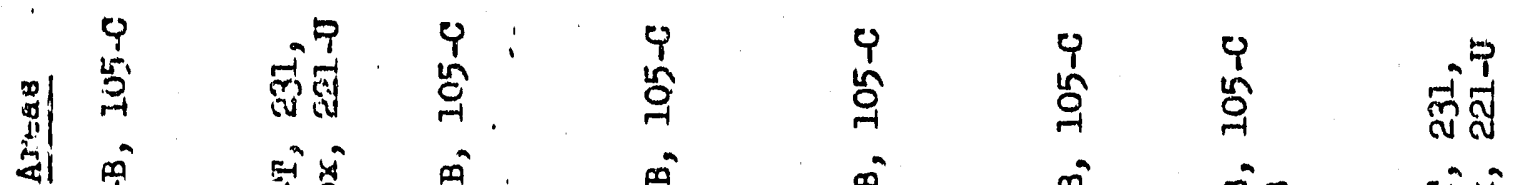

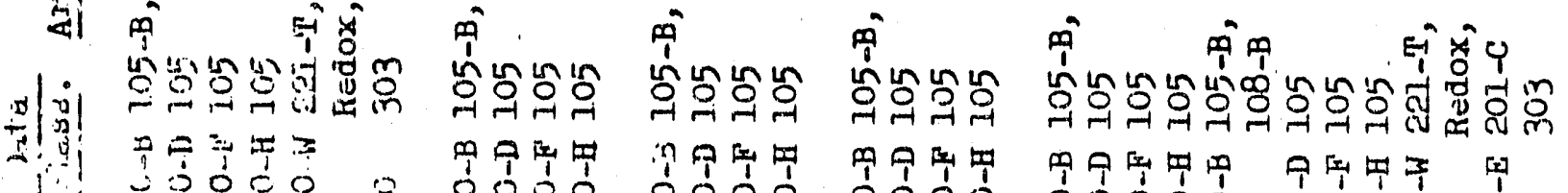

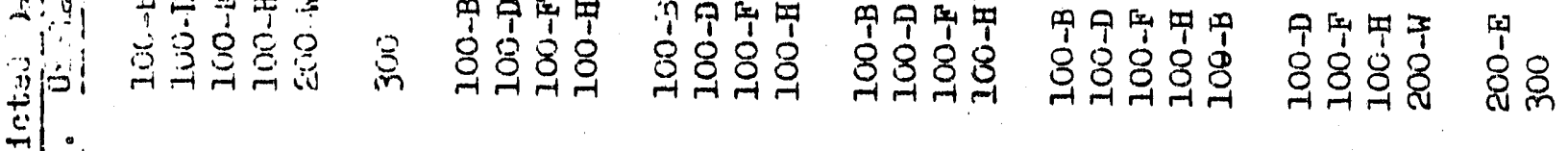

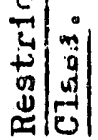

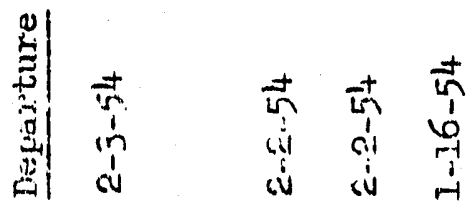

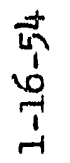

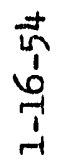

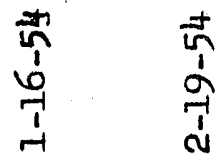

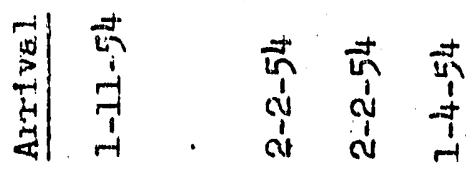
索
戞
苦苦
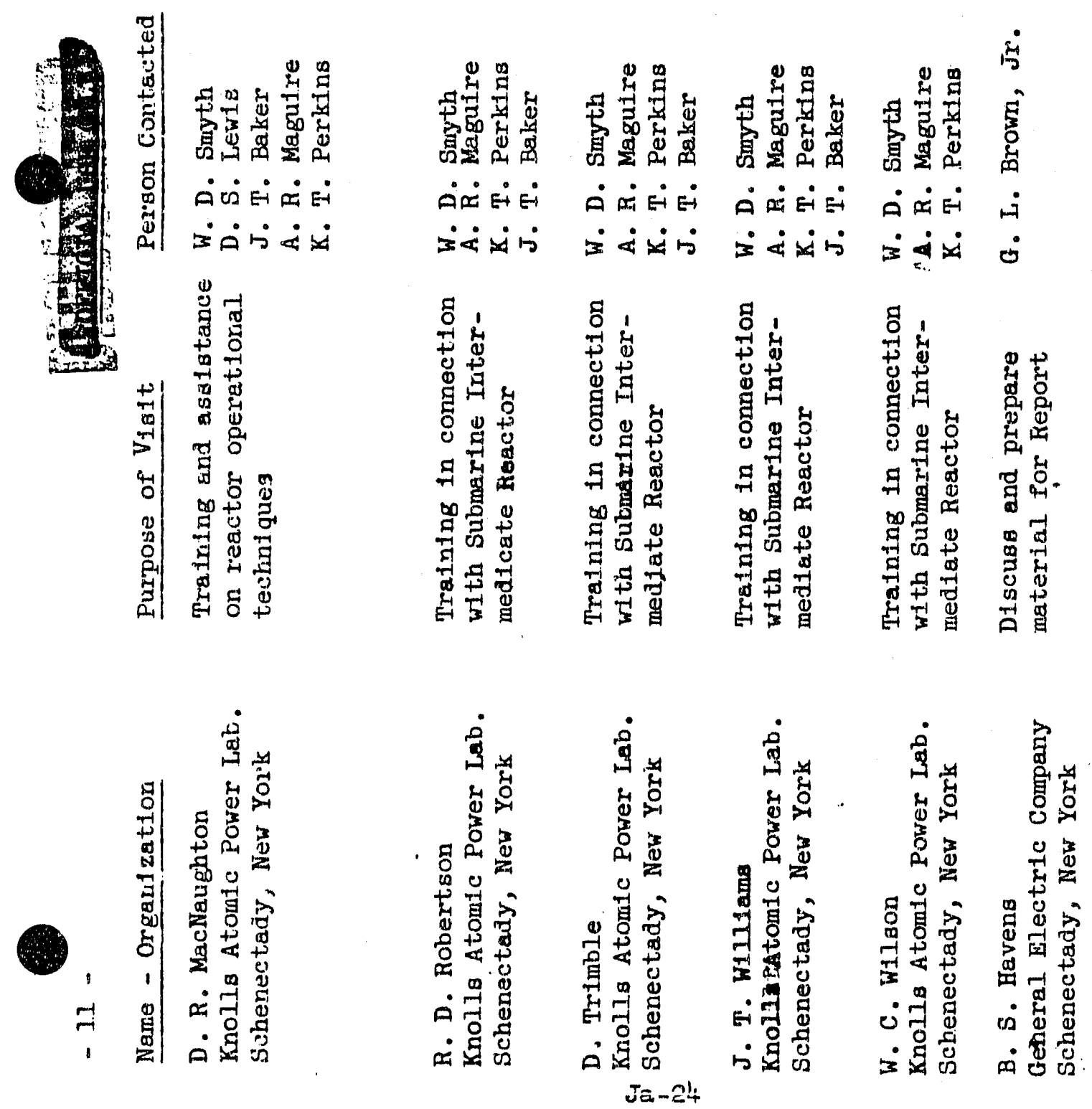
0

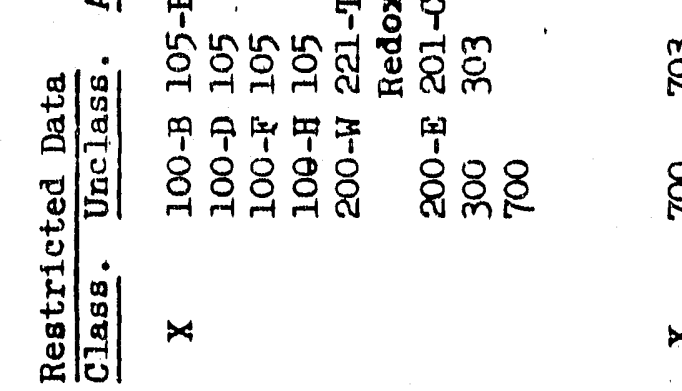

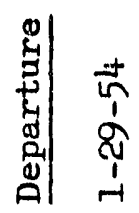

告

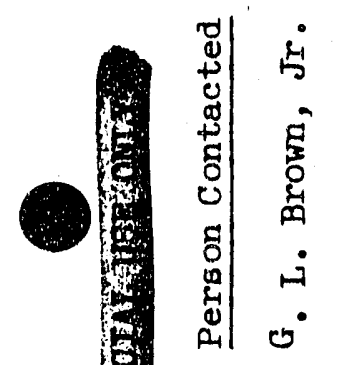

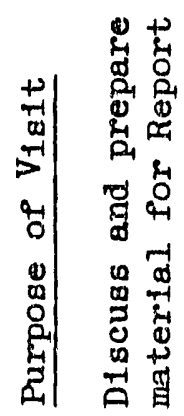

प

p :

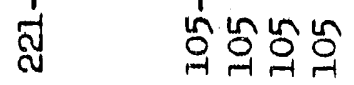

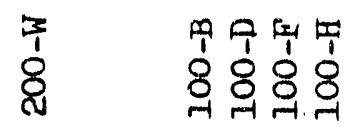

$x \quad x: \quad x \quad x$

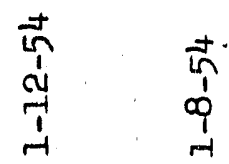

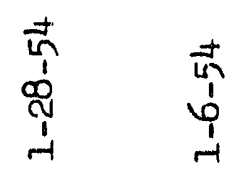

$\begin{array}{cc}\frac{1}{5} & \frac{1}{1} \\ -1 & \frac{1}{1} \\ -1 & -1\end{array}$

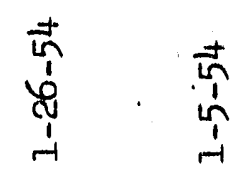

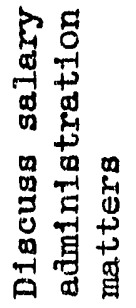

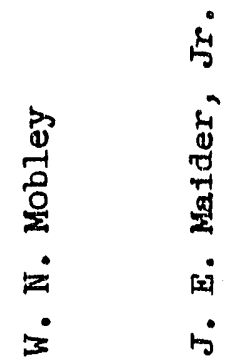

范

告

$\exists 0^{\circ}$

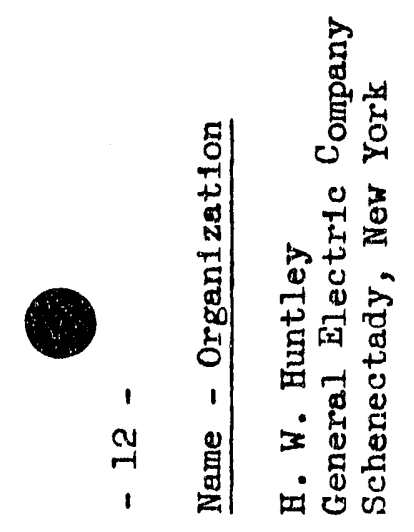

9
$\frac{3}{4}$
3

富 密

is

先

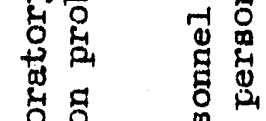

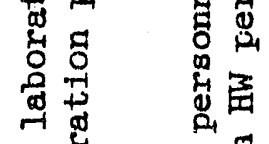

焉

苟焉

జ్d

离

4

पै

$\overbrace{0 \rightarrow 1} 0$

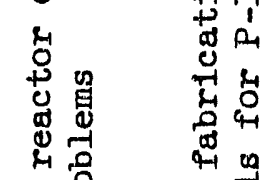

罂落

仓

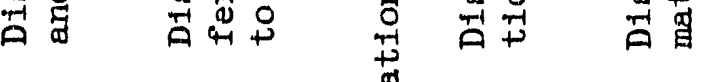


ํำ

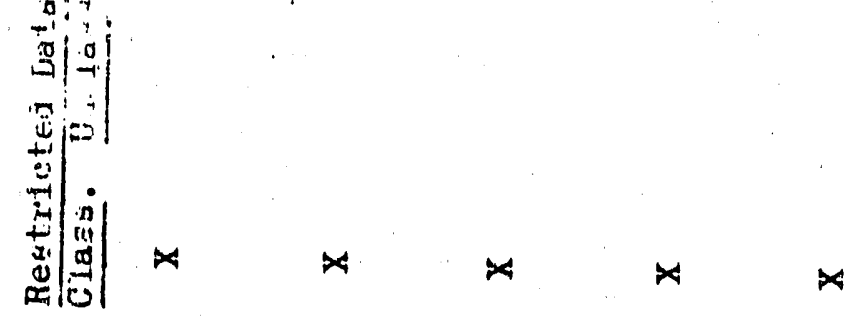

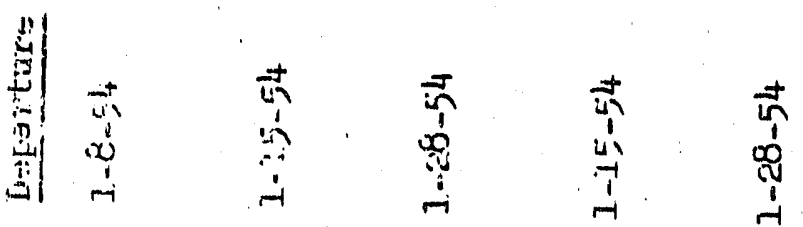

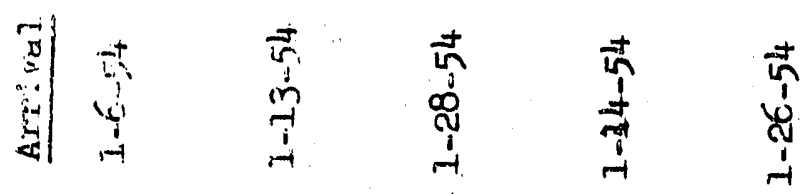

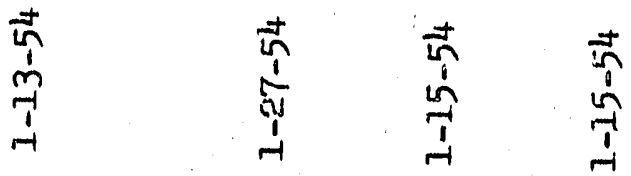

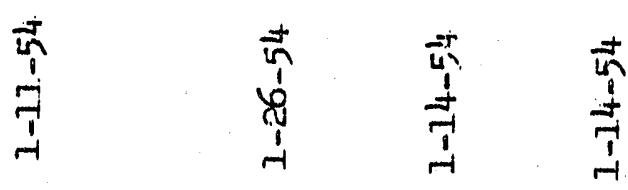

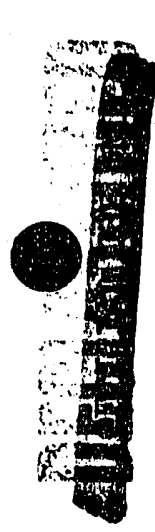

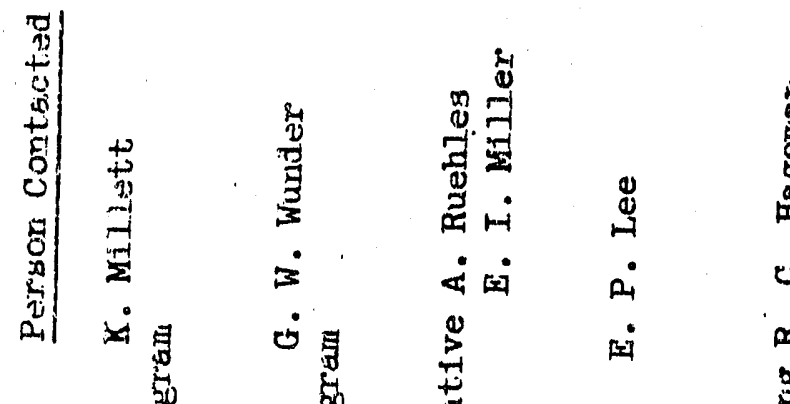

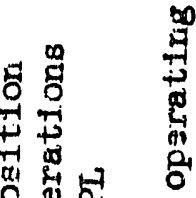

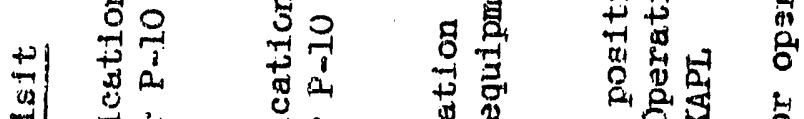

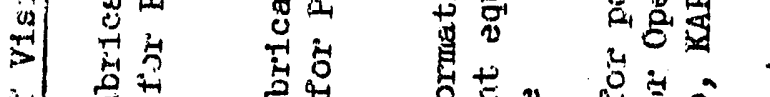

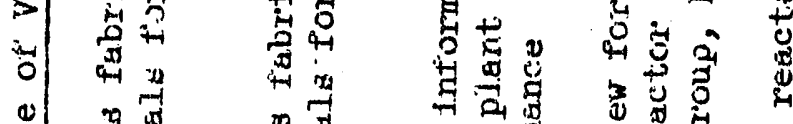

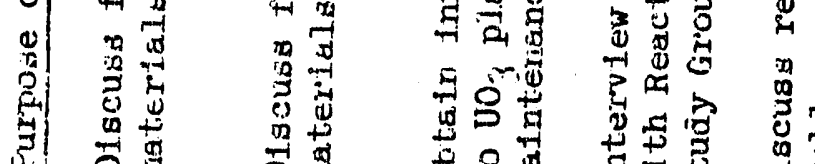

章

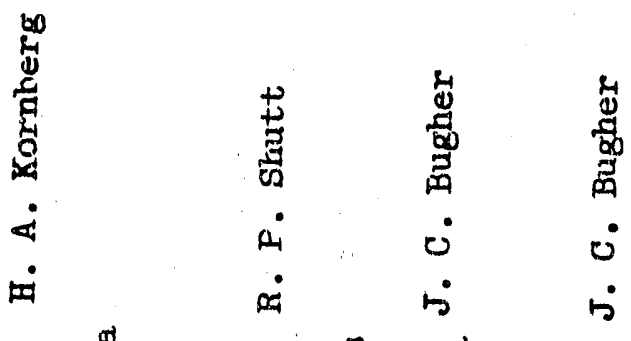

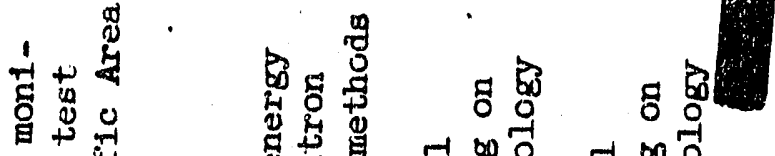

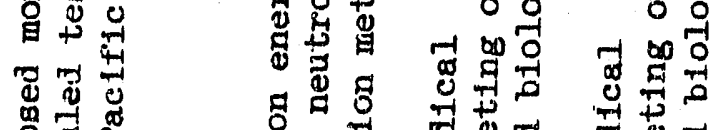

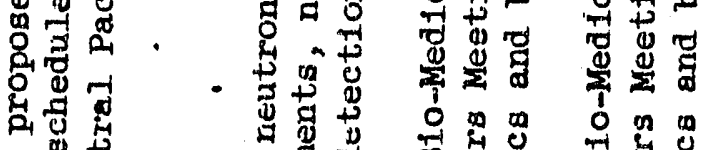

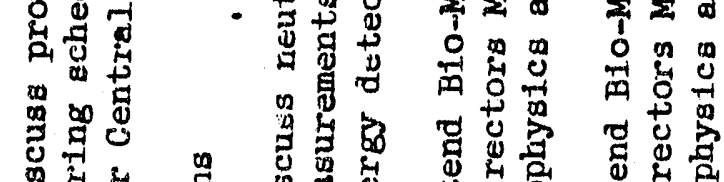

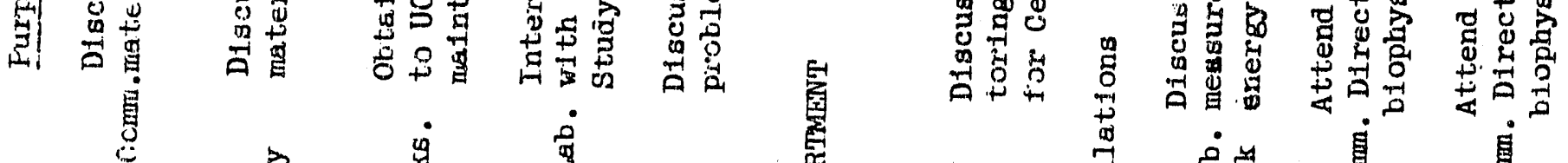

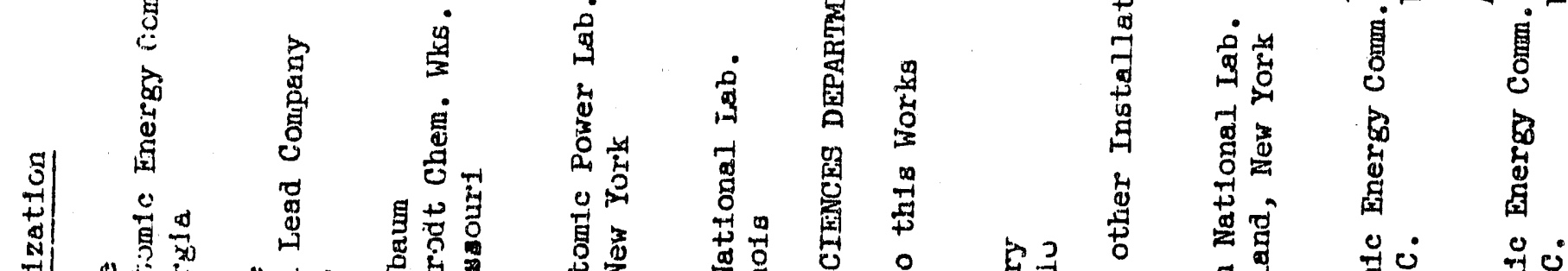

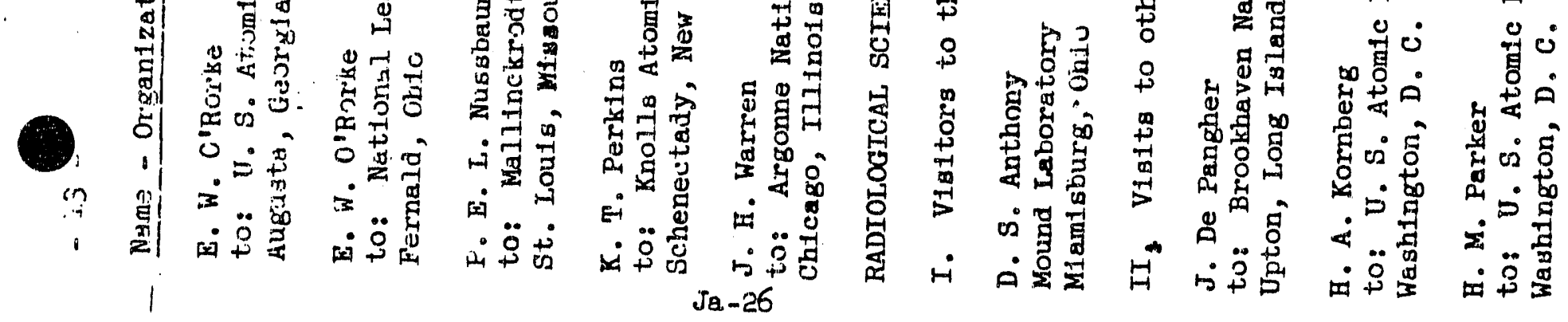


ㅊ.
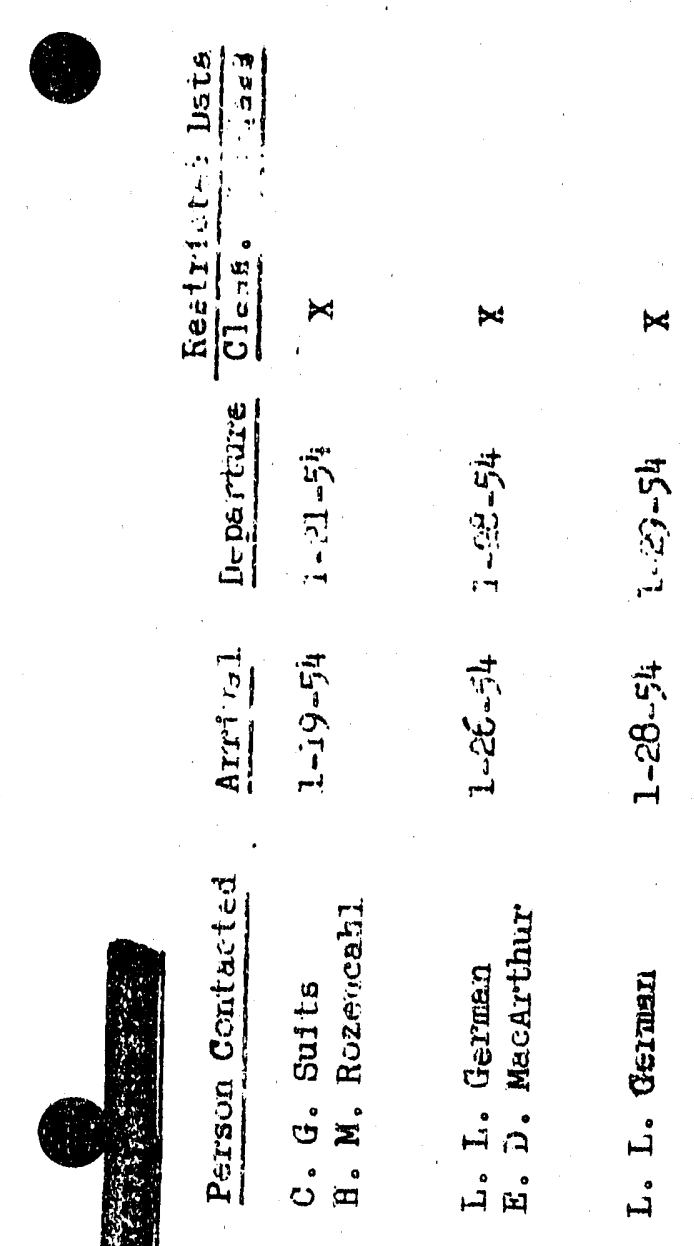

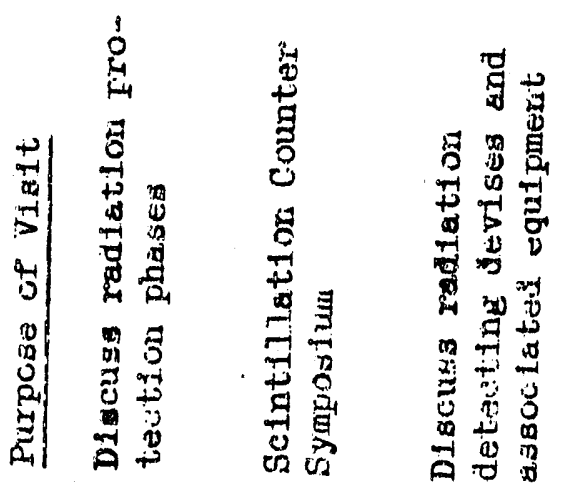

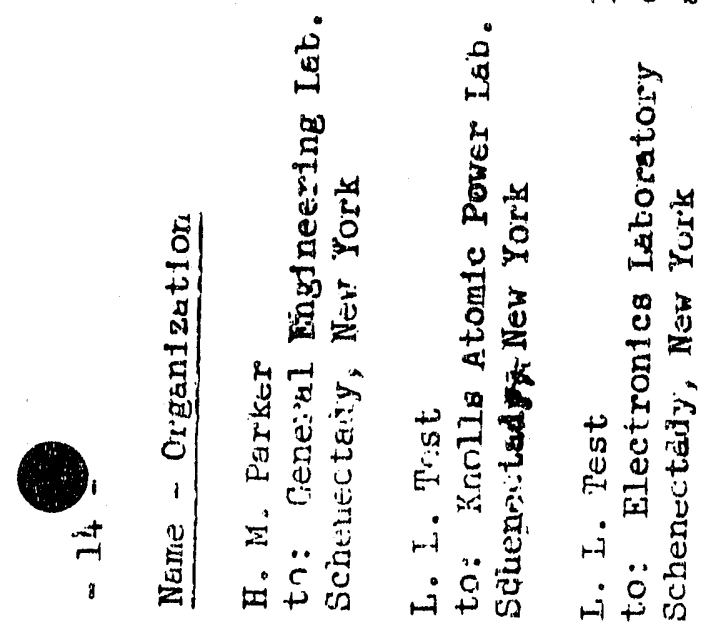

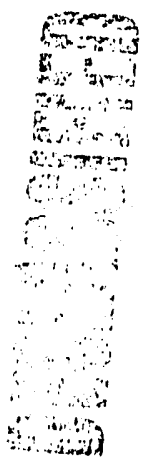


PURCHASING AND STORES SECTION

PLANT AUXILIATY OPERATIONS DEFARTMENT

SUIVIARY JANUARY 1954

Pacific Scientific Company's claim for \$0,160.64 on HWC-20073 has been analyzed and $1 \mathrm{t}$ is a consensus of opinion that this claim is not in order, and should not will be in Richland the week of February but in returm has written us that he

Project $C-573, x \times x-300$ Area procurement was authorized, and every effort is bo-m ing made to procure the material required by the time specified on the requisition.

Preject proposal ERA-748 for the laboratory supply facilities in the 325 Building appuars to be delayed as it has not yet been considered by the A \& B Committee. Pending action on this proposal we have been asked infornally to supply delivery service in the 300 Area from our 3700 Storeroom to other buildings. The expense of such service would not be required if the project were pushed by its ortginators
in the Technical Section.

A total of 154 construction purchase orders have been received whtch include operational spares for $K$ froject, Rurex and liedox. No materlat for K Project or Purex has been received as additional details still are to be worked out before the material is transferred to the Standby Warehousing Sub-Unit.

A tota 1 ot 50 Declaration of Excess documents containing 432 1tems of Standby materials vauled at $\$ 51,535$ were prepared.

Twenty-three formal Excess lists were sent to AEC. These lists contained 739 1tems valued at $\$ 748,191$.

During January material and equipment valued at $\$ 3,780$ were withdrawn from Excess Accounts for use on the project.

Organization and Fersonnel Employees on RoLI

$\frac{12-31-53}{271}$ 271 $\frac{1-31-54}{271}$

$\frac{\text { Change }}{0}$ 
PURCHASING AND STORES SECTION ADMINISTRATION UNIT JANUARY 1954

The following table shows the net dollar value of business, by cost category, and the number of procurement actions placed with different types of vendors.

January 1954

\begin{tabular}{rr}
\hline Cost Category \\
\hline$\$ 0-\$$ & 24.99 \\
$\$ 25-\$$ & 499.99 \\
$\$ 500-\$ \frac{24,999.00}{} \$ 25,000-\$ \mathrm{Up}$
\end{tabular}

Number of Actions

\begin{tabular}{|c|c|c|c|}
\hline $\begin{array}{l}\text { Government } \\
\text { Agency }\end{array}$ & $\begin{array}{c}\text { Smal1 } \\
\text { Business } \\
\end{array}$ & $\begin{array}{c}\text { Big } \\
\text { Business } \\
\end{array}$ & $\begin{array}{l}\text { Educational } \\
\text { and Other }\end{array}$ \\
\hline $\begin{array}{r}10.00 \\
401.73 \\
2,275.00 \\
-\quad-\end{array}$ & $\begin{array}{r}3,984.36 \\
112,648.78 \\
430,635.89 \\
51,499.00\end{array}$ & $\begin{array}{r}1,708.02 \\
41,268.24 \\
353,817.18 \\
537,209.85\end{array}$ & $\begin{array}{r}73.35 \\
85.52 \\
1.307 .41 \\
-\quad-\end{array}$ \\
\hline$\$ 2,686.73$ & $\$ 598,768.03$ & $9.37,003.29$ & $1,466.28$ \\
\hline
\end{tabular}

10
Vendors Contracts . . . . . . . . . 152

Damage Reports Processed ............ 1

Over \& Short Reports

Accounts Payable Pequecessed ....... 4

Difference SLfos rocessedandled ...... 263

Clearance Stips \&

Material Exception Reports Order Change Approvals . 199

Return Orders Issued..... 209

Shown below is a sumimary of the net value of procurement actions placed with vendors for manufactured or shelf Items in the states of Washington, Oregong
Idaho and Other Areas.

\begin{tabular}{|c|c|c|c|}
\hline State & Manufactusad & Shelf & Total \\
\hline $\begin{array}{l}\text { Washington } \\
\text { Oragon } \\
\text { Idaho } \\
\text { Other }\end{array}$ & $\begin{array}{r}471,715.55 \\
96,829.12 \\
665,865 . \overline{45}\end{array}$ & $\begin{array}{r}174,110.98 \\
59,969.44 \\
145.43 \\
71,288.36\end{array}$ & $\begin{array}{r}645,826.53 \\
156,798.50 \\
145.43 \\
737,153.81\end{array}$ \\
\hline Total & $\$ 1,234,410.12$ & $\$ 305,514.21$ & $\$ 1,539,124.33$ \\
\hline
\end{tabular}




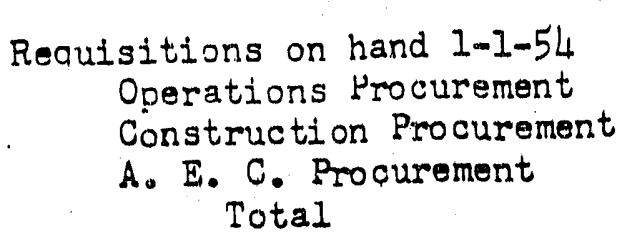

Requisitions Assinged during Jan. Operations rrocurement Construction Hrocurement A.E.C. Hocurement Total

Requisitions flaced during Jan. Operations Procurement Construction rocurement A.E.C. Procurement Total

Requisitions on hand $2=31-54$ Operations frocurement Corstruction Procurement A.E.C. Hrocurement Total

Purchase Orders Placed Operations Yrocurement Essential Material Construction Procurement Local Purchase Total

Value of Orders Placed Operations Hrocurement Essential Material Construction Procurement Local Purchase Total

\section{Alterations Issued HW Operations} Essential Material

HWC Construction Total

Value of Alterations Issued HW Operations Essential Material

HWC Construction Total

Government Transfers

Organization and Personnel Employees on Roll

\begin{tabular}{rrr}
$G$ & $\frac{D}{0}$ & Total \\
725 & 219 & 219 \\
0 & $\frac{37}{256}$ & $\frac{252}{1196}$ \\
\hline 215 & &
\end{tabular}

\begin{tabular}{rrr}
2179 & 0 & 2179 \\
0 & 307 & 307 \\
432 & 49 & 481 \\
\hline 2611 & $\frac{49}{2967}$
\end{tabular}

\begin{tabular}{rrr}
2085 & 0 & 2085 \\
0 & 373 & 373 \\
351 & 41 & 392 \\
\hline 2436 & 414 & 2850
\end{tabular}

$\begin{array}{lll}819 & 0 & 819\end{array}$

$153 \quad 153$

$\frac{45}{198} \quad \frac{341}{1313}$

$\frac{296}{1115} \quad \frac{45}{198}$ $\frac{\text { EWWC }}{1567} \quad \frac{\text { Total }}{1567}$

$\begin{array}{rr}28 & 28 \\ & 297\end{array}$

$\frac{61}{1656} \quad \frac{2}{299} \quad \frac{63}{1955}$

$554,863.87 \$ 554,863.87$ $439,796.15$ $439,796.15$

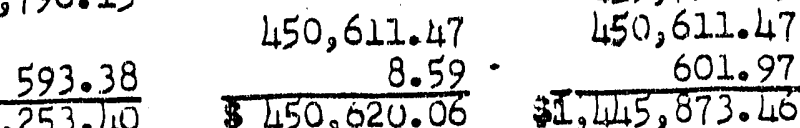
$995,253.40 \quad \$ 450,020.06 \quad \$ 1,445,873.40$ Increase -Decrease No Change Total $30-\frac{13}{4}-\frac{\text { Total }}{5}$ $\begin{array}{rrrr}7 & 4 & 0 & \frac{11}{23} \\ 23 & \frac{3}{60} & \frac{2}{6} & \frac{28}{90}\end{array}$

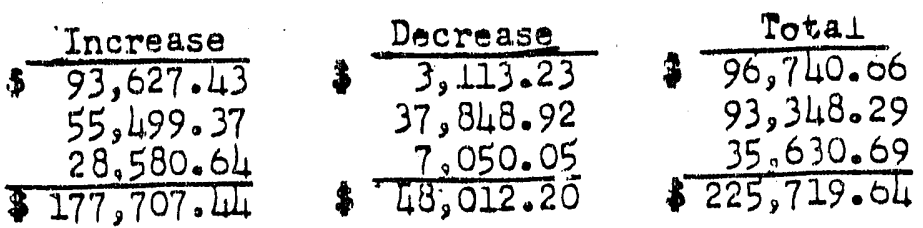
$\frac{\text { OR }}{\frac{12-31-53}{27}} \quad \frac{\text { ORC }}{\mathrm{s}-3} \quad \frac{1-31-54}{25} \quad \frac{\text { Change }}{-2}$ 

be paid. The rendor has been so advised but in is not in order, and should not we in Richland the week of February 8 to further has written us that he Furchase Order HWC-1616 on cancelied because of non-delivery of Supplies Co., Serttle, Washington, was was cancelled wi thout payment of cancellation charges. Project C-573, XXX-300 Area procurement was aut ing made to procure the material recuit was authorlzed, and overy effort is bethe time specified on the requisition. requisitions placed increased 7\%. Requisitions decreased $15 \%$ from December and less than at the end of December. Requisitions on hand at month end wers $30 \%$

Organization and Personnel

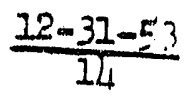

$$
\frac{1-31-54}{17}
$$
$\frac{\text { Change }}{+3}$

The high level of activity in this unit du the addition of 2 Buyers and an Expediter. 


\section{PURCHASTNG AND STORES SECTION

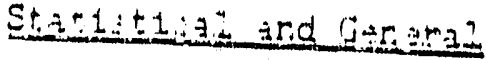

An additional very substantial inserse in workload occurred during fanuaryo tions receivod; November - 1817 four-month period show 0,tober - 1704 requi. open requalition load on hand, as of jer - 1959, and vanuary - 2179. The

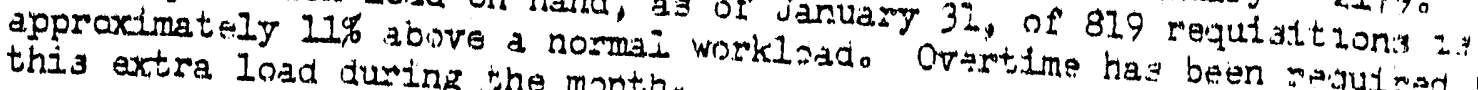
this extra load during the month

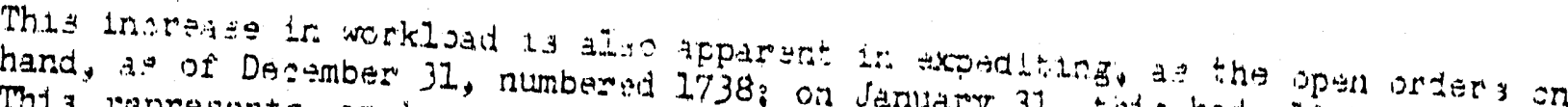

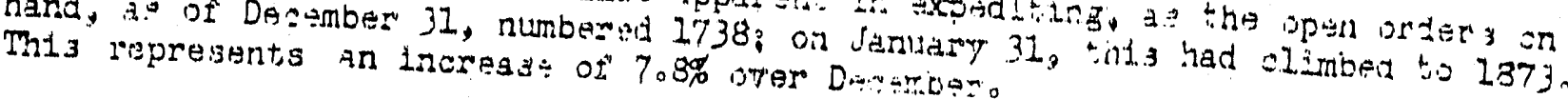

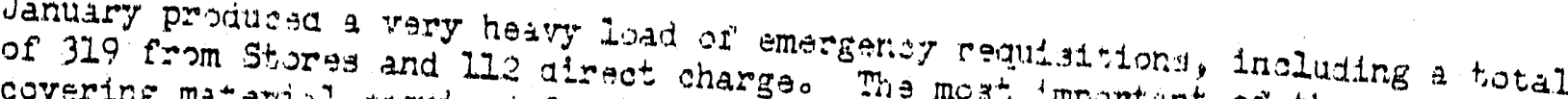
of 319 from St Jras and 112 direct chargoo Tha most importint or thoge wer: ta on ordar by January 32. and $i f$ had $3-x$ programo of thasa, 41 bad ben olater

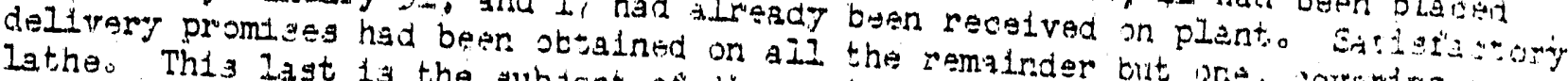

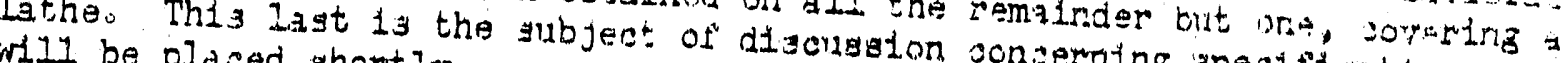
will be placed shortiyo

\section{Esgentiliz Material Contracta}

1. The following contracts have besn somplet $\Rightarrow d$ and aro in foros

Stieam Coal - Independent Coal and Coke Company and Kemmaror Coal

Hydratid Iime - U。 So Gyposum

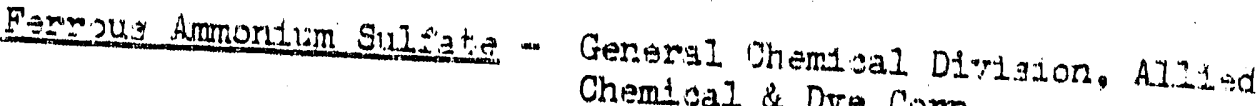
Chemidal \& Dye Corpo

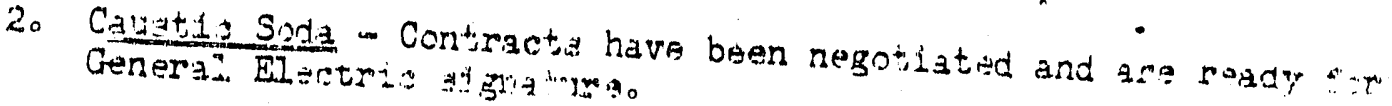

\section{Organization and Porannel -}

Employeas on roll
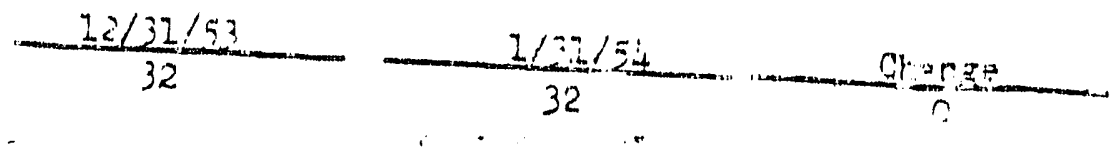


\section{PURCHASIIYG AND S'TORES SECIION \\ STORES UNIT \\ JANUARY 31. 1254}

A total of 50 Declaration of Excess documents containing $4 j 2$ items uf itandby materials valued at $\$ 51,535$ were prepared.

Kalser Engineers dispensed w1 th thelr Central Tool. Storage in White Bluffis which will result in a substantial excessing program of hand tools and supplies. Kalser Engineers also commenceu excessing automotive supplies valued at approximately $\$ 200,000$.

Twenty-three formal Txcess lists were sent to AEC. These lists contained 739 . 1tems valuua at $\$ 758,241$.

In the Excess Material and Equipment Accounts the following items are reported:

Disbursement by Store Order

Transfers to Inventories Offuite Shipments

Receipts
$\$ 72,823$

91,931

438,906

Project proposal ERA-748 for the Laboratory supply facilities in the 325 Building appears to be delayed as it has not yet been considered by the $A$ \& $B$ Committee. Pending action on this proposal we have been asked informally to supply delivery service in the 300 Area from our 3706 Storeroom to other buildings. The expense of such service would not be required if the project were pushed by its originators in the Tecnnical Section.

All office furniture in Warehouse \#12, Store Yard \# 2, has been moved and the balance of the furniture in Warehouse if 13 will be moved to Central Stores when transportation equipment is available.

A total of 154 construction purchase orders have been received which include operational spares for $\mathrm{K}$ Froject, Hurex and Redox. No material for $\mathrm{K}$ roject or Purex has been recelved as additional details still are to be worked out before the material is transterred to the Standby Warehousing -Sub-Undt.

Organization and Personnel Employees on RoLl $\frac{12-31453}{187}$

$\frac{1-31-54}{136}$

Chang 


\section{TRAFEIC TUIT}

Jatribury: 195 i.

STATIST:EAL AND CENERAL

As a raglit of rate roduotionz obtained from the oarmlerg, there was a total savings

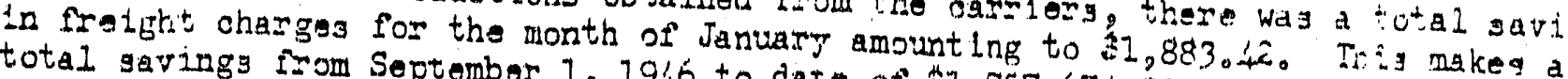
1 , 1946 to dat of $1,757,674000$.

Savinge P.oogrt

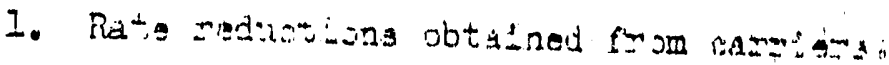

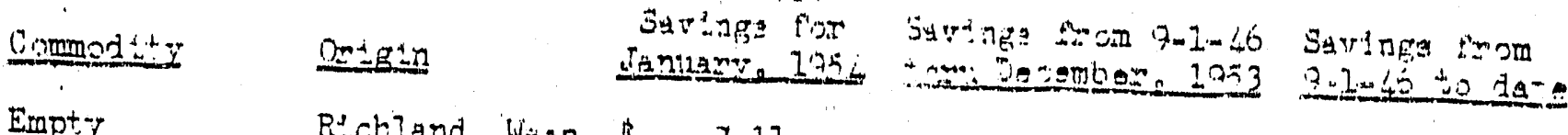

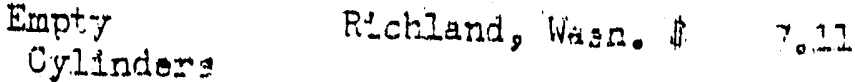

Extrusiona, Phoeniz, Ariz. 34.45

Aluminum

Curbon Dioxide Yakt Wasbo 20.50

Limestone Angonito Utah 640.00

Machinery Los Angeles, Cil. 267.34

Sulfeme Acta Crasse11:, N.J. 713.42

2. Frolght B111 Andzt 1.383 .42

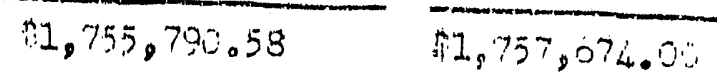

3. Logs \& Damago \& Over-

$11, .79$

116.152 .64

$116,850.43$

onarge Clains

408.26

$135,726.96$

136.135 .25

4. Mokot Rofund Clyims

$\sin .02$

34.567 .34

35.020936

5. Hnsehold Goods Claims

Wonk Talume Roonrt,

$$
\frac{1 \times 9.66}{\$ 3,767.15}-\frac{17,399.14}{10.059,636.66} \text {. } 17.0230 .80
$$

Completod Travel Requesto

Resertrajtons resulting from abora.

$\operatorname{Rin} \pm 1$

$A \pm=$

$1+3$

Hote 1

Expense Accounts Chocked

Pougehold Coody \& Autumoblies 
PURCHASTNO \& STORES SECTION

Wank inlime Recon- (cont,)

Ticket Refund Claims

Filod

Collooted - Number

21

Collectiod - Amourt

$\$ 642.02$

Froight Claims

Fsided

Collacted - Nurbar

Collooted imoun"

Dreser and Shomt 3 Procesosd

Damigo Eepjorts Procosiged

5
5
408025
11
12

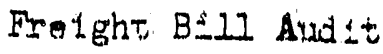

Frolght Shipments Traoed

$\$ 704.79$

Quot.a:10n3

Frsignt Rates

Routies

B11Ls Approved

A土- Expray

Boat

Carloading

Expromis

Rail

Truck.

Carload Shipments

Inbound

Outbound

Regont of Carloeds Rogelved

\section{Commodity}

A1- Fi1:ers

Aluminum Sulphyte

Anhyduras Hydroflourio Actd

Aspha.lt, Liquid

Cablo

Caratia Scda

Cor 1

Elentrac Motous

Funnace Linery

Lime

Limer sok

Methanol

Mothyl Isobutyl Ket, no

Nitr=o Aold

Nitrate of Soda

Palilet.3

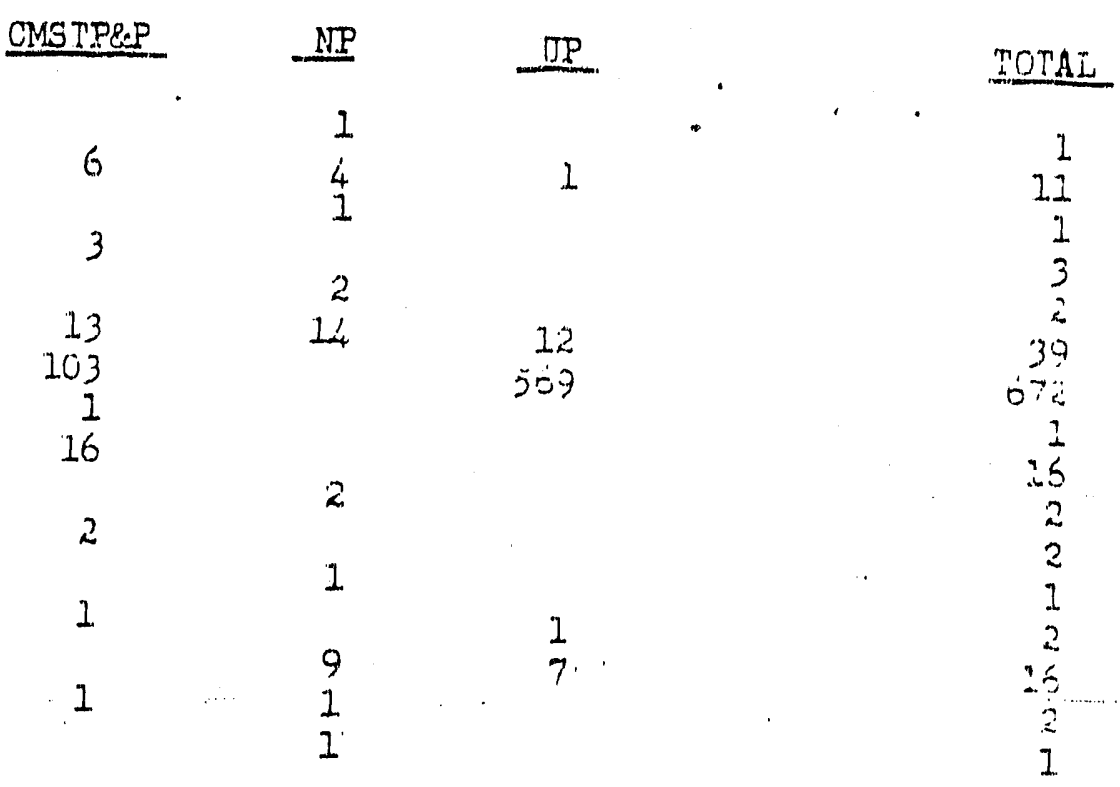

Jboug 
PURCHASING \& STORES SECTION

$$
\frac{\text { TRAEFIC UNTT }}{\text { January, } 1954}
$$

Recort of Carlogds Received (cont.)

Commodity

Paliets

Phogphoric Acid.

SaIt

Soda Ash

Steel Containers

Steel Plates

Sulfamic Acid

Trichlorethylone

$$
\text { Total }
$$

Onganization \& Personne 1

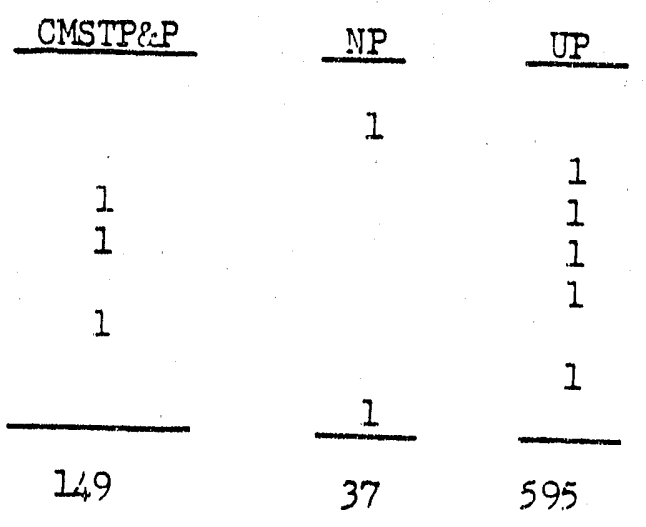

TOTAL

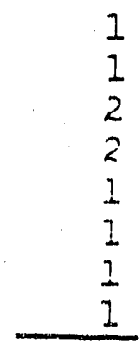

781

$\frac{12-31-53}{9} \quad \frac{1-31-54}{9} \quad \frac{\text { Change }}{0}$




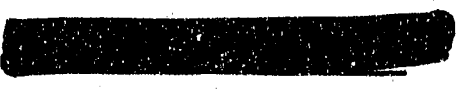

$\mathrm{HW}-30724$

\section{TRANSFORTATION SECTION \\ MONTHILY REPORT \\ January 1954}

GENERAL

Transportation Section personnel forses decreased from 500 to 493 by two new hires, three transfers in, one reactivation - personal 11lness, three terminations, and ten transfers out. This includes the reduction of nine Bus Drivers on January 18 which was primarily made possible by the addition of twenty-two 53-passenger buses to the Plant Bus System to replace 4l-passenger buses. A minimum arinual cost reduction of approxinately $\$ 60,000$ will be realized from decreased expenditures for salaries, continuity of service, all wheelage (fuel, tires, parts).

The Transportiation Sєetion experienced an unusually heavy work load under adverse conditions from the heavy snowfalls and abnormally low temperatures which began on January 15 and continued for several days. Plant roads were kept open and sanded permitting buses and other vehicular equipment to render necessary services on satisfactory schedules. This accomplishment required the integrated resources and teamwork of all Transportation Units.

A Bus Driver sustained a major injury on January 23 while performing wrecker services on Route 4-S north of the 300 Area. The employee was struck above the right Eye by a drun crank while attempting to lower a nickup truck which was attached to the wrecker track. The pickup truck had been at rest on the snow before suddenly breaking through and forcibly pulling the crark from the injured's hand. The employee was hospitalized for observation and treatment.

The Transportation Section was assigned landlord responsibility for the Plant Controlled Area (600 Area) on January 1. Expense codes and work orders have been issued to provide necessary maintenance and a continuation of required services. Costs are being accumulated by type of service for each facility. This procedure will facilitate the preparation of the annual landlord report.

Mr. Fred D. OBerg, Equipment Section, Division of Construction and Supply, Washington, D.C. and local A.E.C. officials made a tour of transportation facilities during week ending January 31 in connection with an A.E.C. survey of motor vehicle management at Hanford. Informal discussions were held with Transportation officials during this period preparatory to the requesting of written data which were furnished on January 29. This information largely corered data relative to inventory, utilization, and assignment of passenger carrying motor vehicles; policy guides and practices including sample forms utilized in eaulpment operational and maintenance activities; ralue of spare parts in inventory including statistical infornatior. per unit and type of equipment, etc. and a narrative resume of parts stocking procedures: coples of representative cost and utilization studies. Copies of all material submitted werg retained in Transoortation files.

Completed estimates and narrative justifications on personnel requirements and overtime hours for all budget units of the Transportation Section from December 31, 1953 through June 30, 1956. This information was furnished to the Financial Department for the preparation of the FY 1956 Operating Budget and the revision of the FY 1955 Operating Budget.

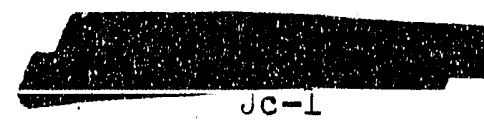




\section{Trans ortation Section}

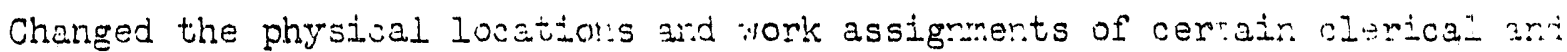

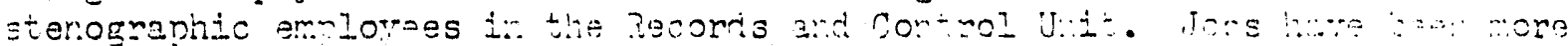

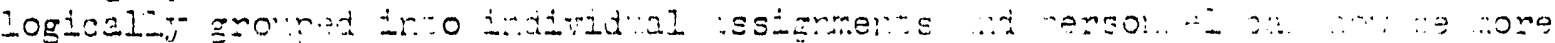
eifectively litilized in line vizh their job classificauions ard gereral capabilities. The new arrargement appears to be more compatible ard is resulting in greater over-all output and improved efficiencr.

Constmaction of the Corsolidated Transportation Facility progressed only from 18.97\% on December 24 to $20 \%$ on january 22 because of the carpenter strike from January 4 until january 18 and inclement weather conditions. This compares with the scheduled progress of 24,0 but there is little donbt that the setbacks will be overcome if :0 further delays occur.

\section{RAIIROAD ACTIVITIES}

Commercial cars handled during January decreased $8.77 \%$ over December primarily because of reduced receipts of coal and constmiction materials. The following recapitulation indicated the distribution of commercial cars handled:

\section{Carload Movements - Loads In Fmoties In Loads Out Fmpties Out}

General Electric Company

A. E. C.

A.E.C. - Kaiser Engineers

Blaw-Knox

Gassland Construction Co.

Granston Inc.

Grove, Shepard, Wilson \& Kruge

Haughton Elevator Co.

L. H. Hof fman Co.

Kalser Engineers

P. S. Lord

D. V. LLbby \& Co.

Soule Steel Co.

Sound Construction Co.

Steel Construction Co. Thome \& Marble Co.

U. S. Army

Wayne Construction Co.

$\begin{array}{rrrr}836 & 12 & 13 & 826 \\ 9 & 1 & 1 & 10 \\ 27 & - & - & 23 \\ 28 & - & - & 22 \\ 1 & - & - & 1 \\ 1 & - & - & - \\ 2 & - & - & 2 \\ 2 & - & - & 2 \\ 1 & 1 & 1 & 14 \\ 165 & - & - & 1 \\ 1 & - & - & 2 \\ 3 & - & - & 5 \\ 8 & - & - & 3 \\ 3 & - & - & 14 \\ 3 & - & - & 2 \\ 1 & 14 & 15 & 1,064 \\ 20 & 15 & & 1\end{array}$

Process service during January was curtalled by production difficulties and actual cars handled decreased $32.76 \%$ over December.

Total car movements including process service totaled 2,545 in January compared to 3,132 in December.

Completed accident damage repairs to Motor Car 1OE-3660 which was involved in the munaway and derajiment of four cement hopper cars on June 2, 1953. AII repairs connected with this incident have been physically completed and will be financially closed in February. Total charges approximating $\$ 3,300$ will be billed to the construction oontractor by the Atomic Energy Conmission. 
Transportation Section

\section{AUTOMOTIYE ACTIVITIES}

The Plant Bus System transported $6.79 \%$ more passengers in January than in December. Increased passenger volume resulted directly from adverse weather conditions. The following statistics indicate the magnitude of service rerdered:

$$
\begin{array}{lc}
\text { Passenger volume } & 146,828 \\
\text { Revenue - bus fares } & \$ 7,341.38 \\
\text { Earnings - transit advertising (December) } & \$ 119.95 \\
\text { Bus trips } & 6,806 \\
\text { Bus miles - passenger carrying } & 159,400 \\
\text { Passenger miles } & 4,346,969
\end{array}
$$

Developed and submitted for consideration a proposal on Patrol Bus Service which would reduce bus operating costs by approximately $\$ 38,000$ annually.

The Richland Bus System transported 36 less passengers in January than in December. One booster bus was placed in temporary service on the Cedar route (8:00 AM and 8:30 AM trips only) to better handle the heavy volume of school children during the inclement weather. The following statistics indicate the volume of service rendered:

$\begin{array}{lc}\text { Total passengers including transfers } & 13,387 \\ \text { Revenue - bus fares } & \$ 839.67 \\ \text { Earnings - transit advertising (December) } & \$ \\ \text { Bus trips } & 1,155 \\ \text { Bus miles - passenger carrying } & 6,122 \\ \text { Passenger miles } & 25,988\end{array}$

Off-Plant chauffeured automobile trips (Company business and/or official visitors) totaled 131 which were rendered to the following locations as indicated:

$\begin{array}{lr}\text { Benton City, Washington } & 3 \\ \text { Enterprise, Washington } & 1 \\ \text { Hinkle, Oregon } & 9 \\ \text { Kennewick, Washington } & 13 \\ \text { Outlook, Washington } & 2 \\ \text { Pasco, Washington } & 70 \\ \text { Pendleton, Oregon } & 21 \\ \text { Prosser, Washington } & 2 \\ \text { Sunnyside, Washington } & 4 \\ \text { Walla Walia, Washington } & 1 \\ \text { Yakima, Washington } & 5\end{array}$

The following tabulation indicates the volume of fuel distribution by Equipment Maintenance personnel:

Stock at start of month Received during month Dispensed during month Stock at end of month

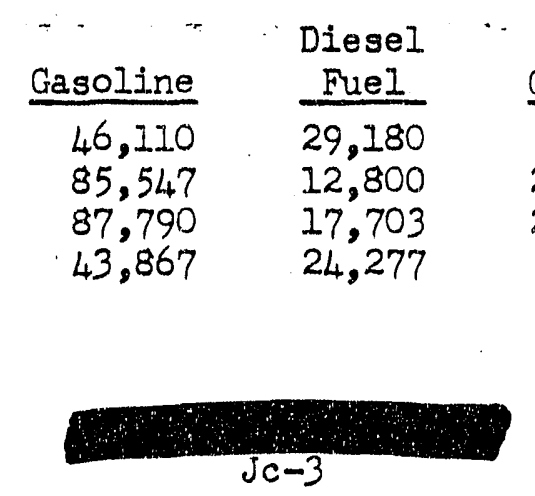

50
Cetane
24,300
24,400
23,200
5,500

White

$\frac{\text { Kerosene }}{1,216} \frac{\mathrm{Gas}}{409}$

4,016

2,282

2,950
0

14

14
395 


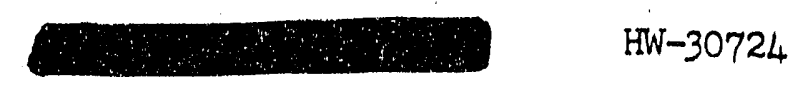

Transportation Section

The following tabulation indicates the volume of inspection and mainterarce service rendered to Hanford Atomic Products Operation automotive and heav, equipment by Equipment Malntenance personnel:

\begin{tabular}{|c|c|}
\hline $\begin{array}{l}\text { Motor overhauls } \\
\text { Class A Inspections and Repairs } \\
\text { Class B Inspections and Lubrications } \\
\text { Semi-monthly Inspections - buses } \\
\text { Weekly Inspections - fuel trucks and } \\
\text { off-Plant vehicles } \\
\text { Other routine maintenance repairs and } \\
\text { service calls } \\
\text { Accident repairs and paint jobs } \\
\text { Tire repairs } \\
\text { Wash jobs }\end{array}$ & $\begin{array}{r}2,470 \\
40 \\
493 \\
372 \\
\end{array}$ \\
\hline & \\
\hline
\end{tabular}

The following tabulation indicates the Plantwide usage of automotive equipment:

\begin{tabular}{llrr} 
Code & Type & No. of Units & Total Mileage \\
\cline { 2 - 3 }$I A$ & Sedans & 337 & 580,889 \\
IB & Buses & 102 & 264,911 \\
IC & Pickup Trucks & 460 & 259,244 \\
ID & Panel,Carryal1, Station Wagons & 153 & 166,701 \\
IE & Armored Cars & 3 & 164 \\
IG & Jeeps & 2 & 280 \\
68 Series & Trucks & 204 & $\frac{95,066}{1,367,255}$
\end{tabular}

Completed the testing and setting of safety valves on air brake tanks for the sixty-two GMC coaches.

The severe cold and heavy snowfall required all garage facilities to devote a sizeable portion of their time in starting equipment, installing.and repairing tire chains, and other related work.

Supervisory responsibility for the 100-B Garage was transferred to L. E. Jones from J. L. Perry effective January 40. This will permit Mr. Perry to better serve the increasing workload of the 200-East and 200-ivest Areas.

Representatives of the Inventory Accounting Unit and the Transportation Section completed the physical inventory of fuels and lubricants on January 20 as scheduled. A member of the Internal Audit Unit was in attendance as an observer. Reconciliatory work is still in progress but tentative results indicate considerable improvement over the previous physical inventory of January 23, 1953.

A new document control procedure was placed into effect concurrent with the physical inventory of fuels and lubricants on January 20. All documents utilized in recording aisbursements are pre-numbered in consecutive order

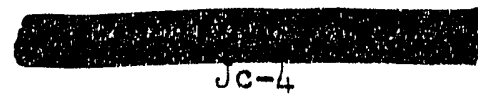


$H W-30724$

Transportation Section

with a separate series for each area or disbursing point. A numerical control register is being maintained at the 1131 office to indicate the receiving date from the field for each document. This register will also readily reflect any missing documents to facilitate whatever follow-up action may be necessary. All documents are formally transmitted from the 1131 office through each step of processing by the General Cost Unit, Inventory Ascounting Unit, and the Computing Unit. This procedure provides maximum accountability of all documents. Discussions are in progress with respect to a continuous audit of IBM disbursing records with actual disbursing documents. This would be performed by the General Cost Unit or the Inventory Accounting Unit. Variances from this source in the past have been reflected as physical shortages or overages by the Transportation Section whereas in several instances they actually represented only IBM key punch errors.

\section{LABOR ACTIVITIES}

The weed control spraying of shoulders and center strips on the Plant primary roads which was begun in December has been deferred until weather conditions are more favorable.

Road maintenance personnel were engaged in covering contamination in the vicinity of the 200-West Area from January 6 until January 18 when inclement weather forced a temporary shutdown. This work to date has consisted of seal coating approximately four miles of paved 20 roadway requiring 37.25 tons of MC5 oil, 480 cubic yards of $\frac{1}{4} "$ rock, and 805 man-hours. A second job requiring the covering of approximately ten acres of non-surfaced areas in the vicinity of the Redox Facility was begun on January 13. Pit-run gravel was hauled into this area and spread to a depth of approximately 6". The work was halted on January 22 by operational personnel with approximately two acres being completed requiring 363 man-hours.

The following is a resume of activities during January connected with the 600 Area:

Several. requests of a routine nature, such as broken windows, ceiling repairs, additional heating units, were processed during the month of January; but, most efforts were directed toward evaluation of over-ali responsiblifties and establishing working relationships with those units which will be directly concerned with the future plans for the gerieral cleanup of the 600 Area.

A survey, of all locations where buildings or material have been sold, was made with a representative of the Stores Surplus Sales Unit to estimate the cost of cleanup of debris left on site by the purchasers. The Atomic Energy Comnission has indicated that they will provide a work order for this part of the site cleanup. Also a survey of ail existing buildings which are to be sold or destroyed was completed with a representative of the Atomic Energy Commission and the Stores Surplus Sales Unit in regard to requirements of site cleanup by successful bidder, and the designation of those structures which will not be sold and can be demolished and burned.

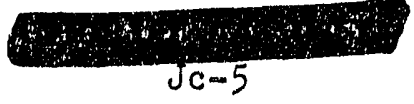


Tral:sportation Section

The Safety and Fire Protection Unit has been contacted regarding the burring or material at various locations and have 1: dicated their desire to furnish personnel and equipment as required.

Arrangements have been completed with the Security and Patrol Unit to discontinue the use of the Patrol storage boxes located at area road intergections. Barricade material of a different type will be carried in each patrol vehicle.

The cooperation extended by all units involved indicates a sincere interest In the problem of good housekeeping for the 600 Area.

Maintenance of primary roads (excludes snow removal) required 906 man-hours: walkways, parking lots and related ground maintenance in the Manufacturing Areas reauired 48 man-hours.

Sanding operations and snow removal on the Plant primary roads and for the Administration Area required 1,280 man-hours. Snow and ice control crews were on continuous duty from January 15 through 21. This work reauired five patrol blades, three snow plows, three sand spreader equipped trucks, four regular dump trucks, and approximately 1,600 yards of sand.

The following tabulation indicates in tons the volume of road asphalt material handled by Road Maintenance personnel:

$\begin{array}{lcc} & \text { MC } 3 & \text { MC } 5 \\ \text { Stock at start of month } & 0 & 105.62 \\ \text { Received during month } & 115.51 & 0 \\ \text { Used during month } & 3.1 .60 & 25.65 \\ \text { Stock at end of month } & 83.91 & 79.97\end{array}$

The following tabulation indicates the volume of road aggregate materials handled by Road Maintenance personnel.s

Stock at start of month Made during month Used during month stock at end of month

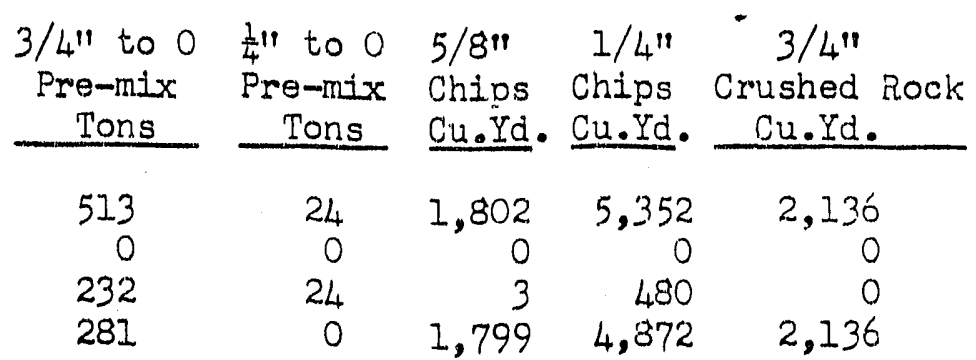




\author{
February 4, 1954 \\ ELECTRICAL DISTRIBUTION AND TRIEPHONE SECTION \\ MONTHLY RRPORT \\ January, 1954
}

GENGRAL

The Section total work force was one hundred and sixty-eight (168) as of January 31 , 1954, a decrease of one from last month.

Process power peak demand for January:

$1-20-54(8: 30 \mathrm{AM}-9: 00 \mathrm{AM}) \quad \frac{\text { Demand KW }}{116,125} \quad \frac{\text { December Comparative KW Demand }}{116,147}$

Four additional employees of this section will attain optional retirement age during the year 1954. Two telephone journeymen and one substation operator would be replaced by trainees and an Electrical Squioment and Methods Analyst would not be replaced should they elect to retire.

In accordance with Management decision, two draftsmen who were on loan from the Engineering Department to this Section were transferred to our rolls effective January 4 .

There was no production loss dus to electrical outages, nor any telephone service interruption during this month in which the systems have experienced the most severe weather conditions since 1950.

EIECTRICAL DISTRIBUTION UNIT

Maintenance and Operation

The major inspection and maintenance of the $230 \mathrm{KV}$ system continued for eight days under Critical Power arrangements before inclement weather halted this work.

The following incidents resulted in minor power interruptions but no lost production during the month:

On January 16, and on two later occasions, steam from 1.07-D and 107-H caused 1 ce to form on power and communication lines near the basins, threatening service. The advisability of underground service at the se locations is being studied.

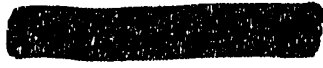

$J d-1$ 
ELECTRICAL DISTRIBUTI ON UNIT

HW- 30724

Maintenance and Operation (Continued)

An automobile struck a $66 \mathrm{KV}$ line pole near North Richland on January 16 tearing two phases fram their tios necessitating replacement of the cross arm and two insulators.

On January 20, automatic splicing sleeves at four locations on striet and flood light circuits falled, probably due to improper installation plus the cold weather. Trucks became contaminated at $202-5$ and were tiad up one and one-half days for cleaning.

Two tubes failed on January 23 in the 251 substation transmitter on the carrier to the 151-F $230 \mathrm{KV}$ line section necessitating call-out for checking and replacement.

System Fixpansion and Planning

Preliminary investigation into location of the now 190-B annex for the increased water plant project indicates a major site clearance problem and an eventual required outage to the 190-B and 105-B buildings. The same condition will probably exist in $100-D$ and $100-\mathrm{F}$.

TELEPHONF UNIT

The new separate telephone directories for Richland Community and for official plant were distributed during January.

The Anderson-Torreta Company of Walla Walla was awarded the contract for installation of a telephone and fire alarm tie cable between North Richland and the RIchland sixth housing addition on their low bid of $\$ 4484.00$. Completion is specified as thirty days after notice to proceed.

An APC letter to the Engineering Department requests drawing revisions on the official telephone exchange in order that a design contract may be submitted for bid. The letter now locates the building at the 706 Laboratory site.

Maintenance and Operation

An eleven pair entrance cable, a larger capacity cordless switchboard, and rewiring were installed in the Seattle-First National Bank in conjunction with their remodeling program.

The Plant Imergency officer switchboard and all cornecting circults for telephone, radio, and alarms were transferred from the $770-B$ Building to the 703 Bullding basement.

System quxpansion and Planning

Approximately 125 feet of 101-pair cable was replaced with 404-pair cable in order to make cable pairs avallable for the Richland-North Richland tie cable.

Work was begun on the installation of a 50-Iine, Wh-trunk switchboard at the C1vil Defense Control Center, 703 Building, and a 12-line, 5-trunk switchboard in the Mobile Control Center.

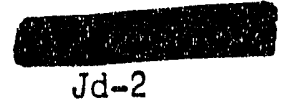


TPLT,FH ONA, UNIT

HW- -30724

System Gxpanston and Planing (Continue(1)

Completed work inoreasing the 300 Area telephone exchange capacity from 400 to 500 11nes. Over 215 telephone trangfers to the $325,326,328$ and 3702 bulldings were made in confunotion with this and the area expansion program.

In proparation of the offlotal exohange, a traffic trunking diagram and a new floor plan were prepared, the equipment speotflications were revised, and the traffio study report was completed.

A sumary of telephone service is as follows:

\begin{tabular}{|c|c|c|c|c|c|c|}
\hline & $\begin{array}{c}\text { Subsorth } \\
\text { In }\end{array}$ & $\begin{array}{l}\text { Stations } \\
\text { vico }\end{array}$ & $\begin{array}{l}\text { Lines } \\
\text { For } \\
\end{array}$ & $\begin{array}{l}\text { Avallable } \\
\text { Service } \\
\end{array}$ & $\begin{array}{l}\text { Sldes Avallablo } \\
\text { For Service } \\
\end{array}$ & $\begin{array}{l}\text { Wxohange Ines } \\
\text { In Se rvice }\end{array}$ \\
\hline & $\begin{array}{l}\text { Res. and } \\
\text { Miso. }\end{array}$ & offlelal & & & & \\
\hline $\begin{array}{l}\text { RIchland } \\
\text { N. RIchland } \\
\text { Procoss Areas }\end{array}$ & $\begin{array}{r}5980 \\
355 \\
5 \quad 24 \\
\end{array}$ & $\begin{array}{r}983 \\
228 \\
1764 \\
\end{array}$ & & $\begin{array}{r}48 \\
172 \\
3 / 44 \\
\end{array}$ & $\begin{array}{r}286 \\
35 \\
-- \\
\end{array}$ & $\begin{array}{r}3973 \\
428 \\
1608 \\
\end{array}$ \\
\hline Total & 6359 & 2975 & & 564 & 321 & 6009 \\
\hline
\end{tabular}

Richland Exchange four-party serv1ce:

January 23,1954

December 23, 1953

Number of Subscrtbers

1144

1132

Number of Vacant Sides

164

152

Ninety-two :92) new requests for residential telephone service were recelved, makling the baoklog four hundred and forty-four $(444)$.

Service orders during the month were a.s followo:

Restdential and comercial

offictal (permanent)

offlolal (temporary)

Total
- 265

261

66

592.

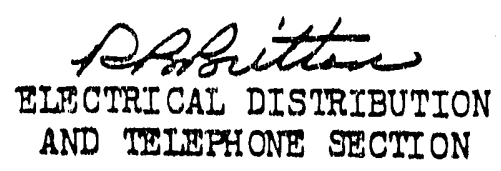

RB BAtton:MAW:ag

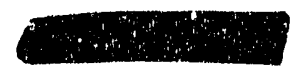

Jd-3 
RLECIRICAL DISTRIBUTION AND TTISTHONP, SFCTION

$H W-30724$

FOR MONTH FINDING JANUARY 31, 1954

744.40115

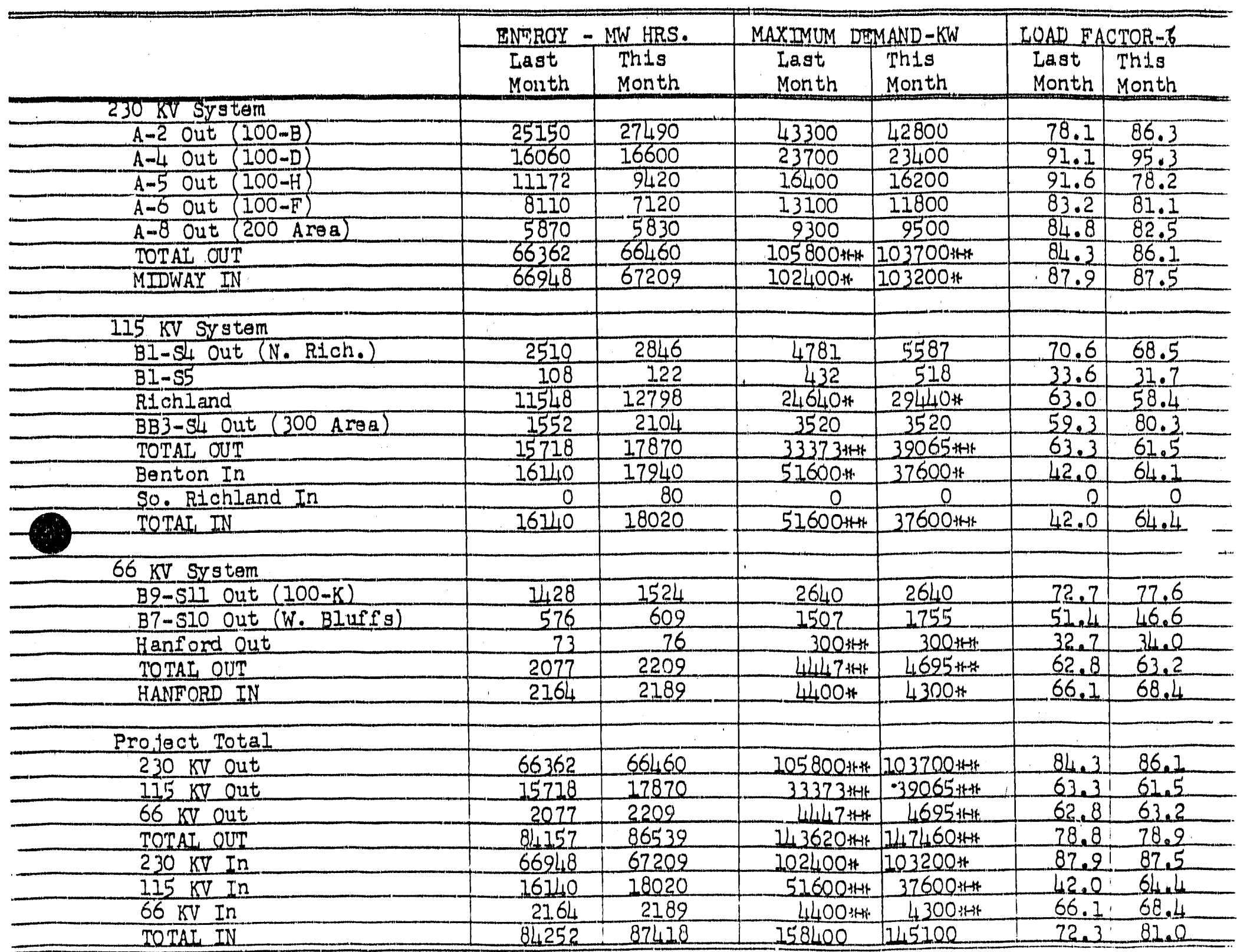

* Denoteg Colnciderital Demand

* Denotes Non-Colncidental Demand
Avarage Power Factor-230 kV Syatem Average Power Factor-115 KV system Average Power Factor... $66 \mathrm{KV}$ system 90.6 92.4 90.7 

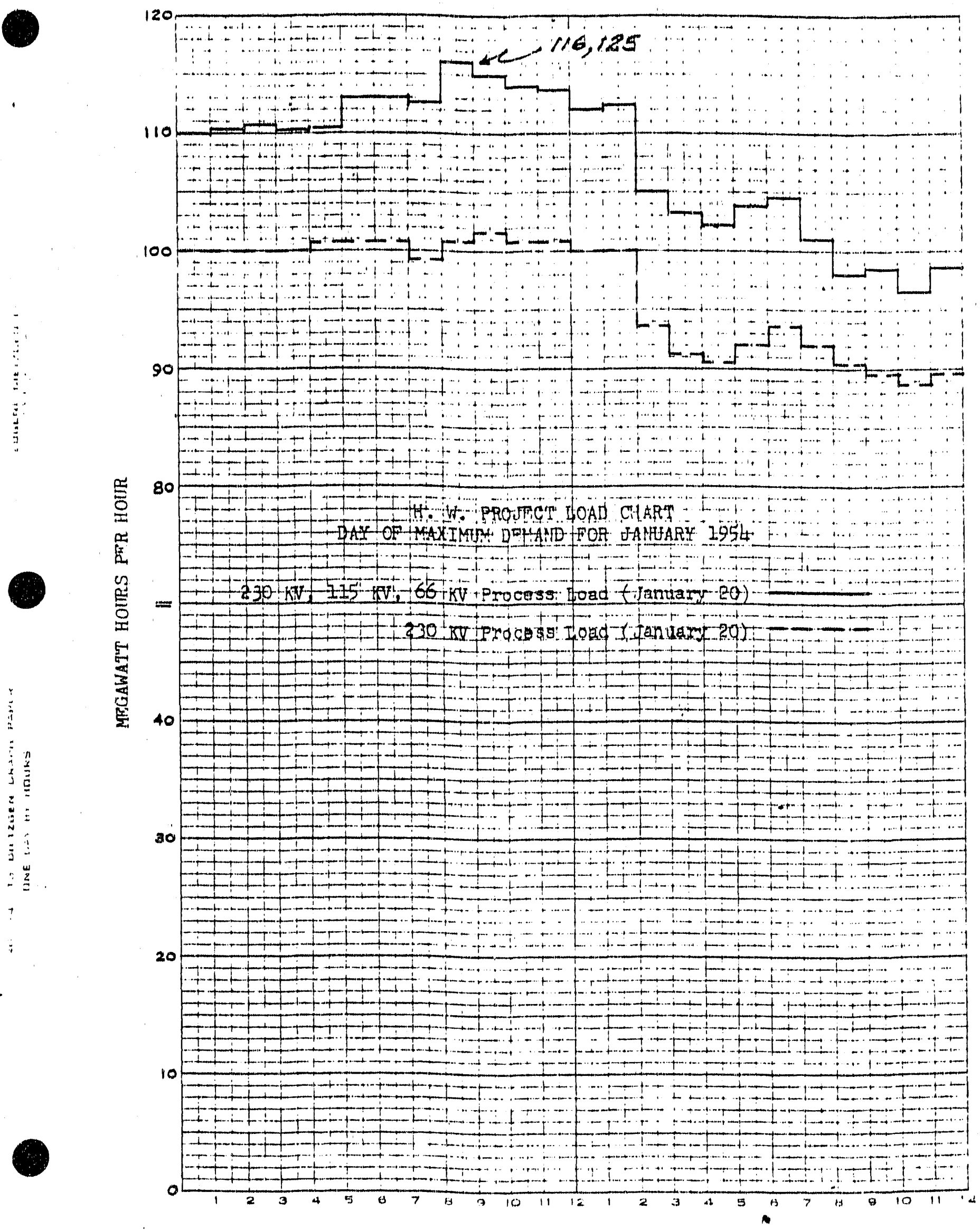


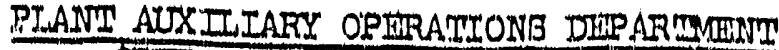

DPERATIONS ANALISIS SECTION

\section{MONLELY FREORT - JANUAFY, 1954}

\section{Personnel Stat1stias}

Followling is the month end surmary of personnel.

Operations Analysis Sectlon

$$
\text { As of 12-31-53 As of 1-31-54 Net Change }
$$

Unit

General

Applied Mathematios

Computiling

Grephica

Procedures

TOTAI

Ex Non-Ex 1otal Ex Non-Ex Total Ex Non-Ex Total

\begin{tabular}{|c|c|c|c|c|c|c|c|c|}
\hline $\begin{array}{r}1 \\
19 \\
8 \\
1 \\
11 \\
\end{array}$ & $\begin{array}{r}1 \\
6 \\
40 \\
11 \\
4\end{array}$ & $\begin{array}{r}2 \\
25 \\
48 \\
12 \\
15 \\
\end{array}$ & $\begin{array}{r}1 \\
20 \\
8 \\
1 \\
11 \\
\end{array}$ & $\begin{array}{r}1 \\
6 \\
43 \\
10 \\
4\end{array}$ & $\begin{array}{r}2 \\
26 \\
51 \\
11 \\
15\end{array}$ & $\begin{array}{r}0 \\
11 \\
0 \\
0 \\
0\end{array}$ & $\begin{array}{r}0 \\
0 \\
+3 \\
-1 \\
0\end{array}$ & $\begin{array}{r}0 \\
+1 \\
+3 \\
-1 \\
0\end{array}$ \\
\hline & & 102 & 41 & 64 & 105 & +1 & 42 & 7 \\
\hline
\end{tabular}

Applied Mathematios Unit

\section{As of 12-31-53 As of $1-31-54$ Net Change}

Staet

Admlnlstrative Btatist1.cs

Technical Statistics

Mathematical Anglysis

Numerical Analysis

Ex Non-Ex Dotal Ex Non-Dx Notal Nx Mon-Ex Dotal

TOTAL

\begin{tabular}{|c|c|c|c|c|c|c|c|c|}
\hline $\begin{array}{l}1 \\
5 \\
3 \\
3 \\
7\end{array}$ & $\begin{array}{l}3 \\
0 \\
2 \\
0 \\
1 \\
\end{array}$ & $\begin{array}{l}4 \\
5 \\
5 \\
3 \\
8 \\
\end{array}$ & $\begin{array}{l}1 \\
5 \\
3 \\
3 \\
8 \\
\end{array}$ & $\begin{array}{l}2 \\
0 \\
2 \\
0 \\
2 \\
\end{array}$ & $\begin{array}{r}3 \\
5 \\
5 \\
3 \\
10 \\
\end{array}$ & $\begin{array}{r}0 \\
0 \\
0 \\
0 \\
1.2\end{array}$ & $\begin{array}{r}-1 \\
0 \\
0 \\
0 \\
11\end{array}$ & $\begin{array}{r}-1 \\
0 \\
0 \\
0 \\
62\end{array}$ \\
\hline 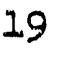 & & 25 & 20 & 6 & 26 & 1 & 0 & 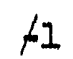 \\
\hline
\end{tabular}

During the month one secretary terminated voluntarliy, and one funlor englneer and one technologlst were resct1vated after 1 Iness and pregonacy leaves, respect1vely.

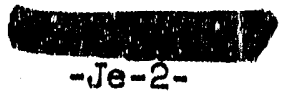


HW- -30724

Computing Injt

$$
\text { As or } 12-31-53 \text { As of } 1-31-54 \text { Net Change }
$$

Ex Non-Ex Total Ex Non-Ex Thtal Ex Non-13x Total

\begin{tabular}{|c|c|c|c|c|c|c|c|c|c|}
\hline $\begin{array}{l}\text { Stafe } \\
\text { Aud1t \& Control } \\
\text { Kay Punchtng } \\
\text { Machlre Processing }\end{array}$ & $\begin{array}{l}1 \\
1 \\
1 \\
5\end{array}$ & $\begin{array}{r}0 \\
6 \\
14 \\
20\end{array}$ & $\begin{array}{r}1 \\
7 \\
15 \\
25\end{array}$ & $\begin{array}{l}1 \\
1 \\
1 \\
5\end{array}$ & $\begin{array}{r}0 \\
6 \\
17 \\
20\end{array}$ & $\begin{array}{r}1 \\
7 \\
1.8 \\
25\end{array}$ & $\begin{array}{l}0 \\
0 \\
0 \\
0\end{array}$ & $\begin{array}{r}0 \\
0 \\
+3 \\
0\end{array}$ & $\begin{array}{r}0 \\
0 \\
43 \\
0\end{array}$ \\
\hline TOMAL & $\varepsilon$ & 40 & 48 & 8 & 4.3 & 5.1 & 0 & 1,3 & 13 \\
\hline
\end{tabular}

Three key punch operators were hired durlng the month of January.

Graphlog Intt

$$
\text { As of } 12-31-53 \text { As of } 1-32-54 \text { Net Change }
$$

Ex Non-Ex Total Ex Non-Ex Dotal Ex Non-Ex Dotal

Staff

Illustrators

Araphic Designer

TOMAI

\begin{tabular}{lll}
1 & 1 & 2 \\
0 & 8 & 8 \\
0 & 2 & 2 \\
\hline
\end{tabular}

$1 \quad 21 \quad 12$

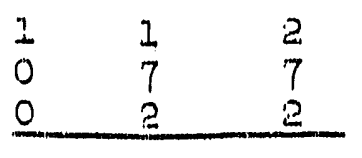

$1 \quad 10 \quad 11$

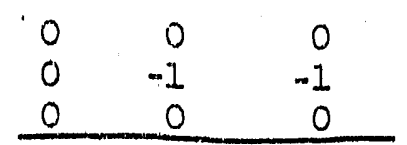

$0 \quad-1 \quad-1$

One graphle 1llustrator terninated during the month of January.

Procedures Untt

\section{As of $12-31-53$ As of $1-31-54$ Net Ohange}

Exx Non-Ex Motal Ex Non-Ex Total Ex Non-Ex Total

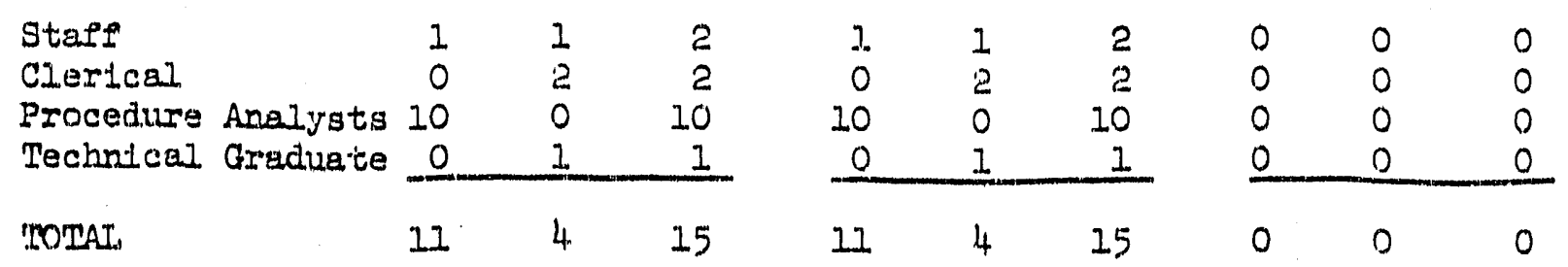




\section{FOR THE MANTJPACTURING DEPARTMMENT}

The final calculations pertalning to the reorlficing of T-Reactor have been completed. The calculations were deslomed to reflect operating conditions at the time of reorlfleing as accurately as posalbl.e. January discharges were accounted for, and new fllm constants supplied for tubes whose flow characteristics wovld be altered appreciably by discharging or 1ncreasing water flow. Several master listiogs of all calculations were made, and, in addition, working I1sts prepared for reference use in making the necessary instrumentation changes. Considerable effort was expended in making these reports avallable to the area eng1neers in time for the reorlficing shutdown. However, this effort is more than compensated for by the savings realized in holding down time to a minimum.

At the request of the Process Improvement Group, an analysis of the recent reorlficing of C-Reactor was made. Of primary interest in this comparison between the predicted and observed values of the panellit pressures following startur w1 th the new orlelice pattern. To obtain this information severai sets of recent data from C-Reactor were comblned. The results of this analysis indicate that a remarkably good prediction was made. Unforturiately, it is not possible to make an accurate estimate of the savings realized by making predictions by machine rather than by intultion. However, enough experience has been accumulated by now to indicate that the savings were considerable.

The first report on panellit gauge calibrations at D-Reactor has been completed. The report is intended to keep a running record of the status of all panellit gauges on this reactor. Information included in the report includes the panelIit base, Installation date, reasons for changing the callbration, and date of last calibration. The data $w 11$ l be brought up to date after each shutdown and a routine report 1ssued.

It was proposed to determine the pumping capacity of a certain type water pump used in the 100 Areas. Due to the unrellability of the pump gauges for determining the flow rate, the rate was measured by the rise of the water level in the reservols which the pum was supplylng. The plow rate and the precision whlch could be attached to the estimate of flow rate vere determined. (Letter Prom D. W. Gaylor to J. D. Baudendistel, "Analysis of Water Flow Data", dated $1-6.54$.

Further analysis of the physical factors affectlng standard operating costs at 200-W is belng carried out. Of primary importance to this study is the efeect of the weather on fuel consumption. At present, several alternative methods of calculating this heat content of the amblent alr are beling 1nvestigated. The present method conslsts of computing the mean moathly temperature and relat1re humldity, and reading the heat content directly from a psychometric chart. The other methods utilize a frequency distribution of degree-hours below a certain level, and a frequency diatribution of wet-bulb thermometer readings over a given perfod. Semple calculations using these varlous methods have been made. The results are presently belng studied by the Plant Engineering Group in order to determine the most accurate method. Whlchever method is used, the necessary date for maklng the calculat1on are belns collected and routinely procesged on punched cards.

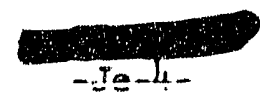


EN-30724

Routine computational work for the Mamiacturing Department this month consisted of data reduction for DR-Reactor, H-Regctor, B-Reactor, D-Reactor, and C-Reactor.

Further data was received and charted on the utilization of the IBM calculator currently beling used by the Production Scheduling Unt of the Reactor Section. A report may be expected in Febmary providing there are no drastic 1ncrease in the current bigh priorlty workload.

For the Manufacturing Department, thwee routine IBM reports and 19 non-routine jobs were completed for a total of 22 IRM service requestis.

\section{FOR THE ENGINEERING DEPARMMENT}

The first of a new type of metal quality report which 1s based on listings and sumations of the varlous metal fropurities and irequency distributions on these variable was prepared. Considerable attention is being given to the type of report on metal quality which would be of interest and benef1t to the most people. It wes finaliy declded that the statisticlani would put out a report ahowing, or at least stating, what information an be flumished and in what yerlous manners. Along with this report the Atcmic Energy Combission will write a cover sheet asking for comments from all persons on the distribution list. By this course of action It will be determined whether a sumary type report, a detall type report, or a comblnation of both 1; desired by the most parties.

A precision study of test pile reactivity measurement based on dih readings for the secondary standards wes condueted for the rourth quarter of 1953 . It was polnted out in this report that the apparent dih value of the secondary standards for the perlod October, November, and December 1953 has changed from that previously observed. (Letter, "Varlation of Test Plle Resulta--Fourth quarter 1953", to W. W. Windsheimer from D. O. R1chards.)

The data from an extensive experiment on the corrosive properties of different metals are now being analyzed. In this experiment, galvanic cells are constructed from plates of dissimilar metals immersed in sodium-dichromate solutions of varying strength. The current produced by each of 384 such cells is recorded daily. These currests, whloh pluctuate in direction, are to be integrated over a given perlod of time to yield the total net charge transferred by the cell. This charge is then related to the corrosive propertles of the metals which molse up the cell. The data $w 111$ be accumlated for perioda of from one to two months before being Integrated. This study is of fundamental importance in selecting reactor materilals with desirable corrosive properties.

Calculations relating to an experiment on the corrosive properties of alumimum were recentily completed. In this experiment, aluminum electrodes were imersed in vartous solutions, and polarization currents and potentials measured with sensitive instruments in an external clrcult. By analyzing these currents and potentials, it was possible to deduce certain constants characterlstic of the corrosion phenomena 10 aluminum under various conditions. The cursenta and potentigls were measured In a serles of observations, or runs. Some 160 rans were made, each constating of from 3 to 20 observations. By the method of least squares, the observations were

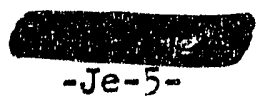


fltted to two different curres, depending on the direction of the cursent. The parameters on these curves were then manipulated to give the values of the desired constants. It has been estimated that approximately 660 nan-hour 3 would have been required to perform these calculations by hand methods, at a cost of approximately $\$ 3000$. By uttlizing machine methods, the same job was done in about 100 man-hours, for a total cost of $\$ 700$. Certain questions relative to the method of fitting these curves are belng considered. These questions are concerned with the best theoretical method of eltting such curves and the criterion which is used to detexmine which set of given sets of estimates are "best".

The computation and tabulation of radoactive decay tables to be used in conjunction with exponential plle flux measurements have been completed. Two tables were prepared, one for use in counting gold folls, the other for use in counting polontum folls. The activity of these folls can be related to the flux most expediently by means of the tables. Ovex 12,000 entries appear in the tables.

The roots of a transcendental equation Involving four different Bessell functions have been found. These roots are necessary to the solution of problems in heat transer in which the texperature distribution in a given model is expreased as an inflnite series. The roots obtained are valid only for one set of parameters appearing in the equation, which were such as to make the determination of the roots a delicate process. It is expected the calculation will be repeated for different sets of parmeters. These roots are not tabulated in the literature, and their publication is being considered.

A thorough analysis of the error in the numerical evaluation of the fast effect Integrals has been made. At the outset of the evaluation of these integrals, which arise in the determination. of the fast fission effect in hollow slugs, an approximation to an uncomon function was developed. Subsequent Investigation showed that this appraximation does not yield the required accuracy. A new proximation was developed, and the calculations repeated. The present analysis indlcates that the error is well within the specifled range. The reliability of the results is thus conslderably enhanced, permitting extensive application to the destgn of the hollow slug.

Work is progressing on the problem concerning the slowlng-down power of water. The numerlcal-experfmental aspects of the problem are completed, contingent on further requests from the customer. These results constitute, by themselves, a large improvement over the present knowledge in this area. The theoret1cal treatwent, however, is conslderably more difficult. Since there are no standard methods of attack, the major task is to formulate an approach. Several such have been surveyed, with one ox two showlng some promise. In any event, a muber of difflcult subsidjary questions $w 111$ have to be resolved before even partial success is attalned.

At the request of the Theoret1cal Phyglcs Group, a new problem on the non-I1near theory of reactor runsway is beling studied. When a plle gets out of control, the fraction of avallable nuclel which have undergone fission (denoted by $\phi$ ) increases atesdily with time in an osc1llatory manner. The non-linear dffferential equation relating $\phi$ with time is the polat of departure in the lnvestigation. So far, this group has revlewed and extended the orlglnal work done by K. Fuchs at I0s Alamos. Further efforts should relate the pile kinetics aspects of the problem wth the

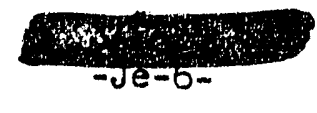


EIW-30724

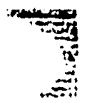

resistance to pile burst effected by the structural members, since the mungway ceases when the plle begins to tily apurt.

Consultations were held with the Exponential Pile Gropo on the feasiblilty of adapting present methods of calculating diffusicn length to a pile with a core of enriched material. Unfortunately, all indlcations are to the conclusion that ent1rely new techniques would have to be devised if any errorcontrol is to be retalned. A second problem from this group involves the value of the transport mean Pree path to be used in multi-region diffusion equations. At the present time there is considerable controversy as to the method of averging over the three regions, graphite, water, and uranium.

Estimates of the rat1os of zirconium to serium and zirconium to sesium countIng rates from four samples of a slug were obtalner, and the magnitude of the varlous sources of error contributing to the variation in these ratios was estimated. The method for estimating these ratios and the information obtained regarding the sources of varlation in the data w1ll be used in designIng a future experiment for determining the distribution of flasion froducts in slugs. (Ietter from D. W. Gaylor to $\mathrm{E}$. M. Kenderman, "Estimates of the Ratios of Counting Rates of Fission Products in Slugs", dated 1-29-54.)

The percent Py content of shapes can be determined falrly qccurately by a rather long process in which anslyses are conducted to determine the amounts of the various impurities in the shapes. Heretofore this has been the standard procedure for determining Pu content. An X-ray method san be used for estimating the percent $P u$ in shapes which 1 s quicker and less expensive than the standard procedure. In oxder to determine the feaslbility of using the $X$-ray method, it was necessary to determine the relationshlp between the Pu assays determined by the standard procedure and the X-ray method. Th1s"relationship along with the sssoclated precision limits enables one to predict, w1.h a given degree of reliablility, Pu content by impurity computationg from Pu content by X-ray. (Letter from D. W. Gaylor to A. E. Smith, "Prediction of Pu Content in Shapes", dated 1-27-54.)

As part of the disaster study, the varlous safe clrcuita in K-pile are being lnvestigated to determine what combination of sarety device pailures could conceivably result in a disaster of some type.

A serles of consultations have been held whth menbers of the Adranced Technology Sub-Section and others on certaln pxoblems related to some economic studies.

Routine computational work for the Englneering Department this month consisted of Special Request Exposure calculat1onz for January, Group Nine Metal Studies calculationa for December, Jattice conductance calculations for B-Reactor, and C-Reactor bot spot calculations for December.

The conversion of Classifled Flle records from a manjul to a punched card system was begun in January. Approximatelij 100,000 carls (out of 1,600,000 cards) were keypunched. Preliminary procedures have been frepared and IBM panels have been w1red to process the cards as they are punched. The

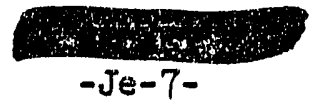


requirsments as to IEM machines, personnel, sards, and spase needed for the oonversion have been oldined. (Sea memoranium to F. M. Thompson From 1:. B. Poland dated January 6, 1954.)

A system of recording the transfers of classlified documents was designed which w11 permit "fleld transiers" of accountability w1thout the use of special machines and without restriction as to time and number. The proposed system will be presented to Classifled Files in February.

Demonstrations on the operation of IBM equipment were given to Classified File supervision personnel.

Pile Technology has requested the Graphles Unit to prepare a serles of drawings to be used in a manual titled "Special Irwadiation". This assignment will require development of jwenty-seven detalled cross-eection views of process bubes, charnels and magazine lacilities showing water flow systems, gas control mechan1sms, shielding apperatus and experimental slug positioning.

Graphles prepared a serlea of illustrations for Fuel Technology to use in a report titled "Characteristles of Uranlum Slug Canning and Adaptability to Hollow Slugs". All iliugtration material was consolidated into fou' Plgures. Figure I Included a drawing of the present Hanford Slug showing 91 corponent parts in sccurnte dimension and a cut-s-way drawing of a grophite block showing the coolant annulas and positioning of a urantum slug. Figure 2 sansisted of three arawings 1Ilustrating existing and proposed coolant lesign; ixternally cooled slugs; internally cooled slugs; and internally-externally cooled 3lugs. Floure 3 inciuded drawings detalling the component parts that are used to fabricate an insulated cap and shows bow these parts are positioned prior to placement in a prepared die for heat processing. Figure 4 consisted of three schematic drawings of slugs 11lustrating "Possible Hanford Slug End Conflgurations to Keep Maximum Surpace Temperature Below the Bolling Point of Plle Water".

Routine graphics work for Fuel Technology Included preparation of nine graphs and a total of twenty-3ix pages of photo copy for document HW-299.16 t1tled, "Characteristics of Hot-Press Canned Aluminum-Silicon Coated Fuel Elements"; cormletion of three pages of photo copy for document HW-29952 t1thed "Comparison of Steam and Water Autoclave"; completion of seven pages of photo copy for a report titled "Induction Heated Elght Inch Slugs" and comoletion of seven pages of photo copy for document HW-30318 titied "Filter Welding Eight Inch Slugs".

Routine graphics work for Applied Research inoluded freparaicion of twenty-two pages of charts and photo copy for a quarterly Progress Report and preparation of three procesa flow charta.

Mwelve non-routine IBM Jobs were completed for the Engineerian Department.

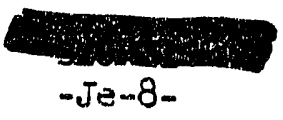


Work was started for the Safety and Fire Frotection InIt on the proparation of a major injury award plan for the Community and Real Eatate Department. It is contemplated that an award plan for this Department wlll be set up as well as one for the plant. In order to assure comprability with the present plant award plan, and analysis and review of the present plan will have to be made.

Work continued on certain studies of Computing Unit operqtions. The urgency of some other problems prevented the desired a tention rom being given to this work whlch rslates to machine ut1lizatilon and operations sontrols. Also, assistance was rendered to the Operations Analysia Section in the estimation of the precision of cost liquidations.

New problem number deaignations have bean prepared and put into oreration for the operations Aralysis Section. The various units of the sestion are now on a comparable besis. All old work orders were closed.

The fallowing assigtance was perpormed by the Procedures Unit for the Comouting Unit: (1) Claszes were given IBM operators on the operation of reproducers, interpreters and collators; (2) Trace machise trouble and re-wire panels; and (3) Fifteen new or revised IBM internal opereting procedures were prepared.

Work is continuing on the IBM prosedures to provide office Equipment with Information regarding office machine rental and repalr costs.

A demonstration on the operation of IBM equipment was given to supervisory persomel from Central Stores.

A considerable amount of assistance was supplied by Graphics to Procedures Unit personnel in Jenuary, primarily in the development of Pormat, flow chart deslom and symbol standards for material to be ueed in Operations Research Progress Reports.

For the Plant Auxiliary Operations Defartment Pourteen routine IBM machine reports and flve non-routine jobs were completed for a total of 19 service requests.

\section{FOR THE COMMUN-TIS OPHRATIONS \& REAL ESTATE DEPARTMENT}

At the request of Internal Audit and Accounta Receivgble, the routine procedures for Electric B1Illing were altered for December. Two separate reports active and terminated, were prepared ratber than the normal sombined report. Procedures were changed to prepare for audit purposez, special balance listings for ageing and verfelcation.

Thirty-two rout1ne IBM machine reports wero completed for the Commity Operations and Real Estate Department. 


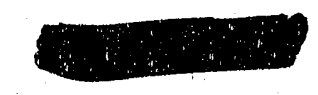

EWH -30724

\section{FOR THE RADIOLOGICAL SCIEENCES DEPARTMENT}

A meetlng has been held with the Experimental Meteorology Unit to d1scuss the operation of an instrument designed to messure wind velocity in a turbulent atmosphere. The instrument $w 111$ be capable of measuring instantaneous speed and direction at extremely short intervals. Because of this, a large amount of data will be produced. A number of possibilities for processing this data have been presented. One is an analog compiter coupled directly to the instrument. Others Involve analog to digital converters, to make the data accessible to digital computing. The turbulence calculations are presently based on a rectengular coordinate syatem, whereas the measurements w1]1 be made in spherical polar coordinates. Atterqts are presentiy being made to formulate the calculat1ons in the spherlcal gecmetry, to facilitate comptation in the event digital computers are used. A very large computing job is indleated in any event, one which will shed more 11 ght on the relative merits of analog and digital computing.

It has been established that the geometry correction factors applied in the past to counting measurements on aquatic blology samles have been in exror. A request has, been recelved to apply the sorrect factors to all past data, which is contained on some 25,000 cards and dates back to 1950. In addition, it was discovered that the wrong source absorption factors have been applied to counts on plankton samples, and these w1Il simllarly be corrected for.

To ensure the efficlent operation of a "wind charger", it is necessary that an adequate average wind speed be maintained. Using wind data from stations 5 and 9 for the months of Jenuary and February of both 1952 and 1953, the total number of observations of wind speeds exceeding a certain minfmum was deternined. In addition to the total number of each such observation, the date and hour of each observation was tabulated.

Routine computational work for the Radiologicgl Sclences Department this month conalsted of Station Wind Study Calculations for November, Weather Study Calculations for December, Aquatic Blology Calculations, and sheep throold and radioanalysis calculations.

Radiological Standards requested Graphics serrice on a rush-basis for the development of two composite maps showlng a recent spread of Ruthenlum Contamination in the Hanford Works West Ares and environs. Th1s work entalled transior of data as readings came in from the Pleld.

Graphics is preparing a booklet on "Radiation Protection" for the Radiological Stamards Unit. Illustrations and plate layouts will be ready for review and Inal approval in February.

PIve routine IBM reporta and one non-routine job were comleted for the Rad10logleal Sclences Department for a total of $\mathbf{s 1 x}$ service requests.

\section{FOR MIE MEDTCAL DEPARTMENTE}

At the request of the Medical Department, rough calcrlation were made to determine the difference between the life expectancy of Richland residents and

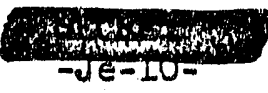


BW-30724? ?

those of the nation. If fearible, mcre exact caloulationa may be made later for publication purposes. The results waze obtainer trom iata used in frevious analyses of Rlchland death rates whioh have recently been published nationally. A rough approximation of a moltality table for R1chland was also made. It has been proposed that a complete mortality table be contructed to assist in the anolys1s of this and related public health questions. (Ietter, "Rlchland L1fe Expectancy Flgures", from L. W. Smith to P. A. Fuqua, M. D.)

A nomographlc aid for use with the Wetzel physlcal fltress grid has been constructed for the Public Health ard Welfare Section. A shart was prepared and 500 soples are being reproduced. A letter explaining the use of the chart will be 1ssued as soon as the copies ars avallable fon distribition by the Publio Health and Welfare Section.

\section{FOR THE EMMPLOYEE AND PUBLIC RELATIONS DEPARTMENT}

The 1953 att1tude survey has been completed. The regort to management has been distributed, and the report to all employees w1ll be sent out very shortiy. The report to management is comprised of: 1) ccmosite results for all employees, 2) results pertinent to twelve major personnel classes formed by three job status groups (non-exemot employees, exemot non-supervisors, and superv1sors) within each of four functional classes (technical, sub-technical, clerlcal-administrative, and production and servica), 3) results for these major personnel classes within each of 19 major orgenizational. groups (iepartments and sections), and 4) results based on analysis of attitudes by length of serrlce and works area. In gddition, the last section of this repcrt presents the findings baged on comparlsons of average scores obtained from the 1952 and 1953 attitude surreys. The report to elployees highlights the composte results for all employees and shows graphically the percentages of employees making savorable and uniavorable (to the Company) responses to each statement on the questionnaire.

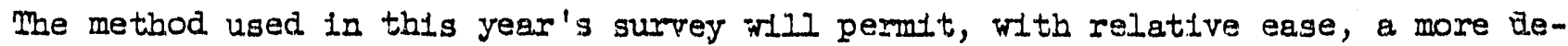
talled analysis of the organizational groups than is presented in the manager's report. Att1tudes toward particular 1tems and attitudes expressed in written comments can be investigated in groxps on a unit level or above. At present, such an analysis is being carried out on the Ocerations Anglisis Section. In addition, worls was begln on the conduet of the survsy that should assist in the conduct of future surveys of this type. Also, a summary report on some unresolved questions about the revised 1952 survey data was prepared at the request of the Employee and Public Relations Department.

Scoplng of the problem to revise the monthly plant-wide absentee avergges and limts was made during the month. The revision 13 necessary becsuse starting January 1 , 1953 absences w1Il Include all absent hours rather than only absences of a full day, and vacations and military encempment w111 be excluded from "avallable hours" in deterntalng the base on whlch the rat10s were computed. The stat1st1cal work involved in making these changes haz been formulated and evaluated, and work w11 begtn as soon as the Procedures Onft can arpply the necessary data. S1nce even a small reduction in the absentee rate san result in substantial sav1nis to the Company, thls work is well worth-while in helping to control absenteelsm. 
$\mathrm{EW}-30724$

Assistance was provided to the Selary Admindstration Section in obtilning a 1sable mathematical relationshlp betreen certaln eacors is the falany atirg plan.

The use of one card form to replace the two cards per exemot employee bas been approved by Salary Administration. This will result in material savings in key punching and operating time and will improve the report appearance and accuracy. Thls change w11l also facilitate the preparation of any special studies wintch may be required in connection with antlcipated changes in the Salary Administration plan. The change to one card will be made colncidently with the change over to the IBM type 407 punched card printing machine.

Public Relations supplied Graphics whth 212 raw data required for the Freparation of slides to be used in the Managex's Annulal Surervisor's Meeting. All orlginal plates were prepared with a copy dimenalon $0.19 .3^{\prime \prime} \times 15.5^{\prime \prime}$ and a minimum letter size of 0.350 inches.

For the Employee and Public Relations Departmont 8 routine reporta and 1 ponroutine IBM Joba were completed tor a total of 9 semiss requests.

\section{FOR THE EINANCIAL DEPARTMNENT:}

IBM procedures sovering special job requests were written to frepare $W-2$ reports, a new Weakly Paymoll Master Flle; a control listing of state taxable earnjags; W-4 statistical reporta; new year insurance deductions for weekly payzoll; a report of non-exempt personnel by organization within area location; a corrected vecation notice flle; and a report of asgregaise annual base rate.

The work order procedure was revised to allow the active sogt to date fille to be run in oustomer within service unit sequence. The plle will be maintained in this sequence.

An estimate was prepared of the cost of procesaing the physical inventory on IBM equipment. The estimate covered the prepgration of the inventory tags end the compution of the value of the inventory.

All payroll and tax panels were rev1sed to comprehend the changes in the F.I.C.A. rates and in the withholding tax ratas.

Graphies york for the Flnanclal Department inciluded plottinas of current data to twenty-g1X EAPO Cost Chamti; making general revisions and plotting current data to the Operating Costs and Budget Charts; and completion of an Accounts Payable Flow Chart.

For the Flnanc1al Department 564 soutine IBM machine reporta and 29 non-routine jobs were completed Por a total of 593 service requesta. In addition 24,827 paychecks and earnlngs statements were prepared and 25,344 cancelled paychecks were reconclled.

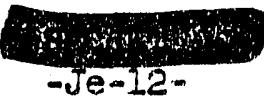


The flrst operations research progress report on finventory coll was 1ssued. The elow of paper work in purchasing and zecelving was show daloally. The basio mathematios model for 1nventory control was outlined, mathematical models control was outlined, and mathematical. models were fltto the time required for peper work transactions in purshasing. Recomenons were made for reducing paper and clerteal work.

Statistionl gnalyses of purchising and recelving data are in Ess. First, a smaller pilot sample was takan and analjued to determine what a seemed amenable to study. Fwom the results of this atudy the decision was moo ilvide the orders intil the method of orderling (telephone, wlre, letter, curchase order form) and to test what differences extsted between thase four nods of ordering
for nine variables. These variables are number of items per or, amount in
dollers of order, store order caption, vendor lo dollers of order, store order ception, vendor location, time jakes to place order, time it takes to recelve order arter flacement, total to place and. recelve ordex, days allowed to receive order by customer, and a required by customer minus date recelved by stores. From this 3 tudy 1 t loected that a
better understanding of purchasing wili be achleved.

A sampling plan was also designed to: a) Investigate the protons of recelving reports that apply to inventory items and to 11 mecto-chargems, and to b) compare the two type: of reports with regard to the averagength of time from wite-1p. The data concerning the two cumplative distwibns bave been gathered, and stat1st1cal analysis is in progress. From lnspon of the data, both distributions appar to conform closely to the same smooturre. The mathematical model of the ourve is beling dereloped.

A Gompertz growth curre was fitted to data on the number of derequired to write up and to deliver inventory items recelved. The comperturve is a logarlthmic growth curre of the form $Y=k a^{b x}$. In this case rpresents the cumulative fequency 1 th which 1 t took $x$ days to write un deliver material. Some data hea also been collected on ordering and ad of 1tems in Stores by H.A.P.O. personnel. It is hoped that by reconstruct the history of ordering and demand, the posstbility of developing 9 mathem ${ }^{2}$ model to predict demand and 1ndicate when to ordex w1.11 be more alearlylicated. Studies are also in process to determine the relationship beth the monthly dollar value of items in general supplies, spare parts, excesad standby
inventorles.

A sampling plan was dealgned for use in eatimating the proport of accounts payable vouchers which are: a) Hanford Works, b) Heneord Works struction, and c) Miscellaseous. The collected data have sluce been rece and wll be given statistical treatment shortly.

An operations research project is in progress to optimlze, on ormal analyticel. basis, the routing of calls in the Richland telephone exchangethe purpose is to minimize the proportion of uncompleted call. resulting footurgtion of mechanleal facilities. During the month considerable time was usa seeking a reasonably complete englneerling lnowledge of the entive Hanforlephone system as a basis for mathematical analys1s. 
From this tneormation. Lt was nonclided that lit lis necessary to restrict the

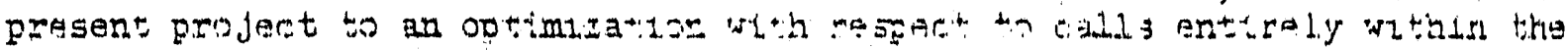

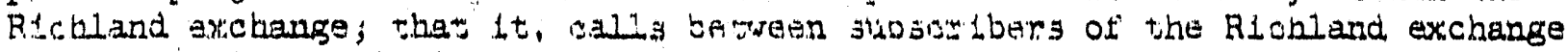
only. It appears that a more comprahensive acalys1s would entall a matinematical model of probibitive comolexity. In gddition, regtritotions on the reorganizat1on of call routing were reviewed and It was found that complete freedom in modifylng switchling armsngements does not exlst. It wad declited that the only part of these armangements in whioh there is sufficlent elexibility to justify further study is the distrubution of connections between flrst and second sel-

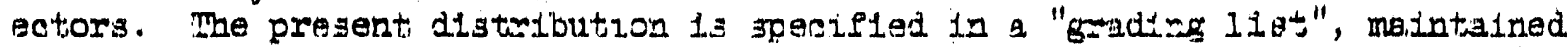
by the Telephone Unit. It 13 expected that; the rastriation of attention $\$ 0$

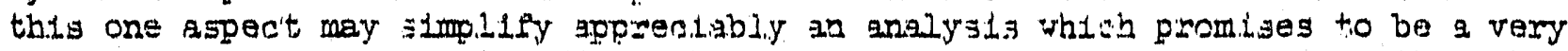
involved one in any erent. Sicce the metering devioes incorporated in the telephone system 1nvolve certain limitatilons, attention was alizo given to an add1tronal method of data collection which does not neces3itgtie the une of these

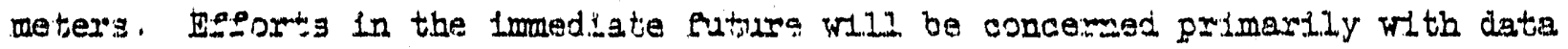
collection and the design of a mathematiogl molel.

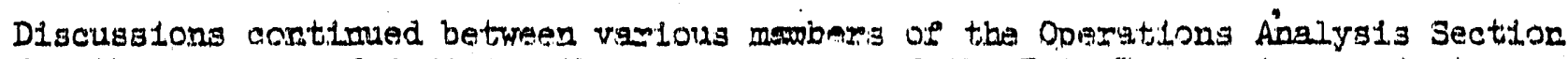
for the purpose of deflning the pxpor sores of the Datio Pronessing project.

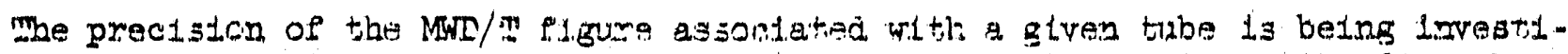
gated ai part of the Data Processing zxoblem. Saveral zeportas on the distribution of water llow in $D$ and $D R$ reactors were prepared for this purpose. In addition to evaluatirug this procision, the various sources of expor ars belns Investigated with respect to thelu reliative imoortance in afeocting tine precision of the IInel result.

An Invegtigation was made at the request of the Measurement Methods Unit to determine the best 3 tatistingl estimate of the pactor which should be used to convert the total welght of $3 k 011$ a aharged into the $3 k$ lll dissolver to the welght of plutonium charged 1.nto the dissolver. Data from 190 recent dissolver batches in which only gkul1s were dissolved were used for the analys13. The possibility of obtalning a preclsion statement to be asaociated. With the factor computed irom the existing deta was also invegtigated. However, the existing data were not taken in such a way as to enable an estimate of the required component of vamiation to be calculated. (Letiter to C. B. MaKee Prom i. A. Merni11. dated 1-29-54.)

Work has been began at the request of the Measurement Methoda Unit to 1nvestigate

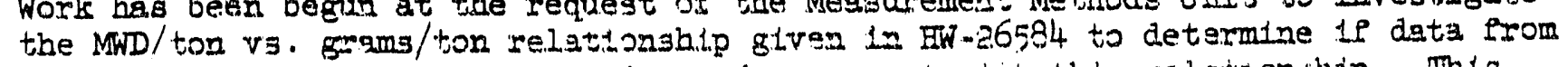
recently processed materolal axe in good agmeement with this nolititonship. This

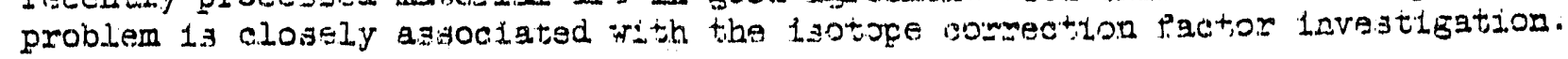

Precialon limita were determined sor the gmount of $\mathrm{VO}_{3}$ in 3 , month end 1nventory. Stat1atieal analyzes were perismed on percent Urantum and persent U235 for composite carload sampias and comozlte lot zemples to arrive at these limitg.

A report was prepared at the request, of the Aimin1 3 rrgtive Practices Stare on utilization of first ald stations. Mh1s report 13 a preliminary step in scopting utilization of first ald stations. Mhis report 1.3 a preliminary step in scomo Usage", from L.W. Smith to E. A. Smith.)

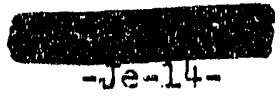




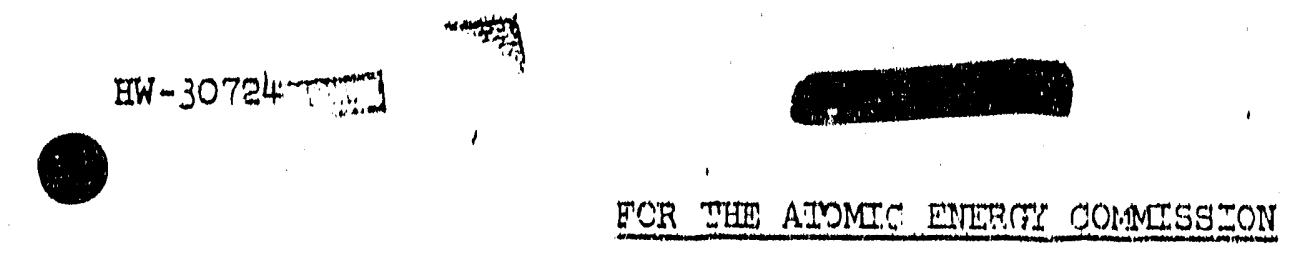

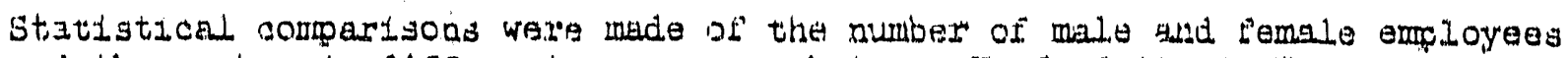
and the number in different age groups betrean Hanford Atomic Froducts Operation and the followlng classes: 1) the total employed in the Undted States, 2) the total employed in manufacturing is the Indted Staties, 3) the total employed In Chemical and Allied Products Industriles in the Ualted states, 4) the total employed In the State of Weahtagton, and 5) the total employed 1n manutacturing in the State of Washlagton. The results show that thare is almost the same ratio of men to women at Hentord Atomic Productz Oparation as In the Chemlual and Allied Prod-. 1ata Industries in the United States, but in ald other cases, s.toniflcant differences were found, (Letiter from V, L. Claris to P. Q. Oarrico.)

Conslderable effort is belng expended on getting the routine release calculations backs on sohedule. In addition, $a$ study of the effect of recent, aharges in production practices on these relegses has best lattiated.

Cerd form, key punching, machine pronels arri prooedures for the anglygis of puroheses were revised to incorporate one diglt of adidtional s.lasidilation and to overcome punching diffloulties. Alphabetic informition (prefixes of HW and HWC) will now be gaus punched rather than kay punched.

A table and titue ser1es chart on Ruptured Slugs was prepared on a rush basts for the Atomic Energy Commisaion together with a number of charta for the Manager's Data Book. The above material was required for the AEC Manager's rocent trip to Weshington, D. C.

One routine IBM report and 3 non-routine jobs Heme completed for the Atomid Eneres Comisation for a totel of 4 service requestis.

\section{METHODG DEVHLOPMUNI}

In many Instances, we are interested in investigating the ratio of two vartables, each of whose distribution is asaumed to be normal. We are usually primarily interested in calculating the mean and the varlance ot the ratio geter knowlng the mean and variance of the numerator and denominator. It has been the practice to apply a well known epproximation formula in thiz case, but there is little indication as to how good an approximation thls formulation provides. The exact diztribution of the ratio of two ladependentily distributed cormal variates was derlved. The results show that the usuel approximations uesa are quite adequate, Firther, knowing the exact distrubution of the ratio, 1 t 19 possible to f1x exact confldence interrals for the ratlo of two anrmal variates each of whose mean is zero. Th13 could not be done using the approximation formilation glnce the approximstion formulas become indeterminate in this case.

It 13 well known that when rounding errors occur, the unferm distribution may be assumed. A gltalition arose where the ratio of two uniformly distributed varlates had to be 1nvestigated. It was possible to works out the exact distribution of this ratio, and to find exset, expresglons for the mean and varlance of the rat10. By means of an exanple, 1 t was shown that the discrepancy between the exact expressions and the approximate expregglong at derived trom the usual

$$
\frac{-J e-25=}{-5 m}
$$


approximation formulas may beoome quite large. The ogae conslid wad was for both varlates beung everywhere positive zuch ithat the risto became lere lere infindte. This situation 1.9 most ilkely to be mat with in praotica.

Frequentily, several regresslons are ostimated and three tests lypotypotheses my be of 1nterest. First, one may wlish to test whether the wagren IJu ILnes have the same slope. Secondly, dopending on the outcome of the tidyestjegt; one may

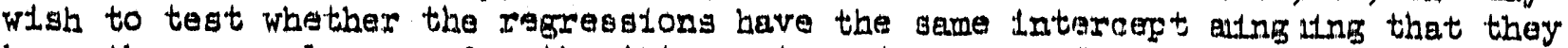
have the same slopes. Or, the interoepts and slopes of the relalorision Ilnea may be tested almultaneously to determine if one comon regreyslone mee may be used. Some of these tests are presanted hil varlous texta, but are nonsolnsolidated. In any one place for assy reference. The methods fon testing thetted ited bypotheses have been assembled.

Simple Inear regression methods are presented in most statiat tex texts and statisticlans are familiar with the procedures involvad. Freqiy, ily, however, the values to which the regesesalons are to be filted are not dandnexuned w1th equal precialon. The best method for eltating the regression itn tin this case is to glve those values whtch have been determined with highenolstolsion more

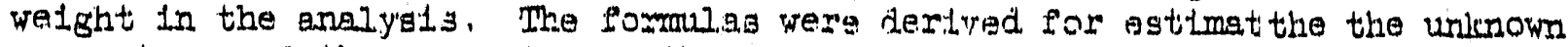
parsmeters and the preciston of the estimates when the observan and are given different welghts in the anglysis.

\section{SUMMAEY}

During the month of January 81. statistical, mathemat1cal, procal, ;al, and graph10al problems were completed, and as of Jamuary 31 , a backlog .76 576 problems were on hand. In addition 627 routine IBM reporta and 70 non-ine ine IBM jobs were sompleted for a total of 697 IBM service requesta; ch, saysheyahecks, 24,827 earning atatements, 7,355 electrio b111s were prepared jh 25 \$ 25,344 cancelled paychecks were reconclled.

A total of 107 new forms were deslgned; 391 orders for form $w$ revilrevlewed of which 12 were rejected and 379 were approved for a total of $1,854,854$ sop: Les.

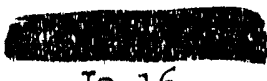


EW-30724 1.
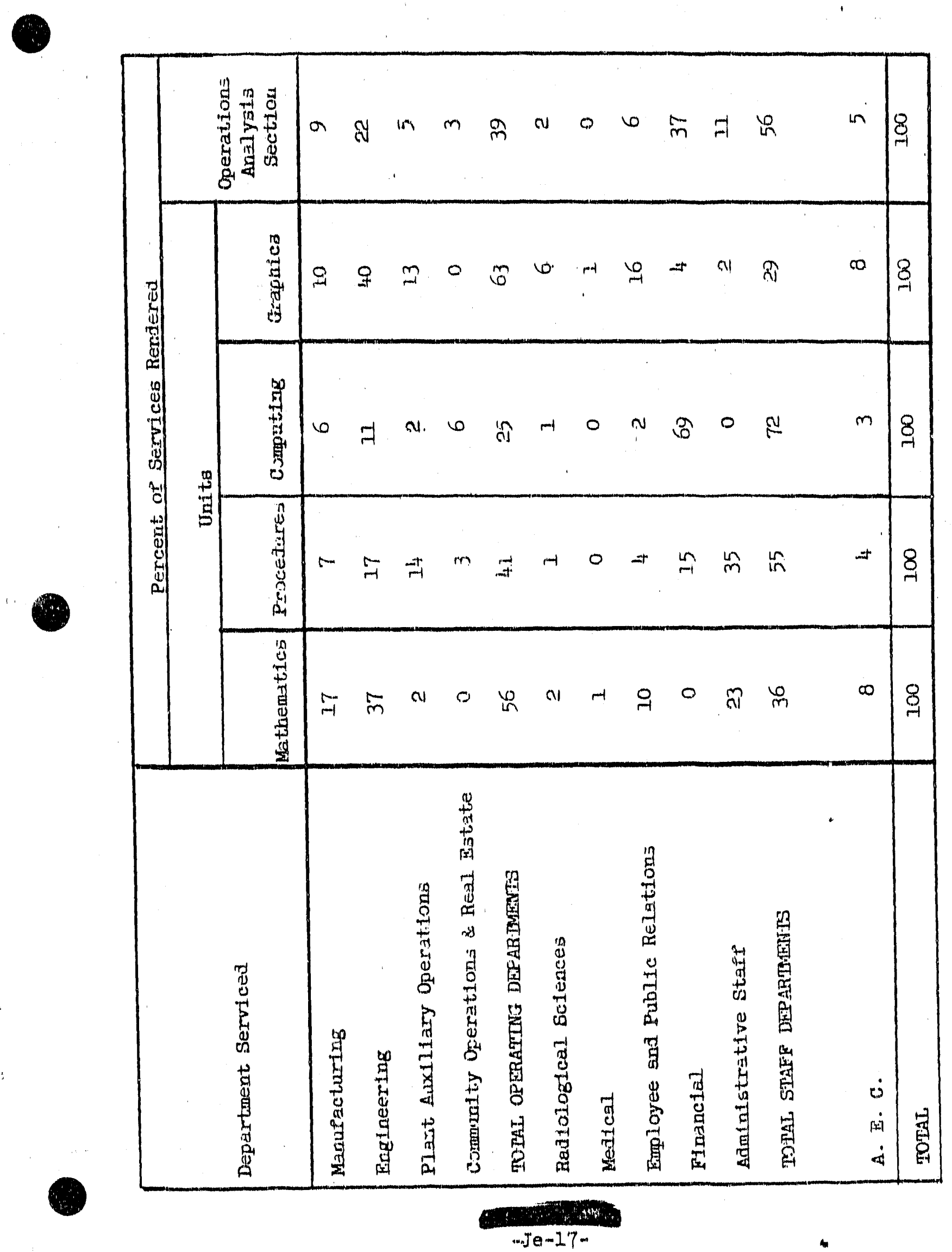


\section{EUPLOYEE AWD PLELIC PELATECNS DEPARTE:H \\ SULMAR: - INUNARY 2954}

\section{EMPLOYEE RELATIONS SECTION}

The number of applicants interriewed in Januagy nas $1,43 \mathrm{~L}$, as cormed with 1,091 for December. In addition, 120 new applicants appliod by nail. Open, nonexempt nontechnical nequisitions decreased for 136 at the beginning of the month to 111 at month end. Seventy loyes were added to the roll and 54 removed during the month. Separations rate decreased from.77\% for fiscal month of December to $.66 \%$ for fiscal month of January. These rates when converted to annual rates are $3.03 \%$ and $8.61 \%$, respectively. Dur ing Jamuary 42 new requests for transfer to other type work were received by Employuent and 28 transfers were effected. Attendance recognition amards rere distributed to 190 employees in January, including 63 wo gualifted for three-year awards.

Two employees died during the month and three employees retired. One hundred and twenty-five visits mere made to employees confined to Kadlec hospital and 54 checks were delivered to employees confined at the hospital or at home. At month end participation in the Pension PIan was $97.3 \%$, Irsurance Plan 99\%, and th. Holoyees Savings and Stock Bonus PIan 47.5\%. At month end the re were 758 regijiered under Selective Service and 750 military reservists were on the roll. Since August 1, 1950, 321 employees have terminated to enter military service, of which 76 have retumed, 17 have not claimed employment rights, leaving 228 still in military-leave status.

A total of 50 new employees attended orientation meetings. Of this number 100\% have signed up to participate in the Pension Plan, $98 \%$ in the Insurance Plan,
and $96 \%$ in the Good Neighbor Fund.

Forty adopted suggestions were approved for awards in January, resulting in cash awards totaling $\$ 1660$ with a total net savings of $\$ 15,254.75$.

During January six KAPL trainees reported to HAPO for an approximate four week training period in the Reactor Section.

HAPO practice of requesting deferments under Selective Service was critically reviewed and consideration given to the feasibility of establishing a release Rotational Program. Following this critical review, decision was reached that no substantial changes should be made at this time. It is anticipated that fewer defements will be granted as time goes on.

The General Manager's annual meeting was held January 12 and 13 at Carmicnel Junior High School with an attendance of 1430 for the two night metings.

Training and Development programs and activities were as follows: Conference Leading was held on January 8 and January 18, with 16 exenpt personnel attending. Effective Human Relations was presented January $6,7,13,14,20,21$, and 28, with 101 supervisory management participating. HOBSO II was held January 7 
Emeloree ard Public Relations

Surnary

QDPLOVEE RELATIOIS SECTION (Continued)

and 26 for 20 guperviscry. Labor llanazement Relations was held January 8, with an at excance of 12 supertiscrs. Principles and lethods of Superrision was praserted to two grougs january $12-23$, with 34 superrisors completing the course. Custecor Meiations ras presented vanuary $23,14,20$, and 27 to 123 propessional

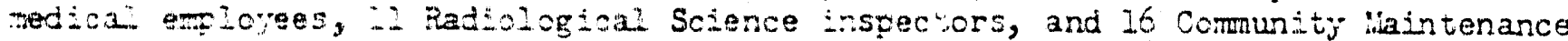
exployees. Special prograz "In Our Hands" aas presented Thursday evening, January L, to 30 Rtohiand Comonlty people. Duxing the month ail Devartment Wanagers Tere sent issus $0:$ ihe 1 exect exployees who had attended the evening Wanagement Development netir.s during 295;, and program attendance transcripts of all exempt persorsel rere distributed to all Section lanagers. Training Activities book for L954 Nas distributed to 190 superrtsory personnel, incluiting all Department Wanagers and Secticn Managers. There were 7 reguests for Fusiness English references and requests tos 65 program transcripts forms.

Prepazaticr. of the 2953 Salety Report was completed and placed in production. "Youn Radtochemistry Building," an information booklet for building occupants, was completed and at month end was at Central Printing awaiting production.

The Itve IE News issues during the month highlighted the General Manager's address to members of management, courses available to Hanford people through the Scmool of Nuclear Engineering, and the Adult Education classes, and top Suggestion award winners for 1953 and January 1954.

\section{PUBLIC RETATIONS SECTION}

The News Bureau issued 46 news releases during the month. Of these, 23 were sent to the local list, including radio stations. Thirteen were distributed to Northwest daily newspapers, and 10 received special distribution.

A special feature on the Uptown Business District was distributed this month and sent to the daily and local lists. Special, longer write-ups on the same subject were sent to "Western City" and "Public Relations Journal."

A special project involving publicity material on protective clothing used at Hanford ("plastic man"), requested by the Schenectady News Bureau, was completed this month. Photographs and write-ups were sent for whatever use they chose to make of them. One complete series of pictures with waite-ups was sent to "Popular Science" magazine and 250 feet of $16 \mathrm{~mm}$ movie film was sent East with accomparying write-up for distribution to the six major television distributing agencies. NBC and CBS have already used the movie footage, and it is assumed that the other networks wi.l工 also make use of' it.

Richland's medical program recejved extensive national newspaper coverage this month. Pictures and biographies of Drs. Sachs, Norwood, and Fuqua were sent to the "Seattle Times" and the "Monogram," at their request, to accompany the writeups they published. A follow-up photograph featuro mas sent to the "Spolme 
Employee and Public Relations Summary

PIBLIC RELATIC:IS SECTION (Continued)

Chronicle", and they devoted a full page to the feature. The national newspaper coverage included the "New York Times" and described Richland's integrated medical program, the story having been originated by the American Medical Association.

Filming of ar entire sequence of the 100-K Reactor model was completed on $16 \mathrm{~mm}$ Kodachrome film. This was an important phase of the GE-AEC Film Footage Program on the Current Expansion Program.

The final print of the motion picture "Getting the Job Done" was delivered to Minor Construction management. This was the fifth feature-length trainingdocumentary motion picture produced by the Audio-Visual Unit since July 1952 for Hanford operating and engineering departments.

Three Hanford Sclence Forum tapes mere loaned to the librarian of the Pasco Senior High School for the use of science teachers as teaching aids. Pasco High School plans to use Science Forum broadcasts as a permanent adjunct in teaching science.

Four Hanford Science Forum radio programs were broadcast by Radio Station KWIE this month. Listener interest is increasing as evidenced by the growing numbers of letters and inquiries received in addition to the participation of high school students from this area.

A total of 192 photography assignments were covered during the month of January, and a total of 6,906 prints were produced. Of the total prints, 3,144 were " $A$ " and "B" badge prints. A total of 3,762 were area and news work.

SAIAARY ADMINIS'TRATION SECTION

Audits in the 4 ield involving conformance with position descriptions and organization structure, the review and evaluation of position descriptions, the detalled study of organization structure, and other administrative work proceeded according to schedule.

L. I. Ferguson, Consultant, Salary Administration Services Department, spent the week of January 18 at Hanford. He brought with him offlcial information reinting to the Company salary plan, and voluminous data to aid us in adapting our salary plan to conform with that of the Company.

A major review of the salary structure at HAPO was begun on January 25. This review includes the analysis of each exempt position, the writing of new position descriptions, and the remevaluation of each position in order to make assignments with in the Company salary structure.

UNION REIATIONS SECTION

A preliminary meeting was held with representatives of the radiation monitoring Inspectors to discuss problems associated with their new bargaining status. On January 13, 1954, a meeting was held with HAMTC representatives of the Instrument 
Employee and Public Relations Sumary

UNION RELATIOIS SECTION (Continued)

Craftsmen's Guild to discuss a new procedure developed by the Manufacturing Department for testing and rating candidates for upgrade to the Instrument Specialist classification. A grievance submitted by 29 expeditors in the Engineering Department, protesting work performed by supervision during their one week furlough for lack of work, was resolved at Step I.

The Ching Panel's assumption of jurisdiction in the Carpenter (Construction) strike effected a return to work on January 18, the Panel hearing to be held in San Francisco on February 3. Master Agreement negotiations with the Building Trades Council are deadlocked on the isolation pay question. No progress is expected until the Ching Panel makes recomendations in the Carpenter dispute. Intermational representatives of both the Machinists and Millwrights met with John Dunlop in Richland in an effort to permanently resolve the jurisdictional problems between the two crafts in the 2101 Building. An answer to the problem was not forthcoming. A one-shift strike of approximately 35 Kaiser Machinists occurred on January 21.

Results of the plantwide review of engineering assistant jobs was presented to the Technical Section. The survey of rates paid Van de Graff accellerator operator was completed. Reimbursement Authorization No. 217 was received from the AEC for the consolidation of the craft Trainee and Helper progression schedules and the elimination of the craft Helper classification. Reimbursement authorizations were requested from the AEC for establishment at HAPO of the Company-wide plan for the hiring of Technical Graduates. Revised classification titles and progression schedules for bargaining unit reproduction jobs were submitted to the HAMTC for their concurrence. A jurisdictional agreement between the Plumbers and the Steamfitters and the Electrical Workers on the assignment of the maintenarice and repair of solenoid valves was received and accepted by the Company. Two meetings were held with an HAMTC comittee representing the Machinists to discuss the differences between job assigrments to Instrument Maker, Tool and Die Maker, and Machinist classifications. AEC auditors during the month checked and audited the Mage Rates Unit's procedures, practices, records, and survey material.

TECHNICAL PERSONNEL SECTION

The FhD recruiting visits have been completed. The records of 180 candidates have been screened with suitable research and engineering supervisors, leaving about 65 to whom visit invitations will be issued.

The Spring recruiting program for new graduates has been planned on a tentative hiring authorization. Reimbursement authorization is anticipated this week covering the rates for new graduates now used by other Divisions of G.E.

Trainees currently number 58. A substantial number of trial placements already arranged should soon reduce the number of trainees remaining on the Rotational Training Program. The termination rate remains very low. of the 13 men trained to date on authorization from the ANP Department, only 2 remain at Hanford-one of these being scheduled to transfer next month.

$$
r-4
$$$$
4
$$ 
Employee and Public Relations Summary

TECHIICAL PERSONNEI SECTION (Continued)

The first semester of the School of Nuclear Engineering is complete al though the records have not yet been assembled. Registration for the second semester is just being completed with a broad program of courses at graduate and college level.

\section{ORGAIIZATION AND PERSONNEL}

$\begin{array}{lr}\text { Total on Roll January 1, } 1954 & 184 \\ \text { Accessions } & 5 \\ \text { Separations } & 4 \\ \text { Total on Roll January 31, } 1954 & 185 * \\ & \end{array}$


Exployre and Public Relations

DIPLOYER RETLATIONS

\section{General}

Two meetings were held at Camichael Junior High School with the management group on January 12 and 13, at which time the General Manager reviewed sine of the highlights of the calendar year 1953 and projected some of the pioblems that would have to be orercome during the current year. The attendance at the first meeting was 740 and the attendance at the second meeting was 690 for a total attendance of 1430 .

\section{Personnel Practices}

Employment

Recember, 1953 January, 1954

Applicantis interviewed

1,091

1,434

472 of the applicants interviered during January re Individuals who applied for employment with the Company for the first time. In addition, 120 applications were received through the mail.

Open Requisitions

December, 1953 January, 2954

Exempt

Nonexermpt,
136

4

Of the 136 open, nonexempt, nontechnical requisitions at the beginning of the month, 80 were covered by interim commitments. Of the 111 open, nonexempt, nontechnical requisitions at month end, 72 were covered by interim commitments. During January, 54 new requigitions were received requesting the employment of 62 nonexempt, nontechnical employees.

December, 1953 January 1954

Pmployes added to the rolis

60

70

Employees removed from the rolls

II

54

NEET GAIN OR IOSS

$-11$

$+16$ 
Imployes and Public Relations

EMPIOYEE RETATIONS

Separation:

Including employees who were latd off for lack of work

Flscal Month

December 2953

Mali Female

$$
\begin{array}{llll}
.49 \% & 1.97 \% & .44 \% & 1.60 \% \\
.47 \% & 1.97 \% & .42 \% & 1.60 \%
\end{array}
$$

Overall Separation:

Flscal Month

December, 1953

Including employees who were laid off for lack of work

Excluding employees who were latd off for lack of work
F'iscal Month January, 1954

$$
.77 \%
$$

$.66 \%$ January, 1954 Male Female

$$
.76 \%
$$

Flscal Month

During Jankary, 7 emplojees left voluntarily to accept other employment, 2 left to enter military service, and 2 left to enter business for self.

\section{Transfer Data}

Accumulative total of requists for transfer received since 1-1-54 Number of requests for traissfer receited during Jamuary Number interviewed in January, including promotional transfers

Transfers effected in January, including promotional transfers Transfers effected since 1-1-54, Including promotional transfers Number of stenographers transferred out of steno pool in January

\begin{tabular}{|c|c|c|c|c|}
\hline & Exempt & Nonexempt & $\begin{array}{l}\text { Comnunity } \\
\text { Firemen }\end{array}$ & Total \\
\hline$\because \cdots$ & $\begin{array}{l}3 \\
-2\end{array}$ & $\frac{44}{19}$ & $\begin{array}{l}2 \\
- \\
- \\
\end{array}$ & $\begin{array}{l}49 \\
21\end{array}$ \\
\hline TOTAT ALOITIONS & 5 & 63 & 2 & 70 \\
\hline
\end{tabular}

\section{ADDITIONS TO THE ROLIS}


Employee and Public Relations

ENPLOTER RETATIONS

TERMITIATIONS FROM THE ROITS

\begin{tabular}{|c|c|c|c|c|}
\hline \multicolumn{3}{|c|}{-5} & \multirow[b]{2}{*}{$\begin{array}{c}\text { Community } \\
\text { Firemen }\end{array}$} & \multirow[b]{2}{*}{ Tot2I } \\
\hline ' & Exampt & Ionaxangt & & \\
\hline $\begin{array}{l}\text { Actual Terminations } \\
\text { Removal from rolls (deactivations) } \\
\text { Transfers }\end{array}$ & $\begin{array}{l}6 \\
4 \\
2 \\
\end{array}$ & $\begin{array}{l}22 \\
20 \\
-\end{array}$ & $\ddot{\infty}$ & $\begin{array}{r}28 \\
24 \\
2 \\
\end{array}$ \\
\hline TOTAL TERMINATIONS & 12 & 42 & $\infty$ & 54 \\
\hline
\end{tabular}

GENERAI

Photographs taken

Fingerprint impressions

$\frac{12-1953}{148} \frac{1-1954}{127} \quad \begin{aligned} & 142 \\ & 157\end{aligned}$

PERSOMNEL SECURTIY QUESTIONNATRES PROCTESSED

General Flectric cases

$12-1953 \quad 1-1.954$

Facility cases

$49 \quad 52$

43.27

TOTAL

92

79

INVESTIGATION STATIOTICS

Cases rucelved during the month

Cases closed

Cases found satisfactory for employment

Cases found unsatisfactory for employment

Special investigations conducted

Cases closed before investigation completed

$\begin{array}{rr}12-1.953 & 1-1954 \\ 75 & 147 \\ 102 & 74 \\ 45 & 81 \\ 6 & 1 \\ 13 & 17\end{array}$

\section{PERPEECT ATMEANDANCE BECOGNITION ANAARDS}

Total one-year awards to date aince January I, 1950

One-joar awards made in January for those qual ifying in December

Total two-year awards to date since January 1, 1950

$-6353$

Twooyear awards made in January for those qualifying in December

Total threemyear awards to date

71

1980

755

Toree-year awards made in Jamuary for those qualifying in December

63

During January, 16 people whose contimity of service was broken while in an inio active status were so Informed by lotter. 
Emplojee and Public Relations

EMPLOYEE RELATIONS

The increase in personal interviews was somewhat the result of a carpentermillwright strike of construction forces.

Six servicemen were interviewed during the month for placement in Ileu of layoff. Of the six, five were placed in other jobs. This is the result of raducing the biss drivers by nine.

Supervisory Selection Program - Eight candidates were tested and test results were interpreted and reported to each subjects evaluator.

Clerical - The Minnesota Clerical Test and the Wonderlic Personnel Test were used to tost 22 clerical applicants during the month.

Metal Handlers - Some hiring in the olassiflcation took place so that it was possible to test nine Metal Handlers in connection with that validation study.

Imployee Benefits

The following visits were made with employees curing the month:

Timployee contacts made at Kadlec Hospital . 125

Salary checks delivered to employees at Kadlec Hospital 4 ?

Salary checks delfvered to employees at hame

7

At month end participation in Benefit Plans was as follows:

Pension Plan

Insurance Plan

Employees Savings and Stock Bonus Plan

December Jenuary

Two employees died during January, namelys

Clarence L. Hunmel.

W $-6657-942$

Claude H. Belcher

$x-200=346$

\section{Plant Auxiliary Operations \\ Commont.ty Operatilons \& Real Fistate}

Thirty letters were written concerning decensed employees and their families during Jamuary, regarding paymont of monies from the Company and answering questions.

Since September 1, 1946, I38 Iffe Insurance claims have been pald totalings $\$ 864,013$. 
Employee and Public Relations

EMPIOYEE RETATIONS

Three employees retired, namely:

$\begin{array}{lll}\text { George G. Iail } & \text { K-20-771 } & \text { Normal Retirement } \\ \text { Robert McFarland } & \text { W- } 3422-942 & \text { Normal Retirement } \\ \text { Boy C. Armstrong } & \text { W-5073-616 } & \text { Normal Retirement }\end{array}$

During January, 36 letters were witten to rotired employees providing them with information of general interest. To date, 279 emplojees have retired at Hanford, of which 148 are continuing their residence in the vicintty.

HAPO practice of requesting deferments under Seloctive Service was erltically revieved and consideration given to the feasibility of establishing a release Rotational Program. Following this critical reviow deatsion was reached that no substantial changes should be made at this time. It $1 . s$ anticilpated that fewer deferments will be granted as time goes on.

Military Reseitre and Selective Service

Statistics with respect to employees who are members of the military reserve are 2.3 follows:

Number of reservists on the rolls

Number of reservists classiffed in Category

Thuber" of reservists classified in Category B

Number of reservists classified in Category $C$

Number of reservists classifled in Category $D$

Number who returned to act1ve duty to date

Number who returmed to active duty in January

Number of reservists for which delaya have been requested

Number of reservists classifled in Category B

Number of reservists classified in Category $C$

Number of reservists clasglfled in Category $D$

Delays reque sted (including renewals)

Delays granted

Delays pending

Delays dented

Delay requests recalled

750

76

54

The statistics whth respect to employees reglstered under Selective Service are as follows:

Employeas reglstared

Fimployees regtstered who are voterans

E ployees reglstered who are non-veterans

Deferments requested to date (Including renewals) 1216

Deferments granted

Number of employees for which deferments bave been requested

175 
Fruployee and Public Belations

WMPLOYEE RETLAIIONS

Number of emplojres classifled in Category B

Number of mplojees classifled in Oategory 0

Number of employees classifled in Category $D$

Deferments dented and appealed at state levels

Deferments denied and appealed at local levels

Deferments dented and held pending appeal at national lovel

Deferments dented by local board and not appealed

Deferments dented by state board and not appealed

Deferments denied at national level (by Chen.Hershey's office)

Deferments denied at national level(by President)

Deferments requested, employees lator reclassifled

Deferments requested, later withdrawn

Delerments pending

$27 \overline{4}$

Military terminations sdnce 8-1-1950 are as follows:

Reservists recalled

Selective Service

124

Women employees enlisted

TOTAL

19

3

9

$\infty$

4

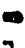

1

38

321

Employees returned fram military service:

Reservists

Selective Service

TOTAL

Known number not claining reermployment rights

Number of employess still in militarymleave status

Suggestion Sy'stem, Workmen's Compensation and [Hab1]1ty Inswrance

Total

Since

December

January $7-15-47$

Suggestions Received

Acknow].edgements to Suggesters

Suggestions Pending Acknowledgement

Suggestions Referred to Depts. For Investigation

Suggestions Pending Referral to Departments

233

212

94

185

219

2.12

60

94

219

Investigations Completed \& Suggestions Closed

167

Suggestions Adopted - No Award

3

60

227

Adopted Suggestions Approved by Comntttoe For Award

Total Net Cash Savings

Total Cash Awards

$\$ 5,908.83$

550

40

$\$ 15,254.75$

$\$ 1,660$

Total. Suggestions out to Investigators

658

726

13225 
Enployes and Publto Relations

\section{DMPLOYEE RETATIONS}

An award of $\$ 840$ was paid to an employee in the Separations Section for his suggestion pertaining to a method of regasketing process connectors under water. This suggestion resulted in labor and material savings.

The second hilghest award of $\$ 320$ was made to an employee in the Technical Section for his suggestion regarding a replsed metalographio sample holder for use In metalographio examination of slugs. A sting of labor resulted from the adoption of this suggestion.

Workmen's Comcensetion

Iyle Kozitka, 8001113 - Date of Injury: 1-26-52; Mroloyer: General Electric Company; Nature of' Injury; Carbon Tetrachlortde Exposure.

Mr. Kozitka dereloped a condition which was determined to be the result of using carbon terrachloride on the job. He rocelved extensive medical treatment and was off work 2lmost continually following the date of the Inotdent. On $12 \mathrm{~m} 2 \mathrm{-53}$ he was examined by conmssion consisting of Doctors P.I. Kendall and A. G. Corrado who advised that he was incupable of putting. In an el ght hour day, that he might work part time at an extremely Ilght job but that he would never be able to retum to a full eight hour day involying even mild efforti. On $1-19-54$ the Department published an order placing Mr. Koritika on the pension rolls effective 1-15-54. In accordance he was remoted from full salary effectivo the date of the penaion.

I. M. Conner, 8000161 - Date of Injury:8 4miom47; Employer: General Filectrice Company; Nature of Injurys Iumbar back.

Mr. Conner sustatned an attack of low back pain fallowling an inoldent at work. His clatm was accepted by the Department and a laminectamy and spinal fusion was subsequentIy performed. He was assigned to work dolng carpenter jobs of 2 very minor nature and since the date of the incident has received prolonged medical care from a variety of sources. He was absent from work for long perlods during the jears following bis infury and the case was finalify closed on $1 \mathrm{~m} 20.54$ by a permanent pertial disability award of $50 \%$ of the maximum allowed for an unspecified disability. It is our understanding that Mr. Conner intends to appeal the closing order. MI. Conner was remored from the rolis on January 29, 1954.

\section{Lffe Insurance}

Code information which is known only to Home off1ce Iffe Underwriters Assoc1ation bas been furnished 29 insurance compantes and Investigation agencies during the month of Jenuary, 1954. This 1s in accordance with an arrangement with tho Underwiters whereby employees on this project might be tnsured on the same besia as those working elsewhere. 
Enployee and Publio Relations

IMPIOYEW REIATIONS

Ingurance Statistios

OLaims reported to Department of Itubor and Industiries

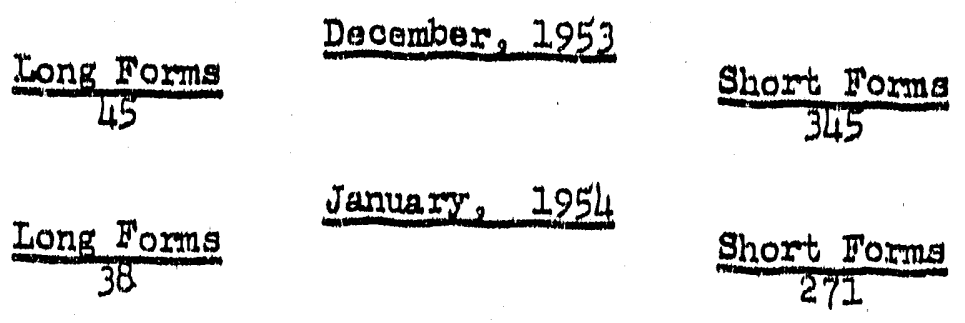

Total SInce Septemisor, 1946 - 18,947

Tlajing reported to Travelers Insurance Company

December Januagy

Total Since September, 1946 - 813

* If the olajms reported to Travelers Insuranoe Company during the month of Jariluary, nine were property damage clatms, two were bodily lajury clatms and one. was both property danage and bodily infury.

WRAINING PROGRAM - COLIATMRAT CONTRACTORS

During the month of Jamuary, six KAPI traineos reported to HAFO for an approximate four weeks tratning pexiod in the Reactor Seotjon. Seven U.S.Navy men

2lso reported here for a two weeks training course. 
Thomoyea and Public Rolationg

Thup.Loyer Relatizone

MRATNING AND DEVGLOFMENT

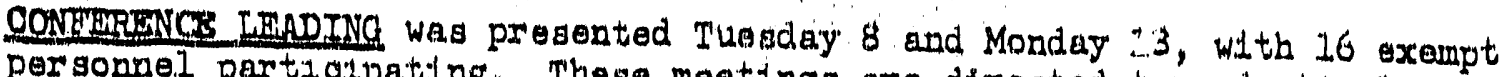
personnel partiolpating These meatings are dirooted toword stimulating laterest in laarning the techniques of leading eroup disousgiong.

MTEECTIVE HTMAN RETATIONS first meetings, a new 12-bour program of throe separate meotings, were held for 7 groups Wednesday and Thur sday 6-7, Wednesday and thursday 1,3-14, Wednesday and Thursdey 20an, and Thur sday 28, with a total attendance of 101 auperrisors. This program deals primartly whth sotual human relations case studies. These cases are presented through various fllms, reoords, and written beckground, allow ing group disoussion of these and other on-tho-job oases of the super-
visors attending.

HOBSO II was prosented Thursday $?$ and Monday 26 f'or 20 supervisory personnel. This program covers the effects of war tine economy, government sontrols, and past-war economy.

IABOR MANAGEMENT RELATIONS was held Friday 8, with an attendanoe of 12 superrisors. This program is a olauso by clause discusgion of the HuA. $M_{0} \mathrm{~T}_{0} \mathrm{C}_{0}$ and other local, agreements with the Company.

PBTNOIPLES AND METHODS OF SUIPHRV ISTON was presented to Groups 6.2 and 62 during the two weaks of January $11-22$, with 34 supervisors completing
the course.

CUSTOMER RETLATIONS was presented Wednesday 13, 20, and 27 to 123 professional and non-professlonal Medicel employees, Thursday 14 to 11

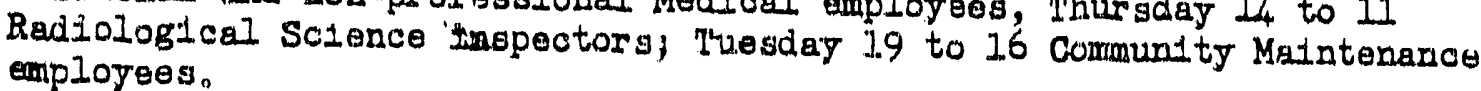

Special program "In our Hands" was presented for Richland Communt ty Thursday erening, January 14 at the Publio Libramy, with 30 people
present.

During the month, all Department Menagers wero sent liats of their exempt employees who had attended the evening Marlagement. Development. meetings during 1953. The Training Activitios Book for 1954 and first quartar program schedule cards were distributed to 190 supervisory management parsonnel of all departments, Including all Department and Section Managors. Trajning Program attendance transcript records from 1948-1953 were prepared for all exempt personnel of all sections and unt ts of each dopartment and distributed to all Section Managers. 


\section{Thiployee and Public Relations}

Employee Relations

There were 7 requests from secretarial personnel for Business English

Two sections in the Engineering Department and a section In Comnunity Operations requested a total of 65 program transcript forms.

Supervisor's Handbook Records:

$$
\begin{array}{lr}
\text { Number issued during Month } & 2 \\
\text { Number returned during Month } & 6 \\
\text { On Hend } & 169
\end{array}
$$

Of the 169 on hand 47 are not usable because of missing pages and 17 bave to be checked for completeness. The remalning 105 are ready for
issuance. 
Employee and Piblis Relations

EMPLOYEE RELATIONS

EMPLOYET COMMUNICATIONS

The 1953 Safety Report, an 01 ght-page, two-color statistical report of last year's safety performanse, was prepared at the request of Safety。 At month's end, it was at Central. Priniting awalting production.

The safety topis tor Febriary, mitme for Actzon," was writter, approyed, and art work completed; at monit's end, it also was at Central Printing awaiting
production.

The March safety topic, "What Blamed Wind," has been written, and approved
by Safert,

Iifeline material for the four January GE NEWS Issues was edited by Special Programs: and the Safety Program Committee Meeting was attendad as secretary
and minutes prepared.

The healtis bulletin for February, "A Backward Glance," was written, approved, art worix prepared and is now at Central Printing awaiting production. A 16mm motion pidture entitiled, "Improving Your Poture," has been obtained for loan to plani groups duming Fobmuany to supplement the heaith bulletin. The Health Activities Meeting in January was attended by a Special Programs writer in an adrisory sapacity。

The cost reduction program, witioh began as a strictly 200 areas program, has been expanded Irito a plant-wide program under the aegls of the suggestion System. An outizne was prepared by Special Programs whit oh reorganized the material prepared by the 200 area people and was approved by them. Writing of initial rougin draftis for two of the leaflets to be distributed to employees

The Jariary issie of "Your Manufacturing Month" was prepared and published.

Final approtel was recitred from the General Manager for the publication of the plant darival report, M1953 at Hanford." The copy, photograpis, captions, char", and dum were approved previously by tine Cereral Manager, but, upon his requestio praduation was held up pending a final decision regarding some recomendastor:s for the repcrt made by the Manager, AEC Hanford Operation Office. Meetings were held at whish these coments were discussed and final decisiors arritred ato The report will be issued as originally prepared, with the substitution of lighter weight paper and coter stock.

The flrst two of a series of posters for Separation's Radiation Monitoring were prepared。 Trey also are at Central Printing awaiting production.

mour Radiochemigtry Buxlding," a 12-page, two-color booklet propared to glve the occupants of briciding 325 information about this new facility, was prepared, approved and at month's erd was at Central Printing awaiting produc-
tion. The Jasuary is sie of the GE REVIEW was distrituted to qualified technical and
engineering people throughout the plant. 
EMPTOYETE REITATIONS

EMPLOYEE COMMUNICATIONS

Twenty frojection engagements were met during the month with showings to approxdmately 400 employees. This includes 15 showings of the IBM film, mplexcing the unknown," to approximately 300 people.

Thirty-geven flims were ordered from off-site for plant organizations.

Servicing employee information racks throughout the plant with Ge publications was resumed during the month.

The following posters were placed throughout the plant during the month: four Sheldon-Claire posters, four Elliot Service Company posters, and 90 copies each of two Ge photo news service posters. In addition, 66 Suggestion System boxes were serviced and posters changed twice.

Arrangements were made for the purchase of a l6m motion picture projector.

Arrangements were made for elimination of the existing wall between rooms 111 and 112 and construction of 5 cubicies made of Hauserman partitions.

"New Packaged Plan" for analyzing performance at HAPO, now offered bj Operations Analysis Section, was reviewed in feature style in the GE NEWS. This otory subsequentIy was released the CNES Bureau and appeared in 7 datly papers; and SUPERVISION MAGAZINE, with national distribution, has requested an expanded version of the story.

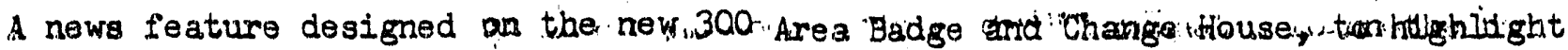
good working conditions at HAPQ was published in the GE NEWS.

A condensed version of the General Manager's address to members of management at his thrual moeting was publinbed in the GE NEWS, propared from an advance copy of Mr. Johnson's talk. A supplementary story was published on the surprise appearance at the Wednesday meeting of the General Manager of the Atomle Products DIVIsion. A follow-up story was published in a subsequent issue covering statements made by a progress in the atomic energy field.

Courses avatlable to project people during the jear through the craduate School and the Adult Education Program of the Richland school system were announced and given continued publicity during the month in the GE NEWS. Included in the publicity was a message by the Ceneral Manager.

Top suggestion award winners for each month of 1953 were feted in a full-page photo feature with eopy explaining the highilghts of the Suggestion System. Two suggestion winners who received a total of $\$ 1160$ in awards during Jamary also were publicized, along with other award winners for the month.

The 300 area's winning the Area Injury Rieduction Award three times during 1953, thereby gaining recognition as "outstanding performer of 1953," was highlighted in the CEE NEW during the month. 


\section{EMPLOYEE RELATIONS}

\section{EMPTOYEE COMMUNTCATYONS}

Emphasis wras glter to Red Crogs Blood Pregram in two suosessive is3res of the GE NEwS. In ono 1s sue a blood donor blank was published on the front page, with supplementary story annorncing tiose who besame Gallon Club members at the January drawing. In a succeeding issue, a stary sovered a forihcoming Bloodmobile visit to Ridenland, and the continued need far bloodo

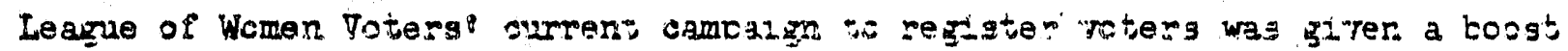

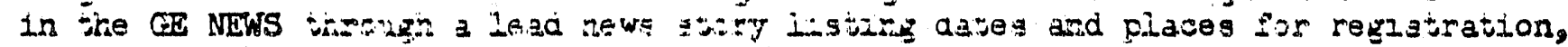

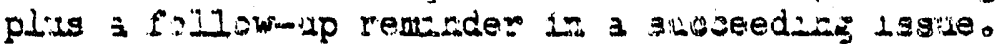

To sare time and labor, and to inomase converance for Transportation and the Central Mat Room, the CW NEWS arranged for tine printer to deliter papers each Frtday in one deilfery, rainex than two as in tise pasto

Two Management News Burloting were distribxted to all exempt employees durise the moniti.

Purchase reouisizion for management Infopmation" pampilets, to be distributad on a wekcly basis throughout the year to exempt employees via deparimental channels, was isgued. The quantity dropped from the $7: 27$ per week ordered in 1953 to 684 for 1954 as a result of surreying departimental needs.

The General Manager's turo-night meeting with members of management was aided through preparation and distribution of ilakets, and publisizing the event through the Managemert News Bulletino

Preparaiton of art work for the 1953 anmual report to the AEC occupied the major portion of the sommercial arifigt g time during the month. This work included making layouts for 48 pages (Included sketches, photos, charis, copy fittings, etso), and producing final art woris for the front and back cover of the report and for 15 inside pages. AII ari work for the report was sukeduled to have been completed during January, but progress was halted temporarly until a deciaion was made by the Geriral Manager 29 to the final form the report. would taike.

Layout and 1 Ilustrations were developed for the Fobruary health bulloisn, and for the Fabruary saiaty topiso

Final art work for MYour Radiodhemistry Builaing" booklei was produced.

Final art woris for tum radiation posters was completed, and layouts and sketches for three additional posters were made.

Additional art work during the month included layitrg out a full-page photo feature for the NewS on Hanford"g "Plastic Man," and providing Inked Arawing of the CR Supsrtisorg Association symbol. 


\section{Employee and Publis Relations}

\section{PUBLIC RELAIIONS}

During the month of January, the News Bureau issued 46 news releases. The
breakdown by category, diatribution, and content was as follows:

Subject

Pay and Benefits

Employment Services

Good WiII

Technology and Research

Utilities and Public Works

Safety, Fire, Security

Education

Health, Medicine, Sanitation

Plant Sextrices

Organization Changes

Bice, Fire
Distribution

8
4
5
6
1
9
3
2
4
3
1

Local

Daily

Spectal

Content

Feature
23

13

Plcture only

Short release

Long release
10

3
27
10
6

Public Relations prepared BAPO's annual contribution to the progress edition of the Walla Walla JnIcn-BULieTLi. Four stories were especlally written for this stories were edited and sent.

The News Bureau blography 1 lies are nearing been sent to most top offlelals at Hanford completion. Questionnalmes have now are returned to the News Bureau, write-ups will be all of the questionnalres are blography plies.

A speclal feature on the Uptow Business Distrint was distributed this month and were sent to WESTHRN CITY and PURIIC REIAIIONS JOURNAI. In

A speclal project lavolving publicity material on protentive clothing used at pleted this month. The following was sent Schenectady News Bureau, was comsets of photos and wite-ups, for whatever use they with the Ir request: two complete serles of plotures with write-upg to they chose to make of them; one feet of $16 \mathrm{~mm}$ movie $11 \mathrm{~m}$, with accompanylng write-up. SCIEITCE magazine; and 250 mejor televisiou distributing agencles. NBC and footage and it is assumed that the other networl oBS have already used the movie the platonlum making procesat our news release announclng that waste heat from was one of the top news storles in be ut1lized to heat the areas production plants lation throughout the State of Washington during 1953. The I1sting wes a comp1newspapers and AP newsmen. The new atom by editors of Assoulated Press member sket:hes of the aEw process were priated heater was Iisted 25th. Storles and reports throughout the State of Wushington. 
Rlubland's medical program recelved extensive coverage in the aation's newapapers and in the MONOGRAM this month. Plotures and blographles of Drs. Sachs, Norwocd, and Fuqua were sent to the Seattle TIMES, and the MONOGRAM, at the request of the two publications, to acsmoany the is remeng about a paper which the three doctors recently prepared about the medical program. A follow-lap phntograph feature on Banford and Richland medical faclilties was sent to the Spolcane CHRONICLE, and they devoted a full page to the feature. The national newspaper coverage incilded the New York TIMES, and contalned a description of Richland's integrated medial program, the story having been origlinated by the American Medical Aisoriation.

Howard Whitman, a regular sontributor to READERS' DIGEST, same to Rlchland during the month to prepare an article for READERS' DIGEST on Richland's medical program. He intervtewed several people connected wtth the medieel program and was taken for man-on-the street type of intervievs tio get the reactions of the average resident to the progriam.

Edwari Costello, fileld representative of the SPOKESMAN REVIEW, visited Public Relations this month and aiscussed with the Newe Bureau Supervisor the speclal needs of the REVIEW.

In a discussion with representatires of Technical Secticn it was decided that notise of slgmiflegnt organlzatinn changes in Technical Sestion will be sent to terhnlcal jovrnals and other interested publications by Public Relations. A form news release was prepaxed and has been approved by Tecbnlcal Section. These forms w1II be fllied out by Indiriduals involved in organization changes and coples will be maje and mailed to selected publications.

Five letters asking for information about Hanford and various aspects of atomic energy were answered thli month. Fact sheets and informative booklets were sent.

Tro completed articles were sent to the GE REVIEW: "Some Aspects of Graphite Moderated Reactor Cooling", by George Roy and Gardner Locke, which is scheduled for the May 1ssue; and "Concrete Shlelds at Hanford", by Harold Davls, scheduled for the July 13sie.

An article by $D$. D. MoCracken ebout the solution of an engineering problem with special IBM procesaing machines in the East has been sent, at the request of International Bus iness Machine Corporation, for use in that soncern's house organ.

The LIlustrated article on the Rad lometallurgy Laboratory, by T.W. Gore, which has been in process for quite some time, is ready to be submitted to MEIAL PROGRESS.

An article on Richland's med1eal program was approved and will be submitted to MEDICAI ADVANCE by the Director of the Medical Deparment.

Four articles abcut work at Hanford were requested this month by the ceneral Electric REVIEW. Authors have been found for the four a rticles and due dates for these articles will 300n be asg lgned. The articles ant the authors are: The Aquat1c BIology Laboratory, R. F. Foster; Effecta of Radioactivity on Planta, J. H. Rediske; Ground Disposal of Atomis Wastes, J. M. Smith; and Blological Hazaris of Plutsalum, R. C. Thompson. 
Employee and Public Relations

is

NUCLEONICS was sent a group of photographs to illustrate an article they are

Laboratory Equipment".

E. B. LaVelle's article, "The Use of Nitrogen as a Purging Gas for the Inert Arc Weiding of Stainless steel Plping or Tubing", has been accepted by InDUS'TRY
AllD WETDING. The report on technical accomplishments at Hanford during 1953 appeared in the
January issue of the REVIEW with very few changes.

A report on the status of signed articles and other articles for publication will be compiled monthly. Copies of this report will be sent to the Schenectady News Bureau to give them a chance to make further use of the material reported on. Manager, General Public Relations, in Manager, Atomic Products Division; Information Branch of A.E.C.; General the New York Office; Chief, Industrial Relations; and others at Hanford who Manage:, HAPO; Manager, Employee and Public interested in sigmed article activity. from talks given by K. K. Campbel celved and sent to the authors for editing. Representatives of Public Relations toured the new PIle Technology and Radiochemistry Laboratoiles this month to find material sultable for signed articles.

Three papers by Hanford authors were cleared this month. They are:

"The Effect of Zirconium Citrate and CaFDTA on Urinary Excretion of Intravenously Administered Plutonium", by I. A. Temple, for Meeting in Kansas City, Mo., on March

"Degree of Accuracy in Electrical Estimating", by W. W. Uliebenstein, for presentation at a meeting of the Rlchland Section of the ATHE on

"Isotople Analyses of Sollds Using a Modifled Commercial $180^{\circ}$ Type Mass Spectrometer", by C.A. Goodall and G. J. Alkire, for presenin Hew Orleans, Loulsiane on May 26-28.

Ben D. Wilson of Plant Engineering made the featured tall, entitled "Working on Jenuary 20 . He the annual Chamber of Comerce banquet at Brewster, Washington, the same afternoon. He showed an assembly of Brewster High School students R. T. Jaske gave apeos Reactor Effluent," before the Oregon chapter, "Space Heating from Atomlc and Ventilating Englneers in Portiand. 
Employee and Public Relations

H. E. Hanticorn wiIl geak at a meeting of the Washington State Society of Professlonal Engineers at Seattle on March 25. His toplc will be, "The Design of Plants for Radiochemical Processing".

Arrangements were made this month for A. B. Greninger to give the feature address at the dedication of a new engineering brilding at $S a n$ Jose Statie College on February 25.

EAPO's General Manager acnetted an engagenent this month to be the feature spealiser for the annual meeting of the ifational Association of Power Engineers at San Francisco in Marsh.

Two aditional requests for speakers sometime in Febriary, one to address 600 students at Whitworth College and one to address 500 stixdents at Whitman college, were recelved this montih. Although arrangementis are being made to obtaln spealsers for these engagementa, a definite comstment has not yet beer made for either.

In answer to a request for information about General Elestria aids to schonls: two members of Public Relations went to Pasco and explained the educational aid program to the Pasen High School librarian. He mill sirculate examples of booklets to bigh school teachers at $\mathrm{Pasco}$ and w1II make all the information avaliable to those who might be interested.

A fifteen-minute motion picture presentation is being assembled from footage made on the recent $B a l l$ 3-X installations. This is a silent version being prepared from master and workprint footage for which a script narrative to match is being written, all for use by Froject Section management.

Members of Public Relations are preparing actual on-the-scene tape recordings of construction antivities and equipment in operation for use on Construction Progress motion picture. Some unique effects are planned from unusual conditlons. Sound effects records on hand have been found inadequate and of poor quality for motion picture requirements.

Aerial motion plcture photography was scheduled to be done on progress in Purex and 100-K construction operations. Snow covered ground conditions provide good Ilght and contrast for needed effects.

The final edited black and whlte workprint of the Orlentation film, "Here's Hanford", was recelved from the stud10. A final. review was held by Employee and Public Relations officlals and bllowling this the first release print was ordered with delivery estimated to be wade about February 12.

Twelve General Electric motion pletures were obtalned for showlngs thls month to comunity organizations. The Rlchland Accomtants Association and Rlchiand. Junior Chamber of Comerce expressed their appreclation for the flims obtained for the ir groups. 


\section{Employee and Public Relations}

Filming of an entire sequence of the 100-K. Reactor model was completed on 16rm Kodachrome f1lm. This was an important phase of the GE-AEC Fillm Tootage Program on the Current Expnnslun Program. This footage will be shown to production personnel for orientation in the functions of the reactor to avold moving the model from place to place and also to have a Atomic Ener and version of the flin to fit into the General Electric.

Project Section officials have reported that over 300 employees and subcontractor personnel have attended showings of the 11 Im "Getting the Job Done", produced at Hanford by Public Relations. They estimate that between 150 and 200 employees are to be shown this $111 \mathrm{~m}$ each month. This figure includes operations personnel. These are training sessions at which all cipal visual medium.

The first preliminary editing of the Construction Progress film footage was begun this month. About 13,000 feet of the f1lm has been processed and work-
print prepared.

The flnal print of the motion picture, "Getting the Job Done" was delivered to Minor Construction Management. This was the fifth feature-length trainingdocumentary motion picture produced by Aud10-V1sual Unit since July, 1952, for Hanford operating and englneering departments.

Filming on the Construction motion plcture continued this month at the $100 \mathrm{~m}$ area on several lmpcrtant phases in the building of the water plant, Reactor Bullitings, and also at Purex Construction axeas.

Three Hanf"ord Sclence FORUM tapes were loaned to the Iibrarlan of the Pasco Senfor High School for the use of the sclence teachers as teaching alds. Pasco High School plans to use Sclence FORUM broadcasts as a permanent

Four Hanford Sclence FORUM radio programs were broadcast by Radio Station KWIE this month. Iistener interest is increasing as evidenced by the growing numbers of letteis and inquiries recelved in addition to the particlpation of high school students from this area.

The Columbla H1gh School science teacher met w1th the Hanford Science FORUM moderator to assist in arrangements for one of the school's outstanding sclence students to appear as guests on the regular program. Larry Blackburn, son of a General Electric employee and a "stralght $A^{n}$ sclence student was selected and appeared on the show. Plctures of the student, his teacher, and the Sclence FORUM moderator were released along with a feature article to local and reglonal newspapers, in addition to the GS ILWB. Arrangements also bave been made, in conperation with the Speaker's Bureau, for guest appearances of star sclence students from other Tr1-city and reglonal high schools.

Two of the serles of ten radio programs titled "For Better Iiving", belng produced for Public Health by Public Relations were prepared this month and 
Fiployee and Public Relations

brcadcast by Radio station kPKN. The program series is belng created from recordings by the Metropolitan Insurance Company, personal interylews with Iccel doctors by en executive member of Public Health, and open and closing announcements with muslo backgrounds made by a member of Public Relations. Publis Health offlcials have expressed satisfaction in the broadcastis and reported considerable listener interest.

A speech dellvered by the Atomic Products Division General Manager before the American Institute of Electrical Engineers at San Francisco was auditioned by nember's of this Section for clearance from a Public Relations standpoint. Only sertiain minor changes vere requested prior to broalcast in the Bay Area.

One spot annourcement to advertise a worthwhile community enterprise was written, recorded on tape with live musical accompaniment, reproduced in disc form and released for broadoast or kPKS, Pasca; KIII, Kennerick; rAIE, Rishland;

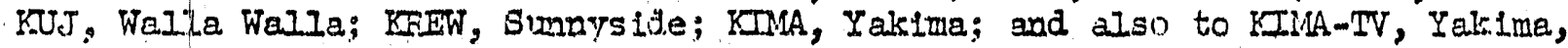
along with a poster to put on the camera.

Arranifements are being made to asalst the Rlehland Chapter of the Americean Chemleal Society in their current educational program for high school students. We are malsing avallable one of our coples of GE's "A is for itom" film to the ir organization for periodic shovings to blgh school students throughout the state of Washington. The film augmenta a presentation conducted by the ACS members for sclence elas.s studients in chemistry and physics. Though not a jointiy sponsored program, because of our position in the fleld as prime contractor, full credit will be given for our efforts.

Complete public address and recording equipment was installed for the General Nanager's Annual Report theetings with supervisors held on January 12 and 13 . Recordings of the General Manager's talks were made on both evenings by merbors of this section. The tapes will be edited and kept for permanent reference with the poselblilty of using unclassifled portions for public relations radio programe.

A total of 192 photography ass lgnments were covered during the month of January, 1954 , and a total of 6,906 printa were produced. Of the total printis, 3,144. were "A" and " $B$ " badge prints, A total of 3,762 were area and news nork.

Projection equipment Inans during the month were: $16 \mathrm{~mm}$ projector and screen, elever times; $3 \frac{1 "}{1 "} \times 4^{\prime \prime}$ lantern silide projector and screen, elght times; $35 \mathrm{~mm}$ sound slide projector and screen, onetime; 35m Goldle projector and screen, one time.

Motion picture film exposed during the month totalled 2,897 feet, Ifrm (B\&W) for 100-K Construction project, and 762 feet of color on the 100-K Project.

Black and white slides were produced and projected for the General Manager's annual meeting. The use of an Arc Projector removed all the difficulties experlenced the previous year in projecting slides. A serles of 66 color 
slides, $3 \frac{1}{4} " \times 4$ ", were produced for radlation monitoring. Ektachrome color film ( 4 "X.") was used in the plase of $35 \mathrm{~mm}$ Kotachrome as a test. A change in method, type and size of fllm was made to increase quality, facilitate this type of shooting with general photographic equipment, and to reduce the cost of producing color slides. Poor weather conditions have made it Impossible to complete several ass ignments requested for the month of January. This has affected the overall production of photographis work.

See attached Stat1st laal Report for Photography Unit. 


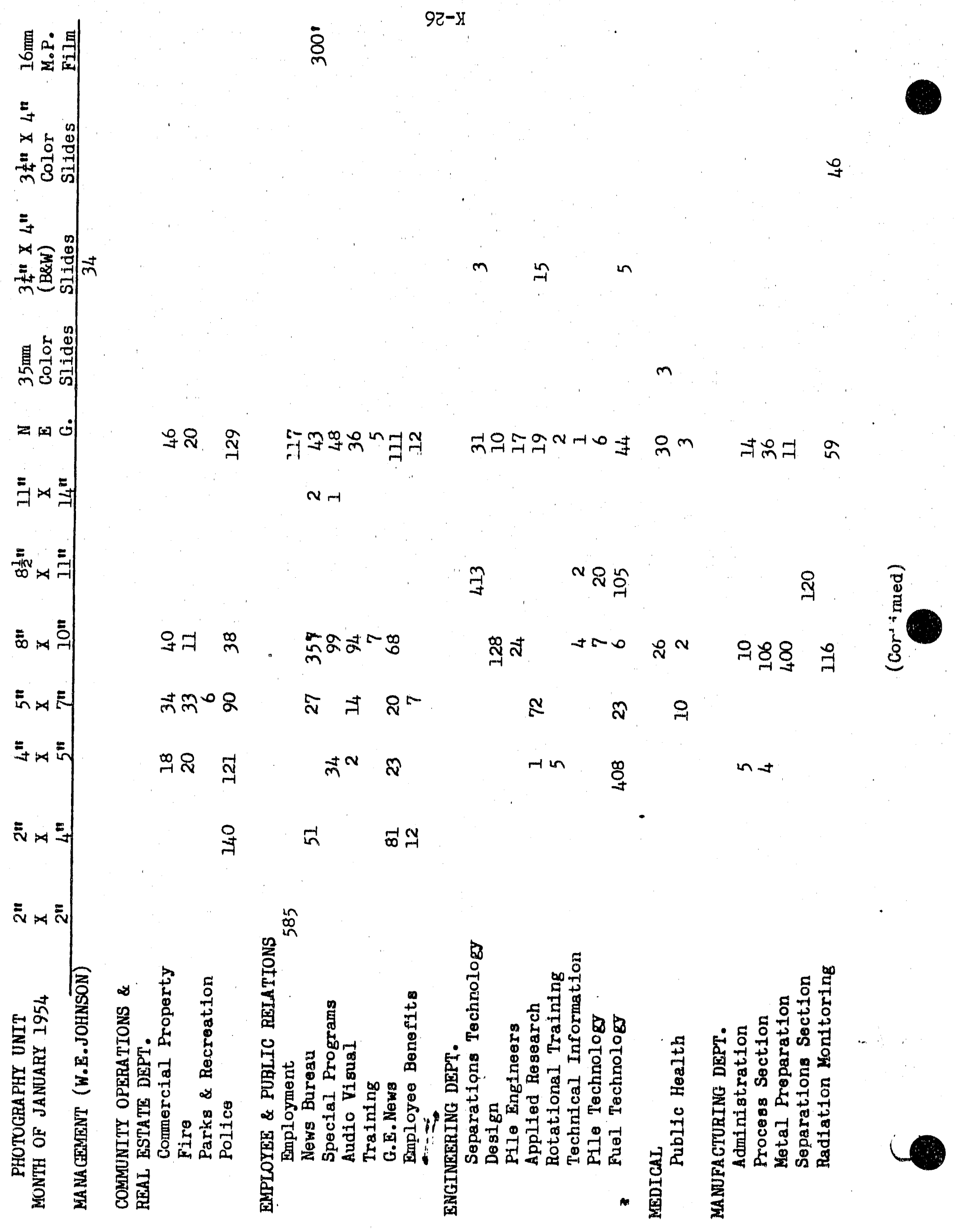




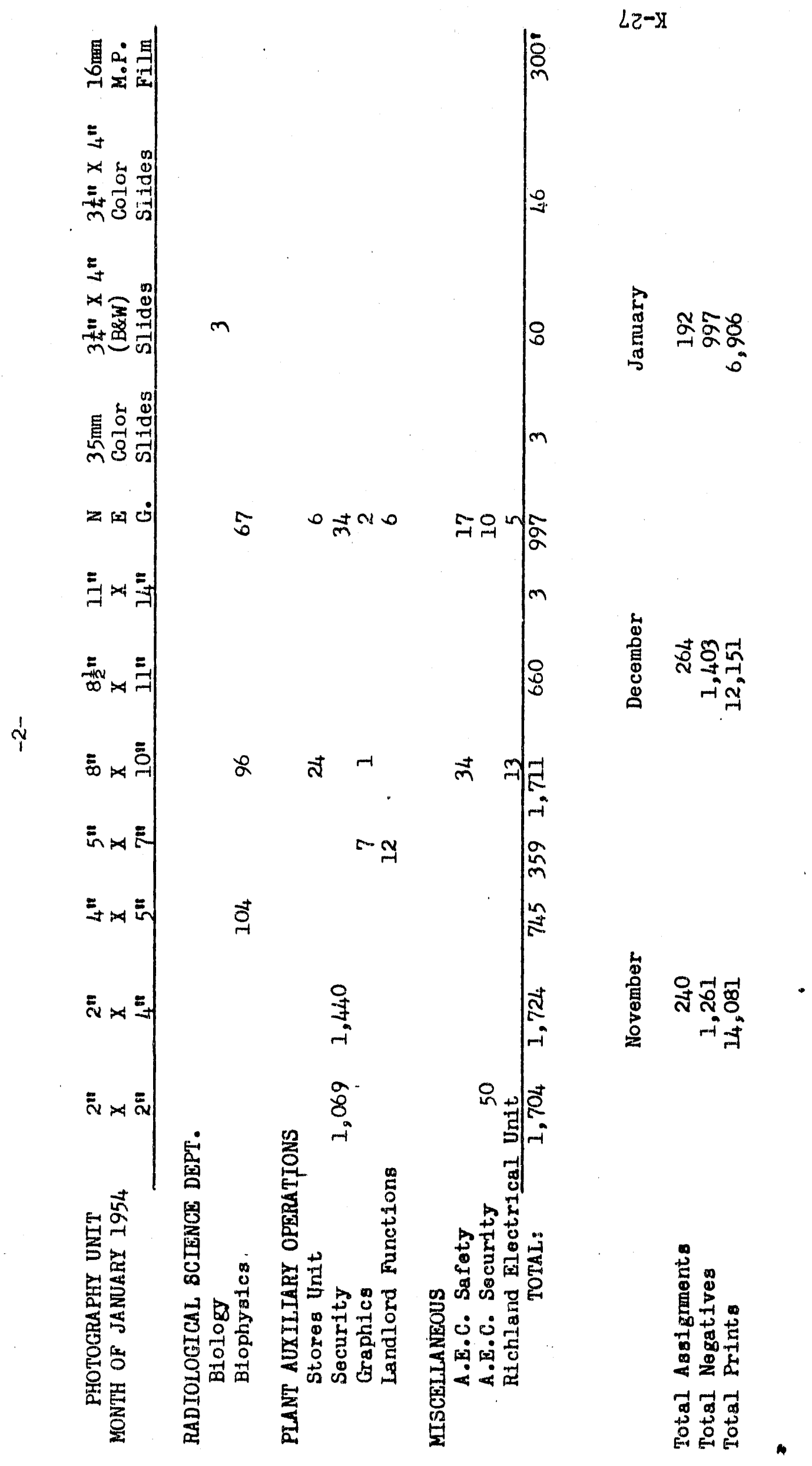


Salary Administration

1. Audits in the Pleld lavolving conformance with position descriptions and organization structure, the review and evaluation of position descriptions, the detalled study of organization structure, and other adminlstrative work proceeded according to schedule.

2. I. L. Ferguson, Consultant, Salary Administration Services Department, spent the week of January 18 at Hanford. He brought with bim of Icial information relating to the Company salary plan, and voluminous data to aid us in adapting our salary plan to conform with that of the Company.

3. A major review of the salary stmucture at HAPO was begun on January 25, and is scheduled to be complete on May 3. This review includes the analysis of each exempt position, the writing of new position descriptions, and the re-evaluation of each position in order to make assignments within the Company salary structure.

4. A letter was prepared advising the A.E.C. of the nature of the Company salary plan in broad outline, and requesting certain changes in our existing salary plan as prerequisites for adoption of the Company plan.

5. The regular quarterly report for the perlod ending December 31, 1953, was conpleted and mailed to the Commission. 
Fumployise and Public Relations

Union Relations

UNION RELATIONS - OPERATIONS PERSONWELC

At the request of the Hanford Atomlc Metal Iredes Counc1l a meoting vas hald on January 4, 1954, wth representatives of the rediat1on monftoring Inspectors to d1scuss problems associated with thelr new bargalning status. The group oxpects to ask for a meetlag in the near future at wh1ch they w111 submt thels proposals regarding senlority, progression schedules, etc., to the Company. The following seems to sumarlize the thinkelng of the group:

1. Want to come Into the unit under the existing Agreement.

2. Job deflnitions need clarlfying to eliminate work assignments out of elassifleation.

3. Method of establishing senfority is causing problems but indications point to a preference for Individual senforlty lists for Separations, Beactor, Metal Preparation, and Radlological Sclences groups.

4. Progression schedules need rev1sion to conform to bargainlng unit.

5. Understandings necessary to eliminate superv1.sora dolng unft work.

6. Revised nomenclature for clessiflcations, plus addition of a trainee.

We are not preparad to agree in toto with the foregolng but anticipate little trouble in reaching a mutualis satisfactory arrangement.

Last month reported concerning an IUE-CIO pet1tion for an MLRB election covering all maintenance and production and some clerlcal workers or the General Flectric Company. We are Informed that the Board is engaged in an inveatigation of the matter which probably will be lengthy and whlch, we feel, will result in the eventual dismissal of the petition. It seems accuratio to predict that the Compang:

1. Will never consent to such an electlon;

2. Would $\nabla 1$ gorously oppose the elect1on in any MLRB hearing that meght develop; and

3. W11l endeavor to get the petition dismissed adminlstratively without a hearing.

On January 13, 1954, a meet1ng was held wh Counc1 representatives of the Instrument Craftamen's Gutld to discuss a new procedure developed by the Manufacturing Department for test1ng and rating candidatos for upgrede to tho Instrument Spec1al1st classif1cet1on. Th1s procedure is Intended to f1ll the need for a unfform method of determining the qualiplcations of potentlal Instruent Spec1allsts. All the Councll's coments ware farorable. 
Thployeo and Public Relations.

As a result of the Carpenter strike approximately 41 expeditors in the Englneering. Department whose work is closely related to construction activities were furloughed for one reek due to lack of work. Twenty-nlne of these employees subsequently submitted a grlevance seaking pay for a.li time spent durling the wook by supervision performing work customarlig assigned to them. The grievance was settled at Step $I$, wlthout back payments, but the group In question 1s quite disgruntied and a number of expeditors are seekfing transfers to other jobs whlah are less susceptible to construction strikes.

\section{Grlovance Stat1st1cs:}

A total of 27 grlevances were recelved and three Step II grlevance meetings were held during the month. A breakdown of the grlevences recelved and processed follows:

\begin{tabular}{|c|c|c|c|c|}
\hline & \multicolumn{2}{|c|}{ All Departments } & \multirow[b]{2}{*}{$\begin{array}{l}\text { Total } \\
\text { Un1t }\end{array}$} & \multirow[b]{2}{*}{$\begin{array}{c}\text { Total } \\
\text { Nonun1t }\end{array}$} \\
\hline & BAVIC & HGD & & \\
\hline Recelved th1s month & 23 & 2 & 25 & 2 \\
\hline tep I & & & & \\
\hline $\begin{array}{l}\text { Pending Decomber } 31 \\
\text { Settled thls month* } \\
\text { Pending Jenuary } 3 I .\end{array}$ & $\begin{array}{r}0 \\
18 \\
.1\end{array}$ & $\begin{array}{l}0 \\
0 \\
0\end{array}$ & $\begin{array}{r}0 \\
18 \\
1\end{array}$ & $\begin{array}{l}5 \\
1 \\
6\end{array}$ \\
\hline
\end{tabular}

\section{Step II}

Pending December 31

Sottled this month**

Ponding January, 31 .

$\begin{array}{rrrr}23 & 0 & 23 & 0 \\ 8 & 1 & 9 & \\ 24 & 2 & 26 & 0\end{array}$

Arbitration

Pending December 31

Settlod this month

Ponding January 31 *

$\begin{array}{lll}4 & 0 & 0 \\ 0 & 0 & 0 \\ 2 & 0 & 0\end{array}$

* Grlevances brought to Step II pr1or to November I, 1953, but nevar processed by the Union are, for the purpose of thls report, consldered sottled at step I.

* Gr1ovances which the Onfon formalis Indeated thelr Intent1on to submt

- to arbitration brit hare taken no further act1on since llotember 1, 1953, are, for the purpose of th1s report, considered settled at Step II. 
Imployee and Public Relations

Grlevance Stat1stics (Contd.):

\section{By Departments}

\begin{tabular}{|c|c|c|c|}
\hline & Recelved & $\begin{array}{l}\text { Settled* } \\
\text { Step I }\end{array}$ & $\begin{array}{l}\text { Settled** } \\
\text { Step II. }\end{array}$ \\
\hline $\begin{array}{l}\text { Manufacturing } \\
\text { Reactor - Un1t } \\
\text { Separations - Un1t } \\
\text { - Nonun1t } \\
\text { Motal Proparation - Wa1t }\end{array}$ & $\begin{array}{r}\frac{11}{4} \\
1 \\
2\end{array}$ & $\begin{array}{r}11 \\
3 \\
1 \\
2\end{array}$ & $\begin{array}{l}3 \\
1 \\
0 \\
0\end{array}$ \\
\hline $\begin{array}{l}\text { Plant Auxillary Operations } \\
\text { Transportation - On1t } \\
\text { Plant Protect1on - On1t }\end{array}$ & $\begin{array}{r}2 \\
-3\end{array}$ & $\begin{array}{l}2 \\
0\end{array}$ & $\begin{array}{l}0 \\
2\end{array}$ \\
\hline $\begin{array}{l}\text { Community Operations \& Beal } \\
\text { UnIt }\end{array}$ & 4 & 1 & 0 \\
\hline $\begin{array}{l}\text { Englnoering } \\
\text { Nonunit }\end{array}$ & 1 & 0 & 0 \\
\hline
\end{tabular}

By Subjects

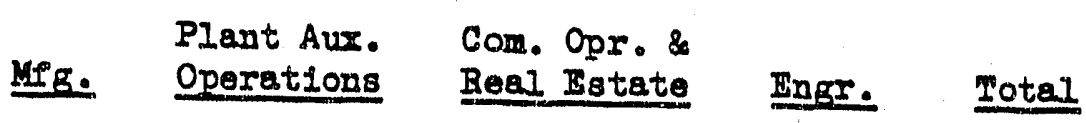

On1t

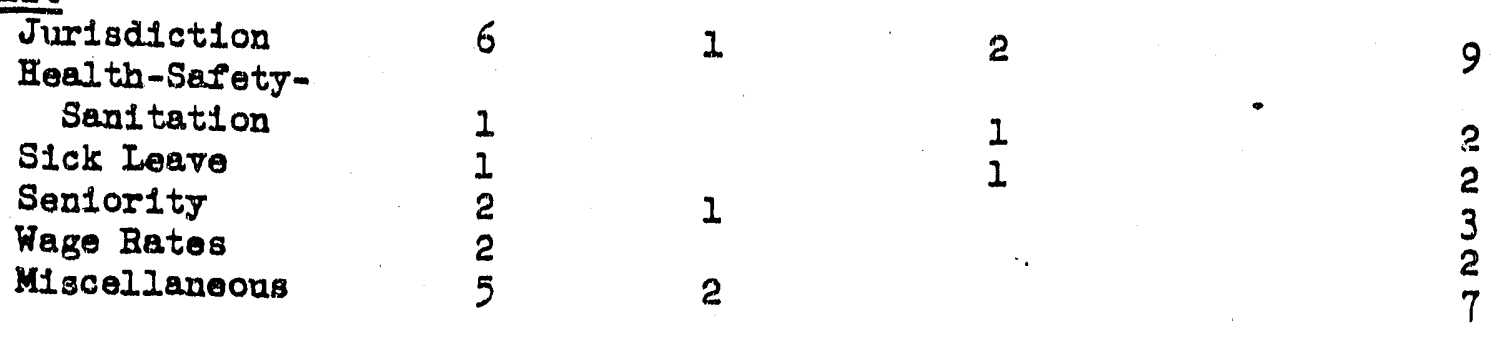

Nonunit

Hork Ass1gnment

Miscellanoous

1

$1 \quad 1$

* Grlevences brought to Step II prior to November 1, 1953, but never processed by the Jnion are, for the purpose of this report, considered settled at Stop I.

* Grlevances whlch the Oalon formally Indicated thelr Intention to submit

- to arbltration but have taken no further action s1nce November 1, 1953, are, for the purpose of this report, considered settled at step II. 
Thuployee and Pablic Relations

\section{CONSTRUCTION LIAISON}

On January 4 all Carpenters and Millwrights in the Tri-City area went on strike as a result of a deadrock in wage negotiations. Work was resumed on the Project beginning January 18 on the bes1s of the Commission's request that the Chlag Panel take jurlsdiction over the dispute. The Panel has scheduled a hearlng to be held in San Franc1sco on February 3. Meanwhile the strike continues In the belance of the Tr1-City area and now has spread to lnclude most of eastern Weshingtion. It seems reasonable to assume that a wage pattern will have developed prior to the time the Panel will be required to make recomendations on wages. However, the subject of 1solation pay will also be before them and It w1ll be laterseting and Informative to observe the manner in which they dispose of this 1asue.

A further weoting on the Master Agreement negotlations wlth the Buflding Trades Counc1l wes held December 28, at which t1me the Contrectors again rejected any Increase in 1solation pay. Other questions of a relatively minor nature vere cleared up in a letter of understanding and the Contractors are now avalting word from the Counc1l. It appears probablo that further discussions will be held in abejance pending the results of the Ching Panel hearing on the 1solation pay question.

International representatives of both the Machlnists and the Millwrights mot with John Dunlop in Richland in an offort to resolvo permanentily the Jurisdictlonal problems between the two crafts in the 2101 Building. This meoting was provided for in the September 23 agreement between the International presidents at the AFL Convention in St. Louls. An ansrex to the problen was not forthcoming.

Approrlmately 35 Kalser Mechln1sts walked off the job the morning of January 21 In protest of a Company docision to move a radial drill press from the machine stop to the pipe shop. Work was resumod on swing shift on the basls of a decision to obtain a drill press from another location for the plpe shop.

\section{WAGE RATES}

Results of the plantwlde rovlew of englneering assistant jobs was completed, and recommendations on classiflcation revisions were given representatives of the Technical Section.

The survey of rates paid Van de Grafe accelerator operator was completed, and thls job was contlaued as Grado 17.

Re1mbursement Author1zation No. 217 was recelved from the Atomlc Finergy Commission for the consolidation of the craft Trainee and Helper progression schodules and the ellnination of the eraft Helper elassification. Indiflduals in the craft Helper classiflcations are belag transferred to the craft rralnoo classiflcations effoct1vo January 4, 1954. 
Relmbursement authorization was requested from the Atomic Energy Commission for the establishment at the Hanford Atomlc Products Operation of the Company-wide plan for the hirlng of Technical Graduates. To malntaln a balanced rate structure, the Atomic Bnerg Commission was also requested to 1ssue rolmbursement authorization for the application of the same plan for Bus1ness Graduates.

A reimbursement authorlzation request was sulumtted to the Atomic InergJ Commission for the establishment of a new cleissiflcation ent1tiled "Service Manual Wr1ter," Grade 24. Th1s job Inrolves establishling and rriting step-by-step procedures to be folloved in the repalr and malntenance of equipment. While tho function is to be established as a non-bargaining unit job, it is planned this Job. Upon completion of this sourneymen, who are skilled in writing, to their eraft Jobs.

Revised classiflcation titles and progression schedules for bargaining unit reproduction jobs wero submitted to the Hanford Atomlc Metal Trades Counc1l for
Union concurrence.

A Jurlsdictional agreement between the Plumbers and Steamfitters and the Flectrlcel Workers on the assignment of the malntenance and repalr of solenold velves was recelved and accepted by the Company. Fleld supervision was advised
by letter concerning thls agreement.

Two meetings were held with a Banford Atomle Metal Prades Councll comittee representing the Machlaists to discuss the differences between fob assignments to Instrument Maker, Mool and Die Makex, and Mechlnist classiflcations. Add1tional meetlngs will be necossary before this problem is resolved.

Atomic Inergy Commission auditors during the month checked and audited the Wage Rates Unit's procedures, pract1ces, records and survey materlel.

Two hundred flity-f1re (255) automat1c lncreases and eloven (1.1) morlt 1ncroases vere processed during January. Requisit1ons for sixty-f1ve (65) prospoct1vo employees and additions to the payroll for forty-f1ve (45) new employees vero reactivetions, one hundreder classiflcation, rate, etc., was made for fifteen (15) temporary reclassif1cations 11 ty-s1x (156) reclassiflcations, olghty-1170 (85) Irom the exempt roll. 
Employee and Pablic Relations

Technical Personnel Section

TECENICAL RECRUITING

During January candidates for the PhD degree were interviewed at

Purdue University

The State College of Washington

Oregon State College

University of Oregon.

Our own perticipation, plus that of other G.E. recruiters at 30 major graduate achools have ylelded the interview records of $180 \mathrm{PhD}$ candidates. Further screenIng at Richiand with interested supervisors has reduced this number to about 65 , of whom a substantial number will be invited to Richland for direct interviews with representatives of the Engineering and Radiological Sciences Departments. The exact.number will be determinet progressively as personnel needs develop.

To interview graduates at MS and BS levels, recruiting has already been conducted at

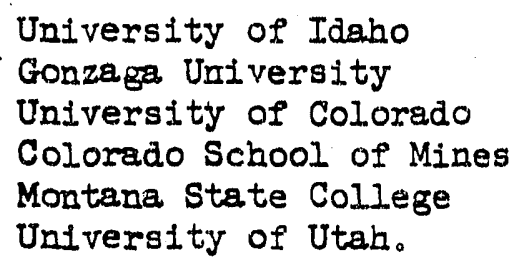

Visits at 14 additional schools are scheduled, and a few others y be added as our total needs can be determined more closely. Starting rates for trainees to put us on an equal footing with Schenectady are now being considered for reimbursement authorization by the Hanford AEC Office. During January Interviews were conducted among experienced engineers who will be available from another prime contractor whose work is being curtailed. We are on the lookout for other gimllar situations, so as to have avalable for consideration some technical men experienced. in atomic energy work.

During Januery a visit to the West Coast Recrulting and Placement Offlcer's Association made clear the following points:

1. Engineering and sclence graduates of 1954 will continue to be in high demand.

2. An increasing number of employers are using the college interviews for screening and are inviting selected men to their headquarters for further visits.

3. The payment of moving expenses for new graduates reporting for work is increasing.

4. To attract the most capable graduates, industrial employers are stepping up promotional activities such as the employment of junfors for the sumer, temporary employment of professors, college visits other than direct recruiting, etc.

In this competition we are holding our own except in the sumer employment of propessors.

$$
\mathrm{K}-34
$$


Binployee and Public Relations

Technical Personnel Section

Last year business graduates were recruited for Hanford only at the four nearby institutions in Oregon, Washington, and Idaho. To provide a greater selection if needed, we have concluded an arrangement with Schenectady to participate with their recruiters at Montana, Utah, and Colorado. Through Mr. Warner of the Apparatus Sales Division, San Francisco Office, we also recelve some excellent referrals from Stanford and University of California.

\section{Rotational Training Program}

During January 2 trainees were placed in the Engineering Department and 1 new man reported, giving a net reduction from 59 (January 1) to 58 trainees (January 3I). Of the present trainees, the Engineering Bepartment has 38, Manufacturing 16, and Radiological Sciences 4. During January 28 of the trainees were transferred to new rotational assignments. Tais work involved 70 personal interviews. As a measure of the increasing interest by the customer departments in rotational trainees, telephone convergations with trainees, or with supervisors regarding trainees, exceeded 500 during the first half of the month. Although not final, a substantial number of placements have been arranged on a trial basis, to be ratified soon.

During January there were no teminations from the rotational program. During the four years of program operation terminations of trainees while on this progrem have totalled only 16 men or $0.74 \%$ per year. A survey of industrial companles in Chemical and Engineering News, April 1951, showed the average 1oss per year throughout the country to be 10--15\%. Terminationg of these trainees after placement have averaged 3.2 o per year.

To date, 13 men have been trained at Hanford for the ANP Department. Dr. Miller, Manager, Engineering, Arco Test Site, ANP Department, was well impressed with the quality. of these thirteen trainees, who were interviewed and hired by this offlce, and with their training. Of the two trainees still at Hanford, one is to transfer to Oak RIdge about February' 15 for speclal testing experlence, the other will probably remain at Hanford until June or July.

\section{Education}

Enrollment for the second semester for the School of Nuclear Engineering is underway. A very broad program of courses is available at both college and graduate level. Three courses for instrument mechanics and trainees, formerly offered during workting hours, are now being offered via evening classes in our School in cooperation with the Manufacturing Department.

The sumary of flrst semester operations and the flnol determination of enrollments as a basis for conflrming the second semester program will be reported next month. 
Employee and Pablle Relations

Techrical Personnel Section

IV. COUNSELING AND INTERNAL TRANSFERS

During January 1 transfer (to KAPL) was completed. This office assisted in the arrangement of 8 transfers within HAPO. In II other cases where this remain with their present work. A very the interested employees was to active involving counseling. 
COMMUNITY OPERAIIIONS AND

REALL IISTATIS DEPAR'DMTRIT

MONTHEY REPORT, SUMMARY

JANUARY, 1954

ORGANTZATION AND PERSONAEHE

Nhumer of emplojees on rolls:

Ceneral Adminlatration

Communtty Operations Section

Administrat10n

Ingdneerling

Publ1c Work Ceneral \& Ut11.

Publ1c Works Labor Crew

Recreation \& C171C Affalrs

L.1brary

Firo

Pol1ce

Flectrical

Sub-Totals

Communty Real Batate Section

Adminiatration

Housing Rental

Malntenance

Commercial Property

Sub-Totals

C171l Defense Program

GRAND TOTALS
SUFTIX BEG.OF MONTH END OF MONTH

310

5

5

340

341

342

343

344

345

346

347

348

350

351

353

357

360

23

149

$\frac{12}{188}$

\begin{tabular}{c}
2 \\
9 \\
27 \\
37 \\
5.5 \\
11 \\
67 \\
51 \\
21 \\
\hline 230.5
\end{tabular}

2

9

27

38

5.5

11

66

50

$\frac{21}{229 \cdot 5}$

188

1

424.5
3
23

150

12

188

0

422.5

CARLRAL

It was decided to plan to oporate the irrigation gystem this sumor bocause of the delay in comploting the Atomlc Enores Commisalon's Projoct deeling with the cond phase of the watex 1mprovement Project bofore the Irrigation sason. The orlginal plans with rospect to this Project 1nfolved the ellmination of the Irrigation syatem this sumer.

The first, sowfall which required plowing and sanding by atreot crew occurred the week end of January 15. Approxlmately $\$ 3,000$ has been exponded to lato on snow and 1 ce control..

We hare boen 1nformod that Blchland has agaln beon accorded high national honors in the 1953 annual Fire Prevention Conteat conducted by the Irational Firo Protection Assoclation. Rlchland vas awardod fourth place nationalis in Class V olt1os (20,000 to 49,000 population), serenteenth in the 1nternational grand awerd competition and for tho third consecutive yoar won flrst place in the State of Waan1ngton. A total of 1,64l ontries, of wh1ch 1,155 wore in the munlo1pal division, came Prom the Untted States, Canada, Hawal1, Puerto R1co and ororseas military inotallations.

The testimonlal report is now belng prepared for Rlchland entry in the United States Chamber of Comerce's National Fire Waste Conteat, to be Judged on or about March 15, 1954. 
One" comorclal lease was exoouted to provldo for the operation of a warehouse and the sale of used furnlture in a Covernment-owned butlding.

One licenge agrement was oxocuted to provide for the 1natallation and operation of a comuntty telorialon gial diatribution system.

One retroactive nonocmerolal lease was oxocuted, oorerling the oocupanos of Goverment-ownod bulld1ng 89-X by the HAMIOC.

F170 sublease enterprises commonoed operat1on.

I17o aublease enterprises terminated.

Ono mblease wo asaigned from a partnership to an individual for cont1nued operation.

Final 1napectlons, cotering two pritately-owned bulidings, were reported.

Three bas1c loase agrements wore amended by supplemental agreementa.

Twenty-three brochures were propared desorlb1ing Corernment-owned bulldings, for uee by ladependent appraisers.

Total housing applicatlons ponding - 248 . 
COMMINITY OPERATIONS SECTION

MONTHUY REPORT

SUMMAR't

JANUARY $\quad 1954$

ORGANIZATION \& PERSONNEL:

ADMINISTRATION

HLECTRICAT

PUBLIC WORKS

RECREATION \& CIVIC AFFAIRS

IIBRARY

POLICE

FIRE

ENYGINEHYRING
BEGINNING OF MONTH

Exempt Non-Exempt

\section{1}

$$
5
$$

12

3

\section{3}

18

67

$\frac{6}{115}$
1

16

52

$21 / 2$

8

33

0

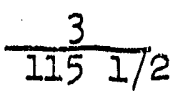

END OF MONTH

Exempt Non-Exempt

1

1

$5 \quad 16$

12

53

$3.21 / 2$

3

8

17

33

66

0

$\frac{6}{1.13}$

Decision was made to plan operation of the irrigation system this sumer because of delay in completion of the A. $\mathrm{B} . C$. project dealing with the second phase of the water improvement project before the 1r-1gation season. Original plans with respect to this project involved the elimination of the irrigation system this summer.

The first snowfall requiring plowing and sanding by street crews occurred the weekend of January 15. Approximately $\$ 3,000$ has been expended to date on. snow and ice control.

Word has just been recelved that Richland was again accorded high national honors In the 1953 annual Fire Prevention Contest conducted by the National Fire Protection Assoclation. Richland was awarded fourth place nationally In Class V cities (20,000 to 49,000 population), seventeenth in the international grand award competition and for the third consecutive year won first place in the State of Waskington. A total of 1,641. entries, of which 1,155 were in the munlclpal division, came from the Unlted States, Canada, Hawa11, Puerto RIco and overseas military installations.

The testimonial report is now being prepared for Rlchland's entry in the United States Chamber of Comerce's National Fire Waste Contest, to be Judged on or about March 15, 1954. 


\section{COMMUNITY OPERATTONS SECTION \\ RICHLAND ELECTRICAL UNIT \\ MONTHLY REPORT \\ JANUARY 1954}

ORGANIZATION AND PERSONNEI

Employees beglnning of month

Transferg in

Transfers out

Terminations

Total ond of month

SYSTEM MAINTEENANCE AND OPERATION

Outside Iines

Poles set and transferwed Anchors set and guys installed

Street. Lights repaired and steel mast arms installed Street lights relamped - Mercury Vapor

Street lights relamped - 6000L and 4000L, 1100 Area

Street light3 relamped $-6000 \mathrm{~L}$ and 4000L, 700 Area

Flood lights relamped, 1100 Area

Flood lights relamped, 700 Area

Stack lights relamped, 700 Area

Primary line footage added

Primary line footage removed

Transformer KVA added

Transformer KVA removed

Net transformer KVA installed

New services installed - residential

New services installed - commercial

Temporary services installed and removed

Scheduled outages - primary

Scheduled outages - secondary

Unscheduled outages - primary

Unscheduled outages - secondary

Standby and escort

High voltage tree triming

Low voltage tree trinoming

TRAPFIC SIGNAIS

Relamping

Operational failures

Installations

Renovals

Boutine maintenance checks

Routine check Bo Ho signal at Van Giesen

$\mathrm{Ib}-1$
Exempt Non-Exempt

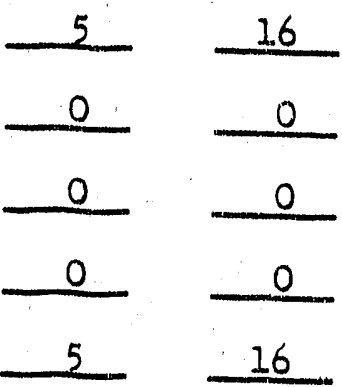

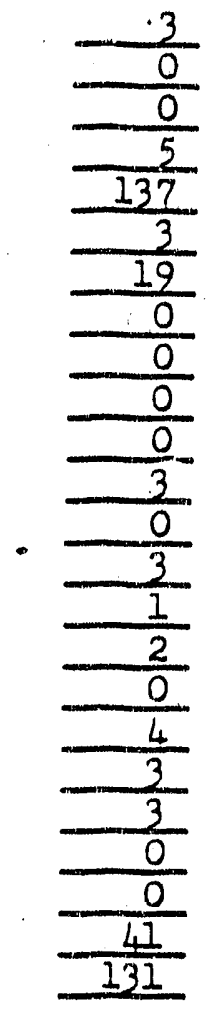


RICHIAND ELECTRICAL UNIT

Total signals in operation - automatic

Total signals in operation - manual

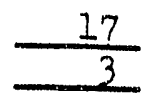

PUBLIC WORKS ETECTRICAL MAINTENANGE

Electrical motors checked and serviced - irrigation

Electrical motors checked and serviced - water

Electrical motors checked and serviced - sewage

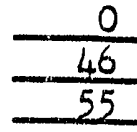

FIRE DEPARTMENT TIEST AND MAINTENANCE

Inside circuit and equipment checks

Outside circuit checks

Inside faults repaired

Outside faults repaired

New circuits placed in operation

New boxes placed in operation

SUESTATIONS

Main feeder and tie breaker checks - BBISI

" " " " " - BBIS2

Secondary and pad located stations -

Checked jumpers, cutouts, grounds and general condition

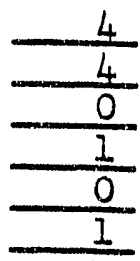

METERING - OPERATION, MAINTENANCE, CONSUMPTION AND REVENUE

Yoltage and load checks

Meters tesied - customers' requests

New meters shop tested

Faulty meters replaced

Damaged meters and covers

Residential read-ins

Residential read-outs

Residential disconnects

Residential reconnects

Meters resealed

Changed out 15 Anp meterg with 50 Amp

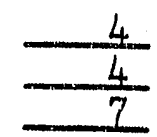

Note: Consumption and revenue reports, under IBM operations, are not available until the 18 th of following month.

Consumption and revenue:

No. of Meterg $\quad$ KWH

Schedule 1 - Fesidential.

7049

$8,345,719$

$\$ 77,545.76$

Schedule 2 - Comercial

Class 1 - (In Lease)

Class 2 - (Metered Bas1s)

63

Class 3 - (Planit Adm。) Conm. Rate

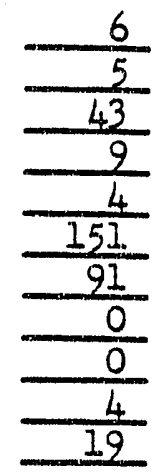

$\begin{array}{rr}774,709 & 6,991.13 \\ 775,183 & 9,127.75 \\ 1,372,962 & 8,297.00 \\ 396,000 & 2,469.00 \\ 52,960 & 435.80\end{array}$


Public Health

1131 Bus Terminal

Central Stores

Stores Excess \& Salvage Yard

Salety \& Fire (1\&2)

Transp. Classification Yard

Photo Lab.

$\begin{array}{rr}\text { KWH } & \text { Revenue } \\ 2,363 & 25.22 \\ 1.50,600 & 940.80 \\ 80,640 & 718.92 \\ 105,900 & 731.70 \\ 576 & 11.14 \\ 2,920 & 29.40 \\ 5,800 & 57.00\end{array}$

.005 Rate

1125 Whse. Area

AEC Airport

Army Dike \#1 \& \#2

Medical Dental Building

Public Library

Central Fire Station

Patrol Headquarters (Bldg. 770)

Sewage Lift Station (Perkins)

Community Adom.

\begin{tabular}{rr}
10,000 & 50.00 \\
35,840 & 179.20 \\
18,400 & 92.00 \\
8,880 & 44.40 \\
7,840 & 39.20 \\
6,960 & 34.80 \\
16,080 & 80.40 \\
20 & .10 \\
471.583 & $2,357.92$ \\
\hline
\end{tabular}

Total 11,268,573 \$101,961.64

\section{COMMENTS}

Connected permanent services to new Safeway Store. Also to commercial maintenance shop on Stevens Drive adjoining Tastee-Frsez。

Disconnected services temporarily to induce payment of bills at following addresses: 706 Torbett, 1308 Totten, 366 Wright, and 615 Blue.

Disconnected service temporarily at 1212 B1rch for tenant to connect new meter loop。

Television routes have been reviewed with both applicants and revised construction specifications have been reviewed and concurred in by Licensor and applicants.

Repaired underground street light wire broken by contractor at Duportail and Hartford.

Cleared grounds on fire alarm circuit \#4 in underground wire.

Assisted Telephone Section with cable alteration at Stevens Drive and Coast Street to increase 101 pair to 404 palr from $\mathrm{MH} 48$ to adjacent junction pole on Work Order No. C-58569.

Rebullt station fence where damaged by cars bumping fence and rotten posts rear of Campbell's No. 2 store. Preventive steps to prevent recurrence are being taken。

Reset transformer primary tapa to Farm shop station to correct voltage to 122 volts. 
RICHLAND ELECTRTCAL UNIT

Station voltage to Bank \#4 was readjusted where controls had varied sufflciently to slightly raise line voltages. Proper checks were made at various points on lines from that bank, to assure correct voltages to customers.

Numbered all transformers in North Rlchland Well Field.

Rernoved unnecessary street light \#913 and adjusted numbering to conform. Numbered strest li.ight circuit $\# 1600$ and main pole line through 6 th Housing Area。

Overhauled $75 \mathrm{HP}$ motor to \#6 domestic water pump in Building 1182. Replaced badly scored sleeve bearing on front end. Work was done in time to prevent bad damage to motor armature. Continued annual maintenance in Building 1182 by pulling end bells to all pump motors, checking and cleaning bearings and armatures。

Installed fire alam box at George Washington Way and McMurray Boad.

Installed new master firs alarm box at front entrance to Building 770 to provide connection for auxiliary circuit.

Repaired trouble alarm indicator at Sewage Treatment Plant.

Installed wiring and hooked up new hot water tank at Community House.

Installed additional receptacles in Building 721 .

Installed new receptacle and replaced defective one in $K$ well chlorinator house。

Repaired two defective damper control motors at Comunity House.

De-energized unused primary line between George Washington Way and Jadwin on Symons, however, line will be left up until status of area north of Symons is determined。

Completed metering of men's and women's dormitories.

Installed $3 \mathrm{Kva}$ transformer and extended service, 2 secondary spans, to serve horse corral and stable on Burlin Road to Mr. C. J. Gant.

Radio interference reports were handled as follows: Radio nolse at 1116 Marshall was traced to heating pad being used in vicinity, checked noise reported at 911 Birch - nothing was evident at time of checking, and nothing further reported at this address.

Planned outages were scheduled as lollows:

Opened fuses to Wells $\mathrm{E}$ and $\mathrm{H}$ in North Bichland Well Field for testing contractors installations.

Outages to two distribution transformers in Gunnison Court for transferring lines to new poles。 


\section{RICHILAND ELECTRICAL UNIT}

Outage to 6th Housing Area, east portion, to remove two construction power disconnects and to move 400 amp pole top switch out of sidewalk area as requested by AEC.

Outage to Dls7 station in 700 Aria to service transformers, clean bushings, test oll, etc. Otl tested $28 \mathrm{kv}-28 \mathrm{kv}$ and $35 \mathrm{kv}$.

Unscheduled outage:

At 7:00 P.M० on January 25, 1954, one man was called out to put \#700 Street light circuit on manual position, and new relay was installed 1-27-54, as it was deemed unnecessary to call out men to tum lights off over sunday. Cost for overtime repairs on Sunday would have exceeded $\$ 60$, and expense for buming circuit was less than $\$ 1.50$. Pollce desk and shift supervisor were notified of arrangement.

\section{Call-Outs:}

Two men and foreman were called out from 5:40 PoM. to $6: 40$ PoM。 1-12-54, to replace blown transformer fuse at 1436 Richie Court. No apparent cause.

Two wires pulled out of splices at rear of 1209 Birch at 6:30 A.M. on 1-20-54, two men were called at that time to open switch to lateral prinary IIne affected, and additional help was used reporting at. regular time. Service was restored at $9: 00$ A.M.

One wire pulled out of splice at rear of 331 Sanford. Three men from $12: 00$ to $2: 45$ A.M. on 1-21-54. Service was restored to lateral at $1: 45$ A.M. 
COMMNITY OPERATIONS SECTION

PUBLIC WORKS UNIT

MONTHLY REPORT

JANUARY 1954

\section{ORGANIZATION AND PERSONNEL}

Employees Beginning of Month

Exempt Non-Exempt

Transfers Out

12

52

Transfers In

$-0$

New Employees

Terminations

Total End of Month

$\begin{array}{cc}- & 1 \\ - & - \\ - & - \\ 12 & 53\end{array}$

\section{SANITATION}

Total weight of waste materials collected and disposed of during January was 1213 tons. No collections were made on the New Year holiday, and routes due on this day were made up on the following Monday. A collection was made at commercial establishments on Saturday, January 2, 1954 to eliminate the possibility of . sanitation problem occurring over the 3 day holiday week end.

\section{ROADS AND STREETS}

Approximately 6" of snow fell on 1-16-54 necessitating removal from sidewalks under the furisdiction of Community Operations and Real Estate Department, and from all arterial streets. Sanding of street intersections and plowing of sidewallks commenced about 9:00 AM and plowing of stret arterials began about 5:00 PM, with crews continuing work unt11 midnight. An additional 4" of snow fell after midnight and 1 was necessary to remove this snow from sidewalks and arterial streets on 1-17-54, with sanding of street intersections being carried on simultaneously. During this reels end of January 16 and 17 a total of 150 man hours of overtime was required to cope with the storm. Between January 18 and 29 , another 50 man hours of overtime was required for sending of streets and intersections. This total of approximately 200 man hours of overtime spent on snow and lee control is in addition to about 300 man hours of regular shift time devoted to this same task.

During the latter part of the month an excessive amount of surface water was caused by melting of the snow and the efforts of this entire group was required to mintain open gutters and storm sewers. 
Community Operations Section

Public Works Unit

Approximately 600 cubic yards of sand and 3.5 tons of rock salt were used in ice control this month, and replenishment of our sund stock pile was accomplished by trucking about 500 cublo yards of material from Horn Rapids Road to our materials yard.

Other routine maintenance of streets, street signs, drainage systems, municipal parking lots and sidewalks ws continued as required.

\section{PARKS AND PUBLIC GROUNDS}

Pruning of all trees and shrubs in Parks property was completed during January.

General clean-up and weed removal was continued in open areas and shelterbelts.

During the latter part of the month this crew was utilized to assist in show removal, waste removal, drainage problems, and other unusual work occasioned by the snow storm and resultant run-off of surface water.

\section{DOMESTIC RATER}

Average daily consumption for January was 6.6852 million galions per day. Peak consumption during the month was 7,893,000 gallons on January 21 .

An average of $5^{\text {H }}$ of gravel was removed from the surface of the south balf of the North Richland recharge basin to remove silt, carried in by the canal from the Yakima River, and thereby increase the rate of percolation at this fleld. The material removed ras used to stabilize a new road which was bladed out to provide access to the new well houses.

The blow-off pipe from the sand trap, and the well by-pass line at $3000 \mathrm{~F}$ well were extended approximately 100 feet toward the Columbia River to eliminate a serious erosion problem at the original termination of these lines.

The one million gallon reservoir at North Richland was drained and cleaned of sand on January 11.

A new "boostex pilot" valve, incorporating spring loaded diaphragm, was installed on the altitude valve the 5 million gallon reservoir on Jenuary 7. This pilot was supplied by the manufacturer as a replacement for the original booster pilot which did not operate satisfactorily under the conditions encountered at this reservoir, and it is the manufacturer's clain that this pilot will operate the altitude valve satiafactorily. Tests have not as yet been run, since water consumption in this season is not sufflciently high to provide trial conditions. 
Commity Operations Section

Public Works Unit

\section{DOMESTIC MATER}

Well Production Average Daily Total Consumption Av. Daily Million Galions Production Million Gellons Consump.

\begin{tabular}{lrrrr} 
Richland & 105.1400 & 3.3916 & 1.12 .7029 & 3.6356 \\
North Richland & 43.1900 & 1.3932 & 50.5251 & 1.6209 \\
Columbia Field & 59.2410 & 1.9110 & & \\
300Area & & & 44.0129 & 1.4198 \\
\hline TOTAL & 207.5710 & 6.6958 & 207.2409 & 6.6852
\end{tabular}

All work on the well header and well equipping contract is now complete, and final inspection and acoptance has been made of these facilities.

Annual inspection and repair of hydrants was continued and this work is now $90 \%$ complete.

\section{SEWERAGE SYSTEM}

Injection of chlorine solution into the North Richland trunk sewer at a point east of $3000 \mathrm{~K}$ well commenced on January 12. This chlorination is to eliminate septic sewage conditions and resultant odors at the Treatment Plant.

Stoppages have occurred in the Bepham sewer main, between Goethals and Casey, several times during the past three years and following a stoppage this month, the line was excavated for inspection. Although some minor deficiencies were found in the line, it was apparent that the major cause of stoppage was the fact that this low flow line entered the manhole at Benham and Casey at the same grade as a high flow $12^{\prime \prime}$ and $8^{\prime \prime}$ running south and north respectively on Casey. This caused sewage to back up in the Benham line and settle out solids which over a period of time built up sufficientiy to stop the main. The outfall of the Benham line was raised 5" by re-grading $60^{\prime}$ of the line, thus giving a clear flow into the manhole, and it is assumed that this will eliminate the recurrent stoppages in the Benham sewer main.

A stoppage occurred in the Abbott sewer main running north to Comstock, and since this line is a frequent offender, excavation for inspection is now in process.

While power driven sewer rod was in use on the Adams sewer, between Goethals and Barth, to remove an obstruction, the tool became lodged in the line and 1t was necessary to excavate the line to remove the tool. 
Community Operations Section

Public Works Unit

Annual inspection of manholes and flushing of mains was continued and this work is now approximately $30 \%$ complete.

Normal operations and routine maintenance of the collection system, lift stations, and Treatment Plant were continued.

\section{SEWAGE}

Total Flow

Milizion Gallons
Average Daily Flow Milizion Gallons

\begin{tabular}{lll} 
Plant No. 1 & 33.630 & 1.085 \\
Plant No.2 & 69.730 & 2.249 \\
\hline Total & 103.360 & 3.334
\end{tabular}

\section{IRRIGATION SYSTEM}

Annual cleaning and maintenance of the canal was continued, and that section of the canal from Horn Rapids Dum to the "Penstock" west of North Richland is complete.

It has been determined that the work necessary to make it possible to eliminate operation of the irrigation pump houses and lines will not have been completed by the next Irrigation season, and it will therefore be necessary to place all necessary facilities in operating condition. Toward this end, the cannl from the Penstock through Richland is now being cleared of willows and weeds, and orerhaul of the purps has been started. 


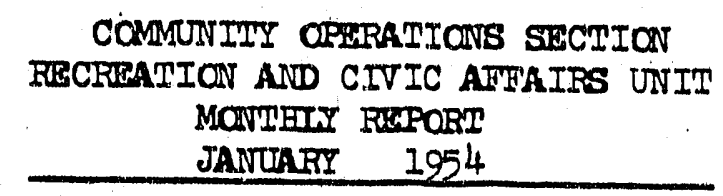

ORCANTZATION ANW FURSONINEL

Brempt Mon-Brempt

$\begin{array}{lcc}\text { Beglnning of Month } & 3 & 2-1 / 2 \\ \text { New Fires } & 0 & 0 \\ \text { Terminations } & 0 & 0 \\ \text { Transfers - IN } & 0 & 0 \\ - \text { our } & 0 & 0 \\ & \frac{0}{3} & \frac{0}{2-1 / 2}\end{array}$

\section{SCEOOTS}

The following is a tabulation of full-time paid school District \#400 personnel as of Januery $31,1954:-$

$\begin{array}{lr}\text { Administration } & 7 \\ \text { Principals and Supervisors } & 14 \\ \text { Clerical } & 25 \\ \text { Teachers } & 305 \\ \text { Health Audiometer } & 0 \\ \text { Cooics } & 45 \\ \text { Bus Driter } & 1 \\ \text { Maintenance } & 21 \\ \text { Operaticns } & 44 \\ & \end{array}$

\section{CTUBB AND ORCANTZATIONS}

As of January 31, 1954, the employees of the I1sted organlzations, exclusire of those lncluded in the Real Istate, Comerctal and Other Properties Unit Beport, Include:-

Iouth Counc11

Boy Scouts

Campire Girls

25

305
0

45

21

462

B1 Spot Club

ofrl scouts

Justice of the Peace

I.W.C.A.

Chamber of Commerce

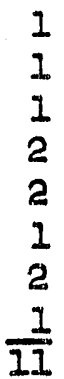

Id-I 
The number and types of organizations presently served by the Recreation and Civic Affalrs Unit include:-

\begin{tabular}{|c|c|}
\hline 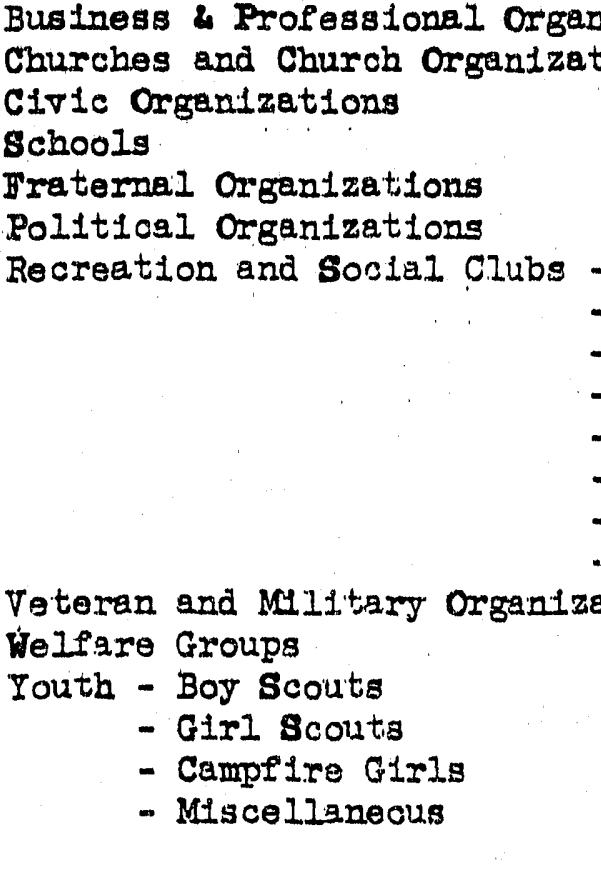 & $\begin{array}{l}\text { Dizations } \\
\text { tions } \\
\text { Alumn } \\
\text { Arts, Mug1e, Theater } \\
\text { Bridge } \\
\text { - Dence } \\
\text { Garden } \\
\text { - Hobby } \\
\text { - Social } \\
\text { Sports } \\
\text { atlons }\end{array}$ \\
\hline
\end{tabular}

\section{RRCRRATION}

The regular monthly meeting of the Parks and Recreation Board was held on Januery 15, 1953 at the Communtty House. The Board olected Mrs. A.A. Jonos as Park Board Chalrman for the calendar year 1954. The Board was Informed that draperles were installed In the Social Hall in January and vonetian bl.Inds would be installed within a few weoks. The next regular meeting of the Board is scheduled for Bebruary 3, 1954.

The Table Tennis Iagure belng sponsored by the Unit started on January 12, 1954 with thirty participants.

On January 23, 1954 the Blectric Model Train Races co-sponsored by our Un1t and Paul's Inc. were held at the Cormunity House with 18 part1cipants and approximately 125 spectators. Gift certificates were pregented to the group winners and runners-up and also to the sweepetakes winner and runner-up. 
Attendance Statist10s - January, 1954

No. of

Sesslons

A. Community House

I. Rec.Un1t Supervised Programs Games Room Act171ties , 24 Crafts Tumbling

Ballroom Dancing

Archery

Movies

Photography

Square Danclng-Elementary

Drametics -Jr.i 8r. E1 4

Adult Table Tennis League 3

Physical Activities -

(Spalalng)

$\begin{array}{rrr}1903 & 591 & 2494 \\ 111 & 19 & 130 \\ 109 & 27 & 136 \\ 125 & 4 & 129 \\ - & - & - \\ 315 & 28 & 343 \\ 10 & 3 & 13 \\ 618 & 36 & 654 \\ 152 & 15 & 167 \\ - & -- & - \\ & 137 & 137 \\ & 89 & 89\end{array}$

II. Affiliated Programs

H1 Spot Clut (Teen-Age) Rec-A-Teers (Young Adults)

Jencing

Jx. Stamp CIub

Int'I Polk Daucers

G.I. Women's Club

Rich. Rod a Gun Club

Y.W.C.A. Supper Club

Junior Symphong

2896

64

389

Aduits

Subtotk1

Spectators 
RECRERAIION AND CIVIC AHTATBSS UNIT

January, 1954

(Parks \& Playgrounds No. of Cont Inued)

Drematios

Sesstors

General Play-Riverside

Ceneral Play-ColumblaSchool Attendence

Jurenlle Plshing

Ir 1ple-0-Ioegue

Play-For-Fin Lague

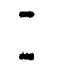

15

$15 \quad 750 \quad 30$

Affiliated Programs

Lake Shore BesebalI

Rich. Softball Assoc.

American Legion Bagebal1 -

Itttlo Ireague Play (JePt.)-

III. Rec. Un1t Speclal Erents ivone

IV. Non-Unit Speclal Events None

V. Beseba 11 \& Softbal1 Book1ngs None

VI. Estimated Use of Non-SuperT1sed PIaygrounds None

8ub-Totals

$=\frac{-}{750}=\frac{-}{30}=$

SUMMARI OF BTATISTICS

No. of

Besslons Youth Adults Spectators Total

Comminty House

Parks and Playgrounds

122

$6348 \quad 2658$

50

9056

Total January Attend.

$\frac{15}{137}$

$\frac{750}{7098} \quad \frac{30}{2688}$

50

$\frac{780}{9836}$

Grand Total. For January -

Cal. Tear Total-To-Date -

9,836

9,836

$I a-4$ 
OOMMUNITI OPFRATIONS SECTION

RICHLAND PUBLIO LIERAEY

MONTHIY RERPORT

January 1954

ORGANIZATION AND PERSONNELL

Employees - Beglnning of Month

Trangfers In

Transfers out

Now Hires

Terminations

End of Month

Exampt

0

0

0

0

0

3
Non-Exempt

0

0

0

8

GENETEI

Circulation

Books

19,165

Magazinos

Pamphleto

84

Records

Interlibrary Loan

1,293

Grand Total

62

21,233

Current Book Stock

Books added this month

27,686

Books withdrawn th1s month

Grand Total

Registration

Adult

Juventile

Total

Total Registered

Borrowers

15,233

Children's story Hour Attendance

Meetings in North Hall 
Miss Tont Hoyler, Children's librarian, talked to the Riohland Preschool P.T.A., at Marcus Whitman Sohool, February 12th, on "Growling Up With Bookg".

The Library has been advised by the Rlohland chapter of the Inights of Columbus that they will continue to financialiy support the OhIldren's Summer Reading Club for 1954. 


\section{COMMUIITY OPERATIOIIS SECTION \\ RICEIAND BOLICE DWPARTMENTI \\ MONTHLT REPORT \\ JANUARY 1954}

ORGAIIIZAIIION

Employees - Beglinaing ot Month
Transfers In
Transfers Out
Nev Hires
Terminations
Total - End of Month

Exempt Mon-Exempt

\begin{tabular}{cc}
18 & 33 \\
0 & 1 \\
1 & 0 \\
0 & 0 \\
0 & 1 \\
\hline 17 & 33
\end{tabular}

\section{GENGRAL}

oir entry is the National Peciestrian Protection Contest, which is conducted by the Amerisan Automobile Assosiation, was compieted and forwarded during the month of January: The contest report form consiats of questions concernIng acoident recorda, Ieglsiation, enforcement, trartic engineering, safety orcanizations, school safety activities, and public laformation.

Amnal reports, including actilyities, crime, and traffic were complled for the year 1953 during the month of January. Crime reports were forwarded. to the Federa: Bireau or Inrestigation, atter completion; the trapfle accident reports Porwarded to the Pational Sarety Councli and Washington State Patrol.

Eiffective January 11 , the Inur 1nvestigative sexgeants were relieved of theix shf.et assigments and assigned to work as a staif unit reporting to staff offlcers. The four sergeant; work in palrs, alternating between swing and day ghifta on the flrst of each month; pne pair workelng Monday through Prlday on the day shift: the other pair working Monday through saturday swing shift, alternating each five day period.

A number of new reference books were purchased and added to the Polfce Ilbrary durlas the month.

A new 16 m. sound film extitied "Ine Talking Car" whs purchased this month for ise 1o our traflic safety program. A number of loan filns were also obtalized on temporary assiganent asi utizized in our traffic safety program.

One Cub Scout troop was escorted through Pollce Headquarters durlag the month of January.

The Pollce Traloling School, conducted by Capt. W. A. Zlegler, for all patrolmen on the force, was concluded on the $8 \mathrm{th}$ of Jamary.

A sizgle blinkens trapfic light was installed at the Intersection of George Washingtion Way and McMurray Road.

Members of the Trafile Controi section conducted a total of 6 trapelc safety meetings during this month.

$$
\text { IFt }-1
$$


IRAFFIC

\begin{tabular}{|c|c|c|c|c|c|}
\hline 1 & .195 & 2952 & 19 & 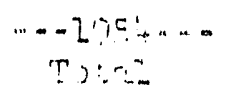 & 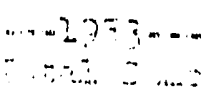 \\
\hline & $\pi+250$ & ס & \&raso & $\because \quad-\quad \cdot:=$ & $\therefore:$ \\
\hline
\end{tabular}

\begin{tabular}{|c|c|c|c|c|c|c|}
\hline Repcrtable accidentis & 29 & 32 & 29 & 2.2 & 32 & $2=$ \\
\hline Property damage accidente & 27 & $2: 7$ & 27 & 17 & 27 & $\overline{10}$ \\
\hline Injury acsidents & 2 & 3 & -1 & 1 & 3 & $i$ \\
\hline Total persons infiged & 2 & 3 & 2 & $I$ & 3 & 1 \\
\hline Fatai accidents & 0 & 0 & 0 & $\sum$ & 0 & $I$ \\
\hline
\end{tabular}

$\begin{array}{cr}\text { Accidents-Daylight hours } & 16 \\ \text { Darimess } & 13 \\ \text { Accidents-Business distribt } & 8 \\ \text { Residential : } & 16 \\ \text { Other } & 5\end{array}$

$\begin{array}{rrr}10 & 11 & 13 \\ 2 & 13 & 8 \\ 20 & 10 & 8 \\ 4 & 16 & 7 \\ 3 & 6\end{array}$

13
8
6
7
6

$A=c i d e n t ; \quad 1$ yyestigats

(2) $16 \quad 20$

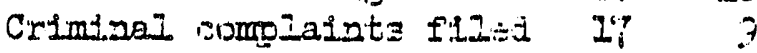

$20 \quad 9$

$9 \quad \frac{9}{9}$

Violations sontribstiles

to acoildedts:

Negligent diriting

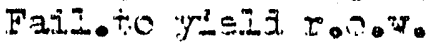

Following too sivesy

Drunk arivisu

Pedestixian risiation

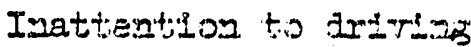

Reckiess dri-ting

Speedias

Unsafe speed

Improper backing

Disregard. stion slgn

Hitt and run

Inproper passing

Improper turn

Falluare to shenal

Wide Itght tium

Wrong side ref rod

Asleep at wheel

Bisugie vilolatilon

Thuning from tronos lane

Def $ə 0+, i r e$ equatpent

Animar is roadway

8

48

I 0

00

00

32

00

$0 \quad 15$

10

0

00

10

01

10

$0 \quad n$

00

00

$0 \quad 0$

0 j

0 ก

North RIchiand:

Reportable acc1denta

Property damage acridents

Injury acoldent:s

$\begin{array}{rrrr}5 & 10 & 6 & 6 \\ 4 & 9 & 5 & 5 \\ 1 & 1 & 1 & 1\end{array}$

20
12
20
$1+9$

$?$

$\begin{array}{rr}13 & \vdots \\ 3 & \frac{2}{3}\end{array}$

3

3

00

30

00

00

50

o

00

0.0

$0 \quad 0$

$0 \quad 0$

$0 \quad 0$

$0 \quad 0$

$0 \quad 0$

$0 \quad 0$

10

00

8

23

0

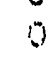

2

16

16

0

0

0

1

0

0

0

0

0

0

0

3

I

-

Richlant

$1953 \quad 2951$

Are. Por Acestent

Are. Por Azcldent

Accideat property

demese

Decomber Jamzary

Des.153 Sian. 174

Dec.52 Jan. 53

$\$ 8,290 . \infty 5 \quad \$ 5,385.8$

$\$ 285.86 \quad \$ 268.31$

. $\$ 219.31 \$ 270.76$

$I F-?$ 


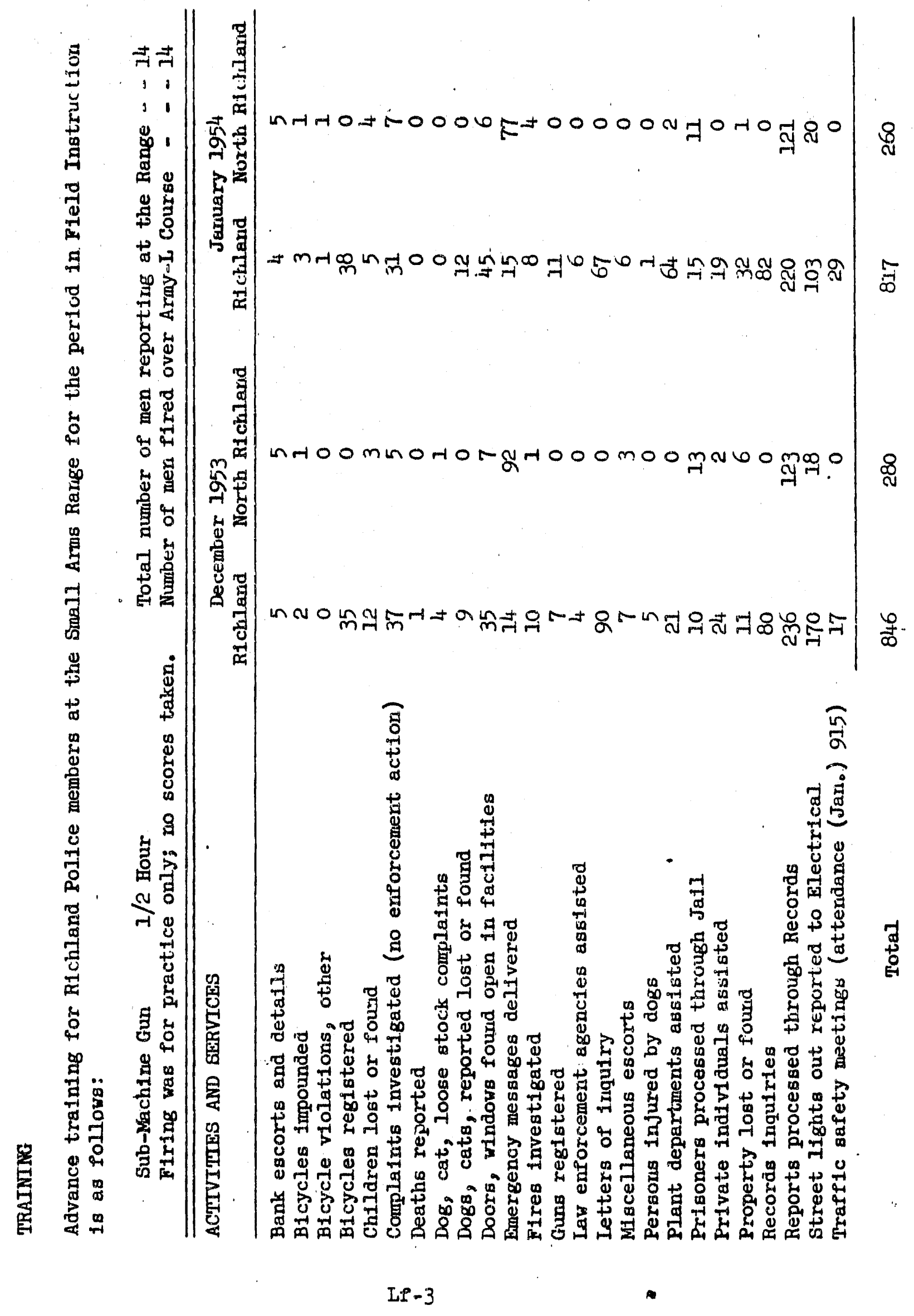




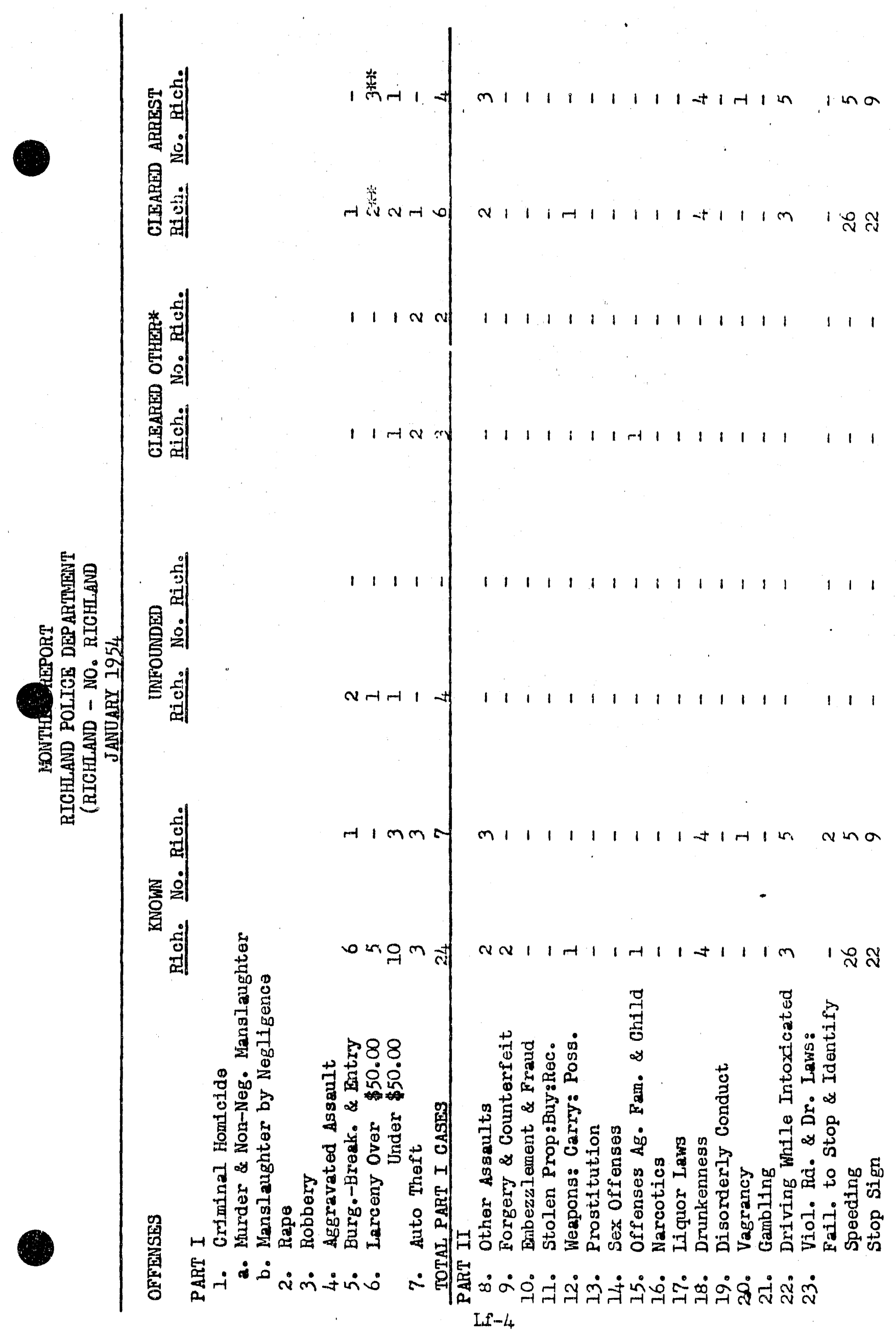




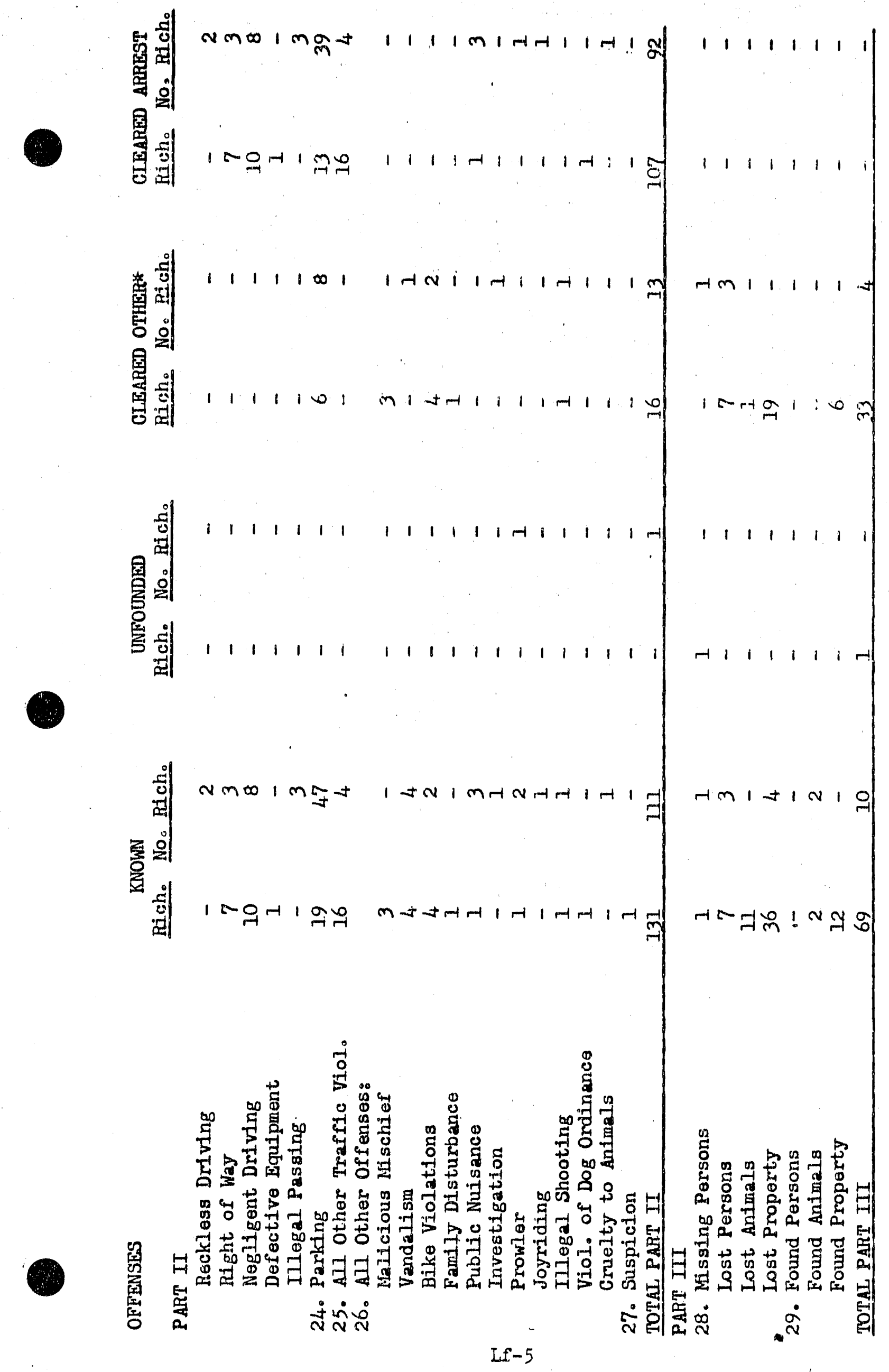




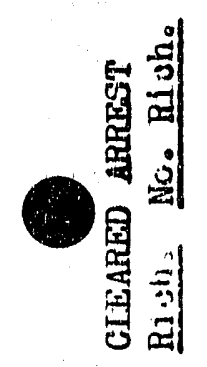

年
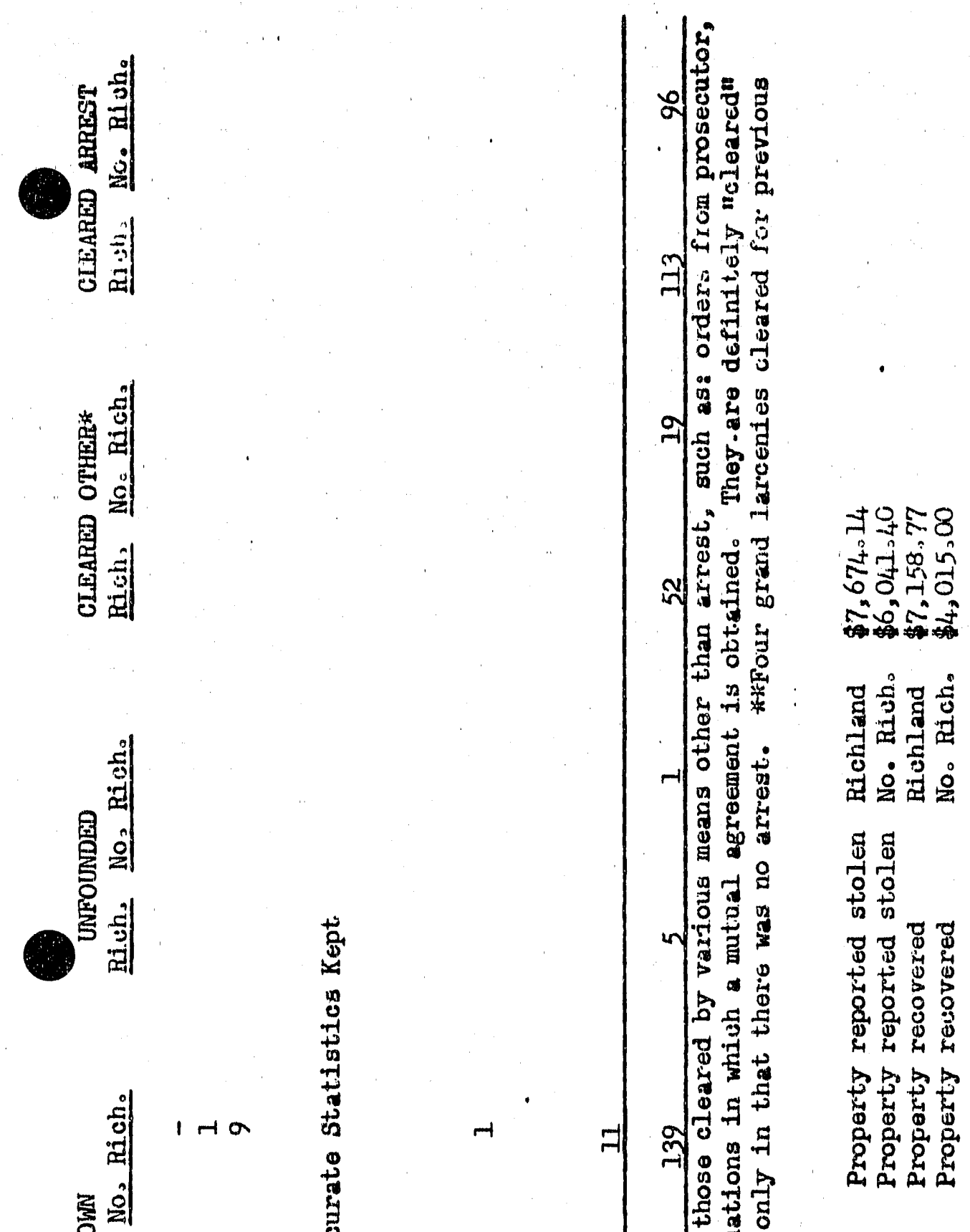

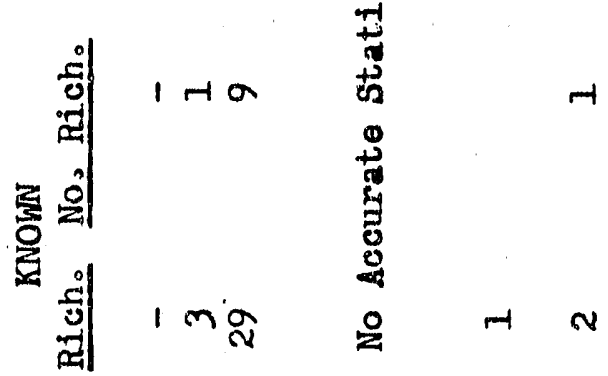

\$

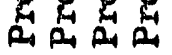

赵峦

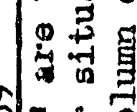

N)

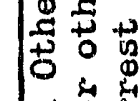

它

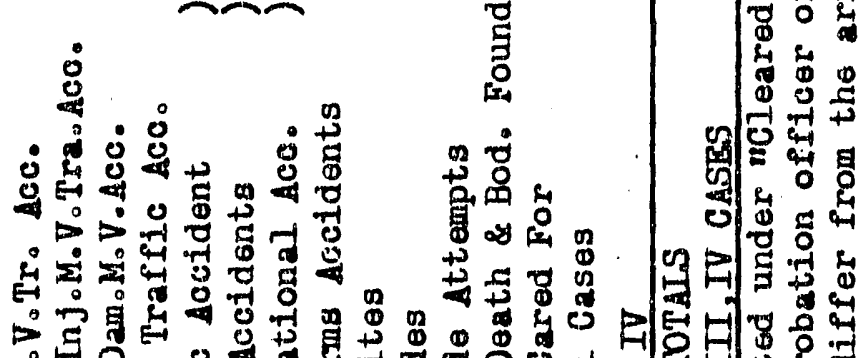

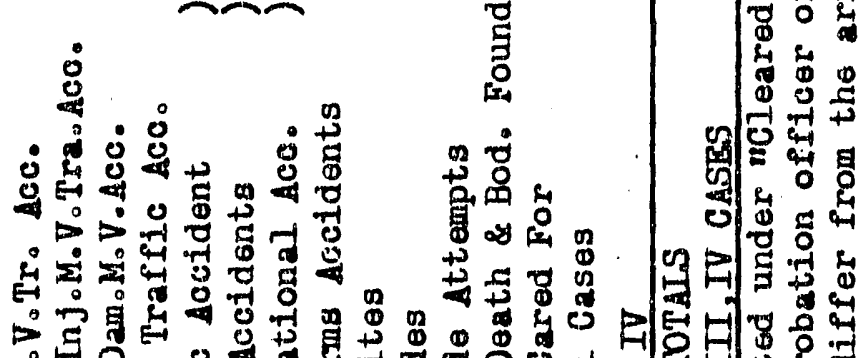

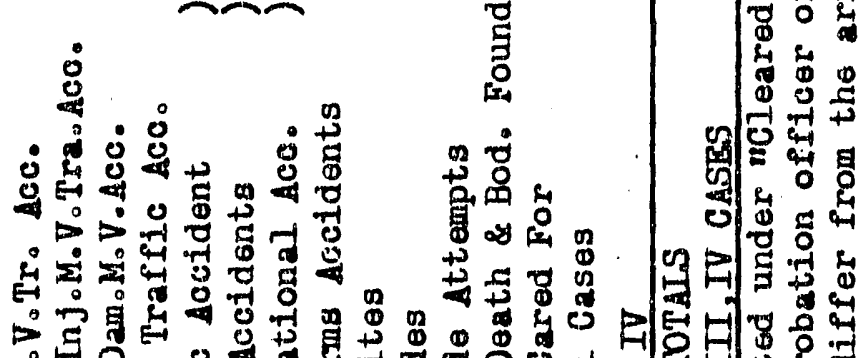

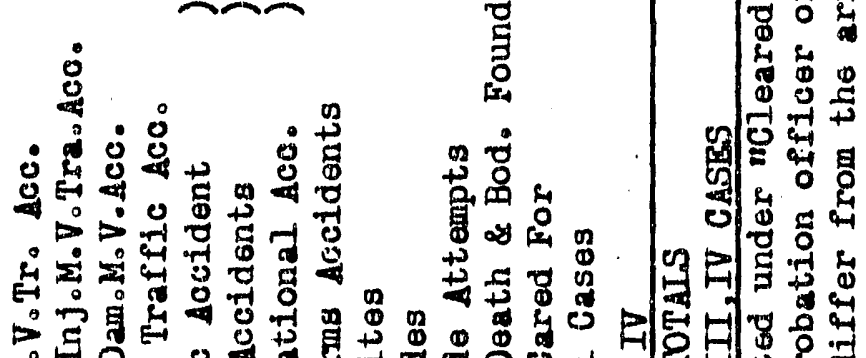

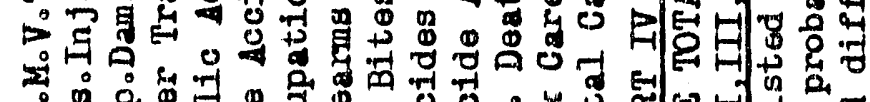

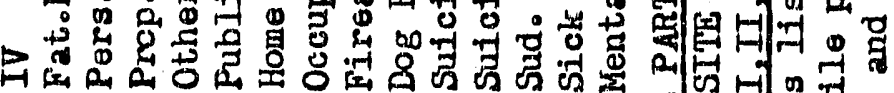

E-

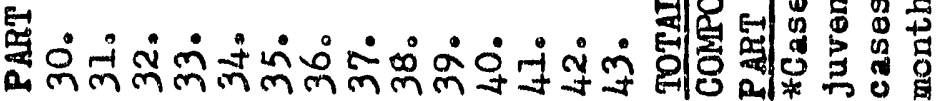




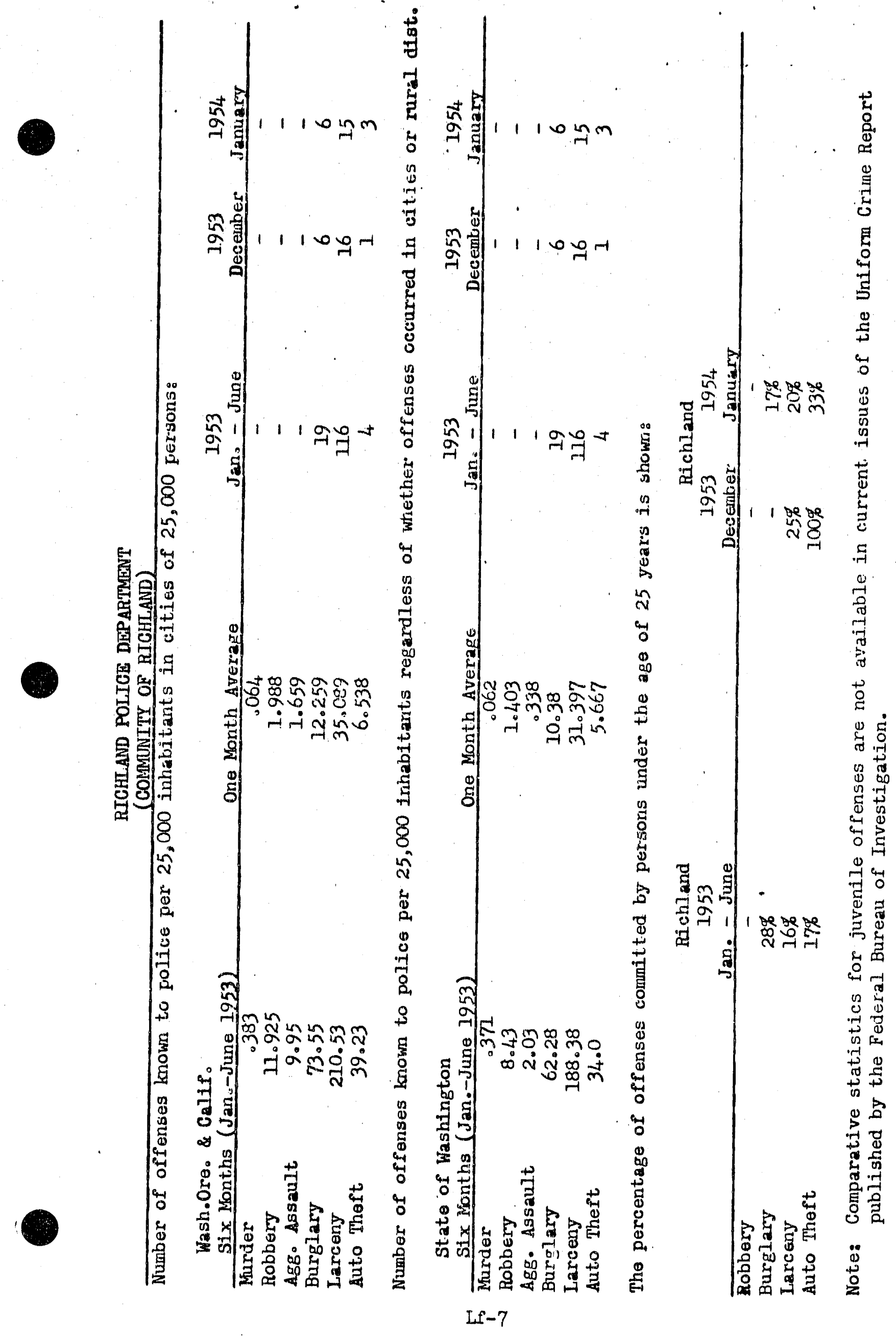




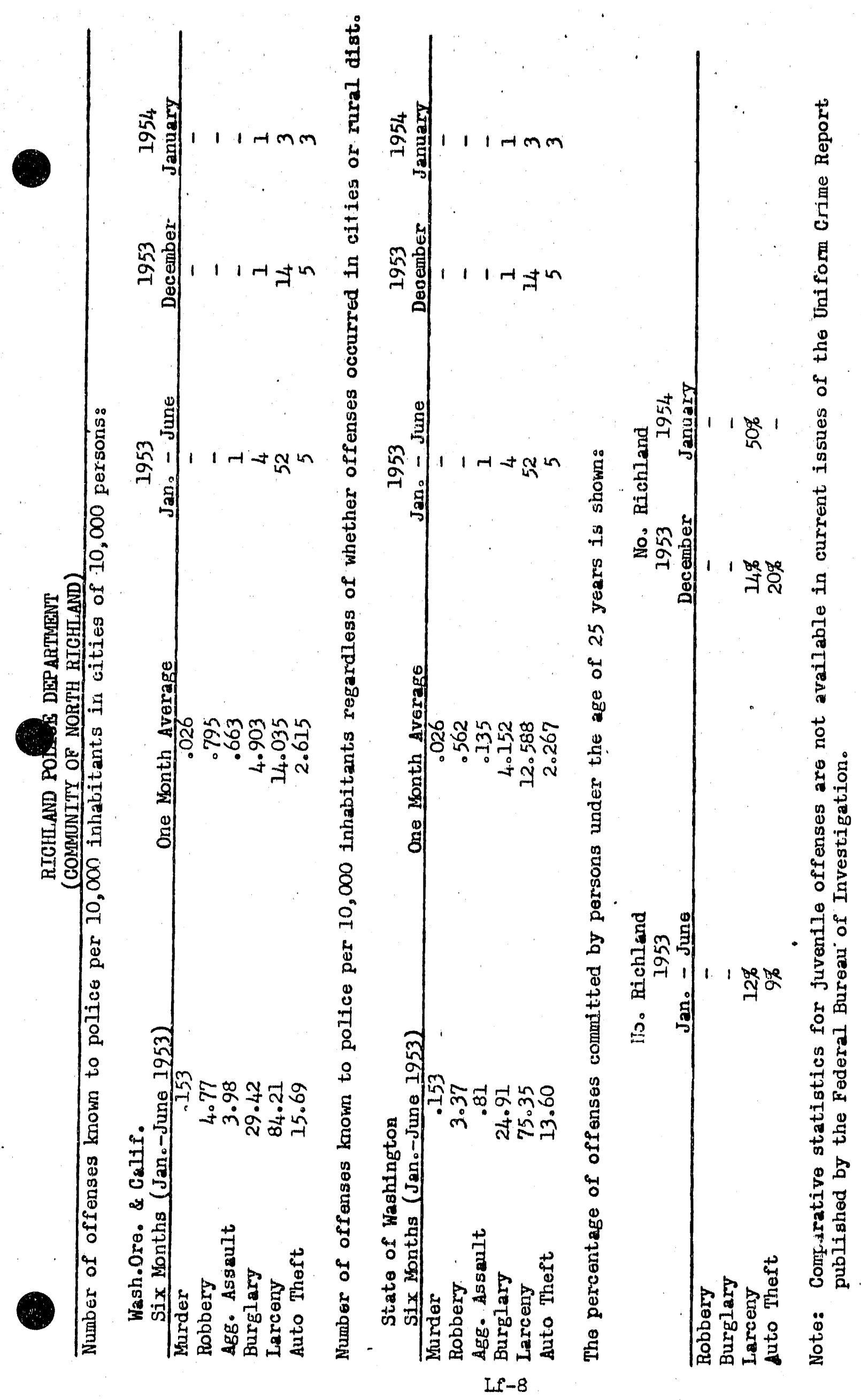




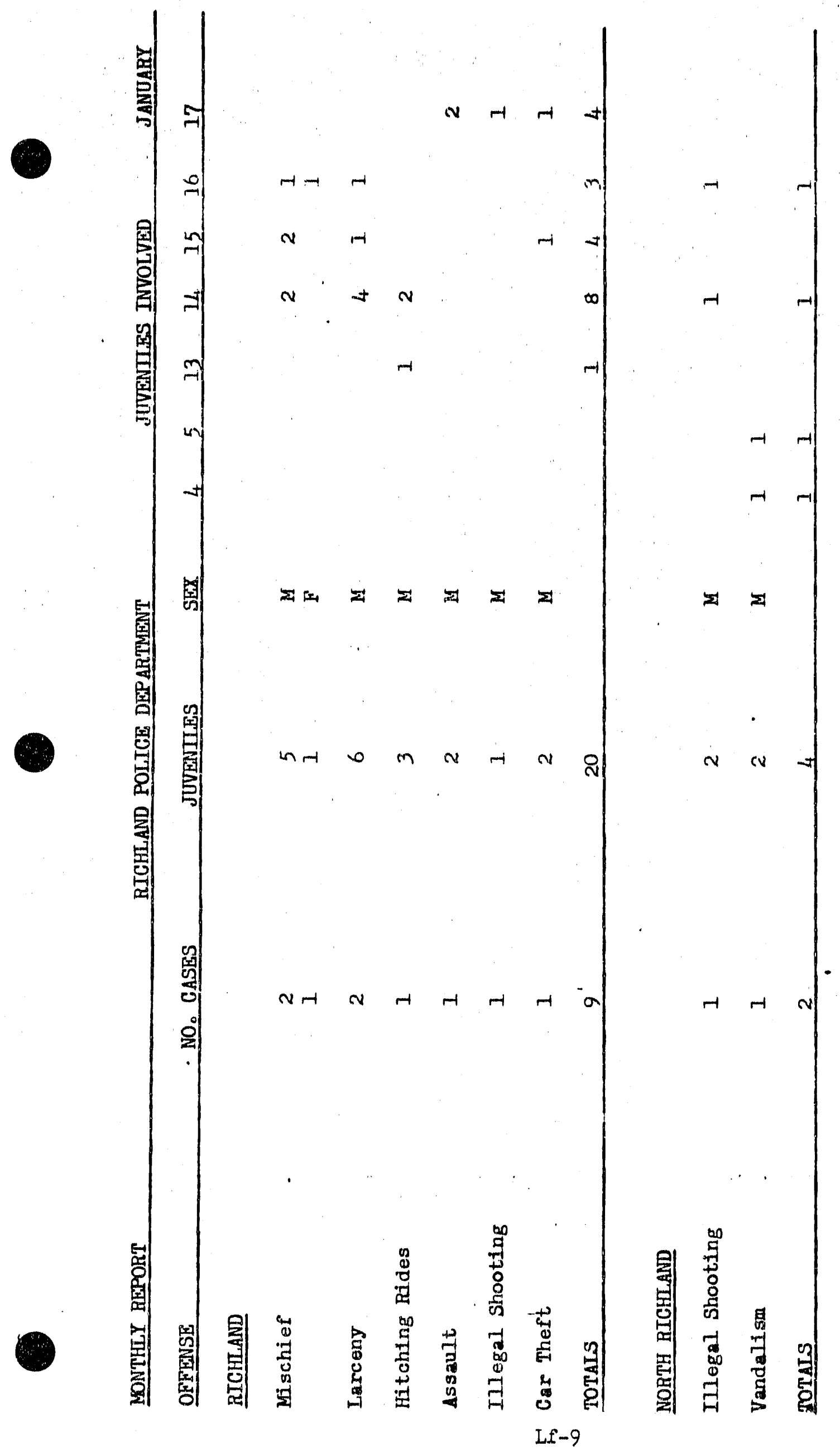




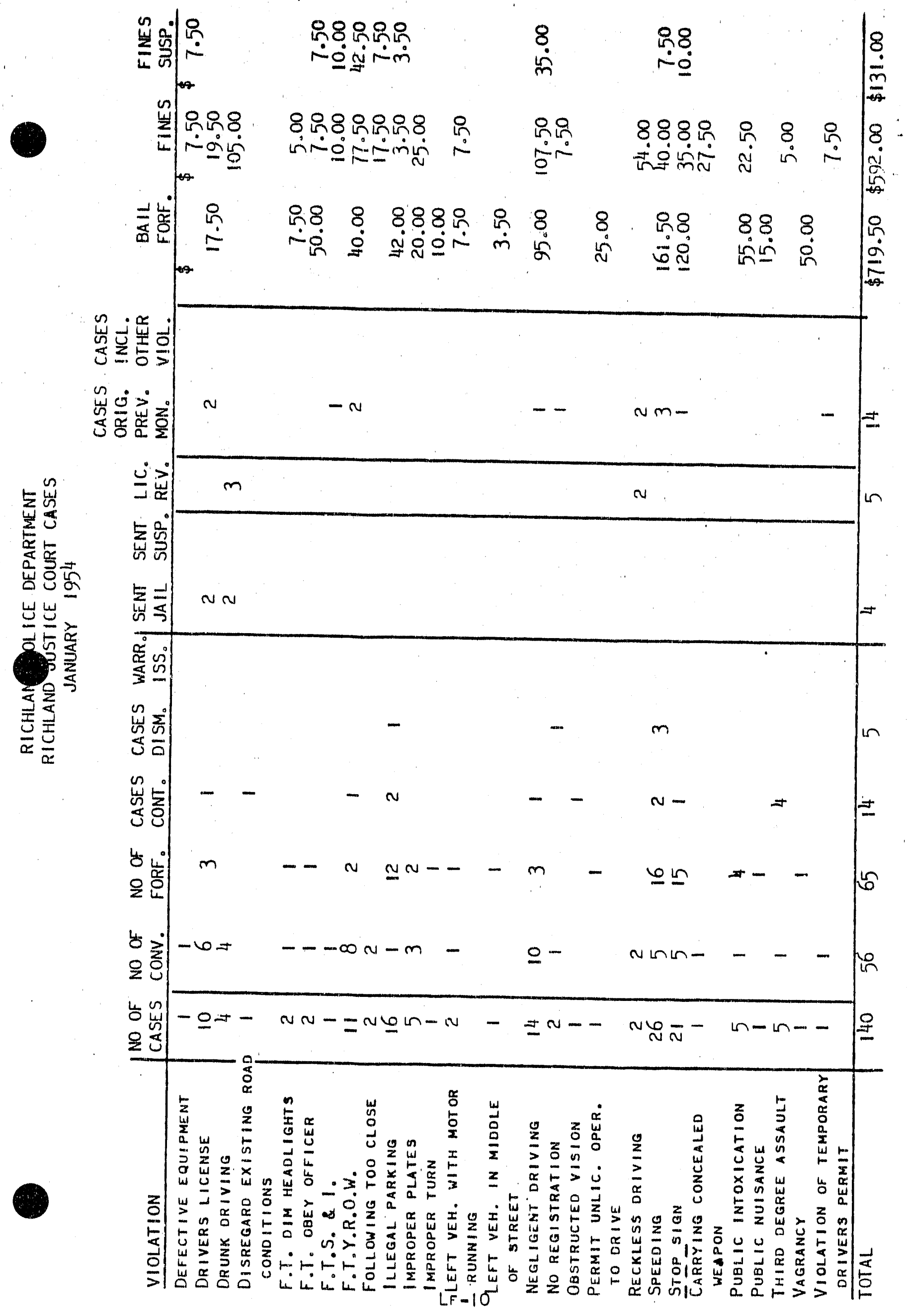




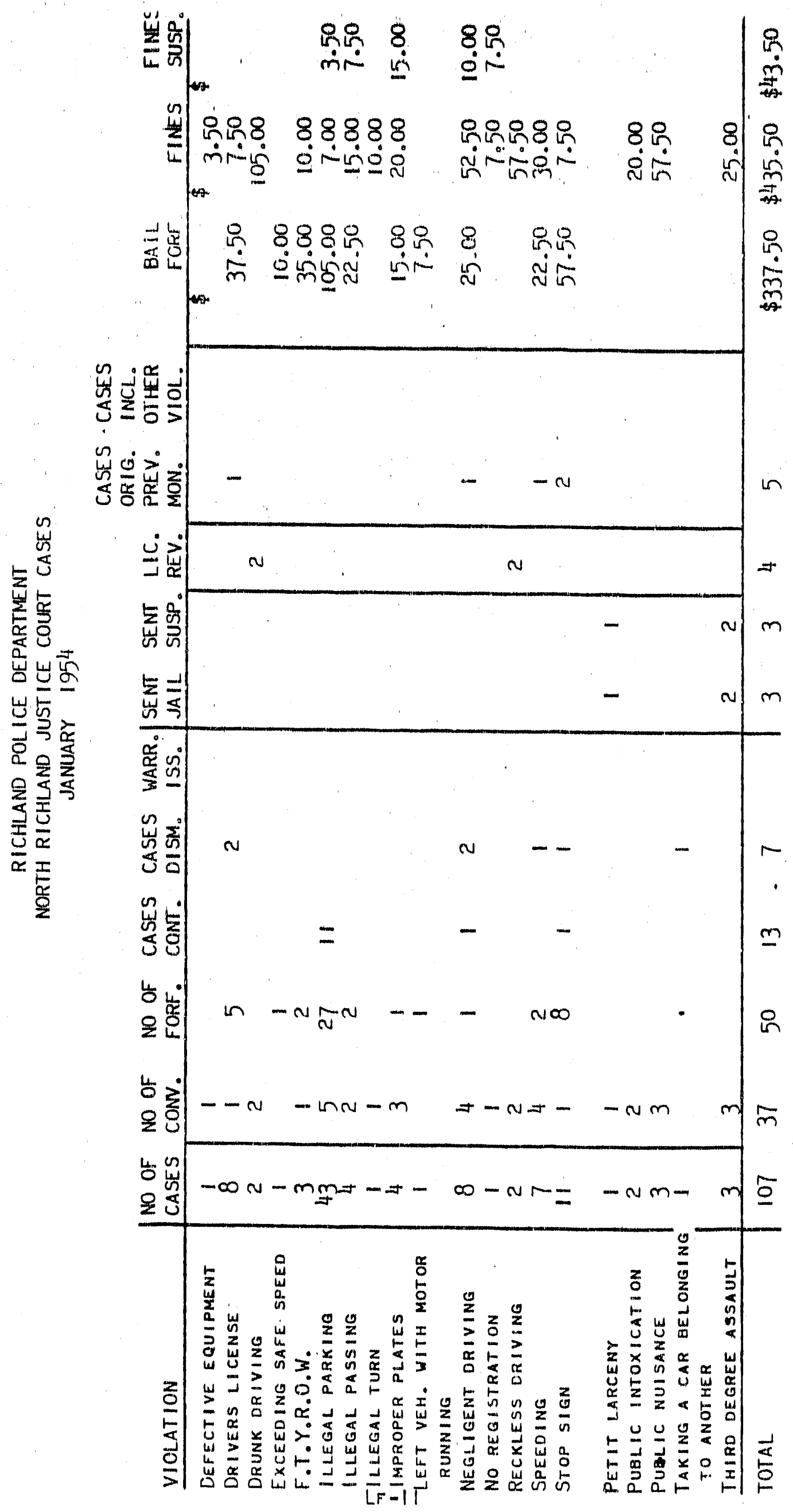




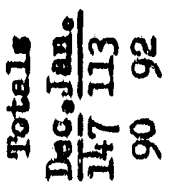

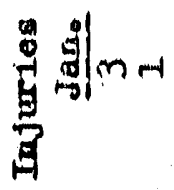

- 9 苟

迎

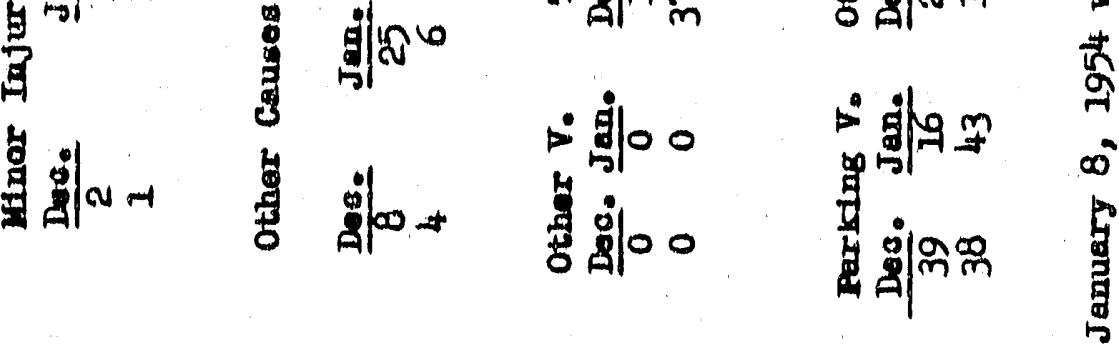

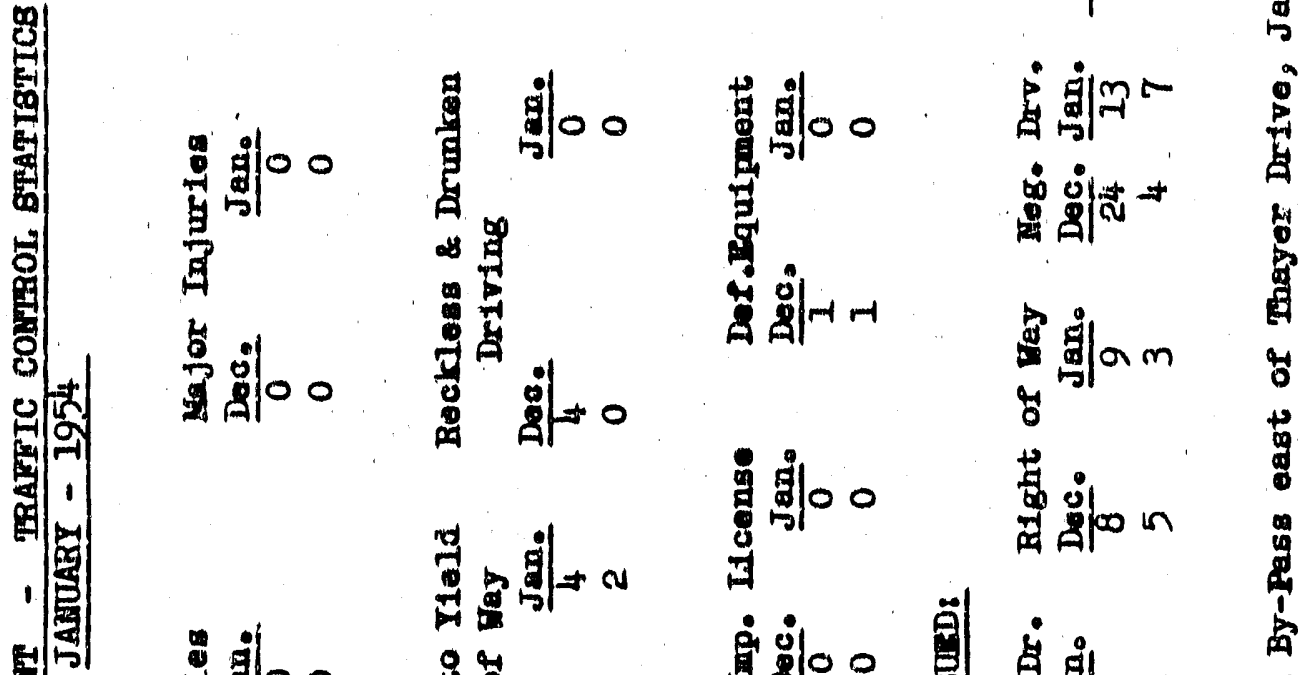

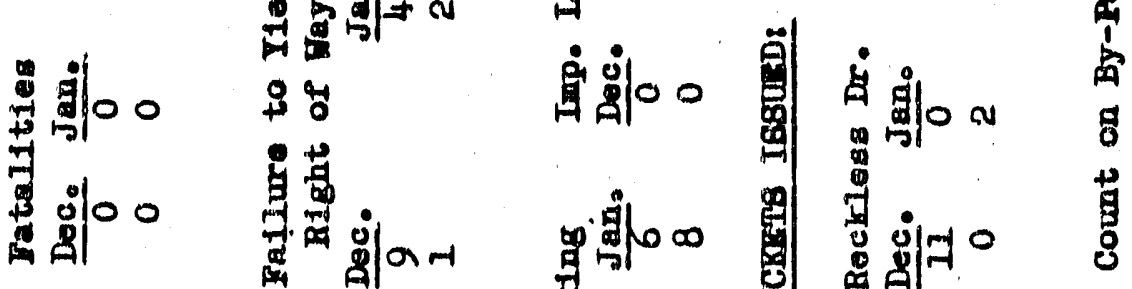

충

率

:

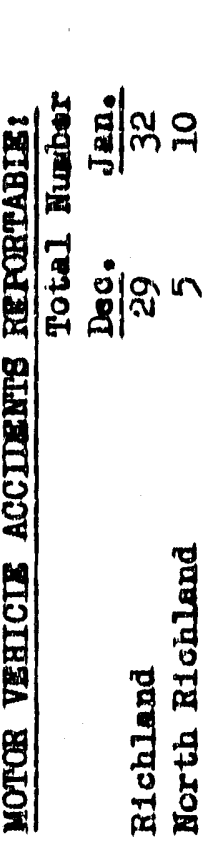

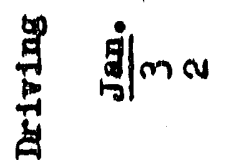
密就的

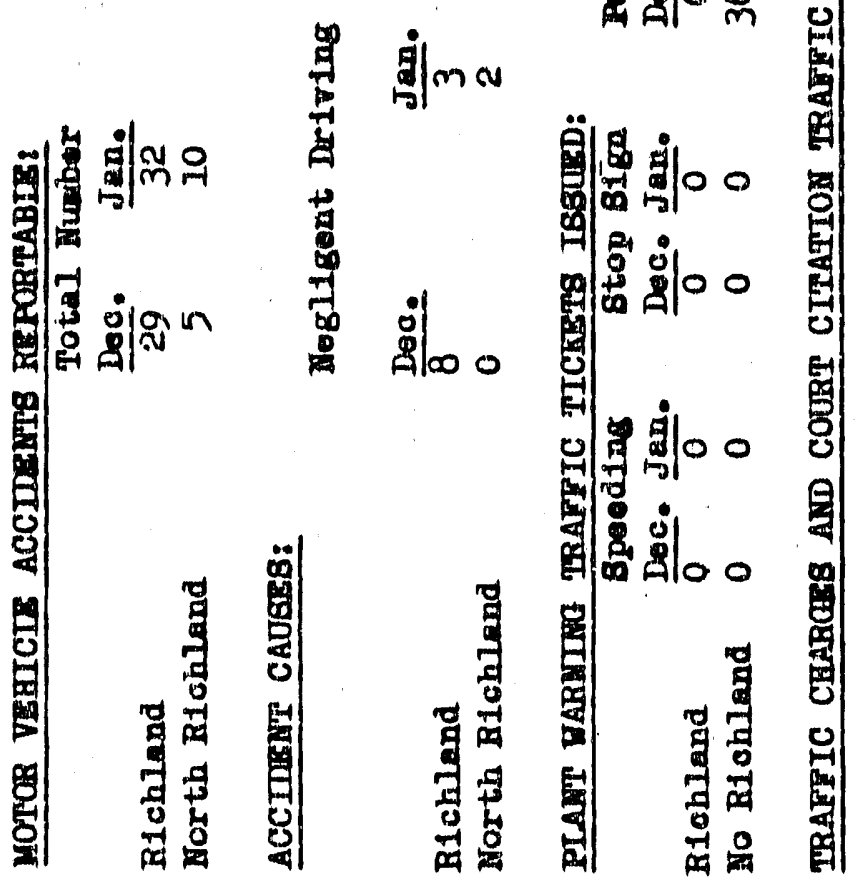

这哥

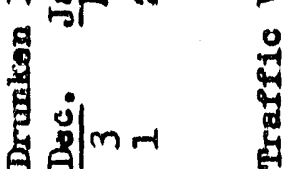

영ㅇ 姁

\%

तै

峦 :

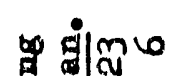

에 $\infty$

:

贻

굴

章

눙

察

娄

- 


\section{COMMUNITY OPERATIONS SEOTION \\ RICHLAND FIRE DEPARIMENT \\ MONTHLY REPORT \\ JANUARY 1954}

\section{Organization and Personnel.}

Mmployees - Beginning of Month
Transfers In
Transfers Out
Terminations
Now HIres
End of Month

Fire Protection

Flre Loss (Estlmated):

Government

Personal

January Total

Response To Flro Alarms

Investigation of Minor Flros \& Inoldents

Ambulance Responses

Inside Schools or Drilla

Outsida Drilis

Safoty Mootings

Security Moetings

Flro Alarm Boxes Tosted
Exempt Non-Exempt

$\begin{array}{rl}67 & 0 \\ 0 & 0 \\ 2 & 0 \\ 1 & 0 \\ 2 & 0 \\ 66 & 0\end{array}$

Riahland North Rlohland

$\begin{array}{rr}\$ 4.00 & \quad \$ .00 \\ 287.50 & \frac{3.421 .00}{\$ 332.50}\end{array}$

$\begin{array}{rr}20 & 16 \\ 7 & 0 \\ 39 & \\ 39 & 18 \\ 7 & 5 \\ 8 & 4 \\ 4 & 2 \\ 216 & 100\end{array}$

On January 2nd, the Fire Department dispatohed one truck to stand by at Riverside Park during the commun1ty Christmas tree bonf1re sponsored by
the Junlor Chamber of Commerco.

On January 12 th, a Brownie Troop of 14 glrls and their leader visited the Central FIre Station.

\section{Fye Prevention}

One hundred fifty $91 \times$ RIohland and 18 North Rlohland fire Inspections during January resulted in 34 hazard reporta. S1x hundred fifty olght flro extingulshers wore inspected, 16 inatalled, 13 recharged, 5 remorod and 14 relocatod. A hundred ninety seven firo hose standpipes were also inspected.

A nowspaper articlo was prepared for publication relative to the hazard of children pleying with discarded Christmes trees.

Word was received from the National. Firo Protection Association that Rlabland was awarded Ist place in the State of Washington, 4 th place nationalig in its population cless and 17 th internationally in the 1953 Firo Provention Contest.

A meet1ng was held with the Chamber of Commerce Flro Prevention Comitteo relative to profected 1954 flro provention activitios.

\section{$\operatorname{Lg}_{g}-1$}


On request of Commint and dippling tank for air cloaning systems in tho now skating rink were Investigated and appreved provided non-flanmable o11 is uaed and venti. lation oquipment is enclosed by a non-oombustible wall.

Inveatlgated a complalat relative to a locked sxd t at the adjolning Uptown Barber and Beauty Shops and referred the matiar to Communtty Engineering.

Amerlcan Legion, Commerclal Roal Estate and Community Engineering wero advised that changes in propane storage at the Amerlcan Legion Hall did not yet meet code requirements. A gas company representative indioated correction would be made.

Investigation was mado of a rei'rigoration pump fallure whloh resultod In a firo alarm at the Desert Inn. It was recomended that a factory mechanto be recalled to go over the equipment.

Recomendations were again made for extension of the Desert Inn's basement sprinkler system and Instaliation of a firo alarm annunciator panel.

Arrangements wore made for disconneoting batteries and steaming out gesoline tanks of automobiles to be displayed in the Uptown Theatro.

Asalstance was given School maintenance ataff in locating a sparo annunciator cirouit at Jason Loo School for addition to fire alarm sygtom. Freezing and bursting of the Chter Joseph Juntor H1gh sprinkler systom also required Fire Marshal assistanco. 


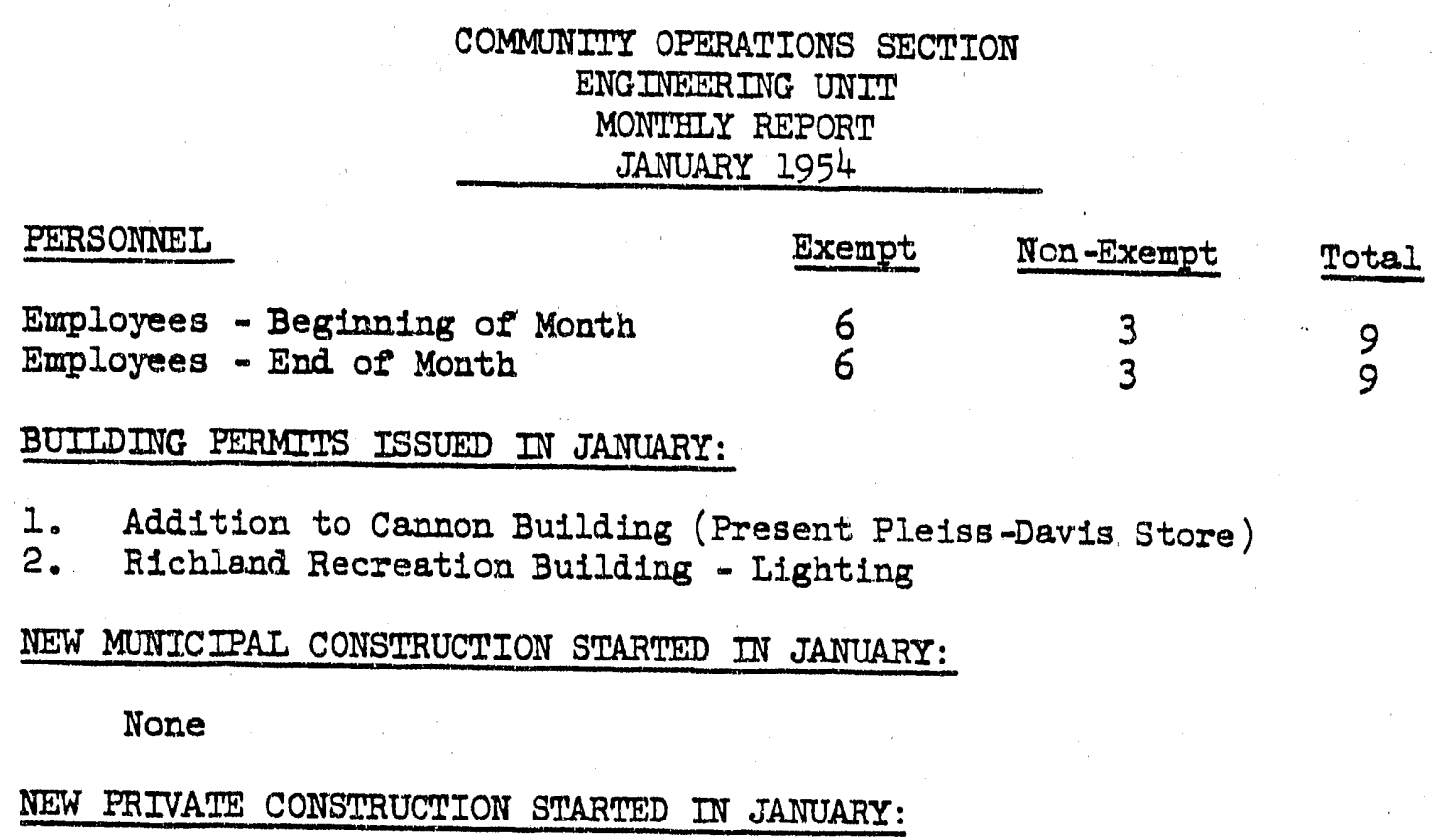

None

ENGINEERING JOBS COMPIETED DURING JANUARY:

Project C 488 - Additional Erosion Control \& Development, Public Areas, F. Y. 1952.

Project $\mathrm{K}-837$ Replace Water Tank, Recreation Building.

Project K-879 Provide Water Sewer Service to Safeway Site.

ESR I 90074 Eros1on Control and Development, Public Areas, F.I. 1953,

Part I - Closed Into Project S-722.

ESR I 90084 Plans, Spec1f1cat1ons, Inspections, CD Joseph Buflding

ESR I 90134 "As BuIlts" General - See ESR 90594

ESR I 90144 Plans, Specifleations, Inspections, R1chland Development Co. Block 2, Uptown. Flnal Inspection January $15,1954$.

ESR I 90214 Des1gn, Plans, Spec1f1cations, Storm Drain, George Washington Wey.

ESR I 90414 Assistance, Tree Planting, Columbla and R1vers1de Parks

ESR I 90424 Rev1sed Iegal Descript1on, I. D. S. Cinurch

ESR I 90444 Rev1sed Legal Description, Parcell S1te, Lee \& Duane

ESR I 90454 Rev1sed map, Sem1-Cormerc1al Area

ESR I 90464 Revised Legal Descr1ption, M1ckey's Shoe Renew1ng. 
ENGINEERING TNII (Cont.)

Completed Engineerins. Johs (Cont.)

ESR I 90534 "As Bullts" Peterson Building (L1nn Motors)

ESR I 90574 "As Bullts" Automat1c Launäry Co., Block 5, Uptown

ESR I 90584 "As Builts" Cannon-Joseph Bu1lding \#2, Block 4, Uptown (BehInd Kennell-Ell13)

ESR I 90554 Utility drawings, Christ the KIng Parish - cancelled.

STATUS OF ENGINEEF TNG TMVב JOSS TO BE COMPIETED:

PROJECTS:

25.7 Kadlec Hospital Grounds Improvements - Final design in progress.

K-753 Flow Control Valve, Sewage Treatment Wet Well - 95\% complete. Ad justments are being made.

K-811 Extend sewer to new comercial bullding, Hartford \& Duportall $90 \%$ complete. Awalting seejing weathe: to replant lawn.

L-728 Installation Fire Insulated Fire Alarm Wire - To be completed as locations are furnished by Fire Department.

I-888 Atr Conditioning, Communtty House - Fully scoped. Froject proposal being prepared.

S-722 Eros1on Control \& Development, F.Y. 1953, Part I - FInaI design in progress.

S-869 Parking Facllittes, Kadlec Hospital - Estimate 75\% complete.

ENGINEERING SERVICE REQUESTS:

I 90014 Free Methodist Church - $99 \%$ complete. No progress this month.

I 90024 First Baptiat Church - 88\% corrlete. Work progressing very slowly。

I 90034 Assembly of God Church - 77\% complete. Work progressing very slowly.

I 90044 Alteration Permitis - An open active Plle.

I 90054 Fngineer ILIson, R1=hland Water - Following construction and providing lialson as needed.

I 90064 Television Antennae - An open active Pile. 
ENGINEGGING UNIT (Cont.)

I 90094 Plans, Specs., Inspections, Grace Bacon Roller Rink - 95\% complete. Open for business. Construct1on progressing.

I 90104 Plans, Specs., Inspections, R1chland Realty Company, Symons and Jadwln (Newberry Store - 99\% complete. Work progressing.

I 90114 Plans, Specs., Inspectlons, Latter Day Saints Storehouse, West Jadwin - 95\% complete. Work progressing slowly.

I 90124 Plans, Specs., Inspections, American Legion - 99\% complete. Exceptions not all cleared by Contractor.

I 90154 Plans, Specs., Inspect1ons, Parcell Bldg., Dupoitall \& Hartford (Semvice Station) - Plans recelved January 28, 1954.

I 90164 Plans, Spess., Inspections, Veterinary Hospital - $90 \%$ complete. Work progressing slowly.

I 90174 Plans, Specs., Inspections, Dians Iangevin Blillding - Construction 99\% complete. Fingl inspection to be made.

I 90184 Plans, specs., Inspect1ons, Safeway Store - $38 \%$ complete. Work shut down gince start of union strike.

I 90194 Landscape Design for 300 Area - Project being prepared.

I 90224 Plans, Specs., Inspections, EH Kidrell, Service Station - Plans not recelved from lessee.

I 90224 Inspection \& Ilaison, Spokane Housing - Materially complete. Exceptions to be cleared.

I 90234 Inspection \& Ilaison, Bauer-Day Housing - Materially complete. Exceptions to be cleared.

I 90244 Plans, Specs., \& Inspections, Church of Nazarene Addition - 60\% complete. Work progressing slowly.

I 90254 Plans, Specs., Inspections, Seattle First National Bank Addition 99\% complete. Final inspection to be made.

I 90264 Plans, Specs., Inspections, Rlchland Helghts Baptist Church, Thayer Drive and Duporta1l - Plans not recelved from lessee.

I 90274. Inspection, McMurray Road - 78\% complete. Awalting warmer weather to complete.

I 90284 Removal of Irrigation System (Est1mate) - Study stage.

I 90294 Replace Water IIne \#5 Well to Lee BIvd. Reservoirs - Scoping and proposal 10\% complete. 
ENGIIEEERING UNIT (Cont.)

I 90304 Project Proposal, Street Construction, FY 1954 - Project proposal submitted.

I 90314 All Salnts Epliscopal, Revised Description - $90 \%$ complete.

I 90324 Design, Englneering, Inspect1on, Walks, Drives at Columbja Playfleld - $90 \%$ complete.

I 90334 Flans, Specs, Inspections, Richland Baptist Church (G.W.W.)Construction $20 \%$ complete. Slow progress due to strike and weather conditions.

I 9034t Instaliation of Ear Screens at Sewage Lift Station - Scoping and proposal 100\% complete.

I 90354 Water Syatem Study for Irrigat1on System DIsposul - Held open for further study.

I 90364 Legal Description, Desext Inn (Vance Prop. Inc.) - 75\% complete.

I 90374 Plans, Specs., Inspections, If Cook Construction \& Maintenance. Bullaing (Between Tastee Freez \& Skating Rink) - $80 \%$ complete. Work progressing raplaly.

I 90384 Field work \& dravings to resurface Easement north of Public Health Bullding - $25 \%$ complete.

I 90394 Installation of Cyclone Fence, Tennis Courts, Riverside Park Fully scoped. Project estimate prepared.

I 90404 Riverside Park Extension - Project to be prepared.

I 90474 Part II, Erosion Control \& Development Public Areas, FY 1953 Held pending mid year review.

I 90484 Revised Legal Description, RIchland Realty, Inc. Block 5, Uptown $90 \%$ complete.

I 90494 Estimate of Cost, Metering Cormercial Buildings for water - 90\% complete. To complete as time permits.

I 90504 Plans, Specs., Inspections, Pleiss-Dav1s Addition - 99\% complete. Final inspection to be made.

I 90514 Legal Description, Carnation Company - 90\% complete.

I 90524 Comfort Station - Project proposal being prepared.

I 90544 Sidewalk Survey - Held up until snow clears from sidewalks.

I 90564 Iegal Description, Automatic Laundry Co. - 75\% complete.

I 90594 "As Buflts" Genergl - Part II - Work progressing.

I 90604 Inspection, 24" Sandtary Sewer, Swlft Blvd., Gribble Street Improvements - Contract by AEC pending. 
SUMMARY

January 1954

ORGAIVIZAYION AITD PERSONIEI:

BEG INNIING OF MONME

END OF MONTE

Real Estate Section 350

Exempt Monexempt

Exempt Nonexempt

2

1

1

Housing \& Maintenance Unit

351

353

$\begin{array}{rrrr}5 & 19 & 5 & 19 \\ 12 & 137 & 12 & 137\end{array}$

Commercial Property Unit

357

$\frac{6}{25} \quad \frac{6}{163} \cdot \frac{6}{25} \cdot \frac{6}{163}$

GENERAL

One commerclal lease was executed to provide for the operation of a warehouse and the sale of used furntture in a Government-owned building.

One license agreement was executed to provide for the instullation and operation. of a communty television aignal distribution system:

One retroactive noncomerclal lease was executed, coverling the occupancy of Goverment-owed bullaling $89 \mathrm{X}$ by the BAMTC.

Five sublease enterprises comenced operation.

Five sublease enterprises terminated.

One sublease was assigned from a partnership to an individual for continued operation.

Final inspections, covering two privately-owned bulldings, were reported.

Three baslc lease agreements were amended by supplemental agreements.

Twenty-three brochures were prepared describing Government-owned bulldings, for use by Independent appraisers. 


\section{HOUSING AND MAINTENANCE UNIT}

$$
\text { January, } 1954
$$

ORGANIZATION AND PERSONNEL

$$
\begin{aligned}
& \text { Number of employees on the payroll: } \\
& \text { Beginning of month: } \\
& 17 \text { exempt } \\
& 156 \text { nonexempt }
\end{aligned}
$$$$
173
$$

End of month:

17 exempt

156 nonexempt

173 
HOUSING UTILIZATION AS OF MONTH ENDING JANUARY 31, 1954

HOUSES OCCUPIED RY FAMIIY GROUPS

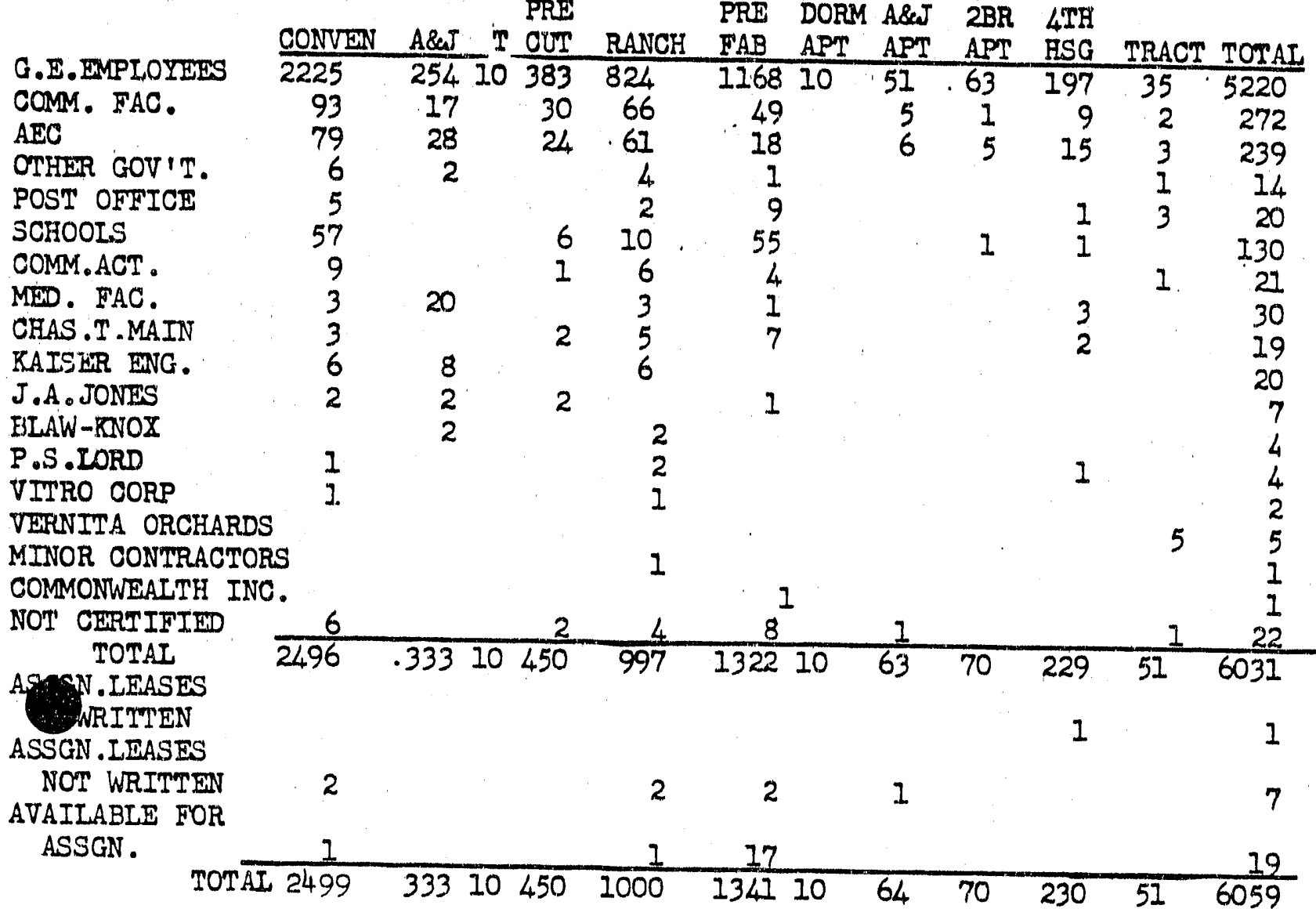

CONVENTIONAL TTYPE

A\&S TYPE

NTI TPPE

PRECUT

RANCH

PREFAB

DORM APTS

A\&W APTS

2BR APTS

FOURTH BOUSING

TRACTS
BEGIN MONTH MOVED IN MOVED OUT FND OF MONTH DIFTEERENCE

$\begin{array}{rrrrrr}2490 & 18 & 12 & 2496 & +6 \\ 333 & 1 & 1 & 333 & \\ 10 & 1 & 1 & 10 & +1 \\ & 449 & 2 & 1 & 450 & -2 \\ 999 & 8 & 10 & 997 & -3 \\ 1325 & 23 & 26 & 1322 & -1 \\ & 10 & 4 & 5 & 10 & \\ & 64 & 1 & 1 & 70 & 71\end{array}$


January 1954

DORMITORY REPORT

Dormitories:

\begin{tabular}{|c|c|c|c|}
\hline & Beds Avallable & Vacent Beds & Occupled Beds \\
\hline $\begin{array}{l}\text { Men } \\
\text { Women }\end{array}$ & $\begin{array}{l}516 \\
381 \\
\end{array}$ & $\begin{array}{l}73^{*} \\
35^{*} \\
\end{array}$ & $\begin{array}{l}443 \\
346 \\
\end{array}$ \\
\hline Total & $897 *$ & $108 * *$ & $789 *$ \\
\hline
\end{tabular}

Weiting IIst

Men

Women
SIngle Rooms
3

Double Rooms

0

HOUS ING

CANCETIATION AND AITOCATIONS

SIRA IGHT CANCEIJATIONS

AIIOCATIONS

Voluntary termination 8

R. O. F.

Discharge

Transfers

Retirement-divorce-misc. 5

Move off project 10

Deatb

$\frac{1}{3}$

Move to Wherry House 3

Total 30

Houses allocated to new tenants

Exchanged houmes

Moves

Turnovers

Total leases algaed

Total cancellations

House asalgned "As Is"

Houses aent to renovation

Move Irom Wherry House to G. E. Applications ponding 


$\begin{array}{ccc}\text { Orders Incomplete } & \text { Trders Issued } & \text { Total Orders } \\ \text { as of December 31 } & 12-31 \text { to 1-30 } & \text { January 30, } 1954 \\ 900 & 2277 & 871 \\ 965 & 475 & 922 \\ & 220 & \end{array}$

Serv1ce orders

Work Orders

Servlce Charges cember $31 \quad 12-31$ to $1-30$

220

Prlnclpal work order loads

Incomplete as of Incomplete as of December 31, 1954 January 30, 1954

Laundry tub replacement

Bathroom renovations (tub, tile, lino.)

Tileboard bathroom

Kitchen floor Ilnoleum

Kitchen cabinet IInoleum

Shower stall

$\begin{array}{rr}16 & 26 \\ 95 & 96 \\ 4 & 10 \\ 62 & 25 \\ 110 & 152 \\ 13 & 16\end{array}$

67 alteration permits were 1ssued, as compared to 116 1ssued during December.

Install automatic dryer

Install water softene..

Install light switch

Install kitchen cabinets

Install fence

Install electrical outlets

Cut opening in wall

Install air cooler

Gonvert to oll

Install driveway

Basement partition installed
1. Install automatic washer

1 Install TV antenna

2 Remove laundry trays

2 Install door chlmes

$4 . \quad$ Basement excaration

3 Install window pane in door

2 Sand \& refinish floors

2 Install additional wiring

1 Install gas range

1 Install clothes poles

2 Reverse range and refer
16

4

2

2

c

1

1

1

1

1

1

I12 inspections were made, as compared to 1446 made in December.

Alteration permito

Bath mirror

Cupboards

FIII

House

Innoleun

Porch \& steps

Recall of range \& refer

Shower stall

Trees

Wells

Yard

Dorms

Cancellations

$\begin{aligned} 39 & \text { Basement } \\ 1 & \text { Cellings } \\ 3 & \text { Doors } \\ 1 & \text { Floorboards } \\ 47 & \text { Laundry tray } \\ 95 & \text { Paint } \\ 9 & \text { Jack \& shim } \\ 13 & \text { Roof } \\ 12 & \text { S1dewalks } \\ 2 & \text { Tollet seat } \\ 3 & \text { Wlndows } \\ 1 & \text { Mlscellaneous } \\ 44 & \text { Renovatlons } \\ 58 & \text { Shows (new tenants) }\end{aligned}$

39 Basement

Cellings

Floorboards

Laundry tray

Jack \& shim

Roof

S1dewalks

lollet seat

ows

Renorations

Shows (new tenants)

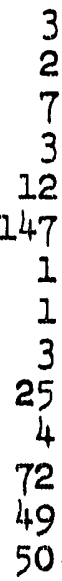

126 Freeze-upg in January due to extremely cold weather.

$$
I \jmath-4
$$


MONTHLY PROGRESS REPORT

INTERIOR REDECORATING REPORT

FISCAL YEAR - 1954

MANPOWER

\begin{tabular}{|c|c|c|c|c|c|c|}
\hline Foreman & Painters & Ord & rs o & I Hand & Carpenters & Dr. Drivers \\
\hline Tappan & 20 & Fep & 46 & Not 6 & $I$ & 1 \\
\hline Lukins & 21 & & 16 & 36 & 1 & 1 \\
\hline Armstrong & 21 & & 47 & 4 & 1 & 1 \\
\hline Total & 62 & & 109 & 46 & $\overline{3}$ & $\overline{3}$ \\
\hline & No. & & & WPLTTED & COMPLETED & BALANCE TO \\
\hline PE U & $\mathrm{SCH}$ & & & Ij illoilT & TO DATE & BE PAINTED \\
\hline
\end{tabular}

\begin{tabular}{crrrr} 
A & 154 & 25 & 113 & 11 \\
B & 364 & 68 & 290 & 74 \\
C & 0 & 0 & 0 & 0 \\
D & 4 & 2 & 4 & 0 \\
E & 41 & 14 & 33 & 8 \\
F & 108 & 13 & 88 & 20 \\
G & 3 & 0 & 3 & 0 \\
H & 79 & 13 & 55 & 24 \\
K & 0 & 0 & 0 & 0 \\
L & 3 & 1 & 2 & 1 \\
M & 2 & 0 & 2 & 0 \\
$Q$ & 6 & 1 & 6 & 0 \\
R & 2 & 0 & 2 & 0 \\
S & 2 & 1 & 2 & 0 \\
T & 6 & 0 & 5 & 1 \\
U & 5 & 1 & 4 & 1 \\
V & 26 & 8 & 20 & 6 \\
Y & 192 & 20 & 165 & 27 \\
$Z$ & 5 & 0 & 5 & 0 \\
IBP & 43 & 9 & 18 & 25 \\
2BP & 146 & 27 & 40 & 106 \\
3BP & 136 & 21 & 30 & 106 \\
Tract & 9 & 2 & 4 & 5 \\
BR Apt. & 9 & 3 & 4 & 5 \\
W-13 Apt. & 3 & 0 & 2 & 1 \\
\hline Total & 1348 & 229 & 897 & 451
\end{tabular}

Est. MH B. F. 33,422

This Mo. Est. MH 11,118

Total Est. $\quad 44,540$

Aotual MH B. F.

This Mo. Actual MH

Total Actual MH
32,466

10,864

43,330 


\section{PLURB ING SHOP}

JOB DESCRIPTION

NO. COMPLETED

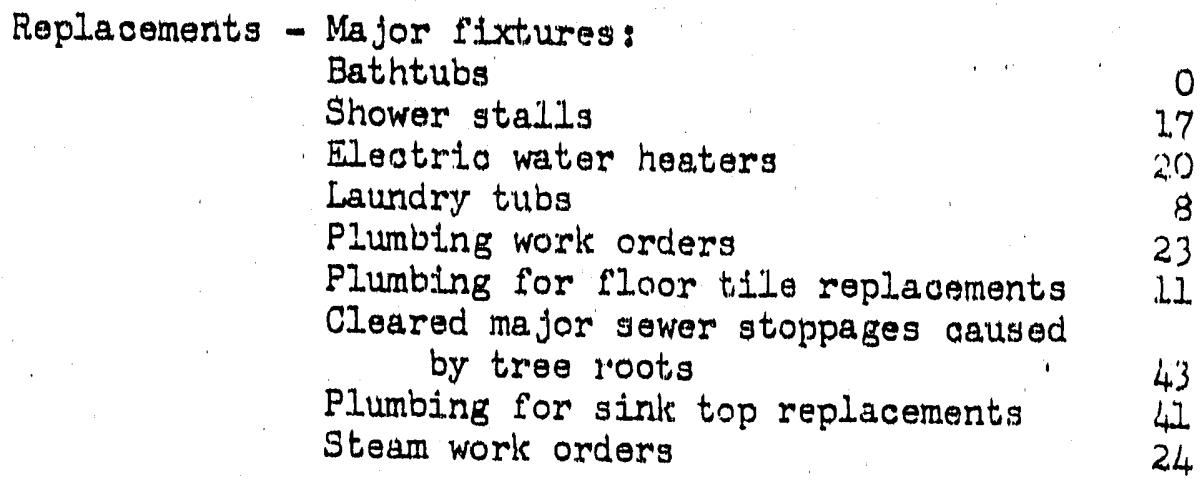

Steam Inspection onoe a week on dormitories, apartments and Government owned commercial buildings

$$
\text { Servida orders } 123 \text { hours }
$$

\section{SERVICE ORDER CREW}

The following is a status report on service orders:

A. On hand at the beglnning of the month

B. Received during the month

C. Completed during the month

D. On hand at the end of the month

E. A total of 171.4 hours were spent on work orders.

F. Back log of serrlce orders ijr araft:

$\begin{array}{ll}\text { Plumbing } & 395 \\ \text { Electirinn } & 209 \\ \text { Carpertiny } & 179 \\ & \\ \text { Total } & 783\end{array}$

NOTE: This report is up to and including the 26 th of January, 1954. 


\section{RENOVATION \& LABOR CREW}

\section{JOB DESCRIPTION}

Renovation orders processed

Sewers dug, backililled \& seeded

Trees rernoved

Trash plokups

Front steps filled with black top

Sldewalks patchad with black top

Dormitory rooms redecorated

Service driveways repalred

Pumped oil at service stations

Spray for silver fish in domitorites

Miscellaneous carpenter repairs, such as weop holes \& screen repair
NO. COMPLETED

49

26

26

1.8

2

2

2

6

2

5 rooms

8

Scrubbed, sealed and waxed several rooms in the men's dormitories.

Dormitories serviced with Iinen and janitor supplies.

$$
L j-7
$$


MECHANICAL SHOP

JOB DESCRIPTION

NO. COMPLETED

A. Milliwright crews

Funnace servidoe orders $\quad 319$

Routine furnace inspections $\quad 265$

General:

Routine serviolng and lubrication of preout houses is in progress, and is approximately $25 \%$ completed.

B. Sheetmetal crew:

$\begin{array}{lr}\text { Replacement of shower stalls } & 16 \\ \text { Replacement of gutters } & 28 \\ \text { Flashing around ranch house cosl hatch } & 14 \\ \text { Prefab window weep tubes } & 3000\end{array}$

\section{CARPEN'TRY}

IOB DESCRIPTION

NO. COMPLETED

Replace bath wall tile

Repalr bath wall tile

Replace bath floor linoleum.

Repair bath flloor Iinoloun

Replace kitchen floor inoleum

Repair kitchen floor linoleum

Roplace steps \& landing IInoloum

Replace bedroom f'loor linoleum

Repalr bedroom floor linoleum

Replace utility room floor linoleum

Repair utility room floor linoloum

Replace dining room filoor Iinoleum

Replace living room floor inoleurn

Repalr Ilving room floor Iinoleum

Replace ranch house floor tile

.

Repair ranch house floor tile

Repal. "rk" house floor tile

Replace Itnoleum - commercial faolitties

Replace metal stripper

Replace kitchen sink top Iinoleum

Repajr kitchen sirk top linol
Replace work bench Iinoleum 
CARPENTRY - cont Inued

JOB DESCRIFTION

NO. COMPLETEI

Replaco kitchen sinks

Repair windows - Shop

3
10

Make new windows - Shop

Dr111 weepholes

Sash balanoes

Repalr window screens - Shop

Make new window soreens - shop

Repair roof - commeralal faolitties

Repalr roof - houses

Repair foundation

Repatr porches

Repair sidirg

Repalr exterior doors - Shop

Repalr Interior doors - Shop

Jack \& shim

Repair wall

Repair celling

Repair basement wall

Repair basement flloor

Repalr floor boards

Thresholds

40

2

2

Time spent - office equipment

Time spent - Shop equipment

Repair for dormitortes

Repair for plumbers

Repaj.r for painters

Repair for service orders

Cablnet doors repalred - Shop - 95

Cablnet doors replaced - Shop (made new)

Cabinet drawers repalred - Shop

Closet door's repaired - Shop

Chempoint - routine

Chempoint - work orders

60

Paint touch-ups completed

Interior carpentry repair to all type houses (4 year cycle)

54

Screen doors repaired - Shop

165

Remodel house - 329 Cullum

Mock-up ... C-58257 
PERSCNNEL - COMMERCIAL PRCPERTY UNIT:

Januar:

Beginning of Month

Ind of Month

12

Net Change

0

PERSONNEL - COMMERCI AL AND NONCOMMERCIAL FACILITIES:

\section{Commercial Noncommercial}

North

Richland Richland

North

\begin{tabular}{|c|c|c|c|c|c|c|}
\hline & Richland & $\begin{array}{c}\text { North } \\
\text { Richland }\end{array}$ & Richland & $\begin{array}{l}\text { North } \\
\text { Richland }\end{array}$ & Richland & $\begin{array}{c}\text { North } \\
\text { Richland }\end{array}$ \\
\hline December & 1,545 & 189 & 121 & 1 & 1,666 & 190 \\
\hline January & 1,558 & 188 & 120 & 1 & 1,678 & 189 \\
\hline Net Change & +13 & -1 & -1 & 0 & $\$ 12$ & -1 \\
\hline
\end{tabular}

Total

SUMMARY OR ROUTINE ITEMS PROCESSED:

Commercial
North
Richland Richland

Noncomercial

North 53

Work Orders

Back Charges

FY Work Orders

FY Back Charges

CONTRACT AND NEGOTIATIONS:

A. Commercial:

1. Leases:

a. Davis Furniture Co. - a lease covering warehouse Building \#125-4 for the operation of a furniture warehouse and sale of used furnt ture.

b. J. H. Whitney \& Co. - a license agreement for the installation and operation of a commity television signal distribution system.

2. Supplemental Agreements;

a. New City Cleaners - to provide for payment of electricity on the basis of meter readings and estabilishes an allowance to Lessee on account of such payment. 
b. Dr. T. M. Armstrong - to provide for lease of additional space in the
Medical-Dental Building and adjustment of rent.

c. Tastee-Freez - to provide for a reduction in the amount of utility
payments.

3. Assignment:
a. The sublease agreement for the operation of the Columbia Book Store, previously operated by Patricia A. Cochrane and Anna L. Peck, a partnership, assigned to Anna L. Peck, an indjvidual.

B. Noncomne reial:

1. Lease: a. HAMTC - a lease covering the government-owned building 8gX during the
period it was oscupied by HAMTC.

GENERAL:

A. Comercial: 1. Dr. L. E. Clark, Chiropodist, opened an offlce in the C.D. Joseph Building,
Uptown Business Area, for professional services.

2. Mrs. Helen Hardy, $d / b / a$ "PInk Cameo" terminated her sublease with Virgil 0 . MeVicker and Wayne \& Velma High have subleased the space for the operation of an apparel store $d / b / a$ "Velma's."

3. Pleiss-Davis, Inc. occupied the govemment-owned warehouse Building \#1125-3, located in the Light Industrial Area, in which they will operate a fumiture warehouse.

4. Serier \& Sullivan terminated their sublease agreement with Stanley N. Randolph effective as of January 31,1954 .

5. Martin-Tuttle and Benson d/b/a "Benson's Dress Shop" terminated their sublease agreement with George Forsyth. 6. Ernie Jarrard terminated his sublease agreement with D. M. Lone covering
the operation of a used car sales lot.

7. Dr. E. W. Moore, Veterinary, opened his building on west Van Giesen for professional services.

8. Knuth Dance Studio terminated its sublease with Automatic Laundry Company. 9. Final Inspection Report on Richland Transfer and Storage Building, located
at 260 Wellsian Way. 10. Final Inspection Report on Richland Development Company, Inc. Building,
Block 2, Uptown Busine ss District.

11. Campbell's Food Lockers, Inc. opened an appliance shop at 239 Symons Street, in the Untown Businese Area. 
12. Brochures describing the premises and outlining the operating experiences were prepared for twenty three commercial factilties. These brochures were prepared for use in connection with the pending appraisals of the properties, primarily, for purposes of lease renegotiations.

B. Noncommercial:

1. One Pasture Permit was issued.

COMMERCIAL PROSPECTS:

Inquiries were received during the month concerning the establishment of the following types of enterprises in Richlarid.

Service Station

Drive-in Restaurant

LI-3 
苞

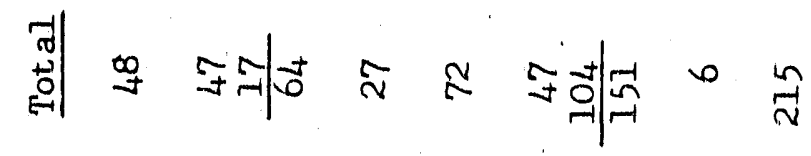

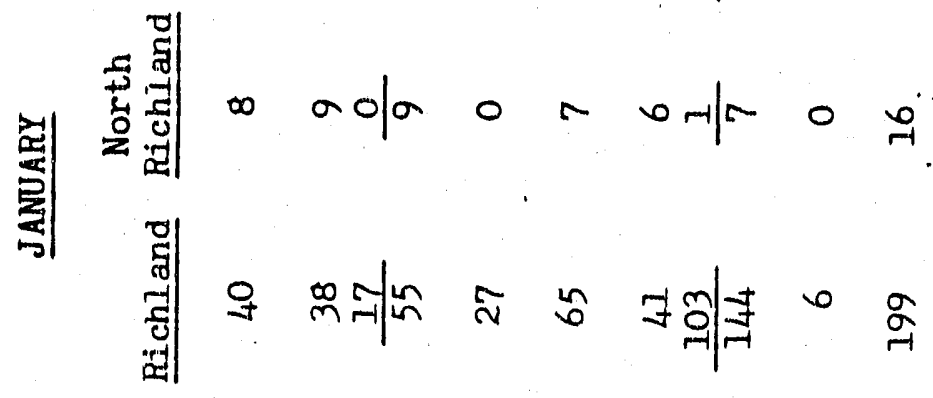

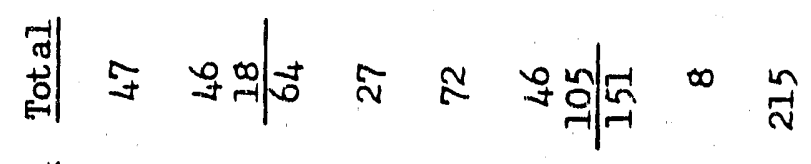

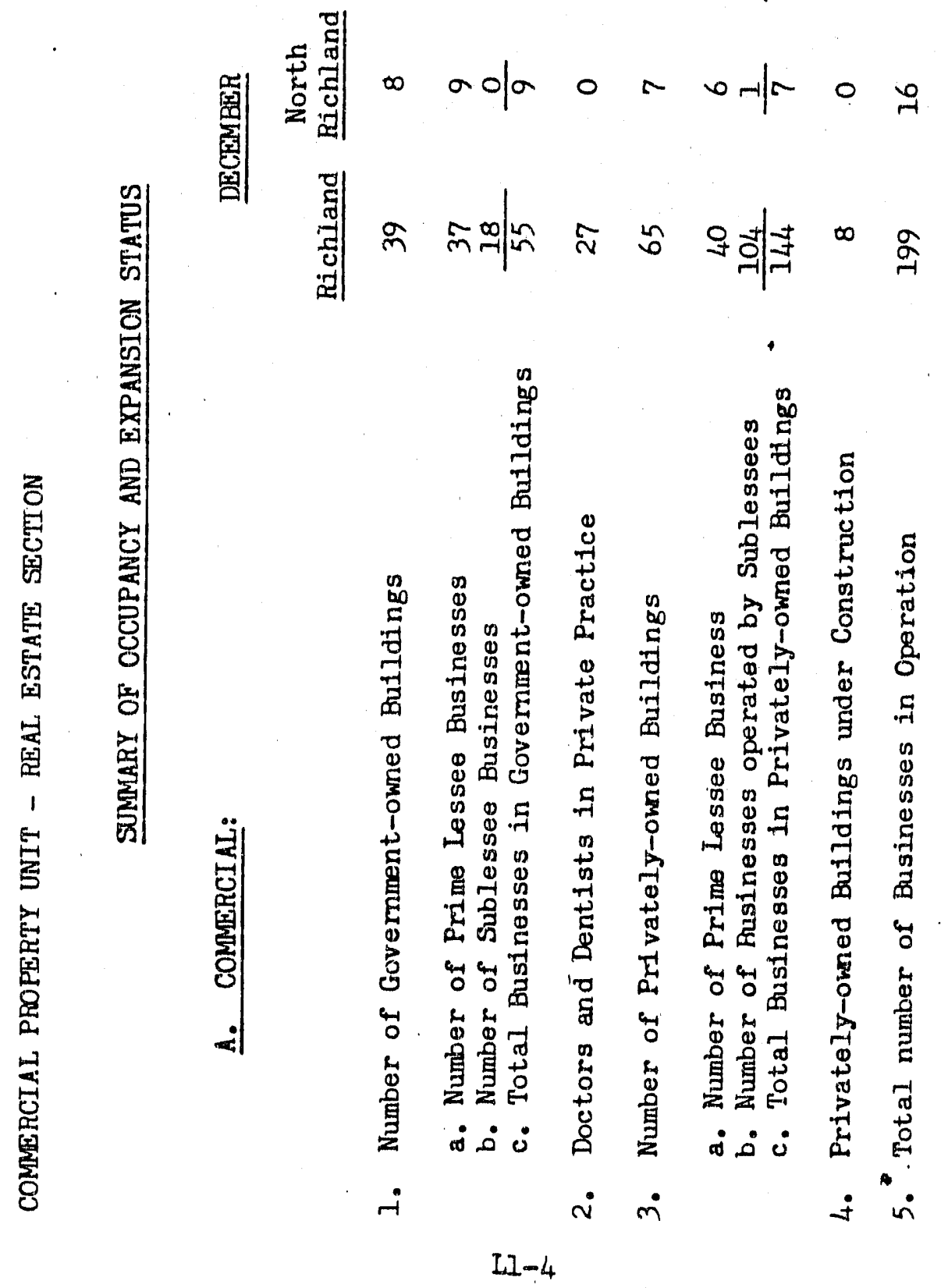




\section{1}

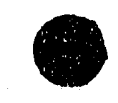

जू

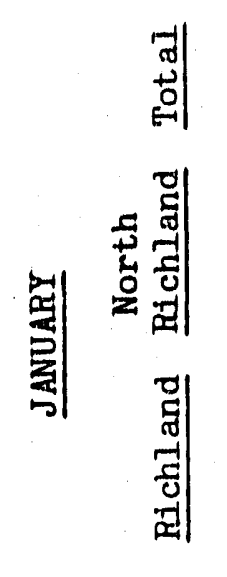

홍<smiles>CC(C)NC(C)(C)C</smiles>

.
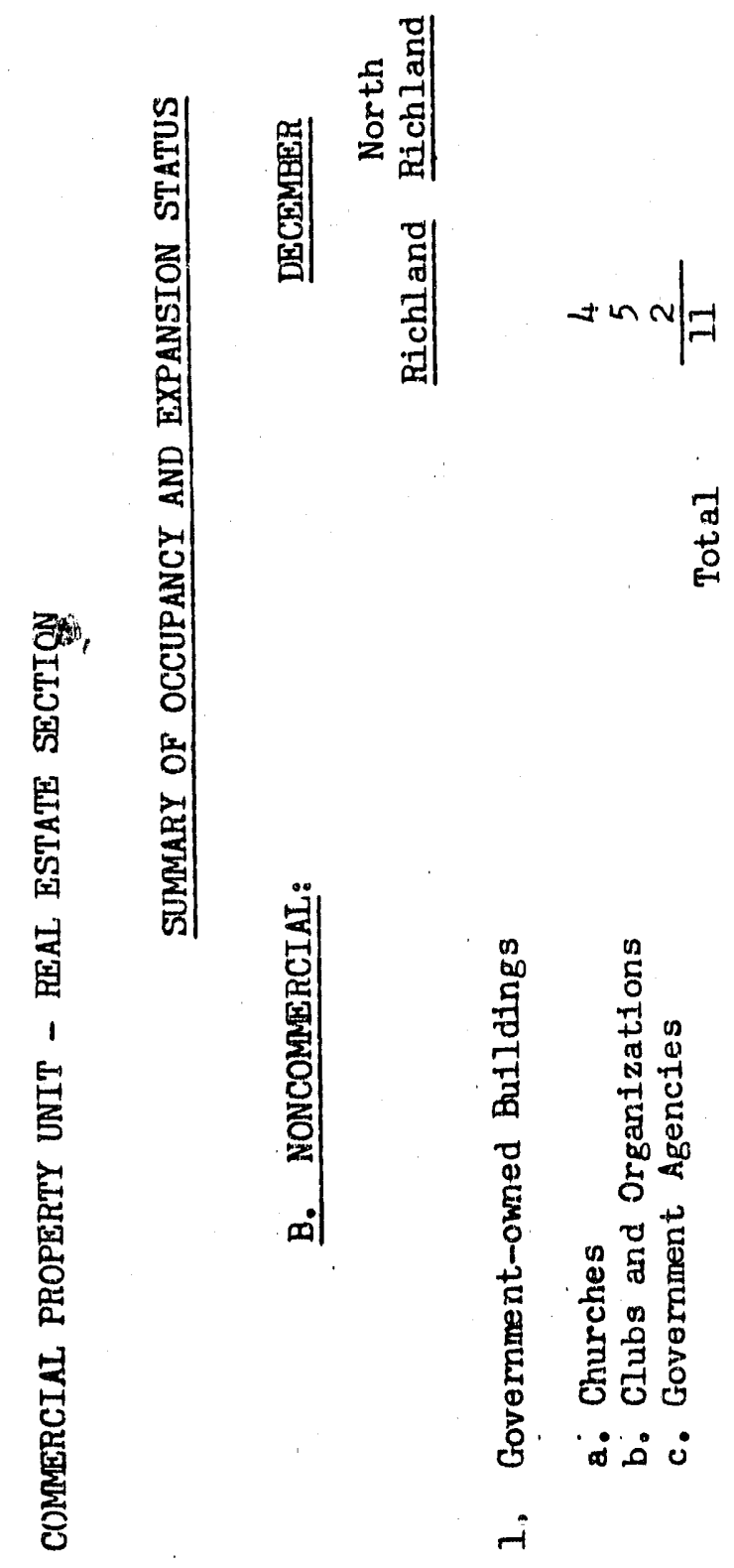

ت10|<smiles>[AlH2][VH2]</smiles>

우임

नำ|ำ

$-1+1$

억

5

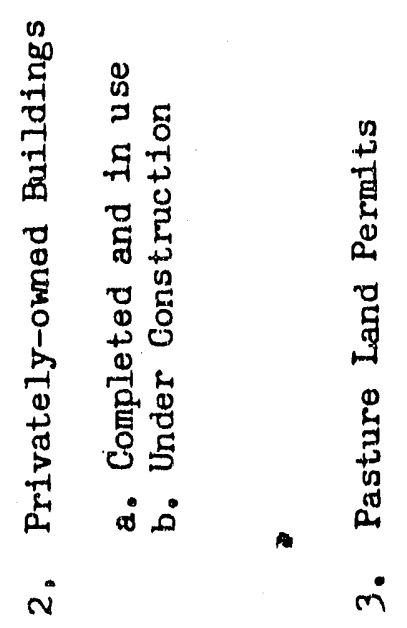



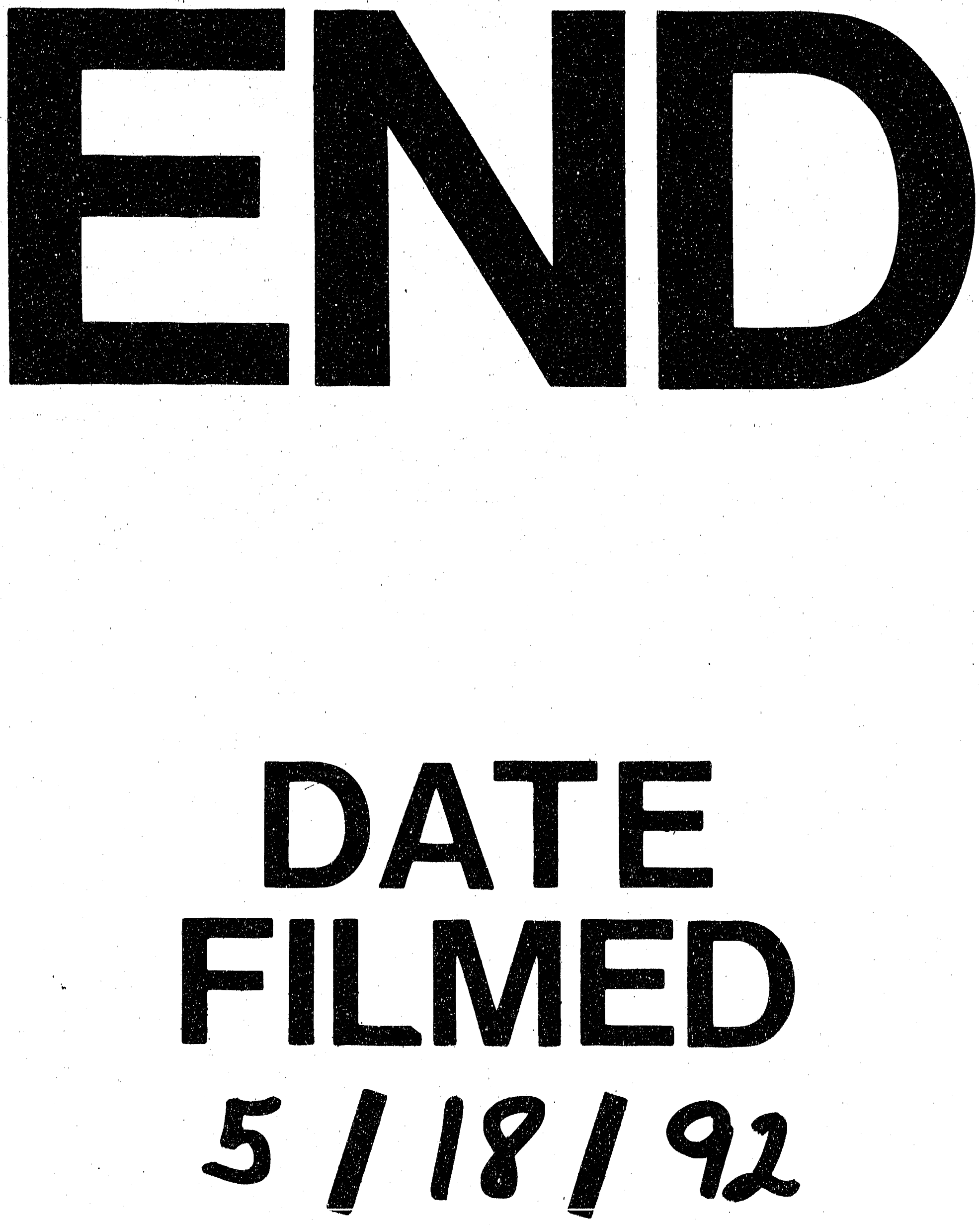

聿 
